\title{
Hanford Cultural Resources Management Plan
}
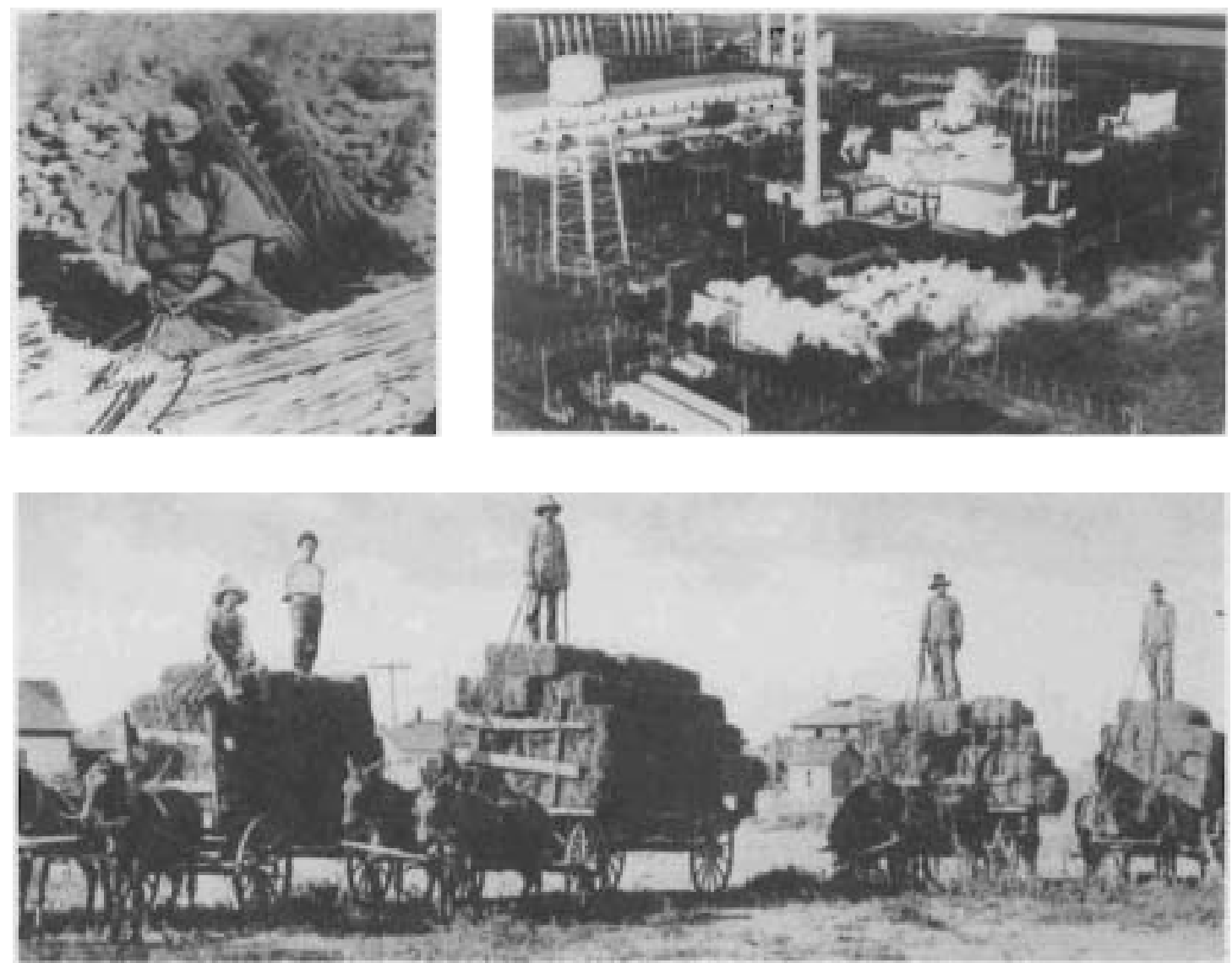

June 1989

Prepared for the U.S. Department of Energy under Contract DE-AC06-76RLO 1830

Pacific Northwest Laboratory

Operated for the U.S. Department of Energy

by Battelle Memorial Institute

\section{()Battelle}




\section{LEGAL NOTICE}

This report was prepared by Battelle as an account of sponsored research activities. Neither Sponsor nor Battelle nor any person acting on behalf of either:

MAKES ANY WARRANTY OR REPRESENTATION, EXPRESS OR IMPLIED, with respect to the accuracy, completeness, or usefulness of the information contained in this report, or that the use of any information, apparatus, process, or composition disclosed in this report may not infringe privately owned rights; or

Assumes any liabilities with respect to the use of, or damages resulting from the use of, any information, apparatus, process, or composition disclosed in this report.

Reference herein to any specific commercial product, process, or service by trade name, trademark, manufacturer, or otherwise, does not necessarily constitute or imply endorsement, recommendation, or favoring by Sponsor or Battelle. 
PNL-6942

UC-600

HANFORD CULTURAL RESOURCES MANAGEMENT PLAN

Edited by

J. C. Chatters

June 1989

Prepared for

the U.S. Department of Energy

under Contract DE-AC06-76RLO 1830

Pacific Northwest Laboratory

Richland, Washington 99352 


\section{ON THE COVER}

Scenes from Hanford's past: an Indian woman weaving reeds on the bank of the Columbia, late 18oos; Hanford farmers harvesting hay, early 1900s; nuclear reactor in operation, 1940s. 


\section{PREFACE}

As a federal agency, the U.S. Department of Energy (DOE) has been directed by Congress and the President to provide leadership in the preservation of prehistoric, historical, and cultural resources on lands it administers, to manage these in a spirit of stewardship for future generations, and to protect and preserve the rights of Native Americans to religious freedom. The purpose of this document is to describe how the DOE-Richland Operations (DOE-RL) will meet those responsibilities on the Hanford Site, pursuant to guidelines for Agency Responsibilities under the Historic Preservation Act (FR 53:31. February 17. 1988).

This document is intended for multiple uses. Among other things. the text is designed as a manual for cultural resource managers to follow and as an explanation of the process of cultural resource regulatory compliance for the DOE-RL and Site contractors.

This document will be updated on an as-needed basis. 


\section{CONTENTS}

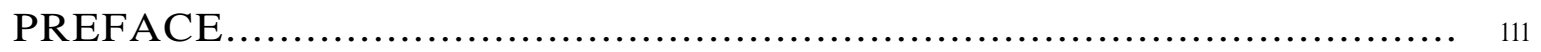

$\begin{array}{lll}1.0 & \text { IN1RODUCI10N } & 1.1\end{array}$

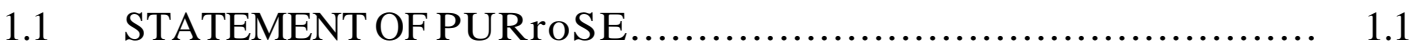

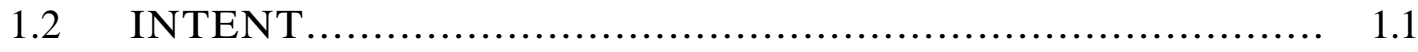

1.3 OBJECTIVES $\quad, \quad \ldots \ldots . . \quad \ldots \ldots \ldots \ldots . . . . . . .11$

1.4 TIIE LEGAL B ACKGROUND ................................... 1.2

1.4.1 The Concept of Cultural Resource......................... 1.2

1.4.2 Laws and Directives for the Preservation and Protection of Cultural Resources............................ 1.3

1.4.3 Native American Religious Freedom and its Protection ........... 1.4

1.5 TIIE HANFORD SITE AND ITS CULTURAL RESOURCE

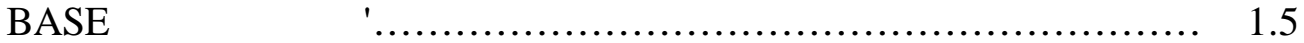

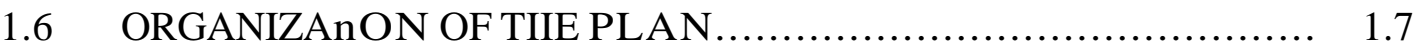

2.0 TIIE DOE MISSION AND ITS POTENTIAL IMPACTS

ON CULTURAL RESOURCES AND RELIGIOUS PRACTICES 2.1

2.1 THE ROLE OF THE HANFORD SITE............................... 2.1

2.1.1 Past Land Use $\quad 2.1$

2.1.2 Present Land Use........................................ 2.7

$\begin{array}{lll}\text { 2.1.3 Present Programs } & 2.10\end{array}$

$\begin{array}{ll}2.2 & \text { POTENTIAL EFFECfS OF HANFORD SITE } \\ \text { ACTIVITIES ON CULTURAL RESOURCES } & 2.12\end{array}$

2.2.1 Categories of Potentially Adverse Effects $\quad 2.14$

2.2.2 Possible Adverse Effects of Hanford Site Programs,
Past and Present

2.3 POTENTIAL IMPACfS ON TIIE FREE EXERCISE OF NATIVE AMERICAN RELIGIONS ................................ 2.20

$\begin{array}{lll}2.3 .1 & \text { Potential Impacts } & 2.20\end{array}$

2.3.2 Possible Impacts of Hanford Site Programs, 
3.0 POLICIES AND PROCEDURES FOR MANAGING CULTURAL

RESOURCES AND CONSIDERING RELIGIOUS PRACTICES

3.1 PRESERVATION OF HISTORIC PROPERTIES ..................... 3.1

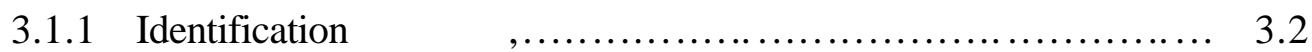

3.1.2 Evaluation and Nomination to the National Register.. 3.13

3.1.3 The Assessment of Effects $\quad, \quad, \ldots \ldots \ldots \ldots \ldots . .19$

3.2 PROTECFION OF HISTORIC PROPERTIES ....................... 3.25

$\begin{array}{lll}3.2 .1 & \text { Education. } & 3.25\end{array}$

$\begin{array}{lll}3.2 .2 & \text { Pemritting Procedures..... } & 3.25\end{array}$

3.2.3 Curation.................................................. 3.26

3.2.4 Management of Site Records............. 3.27

3.2.5 Surveillance and Enforcement............................. 3.27

$\begin{array}{lll}3.2 .6 & \text { Monitoring } & 3.28\end{array}$

3.3 AVOIDING INTERFERENCE WITH THE FREE EXERCISE OF RELIGION

3.3.1 Procedures to be Followed by the DOE-RL........................ 3.29

3.3.2 Procedures for the Discovery and Handling of Human Remains........................................... 3.32

3.4 PLANNED CULTURAL RESOURCE MANAGEMENT

ACTIVITIES, FISCAL YEARS 1989 THROUGH 1994

3.5 PERSONNEL, QUALIFICATIONS, AND SUBCONTRACfOR EVALUATION POLICy ............................................ 3.35

$\begin{array}{lll}3.5 .1 & \text { HCRLPersonnel } & 3.37\end{array}$

3.5.2 Criteria for Selecting Subcontractors............................. 3.37

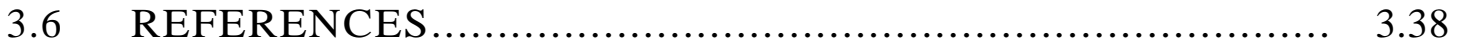

APPENDIX A - THE LEGAL BASIS OF CULTURAL RESOURCE
MANAGEMENT

A.1 FEDERAL REQUIREMENTS .................................... A.1

Historic Preservation......................................... A.1 
$\begin{array}{ll}\text { Protection..... } & \text { A.3 }\end{array}$

Funding ..................................................... A

$\begin{array}{llllll}\text { State Requirements.......... } & \ldots . & . . & \ldots \ldots \ldots . & \text { A. } 5\end{array}$

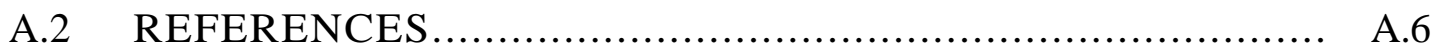

APPENDIX B - mSTORY OF CULTURAL RESOURCES MANAGEMENT ACTIVITY ON THE HANFORD SITE $\quad$ B.1

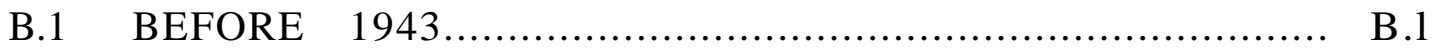

B.2 1943 TO 1966: FROM HANFORD TO THE PASSAGE OF $\begin{array}{ll}\text { THE NATIONAL HISTORIC PRESERVATION ACf } & \text { B. } 2\end{array}$

B.3 1967 TO 1971: NATIONAL PARK SERVICE INVOLVEMENT......... B.2

B.4 1971 TO 1972: MARKINGOFTIIE CEMETERIES B.3

B.5 1972 TO 1981: THE SUPPLY SYSTEM AND OTHER NON$\begin{array}{ll}\text { AEC/ERDA/DOE ACI1VITIES.. } & \text { B. } 3\end{array}$

B.6 1973 TO 1980: COMPLIANCE BY THE AEC/ERDA................. B.4

B. 7 THE EARLY 1980S: CULTURAL RESOURCES MANAGEMENT BECOMES DECENTRALIZED .................................. B.7

B.8 THE MID 1980s: THE RE-ESTABLISHMENT OF CENTRAL CONTROL ........................................................ B. 7

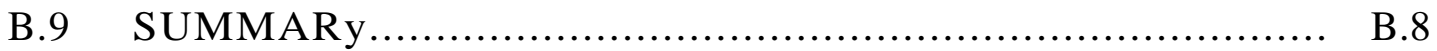

B.10 REFERENCES............................................... B. 8

APPENDIX C - ECOLOGY AND ENVIRONMENTAL HISTORY OF THE
HANFORD SITE $\ldots \ldots \ldots \ldots \ldots \ldots \ldots \ldots \ldots \ldots \ldots \ldots \ldots \ldots \ldots \ldots \ldots \ldots \ldots \ldots \ldots \ldots \ldots \ldots \ldots \ldots$

C.1 THE NATURAL ENVIRONMENT OF THE HANFORD SITE......... C.1

Physiography and Geologic History $\quad, \quad$ C.1

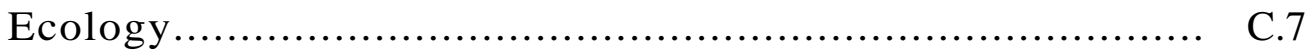

References..................................................... C.11

C.2 PALEOECOLOGY OF THE HANFORD REGION C.14

Geologic Evidence............................................... C.14

Summary: Probable Paleoecology of the Hanford Site................. C. 25 


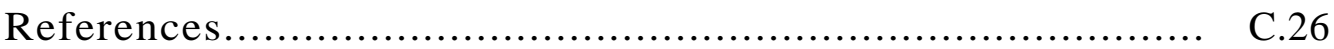

APPENDIX D - OVERVIEW OF EXISTING KNOWLEDGE ABOUT CULTURAL RESOURCES OF THE HANFORD REGION............ D. 1

$\begin{array}{lll}\text { D.1 PALEONTOLOGY } & \text { D. } 1\end{array}$

References........................................................... D. 3

$\begin{array}{lll}\text { D.2 PREIDSTORY D. } 4 & \end{array}$

The Archaeological Record of the Hanford Site..................... DA

Summary of Regional Prehistory ........................................... D.1O

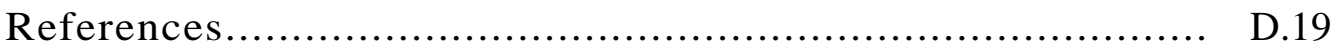

$\begin{array}{ll}\text { D. } 3 \quad \text { ETINOHISTORY, ENTHNOGRAPHY AND INDIAN } & \\ \text { USES OF THE HANFORD SITE } . \ldots \ldots \ldots \ldots \ldots \ldots \ldots \ldots \ldots \ldots \ldots \ldots \ldots \ldots \ldots \ldots \ldots \ldots \ldots \ldots \ldots \ldots \ldots \ldots \ldots \ldots\end{array}$

Native American History Relevant to the Hanford Site.................. D. D. 26

A Synopsis of Sahaptian Culture........................................... D. 31

Native American Use of the Hanford Site............................ D. 38

References........................... D. 42

$D A \quad$ EURO-AMERICAN HISTORY OF THE HANFORD AREA............. D. D.4

Explorers, Fur Traders, Missionaries, Travelers, and

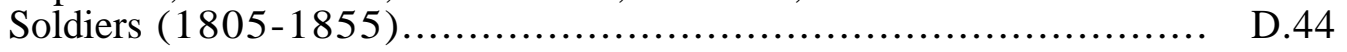

The Beginnings of Non-Indian Settlement: the Relegation of Indians to Reservations, the Mining Boom, Ranching, and Boundary Settlements in Eastern Washington (1855 to Early 1880s)

The Coming of the Railroads, Irrigation Systems, and the Beginning of Town Building (Early 1880s to 1910)

D.60

Area Growth and Development: World War I and the Great

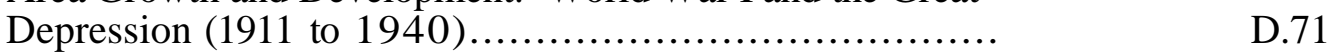

Military Endeavors, the Hanford Nuclear Reservation, the Columbia Basin Irrigation Project, and Population Demographics (1940 to 1980)

1980s and Beyond $\quad$ D.89

References...................................................... D. 90 


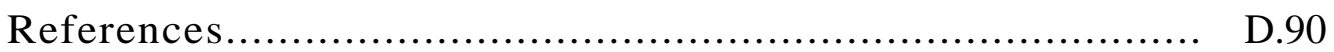

APPENDIX E - ESTABLISHING THE SIGNIFICANCE OF CULTURAL

RESOURCES.

E.1

E.1 CULTURAL CONTEXTS. E.!

The Issue of Ceded Lands........................................... E.1

Places Important to Traditional Religions $\quad$, E.1

Cemeteries................................................... E. 2

Traditional Areas of Residence and Resource-Gathering...... E.2

E.2 lliSTORICAL CON'fEXTS .................................... E.5

E.3 SCIENTIFIC CONCERNS ......................................... E.5

Paleontological Concerns......................................... E.5

Anthropological Concerns......................................... E.5

$\begin{array}{ll}\text { Theoretical Issues } & \text { E.11 }\end{array}$

E.5 REFERENCES .............................................. E. 21

$\begin{array}{cc}\text { APPENDIX F - ARCHAEOLOGICAL SURVEYS PERFORMED ON THE } & \text { F.1 } \\ \text { HANFORD SITE PRIOR TO APRIL 30, } 1988 & \end{array}$

APPENDIX G - WASHINGTON STATE 1liSTORIC PRESERVATION OFFICER'S STANDARDS FOR ARCHAEOLOGICAL SURVEY AND REPORTING

APPENDIX H - FORMS USED IN CULTURAL RESOURCES MANAGEMENT

APPENDIX I - CONTRIBUTORS .......................................... 1.1

$1.1 \quad$ LIST OF CONTRIBUTORS $\quad 1.1$

1.2 BIOGRAPHICAL SKETCHES OF CONTRffiUTORS.................. 1.1

APPENDIX J - LIST OF IIISTORICAL PROPERTIES ON THE HANFORD SITE 


\section{$\underline{\text { FIGURES }}$}

1.1 Range of Cultural Resource Types Pertinent to the Hanford Site............... 1.6

$2.1 \quad$ Land Use on the Hanford Site $\quad: \ldots \ldots \quad 2.2$

2.2 The 300 Area of the Hanford Site, Research and Development Activities.......... 2.6

2.3 The Arid Lands Ecology Reserve, a Natural Preservation Area on the Hanford Site

2.4 Activities That May Adversely Affect Cultural Resources.......................... 2.13

3.1 Timeline for the Performance of Cultural Resource Management Activities at the Hanford Site, from FY 1989 through FY 1994....

C.1 Characteristic Environmental Areas of the Hanford Site........................... C.8

C.2 Paleoecological Sites Mentioned in the Text C.1S

C.3 Summary of Paleoenvironmental Data and Inferred Paleoclimates for the Hanford Site.

D.1 The Ringold Formation and Other Topographical Features on the $\begin{array}{ll}\text { Hanford Site; Fossils Typical of the Formation } & \text { D.2 }\end{array}$

D.2 Archaeological Sites Referenced in the Text................................. D.5

D.3 Projectile Point Styles Typical of Prehistoric Time Periods II Through VIII in theHanfordArea......................................................... D. 7

$D A \quad$ Map Showing Indian-Ceded Lands in the Hanford Region..................... D.27

D.5 Historic Indian Activities in the Hanford Region............................ D.28

D.6 Images of Early Homesteading in the Hanford Region........................ D.S1

D.7 The Creation of Towns in the Hanford Region........... D.64

D.8 Research and Development Activities and Nuclear Energy Production at the Hanford Site ........................................................ D. 82 


\section{TABLES}

$2.1 \quad$ Summary of Reactor Status ........................................ 2.4

2.2 Potential Adverse Impacts of Hanford Site Programs on Cultural Resources 2.17

3.1 Prioritization of Cultural Resource Management Tasks for the Hanford Site...... 3.35

D.1 Wanapum Villages and Other Use Sites. Aboriginal and Historic Periods........ D.39

D.2 Populations in Richland, White Bluffs, and Hanford, $\begin{array}{ll}\text { Washington: 1910-1940 D.81 } & \text { D. }\end{array}$

E.1 Traditional Cultural Contexts and Associated Properties on the Hanford Site..... E.3

E.2 Inventory of Euro-American Period Historic Contexts, Property Types and NR Eligible Properties on the Hanford Site............................ E.6

E.3 Settings With Potential Paleontological Significance on the Hanford Site.......... E.1O

E.4 Inventory of Archaeological Contexts and the Historic Properties Associated with Them in the Mid-Columbia Area.............................. E. 12

E.5 Research Questions Posed for the Mid-Columbia Study Unit. E.20

J.1 Condition, Age and Potential Source of Impacts to Historic Properties on the Hanford Site. 


\subsection{INTRODUcrION}

This chapter sets forth the purpose, intent, and objectives of a plan designed to preserve, protect, and enhance cultural resources on the Hanford Site, Washington. Also included in this introductory chapter are contexts of law and a description of the Hanford Site itself.

\subsection{STATEMENT OF PURPOSE}

As a federal agency, the U.S. Department of Energy (DOE) has been directed by Congress and the President to provide leadership in the preservation of prehistoric, historical, and cultural resources on lands it administers and to manage these in a spirit of stewardship for future generations. The purpose of this document is to describe how the DOE-Richland Operations

Office (DOE-RL) will meet those responsibilities on the Hanford Site, pursuant to Section 106 and Section 11 a of the National Historic Preservation Act of 1966 as amended.

\subsection{INTENT}

The intent of this Plan is to provide the context that will enable the DOE-RL to organize data and develop goals, objectives, and priorities for the identification, evaluation, registration, protection, preservation, and enhancement of historical and cultural properties.

\subsection{OBJECTIVES}

This plan is designed to meet the following objectives:

- Establish policies and procedures for managing cultural resources on the Hanford Site that may serve as the basis for a programmatic agreement between the DOE-RL, the State Historic Preservation Officer for Washington, the Advisory Council on Historic Preservation, and neighboring Indian tribes.

- Outline a process for consultations between the DOE-RL, and the State Historic Preservation Officer, Advisory Council on Historic Preservation, Indian tribes and other interested parties.

- Provide guidance on regulatory compliance to Site managers and DOE contractors, and serve as a manual and reference book for individuals responsible for the Site's cultural resources. 
- Model the distribution of cultural resources on the Hanford Site to facilitate land management.

- Ensure regulatory compliance and minimize the impact of Hanford Site operations on the cultural resource base and free exercise of Native American religions.

\subsection{THE LEGAL BACKGROUND}

\subsubsection{The Concept of Cultural Resource}

For the purposes of this plan, a cultural resource is any phenomenon with demonstrable association with prehistory, historical events or individuals, or extant cultural systems. Cultural resources include such things as archaeological sites, districts, and objects; standing historical structures, objects, or groups of either; locations of important historic events; or places, objects, and living or non-living things that are important to the practice and continuity of traditional cultures.

The concept of cultural resource subsumes three terms with more restrictive meanings. These are "historic property", "traditional use area", and "sacred" or "religious site."

"Historic property" is a legal term and refers to any cultural resource that is listed on or considered eligible for the National Register of Historic Places. An historic property may be an archaeological site, an historical site, or a traditional use area, but not all such phenomena meet the criteria for being historic properties.

A "traditional use area" is any place or landscape that is important to the continuation of a traditional culture. It includes such things as a community, a sacred site, or an area from which food and nonfood resources are obtained

"Sacred sites" are places important to the practice of traditional religions. Their relationship to traditional religions makes it possible for sacred sites to become historic properties, but they are also considered under statutes designed to protect First Amendment guarantees to free practice of religion.

Cultural resources are the representations of our past and the ties for some to the secular and sacred worlds of the present. They are in most cases fmite, unique, fragile, and nonrenewable; and in the rapid industrial, agricultural, and urban expansion of the modem world, they are disappearing at an ever increasing rate. Tangible remnants of the past tie us to the 
continuum that is biological and human history, giving us a sense of who we are, and how we got here, and helping us see where we are going.

Recognizing the human need for a temporal foundation, Congress has passed laws protecting cultural resources. These laws state specifically that objects, sites, districts, and landscapes should be preserved for the inspiration of present and future Americans.

\subsubsection{Laws and Directives for the Preservation and Protection of $\underline{\text { Cultural Resources }}$}

The federal and state laws and directives that govern impacts to cultural resources include the following (see Appendix A for a more extensive discussion):

- National Historic Preservation Act of $\underline{1966} \underline{\text { NHPA) }} 16 \underline{\text { USC }} \underline{470} \underline{\mathrm{et}} \underline{\mathrm{seq}}$. This act creates a National Register of Historic Places (National Register) and requires heads of all federal agencies to consider the impacts of their undenakings on any cultural properties that are listed on the National Register or that are eligible for listing. The regulations implementing Section 106 of the Act require an agency to identify, evaluate, and determine the effects of an undenaking on any cultural resource sites that may be within the area impacted by that undertaking. In addition, they require consultation to resolve effects of an undenaking that are adverse, and establish mechanisms by which comments from consulting patties are to be obtained.

- The National Environmental Policy Act of 1969 CNEPA) 42 USC 4341. This act directs federal agency heads to consider the impacts of their actions on the quality of the environment, including the cultural environment

- Executive Order 11593 (1971). This order directs all federal agencies to comply with the stipulations of NHPA and NEPA with regard to cultural resources and directs them to identify and evaluate all cultural resource sites within the lands they administer. Until such identification and evaluation are completed, federal agencies are to comply with the provisions of Section 106 and to implement regulations for every undertaking.

- The Archaeological Resources Protection Act of 1979 (ARPA) 16 USC 470aa-47011. This Act prohibits the willful or knowing destruction and unauthorized collection of archaeological sites and objects located on federal lands. It also establishes a permitting system for archaeological investigations that requires consultation with concerned tribes prior to permit issuance. 
- The Archaeological and Historic Data Preservation Act of 1974 (AHPA)06 USC 469469c). This act provides federal agencies with the means for funding the mitigation of their impacts on historic properties that contain scientific, prehistoric, historic, or archaeological data.

- The AntiQuities Act of 1906 O6 USC 431-433). This act prohibits destruction of paleontological and archaeological sites on federal lands and regulates their collection under a permitting procedure.

- $\quad$ Historic Sites Act of 1935. This act established a national policy of preserving monuments of the nation's past for public use. It gave the Secretary of the Interior the power to conduct histcrical surveys and to document, acquire, and preserve archaeological sites of national importance. It led to the establishment of the Historic Sites Survey, the Historic American Buildings Survey, and the Historic American Engineering Record.

- The Indian Graves and Records Act of the State Of Washington MCW 27.44) - This law prohibits the willful removal, mutilation, defacement, or destruction of any cairn, grave, or glyptic or painted record of any native Indian or prehistoric people. As written it is limited to state and private lands, lands of county and municipal governments, and special-purpose districts.

- $\quad \underline{\mathrm{RCW}}$ 27.53. This Washington State law prohibits the collection, alteration, or excavation of any prehistoric archaeological materials found below the ground surface without written permission of the State Historic Preservation Officer (SHPO) on state land, or the land owner on private property, or representatives of local and county governments on land under their jurisdiction.

\subsubsection{Native American Religious Freedom and $\underline{\text { its }} \underline{\text { Protection }}$}

The right of all Americans to practice the religion of their choice is guaranteed by the First Amendment to the U. S. Constitution. Recognizing that traditional Native American religions differ from the Judeo-Christian model in their ties to the landscape, Congress passed the American Indian Religious Freedom Act of 1978 (AIRFA) 42 USC 1996. AIRFA specifically states that it is the policy of the United States to protect and preserve for American Indians access to their religious sites and the freedom to worship, through ceremonials and rites, their traditional religions. This law directs agency heads to consult with Native American leaders whenever it is possible that their policies and actions might affect the free exercise of a traditional religion. 


\section{$1.5 \underline{\text { THE }} \underline{\text { HANFORD }} \underline{\text { SITE }} \underline{\text { AND }} \underline{\text { ITS }} \underline{\text { CULTURAL RESOURCE BASE }}$}

The Hanford Site, an area of slightly more than 560 square miles, straddles the Columbia River just north of Richland, Washington. It is a broad, relatively level gravel plain crossed by three northwest-southeast-trending basalt ridges. The climate is semi-arid, and supports various communities of shrub steppe and grassland.

The site contains an extensive record of past human and animal life, the latter beginning as much as 7 million years ago. The Ringold formation, which underlies the Site east of the Columbia River, contains one of the most extensive deposits of Pliocene vertebrate fossils in the state of Washington. Remains of extinct camel, horse, rhinoceros, sloth, deer, sabertooth cat, and mastodon are found with bones of still-common turtles and fishes in beds of conglomerate and river-deposited clay. Mammoth bones are common in the late Pleistocene silts of the Hanford formation, which covers most western portions of the Site, and small mammal remains are abundant in Pleistocene and Holocene loess deposits.

Human beings have lived in the region around Hanford for at least 11,000 years, and by 10,000 years ago had established a river-oriented adaptation that was to evolve into the Indian cultures of historic times. Archaeological sites, some dating back at least 7000 years and others that are potentially older, are numerous on the Site. There are over 130 recorded sites, including the remains of villages with up to 60 houses, fishing camps, game traps, cemeteries, and sites of religious observances. Figure 1.1 shows the range of human occupation over several time periods on the Hanford Site. Due to tight security, most sites have been spared the degree of looting and vandalism that is so common elsewhere in the region, and many are in unusually good condition. Fifty-one of the sites are included, in nine properties listed on the ational Register of Historic Places (National Register). Most of the remaining sites have never been fonnally evaluated for National Register eligibility.

When the first white people visited the Hanford Site vicinity in 1805, they estimated that 3000 native people were living between the modem towns of Vantage and Pasco, Washington. These hunting, gathering, and fishing people were members of the the Wanapum, Chamnapum (a Yakima Band), Walla Walla, Palouse, and Sinkaiuse Tribes and Bands. As colonization by nonIndians increased in the first half of the nineteenth century, friction between the non-Indians and the aboriginal inhabitants also intensified. In 1855 the U.S. Government and representatives of the Yakima, Walla Walla, Umatilla, Cayuse, and ez Perce tribes entered into treaties establishing the Yakima, Umatilla, and Nez Perce Reservations, where their descendents and many members of the 


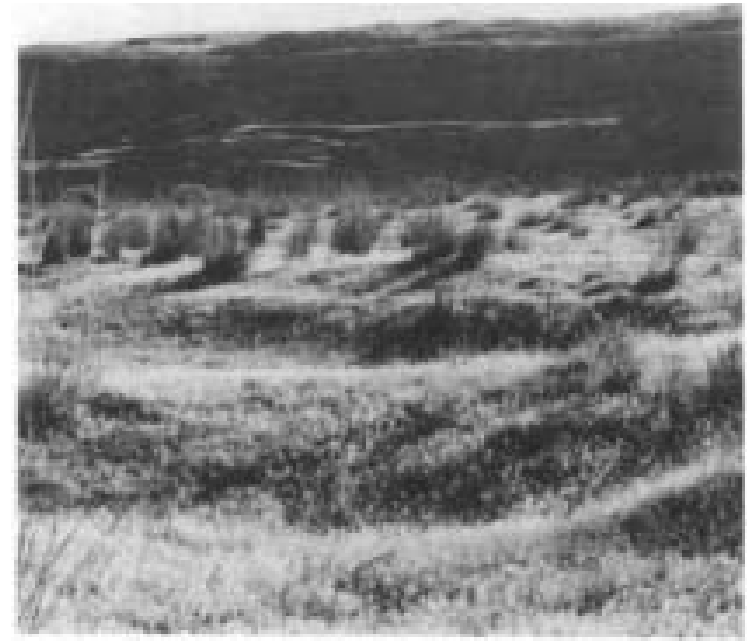

Prehistoric House Depressions

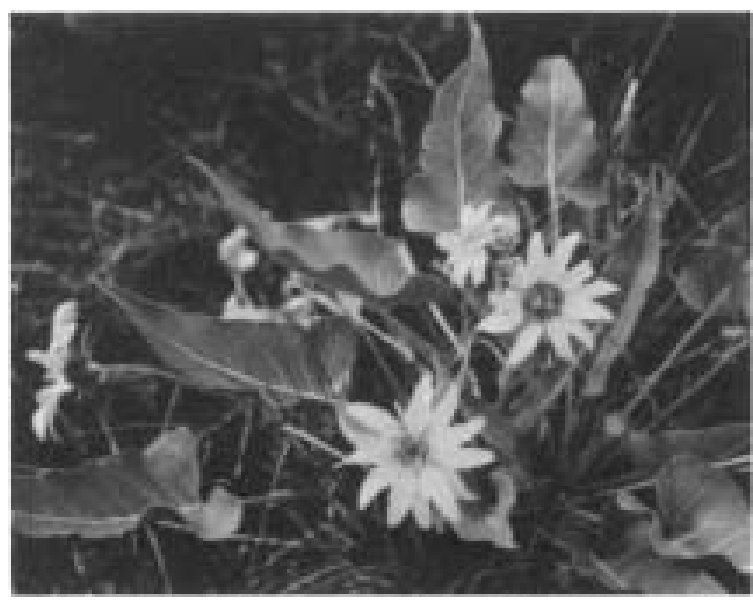

Balsam, a Traditional Food Plant

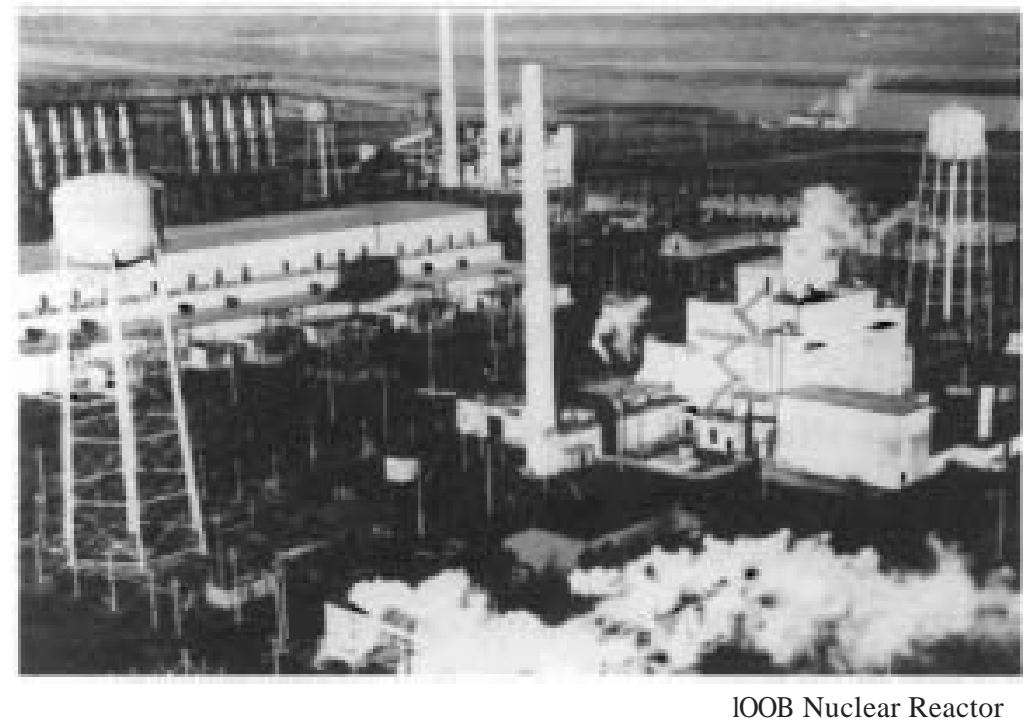

FIGURE 1.1. Range of Cultural Resource Types Pertinent to the Hanford Site 
Wanapum and Palouse bands now reside. Remaining lands, including what is now the Hanford Site, were ceded to the U.S. Government. The Sinkaiuse were eventually moved to the Colville Reservation. Some Wanapums remained in their ancestral home, and they still live just outside the Site boundary. These groups (Colville, Nez Perce, Umatilla, Yakima, and Wanapum) are referred to as "the Tribes" in this document. These people, and many inhabitants of the four reservations, adhere to traditionallifeways to varying extents, including the traditional religion. Most traditionalists practice a form of the Washane or Seven Drums religion, which was revitalized on what is now the Hanford Site and requires the use of natural landscapes and wild foods in its rites.

Following the treaties, non-Indian settlement underwent a rapid sequence of developments, beginning with cattle raising and gold mining prior to the 1880 s, and including the establishment of farms after 1870. It was not until 1905 that the Hanford Site proper became heavily settled. At that time, a consortium of businessmen built a large irrigation system at that time, enabling orchardists and truck farmers to become established. The towns of Hanford and White Bluffs grew up quickly to supply the growing population of farmers. An old cabin, a fruit warehouse, a bank, the burnt-out hulk of a school, pumping plants, and irrigation systems are the only nonarchaeological remnants of early settlement.

In 1943, the U.S. government established the Hanford Site for the production of radioactive metals used in national defense. Early reactors, materials processing plants, and the remains of military installations represent this era. Since then the Site has become a center for radioisotope production, hazardous waste management, and energy research in the Northwest.

\subsection{ORGANIZATION OF THE PLAN}

This document is intended for multiple uses. Therefore, it consists of an abbreviated main text supported by extensive appendices. Among other things, the text is designed as a manual for cultural resource managers to follow and as an explanation of the process of cultural resource regulatory compliance for the DOE-RL and Site contractors.

Chapter 2 establishes the management context, reviewing the DOE's mission, its programs, and their potential impacts on cultural resources and the free exercise of Native American religion.

Chapter 3 presents the policies and procedures that must be followed to ensure compliance with the above-referenced statutes and pursuant regulations. It is the management manual proper. 
The appendices contain supporting material on laws and regulations, extensive reference information, and the forms that are required by cultural resource management procedures, as follows :

- Appendix A: a detailed discussion of the statutes

- Appendix B: an analysis of previous efforts to manage cultural resources on the Site; identification of areas in need of improvement

- Appendix C: a description of the present and past environments of the Hanford Site, important for predicting and understanding the location and content of paleontological and archaeological deposits

- Appendix D: an overview of existing knowledge about paleontology, prehistory, ethnography and ethnohistory, and non-Indian history of the region, included as a basis for predicting the kinds of cultural properties on the Site and establishing their significance

- Appendix E: a discussion of the basis for assigning significance to cultural properties, including an inventory of listed historic properties, to be used in the evaluation process

- Appendix F: data on cultural resource surveys already conducted on site

- Appendix G: Washington State guidelines for the conduct and reporting of archaeological surveys

- Appendix H: forms to be used by cultural resource management personnel.

Many of the appendices have been written by experts in the respective fields, and their styles, which are discipline-specific, have been left intact to enable use of the Plan as an authoritative source on the cultural resources of the Site. A list of contributors and descriptions of their qualifications are provided in Appendix I. 


\subsection{THE DOE MISSION AND ITS POTENTIAL IMPACfS ON CULTURAL RESOURCES AND RELIGIOUS PRACFICES}

This chapter describes the mission and land use of the DOE at the Hanford Site, past and present. It then considers the nature of impacts that land use practices have had or might have on cultural resources. The policies and procedures described in Chapter 3 are designed to minimize these potential impacts.

\subsection{THE ROLE OF THE HANFORD SITE}

Hanford is a U.S. Department of Energy site in southeastern Washington State. It carries out work important to our nation, including: defense programs, waste management, and energy and health research.

\subsubsection{Past Land Use(a)}

This section describes how the major areas of the Hanford Site were developed and how they are currently being used. The locations of the facilities described below are shown in Figure 2.1.

The Hanford Site was established in 1943 as a national security area for plutonium production. In early 1943, approximately a month after the Fermi experiment in Chicago successfully demonstrated that nuclear fission could be controlled in a small reactor, the U.S. Army Corps of Engineers selected the Hanford Site as the location for a facility in which a larger version of the Fermi reactor would be built to produce plutonium for possible use in military weapons. Actual construction started on three reactor facilities and three chemical processing facilities in March 1943. The first of the reactors went into operation approximately 18 months after the start of construction, and the first plutonium was available some 4 months later. During the course of early construction efforts, approximately 94,000 men and women were involved at various times in the project, with a peak on-site population of 51,000.

After World War II, five additional reactors similar to those built during the war were constructed, resulting in a total of eight graphite-moderated reactors using Columbia River water for once-through cooling (i.e., water was circulated through the reactor once then held temporarily for radioactivity monitoring and some heat dissipation prior to release back to the river).

(a) For a discussion of past Hanford Site history, see Appendix D.4. 


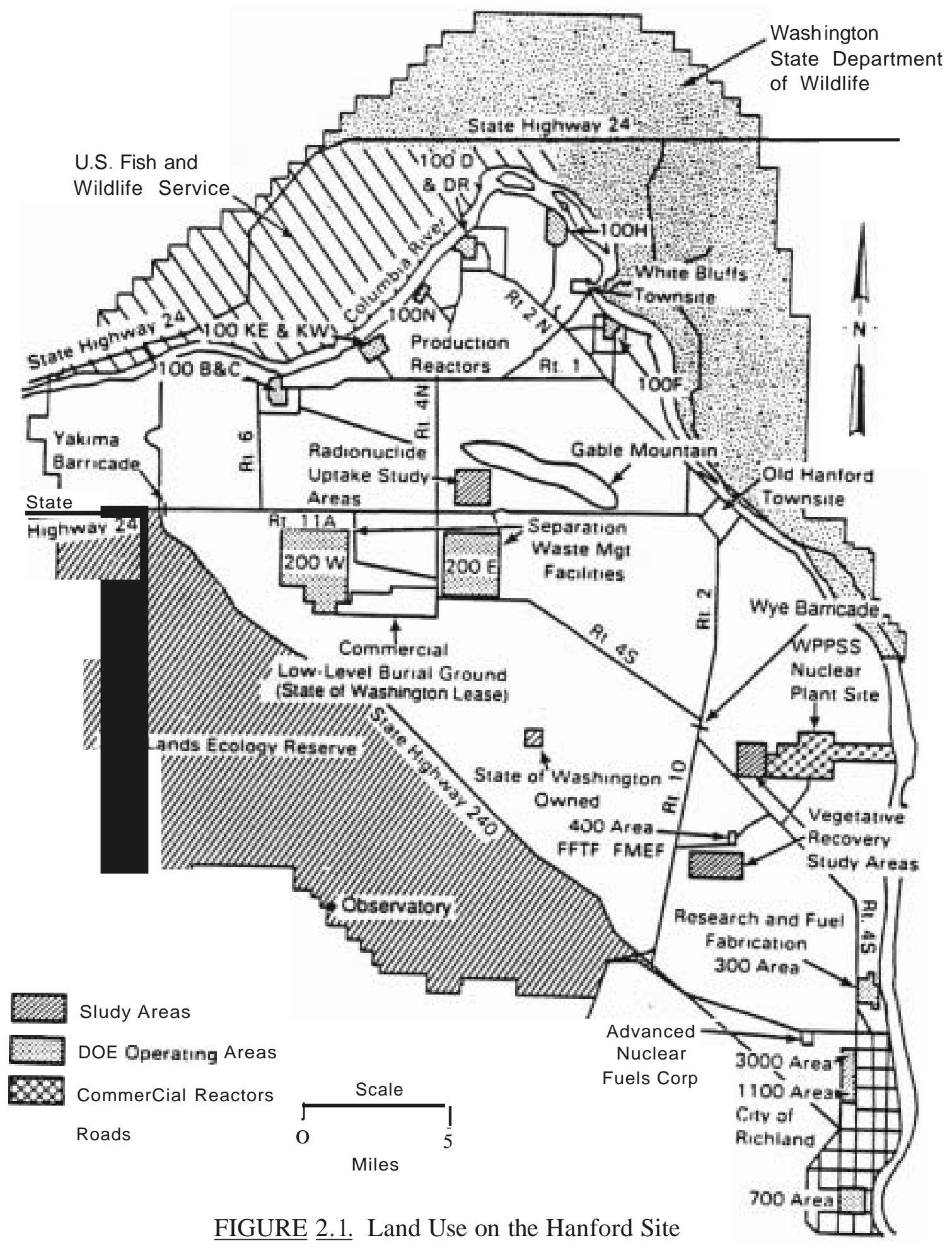


In the early 1950s, construction of the research and development facilities known as the Hanford Laboratories began. This marked the first diversifIcation of the Hanford Site from a dedication to production of defense materials to involvement in peacetime uses of the atom. In 1963, the first dual-purpose reactor constructed in the United States, the N-Reactor, was built at the Hanford Site. In addition to plutonium, the N-Reactor produces byproduct steam that since 1966 has been used by the Washington Public Power Supply System to generate electricity. In early 1964, a Presidential decision was made to begin closing down the older Hanford Site reactors. By the end of 1971, N-Reactor was the only production reactor still in operation. That reactor was put on cold-standby status in 1988.

\section{Areas}

The six 100 Areas, which border the Columbia River in the northernmost portion of the Hanford Site, were chosen as sites for the plutonium production reactors. In the early 1960s, nine production reactors were in operation. Solid waste disposal was eliminated in the 100 Areas in 1973. The status of the reactors is shown in Table 2.1.

\section{Areas}

The fuel-processing, plutonium-separation, and plutonium-fmishing portions of operations on the Hanford Site are located in the 200 East and 200 West Areas, which were established in 1943. Additional activities in these areas include plutonium scrap processing, waste fractionization, laboratory work, and management of high-level, low-level, transuranic, and tankcontained radioactive wastes resulting from the separation process. Individual histories of the various facilities in the 200 Areas are provided below.

The PUREX (plutonium and uranium extraction) Plant was constructed between April 1953 and October 1955. The plant operated until 1972, and then was maintained in standby condition unti11983, when it was restarted. Irradiated fuel from N-Reactor is processed by the PUREX Plant to recover plutonium and uranium.

The reduction-oxidation process (REDOX Plant) for fuel separation preceded the PUREX process. The plant housing the redox facilities was constructed from May 1950 to August 1951, and operated until July 1967, when it was shut down. 
TABLE 2.1. Summary of Reactor Status

\begin{tabular}{|c|c|c|c|}
\hline \multirow[b]{2}{*}{$\underline{\text { Reactors }}$} & \multirow{2}{*}{$\begin{array}{c}\text { Construction } \\
\text { Start }\end{array}$} & \multicolumn{2}{|c|}{ Operation } \\
\hline & & $\underline{\text { Start }}$ & Shutdown \\
\hline 100-B & Aug. 1943 & Sep. 1944 & Feb. 1968 \\
\hline $100-0$ & Nov. 1943 & Dec. 1944 & June 1967 \\
\hline $100-\mathrm{F}$ & Dec. 1943 & Feb. 1945 & June 1965 \\
\hline 100-DR & Dec. 1947 & Oct. 1950 & Dec. 1964 \\
\hline $100-\mathrm{H}$ & Mar. 1948 & Oct. 1949 & Apr. 1965 \\
\hline $100-\mathrm{C}$ & June 1951 & Nov. 1952 & Apr. 1969 \\
\hline $100-\mathrm{KW}$ & Nov. 1952 & Jan. 1955 & Feb. 1970 \\
\hline $100-\mathrm{KE}$ & Jan. 1953 & Apr. 1955 & Jan. 1971 \\
\hline $100-\mathrm{N}$ & May 1959 & Dec. 1963 & Sep. 1988 \\
\hline
\end{tabular}

The U, T, and B Plants were the original fuel separation facilities on the Hanford Site, constructed in the mid-1940s. All three plants were designed to extract plutonium from irradiated fuel using the bismuth phosphate process. U Plant was never used for the designed purpose, but was converted to recover uranium from stored radioactive waste. From 1952 to 1958, waste was sluiced from storage tanks and U Plant was used for uranium recovery. This process is now finished and the building is unused. T Plant was constructed between June 1943 and October 1944 and was last used for fuel separation in 1956. The plant is now used for decommissioning and decontamination of equipment used on the Hanford Site. B Plant was constructed between August 1943 and February 1945 and was operated until 1952. B Plant was converted in 1968 to a waste fractionization plant, which removed cesium-137 and strontium-90 from PUREX current acid waste and high-level radioactive supernatant liquids and sludges. B Plant is now being converted to a facility to separate low-level waste from high-level waste to prepare these wastes for permanent disposal.

The Plutonium Finishing Plant was constructed in 1949. It is the site of plutoniumprocessing operations, including the processing of plutonium scrap materials, as well as laboratory support and shipping and receiving of nuclear material.

Liquid waste containing high concentrations of radionuclides from the chemical-processing plants has been stored on an interim basis in underground tanks in the 200 Areas since startup in 1943. Between 1944 and 1972, Hanford Site nuclear defense activities generated 397,000 cubic meters of liquid radioactive waste. This volume was reduced to approximately 185,000 cubic 
meters of salt cake, sludge,liquids, and slurries stored in 149 single-shell tanks and 20 doubleshell tanks. Wastes generated since 1979 are being stored in double-shell tanks.

A significant quantity of the cesium and strontium was separated from the stored waste and has been convened to dry cesium chloride and strontium fluoride salts, sealed in double-wall metal capsules, and stored in water basins pending use.

Other waste management facilities in the 200 Areas have included low-level-waste burial grounds, retrievably stored transuranic waste trenches, cribs, and ponds. Low-level, solid, radioactive waste resulting from DOE's defense nuclear materials production and research programs is buried in shallow land burial trenches. Since May 1970, solid waste classed as, or suspected of being, transuranic waste has been packaged, labeled, and stored so as to be retrievable for at least 20 years.

\section{Area}

Facilities in the 300 Area, completed in 1943 and the years immediately following, were related to the fabrication of reactor fuel. Those facilities provided fuel manufacturing and technical and service support functions (see Figure 2.2). As the Hanford Site production reactors were shut down, fuel manufacturing activities decreased. For the last 20 years, research and development programs have constituted a major part of the activities in the 300 Area.

4Q() Area

The 400 Area is the site of the Fast Flux Test Facility, a sophisticated reactor for testing advanced reactor fuels, materials, and components. Also included in this area is the Fuels and Materials Examination Facility.

\section{Area}

The 600 Area includes all the Hanfor ite outside of the 100, 200, 300, 400, 1100, and 3000 Areas. The largest subdivision of the 600 Area is the Arid Lands Ecology Reserve (see Figure 2.3), a 31O-square-kilometer tract set aside by the U.S. Atomic Energy Commission in 1968 for ecological studies. Other activities included studies of the Hanford Site for the Basalt Waste Isolation Project (BWIP), which began in 1976 and ended in 1987. The Reference Repository Location for the BWIP was identified in 1978 and covered 47 square kilometers. This site included all of the 200 West Area. The site for the exploratory shafts was identified in 1982. 


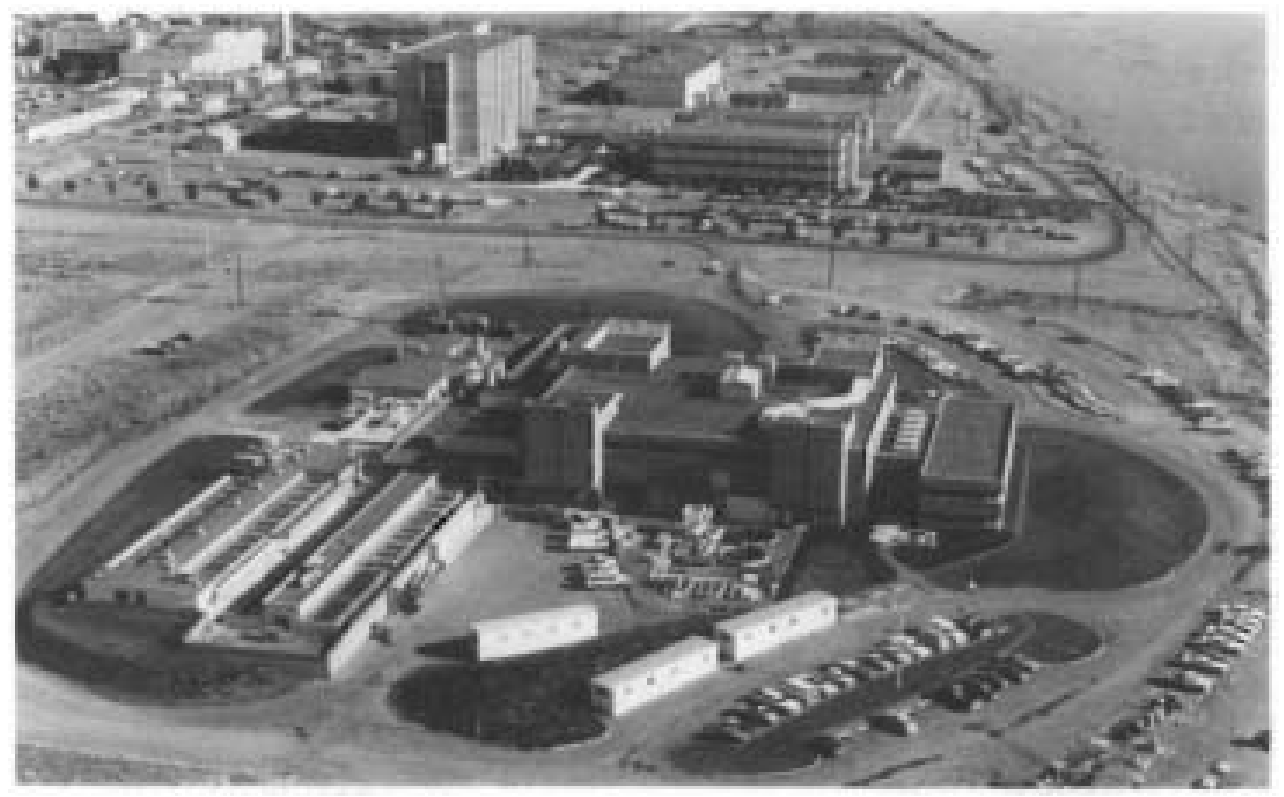

FIGURE 2.2. The 300 Area of the Hanford Site, Research and Development Activities

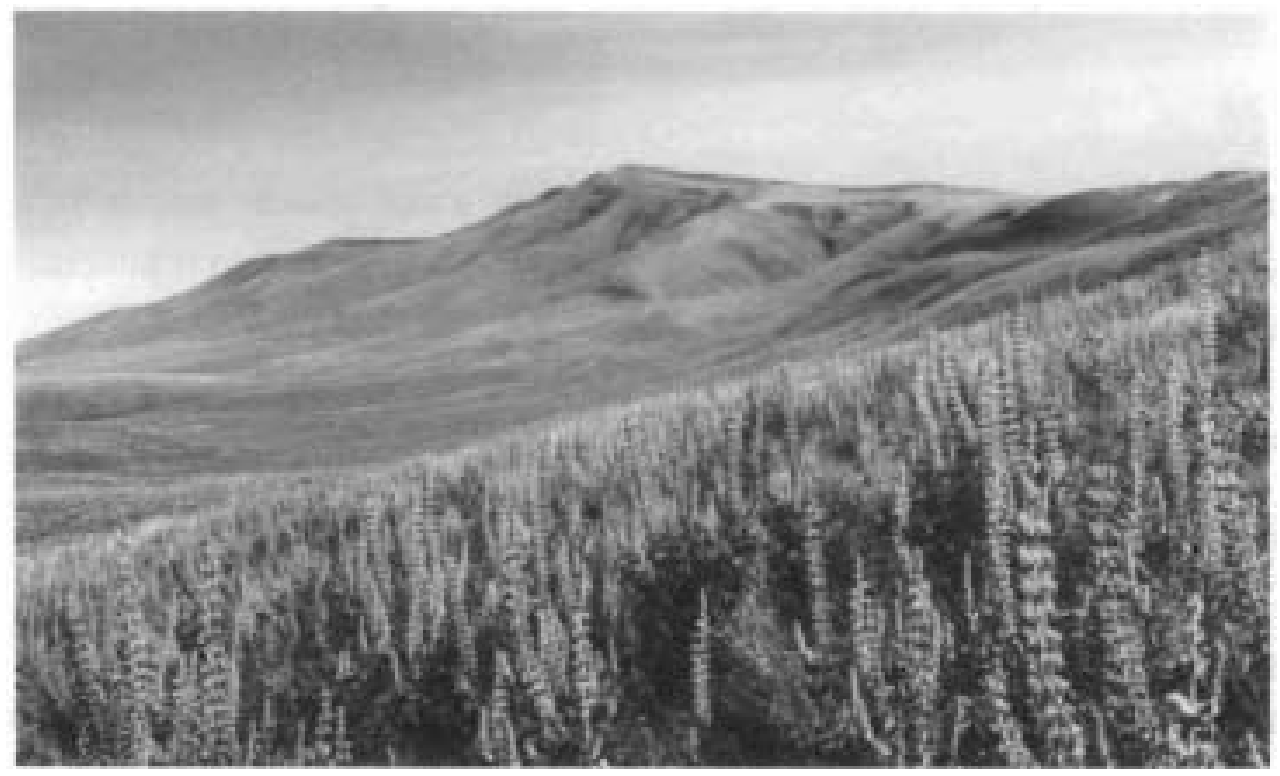

FIGURE 2.3. The Arid Lands Ecology Reserve, a Natural Preservation Area on the Hanford Site 
It is located just west of the $200 \mathrm{West}$ Area and covers approximately 1 square kilometer. The Near-Surface Test Facility was established in Gable Mountain (outside of the Reference Repository Location) during 1982 and 1983 as part of the BWIP. This facility was used to assess the feasibility of radioactive waste storage in basalt formations. Between 1977 and 1988,98 boreholes were sited, drilled, deepened, or otherwise modified for use by the BWIP to support repository site identification and evaluation. Most of these boreholes were located in the 600 Areas. Congress terminated the BWIP in 1987 and these facilities have subsequently been decommissioned and the land reclaimed. During the early 1970s an effort was made to beautify the site. Called the Hanford Site Cleanup, this program demolished old buildings, filled holes, and removed old equipment and other trash from the entire Site.

\subsubsection{Present Land $\underline{\text { Use }}$}

The DOE currently controls the entire Hanford Site and intends to continue to maintain control in the future. The entire Hanford Site is subject to access restrictions to ensure the security of national defense projects and to protect the health and safety of the public. The area north and east of the Columbia River within the Hanford Site is managed by other federal and state governmental agencies for the DOE; some of these areas are open to the public during the hours of daylight. The area south and east of Highway 24 and west of White Bluffs is, however, closed to the public. The area south and west of the Columbia River contains the facilities requiring increased security. Access to that portion of the Site is allowed only to people who have a valid need to enter the area and who have been cleared through security procedures. Within the Site are several DOE operating areas where specific access requirements exist (Figure 2.1). Descriptions of these major areas follow.

\section{$\underline{100} \underline{\text { Areas }}$}

The 100 Areas occupy about 11 square kilometers. They border the south shore of the Columbia River at the north end of the Hanford Site. Eight retired plutonium production reactors are located at these areas. The N-Reactor, which is on standby status, is located in the 100-N Area (Figure 2.1).

\section{0-West and $\underline{\text { 200-East }} \underline{\text { Areas }}$}

The 200 Areas occupy about 15.5 square kilometers on a plateau about 8 and 11 kilometers, respectively, south of the Columbia River. The 200 Areas are dedicated to fuel processing and waste disposal activities. 


\section{$\underline{300} \underline{\text { Area }}$}

This area occupies 1.5 square kilometers just north of Richland. Nuclear research and development and nuclear fuel fabrication are the major functions at this area.

\section{$\underline{400} \underline{\text { Area }}$}

About 8 kilometers north of the 300 Area is the 400 Area, where the Fast Flux Test Facility and the Fuel Material and Examination Facility are located. The entire area has been leveled, and most of the surface is graveled or paved. This area occupies approximately 0.6 square kilometers.

$\underline{600} \underline{\text { Area }}$

Land uses within the 600 Area include the following:

- The Arid Lands Ecology Reserve is a 31O-square-kilometer tract set aside for long-term ecological studies.

- The State of Washington leased a 4-square-kilometer tract to encourage the location of nuclear-related industry. An "Indenture of Lease" was signed on September 10, 1964, for a period of 99 years.

- A O.4-square-kilometer tract of the State of Washington lease has been subleased through the State to California Nuclear, Inc. (U.S. Ecology). U.S. Ecology operates this site for the disposal of commercial low-level nuclear waste.

- The Washington Public Power Supply System (Supply System) leases from the federal government two parcels of land on the Hanford Site. Three commercial nuclear power plants are located on this land. Parcel "A" consists of 4.3 square kilometers and is the site of the the Supply System Unit \#2 nuclear power plant Parcel "A" is leased for 50 years with an additional 1O-year option. Parcel "B" consists of 4.1 square kilometers and is the location of the Supply System Units 1 and 4. Parcel "B" is leased for 30 years with an option for additional time as requested by the Supply System.

- The U.S. Fish and Wildlife Service Refuge occupies approximately 130 square kilometers on the Wahluke Slope under a revocable-use permit from DOE. 
- The Washington State Department of Game administers a site covering 233 square kilometers on the Wahluke Slope. This site is used for recreational game management under a revocable-use permit from DOE.

- The Near-Surface Test Facility is located at Gable Mountain. This facility, which was part of the BWIP, is being decommissioned and the surface disturbance restored.

- The BWIP Exploratory Shaft Site and other borehole pads are being restored, except where such facilities are needed for the Hanford Site environmental monitoring program.

- Observatory and radiotelescope facilities are located on top of Rattlesnake Mountain, in the southwest portion of the Site.

- The Hanford Meteorology Station is located between the 200 Areas. It consists of a 60meter steel tower, equipped with wind and temperature sensors.

- Numerous borrow pits, for quarrying soil, are located throughout this area, west and south of the Columbia River.

- Numerous paved and unpaved roads, fire breaks, and utility lines cross the area.

The areas occupied by the Arid Lands Ecology Reserve, U.S. Fish and Wildlife Service Refuge, and the Washington State Department of Game total about 673 square kilometers. They provide a buffer zone around the areas of nuclear-related activity, and little ground- , disturbing activity occurs in them.

$\underline{700} \underline{\text { Area }}$

The 700 Area is a 1.o-square-kilometer area of downtown Richland. In it are located the Federal Office Building, U.S. Post Office, and other structures owned and operated by the U.S. Government. It is the administrative center for the DOE.

\section{$\underline{1100} \underline{\text { Area }}$}

The 1100 Area occupies 0.6 square kilometers in the southern part of the Hanford Site. This area serves as a center for warehousing, vehicle maintenance, and transportation/distribution. 


\section{$\underline{3000} \underline{\text { Area }}$}

The 3000 Area is located south of the 300 Area and north of the 1100 Area. The Engineer/Constructor uses 0.2 square kilometers in this area for general office space, warehousing, and shops. The Research and Development Contractor has privately owned and leased laboratory facilities here.

\subsubsection{Present $\underline{\text { Programs }}$}

There are four major programs presently operating at Hanford: Defense Production, Defense Waste Management, Advanced Reactors, and Research and Development A short description of each program follows.

\section{Defense Production}

The Defense Production Program at the Hanford Site operates facilities for the production of Special Nuclear Materials. These facilities include the irradiated fuel storage facilities, chemicalprocessing facilities, and product storage and shipping facilities. The program includes operating, maintaining, planning, managing, improving, and decommissioning these facilities as well as constructing new facilities. The program also assists the DOE in developing and studying production program options. Surplus Production Reactor Decommissioning is an ongoing project that is decontaminating and decommissioning the eight production reactors that were built prior to 1960 (Table 2.1). This activity includes dismantling facilities; removing contaminated equipment, construction materials, and soil; and, in many cases, covering reactor sites and contaminated materials with soil barriers.

\section{Defense Waste Management}

Operations related to management of radioactive and nonradioactive wastes at Hanford are conducted primarily in the 200 Areas of the Hanford Site. These activities include receiving, handling, processing, monitoring, storing, and disposing of the wastes, as well as development of technology required to support the waste operations. Several facilities and sites are involved: liquid storage facilities (tanks), evaporators, waste-processing plants, ground disposal and storage sites, underground transfer systems, capsule (cesium and strontium) storage in water basins, and necessary support facilities. Both the Hanford Waste Vitrification Plant and the Grout Facility are 
being used for pennanent disposal of the wastes. The project expects to use up to 4 million cubic meters of borrowed soil and rock, taken from elsewhere on the Hanford Site.

\section{$\underline{\text { Advanced }} \underline{\text { Reactors }}$}

The Advanced Reactors Program at Hanford includes facility operations and technology development in support of the DOE's programs in nuclear energy and other energy research. Principal contributions are to the liquid metal reactor, space power technology, and fusion reactor technology. The major existing facilities in use include the FFIF and its supporting buildings (the Maintenance and Storage Facility, the Fuel Storage Facility, and the Training Center); the Fuel Cycle Maintenance and Examination Facility, including the Secure Automated (fuel) Fabrication Line (currently in layup status); the fuel assembly area; and the laboratories and high-bay facilities in the 300 Area.

\section{$\underline{\text { Research and Development }}$}

The primary mission of the Research and Development Program at Hanford is technology development and deployment, from basic science to technology applications. This mission is broken down into two roles: 1) to develop and deploy technology for energy stability, for national defense, and to enhance the international competitiveness of the United States; and 2) to conduct strategic planning, advanced technology development, and environmental programs to support present and future Hanford missions.

Current research and development activities focus on the following areas:

- basic research in material, chemical, biological, environmental, geological, and engineering sciences

- environment, health, and safety research with emphasis on the mechanisms for health and environmental effects of energy-related radiation and chemicals

- waste management, with emphasis on treatment and containment technologies for radioactive and chemically hazardous wastes (commercial and defense), commercial spent nuclear fuel storage, monitored retrievable storage, geologic disposal, and waste systems integration

- nuclear power systems, with emphasis on advanced reactors for civilian, space, and military applications; and on safety in light-water reactors 
- national security technology, with emphasis on verification, production of Special Nuclear Materials, and strategic defense programs

- energy supplies from renewable and alternative sources, with emphasis on concepts for biomass conversion, wind, and geothennal energy, and energy storage

- energy conservation, with emphasis on efficient energy use in buildings and industrial processes.

Work in these technologies is performed on the Hanford Site for the DOE and for other federal agencies, principally the Nuclear Regulatory Commission, the Department of Defense, and the Environmental Protection Agency.

Research and development in support of these activities and non-defense/multiprogram activities are concentrated primarily in the 300 Area Support services, such as warehousing and fleet and large-equipment maintenance are located in the 1100 Area. Construction support services, some research and development activities, and the remaining health services are primarily located in or near the 3000 Area. Other services, such as administrative support, maintenance, fire protection, and security, are located throughout the Hanford Site.

\subsection{POTENTIAL EFFECfS OF HANFORD SITE ACTIVITIES ON HISTORIC PROPERTIES}

Any alteration of a historic property that changes the characteristics that qualify the property for inclusion to the National Register of Historic Places is considered an effect (36 CPR 800.9). In some cases, effects can be beneficial to historic properties. Building maintenance and renovation can, for example, prolong the life of structures, while Site security policies protect archaeological sites from vandalism. Other effects, however, may damage, destroy, or alter the feeling and association of a property, and so are considered adverse under 36 CPR 800.9. These impacts are treated here under a general category, "adverse effects."

In this section the presumed adverse effects of past activities on the Hanford Site and the potential impacts of present programs are enumerated. Adverse effects are further defined, and the contribution of past and present activities performed or permitted under Hanford Site programs are briefly discussed Examples of activities that may adversely affect cultural resources are illustrated in Figure 2.4. 
Cultural Resource Plan, Hanford DOE Mission and Impacts

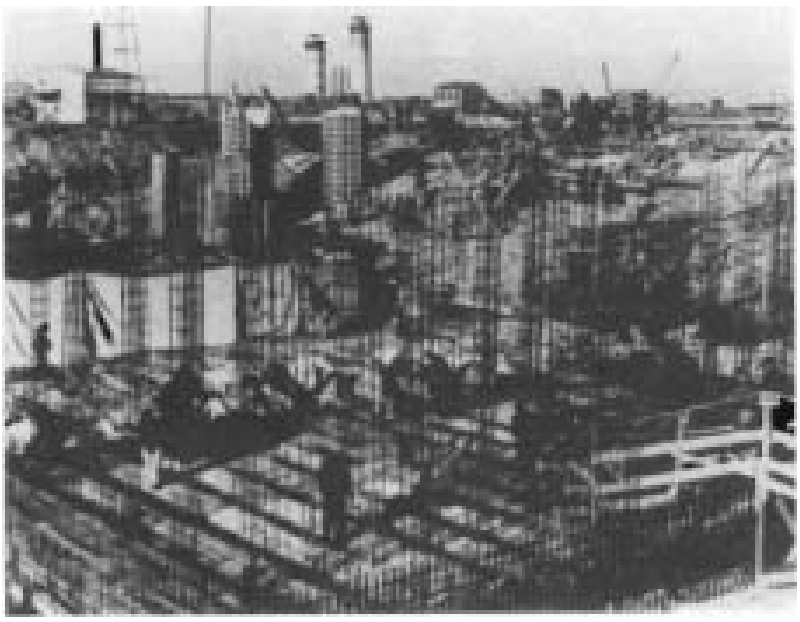

Construction

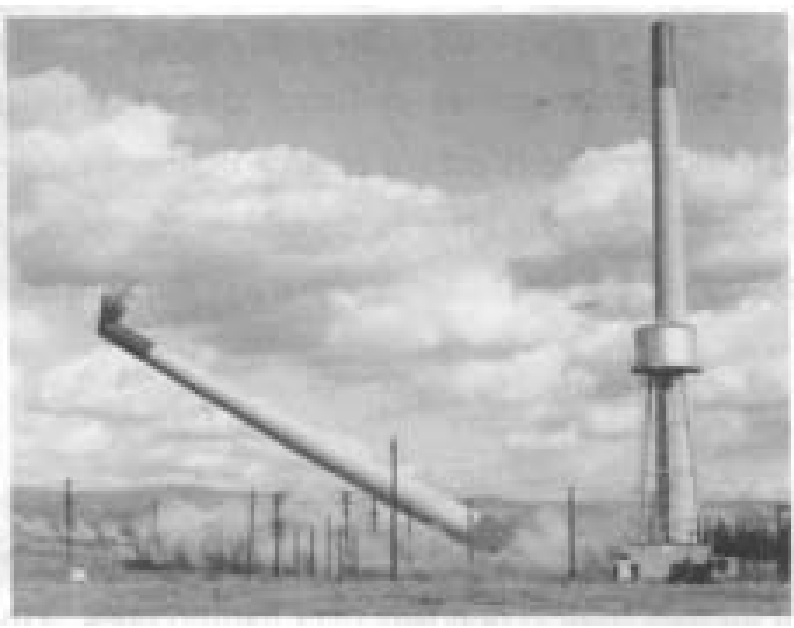

Decommissioning

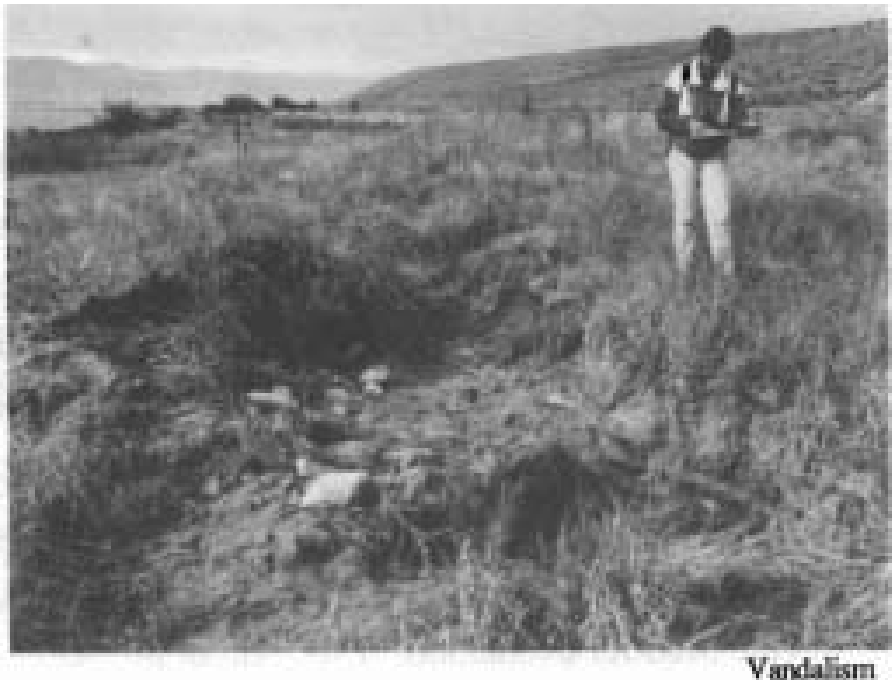

FIGURE 2.4. Activities That May Adversely Affect Cultural Resources 


\subsubsection{Categories of Potentially $\underline{\text { Adverse Effects }}$}

Adverse effects are divided into seven categories: natural erosion, increased erosion, unauthorized collection and vandalism, direct damage or alteration, audible and visual effects, and habitat destruction.

\section{$\underline{\text { Namral Erosion }}$}

Erosion is a process that proceeds in the absence of human activity. Most archaeological and paleontological deposits have been damaged at one time or another by erosion, and many no longer exist as a result. However, when federal agencies undertake management of public lands, and historic properties are found to exist on those lands, then it is the responsibility of the agency to minimize the effects of erosion on those properties. A management policy which programmatically ignores the effects of erosion on properties under its stewardship is following a policy of neglect, and its program is thus having a potential adverse effect on those properties.

\section{Increased Erosion}

Removing ground cover, scarring the landscape with wheeled vehicles, and introducing domestic stock improve access to soil particles by wind and water. Thus, they accelerate erosion of archaeological deposits over natural rates. Unlike neglect, which may permit natural erosive destruction, increased erosion is the result of actions taken by an agency to permit grazing, remove vegetative cover, or allow off-road use of an area by workers or recreationists.

\section{$\underline{\text { Unauthorized Collection and vandalism }}$}

Fossils, prehistoric and historical artifacts, and often human remains are considered to be desirable collectibles by a large segment of the public. Any area where public access is allowed and law enforcement patrols are infrequent is subject to unauthorized collection. Human graves are especially vulnerable because of the widespread belief that they contain large quantities of artifacts. Although it has been more severe in the past, this kind of effect is still a serious problem on most federal lands. Vandalism, the wanton destruction of natural or manmade objects, includes acts ranging from spray painting petroglyphs (ancient rock etchings, which often have sacred meaning) to driving up mountainsides to create tracks, burning or defacing old buildings, or bulldozing an archaeological site to remove it from the need for evaluation. This kind of impact can be severe in areas where the public is allowed access and where workers are given unlimited movement. 


\section{Direct Damage or $\underline{\text { Alteration }}$}

Construction, renovation, land leveling, and decommissioning of facilities can directly affect cultural resources; often, these activities have the most severe impacts of all seven categories. Subsurface and surface artifact deposits may be disrupted or obliterated, buildings destroyed, or the unique characteristics of a building altered or removed. Buildings may lose their context of similar structures, and sacred monuments can be obliterated Especially problematic in the Hanford area is the tendency for bedrock and gravel prominences--often considered sacred by Indian groups--to be exploited for inexpensive fill and aggregate material.

\section{$\underline{\text { Audible and Visual Impacts }}$}

The introduction of noise and creation of scars on the landscape, or the introduction of buildings that are out of character with a neighborhood--all can alter the feeling or association of historic properties.

\section{Habitat Destruction}

Certain species of native plants and animals are important to the cultural practices of this area's Indian people. Certain land use practices, such as agriculture, grazing, and sometimes even construction projects, can severely reduce or eliminate the ecological conditions most conducive to some species' existence. When habitats of sacred species are destroyed, it becomes difficult or impossible to fmd the plants or animals important in the continuity of traditions and the free practice of traditional religion is obstructed.

\section{Contamination}

Much of the DOE's work on the Hanford Site entails production or use of radioactive or hazardous materials. Contamination of cultural resources with such materials could preclude use, study, or scientific excavation. Traditional food plants and animals might be rendered unusable in certain areas. Therefore, contamination is a potentially adverse effect of Hanford Site operations.

\subsubsection{Possible Adverse Effects of $\underline{\text { Hanford }} \underline{\text { Site Programs. Past and Present }}$}

In this section, the potential and suspected actual effects of Hanford Site policies and programs in the past and present are enumerated. Levels of potential adverse effect have been subjectively determined and are designated as none, low, moderate, and high (Table 2.2). Low effect means insignificant impact. Moderate denotes some loss of scientific or historical value or of 
resources or access points important to traditional users. High means the potential for total destruction of a property or properties, or the elimination of historic, scientific or traditional use potentials.

Of the past policies and programs at the Hanford Site, construction of the first reactors and processing facilities is believed to have had the most severe impacts (Table 2.2). The building of workers' housing and the massive earth moving associated with construction of river-sited facilities certainly destroyed archaeological sites, historic buildings, and other cultural properties. The introduction of thousands of workers brought people into contact with the many archaeological sites along the Columbia River, and unauthorized collection was reportedly common. Public access to areas of the Site west of Highway 240 and along the Columbia River after the early 1970s added to the unauthorized collection activity. Contamination from reactor, chemical processing, and laboratory activities may have altered the utility of traditional use areas and the scientific potential of some archaeological sites. Although stock grazing would have increased erosion, the most severe impacts of Hanford Site operations in the past are believed to have been the initial Site construction and the removal of towns and ranches, as well as the unauthorized collection of artifacts and fossils. The Hanford Site Cleanup program resulted in the demolition of nearly all remaining structures from the pre-government era and may have disrupted archaeological deposits in the vicinity of homesteads and other structures. Many of the buildings removed by the Hanford Site Cleanup program had been significantly damaged or destroyed during the 1950s by military and Site security initiatives.

\section{$\underline{\text { Present }}$}

Impacts of current DOE programs and activities are generally not so severe as in the past (Table 2.2). Unauthorized collection and vandalism are less of a problem now and in the foreseeable future because worker access is more restricted, and fewer areas of the Site are available to the public. However, this effect continues to be a potential problem in areas outside the security fence, including those that are managed by agencies other than the DOE. Additionally, research, monitoring, and security activities still bring workers into contact with archaeological and historic sites in remote areas and may result in unauthorized collection. Some contamination may have occurred, but it generally has to have been outside areas with the greatest cultural resource potential. Stock grazing is now restricted to areas east of the Columbia River, so increased erosion 
TABLE 2.2. Potential Adverse Impacts of Hanford Site Programs on Cultural Resources

\begin{tabular}{|c|c|c|c|c|c|c|c|c|}
\hline \multicolumn{2}{|c|}{ Present } & \multirow{2}{*}{$\begin{array}{l}\text { Natural } \\
\text { Erosion }\end{array}$} & \multirow{2}{*}{$\begin{array}{l}\text { Increased } \\
\text { Erosion }\end{array}$} & \multirow{2}{*}{$\begin{array}{l}\text { Collection! } \\
\text { Yandalism }\end{array}$} & \multirow{2}{*}{$\begin{array}{l}\text { Damage or } \\
\text { Alteration }\end{array}$} & \multirow{2}{*}{$\begin{array}{c}\text { Audible! } \\
\text { Visual }\end{array}$} & \multirow{2}{*}{$\begin{array}{l}\text { Habitat } \\
\text { Destruction }\end{array}$} & \multirow[b]{2}{*}{ Contamination } \\
\hline$\underline{\text { Program }}$ & Project or Activity & & & & & & & \\
\hline ARID LANDS & Ecological Research & & & Low & & & & \\
\hline ECOLOOY RESERVE & Land Management & Low & & Low & & & & \\
\hline USBSF\&W & Public Access & & Moderate & High' & Low & Low & Low & \\
\hline MANAGEMENT & Land Management & Low & & Low & & & & \\
\hline WA DEPT OF GAME & Public Access & & Moderate & High & & Low & Low & \\
\hline MANAGEMENf & Stock Grazing & & Moderate & & & & High & \\
\hline SITE MANAGEMENT & Public \& Worker & & & & & & & \\
\hline BYOOE-RL & Access & & & Moderate & & & Low & \\
\hline \multirow{3}{*}{$\frac{N}{N}$} & $\begin{array}{l}\text { Roads \& Utilities } \\
\text { Const. \& MainL }\end{array}$ & & Low & Low & Moderate & Moderate & Moderate & \\
\hline & $\begin{array}{l}\text { Soil/GravellRock } \\
\text { Borrow }\end{array}$ & & & Low & High & High & Moderate & \\
\hline & Land Management & Low & & Low & & & & \\
\hline \multirow{6}{*}{$\begin{array}{l}\text { DEFENSE } \\
\text { PRODUcnON }\end{array}$} & Facilities & & & & & & & \\
\hline & Construction & & Moderate & Moderate & High & Moderate & Moderate & \\
\hline & Facilities & & & Jow & Jow & & & \\
\hline & & & & & & & & \\
\hline & $\begin{array}{l}\text { Facilities } \\
\text { Decommissioning }\end{array}$ & & Low & Low & High & High & Moderate & \\
\hline & $\begin{array}{l}\text { Environmental } \\
\text { Monitoring }\end{array}$ & & Low & Moderate & Low & Low & & \\
\hline
\end{tabular}


TABLE 2.2. (coutd)

\begin{tabular}{|c|c|c|c|c|c|c|c|c|}
\hline & ent & Natural & Increased & Collection! & Damage or & Audible! & Habitat & \\
\hline Program & Project or Activity & Erosion & & & & Visual & Destruction & $\underline{\text { Contamination }}$ \\
\hline DEFENSE WASTE & $\begin{array}{l}\text { Tank: Fanns \& } \\
\text { Cribs }\end{array}$ & & Low & Low & Low & Moderate & Moderate & Low \\
\hline & Engineered Barriers & & & Low & High & Moderate & Moderate & \\
\hline & Field Activities & & Low & Moderate & Low & & & \\
\hline $\begin{array}{l}\text { CNILIAN RADIO- } \\
\text { ACTIVE WASTE } \\
\text { MGT }\end{array}$ & $\begin{array}{l}\text { Decommissioning } \\
\text { \& Reclamation }\end{array}$ & & & Moderate & Moderate & Moderate & & Low \\
\hline $\begin{array}{l}\text { ADVANCED } \\
\text { REACTORS } \\
\text { PROGRAM }\end{array}$ & $\begin{array}{l}\text { Maintenance \& } \\
\text { Construction }\end{array}$ & & & Low & Low & Low & & \\
\hline $\begin{array}{l}\text { RESEARCH \& } \\
\text { DEVELOPMENT }\end{array}$ & $\begin{array}{l}\text { Maintenance \& } \\
\text { Construction }\end{array}$ & & & Low & Low & Low & & Low \\
\hline & Field Activities & & Low & Moderate & Low & Low & Low & \\
\hline & ent & Nabural & Increased & Collection! & Damage or & Habitat & & \\
\hline$\underline{\text { Program }}$ & Project or Activity & $\underline{\text { Erosion }}$ & Erosion & $\underline{\text { Vandalism }}$ & Alteration & Destruction & Contaminatior & \\
\hline $\begin{array}{l}\text { FACILITIES } \\
\text { CONSTRUCTION }\end{array}$ & $\begin{array}{l}\text { Worker Presence } \\
\text { \& Housing }\end{array}$ & & Moderate & High & High & Moderate & & \\
\hline & $\begin{array}{l}\text { Construction of } \\
\text { Reactors. etc. }\end{array}$ & & Moderate & & High & High & & \\
\hline
\end{tabular}


TABLE 2.2. (contd)

\begin{tabular}{|c|c|c|c|c|c|c|c|}
\hline & Present & Natural & Increased & Collection! & Damage or & Habitat & \\
\hline Program & Project or $\underline{\text { Activity }}$ & $\underline{\text { Erosion }}$ & Erosion & $\underline{\text { Vandalism }}$ & $\underline{\text { Alteration }}$ & Destruction & $\underline{\text { Contamination }}$ \\
\hline \multirow{6}{*}{$\begin{array}{l}\text { FACILITIES } \\
\text { OPERATION }\end{array}$} & Worker Access & & & High & & & \\
\hline & $\begin{array}{l}\text { Materials } \\
\text { Prevention }\end{array}$ & & & & & & Modernte \\
\hline & Public Access & & & Moderate & & Low & \\
\hline & Site Cleanup & & & & High & Low & \\
\hline & Stock Grazing & & Moderate & & & High & \\
\hline & $\begin{array}{l}\text { Land } \\
\text { Management }\end{array}$ & Low & & Moderate & & & \\
\hline & & & & & & & \\
\hline
\end{tabular}


resulting from it is likely to be less severe than it was in the past. New construction and the decommissioning of facilities now have the greatest potential for adverse effects on historic properties.

\subsection{POTENTIAL IMPACfS ON THE FREE EXERCISE OF NATIVE $\underline{\text { AMERICAN }}$}

\section{RELIGIONS}

Activities and policies of the DOE on the Hanford Site may potentially affect the ability of Indian people to exercise their traditional religion in specific areas of the Site. Properties that are important to Native American religions may potentially be damaged, destroyed, or have their sanctity disrupted by sound and visual effects. In addition, activities of the government may, in some instances, impact plant and animal species important to religious practices, and security policies may limit access to sacred places.

\subsubsection{Potential Impacts}

Potential impacts on the free exercise of religion are described below, 'and include damage or alteration, audible and visual impacts, destruction of habitats, and limitation of access.

\section{Damage or $\underline{\text { Alteration }}$}

Described above.

\section{Audible and Visual Impacts}

The introduction of noise and creation of scars on the landscape, or the introduction of buildings may intrude on sacred places. Many Indian people still visit sacred landmarks to pray, worship, and meditate. Loud noises and interruption during project work may interfere with the relaxation required for meditation and prayer. Large buildings or changes in the naturallandscape likewise may disrupt this mental process and thus interfere with the free exercise of religion.

\section{Limitation of Access}

There are places on the Hanford Site and elsewhere in the Columbia Basin region that are sacred and must be visited by Indian people if the contact between them and their creator is to be maintained. Certain ceremonies are practiced at cemeteries. When access to cemeteries and other sacred places is not permitted, the Indian people believe that important spiritual contacts may be 
lost. Thus, limitations to access may hamper the free practice of religion and may have an adverse effect on cultural resources.

\section{Contamination}

Much of the DOE's work on the Hanford Site entails production or use of radioactive or hazardous materials. Contamination of ground or water may affect the usability of plants for ceremonies and necessitate restricting access to sacred places such as cemeteries and buttes.

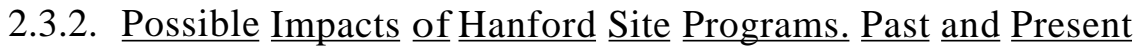

Visual and audible effects have been introduced by building and facilities construction and the introduction of workers. Although worker access has been more restricted during the past decade, such impacts may continue with earth borrowing and new construction. Destruction or contamination of, or damage to, sacred sites may already have resulted from construction and borrow activities, and cattle grazing probably caused destruction of habitats occupied by native plants and animals. Construction and borrowing may threaten sites in the future, but habitat destruction is less likely now because cattle grazing is restricted to areas east of the Columbia River. The need to limit access for safety and security reasons is likely to continue. 


\subsection{POLICIES AND PROCEDURES FOR MANAGING CULTURAL $\underline{\text { RESOURCES }} \underline{\text { AND }} \underline{\text { CONSIDERING }} \underline{\text { RELIGIOUS PRACTICES }}$}

Federal statutes, regulations, and directives assign to the DOE the responsibility for preserving significant historical, archaeological, and cultural sites (historic properties); protecting archaeological and paleontological sites; and avoiding interference with the free practice of traditional Native American religions. The purpose of this chapter is to describe the specific requirements that are placed on the DOE and the procedures that will be followed in meeting them.

Management of cultural resources is the responsibility of the Site Management Division of the DOE-RL, which discharges that responsibility partially through the Hanford Cultural Resources Laboratory (HCRL), a component of the Pacific Northwest Laboratory at the Hanford Site. The actions to be taken by each of these parties in maintaining compliance with relevant statutes and regulations are also discussed in the paragraphs below. Prioritized management activities are described in Section 3.4.

\subsection{PRESERVATION $\underline{\text { OF }} \underline{\text { HISTORIC }} \underline{\text { PROPERTIES }}$}

As described in Chapter 1, preservation is mandated by the National Historic Preservation Act (NHPA). The NHPA establishes the National Register of Historic Places and states (Section 106) that federal agencies must consider the impact of proposed actions on properties that are on or eligible for the National Register. Further (in Section 110), it orders each federal agency to 1) inventory and nominate to the National Register all eligible properties under its jurisdiction; 2) exercise caution pending completion of those inventories to ensure that no property that might qualify for the National Register is inadvertently transferred, sold, destroyed, or demolished without the necessary consideration under Section 106; 3) make detailed records of any registered property that is to be demolished or substantially altered as a result of its action or assistance; and 4) provide for the protection, restoration, and rehabilitation of registered properties under its jurisdiction.

Regulations promulgated to apply the NHPA define the process by which the agency "takes into account" its impacts (36 CFR 800), called the Section 106 Process. The steps in that process are identification of properties, evaluation of their eligibility for the National Register, determination of the effect of the project on eligible properties, determination of whether that effect is adverse, and consultations to be undertaken if the effect is potentially adverse. Adjunct to this process, as a sixth step, is the handling of properties discovered during project implementation. These steps also cover all aspects of Section 110 except for preservation, restoration, and 
rehabilitation of properties, which is referred to here as maintenance. The procedures the DOE will follow to complete these steps are presented in the following sections.

\subsubsection{Identification}

Identification is the process of locating cultural properties, including sites, buildings, objects, structures, objects, and places with a long history of human use (traditional use areas). On the Hanford Site, these include archaeological sites (both historic and prehistoric, Native American, Chinese-American, and Euro-American); historic structures and buildings; Euro-American, Chinese- American, and Native American artifacts; cemeteries (these have an overriding religious significance and will be discussed in Section 3.3); and places traditionally used by Native Americans for religious observation and resource collection. Methods used to identify sites, buildings, and objects differ from those used to identify traditional use areas.

\subsubsection{Identification of Sites. Buildings. and Objects}

Reviews of literature/records and field surveys are the means used to identify cultural resources of this kind. A literature and records review provides information about any known cultural resources and registered historic properties that may be known to exist in a project area and provides background data on the kinds and distributions of cultural resources that might be found in previously unsurveyed lands. Field surveys include the inspection of the land surface and, when necessary, subsurface probing to locate previously unknown sites and objects. Predictive modeling is used to estimate the number, characteristics, and environmental distribution of archaeological sites.

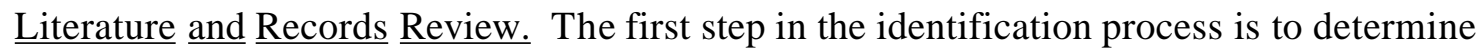
whether the area in question has ever been surveyed for cultural resources, whether the survey met the minimum requirements of precision as described below, whether cultural resources have been found, and whether or not those properties have been evaluated for and/or listed on the National Register of Historic Places. Extant knowledge about the cultural resource sites and objects of the Hanford Site is summarized in Appendix D of this document. For prehistoric resources only, sites and objects are identified in the report, Resource Planning and Protection Process: Mid-Columbia Study Unit. prepared for the Washington State Office of Archaeology and Historic Preservation by Galm, Hartmann, and Masten (1985). The locations of previous archaeological surveys conducted on the Hanford Site are shown on a map provided in the map pocket of this document. This map will be updated annually for the holders of this document. Reports of surveys shown on the map are referenced by number in the associated table found in Appendix F (Table F.2). 
Additional records and literature that are to be reviewed include (but are not limited to) the archaeological site records file, reports on previous cultural resource surveys and excavations in the vicinity of the project site and county land ownership records. Complete copies of up-to-date archaeological site records and all survey and excavation reports for the Site are maintained in the HCRL. When a construction project is planned for an area known to have been settled by EuroAmericans during the pre-Hanford Site years, previous residents and/or local historians may also be consulted for information.

$\underline{\text { Field }} \underline{\text { Surveys. Procedures used to conduct cultural resource surveys follow guidelines }}$ established by the Washington State Office of Archaeology and Historic Preservation. Intensive survey entails pedestrian search of the entire area to be impacted directly or indirectly by a project. The survey is done in transects spaced no more than 20 meters apart, with the fieldworker scanning the area 5 meters to either side of the transect center line. Although some archaeologists recommend transect spacing of 10 meters (in order to ensure discovery of all artifacts; see Schiffer, Sullivan, and Klinger 1978), this high level of intensity is costly when large areas must be inspected. Spacing of 30 meters has been standard in the interior Northwest where huge tracts must be covered in open, relatively artifact-free terrain (e.g., Chatters 1980). A loss of some information has been considered to be the trade-off for increased area coverage. The 20-meter spacing has been chosen for Hanford Site surveys because we estimate that a person scanning an area 5 meters to either side of a center line will discover any surface artifact concentrations larger than 10 meters in diameter, as well as most smaller concentrations. The lowest estimated discovery rate, at 50 percent, is expected for single, isolated artifacts. If a wider spacing of transects were to be used, smaller concentrations and individual artifacts would be recovered at less than 50 percent of their actual frequency. Empirical evaluation of this spacing interval is needed, however, and is addressed under Section 3.4.

Where surface exposure is less than 20 percent, such as in old fields colonized by cheatgrass, the surveyors will scuff the cover from an area 30 centimeters in diameter and expose mineral soil at intervals of 5 meters along the transect lines. In areas where geomorphology indicates the potential for deeply buried artifact deposits, subsurface tests a maximum of 25 meters apart will be excavated by bucket auger (1O-centimeter diameter) up to 2 meters deep, and the matrix will be screened through 114-inch (-8 millimeter) wire cloth. In areas covered by modem fill, backhoe trenches will sometimes be excavated if Holocene sediment deposits are suspected beneath and the setting indicates a high potential for archaeological deposits. 
Infonnation to be recorded for each parcel of land surveyed includes the following:

- the time of day work commenced and ceased

- names of the survey participants

- weather conditions

- light intensity

- a description of the area to be surveyed and the strategy to be used (if it deviates from standard procedures)

- the kind and extent of any previous anthropogenic disturbance to the survey area

- topographic setting, geomorphology, and edaphic conditions

- the percentage of mineral soil exposed

- vegetation and fauna

- the presence, location, and content of any cultural properties, ranging from isolated fmds to dense concentrations and historic fann complexes. Locations will be plotted on USGS 1:24,000 scale maps and on a sketch map at a larger scale appropriate to the size of the cultural property observed

- artifacts collected, if any (see discussion of artifact collection policies, below).

This infonnation and anything else the surveyors deem pertinent will be recorded on Hanford Cultural Resources Survey fonns (Appendix H).

When auger testing is necessary, the location of each test will be plotted on the survey area map, and a profile and description of each test hole (including presence, depth, and description of artifacts) will be recorded in the HCRL laboratory record book.

Each fmd of one or more features (nonportable, nondiscrete artifacts), or of three or more artifacts within 10 meters of each other, will be designated as a site and duly recorded in the files of the Washington State Office of Archaeology and Historic Preservation. All other objects are isolated fmds (isolates). Fonns will be filled out for sites, recording, among other things (see Appendix H): 
- the location by legal description, UTM coordinates, and verbal description

- a description of the site, its dimensions and condition

- estimated depth of deposits

- the topographic, hydrologic, and ecologic context

- the number and density of artifacts and features

- description and enumeration of artifacts, with special reference to temporally diagnostic specimens; temporally diagnostic items (items which help determine the time period) will be drawn

- a sketch map, to scale, of the site and the location of important features or artifacts within it.

No artifacts will be collected from sites during the survey process, except when auger testing or backhoe trenching is used. Photographs documenting the site's extant condition will be taken to aid in future relocation and the site monitoring program. Copies of archaeological site forms will be submitted to the Washington State Office of Archaeology and Historic Preservation (OAHP) for numbering, and will be provided to the Tribes for their records.

Similar forms will be used to record isolated artifacts, but these are less detailed (Appendix H). Isolated artifacts will be collected from the surface if the area surveyed is scheduled for earthdisturbing activities. Where no such disturbance is planned, no collections will be made, since to do so would diminish the future research value of the archaeological resource base. Artifacts excavated during auger testing will, however be collected, cataloged and kept at the HCRL until a suitable repository has been identified by the DOE.

Reporting of surveys will follow the guidelines set forth by the OAHP (Appendix G). Copies of survey reports will be sent to the OAHP and the Tribes. Findings of surveys will be described in an annual report on cultural resource management activities, copies of which will be sent to the same parties.

Predictive Modeling. The Section 110 specification that federal agencies must identify all historic properties on lands under their administration has rarely been practicable, given the scale of federal holdings. Consequently, the Advisory Council has added to its list of acceptable identification procedures the process of predictive modeling. A predictive model estimates the 
Cultural Resource Plan, Hanford

number and distribution of different types of cultural resources based either on a theoretical conception of human behavior (deductive model) or a knowledge of the distribution of cultural resources on a statistically selected sample of the agency's lands (inductive model) (see Kohler and Parker 1987).

Results of predictive modeling cannot be used in lieu of surveys where land disturbance is planned, unless the modeling shows that certain environmental settings always lack cultural resources. Modeling does, however, provide information useful for planning purposes, specifically for the siting of construction, borrow, and other projects, allowing cultural resource probabilities to be included in the site selection process.

The DOE-RL is already using a simple predictive model for the conduct of cultural resource reviews, in order to efficiently apply the efforts of the HCRL. In that model, lands have been classified as either low or high sensitivity, depending on their geographic setting and the likelihood that cultural resources occur in that setting. The classification is based on ethnohistorical information and on the results of archaeological reconnaissance and survey efforts previously conducted on the Hanford Site (e.g. Rice 1980) and the nearby, ecologically similar Pasco Basin (Chatters 1980). Although this model is currently in use, it has not yet been validated. Once a valid predictive model has been generated, the Site will be divided into zones with different levels of cultural resource probability. This zone system can then be used in planning for DOE activities.

Predictive model validation and refmement will include a 10 percent survey of Site lands, an analysis of the cultural properties found during that survey in temporal, functional, and distributional terms, and an extrapolation from these data of the number and distribution of different kinds of cultural resources throughout the area. We anticipate that this work will be conducted over a period of 6 years. The plan calls for the first 5 years to include a sample survey of site lands, the sixth year will be used to analyze and interpret the results of that survey and to conduct a fmal test of the model. The sample survey was begun under the Basalt Waste Isolation Program, and nearly one percent of Site lands have been surveyed using the procedure described below (the survey is documented in a 1988 letter report from the HCRL to the DOE-RL, "Basalt Waste Isolation Project Archaeological and Cultural Resource Surveys").

A stratified random sampling strategy (Mueller 1974, 1975) has been used to select 10 percent (143 square kilometers) of Hanford Site lands for survey. Stratified random sampling first divides the area into parts (strata) that are assumed or demonstrated to be internally homogeneous for environmental characteristics pertinent to human use. Then, each stratum is divided into units of equal size, and some fraction of these units is selected randomly. The advantage of this strategy 
over a simple random sampling design is that it ensures selection of portions of each environmental setting, whereas simple random sampling may often entirely miss some settings. With a stratified random sample, a better representation of the kinds and locations of archaeological properties is obtained.

To apply the stratified random sampling technique, the study area was first divided into parts (environmental zones) that were assumed or demonstrated to be internally homogeneous for environmental characteristics pertinent to human use. The characteristics considered in stratifying the area were topography, surface hydrology, soils, and known distributions of archaeological resources. Although human activity was more likely to have been constrained by distributions of biotic resources than by topography, ecological communities change so often in response to climate, fire, and introduction of new species that current conditions cannot be assumed to represent the conditions that affected prehistoric human use of the area. Because plant communities commonly are determined by water availability, slope, aspect and edaphic conditions, which have changed little in the past few millennia, these parameters should correspond to past distributions of biota, regardless of what those distributions might have been.

Once the environments had been defmed, the entire site was divided into sample units of 16 hectares. This unit size was used because it corresponds to the size of a $1 / 16$ section and can be readily located on maps and on land surveyed in the Government Land Office system. Ten percent of the units in each environmental zone will be chosen randomly for study. A minimum of three sample units will be studied in each environment, so the total number of units and the percentage of area studied in anyone environment may exceed $10 \%$. When the samples are chosen and plots located on the land surface, each unit will be intensively surveyed.

Analysis of the survey data will entail assigning artifacts and artifact concentrations to functional and chronological categories, and statistically analyzing the distribution of each such class over the environmental sampling strata The outcome will be a statistically based estimate of the kind and environmental distribution of archaeological properties on the Hanford Site, presented with the aid of the Site-wide geographic information system. That estimate can then be used to assess the probability that anyone project will disturb cultural resources. It will also be used in evaluating archaeological properties, providing support for statements that may be made about the abundance or rarity of individual properties to establish significance under criteria (a) and (d) of 36 CPR 60.4. Findings of each year's survey work will be summarized in the annual report of cultural resource management activities. 
Cultural Resource Plan, Hanford

\subsubsection{Identification of Traditional Use $\underline{\text { Areas }}$}

Through ethnohistorical research and interviews with Indian elders, the DOE has identified landfonns and localities that were used prior to establishment of the Hanford Site for traditional food, medicine, and mineral resource gathering, and religious activities. This effort will continue, when feasible, in collaboration with the Tribes. Procedures for eliciting information on traditional use areas will follow National Park Service guidelines (Parker and King 1989). To date, cemeteries important to the aboriginal inhabitants of the Site have been identified by elders of the Wanapum Indian Band and have been marked with concrete posts bearing cryptic symbols. Locations identified as important during interviews and research are listed in Table E.1 and should be avoided when future projects are planned.

Review of Ethnographic and Ethnohistorical Literature. As part of the preparation of this plan, a consulting anthropologist reviewed extant literature on the aboriginal cultures and people who inhabited the Hanford Site. Results of that research are incorporated as Section D.3. Since it is possible that references were overlooked during the review and that new texts may come to light in the future, the summary in D.3. will be augmented as appropriate.

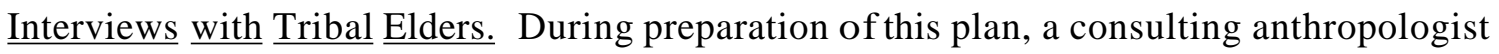
working with the DOE contacted the governments of the Confederated Tribes of the Umatilla Reservation, Yakima Indian Nation, Nez Perce Tribe, and leaders of the Wanapum Band and requested their collaboration in gathering traditional use information (as well as values placed by the tribes on areas of the Site). He was referred to elders who were known to have lived in the area and who were able to discuss the subject. He conducted interviews with elders from the Palouse, Wanapum, and Walla Walla peoples who reside now on the Yakima and Umatilla Indian Reservations. Subjects were place names, activities at named places, resource-gathering activities, and identification of cemeteries and other sacred places. The information obtained through those interviews is presented in Section D.3. The DOE anticipates further collaboration with Tribal governments on the subject of traditional use to augment the information base.

\subsubsection{Impact-Driven Identification: The Cultural Resource Review Process}

The DOE shall exercise caution until its inventories are complete to ensure that no cultural resources are inadvertently destroyed, transferred, sold, or altered. At the Hanford Site this requirement is met through the cultural resource review process. Whenever a Hanford Site contractor acting for the DOE plans a project or undertaking that will disturb the ground, demolish 
a structure (other than waste containment facilities) or increase activity in an area, the initiator is required to obtain a cultural resource review. Projects requiring reviews include (but are not limited to) grubbing; leveling; road or utility line construction; excavation of pits, foundations, and trenches; quarrying of rock and soils; seismic testing; stockpiling of earth; equipment/materials laydown; or demolition. In general, any activity that requires an excavation permit must be reviewed. A description of the cultural resource review process and the means for initiating it has been distributed to all Hanford Site contractors for dissemination to their staffs.

Initiating a Cultural Resource Review. To obtain a review, the initiator contacts the HCRL by mail, providing a completed cultural resource review request form (Appendix C), a copy of which is sent to the DOE-RL, Site Management Division.

Reguired Information. At a minimum, the request form requires a succinct statement of the work to be performed, describing the project, its location and size, and the kind and depth of the planned land disturbance. Exact dimensions must be provided of all areas to be affected by the project, including stockpiling and laydown areas, access roads, and utility corridors. Each form is to be accompanied by a map that identifies the area unambiguously.

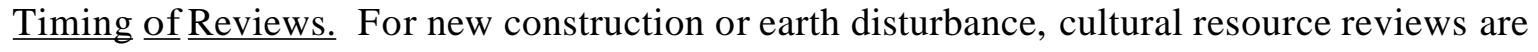
to be requested in the site selection phase of planning so that impacts on cultural resources can be considered in the evaluation of alternative sites. The request must be made no later than the conceptual design review stage to avoid potential impact to construction schedules. For routine repair, maintenance, and facilities upgrading in industrialized areas, requests are to be made as soon as the scale and location of the project are known. At least 30 days are to be allowed for completion of the review.

Exemptions. Because of the nature of DOE activities on the Hanford Site, two kinds of activities will be exempt from cultural resource reviews. These activities are 1) excavations smaller than 5 square feet that are in areas lacking cultural sensitivity and high cultural resource potential, and 2) emergency repair work that is necessary to safeguard public/worker health and safety. Excavations smaller than 5 square feet in areas classified by the HCRL as largely lacking cultural resource potential or cultural senSitivity are not considered undertakings for the purposes of this plan. Emergencies include breaks in waste containment facilities, and leaks in lines carrying emergency water, or dangerous substances such as acid.

These exemptions are not authorized by 36 CPR 800 . Their use on the Hanford Site will be legitimized, however, when this plan becomes the basis for a Programmatic Agreement between 
the DOE-RL, the Washington SHPO, the Advisory Council for Historic Preservation, and participating tribes.

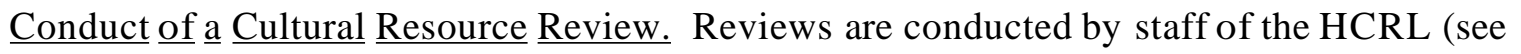
Section 3.5). Each review begins with a literature and records search, as described above (Section 3.1.1.1) to detennine whether a site has already been surveyed for cultural resources or is known to contain historical properties or to be culturally important to Indian groups. If a site has not been surveyed, the review also includes survey and/or monitoring of excavations (see Procedures for Discovery During Implementation, Section 3.1.3.3), whichever is appropriate under local conditions.

Because it is DOE policy to conduct a cultural resources review of any excavation project (which meets the critiera of an undertaking), and because most Hanford projects are in industrialized areas, most cultural resource reviews cover previously disturbed ground. To accommodate this fact, and to allow the HCRL staff to concentrate their efforts on those projects that might pose a threat to known or as-yet-undiscovered cultural resources or properties important to Indian cultures, a classification system has been devised for excavation projects. The procedures to be followed and the products of the review (deliverables) differ by project class.

Three dimensions are used in the classification system: the existence of previous disturbance, the cultural sensitivity and cultural resource potential of a site, and whether or not the undertaking involves an existing structure or building.

- Previously disturbed ground has had its contours altered by leveling, filling, or excavation; or has been contaminated by radiation or dangerous chemicals to the extent that an individual cannot enter the area without wearing protective clothing. Disturbance is determined by observation or aerial photographs and topographic maps.

- $\quad$ "Cultural sensitivity" refers to the religious or secular importance to traditional cultures (see Table E.1).

- $\quad$ "Cultural resource potential" refers to the probability that archaeological, historical, or paleontological materials exist in a setting. In general, areas within 400 meters of water or within 100 meters of trails, buttes, mountains, and prominent hills have a high cultural resource potential.

When a contractor requests a cultural resource review, HCRL staff begins the process by classifying the case then proceeding as described below. 
- Class I: Maintenance in a Disturbed. Low-Sensitivity $\underline{\text { Area. }}$ These projects are maintenance or upgrading of existing facilities in areas of disturbed ground with a low cultural sensitivity and low archaeological potential. Once the HCRL has detennined that a project site fits these criteria, the contractor is given a verbal clearance to proceed. A contact memorandum is prepared documenting the clearance and is submitted to OOE-RL, which transmits a copy to the SHPO and the Tribes.

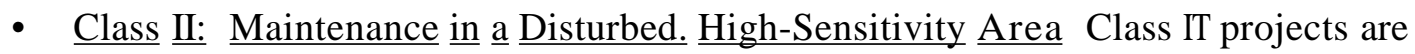
maintenance or upgrading activities in disturbed ground where cultural sensitivity and/or archaeological or paleontological potential is high. Sites that meet the criteria for this class may have archaeological or paleontological materials below the disturbed surface, or may be locations of importance to Indian cultures. If the ground surface is not paved over, a cultural resources survey is perfonned; if it is paved, then HCRL staff will monitor the ground-disturbing activities. If archaeological (including either historical or prehistoric artifacts) or paleontological finds are made in either case, they are evaluated using criteria in 36 CPR 60.4. When a fmd is made during construction, work is to be halted, at least until evaluation is completed by the HCRL in collaboration with the SHPO and the Tribes (36 CFR 800.11). If nothing is found or finds are not significant, letter reports are submitted to the SHPO and Tribes for their infonnation. If a find is significant, fmdings of effect and adverse effect are perfonned according to 36 CFR 800.9. If the effect is potentially adverse, protection and/or mitigation strategies are worked out in consultation with the Tribes, the SHPO, and the Advisory Council. If the effect is not potentially adverse, the SHPO and Indians are given the opportunity to comment (per Section 106 of the National Historic Preservation Act). If the SHPO concurs with a finding of no adverse effect, the Advisory Council is given 30 days to comment. A letter report documents the procedures and fmdings. Findings will be summarized in the annual report of cultural resource management activities.

- Class $\underline{\text { ill: }}$ New Construction in a Disturbed Low-Sensitivity Area. These are new construction projects conducted in disturbed ground where cultural sensitivity and/or archaeological or paleontological potential is low. These are treated in the same way as Class I projects except that the deliverable is a letter of clearance. The greater fonnality of the documentation is due to the scale of the activity and its potential to disturb pristine sediments below the surface.

- Class IV: New Construction in a Disturbed High-Sensitivity Area. These are new construction projects conducted in disturbed ground where cultural sensitivity and/or 
archaeological or paleontological potential is high. Procedures are identical to those followed for Class II.

- Class V: Projects Involving Undisturbed Ground. All projects in undisturbed ground belong to this class. Class $\mathrm{V}$ cases always require a literature and records review and, if no previous surveys have been conducted in the area at the minimum acceptable level of coverage described in Section 3.1.1.1, an archaeological survey. The survey may include subsurface testing if local geomorphology indicates the potential for buried deposits under 12.000 years old. If no cultural resource is found, and there is no known importance attached to the site by Indian people. the contractor is infonned and a letter report is submitted to the SHPO. Indians. and other interested parties for a 14-day review period. If cultural resources are not found and there is no cultural sensitivity. but there is a potential that excavation might unearth archaeological or paleontological materials. the project is monitored by HCRL staff. If a find is made during either surveyor monitoring. it is evaluated as described under Class IT and followed by effect and adverse-effect findings and consultation over mitigation or protection plans. A letter report documents the procedures and findings when surveys cover more than 5 hectares or when cultural resources are found. When no resource is found and the area is smaller than 5 hectares. findings are presented in a letter only. Findings of letter reports will be summarized in the annual report of cultural resource management activities.

- Class VI: Projects Involving Demolition or Remodeling of Existing Structures. Although there are few historical structures on the Hanford Site that predate the nuclear reservation, some facilities and buildings associated with nuclear materials production and other research (particularly those associated with the Manhattan Project) are known to have historical significance. Review of a demolition or remodeling action will include a literature and records review that concentrates on the date of construction and involvement of the facility in research or production programs that have had an impact on the Nation's history. If a structure is found to be of historic significance, effect and adverse-effect findings and consultation over mitigation or protection plans will follow as described under Class IT. A letter report documents the procedures and findings. Findings of letter reports will be summarized in the annual report of cultural resource management activities.

\subsubsection{Evaluation and Nomination to the National Register}

Evaluation refers to the professional assessment of importance based upon criteria promulgated by the Secretary of the Interior for the inclusion of properties on the National Register 


\subsubsection{Evaluation and Nomination to the National Register}

Evaluation refers to the professional assessment of importance based upon criteria promulgated by the Secretary of the Interior for the inclusion of properties on the National Register of Historic Places. According to 36 CFR 60.4, "The quality of significance in American history, architecture, archaeology, engineering or culture is present in districts, sites, buildings, structures, and objects that possess integrity of location, setting, design, materials, workmanship, feeling and association and

"(a) that are associated with events that have made a significant contribution to the broad patterns of our history; or

"(b) that are associated with the lives of persons significant in our past; or

"(c) that embody the distinctive characteristics of a type, period, or method of construction, or that possess high artistic values, or that represent the work of a master, or that represent a significant and distinguishable entity whose components lack individual distinction; or

"(d) that have yielded or may be likely to yield information important in prehistory or history."

Evaluation is the determination of whether sites meet the defined criteria and therefore should receive the consideration afforded the remainder of the Section 106 process. In general historic properties on the Hanford Site are likely to meet criteria (a) and (d), while the few standing structures and buildings that predate 1943 may meet the "representative of a type, period, or method of construction" part of criterion (c). Archaeological properties are most often either "representative of a type ...," or have the potential to yield scientific information (d). Traditional use areas, particularly those that lack an archaeological manifestation, may meet criterion (a), an association with broad patterns of our history, or (c), "representative of a type ...."

According to the Secretary of the Interior's Standards for Evaluation, the objectives of evaluation focus on the relation of a property to historic contexts, which are discussed in Chapter 5. Properties will be considered significant that serve as exemplary examples of historic property types defined for an historic context, have the potential to provide information that will contribute to solving one or more scientific research questions, or which are traditional use areas of primary import to the region's American Indian inhabitants. 


\subsubsection{Procedure for Evaluating Prgperties}

Once a cultural propeny has been identified, a three-step process is to be followed

1. Collect data on the propeny to detennine its integrity, age, characteristics (with reference to historic contexts; Chapter 5), and physical extent. The characteristics of interest and the techniques to be used in data collection will vary for different classes of properties (see below).

2. Identify the appropriate historical context and property type, using the age and characteristics ascertained through Step 1. If no propeny type is appropriate, a new one is defmed, its values identified, and the specific characteristics or data requirements outlined and added to the historic context.

3. The characteristics and integrity of the propeny are compared with integrity and data requirements of the property type. If the comparison is favorable, the property meets the criteria for the National Register. If the comparison is negative, either the property fails to meet the criteria, or its characteristics differ enough from those expected for the property type and context, and a reexamination of the property type is warranted This latter case may be more common for archaeological properties because of the range of variation that probably existed among people's adaptations to local environments.

Collection of data for evaluation differs for archaeological, historical, and traditional use properties.

Archaeological Properties. Identification with an historical context and propeny type requires information both on the age and information potential of an archaeological site. Because archaeological sites are decayed, the often-buried vestiges of human activity areas and settlements, age, and information potential are seldom immediately discernible, and some form of data collection and analysis is necessary. Age is ordinarily detennined by radiocarbon dating, geologic context (stratigraphy), or artifact styles (particularly projectile points, called "temporally diagnostic artifacts"). Occasionally projectile points are present on the site surface, or cut banks provide a view of site stratigraphy; but more often small-scale test excavation is required Data categories relevant to historic property types include stone, bone, and shell tools, features, and animal and plant remains (the latter are the usual sources of material for radiocarbon dating). Procedures to be used to collect data for evaluation of archaeological sites include the following: 
a) Surface inspection and collection. After an archaeological property is identified, HCRL staff traverse the surface in transects spaced 2 meters apart, recording features, artifacts, and any evidence for site stratigraphy that they encounter. Metal, glass, wood, plastic, and stone tools and debitage (unused flakes, cores) are tabulated by functional category according to standard practice, and all temporally diagnostic artifacts are drawn and photographed. Locations of diagnostic artifacts are marked on site sketch maps. No artifacts are collected at this time. Any features observed (e.g., rock cairns, walls, pits, hearths, building foundations, ditches) are described and photographed. This procedure is followed for all sites, as described earlier (3.1.1.1). Sections of woody shrubs or cores from logs used in construction may be collected from historic archaeological sites, when appropriate, for dating of structures and site activities by tree-rings (dendrochronology). If a property is in the path of a planned earth-disturbing project, a grid will be established on the site, and artifacts will be collected and mapped using standard surveying techniques.

b) Test excavation. If surface inspection shows that a site may contain buried deposits, then test excavation is used to collect data for evaluation. Any site that does not consist of artifacts scattered on a surface of glaciofluvial origin, or on cobble-sized, clast-supported fluvial sediments, may include buried deposits. In such cases, test pits are to be excavated to determine the number and horizontal and vertical extent of archaeological components, the functional characteristics of each component, the presence and condition of floral and faunal remains, and, if possible, the season(s) of site occupancy. Test excavations are to be conducted according to the following minimum procedures:

- Establish a datum point and site grid at a minimum interval of 50 meters. Produce or obtain from engineering records a topographic map of the site.

- Determine the site's horizontal extent and number and vertical distribution of components using auger or soil probe testing; include, when feasible and appropriate, one or more of various geophysical techniques (e.g., proton magnetometry, ground-penetrating radar). The sampling interval will vary with site size, and geographic setting. Auger or probe tests should, if possible, reach river gravels or glaciofluvial gravels. The use of a backhoe or other trenching equipment may be appropriate if the site is scheduled for ultimate destruction.

- Excavate not less than two $1 \mathrm{x}$ I-meter pits and not more than 0.2 percent of the site area (unless that percentage is less than the 2 square meters excavated in two test 
- Test excavations must be excavated, at a maximum, in natural geologic and cultural units, or if this is not possible, in lo-centimeter arbitrary levels. All soil matrix must be screened through 6 -millimeter ( $1 / 4$ inch) or finer mesh. These limitations may be waived if initial tests show that certain strata in the site are devoid of artifacts.

- All metal, glass, modified wood, plastic, bone, and chipped and ground stone must be saved. Shell hinges must be saved, or sampled at no less than 25 percent if their density exceeds $200 / 0.1 \mathrm{~m}^{3}$. Heat-modified or broken rock must be counted, and weighed, but need not be saved. Samples of charcoal must be saved and a I-liter sample of soil must be saved from each 10-centimeter level of prehistoric sites for flotation of plant macrofossils, and extraction of plant microfossils.

- Records to be maintained include the completion of excavation fonns ori each vertical unit (per 1 x I-meter horizontal unit), drawings and photographs of all features, and a profile of at least one wall of each test pit.

Analysis of materials collected from test pits may include, but is not limited to, the following:

- detennination of the stratigraphic position of the site in the Holocene sedimentary sequence of the site; analysis of the potential of the sedimentary context to provide data on local environmental conditions

- radiocarbon dating (at least one date per component if appropriate material is available)

- dendrochronology of shrub samples and log cores, if any have been taken

- stylistic and functional analysis of metal, glass, stone and bone artifacts

- analysis of raw materials to identify any exotic items in the artifact assemblage (evidence for trade)

- identification and analysis of all faunal remains, including (but not limited to) data on taxon (identified to the least inclusive taxon possible), element, right or left side, portion, modification, age (when possible), and season of death (when possible)

- identification and analysis of a sample of plant macrofossils (if any) obtained from flotation of the I-liter soil samples (if taken) 
- identification and analysis of a sample of plant macrofossils (if any) obtained from flotation of the I-liter soil samples (if taken)

- extraction, when this action seems potentially productive, of plant microfossils to assess the site's potential to provide data on local plant communities of the past.

c) Data compiled through this analysis will be used to identify the historic contexts with which the site is associated and to determine the property type represented by each component Results are to be reported: the report format will include a description of the site, a summary of the strategy and tactics of data collection and analysis, a description of the results of analysis, and a statement of the site's historic context and property type association and whether or not the site meets the integrity and data requirements of the type.

d) Exception. No test excavations will be conducted at any site that surface characteristics or ethnohistory strongly indicate to be a cemetery. Such sites fall under the category of sacred property, and are addressed in Section 3.3.

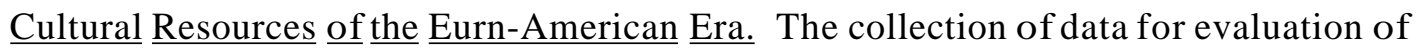
historic properties involves a surface inspection, as described under 3.1.2.1.a, and archival research to establish the property's association with historic events, scientific achievements, and patterns of history, and its architectural style or engineering characteristics. Consultation with historians and architectural historians at the Office of Archaeology and Historic Preservation will be a pan of this information-gathering activity. Sources of information are the summary of local history in Appendix D of this plan, archives of the DOE and Hanford contractors, Government Land Office notes and maps made in the 1880's, books on local history, land ownership records in local title companies and the Benton, Franklin, and Grant County records repositories, and members of the Benton County Historical Society, the East Benton County Historical Society, and the Franklin County Historical Society. In some cases, dendrochronology of logs used in construction or of sagebrush established since site abandonment will be used to date structure ages or site activities.

Traditional Use Areas. Information on traditional use areas is provided in Appendix E. The DOE recognizes, however, that additional information may be required. For any area not yet identified as a traditional use area, Tribal governments will be contacted, to determine whether any elders have knowledge of the area. If allowed, interviews with these elders may be conducted by the DOE or its representatives, or may be conducted by members of the tribe. 


\subsubsection{Detennination of Eligibility and Nomination to the National Register}

The Section 106 process provides the same protection for properties found to be eligible for listing on the National Register as for properties already listed. Because of the amount of time required for listing a property, it is often necessary to obtain a determination of eligibility for properties that may be threatened by federal undertakings so that the Section 106 process can be set in motion and completed within the schedule established for that undertaking. A detennination of eligibility is to be requested when a cultural resource located in the path of a Hanford Site project has been evaluated and found to meet the criteria for eligibility to the National Register, or when the SHPO and DOE disagree on a property's eligibility (see 3.1.2.3.).

Requests for determination of eligibility and nominations to the National Register are to be made on standard forms provided for that purpose by the Washington State Office of Archaeology and Historic Preservation (Appendix H).

\subsubsection{Responsibilities and Consultations}

The collection of data and the determination of whether a property meets the criteria for nomination to the National Register is the responsibility of the HCRL, which conveys its findings to the DOE-RL in letter report, including a description of the undertaking, the evaluation techniques used, the characteristics of the property or properties being evaluated, and the evaluation. The DOE-RL reviews for concurrence, then submits the report to the SHPO for further review and concurrence. The report will simultaneously be sent for comment to the Wanapum band, and Yakima, Umatilla, Nez Perce, and Colville Tribes, and other interested parties who identify themselves. If the SHPO does not respond within 30 days, concurrence is assumed. If the SHPO disagrees or requests additional information, the Cultural Resource Manager. SHPO, and HCRL will confer over data collection and criteria for site evaluation. If. after the conference and collection of additional data, the DOE-RL and SHPO still fail to concur. a request for determination of eligibility will be submitted to the Secretary of the Interior for determination by the Keeper of the National Register. This procedure. consulting with the SHPO and Tribes over the evaluation prior to filing a request for determination of eligibility, provides the SHPO and interested parties with the opportunity to review findings on properties not considered to be eligible by the DOE, and avoids the potential that. once a request for determination of eligibility has been filed with the SHPO, disagreement and further delays might ensue. A determination of eligibility will also be sought if the Advisory Council or Keeper of the National Register request it. 
A cultural resource that has been detennined eligible for the National Register or that has been listed is called a "historic property."

\subsubsection{The Assessment of Effects}

According to 36 CPR 800.9 (a), "an undertaking has an effect on a historic property when the undertaking may alter the characteristics of the property that may qualify the property for the National Register." The effect is considered to be adverse if it may diminish the integrity of the property's location, design, setting, materials, workmanship, feeling, or association in any of the following ways:

- destruction, damage, or alteration of all or part of the property

- isolation of the property from, or alteration of the character of, the property's setting, when that characteristic contributes to the property's eligibility

- introduction of visual, audible, or atmospheric elements out of character with the property or its setting

- neglect of a property, resulting in deterioration or destruction

- transfer, lease, or sale of the property.

\subsubsection{The Avoidance and Mitigation of Adverse Effects}

When the effect of an undertaking on an historic property is expected to be adverse, depending on the circumstances of the undertaking, the DOE will attempt to identify avoidance or mitigation measures in consultation with the Washington SHPO, Advisory Council, Indian Tribes, and other interested parties. Regulation 36 CPR 800 provides for one or more of the following measures:

- avoid the property

- protect the property

- mitigate impacts to the property

- place restrictions on property use

- proceed with the planned action without taking any of these measures.

When the undertaking is expected to destroy, damage, or substantially alter the property, the DOE may either change the location of the proposed undertaking to avoid the historic property, 
take steps to protect the property while maintaining the same project location, or devise a program to mitigate the effects. Avoidance is the preferred alternative and will be used whenever possible. Protection is the second preference; mitigation will be considered as a last resort. When the undertaking involves only the transfer, sale, or lease of property, the DOE may include restrictions or conditions to ensure that historic properties will be adequately preserved. If preservation cannot be ensured, either the property will be retained by the DOE or mitigative actions will be taken before the property changes hands. In those rare cases where the DOE, SHPO, and Advisory Council cannot agree that mitigative measures, avoidance, covenants, or protection constitute avoidance of adverse effects, the DOE may proceed with its planned undertaking following the necessary comment by the Advisory Council (see Responsibilities and Consultations).

A voidance. In all cases "avoidance" means changing the location or design of the undertaking such that it will not alter the feeling, association, or integrity of historic properties. In the case of archaeological properties for which significance is based only on scientific potential, feeling and association have little or no meaning. Then, avoidance will consist only of moving the project or limiting activities of construction personnel such that the condition of the site is unchanged. For historic buildings or traditional use areas, a facility may be redesigned so that it does not alter the feeling or association of the property or diminish its potential future use as a resource-gathering area. Alternatives include the following:

- moving the undertaking to an entirely new location

- designing the project around the historic property

- designing the undertaking such that it is in keeping with its setting

- marking the property "off limits" to construction personnel so it does not sustain inadvertent damage.

Protection Measures. A limited number of options are available for protection. The objective is either to prevent worker and public access to a property that might be subject to unauthorized collection or vandalism (indirect impacts), or to shield a property from direct construction impact. Alternatives for indirect impacts include

- fencing the property to eliminate even inadvertent access by construction personnel and workers at the completed facility (if applicable) 
- posting the property with signs advising the reader that destruction, alteration or collection of historic and prehistoric archaeological materials is a federal crime

- periodic patrolling by the Hanford Site security forces (see Section 3.2, Protection).

Protection from direct impacts is seldom feasible, but may include

- planting vegetation or placing riprap to prevent erosion of sites

- placing a [me soil barrier over the property, with sufficient thickness that the integrity of underlying artifact deposits is not threatened Such a barrier would have to be engineered, and its effectiveness established, through mathematical modeling that takes into account longterm impact of the barrier's weight, and that of the building (if any) on the property in question.

In the case of historic structures or buildings, such as reactors and processing facilities constructed as part of the Manhattan Project, protection may include

- rehabilitation and maintenance of structures as historic landmarks

- adaptive use of buildings such that their architectural characteristics are retained, although they have been renovated for modem uses.

Mitigation. When building renovation threatens to alter the historically significant characteristics of a building or structure, or an undertaking threatens to alter, damage, or destroy an archaeological or historic site, or to alter the useful characteristics of a traditional use area, mitigation of impacts will be attempted only when avoidance and protection are not feasible. Three examples are provided below.

(a) Historic buildings or structures. If destruction or alteration is planned, or when renovation cannot be accomplished without eliminating the historically significant characteristics of a structure, the facility will be documented by record to an extent established through consultation with the chief of the National Register Programs Division, Western Regional Office, National Park Service. Ordinarily this will entail extensive photography of the facility and documentation of its history, and may include measured drawings according to the standards and guidelines of the Historic American Buildings Surveyor the Historic American Engineering Record, whichever applies. If the undertaking is renovation, and it can be accomplished in keeping with the design characteristics of the building or structure, then the DOE will follow this as the preferred alternative. 
(b) Archaeological properties. If the DOE must proceed with an alternative design plan that will substantially alter, disturb, or destroy an archaeological site, then mitigation through data recovery may be the only alternative for avoiding an adverse effect. Data recovery will focus on those characteristics of the property that make it eligible for the National Register. The inventory of historic contexts (Chapter 5) identifies the data that are relevant to each research question and each cell in the historic narrative. Data recovery strategies will be designed to collect data in all relevant categories. Field analysis, and reporting procedures will vary with the data being sought, but will generally follow the tactics described in Section 3.1.2.1. Results of data recovery will be made available to the public as published technical reports. Copies will be sent at least to the following agencies and individuals: the Library of Congress; the Smithsonian Institution; the Washington State Office of Archaeology and Historic Preservation; the leader of the Wanapum Band; Headquarters of the Yakima, Umatilla, Nez Perce, and Colville Indian Tribes; and libraries at universities in the Pacific Northwest region.

(c) Traditional use areas. The Indian Tribes do not recognize mitigation as an alternative when traditional use areas are threatened, and there may be no way to mitigate impacts on a sacred place. However, if the areas are resource-gathering localities, the DOE will consult with the Tribes in an attempt to identify mutually satisfactory mitigative measures. Included among these may be the replacement of traditional resource procurement areas with engineered procurement areas of equal or higher quality.

\subsubsection{Responsibilities and Consultations}

If an historic property may potentially be affected by an undertaking that is sponsored or licensed by the DOE-RL, nine steps will be taken as specified in 36 CFR Part 800.

1. The HCRL will alert the DOE-RL to the potential for an effect.

2. The DOE-RL will prepare a description of the project and the potentially affected property and transmit these to the SHPO. If the property is an archaeological site or traditional-use area, this information will also be sent to the leader of the Wanapum Band, and to the governments of the Yakima, Umatilla, Nez Perce, and Colville Tribes for their views. If the property is historic Euro-American, then the local historical societies will be contacted. All parties will be given a minimum of 15 days to provide their views. Parties may be allowed up to 30 days upon request. 
3. In consultation with the SHPO and Tribes, and with consideration of the views of the Tribes or historical societies (societies), the HCRL and DOE-RL will apply the criteria of effect and adverse effect and prepare a fmding of effect (forms in Appendix H).

4. The DOE-RL will submit the finding to the SHPO for a IS-day comment period, and will provide copies to the Tribes and/or societies as appropriate.

5. A copy of the finding will be made available for public inspection in the Public Reading Room in the Federal Building, Richland

6. If the fmding is that there is no effect and the SHPO does not object within 15 days of receiving that fmding, then the Section 106 process comes to an end. If the SHPO does not concur, then the effect will be considered adverse.

7. If the effect is potentially adverse, the OOE-RL will notify the Advisory Council. The HCRL will consult with the DOE-RL, the manager of the relevant undertaking, the SHPO, and the Tribes and/or societies (depending on whether the property is associated with Native American or Eum-American history, or both). Pursuant to consultations, alternative measures will be devised to avoid, protect, or mitigate the potential impact The consultation process will be led by the OOE-RL, and will be initiated by letter, containing the following documentation:

- a description of the undertaking, including photos, maps, and drawings, as appropriate

- a description of the efforts used to identify the historic properties

- a description of the historic properties that may be affected.

Fifteen days will be allotted for response. Thereafter, the HCRL and DOE-RL will, in consultation with the SHPO, Tribes, and/or societies, devise a plan for avoiding or mitigating adverse effects. The SHPO, Tribes, and/or societies will then be given 15 days to comment on the plan, which will also be provided for public review in the Legal Library. Mter the 15-day comment period, and when the views of interested parties have been considered, the fmal plan will be prepared and submitted to the Advisory Council. If the Advisory Council does not comment after 30 days of receiving the plan, the Section 110 process ends.

8. If, although an effect is expected, it will not be adverse, the DOE-RL will obtain the concurrence of the SHPO and submit to the Advisory Council summary documentation, 
which will also be made available for public review in the Legal Library. If the Advisory Council does not object to the finding within $3 D$ days of receiving documentation, then the Section 106 process is at an end. If the Advisory Council objects, then the effect will be considered adverse. As specified in 36 CPR 800.8, documentation will include the information noted in Step 7 as well as the following:

- a statement of how and why the criteria of adverse effect were found to be inapplicable

- the views of the SHPO, Tribes, other federal agencies (if any are involved), and the public, if any were provided, and a description of the means employed to solicit views.

9. If the SHPO and DOE fail to agree over the effect of a project, when the Advisory Council does not concur with the findings of effect and adverse effect, or when the SHPO, Advisory Council and DOE fail to concur on mitigative measures, the DOE will continue with the Section 106 process, as specified in 36 CPR 800.

\subsubsection{Procedure for Handling Properties Discovered During Implementation of an Undertaking}

In cases where no cultural resources have been found during the identification phase, but where local geomorphology indicates a high probability of buried archaeological deposits, the HCRL will monitor earth-disturbing activities. Monitoring will range from a cultural resource specialist's being present throughout the earth-disturbing phases of construction (when there is a possibility that graves might be encountered) to daily visits by a cultural resource specialist. The intensity of monitoring will be determined by the HCRL, and will be based on evident probability of archaeological deposits, the rate of the earth-disturbing activities, and the cultural sensitivity of the locality. Even where the archaeological potential of an area is considered to be low, the construction contractor is required to watch for bones and artifacts and report any such finds to the HCRL and the Project Manager.

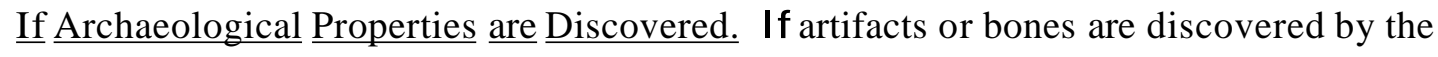
cultural resource specialist monitoring an earth-disturbing activity, or the contractor conducting the disturbance, the contractor will stop work within 3D meters of the fmd until the HCRL has had the opportunity to evaluate it following the procedures in Section 3.1.2. If the fmd meets the criteria for eligibility to the National Register, the DOE-RL will afford the Advisory Council an opportunity to comment pursuant to 36 CFR Part 800.11. During this evaluation period, work outside the 3D-meter radius will be continuously monitored. 
If $\underline{\text { Human Remains }}$ Are Found. If the find includes human remains, those remains are treated according to the Procedures for the Discovery and Handling of Human Remains (3.3.2).

\subsection{PROTECTION OF $\underline{\text { mSTORIC PROPERTIES }}$}

Laws governing the protection of cultural resources are the Archaeological Resources Protection Act (ARPA) and the Antiquities Act of 1906. The ARPA covers archaeological deposits over 100 years old and the paleontological deposits associated with them in time and/or space. The Antiquities Act covers paleontological deposits predating human immigration to North America (12,000 years ago). Seven issues are covered under protection: education, permitting, curation, site records management, surveillance, monitoring, and enforcement for such resources.

\subsubsection{Education}

Worker education will be accomplished by the Site-wide distribution of a flier describing the laws and the penalties for breaking them, and emphasizing the policy of the DOE to ensure enforcement In addition, signs will be posted at the Wye and Yakima Barricades and at the entrance gates to all industrialized areas (100, 200, and 300 Areas) informing workers of the criminality of unauthorized destruction, alteration, or collection of archaeological materials. Signs will also be placed at public road access points, and along the Columbia River's shorelmes and islands to inform the public of applicable laws.

A public education effort will be conducted also. This effort will emphasize Hanford's unique cultural resources and the need for their preservation. It will also inform people about the importance of cultural preservation in general and laws pertaining to archaeological resource protection. It will include presentations through the public news media, a program of outreach to public schools, and construction of informative displays in museum settings.

\subsubsection{Permitting Procedures'}

Procedures for the issuance of permits are described in 36 CPR 229, Protection of Archaeological Resources, Uniform Regulations. Permit applications will be reviewed by the DOE-RL in consultation with the HCRL, the SHPO, and the Tribes, if applicable (see below) before a decision is made to grant a permit The HCRL will consider scientific merit and relevance to this Management Plan; the SHPO will consider effects to the archaeological resource as an historic property; and the Tribes will consider the impact of the activity on their free practice of religion. 
Cultural Resource Plan, Hanford

In keeping with the treatment of human remains as an item of religious, rather than scientific importance, no pennit will be considered or granted for the expressed purpose of excavation and study of human remains. One condition of all permits will require the permittee to follow "Procedures for the Discovery and Handling of Human Remains" (Section 3.3.2).

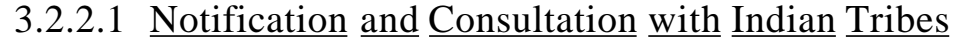

If the DOE-RL determines, after review of the cultural concerns portion of Chapter 5 of this document, that the proposed research may result in harm to, or destruction of, a Tribal religious or cultural site, it will provide the Tribal governments with a copy of the pennit application not less than 30 days before issuing the pennit. If one or more of the Tribes so request, the DOE-RL, the pennit applicant, and the HCRL Director will meet with Tribal representatives to discuss the Tribes' concerns. At that time, alternatives for avoiding or mitigating impacts to cultural or sacred areas will be discussed, and every effort will be made to create a research program acceptable to all parties. The DOE-RL may choose to approve the pennit, deny the pennit, or modify its conditions prior to approval based on these meetings.

\subsubsection{Curation}

Historic and prehistoric artifacts and vertebrate fossils have been collected in the past from. the Hanford Site, and additional collection activity is expected in the future following procedures established herein. Those collections that have already been made (see Appendix D) are currently scattered: the University of Washington, University of Oregon, and the Los Angeles County Museum have fossils collections; Washington State University, the University of Idaho, and members of the Mid-Columbia Archaeological Society house prehistoric and historic artifact collections. Many of the artifacts and records in these collections have never been analyzed, and the condition of the collections and records on them is currently unknown to the DOE. This situation is not in keeping with the intent of ARPA and the Antiquities Act. The DOE intends to establish a curation policy to discharge its stewardship responsibility over such collections. That policy includes the following steps:

- Within two years of the release of this plan, the HCRL will locate and, if feasible, inspect and assess the condition and volume of artifact and fossil collections that have been taken from the Hanford Site. The result of these activities will be an inventory of extant collections.

- The HCRL will then seek to obtain collections that have not been thoroughly analyzed, accession them, and conduct analyses as described in Section 3.1.2.1. Results of these 
analyses will be provided to the public in published reports. The DOE-RL or HCRL may choose a subcontractor to conduct the analysis and reporting activities. During this time, the collections and records will be archived by the HCRL or subcontracting institution.

- The DOE will, in consultation with local tribes, identify a facility or facilities for artifact, fossil, and records curation in accordance with the standards and guidelines developed by the Secretary of the Interior for artifact repositories. That facility may be developed in cooperation with one or more of the Tribes and may be sited in or near the headquarters of Tribal governments.

\subsubsection{Management of $\underline{\text { Site }} \underline{\text { Records }}$}

Archaeological site records are exempt from the Freedom of Information Act and are to be accessed by individuals on a need-to-know basis only. Copies of all site forms will be maintained at the Washington Office of Archaeology and Historic Preservation (which assigns site numbers) the HCRL, the office of the DOE-RL, and the office of the cultural coordinator of each of the Tribes. When a new site is located, an archaeological site form will be filled out for each by the HCRL and sent to the OAHP for number assignment, and one copy will be transmitted by the HCRL to each of the above-described parties. The Tribes will then be responsible for record security, allowing access on a need-to-know basis only.

During fiscal year 1989, the HCRL will establish a file of archaeological site and isolated artifacts that will be updated quarterly. This file will include, at a minimum, site number, name, Universal Transverse Mercator Grid (UTM) location, legal description, age, function, and the presence and condition of features, floral remains, and faunal remains. Data that are recorded in this file will be compatible with geographic information systems being developed for the Site, and the resultant distributional information will be useful for overall Site management

The HCRL will also continue to maintain a complete library of cultural resource-related reports and documents that pertain to the Hanford Site. Tribes and the SHPO will be given access to this library upon request.

\subsubsection{Surveillance and Enforcement}

Enforcement of cultural resource protection laws on the Hanford Site will be the responsibility of the Safeguards and Security Division of the DOE-RL. The Hanford Patrol will conduct frequent, random surveillance of culturally sensitive areas. 


\subsubsection{Training}

Key members of the Hanford Patrol training staff will be sent to training courses on ARPA and its enforcement. These individuals will then train veteran patrol personnel during training sessions over the following calendar year. focusing on surveillance techniques and the gathering of evidence. In subsequent years. the Patrol will include ARPA enforcement in its training program for all new recruits.

\subsubsection{Surveillance}

The Patrol will consult the HCRL for a map of areas with high cultural sensitivity. either related to Native American sacred sites and traditional use areas or to archaeological, historic, and paleontological properties. The HCRL will also be consulted on ways to recognize illegal acts related to these areas. The Patrol will then conduct surveillance of the identified areas on a random schedule by boat, helicopter, or patrol car. Each area should be patrolled at least once per week. Higher frequencies of surveillance will be conducted for sites accessible from the river during salmon-fishing season (August and September).

\subsubsection{Enforcement}

It is the policy of the DOE-RL to seek prosecution of all apprehended violators of ARPA. The Patrol will, therefore, focus its training effons on the most appropriate procedures for apprehending violators and collecting evidence when successful prosecution is intended. Successful prosecutions will be publicized to send a message to other potential violators that the DOE-RL does not intend to overlook the unauthorized collection, damage. or alteration of archaeological resources.

\subsubsection{Monitoring}

As manager of the Hanford Site, the DOE is assigned the stewardship of all archaeological resources, traditional use areas, paleontological deposits. and historical properties onsite. DOE-RL therefore has the responsibility for determining whether its management and protection policies are effective and when they are inadequate. To determine the impact of DOE policies and to safeguard cultural resources from destruction by natural process or unauthorized excavation and collection, the HCRL will maintain a monitoring program. The determination of which properties will be monitored will be accomplished in the following manner. 
In ensuing years, dependent on funding, the HCRL staff will divide known cultural properties into categories, based on artifact and feature content, geographic location, and the traditional activities perfonned there. Forty percent of the sites in each category that are already listed in Archaeological Districts will be chosen randomly, and 20 percent of the properties in each category that are not listed on the National Register (approximately 30 sites). During the first calendar year of the program, these properties and all known cemeteries will be visited Their boundaries will be determined and mapped, their conditions assessed, the kinds and approximate proportions of surface artifacts and features recorded, and photographs taken. This infonnation will serve as the baseline condition of the sample of properties at the implementation of this Plan. If feasible, half of these sites will be revisited the following year to determine whether their condition has changed; the remaining half will be revisited a year later. Changes will be documented by making marginal notes on copies of the original description, and by taking additional photographs. Each year thereafter (if feasible), until all properties have been so documented, the condition of an additional 10 percent of known properties will be recorded in this manner, and that 10 percent will replace an equal portion of the original sample in the following year's monitoring activities. By the sixth year, dependent on funding, all properties will have been documented, and one third will be inspected for changes each year thereafter.

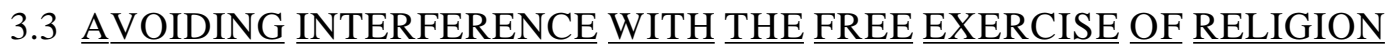

The American Indian Religious Freedom Act (AIRFA) requires the managers of federal agencies to take into account the potential effects of agency undertakings on the free exercise of Native American religions. The DOE-RL intends to comply with AIRFA in a spirit of cooperation and understanding.

Procedures for complying with AIRFA have been developed by the DOE in an Enviromnental Guidance Program reference book entitled American Indian Religious Freedom Act (ORNL 1987). The DOE-HQ suggests that the procedures proposed in that document ("Department of Energy Summary Statement to the Interagency Task Force on Indian Religious Freedom") be followed whenever an environmental review, environmental assessment, or environmental impact statement is required.

\subsubsection{Procedures to be Followed by the DOE-RL}

Steps to be followed by the DOE-RL in complying with AIRFA are an elaboration on the procedures required by the DOE-HQ. 


\subsubsection{Inventory of Places Important to Native American Groups}

The HCRL has attempted to detennine, through interviews with Tribal elders. the location and use of culturally important places on the Hanford Site. These have been enumerated in Appendix E. Additional areas are expected to be added to that list in future years with the assistance of the Tribes, following procedures discussed in Section 3.1.2.1.

\subsubsection{Ascertain the Relation of $\underline{\text { Project }} \underline{\text { Site to }} \underline{\text { Religion }}$}

As a part of the Cultural Resources Review Process (Section 3.1.1.), the the DOE-RL will, in consultation with the HCRL, detennine if a proposed project or activity has the potential to affect the free practice of religion. If the potential for an effect exists, the HCRL will review extant records, including Chapters 4 and 5 of this Plan, to detennine whether the site at issue is related to the religious rites or ceremonies or is considered to be sacred by any traditional religion currently being practiced by any members of the Tribes. The traditional religion now practiced by some members of the Yakima, Umatilla, Nez Perce, and Colville Tribes, and by nearly all members of the Wanapurn Band, is the Washane or Seven Drums religion. Places valued by followers of this religion are discussed in Appendix E. If the site is related to religious practices, or the proposed project or activity has effects that may impact the use of nearby areas for religious purposes, the proposed project or activity may affect the free exercise of Native American religions.

The HCRL will then discuss its fmdings with the DOE-RL. If the undertaking may affect the free practice of religion. then the DOE-RL will proceed as described in Section 3.3.1.3 below. If there appears to be no relationship of the project or activity to religion, or the proposed activity will not alter the physical relationship to the landscape or intensify the DOE's activities on it. then the HCRL will recommend that no further action be taken. If the results are ambiguous, the DOE-RL will contact the Tribal governments for further information (as described in Section 3.1.1.2.)

\subsubsection{Consultation}

If the DOE-RL fmds, on the basis of ethnographic information available to it, that the site of the proposed undertaking may affect the free practice or religion, then the DOE-RL will consult with appropriate leaders of the Tribes. The purpose of this consultation will be twofold. to determine whether the proposed action will infringe on the free exercise of religion in any way, and to gain an understanding of any potential impact on the traditional religion. The most critical issue of concern is whether or not the proposed action will deny access to or damage or destroy a sacred site or otherwise infringe on the free exercise of religion. 
If consultation indicates that the proposed DOE action may infringe on the free exercise of religion, beyond general disturbance of the landscape in areas not accorded specific sanctity (see Section 5.1), then the DOE-RL will attempt to identify alternatives to the proposed action. The DOE-RL, the manager of the proposed undertaking, other cognizant DOE officials, and Tribal leaders will meet to discuss these alternatives and attempt to reach a mutually satisfactory resolution of the religious issue.

The Consultation Process. The DOE-RL will begin its consultation with the transmittal of a letter to the Cultural Committees (with a copy to the Tribal Council Chainnan) describing the undertaking and requesting that the religious leaders be contacted. That letter will include the following:

- a description of the proposed undertaking

- a set of maps sufficient to accurately show the location and scale of the proposed undertaking and its relationship to known sites of religious importance

- a statement of the project's purpose and justification

- a request for the views and suggestions of the religious leaders

- the date by which a response is required.

The Tribes will be given 30 days to respond to this request. If no response is received within that time, then the DOE-RL will assume that the undertaking will have no impact on religious practices.

If, in their response to the DOE-RL's request, a tribe suggests that the proposed undertaking will affect their free practice of religion, then the DOE-RL will arrange a meeting. At that meeting, tribal representatives will be given an opportunity to express their concerns about the impact of the proposed undertaking on religious issues, and to discuss any identified alternatives to the proposed action. The DOE-RL will consider all statements in formulating its decision and incorporate Tribal concerns to the extent feasible.

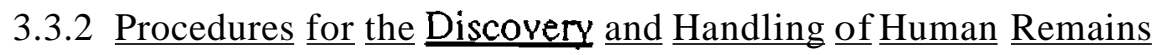

There are nine known Native-American cemeteries on the Hanford Site, confmed largely to islands and to the terraces behind heavily used campsites. Additional unknown cemeteries and isolated graves may also exist. As construction activities, recreational use, and natural erosion 
progress, soil that now protects these graves may be gradually or suddenly removed, exposing the human remains and goods buried with them to the elements and tempting relic hunters into grave robbery.

In the minds of many Native Americans, those ancient graves are of utmost importance. Many members of the tribes trace at least some pan of their ancestry to the Hanford Reach. The Wanapum people, some of them actually born on what is now the Hanford Site, still reside just north of the Site boundaries at Priest Rapids Dam. The bones interred on the Columbia River's shores and islands are the remains of their ancestors and ancestors of other tribes in the region. Those remains and the offerings buried with them are sacred to Indian people. Thus, the Tribes are adamant in their desire to prevent disturbance of their ancestors' graves and in their insistence that when a grave is disturbed, it should be treated with respect and the contents reburied with traditional ceremony.

To ensure compliance with federal mandates and the desires of the Indian people who trace their heritage to the Hanford area, the following procedures shall be followed if and when human remains are discovered on DOE-owned lands. These policies are consistent with policies of the Advisory Council, established on September 27, 1988 (Advisory Council 1988). Initially, because few people are able to distinguish human bones from those of other large animals, any fmd of clustered, large bones shall be treated as if it were human.

When suspected human remains are discovered on DOE lands the following procedures will be followed:

1. The fmder shall not disturb the bones, but immediately contact the DOE Safeguards and Security Division (SAS) (or the county sheriff, who will occasionally receive such reports).

2. An agent of the SAS shall then, without removing any bones or other materials from the site of discovery, contact the county coroner with jurisdiction and the DOE-RL.

3. The SAS, in consultation with the DOE-RL, shall institute such interim measures as are deemed necessary to protect the remains.

4. The DOE-RL shall contact representatives of Tribes with traditional claims to the area, report the incident to them, and provide the tribe(s) with the opportunity to take pan in an inspection of the discovery. The manager shall also ask the HCRL Director or a designate to inspect the find. 
5. The sheriff of the county in which the fmd is made, the fmder (if available), Cultural Resource manager, HCRL Director or designate, and Tribal representative(s) will visit the skeleton find and determine whether it is indeed human; and, if human, determine whether ancient or modem and establish jurisdiction as either law enforcement or DOE site management. If the remains are modem and fall under jurisdiction of law enforcement, this procedure ends.

6. If jurisdiction is the DOE's, and the skeleton is Native American, then the Tribes are to be consulted for their choice of disposition. If conditions favor protection in place, and this is the tribe's preference, then the necessary action shall be taken. If protection is not feasible, or if the tribe is not satisfied with protection as an alternative, then the remains shall be exhumed, following any ceremonies deemed appropriate and prudent, given the concerns of the Tribes and degree of threat to the remains from construction activity, looters, or erosional forces.

7. Exhumation shall be conducted by qualified personnel. Tribal representatives may observe or participate in the exhumation process if they are available and so desire. Appropriate records are to be kept as work progresses. Photographs will not be taken if the Tribe with historical ties to the grave site so desires, but photographic documentation will be necessary if the grave is the site of a suspected ARPA violation. At all times the remains are to be treated with the respect ordinarily accorded the recently deceased.

8. The skeletal remains, soil samples, and any associated artifacts will be taken to the HCRL for study and description. If approved by the Tribe with historical ties to the grave site, analyses may include but not be limited to osteological description and forensic analysis to determine age, sex, stature, cause of death, pathologies, handedness, musculature and congenital abnormalities. No destructive analyses will be performed without written pennission from the Tribe with historic ties to the grave site (hence, with jurisdiction over the remains). Analyses on artifacts and soil samples will attempt to determine the time of burial through stylistic analysis of artifacts and/or radiometric dating, and diet and/or season of death through analysis of soils from abdominal cavities. Other data of anthropological concern are also to be recorded. This analysis is to be completed within a time span agreed to by the DOE, the Tribe, and the HCRL.

9. Human remains and all goods found buried with them are to be turned over to the Tribe for reburial. Cost of any reburial (that becomes necessary as a result of violations of ARPA or direct DOE Action) may be borne by the DOE or, if identifiable, the party who knowingly 
disturbed the remains. The legal basis for requiring the offending party to pay costs can be found in ARPA. Reburial may take place at a location (to be designated) on the Hanford Site, or at an off-site location chosen by the Tribe.

10. The HCRL will provide a report on the exhumation and results of analyses within a time agreed to with the DOE.

11. If the skeleton is not Native American, but is still historic and not within the jurisdiction of law enforcement, the above procedures will be followed except that there will be no Tribal involvement beyond Step 4. Historical records searches and interviews with informants who once lived on the Hanford Site will be used to detennine the identity of the remains and to

- locate the next of kin for reburial. If identity cannot be established and/or no next of kin can be found, the DOE will arrange for reburial in a suitable cemetery offsite.

\subsection{PLANNED CULTURAL RESOURCE MANAGEMENT ACTIVITIES, FISCAL YEARS 1989 THROUGH 1994}

The DOE-RL plans to conduct a seven-part program to manage the cultural resources of the Hanford Site. The following tasks are included: 1) the conduct of NHPA Section 106 compliance reviews, 2) verification, evaluation and documentation of known cultural resource sites as a baseline for management, followed by a monitoring program, 3) development and implementation ofproteetive measures, 4) implementation of a curation program, 5) evaluation of cultural resources for eligibility to the National Register, 6) a public education effort, and 7) evaluation and refmement of the predictive model of archaeological site distributions used for site planning. Four of these tasks have been subdivided into subtasks, for a total of eleven planned actions. These actions have been prioritized (Table 3.1), and Figure 3.1 presents the schedule for implementation. Actions will be taken in order of priority, as funding permits.

At the end of each fiscal year, an annual report of cultural resource management activities will be produced. This report will summarize the activities and findings of the HCRL and will present any conclusions derived from those findings about regional prehistory or history.

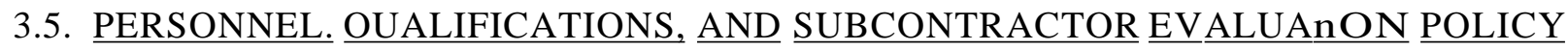

Key personnel who will implement this Plan include the DOE-RL, The HCRL Director, Cultural Resource Specialists, Cultural Resource Technicians, and potential subcontractors. Minimum qualifications for personnel and criteria for evaluating potential subcontractors are summarized below. 


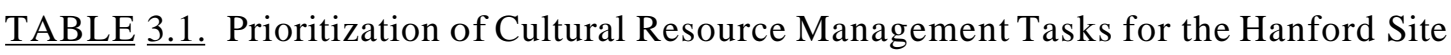

\section{Task}

Conduct Section 106 compliance reviews.

Verify, evaluate, and document the condition and extent of cultural resources as a baseline for management

Assess needs for cultural resource protection.

Implement protective measures.

Monitor the condition of historic properties on a 3-year rotating schedule.

Locate collections and records from authorized archaeological investigations on the Hanford Site.

Curate and report on these collections, following standards and guidelines of the Secretary of the Interior.

Evaluate known cultural resources for eligibility to the National Register of Historic Places, beginning with the proposed Gable Butte/Gable Mountain Cultural District and Wahluke Archaeological District

Plan public education effort.

Initiate efforts to educate the public and Hanford Staff about the importance of Cultural Resource preservation and protection.

Evaluate current model of archaeological resource distributions by a sample inventory of $10 \%$ of Site Lands.

Collect information on regional Ethnohistory.

Conduct a systematic survey of the Columbia River shoreline.
$\underline{\operatorname{Date}(\mathrm{a})}$

Ongoing

Begin Q1 1989

Q11990

1990

Begin Q1 1989

Q3 1989

Complete by 1994

Begin Q3 1989

Q11989

Begin Q4 1989

Begin Q3 1989

Begin Q1 1990

Begin Q3 1990

(a) by quarter and fiscal year.

\subsubsection{HCRL Personnel}

The HCRL Director must have a Ph.D. in anthropology, archaeology, history, or a related discipline, or an MA and at least 5 years' experience in one of those fields. That person will also have at least 2 years' experience in managing cultural resource projects, either in the federal service or the private sector (including university cultural resources management programs), be familiar with archaeology, and have interacted with Native American groups for at least one year. 


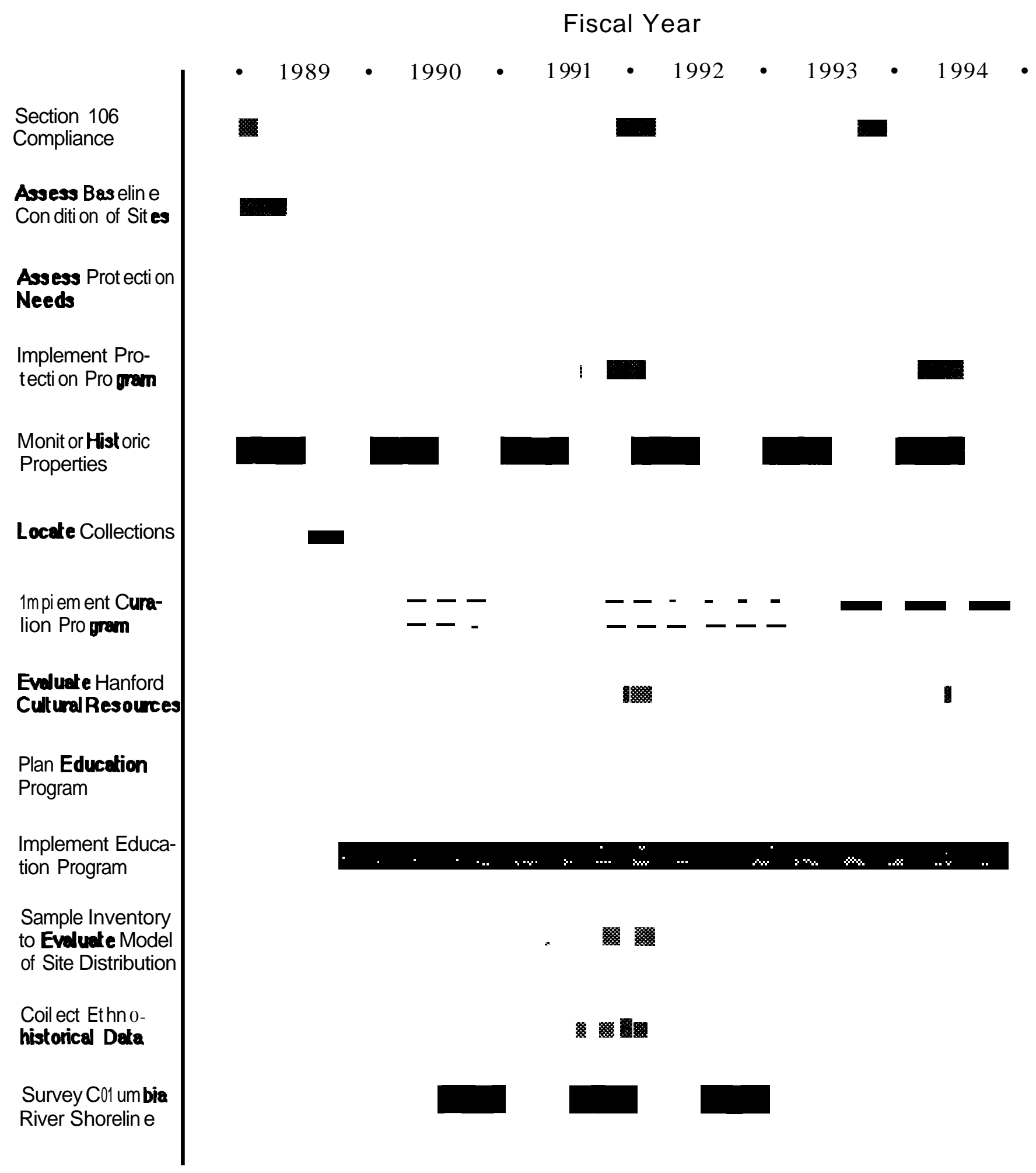

FIGURE 3.1. Timeline for the Performance of Cultural Resource Management Activities at the Hanford Site, from FY 1989 through FY 1994 
Cultural resource specialists are the individuals who will conduct cultural resource reviews or supervise data collection activities in the field. A cultural resources specialist will have an MA degree in anthropology, archaeology, history, paleontology, or a related field; or a B A degree and at least 2 years' experience in one of those fields. These specialists will, within one year of hiring, undergo training in the implementation of the National Historic Preservation Act.

Cultural resource technicians will have at least 2 years of post-secondary education in anthropology, archaeology, history, paleontology, or a related discipline and/or training or experience in the conduct of archaeological sUIVeys and/or geological field studies. Before conducting any data-collecting activities, they will undergo training in the cultural resource base of the Hanford Site and the procedures established in this Plan.

\subsubsection{Criteria for Selecting $\underline{\text { Subcontractors }}$}

Subcontractors may be selected to conduct any of the many cultural resource management activities at the Hanford Site. Potential subcontractors include ethnohistorians, historians, paleontologists, geologists, paleobotanists, analytical laboratories, and archaeological data collection finns. Subcontractors will be evaluated by a scientific review panel that may include other professional archaeologists and members of Indian tribes, on the basis of the following criteria, among others:

- quality of the plan to conduct the scope of work and its confonnance to the policies in this Management Plan

- credentials of the principal investigator, who must meet the minimum qualifications for a cultural resource specialist

- demonstrated ability to do the assigned work, in the time allocated, including examples provided of similar work for others

- demonstrated timeliness

- cost.

\subsection{REFERENCES}

Advisory Council. 1988. Policy Statement Regarding Treatment of Human Remains and Grave Goods. Advisory Council on Historic Preservation, Washington, D.C. 
Chatters, J. C. 1980. Cultural Resources of the Columbia Basin Project: An InventOlY of Selected Parcels. Reconnaissance Report No. 32, Office of Public Archaeology, University of Washington, Seattle, Washington.

Galm, J. R., G. D. Hartmann, and G. D. Masten. 1985. "Identification Component." In Resource Planning and Protection process. Mid-Columbia Study Unit Washington State Office of Archaeology and Historic Preservation. Department of Community Development, Olympia, Washington.

Kohler, T. A. and S. C. Parker. 1987. "Predictive Models for Archaeological Resource Location." Advances in Archaeological Method and Theory, Vol. 9, Academic Press, New York.

Mueller, J. W. 1974. "The Use of Sampling in Archaeological Survey." Memoirs of the Society for American Archaeology. No. 28.

Mueller, J. W. 1975. Sampling in Archaeology. University of Arizona Press, Tucson, Arizona.

ORNL. 1987. American Indian Religious Freedom Act, Environmental Guidance Program Reference Book. ORNL/M-483, prepared forU. S. Department of Energy by Oak Ridge National Laboratory, Oak Ridge, Tennessee.

Parker, P. L. and T. F. King. 1989. Traditional Cultural Properties: Guidelines for Evaluation. National Register Bulletin 38, National Park Service, U.S. Department of the Interior.

Rice, D. G. 1980. Overview of Cultural Resources on the Hanford Reservation in South Central Washington State. Report submitted to U.S. Department of Energy, Richland Operations, Richland, Washington.

Schiffer, M. B., A. P. Sullivan, and T. C. Klinger. 1978. "The Design of Archaeological Surveys." World Archaeology 10: 1-28.

* This unpublished report is available through the Hanford Cultural Resources Laboratory, Pacific Northwest Laboratory, Richland, Washington. 


\section{APPENDIX A}

\section{THE LEGAL BASIS OF CULTURAL} RESOURCE MANAGEMENT 


\section{APPENDIX A}

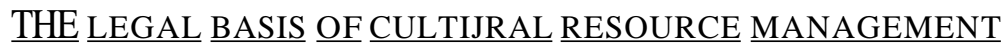

This section includes a discussion of federal and state laws, regulations, and an executive order that provide for the management and protection of cultural resources. These laws, executive order, and regulations constibJte one of the primary "drivers" for implementation of cultural resource management programs and provide one rationale of the need for their existence.

The legal requirements are discussed under the headings of Federal and State requirements. Within the Federal Requirements section, subsections deal with the areas of historic preservation, resource protection, and funding. Then each statute or executive order is presented in order of adoption, from the Antiquities Act of 1906 through the Archaeological Resources Protection Act of 1979. Presenting the discussion in this manner allows the reader to understand the historical development of cultural resource management law.

\section{A.1 FEDERAL REOUIREMENTS}

The Hanford Site, as a federal facility, is subject to the requirements of federal laws, executive orders, and regulations regarding the management and protection of cultural resources. This section discusses stabJtory and regulatory requirements that have their basis in federal law.

\section{Historic Preservation}

The four stamtes and executive order discussed below set forth federal policy requiring consideration of historic preservation values in the conduct of federal agency activities.

\section{Historic Siles Buildings and AntiQuities Act. as amended. 16 USC $461-467$}

The purpose of the Historic Sites Act of 1935 was to declare a national policy of preserving, for the public, historic sites, buildings, and objects of national significance, and to provide the Secretary of the Interior with the power to restore and maintain such sites. The primary effect of this statute was to establish a National Survey of Historic Sites and Buildings, a forerunner to the National Register of Historic Places. The passage of the Act has also led to the establishment of the Historic Sites Survey, the Historic American Buildings Survey, and the Historic American Engineering Record within the National Park Service (Bell 1985).

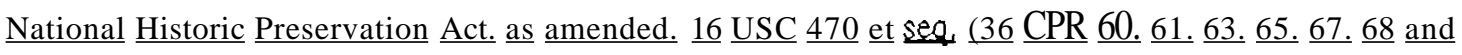

The National Historic Preservation Act of 1966 (NHPA) is the cornerstone of national policy on historic preservation. It states that the Federal government's policy is to provide leadership in the preservation of the prehistoric and historic resources of the United States. In addition, NHPA establishes the following:

the "Section 106 process," which is detailed below

the National Register of Historic Places

state and local historic preservation programs that provide for the designation of a State Historic Preservation Officer (SHPO) (Bell 1985)

the Advisory Council on Historic Preservation, an independent federal agency that advises the President, Congress, and other federal agencies regarding historic preservation issues (Bell 1985).

Section 106 of the Act provides a process that Federal agencies must follow in developing policies and plans and carrying out activities. The Section 106 process, as it is called, ensures that federal agencies have considered the impact of their actions on properties on or eligible for the National Register of Historic Places ("historic properties"). The National Register is maintained by the U.S. Department of the Interior and contains properties significant in American history, architecture, archaeology, engineering, and culture. Federal regulation 36 CPR 60 authorizes and expands the National Register, and describes the process by which historic properties may be nominated to the Register; 36 CPR 63 provides the procedures to be applied when an agency and the State Historic 
Preservation Officer (SHPO) agree that a property is eligible. A proposed role was published in the August 5,1986, Federal Register to combine these two regulations, but no action has yet been taken to make this a final rule.

The Section 106 process is spelled out in 36 CFR 800 and consists of five basic steps (Bell 1985):

1. Identify/evaluate historic properties.

2. Assess effects of the proposed undertaking on those properties.

3. Consult with the SHPO and other interested parties, including Indian Tribes, on ways to avoid, reduce, or minimize adverse effects.

4. Provide an opportunity for the Advisory Council on Historic Preservation to comment.

5. Make a final agency decision about whether and how to proceed with the undertaking.

Federal agencies may fulfill their Section 106 requirements for large or complex projects by developing a programmatic agreement, through consultation with the Advisory Council, the SHPO, and other interested parties such as concerned Indian tribes and groups. A programmatic agreement establishes a process for making decisions regarding cultural property identification, evaluation, and treatment (36 CFR 800.3 and 800.13). Establishing the programmatic agreement at the outset of a large project can eliminate the need to execute separate determinations of eligibility and effect for each property. Alternatively, the Section 106 process can be complied with through following Sections 4,5, and 6 of 36 CFR 800 for each individual activity (U.S. DOE 1981).

Section 110 of the Act, which was added to NHPA by the 1980 amendments, places a continuing responsibility on DOE and other federal agencies to establish programs to locate, evaluate, and nominate to the National Register historic properties under their control (U.S. DOE 1987). In addition, Section 110 directs federal agencies to include the costs of preservation activities as eligible project costs in all agency undertakings. The National Park Service has proposed "Guidelines for Historic and Archaeological Resource Management Federal Agency Responsibilities Under Section 110 of the National Historic Preservation Act" (53 FR 4727, Feb. 17, 1988).

The DOE's responsibilities for previously unidentified properties discovered during implementation of an undertaking are set forth at 36 CFR 800.11. Several options are provided for complying with 36 CFR 800.11: 1) developing a plan for treatment of such properties before the activities proceed, 2) complying with Section 800.6 when properties are discovered, 3) developing and implementing actions that take into account the effect of the undertaking on. the property and the comments of the Council, or 4) complying with the Archaeological and Historic Preservation Act (AHPA) [16 USC 469(a)-(e)] if the property is principally of archaeological value and subject to the requirements of AHPA.

Following the development of the Hanford Cultural Resources Management Plan, DOE-Richland Office will prepare a Programmatic Agreement to govern all activities on the Hanford Site. Prior to the development of this agreement, the Section 106 process will be followed separately for each applicable activity.

National Environmental Policy Act. 42 USC 4321-4361. 40 CFR 1500-1508. 10 CPR 1021: Executive Order 11514. as amended bv Executive Order $\underline{11991}$

The National Environmental Policy Act (NEPA) of 1969 was the fmt federal statute tc provide for general protection of the environmenL The "action-forcing" provisions of the Act in Section 102(2) require federal agencies, among other things, to utilize a systematic, interdisciplinary approach to insure the use of the natural and social sciences and the environmental design arts in planning and decisionmaking for activities that may impact the human environmenL Federal agencies must also prepare a "detailed statement" (an environmental impact statement, or EIS) for "major federal actions significantly affecting the quality of the human environment."

The regulations implementing NEPA require that any EIS present the environmental consequences of the action proposed by the federal agency, including a discussion of urban quality, historic and cultural resources, and the design of the built environment [40 CFR 1502.16(g)]. These regulations also stipulate that agencies prepare draft environmental impact statements that are simultaneous and integrated with any environmental impact analyses and related surveys and studies required by other environmental statutes such as NHPA (40 CFR 1502.25).

The significance ofNEPA to cultural resource management, according to McGimsey and Davis (1977), is that it involves the archaeologist in the early planning stages of a project asking the archaeologist to evaluate the 
effect of a proposed action and its alternatives on cultural resources, and requesting a determination of appropriate mitigation.

Before any actions are taken on the Hanford Site, DOE must consider whether these actions are "major federal actions significantly affecting the quality of the human environment" In any environmental review, the effect of a proposed action on Hanford's ,cultural resources must be determined (RL Order 5440.1A).

\section{American Indian Religious Freedom Act $\underline{42}$ USC 1996}

The purpose of the American Indian Religious Freedom Act (AIRFA) of 1978 is to reaffIrm Native American rights regarding religious freedom, which are guaranteed by the First Amendment The stablte was adopted in response to the recognition that these rights had previously been interfered with by Federal actions that have included denial of Native American access to, and protection for, physical locations and resources that are sacred and sometimes required for the practice of Native American religious rites and ceremonies (U.S. DOE 1987). Federal land managers are directed to act in such a way as to protect and preserve the access of Native American people to sacred lands and their rights to worship in their traditional manner. Although AIRFA itself does not require consultation between federal agencies and Native American groups over specific undertakings, case law has done so. In Wilson v. Block (1983), for example, the court ruled that "an agency undertaking a land use project will be in compliance with AIRFA if in the decision-making process, it obtains and considers the views of Indian leaders."

The Hanford Site contains locations that are considered sacred to Native American people in the Northwest (most notably, Gable Mountain, Gable Butte, Rattlesnake Mountain, Goose Egg Hill, and cemeteries). The DOE will continue to seek Native American input on the impact of its activities on their religious practices.

Guidance for implementing AIRFA has been prepared by DOE (U.S. DOE 1987), Sharples and Salk (1988), and the Federal Agencies Task Force (1979).

\section{Executive Order 11593. Protection and Enhancement of the Culbural Environment}

The purpose of Executive Order (EO) 11593, signed May 13, 1971, is to establish a policy of federal leadership in "preserving, restoring, and maintaining the historic and cultural environment of the Nation." EO 11593 states that federal agencies are responsible for locating, inventorying, and nominating to the National Register of Historic Places those sites that appear to qualify for listing. It further urges federal agencies to exercise caution while the identification process is ongoing so that eligible properties are not transferred or substantially altered. The major requirements of EO 11593 discussed above were incorporated into the National Historic Preservation Act's 1980 amendments.

The Hanford Cultural Resources Management Program includes as one of its responsibilities the inventory and assessment of sites on DOE-Hanford lands to locate sites eligible for the National Register.

\section{Protection}

The two statutes discussed below are concerned with protection of cultural resources. Under these Acts, unauthorized removal of cularal resources is subject to criminal sanctions (under the Antiquities Act) and civil penalties (under the Archaeological Resources Protection Act),

\section{Antiguities $\underline{\text { Act. }} \underline{16} \underline{\mathrm{USC}} \underline{431-433:} \underline{43} \underline{\mathrm{CPR}} \underline{3}$}

The Antiquities Act of 1906 was the first federal stablte to protect cultural resources, or "objects of antiquity," as they are referred to in the Act It prohibits the appropriation, excavation, injury, or destruction of these objects on federal lands except with the permission of the federal land manager. The Antiquities Act also protects paleontological resources. It provides criminal penalties for those who violate its provisions, as well as providing a permit system under which archaeological investigations and excavations may be conducted. Collections obtained by permit under the Act are required by the regulations to be preserved in a public museum. The Antiquities Act also authorizes the President to declare locations as national monuments.

With the exception of items related to paleontological resources, the Antiquities Act requirements have generally been subsumed by those of the Archaeological Resources Protection Act (discussed below).

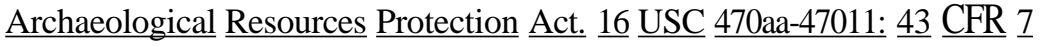

The purpose of the Archaeological Resources Protection Act (ARPA) of 1979 is to protect archaeological resources on public and Native American tribal lands by providing criminal and civil penalties for the unauthorized 
excavation and removal of these resources, and by prohibiting the buying and selling of archaeological resources illegally. The ARPA and its implementing regulations provide for the excavation and removal of archaeological resources on public and Indian lands; the resources removed from public lands remain the property of the United States government, and those removed from Indian lands remain the property of the Indian or Indian tribe having ownership rights (43 CPR 7.13). The Act provides a process by which Native Americans can become involved in the consideration of tribal religious or cultural sites that may be impacted by archaeological investigations. ("Public lands" as defined by the Act include all land owned by the Federal government, so the Act is applicable to Hanford activities.) The Act and its regulations also contain a provision that ensures the confidentiality of archaeological resource information, which is exempt from the Freedom of Information Act

The resources protected by ARPA are stipulated in its implementing regulations at 43 CPR 7.3 as archaeological resources, which are defmed as "any material remains of human activities which are at least 100 years of age, and which are of archaeological interest." The regulations then provide, under the defmition of "archaeological interest," a list of items that include surface or subsurface structures, shelters, facilities, or features; surface or subsurface artifact concentrations or scatters; whole or fragmentary tools, implements, containers, weapons and weapon projectiles, clothing, and ornaments; by-products, waste products, or debris from manufacture; organic waste; human remains; rock carvings, rock paintings, intaglios and other works of artistic or symbolic representation; and rockshelters and caves. Paleontological remains, as well as coins, bullets, and unworked minerals and rocks, are not considered to be of archaeological interest and are not protected under ARPA, unless paleontological remains are associated with archaeological resources.

One of the provisions of ARPA requires pennits for excavating and removing archaeological resources, but the regulations do give the provision that persons carrying out official agency duties associated with the management of archaeological resources need not obtain a pennit However, the agency must ensure that the requirements of pennitting presented at 43 CPR 7.8 and 7.9 have been met by other documented means. The Act also requires DOE to ensure that any such duties that might result in harm to or destruction of any Indian tribal religious or cultural site, as detennined by DOE, have been the subject of consideration under 43 CFR 7.7.

The Act provides for both civil and criminal penalties. The federal land manager may assess a civil penalty against anyone who has excavated, removed, or damaged archaeological resources on the federal agency's lands, without authorization; and against anyone who has sold, purchased, exchanged, transported, or received archaeological resources (43 CFR 7.15). Section 6 of the Act prohibits these activities and establishes the criminal punishment as a fine of not more than $\$ 10,000$ dollars or imprisonment of one year or less.

\section{Funding}

The two statutes discussed in this section provide for preservation of data, but also contain provisions for funding of projects.

\section{The Reservoir $\underline{\text { Salvage Act }} \underline{\text { O6 }} \underline{\text { USC }} \underline{469-469 \mathrm{c})}$}

This act, adopted in 1960, provides for salvaging and preserving historical and archaeological data to be destroyed by reservoir or dam construction sponsored by the federal government. It was extensively amended in 1974 by the Archaeological and Historic Preservation Act (see below).

\section{The srchaedogical and Historic Data Preservation Act 06 USC 469-469c) (ARPA) of 1974}

This act is designed to preserve historic and archaeological data threatened by dam construction or other terrain alterations caused by a federal construction project, federally licensed activity or program. The Act essentially provides federal agencies with a means by which they can mitigate the effects of their impacts on historic properties that contain scientific, prehistoric, historic, or archaeological data (42 FR 5375). AHPA amended the Reservoir Salvage Act of 1960, which is discussed above.

Whenever a federal agency fmds or is notified that its activities may cause irreparable loss or destruction of significant scientific, prehistorical, historical, or archaeological data, the agency must notify the Secretary of the Interior. The agency can request the Secretary to recover. protect, and preserve such data, or it may do so on its own with appropriated funds. The resultant reports must be available to the public.

If the agency requests the Secretary of the Interior to perform the recovery activities, it may assist the Secretary and/or transfer to him funds not more than one percent of the total project appropriation, except in cases in which the project is 50,000 dollars or less. According to Public Law 86-515, which amended AHPA in 1980, the costs of site identification, surveys. and evaluations are considered as planning rather than mitigation costs. In 
addition, Public Law 86-515 authorized federal agencies to waive, in certain cases, the one percent limitation, provided that they have the concurrence of the Secretary of the Interior and that they have notified the appropriate Congressional committees.

On January 28, 1977, the Department of Interior published (42 FR 5374) proposed guidelines establishing methods, standards, and reporting requirements for the recovery of scientific, prehistoric, archaeological and scientific data. These guidelines have never been fmalized, even though the National Park Service published a notice of intent (50 FR 43587, October 28,1985) to prepare regulations to do so, to be codified at 36 CPR 66. The Department of Interior states that to determine when to apply the Act to mitigate a project's effects, it is necessary to follow the steps set forth by NEPA, NHPA, and Executive Order 11593.

McGimsey and Davis (1977) quote the Interagency Archaeological Service (IAS) of the National Park Service, clarifying the one-percent limitation. First, it applies only to costs of recoverying historic and archaeological data, not to planning conducted under NEPA, NHPA, etc. Second, if the cost of inventory, evaluation and data recovery should exceed one percent of project funds, the agency is still required to fulfill its responsibilities under NEPA, NHPA, and EO 11593. The lAS further states that prior to construction, the agency should consider mitigation under a Memorandum of Agreement pursuant to NHPA. Here, the agency should identify impacts that cannot be mitigated within the one-percent ceiling and should look into other mitigative measures or institute a means to obtain additional dollars.

Other important aspects of the Archaeological and Historic Preservation Act include its establishment of a legislative precedent for the analysis and publication of data, and its emphasis on the recovery of data rather than of sites (McGimsey and Davis 1977).

\section{State Requirements}

Washington has developed statutes that address cultural resource protection and management within the State. These statutes are discussed below.

\section{Revised Code of Washington 27,44: Indian Graves and Records}

This Washington law prohibits the unauthorized disturbance (including removal, defacement, or destruction) of Indian graves, cairns, glyptics, or painted records and has deemed such activity a misdeamor. The DOE-RL has prepared a Site policy for the handling of human graves (Section 3.3).

\section{Revised Code of Washington 27.53: Archaeological Sites and Resources}

RCW 27.53 prohibits the collection, alteration, or excavation of any prehistoric archaeological materials below the ground surface without written permission from the SHPO. It also sets up the Washington Archaeological Research Center. This law applies to state or private land, not to DOE land; however, similar provisions in federal statutes such as the National Historic Preservation Act, the Archaeological and Historic Preservation Act, and the Archaeological Resources Protection Act cover federal lands.

\section{Revised Code of Washington 27.34' Archaeology and Historic Preservation}

This statute establishes the Washington State Office of Archaeology and Historic Preservation (OAHP). The stablte requires that the director of the Office is responsible for appointing the preservation officer (the SHPO). The OAHP is also responsible for maintaining the State Register of Historic Places. Another office created by this statute is the State Advisory Council on Historic Preservation, which has nine members appointed by the Governor and is responsible for 1) advising the Governor on matters relating to historic preservation, and 2) reviewing and recommending nominations for the National and State Registers of Historic Places. Finally, the Washington State Heritage Council is created, which maintains a State plan pertaining to archaeology, history, and historic preservation and monitors implementation of the Plan by State historical societies.

The duties of the SHPO as outlined here include review and evaluation of nominations to the National and State Registers of Historic Places and the scheduling of them for review by the State Advisory Council on Historic Preservation. Following Council review, the Council will transmit its recommendations to the SHPO. The SHPO will submit the nomination to the Keeper of the National Register, unless he or she determines that the property does not meet the National Register criteria. Of note is the fact that federally affected properties determined to be ineligible for the National Register under federal regulations will be evaluated by the SHPO for inclusion on the State Register without referring the nomination to the Council for consideration (WAC 25-12-060). 


\section{A.2 REFERENCES}

Bell, C. R. 1985. Federal Historic PreservatiQn Case Law: A Special Repon. Advisory CQuncil Qn HistQric PreservatiQn, Washington, D.C.

Federal Agencies Task Force. 1979. American Indian Religious Freedom Act Report. Federal Agencies Task FQrce, Washington, D.C.

McGimsey, C. R., III, and H. A. Davis, ed. 1977. The Management Qf Archeological Resources. ("The Airlie HQuse Report"). Special PublicatiQn Qf the Society fQr American ArchaeolQgy, Washington, D.C.

Sharples, F.E., and M. S. Salk. 1988. The American Indian ReligiQUS Freedom Act: Guidance for Comnliaoce by Federal Agencies. First RevisiQn. ORNL-6166/RI, Oak Ridge NatiQnal Laboratory, Oak Ridge, Tennessee.

U.S. Department QfEnergy (U.S. DOE). 1987. American Indian ReligiQus Freedom Act ORNL/M-483, Environmental Guidance PrQgram Reference Books, Oak Ridge NatiQnal Laboratory, Oak Ridge, Tennessee. 


\section{APPENDIXB}

\section{HISTORY OF CULTURAL RESOURCES MANAGEMENT ACTIVITY ON THE HANFORD SITE}




\section{APPENDIXB}

\section{MSIQRY OF CULTIJRAL RESOURCES MANAGEMENT \\ SCTIVTY ON $\underline{\text { THE HANFORD }} \underline{\text { SITE }}$}

This section traces archaeological research and efforts to manage the cultural resources of the Hanford Site from its inception in the 19408 to the late 19808. It is based on the open literature and communications and reports found in the files of the U.S. Department of Energy. Richland Operations Office (OOE-RL). The intent is to explore and evaluate past efforts to comply with statutes governing cultural resource protection and preservation in order to identify any issues that might require special attention in the development of systems for managing the Hanford Site's cultural resources.

Seven major issues can be identified in past cultural resource management activities at the Hanford Site.

- The inventory of cultural resources is incomplete. Since 1968. there has been no systematic effort to identify and evaluate archaeological and cultural sites. although such efforts have been recommended.

o Consistent policies and procedures for compliance with various laws and regulations have not been established.

- Archaeological resource protection is nascent; signs informing the public of the Antiquities Act were placed on a few sites. but have fallen into disrepair. There is no systematic monitoring program for assessing the effectiveness of DOE's protection and preservation activities.

- A policy for artifact curation is lacking. Some collections are housed in several universities; the largest are in the homes of amateur archaeologists.

- Few of these collections have been thoroughly analyzed and reported in a form useful for public study.

- There is no systematic means for considering the impact of DOE activities on Native American Religions. pursuant to A1RFA. In fact. prior to BWIP, no reference to this issue can be found.

- A lack of documentation is pervasive. Reasons why some sites and districts were chosen over others for nomination to the National Register are not presented explicitly. Although consideration was reportedly given to the historical significance of homesteads and other sites prior to the Hanford Site Cleanup. there is no documentation of evaluations made for each structure. The same is true of the printed record on cultural resource surveys and excavations. Details such as the techniques used in inventory and evaluation are not explicitly presented. nor are the reasons for choices of which sites to evaluate through excavation.

\section{B.1 BEFORE 1943}

One archaeological study included the Hanford Reach of the Columbia River prior to the formation of the Hanford Engineering Works in 1943. During 1926 and 1927, Herbert Krieger of the Bureau of Ethnology, Smithsonian Institution, conducted a survey "to determine how far the general Plateau Culture may be classified according to its subareas and to what extent these subareas interrelate with each other and with early cultures on the north. west and east" (Krieger 1928, p. 1.) Krieger interviewed private collectors. studied and described private collections from graves and village sites, and excavated a site at Wahluke. According to his description. the site at Wahluke included 30 house pits with stone-capped rims up to $30 \mathrm{feet}$ in diameter and a nearby cemetery. Krieger seems to have concentrated on the cemetery. in which he excavated an unspecified number of graves. Both primary and secondary interments were included, and nearly all had been cremated. The secondary burials ordinarily included multiple individuals. Skulls were often artificially deformed. with flanening in both the frontal and occipital areas. The artifacts illustrated in publications on this study are typical of the last 2000 years of regional prehistory. Artifacts and at least some of the human remains are assumed to have been taken to the Smithsonian Institution. where they may still be housed.

Despite the early date of Krieger's study. it is the only archaeological investigation in the Hanford Reach of the Columbia River that was pursued purely to answer a research question. All other work in the vicinity has been impact driven. 


\section{B.2 1943 TO 1966: FROM HANFORD TO THE PASSAGE OF THE NATIONAL MSTQRIC PRESERVATION ACT}

In 1947, twenty years after Krieger's research, the Smithsonian Institution again sent an archaeological survey team to the Hanford Reach as a part of its River Basin Surveys program. The River Basin Surveys were initiated after the Reservoir Salvage Act of 1935 provided funds for the identification and emergency excavation of archaeological sites scheduled to be inundated by federal water control projects. During the planning for McNary Dam, a team under the direction of Phillip Drucker conducted a survey of the reservoir pool, which extends a short distance up the southeastern border of the Hanford Site. They reported eight archaeological sites within the Hanford boundaries, none of which was directly threatened by the reservoir (Drucker 1948).

During the next two decades, there was no archaeological activity, but the first efforts at cultural resources management are evident in OOE-RL meso In 1951, Puck Hyah Toot (ak.a. Johnny Buck), late leader of the Wanapum people at Priest Rapids, expressed concern over the looting of graves in Priest Rapids Canyon and at Wanawisha Cemetery in Richland. He requested the construction of fences and the erection of signs stating that digging was prohibited. While the cemeteries in Priest Rapids Canyon were outside the Site boundaries, the Wanawisha Cemetery was then in Federal hands. The Atomic Energy Commission (AEC) responding to Puck Hyah Toot's request, questioned the wisdom of marking the cemeteries, concerned that this might simply invite further looting. The same request was then made through the Bureau of Indian Affairs, but the concern over calling attention to graves was re-expressed, and the issue was apparently dropped.

The request for cemetery protection was repeated In 1953. This time, Puck Hyah Toot and another man, Tomalawash, whose ancestors had lived near Richland, asked to tour the Site and observe the condition of additional Wanapum cemeteries. The AEC responded favorably, seeing this as an opportunity to record the cemeteries so they could be protected in the future. Maps were provided by Qick Relander, a journalist from Yakima who had conveyed the Wanapums' request; he asked also that the AEC representative who served as escort mark the locations of village sites and cemeteries. Relander was gathering information for Native Land Claims cases that were then before the Federal court. Five cemeteries were visited by the Wanapums and R. M. Gilbert, an AEC representative, and all were reportedly intact. Maps showing their locations were filed for use in Site planning. Relander later published the infonnation, except for cemetery locations, in his book Drummers and Dreamers, a history of the Wanapum people and their neighbors.

The need for active grave protection measures resurfaced in 1955, this time with positive results. The manager of AEC's Community Section observed that looters had been disturbing graves at Wanawisha. Noting that this was a criminal act under RCW 27.44 (Indian Gmves and Records) he requested that the area be periodically patrolled by police and that signs be posted. The signs were to read " Indian Burial Ground, Digging is Prohibited by State and Federal Law." This request was apparently granted.

The final action taken on the cemetery issue until the 19708 was a cleanup of the Wanawisha cemetery by students of a Washington State history class from Richland's Columbia High School. The cemetery was later sold to the Yakima Indian Nation and is now fenced and designated as a cemetery.

\section{B.3 1967 TO 1971: NATIONAL PARK SERVICE DNYOLYEMENT}

Following passage of the landmark National Historic Preservation Act (NHPA), the first large-scale archaeological survey of Hanford Site lands was initiated in 1967 by the National Park Service for the U.S. Army Corps of Engineers as a part of studies for the proposed Ben Franklin Dam (Rice 1968a). David G. Rice, then a student at WashingtOn State University, conducted the field work with assistance from members of the MidColumbia Archaeological Society and the cooperation of the Atomic Energy Commission. The project covered lands along the Columbia River below the 4()(..foot elevation contour upstream from Wooded Island. Property adjacent to the six production reactors was not inspected, however. Eighty.five archaeological sites were identified on the Hanford Site, including the village and cemetery excavated by Krieger at Wahluke. Test excavations were also conducted at Locke Island and a few other sites, but the results of that work have not been reported.

Following completion of the Ben Franklin Dam survey, the Interagency Archaeological Services (1AS), of the National Park Service, suggested to the AEC that similar work could be conducted on the rest of the Hanford Site. The AEC was receptive, and in the summer and fall of 1968 David Rice conducted a reconnaissance of selected areas. First priority was given to areas scheduled for proposed construction and sites for mdioactive waste burial. Areas adjacent to the Columbia River that might be candidates for industrial development received second priority. 
Springs, ridgetops, cliffs, and other spots that experience had shown to be common settings for archaeological sites were inspected as time allowed. Twenty-six additional sites were recorded (Rice 1968b). Artifacts are kept in the Richland home of a longtime member of the Mid-Columbia Archaeological Society.

The archaeological reports that resulted from these surveys (Rice 1968a and b) were consistent with the state of the art for archaeology at that time. The reports described 111 sites on Hanford, which is $90 \%$ of those known currently. They serve as the primary data base for cultural resource management activities today.

From 1968 through 1971, the AEC used the lAS as its consultant on cultural resource issues. The lAS referred the questions to Rice, who was then at the University of Idaho. The primary issue during this period was the potential impact on cultural resources of the proposed reopening of the Columbia River to public access. Rice, who commented on three alternative proposals, suggested that all posed a threat to cultural resource sites, especially cemeteries. Opening the river to public use, he noted in a letter to the AEC, would expose 95 known sites to the "destruction and degradation that every other portion of the Columbia/Snalce drainage has been subject to for the last 25 years." Echoing this concern, the lAS recommended that any steps toward public access to the river banks should include provisions for the preservation of archaeological resources.

In 1970 the river was opened from Richland to Ringold, with no apparent protection measures being taken. Then, in 1971, islands and the east bank of the Columbia River were opened to public use upstream to Hanford Island. The $\mathrm{ABC}$ committed itself at this time to the posting signs at burial areas to discourage trespass, and the news release reporting the river's opening noted the applicability of the Antiquities Act to the reopened lands.

\section{BA 1971 TO 1972: MARKING OF THE CEMETERIES}

The issue of cemetery fencing resurfaced in 1971 at the request of the Wanapum Band In response to their request the $\mathrm{ABC}$ sought funding to protect the five cemeteries that had been identified by Puck Hyah Toot and Tomalawash 20 years earlier. By 1972 the ABC had decided that rather than fencing the sites, the corners would be marked with 9-inch-diameter concrete posts. Each post was set with a brass medallion bearing the National Park Service symbol for a cemetery, used by the River Basin Survey from 1948 to 1969. This action was taken, but at the cemetery at $100-\mathrm{K}$ the posts were placed incorrectly. Posts designating that cemetery are located just upstream of its actual position, according to Gilbert's 1953 maps and the plans drawn up for theprojecL

\section{B.5 1972 TO 1981: THE SUppLY SYSTEM SND OTHER NQN-AECIERPAIDOE ACTIVTTES}

From 1972 to 1981, the Washington Public Power Supply System (the Supply System) sponsored archaeological surveys, monitoring, and small-scale excavations in compliance with federal statutes and $\mathrm{ABC}$ and Energy Facilities Site Evaluation Council guidelines. Seventeen archaeological activities were conducted by David Rice (1983) of the University of Idaho, most in conjunction with siting of the Hanford Generating Plant near 100-N and the WNP reactors 1,2, and 4 near the southeast comer of the Site.

Seven research goals guided fieldwork on the Supply System projects:

1. to establish a local chronological sequence of culture types for the Hanford Reach of the Columbia River

2. to characterize the prehistoric occupations in the sequence in terms of their material culture

3. to determine whether a connection exists between the pithouse occupations identified and the salmon fishery at Coyote Rapids. Intensive salmon exploitation, through the use of new technologies, was cited by Nelson (1973) as the cause for the development of pithouse villages on the Southern Plateau, so a comparison of faunal assemblages from pithouse and non-pithouse deposits would have been essential for evaluating his model.

4. to provide documentation for Wanapum acculturation and basic continuity or discontinuity of Wanapum lifeways with those of the prehistoric period

5. to determine whether river bank sites were related to fIShing stations on the river

6. to look: for evidence for placer mining 
7. to identify evidence on the river bank for trails marked on 19th-century maps.

Rice's concern for evidence of placer mining and Indian trails was the first attention paid to historic-era cultural resources in the Hanford Reach.

Archaeological survey for the Hanford Generating Plant revealed two new archaeological sites in an area that could not be inspected in 1967. Rice proposed to conduct test excavations at these sites, citing Goals 1 through 4 (above) as motivations for the research. To acquire data for answering these questions, a single test trench was excavated in one of two house pits at 45BN18O, and a larger-scale test excavation was conducted in 45BN179 (Rice 1980,1983). Less than 16 square meters was exposed at 45BN179, and most of that area was only taken down through the upper two culural strata. Although only small numbers of artifacts were recovered, Rice was able to conclude that 45BN179 had been occupied intermittently for up to 7000 years and that 45BN180 was probably used within the last 2000 years. Reports on this work provide good illustrations of excavations and geologic stratigraphy, but artifact descriptions are meager and faunal analyses are cursory. Consequently, the data as currently presented are inadequate for answering any of the questions Rice posed, except perhaps for the question of cultural chronology.

While monitoring construction of water intake facilities for WNP reactors, University of Idaho archaeologists made two minor fmds. They observed a stratum containing fire-cracked rock and lithic flakes during trenching for WNP-2 and a ftre-hearth below the beach cobbles at the water intake for WNP-1 and 4 (45BN 257). The hearth was radiocarbon dated at $1600 \pm 38 \mathrm{yr}$ B. P. (Rice 1980, p. 85). Neither find was considered to be signiftcant.

Fieldwork for the Supply System was completed in 1981, and a comprehensive technical report was prepared (Rice 1983). An illustrated, layman-oriented report was also produced through cooperation between the Supply System, DOE-RL, and the U.S. Army Corps of Engineers (Rice 1982). Finds from the projects are archived at the University of Idaho.

At the same time as Supply System facilities were being constructed, additional surveys were conducted on the Hanford Site by other private and public agencies. A survey and evaluation of cultural resources in the McNary pool by the U.S. Army Corps of Engineers included a re-inspection of archaeological sites between Richland and Wooded Island (Cleveland et al, 1976). A potential bridge corridor just south of the 300 Area was surveyed for the Department of Transportation in 1977 (Morgan 1981). Surveys of linear rights of way for the Bonneville Power Administration (Smith et al. 1977; Jackson and Hartmann 1977; Lynch 1976) and for Puget Power (ERTEC 1982) revealed a few additional cultural resources, mostly historic archaeological sites, but none was considered eligible for the National Register.

\section{B.6 1973 TO 1980: COMPLIANCE BY THE $\underline{\text { AECIERDA }}$}

At its outset, archaeological work that accompanied the Supply System developments was the first instance of purposeful compliance with the NHPA on the Hanford Site, initiated by a non-AEC utility consortium. In mid1973 an AEC initiative was begun.

In May 1973, David Rice began an effort to persuade AEC officials to nominate archaeological sites to the National Register of Historic Places. That effort was not immediately successful, but it ultimately led to the National Register listing of nearly half the archaeological properties on the Hanford Site. Initial opposition to the nomination process is exemplifted in a letter from the AEC to Rice on June 22, 1973: "In consideration of current and possible future AEC programmatic requirements we do not consider current nomination of sites to be in the best interest of the AEC since such nominations could pose programmatically unacceptable delays while awaiting action by the Advisory Council on Historic Preservation .... "(a) However, the AEC also expressed its commitment to the spirit of cultural resource legislation, noting that "In the meantime [until sites were ultimately nominated to the National Register], we have taken positive action to protect sites in the Vernita area [signs citing the Antiquities Act posted at 45BN157] and will continue to provide protection and respect the integrity of other sites located within the confmes of the project When necessary we will arrange for excavation prior to any activity which might affect their historic value."

(a) Letter from L. T. Bright to D. G. Rice. June 22, 1972. 
Such defacto compliance was not acceptable to Rice, who continued to pursue the matter. Through communication with the Departmental Consulting Archaeologist (Department of the Interior), he assured the $A B C$ that Advisory Council reviews did not necessarily entail delays in project implementation. Further, he cited clauses in EO 11593 which he interpreted "to mean that federal agencies shall no longer act unilaterally regarding antiquities resources on their lands ... "(letter dated August 21,1973). Finally he observed that he was coming under public pressure to nominate all 105 sites on the Hanford Reach and that the NHPA provided for nominations by private citizens. If the $A B C$ did not act soon, he noted, public interest would probably result in an independent nomination effort. He thought it preferable for the $A B C$ to initiate the nomination.

The argument was persuasive. By October 1973, the AEC no longer opposed the nomination of historic properties on the Hanford Site, but had begun to discuss which sites were to be nominated. Thus began the fJ'St era of compliance with Cultural Resource laws and regulations by the agency managing the Hanford Site.

The following year, Rice was retained as an archaeological consultant with a five-fold assignment

1. to conduct culaural resource reviews and surveys for project cleanup

2. to conduct archaeological and historical surveys of lands proposed for exchange and lease

3. to evaluate cultural resource sites and prepare nominations to the National Register

4. to conduct archaeological excavations, if needed

5. to prepare reports on his findings.

This was an ambitious agenda, but funds were limited.

Over the next three years, Rice pursued his assignment with assistance from the Mid-Columbia Archaeological Society and sbldents at the University of Idaho and Columbia Basin College. Surveys of sites targeted for "Project Cleanup" called attention to a log structure at East White Bluffs Landing, a cobblestone building (the Bruggeman cobblestone workshop) east of Vernita Bridge, and a badly vandalized archaeological site near Vemita. Excavations were conducted at the log structure (Rice 1976), and it and the cobblestone warehouse were measured and described for possible nomination to the National Register or the Historic American Buildings Survey. Weekend excavations were conducted in 1974 and 1975 at the Vernita Site (45BNI57) to curtail diswrbance, evaluate the significance of possible deeply buried, undisturbed deposits, and to consider the site's eligibility for nomination to the National Register (Den Beste and Den Beste 1974). Twelve sites and districts were nominated to the National Register, of which nine have thus far been listed.

Numerous cleanup, lease, and exchange projects were surveyed, all with negative results. These included such large projects as the Fast Flux Test Facility, lands leased to Exxon Nuclear (now Advanced Nuclear Fuels) and the State of Washington (waste burial grounds managed by U.S. Ecology), all located well inland from the Snake and Yakima Rivers. Known archaeological sites were monitored for disturbance. Rice also consulted on the removal of abandoned farm implements and machinery from old farmsteads and their transfer to Olmsted State Park near Ellensburg, and on the stabilization and preservation of the Allard Pumping Plant near Coyote Rapids.

In addition to its technical achievements, the culural resource management program in the mid-1970s included training of DOE personnel. A member of the Waste Management Division participated in a cultural resources training workshop sponsored by the U.S. Army Corps of Engineers in February 1976, and the next month Rice conducted a similar workshop for ERDA personnel at Richland Operations (Rice 1987a).

All things considered, the cultural resource management program at Hanford was equivalent to most federally sponsored cultural resource management programs of its day, although its primary reliance on volunteer labor was atypical. There are two exceptions to this statement, however. The records of individual inventory projects, especially those affected by the Site cleanup, are poorly documented, if at all. Most farmsteads were leveled and their potential as archaeological deposits destroyed, but nowhere in the records is there evidence for an evaluation of their significance, or the lack thereof, that would justify a decision to destroy. The artifacts from East White Bluffs are housed at the University of Idaho, but the extensive, as-yet-unanalyzed collection from Vernita is kept in a private home.

The close of Rice's FY 1977 contract with the ERDA marked the end of systematic culbural resource compliance at the Hanford Site for nearly a decade. Many of Rice's projects were left incomplete. Artifacts and other materials from Vernita had not been analyzed, and no repon on the project had been produced. National Register nominations of the log house at White Bluffs, the Bruggeman cobblestone warehouse, and other historic sites have 
not yet been pursued. Likewise, archaeological survey of the Arid Lands Ecology Reserve, listings of Indian place names and uses of the Hanford Site, and a detailed review of historic land use (which Rice had proposed to conduct) had not been completed.

A year later, Rice began an effort to complete some of these lasks, recommending to DOE-RL that he summarize in an overview the work he had done between May 1974 and September 1977. In a justification for laking the recommended action, the ERDA used a statement that was later misinterpreted. "For this $\$ 8115$ we can satisfy the requirement of addressing the impact of projects on sites for NEPA and 36CFR800. But this will not eliminate the need for an archaeological survey during new consuuetion.n In later years, the first sentence became separated from the qualifier (see the early 1980s).

Funds for Rice's overview of cultural resources and cultural resource management activities on the Hanford Site were allocated in January 1980, and Rice completed the task in the late summer of 1981. His report, Overview

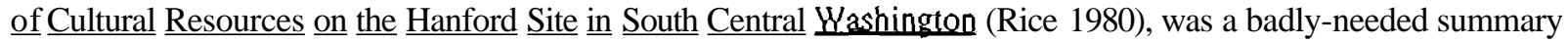
of information on cultural resource management activities and culdural resource sites. It summarizes the history and prehistory of the area as it was then known, lists archaeological surveys done on site, describes cultural resource properties and potentially significant historic suuetures, and provides the only extant description of the archaeological material recovered from the Vernita site. Finds at Vernita were similar in all respects to those obtained at the Hanford Generating Plant site, but discussions of site stratigraphy, artifacts and faunal remains were again brief, indicating that much analysis remains to be done. [A similar overview, which concentrated on land adjacent to the Columbia River, was prepared by Rice and Chavez (1980) at the same time as the Hanford Site Overview.]

The most significant contribution of Rice's overview consisted of his recommendations for the management of cultural resources on the Hanford Site. For DOE to meet its obligations under federal statutes and regulations, it should accomplish the following activities:

Conduct a reconnaissance of the Hanford Site lands following a micro-environmentally stratified sampling design. A 10 percent surface smvey of the Arid Lands Ecology Reserve was recommended as a first step in fulfilling this need.

- Conduct intensive archaeological surveys of project lands where ground-altering undertalings were planned in order to meet requirements of NEPA and Section 106 of NHPA.

- Prepare case studies summarizing the significance of eight archaeological sites and seven historic structures and sites, and submit them in support of National Register nominations of those properties. Limited test excavations were recommended to properly assess the archaeological sites. The identified archaeological sites were at Vernita (45BNI57), the Hanford Generating Plant (45BN179), East White Bluffs Landing (45FR265 and -266), and Coyote Rapids (45BNI52, 45GR312, -313, and -314). Historic sites were the Allard Generating Plant, the Hanford irrigation ditch, the Hanford and White Bluffs townsites, the Wahluke ferry landing, and the log and cobblestone structures at East White Bluffs and Bruggeman's Orchard, respectively.

- Increase surveillance of known cultural resource sites and ongoing surface-altering projects in view of the severe penalties for site vandalism and destruction provided by the Archaeological Resources Protection Act. Rice suggested hiring a full-time cultural resource specialist to accomplish this and other tasks.

Conduct an anthropological study of places important to Native American Groups to avoid litigation that might arise from inadvertent violation of the American Indian Religious Freedom Act

- Consider alternative programs for protection of historic structures, such as the 100-B and -C reactors, including the Historic American Buildings Survey and the Historic American Engineering Record.

It is in these recommendations that the flJ'St references to the Archaeological Resources Protection Act of 1979 (ARPA) and the American Indian Religious Freedom Act of 1978 (AlRFA) appear.

The need for a program of artifact curation, as specified in ARPA, was not addressed in the overview, although Rice had addressed the problem in a letter to DOE-RL dated June 13,1980. The overview did, however, identify the whereabouts of collections made by the various smvey and excavation teams who had worked the area since the 1920s (Rice 1980: Appendix A). The Smithsonian Institution, University ofIdaho, Washington State University and homes of members of the Mid-Columbia Archaeological Society (MCAS) were cited as repositories. 


\section{B.7 THE EARLY 1980\$: CULTURAL RESOURCES MANAGEMENT BECOMES PECENTRALIZED}

After 1980, cultural resource management was largely delegated to Hanford Site contractors, with DOE-RL playing a minor oversight role. As a result, compliance with Section 106 and ARPA became haphazard as each company followed its own interpretation of the regulations. It was in this era that the ERDA's words were misinterpreted to the detriment of adequate attention to cultural resoure issues. Cultural resource inventory and evaluation activities were conducted for several of the larger-scale undertakings, including the Skagit/Hanford Nuclear Plant siting (ERIEC 1981, 1982; Rice 1981) New Production Reactor Siting, and the Basalt Waste Isolation Project (Rice 1984a and b). However, many smaller-scale land-diswrbing activities went unmonitored. Instead, project personnel referred to Rice's overview (1980) or to his 1968 archaeological survey reports as if they constituted complete inventory of the Hanford Site. If those reports showed no archaeological sites in the project area in those reports, then compliance documents stated that no cultural resource concerns existed. Although it is possible that this process did no actual harm to cultural resources, it may have left the outside observer with the suspicion that damage was being done and that the laws were being given inadequate attention.

Protection of known cultural resources was seemingly left in the hands of amateurs or interested professionals working outside the Hanford hierarchy. Rice and the MCAS were evidently the most active, alerting the DOE to vandalism and unauthorized artifact collecting in violation of ARPA. One report from the MCAS motivated DOE-RL to direct Rockwell Hanford Operations to implement weekly surveillance of National Register properties, contact the MCAS for training in site protection, instruct employees to report unauthorized digging and to post "no trespassing signs around the nine historic properties, and limit infonnation on site locations."(a) Signs were placed, but no record could be found of compliance with the other directives.

The Corps of Engineers and Washington Department of Transportation conducted surveys of small portions of Hanford in the early 1980\$. A survey of a bridge corridor south of the 300 Area relocated one already known site (Morgan 1981). After another resurvey of the upper McNary pool (Thoms 1983), the Walla Walla District Corps of Engineers proposed to nominate the entire pool margin above Richland to the National Register as the Hanford South Archaeological District. The Washington State Advisory Council on Historic Preservation concurred with the nomination, but it was later withdrawn by the COE.

\section{B.8 THE MID 1980s: THE RE-ESIABLISHMENT OF CENTRAL CONTROL}

It was the Basalt Waste Isolation Project (BWIP) that ultimately stimulated creation of a cultural resource program managed by in-house DOE personnel. The half-decade of inconsistent attention to cultural resources had already begun to alarm local Indian tribes, the Washington State Historic Preservation Officer, and professional archaeologists, but it was agitation over the potential nuclear waste repository that heightened their concern. The Indian tribes were especially concerned about the lack of compliance with the American Indian Religious Freedom Act. The elevation of treaty Indian tribes and the State of Washington to Affected Party status under the Nuclear Waste Policy Act gave them the power to effect changes after the Hanford Site was chosen in 1986 as one of three potential sites for the nation's first nuclear waste repository.

As the need for central control over the management of cultural resources became apparent, OOE-RL managers saw the need to reassert control over cultural resource compliance activities. They once again called in David Rice to advise them on the appropriate fonn for a program of compliance, which he did in January 1986. Using resources available through the Basalt Waste Isolation Division (BWID), DOE-RL initiated a cultural resources program under the Site Management Division (SMD) (Rice 1987a) in the fall of 1986. Simultaneously, under the Sitewide Service Assessment Program, the Pacific Northwest Laboratory (pNL) had been allocated funds to initiate what was then referred to as the Hanford Cultural Resources Center, which would maintain a data base of cultural resources information and provide technical support to DOE-RL. On a third front, DOE-BWID contracted with Argonne National Laboratory (also in 1986) to write a plan for the design of cultural resources research under BWIP. Throughout this period of change, Rockwell Hanford Operations [later Westinghouse Hanford Company (WHC)] continued to act independently, hiring Rice to survey Gable Butte and Gable Mountain (Rice 1987b) and referring to older documents for site-specific compliance with NHPA and NEPA.

(a) Letter from K. Bracken dated April 23. 1983. 
(WHC)] continued to act independently, hiring Rice to survey Gable Butte and Gable Mountain (Rice 1987b) and referring to older documents for site-specific compliance with NHPA and NEPA.

In 1987 PNL hired a full-time staff of cultural resource specialists, who established the Hanford Cultural Resources Laboratory (HCRL). Under guidance from DOE-RL and DOE-BWID, the HCRL established procedures for compliance with cultural resource laws prior to any earth-disturbing activity on site. Procedures were also established for treatment of human burials, and consultation with Indian peoples was initiated by DOE-RL pursuant to AIRFA, ARPA, and 36 CFR 800. With establishment of this new program, DOE-RL reasserted central control. This management plan codifies that control as well as the policies that will be followed in its implementation.

\section{B.9 SUMMARY}

Archaeological research and efforts to maintain culturally important sites in the area now known as the Hanford Site began in the late 1920s and have continued off and on since that time. The record of cultural resource protection and preservation is not perfect, but neither does it show a methodical disregard for cultural resources.

Following the first (and only) purely research-oriented investigations to touch on the area, there was a hiatus of over 20 years before the first evidence of attempts to manage cultural sites appears in the written record. Concerns raised by Indian leaders over the integrity of Wanapum Indian cemetaries held the attention of AEC land managers in the early 1950's, but it was another 20 years before steps to protect the cemeteries were actually taken. These steps have, however been effective; none of the marked cemetaries shows evidence of recent disturbance and most are completely intact.

The AEC reacted slowly to the passage of the National Historic Preservation Act in 1966 and the issuance of Executive Order 11593 in 1971. In fact, from the late 1960s through the 1970s the initiative for all compliance activities on the Hanford Site came from outside the agency. During the early 1980s, compliance was decentralized, with each Hanford contractor handling the issue in its own way. The situation began to change in the middle 19808, with the passage of the Nuclear Waste Policy Act and issuance of directives from DOE-Headquarters identifying compliance with cultural resources regulations as pan of the agency's mission. Cultural resource management was centralized at DOE-RL and standard policies and procedures were established, as presented in this plan.

\section{B.1O REFERENCES}

Cleveland, G., F. Cochran, J. Giniger, and H. Hammatt. 1976. Archaeological Reconnaissance on the MidColumbia and Lower Snake Reservoirs for the Walla Walla District. Coros of Engineers. Washington Archaeological Research Center, Washington State University, Pullmand, Washington.

Den Beste, K., and L. Den Beste. 1974. Background and HistOl)' of the Vernita Site f45BN157). Annual Report of the Mid-Columbia Archaeological Society, pp. 10-15, P.O. Box 901, Richland, Washington.

Drucker, P. 1948. An Sopraisal of the Archaeological Resources of the McNary Reservoir. Oregon.Washington. Columbia Basin Project, River Basin Surveys, Smithsonian Institution, Washington, D.C.

ERTEC. 1981. Cultural Resources Suryey and Exploratory Excavations for the Skagit-Hanford Nuclear Power Project. ERTEC Northwest, Seattle, Washington.

ERTEC. 1982. $\underline{\mathrm{A}} \underline{\mathrm{Cultural}} \underline{\mathrm{Resources}} \underline{\text { Overview }} \underline{\text { and }} \underline{\mathrm{Scenic}} \underline{\text { and }} \underline{\text { Natural Resources }} \underline{\text { Assessment }} \underline{\text { for }} \underline{\text { the }} \underline{\mathrm{Skagit}-}$ Hanford Nuclear Power Project ERTEC Northwest, Seattle, Washington.

Jackson, J. B., and G. Hartman. 1977. Srchacolorical SurveY from Lower Monumental Substation to Ashe Substation. Project Report Number 38, Washington Archaeological Research Center, Washington Station University, Pullman, Washington.

Krieger, H. W. 1928. "A Prehistoric Pithouse Village Site at Wahluke, Grant County, Washington." In Proceedings of the United States National Museum 73:1-29, United States Government Printing Office, Washington, D.C. 
Lynch, A. J. 1976. An Archaeological Test of an Aboriginal Burial Site Near Richland. Washington, Prepared for the Washington Archaeological Research Center by the University of Idaho, Moscow, Idaho.

Morgan. 1981. Archaeological Reconnaissance of the North Richland Toll Bridge and Associated Access Roads [6909). Archaeological and Historical Services, Eastern Washington University, Cheney, Washington.

Nelson, C. M. 1973. "Prehistoric Culture Change in the Intermontane Plateau ofWestem North American." In The Explanation of Culture Change: Models in Prehistory, ed. C. Renfrew, pp. 371-390, London.

Rice, D. G. 1968a. Archaeological Reconnaissance: Ben franklin Reservoir Area. 1968. Washington State University, Laboratory of Anthropology, Pullman, Washington."'

Rice, D. G. 1968b. Archaeological Reconnaissance: Hanford Atomic Works. U.S. Atomic Energy Commission, National Park Service, and Washington State University, Pullman, Washington.'"

Rice, D. G. 1976. A Log Structure at White Bluffs Landing Franklin County. Washington: A Case Study in Historical Archaeology. University ofIdaho Anthropological Research Manuscript Series, No. 25, Laboratory of Anthropology, University ofIdaho, Moscow, Idaho.

Rice, D. G. 1980. Overview of Cultural ResourceS on the Hanford Reservation in South Central Washington Stare. RL-E-80-0043, prepared for the U.S. Department of Energy, Richland Operations, Richland, Washington.

Rice, D. G. 1981. Archaeological Transects Through Interior Dunes on the Hanford Reservations. Washington. Prepared for the U.S. Department of Energy Richland Office, Richland, Washington."'

Rice, D. G. 1982. Cultural Resources at Hanford. Washington Public Power System and U. S. Department of Energy, Richland, Washington.

Rice, D. G. 1983. Archaeological Investigations at Washington Public Power Supoly System Nuclear Plants on the Hanford Reservation. Washington. Washington Public Power Supply System, Richland, Washington.'"

Rice, D. G. 1984a. Archaeological Inventory of the Basalt Waste Isolation PrQjecL Hanford Reservation. Washington. SD-BWI-7A-007, prepared for Rockwell Hanford Operations, Richland, Washington.

Rice, D. G. 1984b. Archaeological Survey and Monitoring of Initial Excavations Within the Basalt Waste Isolation Project Reference Repository Location and Associated Drill Borehole Site Locations. Letter report to Rockwell Hanford Operations, Energy Systems Group, Richland, Washington.

Rice, D. G. 1985. Archaeological Survey of a Potential Barge Unloading Site at the $\underline{300}$ Area at Hanford. Prepared for Westinghouse Hanford Company, Richland, Washington.

Rice, D. G. 1987a. An Administrative History of the Involvement and Particioation of Richland Qperatjons U.S. Deparment of Energy in Cultural Resources Management at the Hanford Site. Washington. Prepared for Rockwell Hanford Operations, Richland, Washington.

Rice, D. G. 1987b. Archaeological Reconnaissance Qf Gable Butte and Gable Mountain on the Hanford Site. Washington. Prepared for Westinghouse Hanford Company, Richland, Washington.

* This unpublished report is available through the Hanford Cultural Resources Laboratory, Pacific Northwest Laboratory, Richland, Washington. 
Qregon. Washington Archaeological Research Center Project Report 42, Washington State University, Pullman, Washington.

Thoms, A. V. 1983. Archaeological Investigations in Uoder McNarv Reservoir: 1981-1982. Laboratory of Archaeology and History Project Report No. 15, Washington State University, Pullman, Washington. 


\section{APPENDIXC}

\section{ECOLOGY AND ENVIRONMENTAL} HISTORY OF THE HANFORD SITE 


\section{Cultural Resource Plan, Hanford}

Appendix C

\section{APPENDIXC}

\section{ECOLOGY AND ENVIRONMENTAL

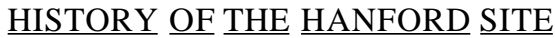

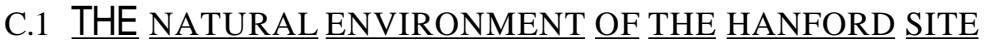

\section{Physiography and Geologic History}

The Hanford Site is located in a physiographic depression known as the Pasco Basin and extends from latitude $46^{\circ} 18^{\prime} \mathrm{N}$ to $49^{\circ} 49^{\prime} \mathrm{N}$ and longitude $119^{\circ} 17^{\prime} \mathrm{W}$ to $119^{\circ} 52^{\prime} \mathrm{W}$. It is bounded on the north by the Saddle Mountains and Sentinel Gap, on the west by the Umtanum Ridge, Yakima Ridge, and Rattlesnake Hills, and on the east by the Columbia River and the White Bluffs. South of the Reservation the Yakima River enters the Columbia from the west, and the Snake and Walla Walla rivers enter from the east. The Hanford Site is bisected by Highway 240, which trends to the northwest. To the west of Highway 240 and north of the Yakima River Road are the lands that make up the Arid Lands Ecology Reserve, which extends to the top of Rattlesnake Mountain. Maximum relief in the area is 853 meters, ranging from an altitude of 92 meters along the Columbia River to an altitude of 945 meters on Rattlesnake Mountain.

Geologic features in the area primarily consist of a large, widespread inland flat punctuated by monoclinal escarpments and tilted basalt outcrops. The inland flat extends south and west of the Columbia River to the Yakima River and the base of the Rattlesnake Hills. In the southeastern half of the inland flat area, the ground surface is covered with large, northeast-trending, stable or semi-active sand dunes. Active dunes are confmed to an area near the Columbia River, about 18 kilometers due north of the city of Richland.

Discontinuous monoclinal escarpments tens of meters high occur in various locations on the Hanford Site, and are believed to be the result of large flood events that occurred during the last glaciation. The 2OO-Area plateau, for example, is a large gravel flood bar located in the central portion of the Site; to the north and east the ground surface slopes off at angles of up to 20 degrees. East and south of the 200-Area plateau are smaller escarpments trending predominantly north-south, and these may also reflect landforms created during flooding.

Tilted basalt outcrops flanking the Site include the Rattlesnake Hills, Yakima Ridge, and Umtanum Ridge. These features, dissected by numerous gullies, are flanked with alluvial fans and landslide deposits. Within the confmes of the Hanford Site, upthrust basaltic strata include Gable Mountain and Gable Butte. These northwesttrending rocky promontories, located in the northern portion of the Site, are tilted to the south. Though dissected, they are flanked only with talus.

The hydrology of the Hanford Site is dominated by the Columbia River. The Hanford Reach, the last freeflowing reach of the river in eastern Washington, extends from Priest Rapids Dam to the head of Lake Wallula, which was created by McNary Dam downstream of the Site. The Columbia in this region is characterized by a narrow modern floodplain, one-to-two terrace levels, numerous point bars, and numerous islands. Several islands extending more than 1.7 kilometers in length are located between Richland and the Vernita Bridge: an unnamed island between Columbia River miles (RM) 341 and 343, another unnamed island between RM 343 and 344 , Johnson Island (RM 345-346.5), Wooded Island (RM 348-351), Homestead Island (RM 351.8-353), another unnamed island between RM 353 and 354, Savage Island (RM 356-361), Locke Island (RM 371-373), and an unnamed island between RM 374 and 375. No natural perennial or ephemeral tributaries flow directly into the Columbia River from the Site, although both confmed and unconfined groundwater aquifers eventually discharge into the river via a network of springs. The Yakima River plays a minor role in the hydrology of the Site, serving mainly as the trunk stream for ephemeral streams emanating from the Rattlesnake Hills, notably Dry Creek and Cold Creek. Nonriverine, perennial sources of water on the Site include Snively Spring and Lower Snively Spring, located on Rattesnake Mountain; Rattlesnake Spring and Benson Spring, located at the foot of Rattlesnake Mountain; and West Lake, located at the foot of Gable Mountain.

The geology of the Hanford Site consists of four major units. At the base are the Miocene-age Columbia River Basalts and interbedded sedimentary units. Overlying the basalts throughout much of the Site is the MioPliocene Ringold Formation, a fluvio-Iacustrine sedimentary unit noted for its vertebrate fossil content Pleistoceneage deposits consist of glaciofluvial sediments, including flood channel gravel (pasco gravels) and fine overbank sand and silt (Touchet Beds). Within the past 10,000 years, alluvium, debris flows, dune sand, loess, landslide debris, talus, and colluvium have all been deposited in various locations on the Site. 


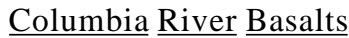

The Columbia Plateau comprises the Columbia River Basalt Group, a tholeiitic flood basalt covering an area of 2 X 105 square kilometers with an estimated volume of 2 X 105 cubic kilometers. The magma erupted as massive sheetfloods from north- to-northwest-trending linear fissure systems tens of kilometers long (now exposed as dikes) about 16.5 to 6 million years ago, during the Miocene Epoch. An estimated 99 percent of this activity took place over an interval of 2.5 to 3 million years, centered around 15 million years ago, with an estimated average frequency of once every 10,000 years. Flows were less frequent during the period between 14 and 16 million years ago, allowing erosion of the basalt and deposition of interflow sediments between events (Swanson and Wright 1978). Because the area was actively subsiding during this time, the Plateau is actually a featureless basin, with its center near Pasco. The basalts are at least 1460 meters thick in the center of the basin (Gaylord and Porter 1987).

Many of the basaltic flood sheets are separated by interflOW sedimentary deposits. The sedimentary deposits had two main sources and two minor sources for their detritus. The two main sources consisted of rivers draining older pre-basalt rocks, including Cretaceous-age granite and granodiorite plutons, and the concurrently erupting calcalkaline volcanos in the Cascades. The explosive Cascade eruptions poured forth pyroclastic pumice and ash, instigated volcanic lahars (mudflows), and fed existing rivers with increased amounts of sediment The interbedded Ellensburg Formation, for example, has been interpreted as representing deposition from volcanic-induced hyperconcentrated flood flows (Smith 1986). The two minor sources of detritus are collections of diatom tests in shallow lakes that existed for hundreds of years on the plateau surface, and minor erosion of the basalt itself.

Deformation began in the Pasco Basin during the late Miocene epoch, towards the end of the period of basaltic activity (Myers et al. 1979). This deformation led to the creation of the anticlinal ridges surrounding the basin, including the Rattlesnake Hills, Yakima Ridge, Umtanum Ridge, and the Saddle Mountains, as well as the Gable Mountain anticline within the basin. Two synclines, the Cold Creek syncline and the Pasco syncline, also formed during this episode of deformation. Gable Mountain and Gable Butte separate the synclines on the Hanford Site; north of Richland they merge into a single syncline (Gaylord and Porter 1987).

\section{The Ringold FOrmation}

The Plio-Pleistocene Ringold Formation unconformably overlies the Columbia River basalt on much of the Hanford Site, except where it was eroded prior to deposition of later sediment, or where the basalt itself crops out. Within the Site boundaries, the Ringold Formation is only exposed east of the Columbia River, where it forms a series of bluffs that extend north from Richland for about 40 kilometers. These cliffs, known as the White Bluffs, are the type locality for the Ringold, and range in altitude from 100 to 300 meters, averaging about 155 meters. Well logs indicate that subsurface Ringold is present throughout most of the Pasco Basin (Gustafson 1978).

Stratigraphically, the Ringold Formation has been divided into four major textural facies, consisting of basal,lower, middle, and upper strata. Facies distribution tends to be laterally variable, and not all facies are represented at alllocations. The upper section is often missing because of erosion, and the basal and lower sections pinch out over anticlinal ridges. On the ridge flanks, the Ringold sediments interfinger with slope-derived talus and colluvium. Basal, lower, middle, and upper strata are known from well cores and from the White Bluffs, although basal and lower strata are not exposed in the cliffs.

Basal Ringold strata consist of boulder and cobble conglomerates with thin interbeds of silty sand and localized patches of silt and clay. Basal strata may be as thick as 45 meters within the Pasco Basin, and are generally thicker in the deepest portion of the Cold Creek syncline, suggesting that this unit was deposited during deformation (Tallman, Lillie, and Fecht 1981). Basal strata commonly contain one to three rming-upward sequences;(a) no sedimentary structures are visible in the well cores (Gaylord and Porter 1987). Clasts consist primarily of basalt, but include granite, quartzite, and other exotic lithologies. The unit $i s$ generally cemented with silica or calcium carbonate (Tallman, Lillie, and Fecht 1981).

Clay, silt, sand and occasional gravel stringers of the lower Ringold unit gradationally overly the basal Ringold strata. In the White Bluffs, Gustafson (1978) has estimated the thickness of lower Ringold strata to be on the order of 100 meters. Within the Cold Creek syncline, the unit ranges in thickness from 5 to 35 meters,

(a) Size of the sediment particles becomes progressively finer toward the top of the bed. 
thinning updip and pinching out over anticlinal ridges. This distribution suggests that deposition was subsequent to defonnation of the syncline.

Gaylord and Porter (1987) have further subdivided lower Ringold strats into three subunits for the purposes of description and stratigraphic interpretation. These are the lower clay subunit [the "blue clay" facies of Newcomb (Newcomb 1958; Newcomb, Strand, and Frank 1972) and others], the sand and gravel subunit, and the upper clay subunit. The subunits are laterally discontinuous across the Pasco Basin, but tend to occur stratigraphically in these positions when they are present

The lower clay subunit is composed of brown and blue clay and silt, sandy silt, some fine to ccarse-grained sand, and pebbly lenses. In well logs, the subunit ranges in thickness from 0 (absent, Le., never deposited or subsequently eroded) to 30 meters. Although sedimentary structures are not discernable in the logs, several fmingupward sequences of sand, silth and clay are locally present

Unconfonnably overlying the lower clay subunit are 3 to 36 meters of coarse sand and pebble/cobble conglomerate. Interbeds of clay and silt, as well as fming-upward sequences of gravel, sand, silh, and clay are common throughout.

The upper clay subunit consists of brown and blue clay, silh and silty sand 0 to 30 meters thick. Also present in the subunit are thin stringers of medium-grained sand Contacts between the middle sand and gravel subunit and the upper clay subunit are conformable, and, where the middle subunit is missing, the contact between the lower and upper clays is virtually indistinguishable.

The middle Ringold conglomerate unit abruptly overlies the lower Ringold throughout the Pasco Basin. The middle Ringold consists of matrix and clast-supported pebble-to-boulder conglomerate approximately 8 to 60 meters thick. The unit is thickest in the Cold Creek syncline, but instead of pinching out against anticlinal ridges, it tends to drape over them, suggesting that deposition of the unit $\propto$ ccurred after basin subsidence had ceased. In the White Bluffs exposure, this unit is 50 meters thick and is an important fossil-bearing stratum (Gustafson 1978). Interbedded with the boulder conglomerates are fme to coarse-grained, often cross-bedded sand and silty and sandy conglomerates, crudely defmed as fming-upward sequences. Pebbles and cobbles consist of basalt quartzite, volcanics, and other exotic lithologies. The conglomerates range from unconsolidated to extremely well-cemented

The upper Ringold unit is a heterogeneous assemblage of massive to faintly laminated silt and clay, laminated or cross-bedded silt and fme sand, thin gravel stringers, and one extensive volcanic tuff stratum. The upper Ringold sharply but conformably overlies the middle Ringold everywhere, and strata up to 150 meters thick crop out in the White Bluffs. Gustafson (1978) has documented a repetitive vertical sequence of successive beds of siltstone, conglomerate, cross-bedded white sandstone, silty sandstone, and siltstone. The thin conglomerate beds, composed of granitic, volcanic, quartzitic, and argillaceous nodules with numerous fragments of limonitized fibrous wood, are important fossil-bearing strata. The uppennost portions of the bluffs are impure siltstone with interbedded sandstone, capped by a caliche horizon up to 5 meters thick. Beds in the upper Ringold appear to be laterally continuous, and contain localized thin caliche horizons and paleosols. Preservation of the wff is incomplete, but where it occurs it is unifonn in thickness and suggests deposition on a surface of low relief. In some areas it is underlain by a buried soil

Sedimentary structures, bedding, and grain-size distributions all indicate that the Ringold Formation was deposited by a major river system flowing through the Pasco Basin (Tallman, Lillie, and Fecht 1981). The predominance of basaltic boulders and cobbles, as well as the paucity of finer sediment, suggests that the basal unit is the result of deposition in a braided series of local streams eroding sWTOunding highland areas. The addition of larger quantities of clay, silt, and sand during lower Ringold time indicates a transition from a high-energy fluvial regime to a lower-energy system, with the fonnation of a floodplain and possible episodes of shallow-water ponding. The discontinuous nature of the coarse sand and pebble conglomerate in lower Ringold facies suggests lateral restriction of main river channels. During middle Ringold time the river system again changed in character, possibly due to a drop in base level. The lateral continuity of almost exclusively coarse sediment indicates that deposition occurred along an extensive high-energy braidplain, with a locus of maximum deposition parallel to the Cold Creek syncline. Based on isopach (subsurface relief) maps of middle Ringold strata, Gaylord and Porter (1987) have inferred that the fluvial system responsible for the deposition of these strata entered the Pasco Basin south of the present Columbia River, and exited between Richland and Rattlesnake Mountain. A second channel may have existed north and east of Gable Mountain. Deposition of upper Ringold heterogeneous strata has been variously interpreted to be the result of channel migration across an actively aggrading floodplain (Gustafson 1978), the low-energy, channelized floodplain of a major fluvial system (Tallman, Lillie, and Fecht 1981), or sheet-like deposition across most of the 
basin in a lacustrine to deltaic setting (Gaylord and Porter 1987). Paleosols and caliche horizons represent extended subaerial exposure of upper Ringold strata.

Following the deposition of Ringold strata, a period of extensive erosion and soil fonnation ensued. The erosion is inferred to be a consequence of base-level lowering at Wallula Gap and subsequent downcutting by a protoColumbia River and its tributaries (Brown 1970; Newcomb, Strand, and Frank 1972). Gaylord and Porter (1987) recognized two stages of erosion removing as much as 150 meters of Ringold strata in the Pasco Basin. The first erosion episode produced a terrace level 30 to 45 meters below the top of the White Bluffs, and the second excavated the Ringold Fonnation to the stratigraphic position it currently occupies beneath the surface of the Hanford Site. Some, if not most, of the second stage of erosion may have been a result of subsequent catastrophic flooding. Extensive soil fonnation is indicated by the thick caliche horizon capping sediments in the White Bluffs.

\section{The Hanford Formation}

A sequence of glaciofluvial sediments, informally tenned the Hanford Fonnation by Tallman, Lillie, and Fecht (1981), overlies the Ringold Formation west and south of the Columbia River on the Hanford Site. The sediments have been divided into two distinctive textural facies. The Pasco gravels (Brown 1975) range in grain size from boulders to fine sand, and are the predominant subsurface facies in the area. The Touchet Beds (Flint 1938) are made up of rhythmically bedded sand, silt, and clay, and the uppennost beds crop out in Dry Creek Canyon. The age of the deposits is not well constrained, but most researchers (e.g., Waitt 1980; Tallman, Lillie, and Fecht 1981; Gaylord and Porter 1987) believe that these deposits are the result of glaciofluvial activity associated with the last continental glaciation episode 20,000 to 11,000 years ago.

The Pasco gravels, approximately 0 to 80 meters thick, consist of a wide range of grain sizes, bedding, and sedimentary structures. As exposed in various excavations and well logs across the Hanford Site, sediments range in size from boulders to fine sand, with no predominance of a single size class. Towards Rattlesnake Mountain, the cobbles and boulders tend to interfinger with finer-grained beds composed of fine and coarse-grained sand, silty sand, and silt (Gaylord and Porter 1987; see also Brown 1959). Clasts are composed of basalt, with some granitic, metamorphic, and sedimentary rocks. Beds are generally nonnally graded, although massive bedding and horizontal bedding with rare parallel lamination also occur. Observed sedimentary structures include trough cross-stratification in the coarser fraction and ripple drift stratification in the fme component. Topographic expression of the Pasco gravels across the basin includes large-scale channel bars and current ripples.

Touchet Bed deposits up to 5 meters thick are exposed in the headwall of Dry Creek Canyon, a tributary of the Cold Creek Valley located on the northern flank of Rattlesnake Mountain. The exposure consists of twenty or so rhythmically bedded deposits of silty, very fine sand that grades to slightly sandy silt and silt with some clay. Each textural class of sediment is associated with distinctive sedimentary structures; very fme sand produces parallel laminations, slightly sandy silt comprises wavy climbing ripple laminations (with ripple crests oriented up-canyon), and silt deposits are invariably massive. Discontinuous scour of fine-grained deposits and fill with lenses of coarse sand, granules, and pebbles are present but uncommon. Contained within the graded sequence, near the top of the Touchet exposure, are two laterally continuous bands of pale pinkish-white tephra 20 to 25 centimeters thick. Ash layers are separated by a bed of massive silt Numerous carbonate horizons are present in the exposure, generally in the silty massive portion of each rhythmite, and animal burrows and root traces are common in basal sand.

The Pasco gravels and Touchet Beds represent deposits of "catastrophic" floods that occurred when ice dams failed along the continental glacier margin in Montana, Idaho, northern Washington, and southern British Columbia (Tallman, Lillie, and Fecht 1981). Most workers (Baker 1971; Waitt 1980; Atwater 1984) agree that the most likely source of floodwaters was glacial Lake Missoula in Montana; drainage of the lake ensued each time the water rose high against its ice-sheet dam (the Purcell Trench lobe), possibly floating the dam as well as spilling over (Waitt 1980; Atwater 1984, 1987). Radiocarbon dating of rhythmites and identification of the ash couplet as Mt. St Helens set " $S$ " (dated at 13,000 yr B. P. by Mullineaux et al. 1977) in southern Washington, and counts and radiocarbon dating of varves in the Sanpoil Valley (Atwater 1986) indicate that Missoula flood deposits posi-dade 19,000 years B.P. (Atwater 1987).

The Pasco gravels are the result of deposition in numerous anastomosing channels across a broad braidplain, formed as floodwaters were debouched into the Pasco Basin. According the Tallman, Lillie, and Fecht (1981), floodwaters entered the basin by three routes: 1) through Sentinel Gap, 2) across the northeastern flanks of the basin through several coulees, and 3) down the Snake River. Evidence for this is the existence of coarsest gravels immediately south of Sentinel Gap and south of the Gable Mountain/Gable Butte constriction, as well as below the mouth of the Snake River. 
Fine-grained, rhythmically bedded Touchet Beds fonned when floodwaters were hydraulically impounded behind Wallula Gap, resulting in the creation of a temporary lake reaching an elevation of 365 meters in the basin (Tallman, Lillie, and Fecht 1981) and backflooding up tributary canyons. Evidence for backflooding in Dry Creek Canyon is given by ripple crests oriented up-valley in the rhythmites. Graded bedding indicateS that the sediment was carried in suspension and settled out as current velocities diminished, once floodwaters had entered the tributaries.

The number of Pleistocene floods that inundated eastern Washington is currently under debate. Locally, three sedimentary sequences identified in boreholes are interpreted to be three separate flood events (Brown 1981; see also Baker 1978 and Waitt 1978). Stratigraphic evidence for as many as twelve floods is present in the Spokane area (Stradling, Kiver, and Rigby 1980). Waitt (1980) saw evidence for at least 40 floods in the Touchet Beds of southern Washington, and Atwater (1986) has counted as many as 89 inundations of the Sanpoil River valley and its tributaries. Alternative hypotheses by Baker (1973) and Bjornstad (1980) suggest that the sedimentary cycles (fmingupward sequences) interpreted by others to represent individual flood events are actually multiple hydraulic pulses in one major event.

Although individual floods are difficult to discern in boreholes or pits in Pasco gravels, evidence from Touchet Beds exposed in Dry Creek Canyon and elsewhere suggest that each rhythmite represents a single flood event The Mt. St. Helens " $S$ " ash set exists hundreds of meters below the maximum level of hydraulic ponding in the basin"system, without any indication that the ash was waterlaid. Furthermore, massive sediment exists above, below, and between ash layers. These characteristics indicate an eolian origin of deposition for the ash, and subaerial exposure of graded rhythmites between inundations. Other evidence includes the presence of massive beds, suggesting either an eolian origin or wind-reworking of fluvial sediments, the occurrence of scour of rhythmites and filled-in with gravel, probably representing localized channeling between flood events, and filled-in rodent burrows meters below the surface. Animal burrows in flood sediments indicate periods of surface stability long enough for recolonization by plants and rodents. Given the scale of the slackwater deposits, this period must have lasted years.

\section{Holocene Deposits}

Pleistocene and Holocene sediments of diverse origins unconformably overlie deposits of all ages on the Hanford Site. Eolian sediments (dune sand and loess) blanket most of the area to varying depths. Recent alluvium is present on the floodplains of the Yakima and Columbia Rivers and in the Cold Creek and Dry Creek valleys. Minor amounts of talus and colluvium flank anticlinal ridges.

Stable and semi-active dunes and massive eolian sediments occur across the Hanford Site. These deposits are generally 1 to 1.5 meters thick, although in more active areas dune sand may be as thick as 10 meters. Dune deposits consist of silty very fme to medium sand, with up to 15 percent (by volume) coarse sand, granules, and pebbles; the coarser constituents generally act as surface lag in blowout areas between vegetation. Sedimentary sttuetures observed in dune sand include large-scale eolian cross-bedding and small-scale wind-ripple stratification, the latter being confined to the finer grain sizes. Eolian sediments often contain animal burrows and calcium carbonate Stage I (Gile, Peterson, and Grossman 1966) development.

Holocene alluvium occurs within and adjacent to both perennial and ephemeral surface water systems. Perennial systems include the Columbia and Yakima rivers. Along the Columbia River there are at least two and possibly three post-Missoula flooding constructional terraces, but little work has been done on the stratigraphy, sedimentology, or chronology of the deposits. Yakima River alluvium has not been examined.

The alluvium of ephemeral stream deposits has been studied in slightly more detail. As exposed in Dry Creek Canyon, Holocene strata are characterized by flash flood deposits. Touchet Beds are truncated by basaltic diamictons up to 2 meters thick. The diamictons consist of angular cobbles and boulders in a poorly sorted sand and silt matrix. Overlying the diamictons are graded and massive beds of sand and silt containing evidence of scour and fill and channel shifting. A 30-centimeter-thick layer of ash from Mt. Mazama (dated at $6850+40$ yr B. P. by Bacon 1983) occurs within 1.5 meters of the surface, and multitudinous organic stringers suitable for radiocarbon dating cross-cut the graded beds, but stratigraphic description and analysis have been insufficient to establish the chronology of flash-flooding in ephemeral stream channels on the Hanford Site.

\section{Topography and Bydrology}

The geologic history of the area is reflected in the resultant topography of the Hanford Site. Anticlinal ridges flanking the basin and contained within it are the result of late Miocene deformation of previously deposited sheetflood basalts. The Columbia River exists as a stream within a much larger drainage channel formed during the 
waning periods of continental glaciation 13,000 to 12,000 years ago. Dunes and eolian sediments that blanket the basin do so in response to wind activity that has been prevalent for the last 10,000 years.

The topography of the Hanford Site can be divided roughly into 16 distinctive subenvironments based on relief, distance from perennial water sources, and, in a few cases, sedimentology of the substrate. The following subenvironments have been identified: inland flat area, bergmounds, and long, linear escarpments, areas of stable and semi-active dunes, the slopes of Rattlesnake Mountain (including Snively Basin, nestled in its northern flank), the mid-basin buttes, landslides and alluvial fans, sediments of the Cold Creek Valley and other ephemeral stream deposits, non-riverine perennial water sources (springs), and the Columbia River.

The inland flat is an area of low relief adjacent to the Columbia River in the northern half of the Hanford Site. The inland flat encompasses the entire area between the river and the Cold Creek syncline/Rattlesnake Hills. except where punctuated by escarpments or buttes, or covered with small patches of stabilized dunes. This extensive flat area is the remnant of the late Pleistocene (Missoula flood) braidplain. The substrate is composed almost exclusively of Pasco gravels, with a thin covering of eolian sediment. Bergmounds are located near the river in the northern portion of the inland flat area, up the Cold Creek Valley. and on the flanks of Rattlesnake Mountain. According to Fecht and Tallman (1978), these landforms are the result of large icebergs grounding during flooding. The bergs not only protected underlying sediments from erosion. but dropped ice-rafted debris as they melted, forming irregularly spaced gravel mounds.

Northwest-southeast to north-south trending escarpments are narrow zones of moderate slope separating areas of little to no relief. They occur in all portions of the basin. and represent the lee faces of large-scale, coarsegrained braidplain bars that formed during late-Pleistocene flooding.

Stable and semi-active dune fields cover the southern portion of the Site, from the Columbia River to Rattlesnake Mountain. Stabilized northeast-trending longitudinal dunes cover the south central portion of the basin; semi-active. largely parabolic dunes occur to the north and east, along the Columbia River. Dune fields are the product of prevailing winds from the southwest, probably extant subsequent to the last Missoula flood. Dune sand is chiefly reworked fme-grained glaciofluvial sediment (Tallman, Lillie. and Fecht 1981).

Anticlinal ridges within and flanking the basin provide most of the topographic relief on the Hanford Site. Buttes, including Gable Mountain and Gable Butte, are areas of high relief surrounded by inland flats. The slopes of the Rattlesnake Hills, Yakima Ridge. and Umtanum Ridge can be further subdivided into moderate slopes. steep slopes, and very steep slopes, based on relief. Moderate slopes are areas of moderate relief with varying degrees of dissection. Steep slopes have steeper relief and little dissection; very steep slopes have extremely high relief. and are generally located near ridge crests. Snively Basin, on the northern flank of Rattlesnake Mountain, is an upland area of moderate to steep relief dissected by steep. narrow canyons.

Alluvial fans and landslide deposits flank the slopes of the Rattlesnake Hills and White Bluffs. On the Hanford Site. alluvial fans emanate from Snively Canyon and the Benson Spring drainage on the northern side of Raluesnake Mountain. Like fans in other semi-arid regions, Hanford fans are constructed of multiple surfaces (segments), with the oldest surfaces highest in elevation on the outer margins and progressively younger and lower surfaces set down within the main body of the fan. The sedimentology of the Snively Canyon fan consists of massive debris flow deposits of angular basalt cobbles in a silty sand matrix. Data from boreholes indicate that the fan is dominantly Ringold-age (pliocene) fanglomerates, veneered with later fan deposits. Touchet Beds. eolian silt, and ML St. Helens set liS" and ML Mazama tephras. The fan was largely built during periods of greater runoff, as indicated by the thin sediment cover overlying the ash beds (Brown 1970).

Jumbled, hummocky landslide deposits occur along the northern and eastern slopes of the Rattlesnake Hills and the western slope of the White Bluffs. From his study of landslides in the Pasco Basin, Brown (1968) concluded that the primary cause of landsliding in this region appears to be saturation of the ground (due to elevated or perched waler tables) on steep or oversteepened slopes. He then postulated that landslide activity in the basin has been confmed to two major time periods: 1) during flooding of the basin by glacial melt and floodwaters between 19,000 and $11.000 \mathrm{yr}$ B. P., and 2) during this century. as a result of elevated water tables associated with the Columbia Basin Irrigation Project. Topographic evidence supports this idea to some degree. Older slide deposits are characterized by deeper soil development, more extensive vegetation. and subdued topography. Younger slides block modern roads. are markedly unvegetated. and have raw, highly visible slide scarps.

Ephemeral stream deposits make up a relatively small portion of Hanford Site topography at the base of the Rattlesnake Hills, in the Cold Creek and Dry Creek valleys. Geologic mapping of Cold Creek deposits divide the 
sediments into two textural facies (fme and coarse-grained) and assign a late Pleistocene age to each. Dry Creek Valley strata, as previously discussed, are composed of sediments spanning the late Pleistocene and Holocene. Ephemeral stream deposits generally exhibit moderate relief, except where flash floods have incised deep, steep-walled canyons.

Nonriverine perennial water sources include Benson Spring, Snively Spring, Lower Snively Spring, and Rattlesnake Spring on or adjacent to Rattlesnake Mountain, and West Lake, at the base of Gable Mountain. These water sources exist for a variety of reasons, but the two most common reasons on the Hanford Site seem to be the occurrence of perched water tables, or the aqueous disposal of waste, which yields artificial recharge and the creation of nodes in the water table. An example of the former situation is Rattlesnake Spring, which, according to Brown (1970), is the result of a nearly flat-lying, virtually impermeable bed of compact silt that perches an already high water table. Artificial recharge has caused West Lake to become a perennially open body of water.

The Columbia River is the only major perennial surface water resource within the Hanford Site. Above Richland, the Columbia drains an area of many thousands of square kilometers in Washington, Idaho, Montana, and British Columbia. The discharge of the river varies seasonally. Peak runoff occurs from May through July, corresponding with the melting of alpine snowpacks in the Okanogan Highlands and Rocky Mountains. Flows decrease to base flow in October and remain low throughout the winter, unless augmented by winter thunderstorms. The daily discharge at Pasco, Washington, ranges from an autumn low of $1600 \mathrm{~m}^{3} / \mathrm{s}$ to a spring high of 11,000 $\mathrm{m}^{3}$ Is (Nelson and Haushild 1970; no period of record specified). Average annual discharge is about $3400 \mathrm{~m}^{3} I s$ (Rice 1980). No perennial or ephemeral tributaries enter the Columbia River between Priest Rapids Dam and the Yakima River confluence just south of Richland.

The Hanford Reach is the last free-flowing (undammed) stretch of the Columbia River, and, as such, the channel retains much of its pre-dam morphology. Width of the river ranges from 360 to 550 meters, and depth from 3 to 12 meters during average annual flow conditions (Rice 1980). The river channel is essentially straight, with little to no meandering or point bar formation. From Priest Rapids Dam the river flows northeast, up and around the horn of the Columbia, then southeast, and fmally south towards Pasco. The configuration of the present-day channel is a consequence of the final Missoula flood, which occurred about 12,000 years ago; the flow path is probably controlled by the presence of Pleistocene flood bars and outwash fans. Because the Pleistocene features were formed at much higher discharges and greater stream power, the modern-day channel is stable.

The sediment load of the Columbia River ranges from boulders to clay, and sediment discharges vary seasonally. Bedload consists of cobbles and boulders, which may move only during the spring floods. Sand, silt, and clay make up the suspended load, which, on the whole, is low, ranging from a few milligrams per liter during low flows to several hundred milligrams per liter of equal parts of sand and mud during the spring floods (Nelson and Haushild 1970). Sediment is stored in the Reach along the narrow modern floodplain, within the one or two older constructional terraces, and as mid-channel islands. Island location and spacing are most likely the result of Pleistocene channel bar placement in the Hanford Reach, and the surfaces have probably received fme sediment into modern (pre-dam) time.

The groundwater hydrology of the Hanford Site consists of a two-aquifer system. The confmed aquifers are contained within the sedimentary interbeds and weathered flow tops between flood basalts. Groundwater from topographically high areas moves laterally through the basalts, and is eventually discharged to the unconfmed aquifer where the two intersect, as at West Lake. The unconfined aquifer is contained within the fluvial and glaciofluvial sediments overlying the basalts; flow is primarily through the Middle Ringold conglomerate in the eastern portion of the site and in Pasco gravels to the west. Near the river, Recent alluvium is thick enough to contain at least a portion of the unconfined aquifer. Flow of groundwater within the aquifer is from the western highland areas eastward to the Columbia River. The water table is therefore highest in elevation in the Cold Creek Valley, occurring just a few meters below the surface. Beneath the 200-Area plateau, the water table is 75 to 90 meters in depth, and reaches its lowest elevation at the river. The unconfmed aquifer receives natural recharge from precipitation, surface runoff, and the Columbia and Yakima rivers during flooding. Over the entire reach, the aquifer discharges between 1.4 and $1.7 \mathrm{~m}^{3} / \mathrm{s}$ to the river through the bed and banks.

\section{Ecology}

The Hanford Site is composed of diverse ecological areas. Figure C.1 illustrates some representative features. 


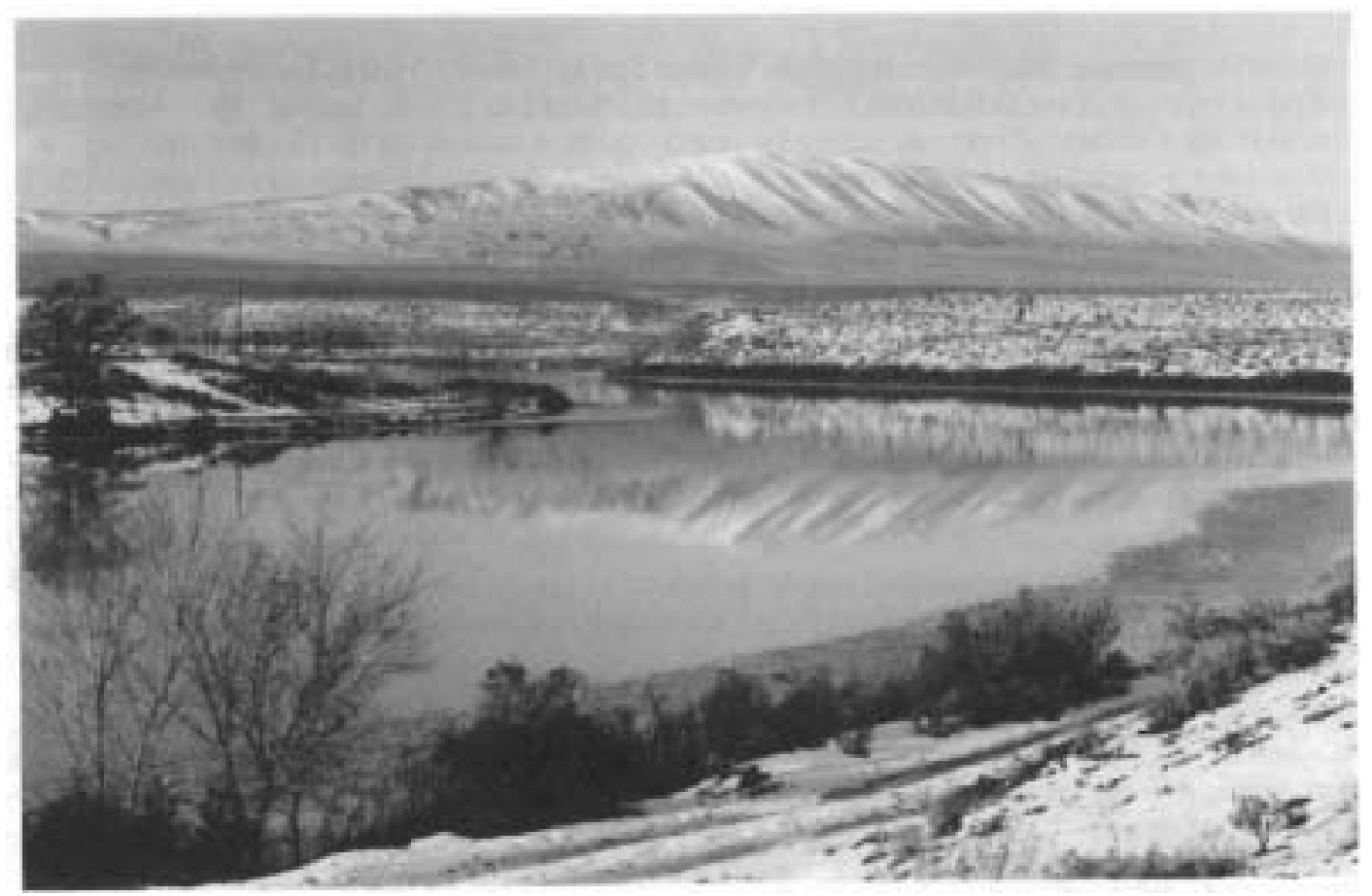

FIGURE C.1. Characteristic Environmental Areas of the Hanford Site

\section{$\underline{\text { Snively Basin }}$}

The natural vegetation growing on silt loam soil in the Snively Basin is classified as Artemisia tridentata/Agropyron spicatum habitat type (Daubenmire 1970). The natural vegetation on the stony soils is representative of the Eriogonum thymoides/Poa sandbergii habitat type at the higher elevations and Eriogonum sphaerocephalum at the lowest elevations.

Elk (Cervus elaphus), mule deer (Odocoileus hemionus), coyote (Canis latrans), badger (Taxidea taxus) and bobcat (Lynx rufus) are the resident big game and predatory mammals in the Basin. There is a small population of sage grouse (Centrocercus urophasianus), but the chukar partridge (Alectoris chukar) is the most abundant game bird (Rickard, Hedlund and Schreckhise 1974).

The characteristic breeding passerine birds in the shrub-steppe area are homed larks (Eremophila alpestris) and western meadowlarks (Stumella neglecta). Less-abundant breeding passeTines are Brewer's sparrows (Spizella brewerii), grasshopper sparrows (Ammodrammus savannarum), and vesper sparrows (Pooecetes gramineus). The streamside vegetation that borders the spring at the abandoned homestead site in the Snively Basin provides nesting habitat for California quail (Lophortyx califomicus), Chinese ring-necked pheasants (Phasianus colchicus), northern orioles (Icterus glabula), lazuli buntings (Passerina amoena), yelfow warblers (Dendroica petechia), western kingbirds (Tyrannus verticalis), yellow-breasted chat (Icteria virens), and others (Cushing 1988).

\section{Buttes}

Gable Mountain and Gable Butte are isolated areas of raised relief centrally located on the Hanford Site. These areas consist of two primary habitat types: the Artemisia tridenlala/Poa sandbergii habitat and the Artemisia rigida/Poa sandbergii habitat. Stiff sage (A. rigida) is restricted to the buttes on the Hanford Site. Other species of interest include Carey's balsamroot (Balsamorhiza careyana), desert parsley (Lomalium macrocarpum), and numerous buckwheat species (Eriogonum spp.). 
The characteristic birds nesting on these areas are the chukar partridge, rock wren, and prairie falcon (Falco mexicanus). The chukar nests in the ground. usually in grass cover. The rock wren nests in talus, and the prairie falcon nests on ledges of steep cliffs. Red tailed hawks (Buteo jamaicensis) nest on Gable Butte. Mammals include mule deer, coyotes, badgers, and bobcats as the primary large herbivores and predators. Small mammals include bushy-tailed woodrat (Neotoma cinerea), sagebrush vole (Lagurus curtatus), deer mouse (Peromyscus maniculalus), Great Basin pocket mouse (Perognathus parvus), and black-tailed hares (Lepus califomicus). Northern Pacific rattlesnakes (Crotalus viridis) occur in and near the talus areas (Marr et al. 1988).

\section{$\underline{\text { Stable Dunes }}$}

There have been no faunistic surveys made of the stabilized sand dunes on the Hanford Site. The most detailed studies are those conducted as terrestrial ecology baseline studies in the early 1970's at the Washington Public Power Supply System's WNP-2 Nuclear Reactor Station in the southeastern sector of the Site. There, trapping studies were done to determine species composition and relative abundance of small mammals. The most abundant small mammal was the Great Basin pocket mouse with lesser numbers of deer mice, western harvest mice (Reithrodontomys megalotis), and northern grasshopper mice (Onychomys leucogaster). Stabilized sand dune habitats support nesting populations of sage sparrows (Amphispiza belli), western meadowlarks, loggerhead shrikes (Lanius ludovicianus), long-billed curlews (Numenius americanus), burrowing owls (Athene cunicularia), and homed larks (Eremophila alpestris) (Hedlund and Rogers, 1976; Rickard, Hedlund and Schreckhise 1974).

The plants characteristic of stabilized dunes are prickly-pear cactus (Opuntiafragilis), scurf-pea (Psoralea lanceolala), pale evening primrose (Oenothera pallida), tarweed fiddleneck (Amsinckia lycopsoides), indian rice grass (Oryzopsis hymenoides), needle-and-thread grass (Stipa comara), cheatgrass (Bromus tectorum), big sagebrush (Artemisia tridentala), and bitterbrush (Purshia tridentata). Bitterbrush provides browse for mule deer. Stabilized dunes are the habitat for Thompson's sandwort (Arenariafranklinii var. thompsonii), a rare species in the State of Washington.

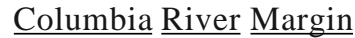

Islands in the Columbia River provide preferred nesting habitat for a resident population of Great Basin Canada geese (Branta canadensis moffittl). The nesting season extends from March to May, and the brood-rearing season occurs between May and August Other birds nesting on the islands include ring-billed gulls (Larus delawarensis), California gulls (L. califomicus), and Forster's terns (Sternaforsten). Trees growing along the river provide nightroosting sites for aggregations of bald eagles (Haliaeetus leucocephalus) that spend October through February foraging upon spawned-out salmon and waterfowl. Trees also provide nesting sites for several colonies of great blue herons (Ardea herodias). Herons are year-round residents of the Hanford Site. Their nesting season extends from April through June. The steep-faced bluffs (White Bluffs) along the eastern shore of the river provide nesting places for thousands of cliff swallows (Petrochelidon pyrrhonota). The nesting season is May and June. In winter, the margins of the Columbia River provide resting habitat for thousands of migrating waterfowl. The most abundant birds are mallards (Anas platyrhynchos) and lesser Canada geese (Cushing 1988; Fitzner et al. 1979).

The primary big game animal in this region is the mule deer. Islands in the Columbia River provide preferred fawning habitat for this animal. Deer swim from me shore to the islands to give birth and then return to the shore when the fawns are more mobile. Furbearers include muskrats (Ondatra zibetheca), mink (Mustela vison), longtailed weasel (Mustelafrenata), and beaver (Castor canadensis). Other mammals to be found along the river margins include Great Basin pocket mice, deer mice, western harvest mice, montane voles (Microtus montanus), Merriam's shrews (Sorex merriami), vagrant shrews (Sorex vagrans), striped skunks (Mephitis mephitis), and raccoons (Procyon lotor) (Hedlund and Rogers 1976; Rickard, Hedlund and Schreckhise 1974).

The shoreline of the Columbia River supportS a narrow zone of riparian plants characterized by small isolated stands of tree and shrub willows (Salix spp.) interspersed with semi-aquatic herbaceous plants, such as reed canary grass (phalaris araundinacea) and others. Persistent-sepal yellowcress (Rorippa calycina var. columbiae) occurs in this habitat. It is listed as an endangered plant species by the Washington State Department of Natural Resources. (Fitzner et al 1979).

The river itself is inhabited by 44 species of fish, 28 of which are native (Cushing 1988). The most economically important of these, now and in the past, are the anadromous salmonids--chinook (Oncorhynchus tshawytscha), sockeye (0. nerka), and coho (0. kisutch) salmon, and steelhead trout (0. mykiss). Salmon runs begin with the spring run of chinook in April and end with the fall chinook in October-November. The fall chinook spawn in the Hanford Reach in great numbers, primarily along Islands near the White Bluffs. Other large, common 
native fish are the largescale sucker (Catostomus macrocheilus), bridgelip sucker (C. columbianus), white sturgeon (Acipenser transmontanus), northern squawfIsh (Ptychocheilus oregonensis), Pacific lamprey (Entosphenus tridentata), mountain whitefIsh (Prosopium williamsoni), Dolly Varden (Salveiinus malma), and cutthroat trout (Oncorhynchus darla).

\section{$\underline{\text { Active }} \underline{\text { Sand Dunes }}$}

There have been no faunistic surveys made of the active sand dunes on the Hanford Site. The dunes are used as fawning areas for a few mule deer. Ferruginous hawks, listed as an endangered species in the State of Washington, nest on power line towers near the sand dunes. Vegetation on active dunes is dominated by Indian rice grass.

Slopes of the Rattlesnake Hills and Yakima River

The moderate and steep slopes of the Rattlesnake Hills range in elevation from 850 to 3600 feet above mean sea level. The major plant habitat types are Artemisia tridentata/Agropyron spicatum, Artemisia/Poa sandbergii, Eriogonum thymoides/P. sandbergii, Eriogonum sphaerocephalumlP. sandbergii, and Eurotia lanata/P. sandbergii (Cushing 1988).

The characteristic birds are the chukar partridge, Hungarian partridge, Brewer's sparrow, sage sparrow, western meadowlark, homed lark, and sage grouse. Big game animals are the elk and mule deer. Other game animals include the white-tailed hare (Lepus townsendil) and Nuttall's cottontail (Sylvilagus muttalli). Black-tailed hares occur in this area, but their densities decline with increasing elevation, such that relatively few occur above 1200 feet. Predators include the badger, coyote, bobcat, and long-tailed weasel. Small mammals include bushy-tailed woodrats in rocky areas, and sagebrush voles at the higher elevations, Townsend's ground squirrel (Spermaphilus townsendii) in lower elevations, and Great Basin pocket mice, deer mice, northern pocket gophers (Thomomys talpoides), and harvest mice throughout. The northern grasshopper mouse apparently occurs only in the Artemisia/Poa habitat (Cushing 1988).

\section{$\underline{\text { Non-Riverine Perennial Water } \underline{\text { Sources }}}$}

The best-developed corridors of streamside tree/shrub communities occur at Rattlesnake Springs and Snively Springs. These thickets provide nesting sites for a variety of birds, including the California quail, northern oriole, western kingbird, yellow warbler Brewer's blackbird (Euphagus cyanocephalus), black-billed magpie (Pica pica), long-eared owl (Asio otus), and common crow (Corvus brachyrhynchos). Chinese ring-necked pheasants also nest in these areas. Mule deer are common in these areas, as are elk during the rutting season. Long-tailed weasels, bobcat, badger, and coyote are the mammalian predators in the area. Montane voles, Great Basin pocket mice, deer mice, western harvest mice, sagebrush voles, Merriam's shrews, and vagrant shrews are relatively common small mammals. Mink have also been reported in the area. The Northern Pacific mattlesnake occurs in the area, as does the side-blotched lizard (Uta stansburiana), the Great Basin spadefoot toad (Scapmopus intermantanus), the western toad (Bufo boreas), and the Pacific treefrog (Hyla regilla) (Cushing 1988).

The streamside vegetation consists of a narrow corridor of deciduous trees: cottonwoods and willows intermingle with squawberry (Ribes aureum), service berry (Amelanchier alnifolia), blue elderberry (Sambucus cerulea), chokecherry (Prunus virginianus), wild rose (Rosa spp.), mock orange (Philadelphus lewisil) and virgin's bower (Clematis iigusticifoiia). The only greasewood (Sarcobatus vermiculatus) on the Hanford Site is found in this area.

\section{Cold Creek Valley}

The vegetation of the Cold Creek Valley is representative of the Ariemisia tridentata/Poa sandbergil and Grayia spinosa/Poa sandbergii habitat types. (Rickard 1988). Trees planted around military installations in the 19505 still survive and provide nesting sites for Swainson's hawk (Buteo swainsoni), northern oriole, western kingbird, and black-billed magpie. The characteristic nesting shrub-steppe birds are the western meadowlark, sage sparrow,longbilled curlew, burrowing owl,loggerhead shrike, homed lark, and lark sparrow (Chondestes grammacus). Northern harriers (Circus cyaneus) also nest in this area (Rogers and Rickard 1977).

Big-game occupants are elk and mule deer. Elk use of this area is limited primarily to the fall and winter months. Other mammals in the area include black-tailed hare, bobcat, badger, coyote, Great Basin pocket mouse, northern pocket gopher, Townsend's ground squirrel, and deer mouse. Side-blotched lizards and Northern sagebrush lizards (Sceloporus graciosus) are common lizards of the area (Marr et al. 1988). 
Inland Flats

The vegetation of this region is a mosaic of shrubs and grass-dominated stands created by wildfIres. Natural vegetation is a mixture of annual and perennial grasses, especially cheatgrass and Sandberg's bluegrass, with an overstory of short-statured, widely spaced shrubs. Carey's balsamrool, pale evening primrose, large-flowered desert parsley, and turpentine cymopterus (Cymopterus terebinthinus) are common forbs. Common grasses include Sandberg bluegrass, downy wheatgrass (Agropyron dasytachyum), bottlebrush squirreltail (Sitanion hystrix), and needle-and-thread grass. The primary community is the Artemisia tridentata/Poa sandbergii habitat type. A few representatives of the Grayia spinosa/Poa sandbergii habitat type may also be found (Rickard and Schuler 1988; Rogers and Rickard 1977).

Characteristic nesting bird species include the western meadowlark, sage sparrow, burrowing owl, mourning dove (Zenaida macroura), homed lark, long-billed curlew, lark sparrow, and loggerhead shrike. Western meadowlark and sage sparrow are the most abundant breeding birds. Swainson's hawks and black-billed magpies nest in the trees to be found around abandoned military installations. Ferruginous hawks (Buteo regalis) occasionally nest on trees and power poles in the area. Mammals include mule deer (relatively scarce), black-tailed hare, badger, coyote, Great Basin pocket mouse, Townsend's ground squirrel, northern pocket gopher, deer mouse, and western harvest mouse. Side-blotched lizards are the most common herpetile of this region. Predominant snakes are the yellow-bellied racer (Coluber constrictor) and the Great Basin gopher snake (Pituophis melanoleucus) (Rogers and Rickard 1977; Schuler, Rickard and Sargeant 1988).

$\underline{\text { References }}$

Atwater, B. F. 1984. "Periodic Floods from Glacial Lake Missoula into the Sanpoil Ann of Glacial Lake Colwnbia, Northeastern Washington." Geology 12:464-467.

Atwater, B. F. 1986. Pleistocene Glacial-lake Deposits of the Sanpoil River Valley. Northeastern Washington. U.S. Geological Survey Bulletin 1661, U.S. Geological Survey, Reston, Virginia

Atwater, B. F. 1987. "Status of Glacial Lake Columbia During the last Floods from Glacial Lake Missoula." Quatemary Research 17:182-201.

Bacon, C. R. 1983. "Eruptive History of Mount Mazama and Crater Lake Caldera, Cascade Range, U.S.A." Journal of Volcanology and Geothermal Research 18:57-117.

Baker, V. R. 1971. "Paleohydrology of Catastrophic Pleistocene Flooding in Eastern Washington." Gicological Society of America Abstracts with Brograms 3(7):497 (Abstract).

Baker, V. R. 1973. Paleohydrology and Sedimentology of Lake Mjssoula Elooding in Eastern Washington. Special Paper 144, Geological Society of America, Boulder, Colorado, 79 pp.

Baker, V. R. 1978. "Quaternary Geology of the Channeled Scabland and Adjacent Areas." In The Channeled Scablands. V. R. Baker, and D. Nwnmudal, eds., pp. 17-35. CR 157260, National Aeronautics and Space Administration, Washington, D.C.

Bjornstad, B. N. 1980. Sedimentology and Depositional Envjronment of the Touchet Beds. Walla Walla River Basin. Washington. RHQ-BWI-SA-44, Rockwell Hanford Operations, Richland, Washington.

Brown, D. J. 1959. Subsurface Geology of the Hanford Separation Areas. HW-61780, General Electric Hanford Atomic Products Operation, Richland, Washington.

Brown, R. E. 1968. $\underline{\text { A Study }}$ of Reported Faulting in the Pasco Basin. BNWL-662, Pacific Northwest Laboratory, Richland, Washington.

Brown, R. E. 1970. Interrelationships of Geologic Formations and Processes Affecting Ecology as Exposed at

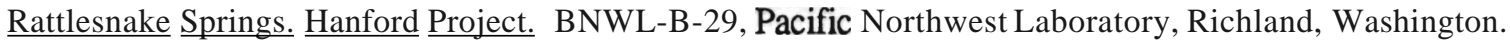


Brown, R. E. 1975. "Ground Water and the Basalts in the Pasco Basin." In Proceedings of the $\underline{\text { 13th Engineering }}$ Geology and Soils Engineering Symposium. pp. 13-140, University of Idaho, Moscow, Idaho.

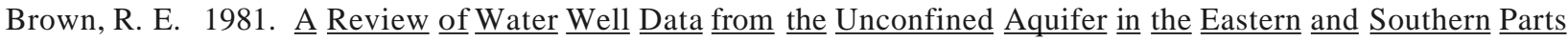
of the Pasco Basin. RHO-BWI-C-56, Rockwell Hanford Operations, Richland, Washington.

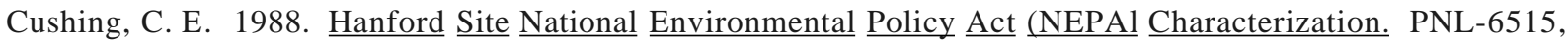
Pacific Northwest Laboratory, Richland, Washington.

Daubenmire, R. F. 1970. Steppe Vegetation of Washington. Washington Agricultural Experiment Station, Technical Bulletin 62. Washington State University, Pullman, Washington.

Fecht, K. R., and A. M. Tallman. 1978. "Bergmounds Along the Western Margin of the Channeled Scablands, South-Central Washington." Geological Society of America Abstracts with Programs. 10(7):400.

Fitzner, R. E., K. A. Gano, W. H. Rickard, and L. E. Rogers. 1979. Characterization of the Hanford $\underline{300} \underline{\text { Area }}$ Burial Grounds. PNL-2774, Pacific Northwest Laboratory, Richland, Washington.

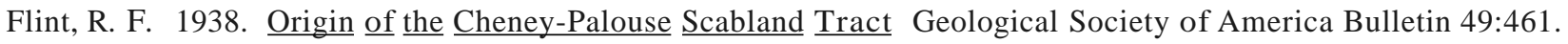

Gaylord, D. R., and E. P. Porter. 1987. Proposed Short and Long Tenn Plans for Development of Conceptual Models of Flow and Transport Characteristics Within Hanford Reservation Post-Basalt Sedimentary Deposits. Prepared for Pacific Northwest Laboratory by Washington State University, Pullman, Washington.

Gile, L. H., F. F. Peterson, and R. B. Grossman. 1966. "Morphological and Genetic Sequences of Carbonate Accumulation in Desert Soils." Soil Science 101(5):347-360.

Gustafson, E. P. 1978. The Vertebrate Faunas of the Pliocene Ringold FOrmation. South Central Washington. Museum of Natural History Bulletin No. 23, University of Oregon, Eugene, Oregon.

Hedlund, J. D., and L. E. Rogers. 1976. Characterization of Small Mammal Populations Inhabiting the B-C $\underline{\text { Crib }}$ Environs, BNWL-2181, Pacific Northwest Laboratory, Richland, Washington.

Marr, N. V., C. A. Brandt, R. E. Fitzner, arid L. D. Poole, 1988. Habitat Associations of Vertebrate Prey Within the Controlled Area Study Zone. PNL-6495, Pacific Northwest Laboratory, Richland, Washington.

Mullineaux, D. R., R. E. Wilcox, R. Fryxell, W. F. Ebaugh, and M. Rubin. 1977. Age of the Last Major Scabland Flood of Eastern Washington, as Inferred from Associated Ash Beds of Mount St. Helens Set."

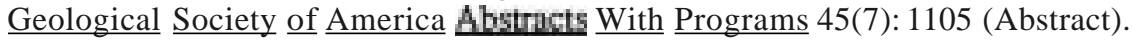

Myers, C. W., S. M. Price, J. A. Caggiano, M. P. Cochran, W. J. Czimer, N. J. Davidson, R. C. Edwards, K. R. Fecht, G. E. Holmes, M. G. Jones, J. R. Kunk, R. D. Landon, R. K. Ledgerwood, J. T. Lillie, P. E. Long, T. H. Mitchell, E. H. Price, S. P. Reidel, and A. M. Tallman. 1979. Geologic Studies of theColumbia Plateau. $\underline{\text { a }}$ Status Report. RHO-BWI-ST-4, Rockwell Hanford Operations, Richland, Washington.

Nelson, J. L., and W. L. Haushild. 1970. "Accumulation of Radionuclides in Bed Sediments of the Columbia River Between the Hanford Reactors and McNary Dam." Water Resources Reseanch 6(1):130-137.

Newcomb, R. C. 1958. "Ringold Formation of Pleistocene Age in Type Locality, the White Bluffs, Washington." AmeriCan Journal of Science 256:328-340.

Newcomb, R. C., J. R. Strand, and F. J. Frank. 1972. Geology and Ground-Water Chamacteristics of the Hanford

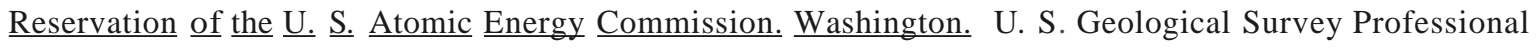
Paper 717, U.S. Geological Survey, Reston, Virginia. 
Rice, D. G. 1980. Overview of Cultural Resources on the Hanford Reservation in South Central Washington State. RL-E-80-0043, prepared for the U.S. Department of Energy Richland Operations, Richland, Washington.

Rickard, W. H. 1988. Natural Vegetation at the Proposed Reference Repository Location in Southeastern Washington. PNL-6402, Pacific Northwest Laboratory, Richland, Washington.

Rickard, W. H., J. D. Hedlund, and R. G. Schreckhise. 1974. Mammals of the Hanford Reservation in Relation to Management of Radioactive Waste. BNWL-1877, Pacific Northwest Laboratory, Richland, Washington.

Rickard, W. H., and C. A. Schuler. 1988. Descriptions of Plant Communitjes at the Proposed Reference Repository I.ocation and Implications for Reclamation of Disturbed Ground. PNL-6494, Pacific Northwest Laboratory, Richland, Washington.

Rogers, L. E. and W. H. Rickard. 1977. Ecology of the 200 Area Plateau Waste Management Environs: A Status Report. PNL-2253, Pacific Northwest Laboratory, Richland, Washington.

Schuler, C. A., W. H. Rickard, and G. A. Sargeant 1988. Bird Associations with Shrubsteppe Plant Communities at the Proposed Reference Repository Location in Southeastern Washington. PNL-6493, Pacific Northwest Laboratory, Richland, Washington.

Smith, G. A. 1986. Coarse-Grained Non-Marine Volcaniclastic Sediment Teminology and Depositional Process. Geological Society of America Bulletin 97:1-10.

Stradling, P. E, E. P. Kiver, and J. G. Rigby. 1980. Late Pleistocene Floods and Landforms in the Spokanc. Washington Area. RHO-BWI-SA-61A, Rockwell Hanford Operations, Richland, Washington.

Swanson, D. A., and T. L. Wright. 1978. "Bedrock Geology of the Northern Columbia Plateau and Adjacent Areas." In The Channeled SCablands, edt V. R. Baker and D. Nummedal. CR 157260, National Aeronautics and Space Administration, Washington, D.C.

Tallman, A. M., J. T. Lillie, and K. R. Fecht. 1981. "Suprabasalt Sediments of the Cold Creek Syncline Area." In Subsurface Geology of the Cold Creek Syncline, edt C. W. Myers and S. M. Price. RHO-BWI-ST-14, Rockwell Hanford Operations, Richland, Washington.

Wain, R. B., Jr. 1978. "Post-Miocene Stratigraphy and Tectonism of Parts of the Great Columbia Plain and Adjacent Cascades, Washington." In Tectonics and Sejsmicity of the Columbia Plateau Workshop. Meeting Volume. Rockwell Hanford Operations, Richland, Washington.

Waitt, R. B., Jr. 1980. "About Forty Last-Glacial Lake Missoula Jokulhlaups Through Southern Washington." Journal of Geology 88:653-679. 


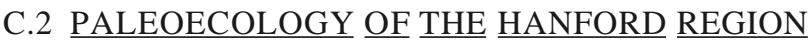

Human beings, like all animals, exist in an ecological context, and as their environment changes, they are often forced to either readapt or face a decline in numbers. Therefore, an understanding of the human past cannot be obtained without a detailed knowledge of the environments with which people interacted. The Archaeological Resources Protection Act of 1979 recognizes this relationship, stating that paleontological remains, which are the source of infonnation about past environmental conditions, are archaeological resources so long as they are found in association with artifact deposits. For purposes of this plan, association is taken to include coincidence in either time or space.

Paleoecological information can be obtained through a growing variety of disciplines, including geology, paleobotany, paleontology, stable isotope studies, and paleogeochemistry. Sources used here are geologic and biotic. From geologic evidence, one can formulate climatic periods, then look at the responses of flora and fauna. Figure C.2 indicates some of the paleoenvironmental conditions discussed in this section.

Virtually no paleoecological studies have been carried out on the Hanford Site, and few have been conducted within 50 kilometers of Site boundaries. As an alternative to direct evidence of the Site's paleoenvironments, scientists have assembled data from the entire Columbia Basin and highlands surrounding it to formulate a moving image of climate, fluvial hydrology, and biota from 13,000 years ago to historical times. This evidence, which comes from areas with moister climates, is then used to extrapolate the possible paleoecology of the Hanford Site (Figure C.3). The extrapolations are understood to be hypothetical, and will ultimately need to be evaluated with hard evidence from the Hanford area.

\section{$\underline{\text { Geologic Evidence }}$}

Landfonns and sedimentary deposits result from geologic processes that commonly include water, ice, and wind. Ice in the form of glaciers carries or pushes particles downslope as it advances. Ice fonning in rock crevices widens them and, upon thawing, may result in particles spalling from bedrock. Water transports different sizes and amounts of particles, depending on the velocity and volume of its flow and the availability of sediment for transport. Wind transports fme particles in proportion to its velocity, but only when they are exposed to air. Morraines and drift deposits left by glaciers provide evidence for ice expansion. Fluvial sediments, dunes, loess, and strata of angular rock result from water, wind, and ice expansion. Through study of the long-term variations in the relative importance of each geologic process, paleoecologists are able to generate a partial picture of long-tenn climatic change in the vicinity of the Hanford Site.

\section{Glaciation}

The Hanford Site is not high enough in altitude or latitude for glaciers to develop, so the relevance of glacier fluctuations to the project area may not be immediately apparent. However, dated moraines left by prehiS toric glacial advances provide excellent proxy evidence of climatic fluctuations that are often of regional scope.

Fluctuations in montane or continental glaciers are controlled by changes in the balance between temperature and precipitation. When snowfall in the area of the glacier's origin exceeds snowmelt, the glacier advances; the converse results in glacier recession and, if prolonged, its disappearance. Synchronous glacial fluctuations occur in response to regional variations in precipitation and temperature, and synchronous world-wide glacial advances or recessions occur in response to synchronous temperature changes only. Geologic evidence for the longterm behavior of glaciers therefore provides a measure of past climatic change, and can, under the right conditions, serve specifically as an indicator of paleotemperature.

The Okanogan lobe of the Fraser Glaciation lay to the north of the Waterville Plateau, and was undergoing rapid recession by 13,000 yr. B. p.(a) Montane glaciers of the Rat Creek Stade were simultaneously wasting in the southern Washington Cascades. By 11,000 yr B. P., continental glaciers had receded to the international boundary (Waiu and Thorsen 1983) and montane glaciers had all but disappeared (porter, Pierce, and Hamilton 1983). The continental glaciers had wasted to virtual nonexistence by about 10,000 yr. B. P. This steady wasting, although

(a) This convention refers to radiocarbon years before 1950. Radiocarbon years are computed based on the Libby half-life of 5530 years. 


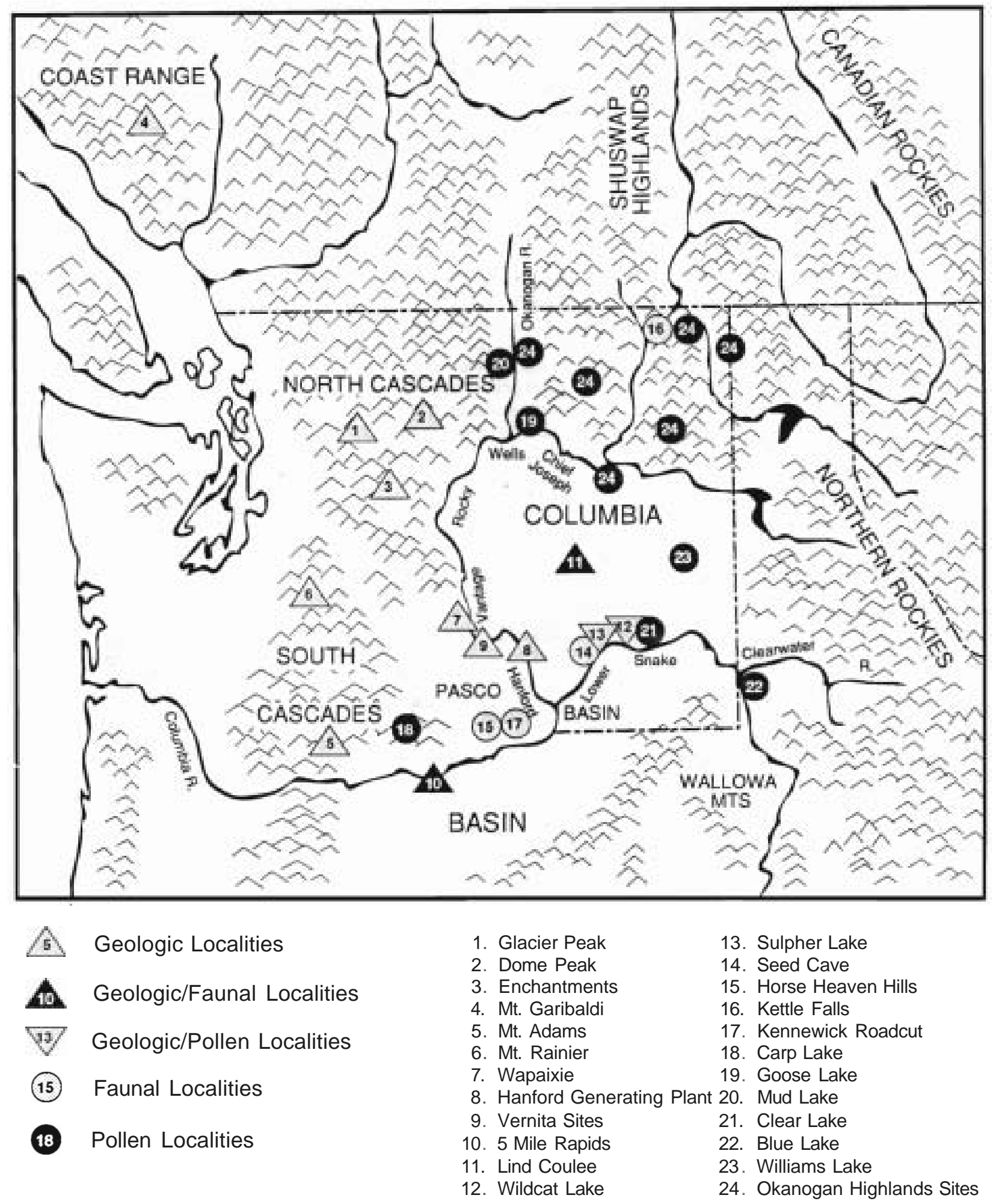

FIGURE C,2. Paleoecological Sites Mentioned in the Text 
Cultural Resource Plan, Hanford

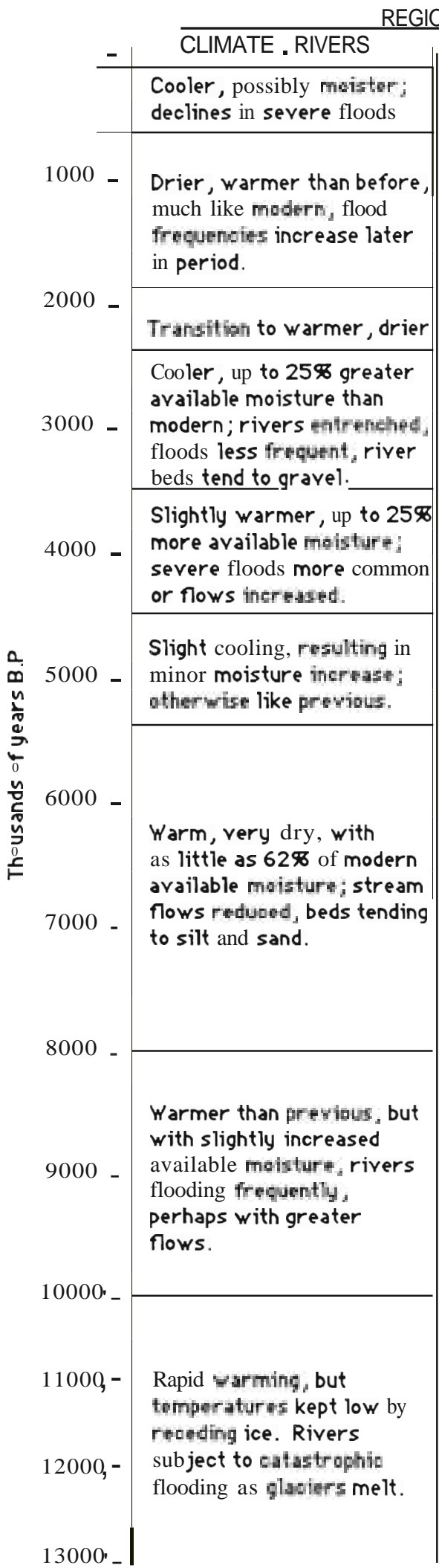

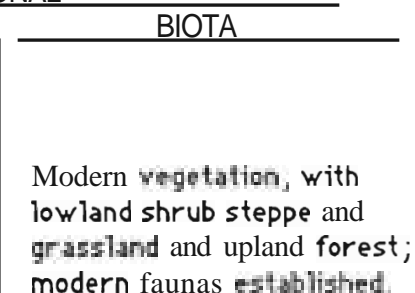

modern faunas stablished

Cold-adapted conifers move downslope; steppe vegetation remains dense, salmon runs seasonally restrioted.

Forests expand in to highlands around basin; steppes become dense; fish improve ungulates more common.

Possible, slight increase in density of steppe vegetation.

Shrub steppe dominates region, including lower mountains; terrestria 1 animal biomass low; fish reduced due to stream bed conditions, turbidity.

Orasslands cover most 01 basin, grading to shrub steppe in southeast; fauna includes bison and other grassland species.

Cold-adapted steppe tundra with diverse mammalian fauna; aquatic faunas poorly established in some major rivers
INFERRED ENVI RONMENT HANFORD AREA

Essentially modern; shrub steppe with a mean precipitation of $16 \mathrm{~cm}$; rivers as modern but for periodic variation in flow rates and flooding frequenoies.

Moist interval, beginning warm and later becoming cooler; mean available moisture of ca $21 \mathrm{~cm}$; stepp veg. dense; greater mammal biomass; fish resource improving; seasonally restrieled later in period.

Hot, dry climate with as little as $11 \mathrm{~cm}$ available moisture annually; veg. a sparse sagebrush, chenopod steppe with more extensive dune formation, reduced mammal biomass; salmon fishery declines, other aquatic resources more reliable.

Cooler, perhaps moister than modern; grass dom. steppe; faunas possibly with bison; river flows high; fish and other aquatic resources recovering from glacial meltoff.

Cold, dry shrub steppe; rivers subject to catastrophic flooding; diverse terrestrial fauna; poorly established aquatic fauna.

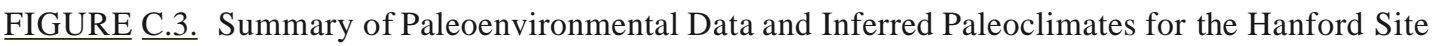


punctuated by a few brief readvances (Waitt and Thorsen 1983) is indicative of a steady wanning of temperatures in the northern Hemisphere. The presence of such a mass of ice would, however, have exerted a profound influence over the regional air and ocean temperatures, creating a cooler climate than might otherwise be expected.

Continental glaciers have not redeveloped in the last 10,000 years, but three readvances of montane glaciers appear to have been synchronous in the northern Rockies and Cascades. A fourth minor readvance is evident in a few high peaks in the northwest Cascades (Burke and Birkeland 1983; Crandell and Miller 1964; Porter and Denton 1967).

Beget (1981) has found evidence for an early Holocene advance of montane glaciers between 8500 and 7500 yr B. P., with most evidence pointing to the period between 8500 and $7900 \mathrm{yr}$ B. P. In northwestern North America, this event is expressed in the White Chuck moraine on Glacier Peak, estimated to date between 8400 and 8300 yr B. P. (Beget 1981, 1984). Moraines that predate Mazama volcanic ash (6850 yr B. P.) and are clearly much younger than Rat Creek morraines (13,000 yr B. P.) have been reported in numerous other locations, including the Brisingamen advance in the Enchantments (Waitt, Yount, and Davis 1982), the McNeeley Drift on Mt. Rainier (Crandell and Miller 1964,1974), in the Wallowa Mountains (Kiver 1974), and the Dunn Peak Morraine in the Shuswap Highlands (Duford and Osborn 1978).

There is evidence of a minor readvance of northern Hemisphere glaciers during the middle Holocene (4500 to 5500 yr B. P.; Denton and Karlen 1973) that in the Northwest appears to be confmed to the northwestern Cascades and coastal mountains of British Columbia. The South Cascade Glacier on Dome Peak in the North Cascades of Washington sheared off trees dated between 4600 and 4900 yr. B. P. (Miller 1969), and the Sphynx Glacier on Mt. Garibaldi advanced betweeen 5500 and 5000 yr B. P. The Gamma Peak advance on Glacier Peak predates 3400 yr B. P. and postdates 5500 to 5700 yr. B.P.; it probably is contemporary with the other two events. Duford and Osborn have suggested that the Spahats morraine in the Shuswap Highlands may be contemporary, but it may also be associated with the first neoglacial advance identified by Alley (1976).

The first of two widespread neoglacial advances of montane glaciers, which are also expressed throughout the Northern Hemisphere, occurred between 3500 and 2500 B. P. (Denton and Karlen 1973; Crandell and Miller 1964; Porter and Denton 1967). The most precisely dated expression of this advance in the Cascade Mountains is the Burroughs Mountain Drift, which was deposited between 3500 and $2000 \mathrm{yr}$ B. P. The Tideman Glacier on Mt. Garibaldi in the British Columbia Coast Range advanced between 2200 and 3000 yr B. P. Contemporary advances in the Rocky Mountains reached their maximum extent between 2600 and $2800 \mathrm{yr}$ B. P. (porter and Denton 1967). Morraines elsewhere in the northwest that are estimated to correspond to the early neoglacial advance have been found on ML Adams (Mahaney, Fahey, and Lloyd 1981), as well as in many areas of southern British Columbia (Alley 1976), and are postulated for the Enchantments (Waitt, Yount, and Davis 1982).

A final readvance, expressed in two stages, corresponds to the widely recognized and historically documented Little Ice Age. The early Garda Drift on ML Rainier dates between 1300 and 1600 A. D., and the later drift dates to the nineteenth century Eagle Cap 1,2, and 3 in the Wallowas (Kiver 1974), moraines I and II on Mt Adams (Mahaney, Fahey, and Lloyd 1981), the Brynhild advance in the Enchantments (Waitt, Yount, and Davis 1982), and the Raft Mountain advance in the Shuswap Highlands (Duford and Osborn 197.8) correspond to one or the other of these episodes.

Evidence of retreat and readvance of small montane glaciers during the Holocene allows the identification of both long-wave and short-wave variations in regional temperature. At 13,000 yr B.P., the continental glaciers were in recession, but the mere proximity of such masses of ice on land and glacial meltwater in rivers and the Pacific Ocean certainly depressed air temperatures in the Northwest Subsequently, conditions have been wanner. Although there have been four episodes of secular cooling at approximately 8500 to 7900,5500 to 4600,3500 to 2500 and 600 to $100 \mathrm{yr}$ B.P., in none of these cases, were temperatures as low as during the late Frasier Glaciation or during the first two millennia of its melt.

\section{Sedimentology of Cave and Rockshelter Deposits}

Sediments deposited in caves and rockshelters consist of rock spalled from their roofs, of silt, sand, and organic matter deposited by wind (eolian), organic matter deposited by animals, and, occasionally, of fluvial deposits. Rock spalling is assumed to result from water penetrating crevices in bedrock, freezing there and expanding the crevices, and releasing a spall from the bedrock surface when it thaws. Thus, the existence of moisture and seasonally cold temperatures can be inferred from the predominance of rock spall in cave sediments. Eolian sediment is derived from the ground surface around the cave and is presumed to be deposited more rapidly when little moisture 
is available and vegetation cover is sparse, and less rapidly when vegetation is dense. The relative proportions of these two sediment types, and the rate of their buildup, can be taken as indicators of local climatic conditions.

The sedimentary history of Columbia Basin caves and rockshelters has been studied by Fryxell (1963), who saw a consistent pattern throughout the region. Rock spall was the predominant sediment type prior to $8000 \mathrm{~B}$. P., with liule or no eolian sediment filling the interstices between rock fragments. At $8000 \mathrm{yr}$ B. P. there was an abrupt decline in the occurrence of rock spall, and eolian sediment was deposited almost exclusively until approximately 7000 to $7200 \mathrm{yr}$ B. P. Rockfall was again abundant for a brief interval before the deposition of Mazama ash (6850 B. P.). This was followed by nearly two millennia during which rockfall was virtually absent and eolian ash and silt were the primary sediments deposited. Rockfall then began to increase around 4000 to 4500 yr B. P., although it was still mixed with a substantial amount of eolian material; the rockfall reached a peak after $3000 \mathrm{yr}$ B. P. and declined thereafter. Rockfall was reduced to near mid-Holocene levels after $2000 \mathrm{yr}$ B. P., and a [mal episode of rockfall deposition marked the time of the Little Ice Age. Fryxell's findings are consistent with the stratigraphy of recently excavated portions of Seed Cave, on the lower Snake River (Thompson 1985), and with Wapaixie Rockshelter on the middle Columbia (Chatters 1979).

From the depositional sequence observed by Fryxell, we can infer that local climates were cooler and/or wetter up until $8000 \mathrm{yr}$ B.P., followed by a rapid warming or drying that lasted several centuries. Conditions were again cooler and/or moister for a brief interval around $7000 \mathrm{yr}$ B. P., followed by a mid-Holocene period of marked aridity, during which vegetation cover was sparse. A return to cooler and/or wetter conditions began after $4500 \mathrm{yr}$ B. P., reached a peak shortly after $3000 \mathrm{yr}$ B.P., and had ended by around $2000 \mathrm{yr}$ B. P. Warmer and/or drier conditions then prevailed until the cooling process that began after $650 \mathrm{yr}$ BY. and lasted into the 19th century.

\section{Fluvial Gicomorphology}

The floodplains of the Columbia, Snake, and Okanogan Rivers in eastern Washington provide evidence of approximately synchronous changes in aggradation, entrenchment, and flow. Sediment records in minor tributaries show evidence that changes in these small systems coincided with those in the trunk streams, but were often their opposite. Due to irregularities in the numbers and kinds of dates that have been obtained from each river or stream system, many of the observed events mayor may not have been precisely coeval, but viewed together they show regional tendencies in the behavior of Columbia Basin fluvial systems.

During the Fraser Glaciation, when the Okanogan lobe of the Cordilleran glacier buried the area from Chelan to Spokane northward and montane glaciers filled many valleys in the rockies, seasonal meltwater filled the Columbia and Snake River canyons. Where canyon walls were wide enough to accornodate it, the channels were wide and braided. Periodically, perhaps as many as 40 times (Waitt 1980), massive floods burst across the Columbia Basin, scouring broad channels into the basalt bedrock and filling the Pasco Basin with gravel on the north and east, and with slackwater sand and silt elsewhere. Each flood created a temporary lake in the Pasco Basin while meltwater escaped through the Wallula Gap, contributing to the broad gravel bars and many dry channels that today cross the Hanford Site.

From 13,000 to $10,000 \mathrm{yr}$ B. P., the Cordilleran ice sheet was wasting rapidly and montane glaciers were in recession. Meltwater continued to fill and scour the canyons of the Snake and middle-lower Columbia rivers. Floodplain sediments were being deposited at Five Mile Rapids, near the Dalles of the Columbia during the latter half of this period (Cressman 1960). At Chelan, the outwash fan of the local montane glacier temporarily blocked the Columbia's channel, forming a glacial lake (Brewster) that filled the Columbia River canyon and the lower Okanogan River Valley. The bursting of this ice dam caused the last major flood down the Columbia River at about $10,000 \mathrm{yr}$ B Y. During this period, overbank sediment was building up in Lind Coulee, indicating the presence of a perennial stream (Moody 1978).

The Snake River began to aggrade its first floodplain after 10,000 yr B. P. (Hammau 1977), and similar aggradation appears to have begun on the Columbia River in the vicinity of Wenatchee at about the same time (Galm and Masten 1985). On the basis of the height of the floodplain above modem river beds, Hammau estimates that stream flows were considerably greater than they are today. Although his conclusion is still plausible, Hammatt neglects the probability that the Snake has become continued in Lind Coulee (Moody 1978), but eolian reworking of the deposits may indicate a stream of lower capacity.

While floodplains were developing on the mid Columbia and lower Snake rivers, the Okanogan River and the Columbia River above the mouth of the Chelan were eroding their way through glacial outwash gravels and lacustrine silts (FryxellI963). The first episode of aggradation that is evident on floodplain terraces in that reach is 
dated at approximately 8000 yr B. P. (Chatters 1986; Mierendorf 1983). This episode was short-lived, as vertical accretion had slowed by $7900 \mathrm{yr}$ B. P. in that area (Chatters 1986) and had effectively ceased on the lower Snake River (Hamman 1977). Fluvial sedimentation also ceased in the Lind Coulee not long after $8700 \mathrm{yr} \mathrm{B.} \mathrm{P.}$

Eolian sedimentation replaced fluvial deposition on lower Snake River terraces from 8000 to 5000 B. P., and vertical accretion slowed considerably on the Columbia above Rock Island Dam (Chatters 1984, 1986; Mierendorf 1983) and in the Dalles Area (Cressman 1960). Rivers evidently became entrenched, and flows were ordinarily insufficient to overtop the channel banks. Evidence of just how reduced flows were in the Columbia River can be seen near Vantage, Washington in the presence of eolian sediments containing Mazama ash and ventifacts below the modem nonnal river levels (Richmond et al. 1965). Dune deposits atop early Holocene alluvium in the vicinity of Richland, Washington, contain Mazama ash and indicate that similar conditions were extant in the Hanford Reach of the Columbia River at this time.

The only exception to a pattern of reduced flows and entrenchment is seen in the lower Okanogan River (Hoover 1986) and on the Columbia just below the Okanogan's mouth. There, aggradation continues in the Okanogan up until the Mazama ashfall, and a minor aggradation episode is discemable in Columbia River sediments between around 7000 and $6750 \mathrm{yr}$ B.P. An episode of erosion has been identified in minor tributaries along the midColumbia Canyon at about this same time (Cochran 1978; Pavish 1973).

Sometime during the period between 5000 and $4000 \mathrm{yr}$ B. P., a period of widespread soil fonnation is evident. A soil found near the base of excavations at the Vernita site (Rice 1980) dated to $4900 \mathrm{yr}$ B. P., and high terraces in the vicinity of Grand Coulee Dam contain a paleosol fonned just prior to $4700 \mathrm{yr}$ B. P. (Chatters 1984). Soils fonned on floodplain loess in the lower Snake River Canyon sometime during this interval, although dating is imprecise (Hammatt 1977). Formation of the soil, in the absence of aggradation or any other evidence of increased stream flow, evinces a period of surface stability that probably resulted from locally cooler temperatures (see glacial evidence, above).

Flows, or at least peak floods, increased markedly throughout the basin after this soil formation episode. The period, from 4500 until sometime before $3500 \mathrm{yr}$ B. P., is marked by rapid aggradation of a new floodplain terrace and the building of point bars in wider reaches of the major canyons. On the Snake River, Hammatt (1977) sees this episode as beginning approximately $4000 \mathrm{yr}$ B. P. Chatters (1984) notes initial aggradation after $4700 \mathrm{yr}$ B. P. in the Chief Joseph Reach of the Columbia, but his earliest dates are based on shell, which provides inaccurate dates after $5000 \mathrm{yr}$ B. P. (Chatters 1986). Charcoal dates on graded overbank sediments and cross-bedded point bar deposits generally postdate $4500 \mathrm{yr}$ B. P. (Chatters 1984, 1986; Lohse 1984). In the Wells Reservoir area of the Columbia and lower Okanogan Rivers, this aggradation begins as early as $4400 \mathrm{yr}$ B. P., has effectively ceased by $3800 \mathrm{yr}$ B. P., and is followed by a period of wind erosion that lasts until $3300 \mathrm{yr}$ B. P. (Chatters 1986; Fryxell 1963). Alluvium below the Wells area is imprecisely dated, but Mierendorf (1983) reports an aggradation episode predating $3000 \mathrm{yr} \mathrm{B}$. P. Alluvium containing artifacts attributable to the period from 4500 to $2500 \mathrm{yr} \mathrm{B}$. P. exists at the Hanford Generating Plant and Vernita Sites in the Hanford Reach (Rice 1980), but no radiocarbon dates are available.

Vertical accretion of fluvial sediments continued along the Snake River, albeit at a slower pace, until approximately 2000 yr B. P. (Hamman 1977), and on the Chief Joseph Reach of the Columbia until 2400 yr B. P. In the Wells area, slow accretion began again after $3300 \mathrm{yr}$ B. P. and continued to as late as $2200 \mathrm{~B}$. P. (Chatters 1986; Hoover 1986). The relative abundance of bivalve species from that reach (see Faunal Communities), however, shows that the Columbia and Okanogan river channels were undergoing entrenchment from 3300 to $2400 \mathrm{yr}$ B. P., as opposed to the channel aggradation seen in the previous millennium.

The interval between 2500 and $2000 \mathrm{yr}$ B. P. is one of transition in fluvial systems throughout the region. Soil fonnation is observed on the Snake River floodplains beginning at $2000 \mathrm{yr} \mathrm{B}$. P. (Hamman 1977), while rapid erosion of sediment stored in alluvial fans and the initiation of a new episode of fan fonnation occurred between 2500 and $2260 \mathrm{yr}$ B. P. in the Chief Joseph Reach (Chatters 1984). Erosion also characterizes the alluvial record in Vantage area tributaries at this time (Cochran 1978; Pavish 1973). In the Wells area, deposition effectively ceased after $2500 \mathrm{yr} \mathrm{B}$. P. on the terrace that had begun aggrading at $4400 \mathrm{yr} \mathrm{B}$. P., and a new terrace began forming (Chatters 1986). Relative abundance of bivalve species dating between 2400 and $2200 \mathrm{yr} \mathrm{B}$. P. is consistent with an episode of rapid stream bed aggradation during this time. Mierendorf (1983) observed aggradation sometime after $3000 \mathrm{yr}$ B. P. and prior to $1400 \mathrm{yr}$ B. P., which may correspond to this time of transition. Finally, a depositional unconformity with an estimated age of 2000 to $2500 \mathrm{yr} \mathrm{B}$. P. is recognized in sediments in the Hanford Reach (Rice 1980). 
Essentially modern conditions seem to have prevailed after 2000 to $1600 \mathrm{yr}$ B. P. Vertical accretion occurred on a new floodplain in the Chief Joseph Reach (Chatters and Hoover 1986), and continued until the consbUction of Grand Coulee Dam. This process apparently also occurred in the Wells area. Hammatt (1977) sees the Snake River stabilizing in its channel, with eolian deposition on the floodplain surface. Vertical accretion was renewed in the Hanford Reach and continued until the last great flood in 1948.

Some long-tenn variations in stream flow are evident in the past two millennia. Chatters and Hoover (1986) note that in the Chief Joseph Reach, at least, flooding frequencies varied, with the greatest intensity of major floods occurring between 560 and $980 \mathrm{yr}$ B. P. Mierendorf (1983) saw evidence in the Rocky Reach of the Columbia of a fourth episode of aggradation after $500 \mathrm{yr}$ B. P.

\section{$\underline{\text { Sedimentation in } \underline{\text { a Bedrock }} \text { Basin }}$}

Pollen cores from Wildcat Lake, near the mouth of the Palouse River, have provided a record of sediment deposition spanning the Holocene. Wildcat Lake fills a basin created by glacial floods estimated at 13,000 yr B. P. (Mehringer 1985b). Deposition of sediment, which Mehringer presumes was washed from the basin walls, but which was more likely of eolian origin, was initially slow from the base of the extracted core, dated from $10,600 \mathrm{yr}$ B. P. until 8000 yr B. P. Subsequently, sedimentation was very rapid until 5400 yr B.P., then began to slow between 5400 and 4500 yr B. P. From the latter date until $2400 \mathrm{yr}$ B. P., sediment was deposited at a rate equal to that of the early Holocene, but subsequently increased to a more rapid rate (Mehringer 1985b, Figure 2). Assuming that eolian sedimentation rates are inversely related to the density of vegetation, and that vegetation cover is related positively to effective moisture, then effective moisture was greater than it is today before 8000 and between 5400 to 4000 and $2400 \mathrm{yr}$ B. P., and was lower during the middle Holocene.

\section{Summary}

Eight climatic periods are discernable when the glacial, fluvial, aeolian, and rock spalling records are juxtaposed. The dating of those periods, the climatic and fluvial conditions that prevailed at the time, and the impact of these conditions on human activity in the study area or on our ability to discern it, are as follows:

$\underline{13.000}$ to $\underline{10.000 . y r} \underline{B}$. $\underline{\text {. }}$ Cool glacial climates were beginning to ameliorate, resulting in the rapid wasting of glaciers. Meltwater filled the major river valleys, making them at least seasonally uninhabitable. Lakes were fonned in some reaches, and their bursting caused catastrophic floods that further scoured the river channel in the Hanford Reach. Any trace of human activity that might have existed on late glacial river banks in that area was probably obliterated.

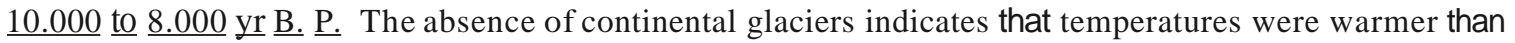
they had been previously, but low rates of sedimentation in Wildcat lake, rapid deposition of rock spall, and fluvial deposits representing a perennial stream in the middle Columbia Basin at Lind Coulee evince greater effective moisture and possibly cooler conditions than exist today. Readvance of montane glaciers between 8500 and $7900 \mathrm{yr}$ B. P. shows that that period, at least, was cooler than the Holocene nonn. Flows in the major rivers had declined, but rapid buildup of sediment on floodplains shows that overbank flooding was frequent and flows were generally as high or higher than they are today. Stabilization of the rivers' channels at this time should have made their banks more attractive for settlement during most of the year, and rapid sedinentation should have sealed artifact deposits. Sediments of this age appear to be present in many areas of the Hanford Reach, although their presence has not been confimmed with radiocarbon dates. (Some fluvial sediments do, however, exist beneath Mazama ash.)

$\underline{8000} \underline{\text { to }} \underline{5500} \underline{\mathrm{yr}} \underline{\mathrm{B}} . \underline{\mathrm{P}}$. All lines of evidence support the conclusion that this was the driest part of the Holocene. Rock spalling was reduced to nearly nothing, and eolian deposition increased in bedrock basins, caves, and the open land surface to its maximum Holocene rate. River flows were reduced substantially, to the extent that floodplain surfaces, at least on the middle Columbia River, were below mean modern water levels. These data compel the inference of greatly reduced plant cover in the Columbia Basin region and the existence of few active streams. One brief cooler or moister period may have occurred just prior to $7000 \mathrm{yr}$ B. P., followed by minor stream aggradation in the Okanogan River Basin and adjacent Columbia River floodplain, and erosion in minor east-flowing tributaries along the middle Columbia.

The Hanford Site is semi-arid today, with virtually no surface water, and few small streams enter the Columbia or Snake River within 50 kilometers of Site boundaries. Plant cover is sparse in most areas where Asian grasses do not fonn dense mats. The evidence presented above suggests that even less water was available in the past, and that plant cover was even lower. Lack of water and low terrestrial primary productivity probably limited 
the numbers of people that could have survived in the area and confmed their activities largely to areas near the river. Because of lowered river levels, much of the archaeological record of this era may have been lost when river levels rose. Artifacts of the mid-Holocene age are in fact most often found in lagged gravel deposits (Hartmann, Landis, and Morgan 1982; Rice 1980).

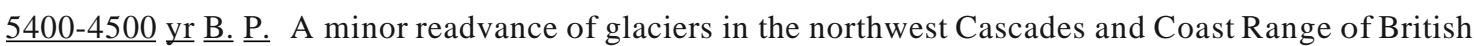
Columbia indicates a brief episode of cooling that was expressed only in moister environments. From this conclusion it can be further inferred that the environment east of the Cascades, though cooler, remained dry. The decreasing sedimentation rate in Wildcat Lake shows that the result of cooling was elevated effective moisture, which promoted increased ground cover. Soil formation on floodplains, in the absence of evidence for aggradation or increases in rock spalling, is further evidence that although the climate was cooler and evaporation rates were reduced, there was no apparent increase in precipitation or river flows.

$\underline{4500} \underline{\text { to }} \underline{3500} \underline{\operatorname{yr}} \underline{B}$. $\underline{P}$. A marked increase in aggradation of trunk streams, slowed sedimentation in lake basins, and elevated rock spalling rates indicate markedly increased effective moisture. The absence of montane glaciers at this time shows that available moisture rose in response to precipitation, not cooling. The period appears to have been relatively warm and wet Rivers responded to this change with greatly increased flows and/or a sharp rise in the magnitude and frequency of severe floods.

$\underline{3500} \underline{\text { to }} \underline{2400} \mathrm{yr} \underline{\mathrm{B}} . \underline{\mathrm{P}}$. The early neoglacial readvance was accompanied by entrenchment with continued, although slower accretion of sediment on floodplain surfaces, a crescendo of rock spalling activity, and continued low sedimentation rates in Wildcat Lake. In combination, these conditions show that high effective moisture, probably including elevated rates of precipitation, continued during a period of secular cooling.

$\underline{2400}$ to $\underline{2000)}$ yr $\underline{B}$. P. During some portion of this period, many paleoecological records show evidence of transition. Glaciers receded, rock spalling rates showed a sharp decline, erosion occurred in alluvial fans and the floodplains of small tributaries, sedimentation rates increased in Wildcat Lake, and soils formed on the lower Snake River floodplains. On the upper Columbia River, this interval was marked by initiation of a new aggradation episode. These changes appear to represent initiation of a relatively drier, warmer climatic episode.

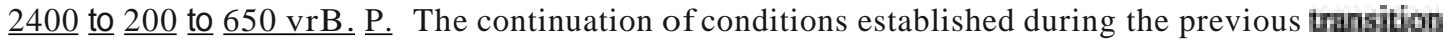
resulted in a stabilization of vegetation cover and renewed entrenchment of streams. Climates were much like they are today. Flooding frequencies did increase on the upper Columbia during the latter part of this period, but no other change is evident

$\underline{650}$ to $\leq 100$ yr $\underline{B}$. $\underline{P}$. Montane glaciers advanced during this period and, coupled with an increase in rock spalling, indicate show cooler temperatures and relatively moist conditions. A marked decline in the frequencies of major floods during this period shows that water was being bound up in glaciers and ice fields rather than melting off rapidly in late spring as it does today.

\section{Biota}

Fluctuations in the presence, geographic distribution, and relative frequencies of plant and animal taxa are often used as proxy indicators of climatic conditions. What is done here, instead, is to use these data to suggest the distribution and content of plant and animal communities during the terminal Pleistocene and Holocene and only to clarify or serve as a cross check on climatic inferences made from geologic evidence. The climatic periods described above are used as a framework for this discussion. As was the case for geologic data, there has been little direct study of biota in the Hanford Site or its immediate vicinity. Consequently, changes in the flora and fauna of surrounding sites are used to generate inferences about the Site's paleoecology.

\section{Flora}

Indications of the flora of the Columbia Basin and surrounding highlands have been obtained from pollen cores taken from the following Washington locations: the Okanogan Highlands (Mack, Bryant, and Fryxell1976; Mack et al. 1978; Mack, Bryant, and Valastro 1978; Mack, Ruuer, and Valastro 1978, 1979; Baker 1983; Barnosky, Anderson, and Bartlein 1987; and Mehringer 1985a); Williams Lake Fen, near Cheney (Nickmann 1979); Wildcat Lake near Hooper, and Sulphur Lake near Connell; (Mehringer 1985b); and from Carp Lake in the Horse Heaven Hills, north of Goldendale (Barnosky 1984, 1985). The Okanogan Highland sites, Williams Lake Fen and Carp Lake, are in forested areas today; Sulphur and Wildcat Lakes are in a vegetation zone characterized by sagebrush/bluebunch wheatgrass (Artemisia tridentata/Agropyron spicatum) and bluebunch wheatgrass/Idaho fescue (Agropyron spicatumlFestuca idahoensis), respectively (Daubenmire 1970). Pollen from Seed Cave (Thompson 
1985), located in the Snake River Canyon adjacent to the bluebunch wheatgrass/ Idaho fescue zone, is also considered briefly. All sites are in areas with greater annual precipitation than that of the Hanford Site. The following paragraphs present the distribution and content of plant communities inferred from these pollen records with extrapolations to estimate paleoconditions on the Hanford Site. For details, the reader is referred to the documents cited above.

$\underline{13.000} \underline{\text { to }} \underline{10,000}$ yr $\underline{B}$. P. During this period of gradually warming temperatures, a sagebrush-dominated steppe characterized most of what is now eastern Washington. In the Okanogan Highlands, this steppe was tundralike, and included stands of alder, birch, spruce, fir and cold-adapted pine (whitebark or limber pine), The area around Williams Lake was similar, but groves of lodgepole pine occurred in the place of more cold-adapted conifers, probably on rocky outwash soils and flood channels (Bamosky, Anderson, and Bartlein 1987). Trees were largely absent from the Carp and Wildcat Lake areas. Given its virtually ubiquitous distribution in the Columbia Basin, it is realistic to assume that a similar cold-adapted steppe community was present over the Hanford Site, perhaps with pine, birch, willow and alder thickets along the river and in other wet or well-protected areas.

$\underline{10.000} \underline{\text { to }} \underline{80 \mathrm{PO}} \mathrm{yr} \underline{\mathrm{B}} . \underline{\mathrm{P}}$. As temperatures warmed around Carp Lake, conditions evidently became more arid. Chenopods (greasewood, saltbrush, hopsage) became common in the surrounding sagebrush steppe, and trees were still absent Elsewhere there was a grass-dominated steppe, which may have developed in response to relatively moister conditions than had previously prevailed. After $9000 \mathrm{yr}$ B. P. in the Wildcat Lake area and Okanogan Highlands, and after $8500 \mathrm{yr}$ B. P. in the Williams Lake area, grasses were giving way to a sagebrush steppe. Mehringer suggests that the sagebrush species around Wildcat Lake was at first primarily the more mesophytic Artemisia tripartita, rather than the xerophytic A. tridentata. By $8500 \mathrm{yr}$ B. P., ponderosa pine forest had established itself around Carp Lake. Barnosky $(1984,1985)$ interprets this as an indicator of increasing moisture, whereas other records show defmite drying at the same time. Two possible explanations for this difference are that the influx of forest in the eastern flank of the Cascades is a manifestation of migration rates, or edaphic responses, and not of climate (Mehringer 1985b) or that the climate around Carp Lake follows that of the western slope of the Cascades, which was wetter at this time (Barnosky 1984).

$\underline{8 Q(0)-5400} \mathrm{yr} \underline{\mathrm{B}} \underline{\mathrm{P}}$. The ponderosa pine forest remained in the Carp Lake area, but elsewhere a dry sagebrush steppe prevailed. Several pollen sites in the Okanogan Highlands dried out, and a depositional hiatus represents a part of this period. At Wildcat Lake, ambrosia-type composites (ragweed, an indicator of poor vegetation cover) became more abundant Remnants of a tree line 100 meters above that which exists today in the North Cascades, is believed to be of mid-Holocene age. This evidence indicates that conditions were not only dry, but considerably warmer than today (at least in summer). A possible reversal of a generally dry, warm climate apparently occurred 7200 to $7400 \mathrm{yr}$ B. P., with a slight increase in grass pollen at Wildcat Lake. Between 7200 and $7860 \mathrm{yr}$ B. P., increases in the percentage of pine pollen at Goose Lake (in the southern Okanogan Highland) are interpreted by Nickmann and Leopold (1985) to be an indicator of moister conditions, but a decline in the productivity of steppe plants is equally plausible.

The environment of the Hanford Site at this time can be inferred from differences between modem and midHolocene floras in now more-mesic areas. Mehringer (1985b) suggests that a change of \pm 2 degrees $\mathrm{C}$, or of $\pm 1 \mathrm{O}$ centimeters of precipitation, could account for the observed variation in Holocene floras at Wildcat and Sulphur Lakes. Modem precipitation at these lakes is approximately 30 centimeters; a 10 -centimeter decline represents 33 percent. Chatters (1986) suggests that available moisture equivalent to 38 percent (15 centimeters) less than that of today would account for mid-Holocene vegetation at Mud Lake in the Okanogan Highlands. If a 33-percent decline is taken as the more conservative estimate, available moisture of the Hanford Site in the mid-Holocene would be the equivalent of 10.8 centimeters (it is now 16.1 centimeters). With such a minimal amount of moisture available, sparse vegetation cover and plants adapted to shifting sand would be expected, such as needle and thread grass (Stipa comata) and Indian rice Grass (Oryzopsis sp). A greater density and more widespread distribution of chenopods like greasewood (Sarcobatus vermiculatus) and spiny hopsage (Grayia spinosa), and a reduction in the density and proportion of other bunch grasses relative to sagebrush would also be expected.

$\underline{5400} \underline{\text { to }} \underline{4500}$ yr $\underline{\text { B. }} \underline{\text { P. }}$ Mehringer (1985b) reports that sagebrush was at its peak relative to grass during this period, but was declining in the latter centuries. A slight, gradual decline in the proportion of sagebrush also occurs in some Okanogan Highland cores, and pine or Douglas fir forests develop abruptly, after 4700 yr B. P. In general this evidence corroborates the geologic evidence that this interval was predominantly cooler but still dry. Increases in available moisture are evident in the north by 4700 B. P. (Mehringer 1985a).

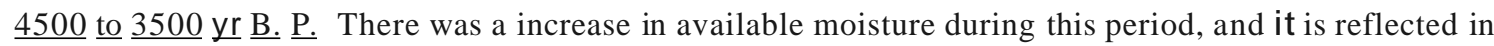
the pollen record. Wildcat Lake and Seed Cave were surrounded by a grassland that retained a high proportion of 
sagebrush, but Mehringer believes that, given the sedimentary evidence for a dense ground cover, this was likely to have been sagebrush in a plant community resembling that of sagebrush/Idaho fescue, which occurs in the most mesic areas of the Columbia Basin steppes (Daubenmire 1970). Forests had expanded into the Williams Lake area and throughout the Okanogan Highlands. Western red cedar, hemlock, and Douglas fir appeared in the vicinity of Carp Lake.

$\underline{3500} \underline{\text { to }} \underline{2400} \underline{\mathrm{vr}} \underline{\mathrm{B}} \underline{\mathrm{P} .}$. Vegetation retained the characteristics of the previous period, with two exceptions. Sulphur Lake exhibits a flora like that of Wildcat Lake during this period, indicating a further increase in available moisture to the west of the latter site. Cold-adapted trees, including whitebark or limber pines, spruce, and fir, increased in abundance in some sites in the Okanogan Highlands, and the frequency of conifer pollen in general reached a peak between 3000 and approximately $1600 \mathrm{yr}$ B. P.

From 3500 to 2400 yr B. P., available moisture in the vicinity of Wildcat Lake may have reached the equivalent of a lo-centimeter increase in precipitation over the present (Mehringer 1985b). Again, if that increase is extrapolated to the Hanford Site as a percentage of modem levels, the result is an equivalent of 21.4 centimeters of precipitation. This amount would have meant that the area was still in the big sagebrush/bluebunch wheatgrass zone, like that of today, but that vegetation densities would have been greater, and the dune flora subdued as dunes were stabilized, and as chenopod and sagebrush densities declined.

$\underline{2400} \underline{\operatorname{vr}} \underline{\mathrm{B}} . \underline{\mathrm{P}} \underline{\text { to }} \underline{\text { the }} \underline{\text { Present }}$ Essentially modern floras characterize this period throughout the region. At Wildcat Lake and Seed Cave, grass increased in relation to sagebrush as the modem grass steppe formed. One sharp decline in grass pollen around $550 \mathrm{yr}$ B. C. corresponds to drying in nearby Clear and Blue Lakes (Mehringer 1985a and $b$ ). This arid interval may have had a strong negative impact on productivity in the semi-arid Hanford area.

\section{Fauna}

Data on the late glacial and Holocene fauna of the southern Columbia Basin comes largely from loess and glacial flood deposits for the earlier period and from archaeological sites and caves for the Holocene.

Late Glacial. In eastern Washington, the record for this period is provided by scattered fmds of extinct fauna in the Horse Heaven hills (Fry 1969; Randolph and Rice 1975) and elsewhere in the Columbia Basin (Lyman and Livingston 1983), thousands of small mammal remains from a loess deposit near Kennewick, Washington (Rensberger, Barnosky, and Spencer 1984), and mammal remains from the Palouse River Floodplain outside Marmes Rockshelter (Gustafson 1972). The faunal community they represent is without modern analogs. Cold-adapted forms, such as northern bog lemming (Synaptomys borealis), heather vole (Phenacomys intermedius), and arctic fox (Alopex lagopus) shared the habitat with temperate grassland species like sharptail grouse (Pediocetes phasianellus ) and bison (Bison antiquus), and many arid-land species: the pygmy rabbit (Sylvilagus idahoensis), Great Basin Pocket Mouse (Perognalhus parvus), sage vole (Lagurus curtatus), Ord's Kangaroo Rat (Dipodomys ordi), and the kangaroo mouse (D. microps). Some species were also present that are now more common in, or even restricted to, conifer forests or forest edge habitats, including elk (Cervus elephas) and pine marten (Martes americanus). The forest and grassland species are confined largely to more easterly and higher elevation sites, the aridpland species to the western and lower elevation portions of the region. Such extinct forms as mammoth (Mammathus $s p$ ), horse (Equus sp) and camel (Camelops sp) are also found, but details of their habitat preferences are unknown; all were presumably open country dwellers, however.

Elements of this fauna, including marten, fox, mammoth, elk, bison, and most species still present in the region in historic times, continued to be present until nearly 10,000 yr B. P., but most now-extinct species were apparently gone.

$\underline{10,000}$ to $\underline{8000} \mathrm{yr} \underline{\mathrm{B}}$. $\underline{\mathrm{P} .}$. Few sites have provided evidence pertaining to this period. Marmes Rockshelter (Gustafson 1972), Five Mile Rapids in the Dalles area (Cresman 1960), the Lind Coulee Site (Irwin and Moody 1978), Kettle Falls (Chance and Chance 1982, 1985) and Seed Cave (Thompson 1985) have been the most informative. Some information can be gleaned from the Kennewick Roadcut (Rensberger, Bamosky, and Spencer 1984), but numbers of specimens are small. Aquatic animals are represented in river-sited collections for the first time.

At Lind Coulee (8700 yr B. P.) in the central, nonriverine part of the Basin, the following terrestrial species, the sort to be expected in a grass steppe, were found: Bison (the extinctB. antiquus) elk, ground squirrels, including both the Columbia and Washington species (Spermophilus columbianus and S. washingtoni), gophers (Thomomys talpoides), montane vole (Microtus montanus), striped skunk (Mephitis mephitis), badger (Taxidea 
taxus) and red fox (Vulpes vulpes). Species now confined to more-arid land, with the possible exception of the pygmy rabbit, were conspicuously absent Aquatic birds and mammals were ducks, geese, the otter (Lutra canadensis), muskrat (Ondatra zibethecus), and beaver (Castor canadensis).

Farther to the south, in the Mannes Rockshelter and other nearby sites, faunas included a relatively high ratio of elk to deer (Odocoileus sp), also mountain sheep and pronghorn antelope (Antilocapra americana). Pocket mice, gophers, ground squirrels (Spermophilus, sp), and deer mice (Peromyscus maniculatus).were present in nearly equal proportions. The sage vole was absent, and the montane vole was rare. This pattern is consistent with the idea of a sagebrush-grass steppe, but indicates relatively poor ground cover in the vicinity of the site.

Riverine faunas by this time included salmon, suckers, and various bivalves on the Columbia, but there were few salmon in Snake River sites. In the Snake River, the pearl mussel (Margaritifera margaritifera) which prefers stable gravel to sand-bedded streams (Vannote and Minshall 1982) is high in proportion to the species Gonidea angulata, which competes better in aggrading, sandy, or silty beds (Lyman 1980).

$\underline{8000} \underline{\text { to }} \underline{4500} \mathrm{yr} \underline{\mathrm{B}} \underline{\mathrm{P} .}$. Until the fall of Mazama ash, elk retained importance on the lower Snake River, but became relatively rarer thereafter (Gustafson 1972). The species was absent from sites in the upper-middle Columbia throughout this period (Chatters 1986). The relative frequency of elk shows a progressive decline in a downriver direction, and the animal was probably absent from the Hanford area. Deer continued to be present in all areas, and mountain sheep also occurred, although they were rare. Small-mammal collections from Seed cave and Kennewick show that sage voles, Great Basin pocket mice, Townsend's ground squirrels, and gophers (in that order) predominated in the Hanford vicinity, and kangaroo mice (absent today) were also present. At Seed Cave, to the east, the early Holocene small-mammal fauna persisted until 6850 B. P., after which the ratio of gophers declined and voles were entirely absent

Riverine fauna included salmon, trout (Sa/mo or Salvelinus spp), sturgeon (Acipencer transmontanus) suckers, other fishes and bivalves. Ratios of Margaritifera to Gonidea decrease during the period on both trunk streams (Chatters 1986; Lyman 1980). Staff of the Hanford Cultural Resources Laboratory have observed that sites of apparent mid-Holocene age just south of the Hanford Site also contain an abundance of Gonidea. This is evidence of more sand and/or silt in the bed load of the rivers, and has important implications for the availability of different salmon species. Silty and sandy bottoms are not conducive to spawning effectiveness, so the fall chinook (Oncorhynchys tschawytscha), which is a main channel spawner, may not have been as abundant as it is today. Additionally, reduction in stream flows probably meant a reduction in spawning habitat of lower-order streams, and ,must have had a negative impact on populations of other salmon species.

$\underline{4500}$ to $\underline{2400} \mathrm{yr}$ B. $\underline{P}$. Increases in the ratio of elk and mountain sheep to deer occurred in the upper Columbia River drainage (Chatters 1986), but no similar change is reported for the Snake River (Gustafson 1972). In Seed Cave, the increase in vegetation density evident from other data is corroborated by the abrupt rise to dominance of voles (Microtus), which occupy such habitats. Early in this period the ratio of Margaritifera to Gonidea is still low on the upper mid Columbia., showing that aggradation of floodplains was accompanied by aggradation of the stream bed, at least in that area.

After 3300 B. P., bison returned to the central Columbia Basin (Schroed11973) and were even found in the Hanford Reach sometime during this period (Harkins 1980). There was a rise in the relative frequency of mountain sheep, and marten or fisher (Martes sp) occurred for a brief period in the Wells region of the Columbia. Gonidea nearly disappeared from the bivalve fauna in that reach of the Columbia River during that period, and Rocky Mountain whitefish (Prosopium williamsoni) appeared in the fish fauna (Chatters 1986). Similar decline in Gonidea frequencies occurred on the Snake River (Lyman 1980). All these changes are consistent with a moister, cooler climate, expansion of grass and forest habitat and an entrenching, gravel-bedded stream. If stream conditions were similar in the mid-Columbia, then this must have been a period of enhanced salmon-spawning habitat in trunk streams and probably expanded spawning area in smaller tributaries. Ungulate biomass was probably elevated in response to increased forage.

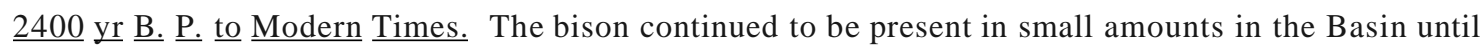
approximately $1000 \mathrm{yr}$ B. P., then disappeared. The sage vole replaced the montane vole as the primary small mammal in Seed Cave, supporting Mehringer's surmise that a denser, sagebrush/Idaho fescue type of vegetation was replaced by the more open bluebunch wheatgrass/fescue community of today. A similar, though less pronounced increase in Lagurus occurred in the Chief Joseph Reach (Livingston 1985). Otherwise, except for a brief return of Gonidea in bivalve assemblages of the Wells Region during the initial aggradation episode after $2400 \mathrm{yr}$ B. P., faunal records appear to have differed liUle from those of the historic period. Archaeological excavations at 
Strawberry Island, which is located near the mouth of the Snake River in the same habitat as the Hanford Site, provided an assemblage dated between 140 and $1395 \mathrm{yr} \mathrm{B.} \mathrm{P.} \mathrm{Pronghorn} \mathrm{was} \mathrm{the} \mathrm{most} \mathrm{common} \mathrm{species} \mathrm{of} \mathrm{ungulate}$ (92 percent) and jackrabbit (Lepus cfcalifornicus) was the most common mammal represented.

Summary Probable Paleoecology of the Hanford $\underline{\text { Site. }}$

From the foregoing records of regional temperature, available moisture, river flow patterns, and biota, it is possible to infer the ecological conditions that may have existed on the Hanford Site from the Late Glacial through the Holocene. We repeat that this is an extrapolation and is, therefore, a complex of hypotheses that have not been evaluated with hard evidence.

Around 13,000 yr B. P., general warming of the global climate tipped the balance between snowfall at the source of montane and continental glaciers and ablation at the glacier termini. The glaciers, which lay as little as 150 kilometers to the north, began to waste rapidly. The Columbia River and (to a lesser extent) the Yakima were swollen with the icy, sediment-laden melt water and formed broad, shifting channels. At least once, around 10,000 yr B. P., a catastrophic flood swept down the Columbia River channel, leaving massive gravel bars and forming, as it receded, the modem course of the river. The local climate was cool but dry, supporting a cold-adapted shrub-steppe inhabited by animals that today live in mutually exclusive ranges. The heather vole and bog lemming of today's high altitudes and latitudes coexisted with the sage vole, pocket mouse, and kangaroo mouse and rat of dry, sparsely vegetated areas. Bison, mammoth, camel, horse, elk, deer and pronghorn were living in the vicinity. However, aquatic life was probably made scarce by the constant flushing of river channels and the heavy load of glacial sediment in the water.

Climates generally cooler and moister than the present characterized the next 2000 years. Glaciers ceased to have a major impact on the Columbia River, which began developing a floodplain in wider reaches of its channel (such as near Richland and the White Bluffs townsite). Salmon, suckers, and other fishes became common, and the large bivalves Margaritifera and Gonidea inhabited the variable river bottom. A mesic grass-dominated shrub steppe, probably similar to that found north of Connell today, covered lower elevations of the Site, with grassland extending well down the slopes of buttes and Rattlesnake Mountain. Cold-adapted small mammals had disappeared northward. The mammoth, horse, and camel were gone, but bison, elk, and smaller ungulates survived.

Gradually, from 9000 to $8000 \mathrm{yr}$ B. P., the climate became warmer and drier; it was decidedly arid from the latter date until at least $5400 \mathrm{yr} \mathrm{B.} \mathrm{P.} \mathrm{Based} \mathrm{on} \mathrm{observed} \mathrm{evidence,} \mathrm{we} \mathrm{suspect} \mathrm{that} \mathrm{moisture} \mathrm{near} \mathrm{the} \mathrm{Hanford}$ Meteorology Station would have been equivalent to 11 centimeters of rain. That is insufficient moisture to support many of the grasses now on site, and a predominantly sagebrush/chenopod (possibly hopsage) community probably covered most areas of low elevation. Grasses that inhabit shifting dunes, such as needle-and-thread grass and ricegrass, might have been much more common. Hanford must have been a forbidding place, with winds constantly blowing sand about the largely denuded landscape. Pronghorns and jack rabbits would have been the primary terrestrial herbivores, but in relatively low numbers. Unless groundwater springs continued to flow, which is questionable, the only water available was in the Columbia and Yakima rivers, which were much smaller than today. Siltier or sandier bottoms made these channels poor spawning habitat, and the reduction in upper-basin spawning areas meant greatly reduced fish runs (compared to those of modem times). Gonidea was the common bivalve in sandier areas of river bottoms.

Moister conditions returned with cooling temperatures around $5400 \mathrm{yr}$ B. P., although low precipitation probably continued. Soil formation in the Hanford vicinity around $5000 \mathrm{yr}$ B. P. shows that the land surface began to stabilize. River flows appear to have remained relatively low; but with less sediment entering the fluvial system from the landscape, it is possible that salmon-spawning habitat in the Columbia River improved. Animals requiring better ground cover might have reappeared, such as mountain sheep and elk, but in small numbers.

Between 4500 and $2400 \mathrm{yr}$ B. P., conditions became decidedly moister, especially in the latter half of that period. The rivers re-established higher floodplains, initially undergoing rapid aggradation, then stabilizing and reentering a downcuttting mode punctuated by frequent large floods. Bottoms would have been initially not conducive to main-channel salmon and steelhead spawning, but by 3700 or so, gravel bottoms would have provided habitat like that of today. Cooler conditions during the first neoglacial period probably limited the productivity of salmon and other migratory species to short seasons. With moisture at a maximum equivalent to over 21 centimeters of precipitation, the steppe on site would have been more dominated by grasses such as bluebunch wheatgrass and fescue, making the place less favorable for pronghorn but better for sheep, elk, and even bison. 
After $2400 \mathrm{yr}$ B. P., the modern environment had developed; river flows were reduced some in a more-arid environment, and the modern shrub steppe became established. Pronghorn and jackrabbit again became the primary land fauna. A major difference would have been an increase in the time period during which salmon spawned and other migratory species traversed the area.

Climates fluctuated in the last 2400 years. A dry cycle around $550 \mathrm{yr}$ B. P. and cooling from 650 to $100 \mathrm{yr}$ B. P. must have had ecological impacts, but what these were remains to be established.

\section{$\underline{\text { References }}$}

Alley, N. F. 1976. "Post-Pleistocene Glaciations in the Interior of British Columbia." In Programme and Abstracts, Geological Association of Canada. p. 6.

Baker, R. G. 1983. "Holocene Vegetational History of the United States." In Late Quatemary Environments of the United States, ed. H. E. Wright, pp. 109-127. University of Minnesota Press, Minneapolis, Minnesota.

Barnosky, C. W. 1984. "Late Pleistocene and Early Holocene Environmental History of Southwestern Washington

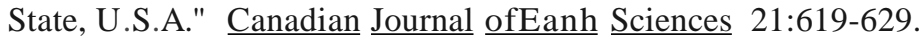

Barnosky, C. W. 1985. "Late Quaternary Vegetation in the Southwestern Columbia Basin, Washington." Quatemary Research 23:109-122.

Barnosky, C. W., P. M. Anderson, P. J. Bartlein. 1987. "The Northwestern U.S. During Deglaciation; Vegetational History and Paleoclimatic Implications." In North America and Adiecent Oceans During the Last Deglaciation, eds. W. F. Ruddiman and H. E. Wright, Jr., pp. 289-321. The Geological Society of America, Inc., Boulder, Colorado.

Beget, J. E. 1981. "Early Holocene Glacier Advance in the North Cascades Range, Washington." Geology 9:409413.

Beget, J. E. 1984. "Tepronchronology of Late Wisconsin Deglaciation and Holocene Glacier Fluctuations Near Glacier Peak, North Cascade Range, Washington." QuaternaIy Research $21: 304-316$.

Bonnichsen, R., D. Stanford, and J. L. Fastook. 1987. "Environmental Change and Developmental History of Human Adaptive Patterns; The Paleoindian Case." In North America and Adjacent Oceans During the Last Deglaciation, eds. W. F. Ruddiman and H. E. Wright, Jr., pp. 403-424. The Geological Society of America, Inc., Boulder, Colorado.

Burke, R. M., and P. W. Birkeland. 1983. "Holocene Glaciation in the Mountain Ranges of the Western United States." In The Holocene, Vol. 2 ofLate Quatemary Environments of the United States, ed. H. E. Wright, Jr. University of Minnesota Press, Minneapolis, Minnesota.

Chance, D. H., and J. V. Chance. 1982. Kettle Falls: 1971/1974. Anthropological Research Manuscript Series 69, University of Idaho, Moscow, Idaho.

Chance, D. H., and J. V. Chance. 1985. Kettle Falls: 1978. Laboratory of Anthropology, University of Idaho, Moscow Idaho.

Chatters, J. C. 1979. Exploratory Excavations aUhe WA-PAJ-XJE Archacological Site Complex 45KT241. Reconnaissance Report No. 23, Qffice of Public Archaeology, University of Washington, Seattle, Washington.

Chatters,J. C. 1984. Human Adaptation Along the Columbia Rjver4700-1600 B,P. Central Washington University, Ellensburg, Washington. 


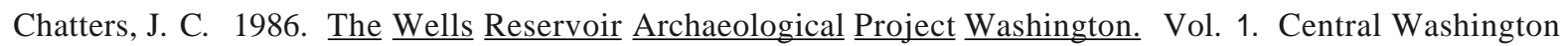
University, Ellensburg, Washington.

Chatters, J. C. and K. A. Hoover. 1986. "Changing Late Holocene Flooding Frequencies on the Columbia River, Washington." Quaternary Research 26:309-320.

Cochran, B. D. 1978. "Late Quaternary Stratigraphy and Chronology in Johnson Canyon, Central Washington." Master's thesis, Department of Anthropology, Washington State University, Pullman, Washington.

Crandell, D. R., and R. D. Miller. 1964. Post-Hypsithennal Glacier Advances at Mount Rainier. Washington. U.S. Geological Survey Professional Paper 501-D:DllO-114, U.S. Geological Survey, Reston, Virginia.

Crandell, D. R., and R. D. Miller. 1974. Quaternary Stratigraphy and Extent of Glaciation in the Mount $\underline{\underline{\text { Rainier }}}$ Region. Washington. U.S. Geological Survey Professional Paper 847, U.S. Geological Survey, Reston, Virginia.

Cressman, L. S. 1960. "Cultural Sequences at the Dalles, Qregon." Transactions of the American Philosophical Society 50(10), Philadelphia, Pennsylvania.

Daubenmire, R. 1970. Steppe Vegetation Of Washington. Washington Agricultural Experiment Station Technical Bulletin 62, Pullman, Washington, $131 \mathrm{pp}$.

Denton, G. H., and W. Karlen. 1973. "Holecene Climatic Variations - Their Pattern and Possible Cause." Quaternary ReSearch 3:155-201.

Duford, J. M., and G. D. Qsborn. 1978. "Holocene and Latest Pleistocene Glaciations in the Shuswap Highland, British Columbia" Canadian Journal Of Earth $\underline{\text { Sciences }}$ 15:865-873.

Fry, W. E. 1969. "A Paleontological Site Survey Conducted in the Horse Heaven Hills of South-Central Washington." Northwest Science 43(4): 156-61.

Fryxell, R. 1973. Salvage of Geochronological Infonnation in the Wells Reservoir Area. Washington (1964-1972). Prepared for the National Park Service by the Laboratory of Anthropology, Washington State University, Pullman, Washington.

Fryxell, R. 1963. "Through a Mirror Darkly." The Record, Washington State University, Pullman, Washington.

Galm, J. E, and R. A. Masten, 008. 1985. Avey's Orchard: Archaeological Investigation Of $\underline{\text { a Later Prehistoric }}$ Columbia River Community. Eastern Washington University Reports in Archaeology and History, Report No. 100-42, Cheney, Washington.

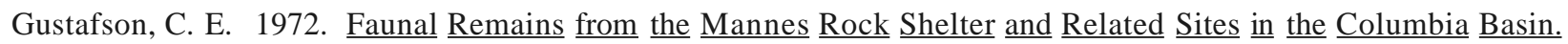
Ph.D. dissertation, Washington StateUniversity, Pullman, Washington.

Hammatt, H. H. 1977. Late Quaternary Stratigraphy and Archaeological Chronology in the Lower Granite

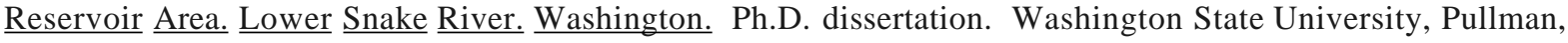
Washington.

Harkins, S. K. 1980. The Prehistoric Occurrence and Aboriginal Utilization of Bison $\underline{\boldsymbol{s} \boldsymbol{\text { in }}} \underline{\underline{\text { the }}} \underline{\underline{\text { Central Columbia }}}$ Basin. Washington. Master's thesis, Washington State University, Pullman, Washington.

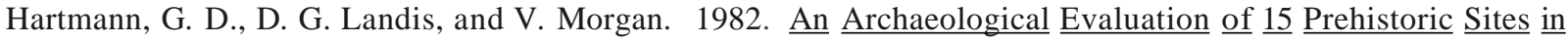

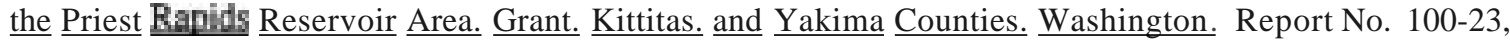
Eastern Washington University Reports in Archaeology and History, Cheney, Washington. 
Hoover, K. A. 1986. A Quantitative Reconstruction of the Paleohydrology and Paleohydraulics of the Holecene Alluvial Stratigraphy. Qkanagan River. Washington. Master's thesis, Department of Geological Sciences, University of Washington.

Irwin, A. M., and U. Moody. 1978. The Lind Coulee Site 45GR97. Project Report 56, Washington Archaeological Research Center, Washington State University, Pullman, Washington.

Kiver, E. P. 1974. "Holocene Glaciation in the Wallowa Mountains, Oregon." In Proceedings of $\underline{\text { a }} \underline{\text { Symposium, }}$ edt W. C. Mahaney, pp. 169-196. Geographical Monograph No.5, York University-Atkinson College, Toronto, Canada.

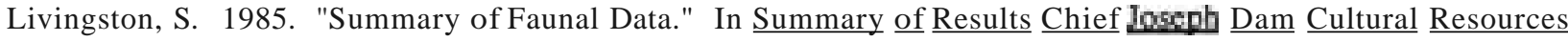
Project Washington, edt S. K. Campbell, pp. 365-411. Prepared for U.S. Army Corps of Engineers by the Qffice of Public Archaeology, University of Washington, Seattle, Washington.

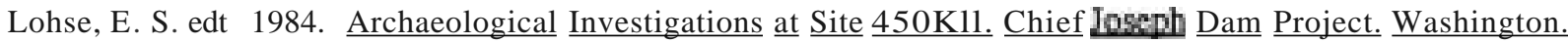
U.S. Army Corps of Engineers, Seattle, Washington.

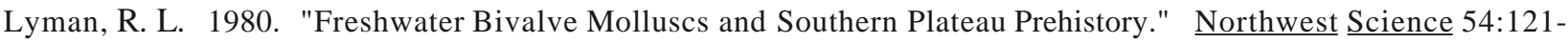
135.

Lyman, R. L., and S. D. Livingston. 1983. "Late Quaternary Mammalian Zoogeography of Eastern Washington." Quaternary ReSearch 20:360-376.

Mack, R. N., V. M. Bryant, Jr., and R. Fryxell. 1976. "A Pollen Sequence from the Columbia Basin Washington: Reappraisal of Post Glacial Vegetation." American Midland Naturalist 95:390-397.

Mack, R. N., V. M. Bryant, and S. Valastro. 1978. "Late Quaternary Pollen Record from Big Meadow, Pend Orielle County Washington." Ecology 59:956-966.

Mack, R. N., N. W. Rutter, V. M. Bryant, Jr., and S. Valastro. 1978. "Reexamination of Post Glacial Vegetation History in Northern Idaho." Quatemary Research 10:241-255.

Mack, R. N., N. W. Rutter, and S. Valastro. 1978. "Late Quaternary Pollen Records from the Sanpoil River Valley Washington." Canadian Journal of Botany 56:1642-1650.

Mack, R. N., N. W. Rutter, and S. Valastro. 1979. "Holecene Vegetation History of Qkanogan Valley Washington." Quaternary Research 12:212-225.

Mahaney, W. C., B. D. Fahey, and D. T. Lloyd. 1981. "Late Quaternary Glacial Deposits, Soils and Chronology. Hell Roaring Valley, Mount Adams, Cascade Range, Washington." Arctic and Alpine Research 13(3):339-356.

Mehringer, P. J. 1985a. "Late-Quaternary Pollen Records from the Interior Pacific Northwest and Northern Great Basin of the United States." In Pollen Records of Late-Quaternary North American Sediments, edt V. A. Bryant and R. G. Holloway pp. 167-189. American Association of Stratigraphic Palynologists, Dallas, Texas.

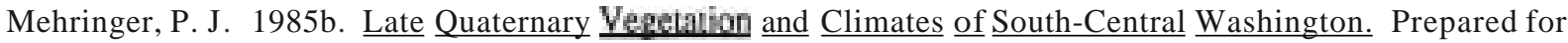
Battelle Pacific Northwest Laboratories by the Department of Anthropology, Washington State University, Pullman, Washington.

Mierendorf, R. R. 1983. "Fluvial Processes and Prehistoric Settlement Patterns Along the Rocky Reach of the Columbia River." In Cultural Resources of the Rocky Reach of the Columbia River, Volume II, pp. 633-644, eds. R. F. Schalk and R. F. Mierendorf. Center for Northwest Anthropology, Washington State University, Pullman, Washington. 
Miller, C. D. 1969. "Chronology of Neoglacial Moraines in the Dome Peak Area, North Cascade Range, Washington." Arctic and Alpine Research 1:49-66.

Moody, U. L. 1978. Microstratigraphy. Paleoecology. and Tephrachronology of the Lind Coulee Site. Central Washington. Ph.D. dissertation, Washington State University, Pullman, Washington.

Nickmann, R. 1979. The Palynology of Williams Lake Fen Sookane County. Washington. Master's thesis, Department of Geology, Eastern Washington University, Cheney, Washington.

Nickman, R., and E. B. Leopold. 1985. "A Postglacial Pollen Record from Goose Lake, Okanogan County, Washington: Evidence for an Early Holocene Cooling." In Summary of Results. Chief Ioseph Dam Cultural

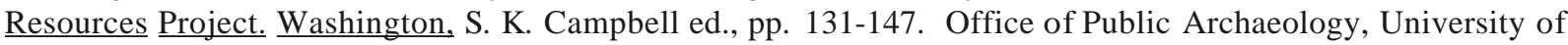
Washington, Seattle, Washington.

Pavish, M. 1973. Stratigraphy and Chronology of Holocene Alluvium Between the Cascade Crest and the

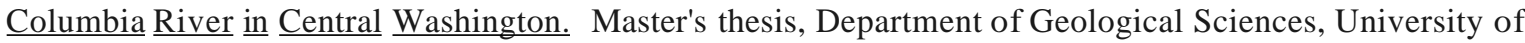
Washington, Seattle, Washington.

Porter, S. C., and G. H. Denton. 1967. "Chronology of Neoglaciation in the North American Cordillera." AmeriCan Journal of Science 265:201.

Porter, S. C., K. L. Pierce, and T. D. Hamilton. 1983. "Late Wisconsin Mountain Glaciation in the Western United States." In Late Ouaternary Environments of the United States, eds. H. E. Wright, Jr. and S. C. Porter, pp.71-111. University of Minnesota Press, Minneapolis, Minnesota.

Randolph, J., and D. G. Rice. 1975. A Preliminary Report on an Archaeological and Paleontological Survey in the

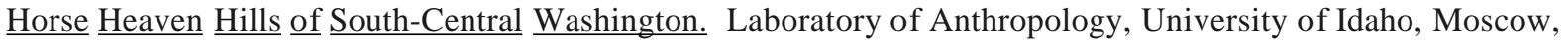
Idaho.

Rensberger, J. M., A. D. Bamosky, and P. Spencer. 1984. Geology and Paleontology of a Pleistocene-to-Holocene

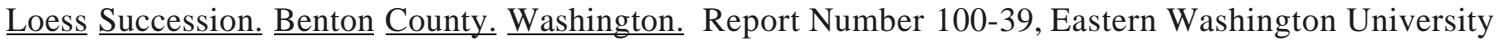
Reports in Archaeology and History, Cheney, Washington.

Rice, D. G. 1980. Overview of Cultural Resources on the Hanford Reservation in South Central Washington State. RL-E-80-0043, prepared for the U.S. Department of Energy Richland Operations Office, Richland, Washington.

Richmond, G. M., R. Fryxell, G. E. Neff, and P. Weis. 1965. "The Cordilleran Ice Sheet of the Northern Rocky Mountains, and Related Quaternary History of the Columbia Plateau." In The Ouaternary of the United States, E. H. Wright, Jr., and D. G. Frey ed., pp. 231-242. Princeton University Press, Princeton, New Jersey.

Schrocdl, G. F. 1973. The Archaeological Occurrence of Bison in the Southern Plateau. Laboratory of Anthropology Reports of Investigations, No. 51, Washington State University, Pullman, Washington.

Thompson, R. S. 1985. Paleoenvironmental Investigations at Seed Cave (Windust Cave H-45FR46), Franklin County. Washington. Report Number 100-41, Eastern Washington University Reports in Archaeology and History, Cheney, Washington.

Vannote, R. L., and G. W. Minshall. 1982. "Fluvial Processes and Local Lithology Controlling Abundance, Structure, and Composition of Mussel Beds." In Proceedings of the National Academy of Sciences, 79:41034107.

Waitt, R. B., Jr. 1980. "About Forty Last-Glacial Lake Missoula Jokulhlaups Through Southern Washington." Journal of Geology 88:653-679. 
Waitt, R. B., Jr., and R. M. Thorsen. 1983. "The Cordilleran Ice Sheet in Washington, Idaho, and Montana." In Late-Quaternary Environments of the United States 1:52-70, ed. S. C. Porter and H. E. Wright, Jr. University of Minnesota Press, Minneapolis, Minnesota.

Waitt, R. B., Jr., J. C. Yount, and P. T. Davis. 1982. "Regional Significance of an Early Holocene Moraine in Enchantment Lakes Basin, North Cascade Range, Washington." Quatemary Research 17:191-210 


\section{APPENDIXD \\ OVERVIEW OF EXISTING KNOWLEDGE ABOUT CULTURAL RESOURCES OF THE HANFORD REGION}




\section{APPENDIX 0 OVERVIEW OF EXISTING KNOWLEDGE $\underline{\text { ABOUT }}$ CULTURAL RESOURCES OF THE HANFORD REGION}

\subsection{PALEONTOLOGY}

The remains of animals and plants provide evidence of past life or environmental conditions, and thus have the ability to elucidate scientific information about past climates, ecosystems, and subsistence bases. As such, they are regarded as important cultural resources. Paleontological resources are common in formations of various ages on, and adjacent to, the Hanford Site. Animal (and possibly plant) fossils abound in the Plio-Pleistocene Ringold Formation (see Figure 0.1), small mammal fossils are common in a long sequence of Pleistocene wind-deposited sediments south of Kennewick, and discoveries of animal remains are becoming increasingly common in latePleistocene Touchet Beds throughout the Pasco Basin. The potential fossil content of Holocene-age eolian and fluvial sediment has not been fully explored. The composition and distribution of plant and animal fossils within these formations can indicate climatic and other environmental conditions extant at the time of deposition. Despite these potentials, few systematic paleontological surveys have been conducted on the Hanford Site.

The Ringold Formation crops out in the White Bluffs, east of the Columbia River and north of Richland. Major fossil-bearing beds include the middle Ringold conglomerate and upper Ringold strata. The fauna contained in middle Ringold sediment is considerably older than--and quite different from--that contained in the upper levels. For this reason, Gustafson (1978) has named the older fauna the River Road local fauna, while upper Ringold fossils have been termed the White Bluffs local fauna

The River Road local fauna currently consists of two specimens, one of which has been positively identified at the genus level (Gustafson 1978). Both specimens are from the Class Mammalia, but represent two different Orders, Perissodactyla and Artiodactyla The better-identified specimen is a left mandible with incisors belonging to the genus Teleoceras, Family Rhinocerotidae. Teleoceras, according to Gustafson (1978) is a characteristic preBlancan-age (pre-Pliocene) genus, and the Ringold specimen is probably late Hemphillian in age. The other specimen, less well-defined, is the proximal portion of the radioulna, similar in morphology to the genus Camelops, Family Camelidae. It is probably ancestral to Camelops, given its deduced late Hemphillian age.

The White Bluffs local fauna is larger and more diverse. Identifiable fossils include many species of fish, frog or toad, turtle, ground squirrel, rabbit, marmot, pocket gopher, mouse, beaver, sloth, woodrat, and other rodents; many of these species are represented by ancestral forms not extant in modem fauna. Larger mammals from the upper Ringold include coyote, borophagine dog, bear, cougar-sized cat, mastodon, camel, deer, and a large species of horse. According to Gustafson (1978), this fossil mammalian assemblage represents a North American Mammal Age of early Blancan (late Pliocene), about 3.4 to 1.6 million years old.

The River Road fauna is too incomplete to be diagnostic of any particular paleoenvironment. The White Bluffs local fauna, in contrast, suggests a rather specialized habitat (Table 1 from Gustafson 1978). Most striking is the high relative abundance of larger mammals adapted to browsing rather than grazing. Vegetation preferences among the browsers indicate that woodland habitats were prevalent on the Ringold floodplain. The lower vertebrates, including fish, turtles, and frogs, suggest that quiet-water ponds and marshes were also present.

Animal remains of Pleistocene age have been found at numerous locations in the Pasco Basin, though not specifically on the Hanford Site. A loess (wind-deposited silt) succession dating from about 175,000 yr BY. to post-6800 yr B.P., containing a large microfaunal assemblage, is exposed in a roadcut south of Kennewick, Washington (Rensberger, Barnosky, and Spencer 1984). Whole mammoth skeletons have been retrieved from Touchet Beds west of Walla Walla, Washington (Scott and Clem 1967), at the edge of the Horse Heaven Plateau in southwestern Benton County (Newcomb and Repenning 1970), and south of the town of West Richland. A paleontological survey conducted in the Horse Heaven Hills (Fry 1969) revealed 31 sites at which vertebrate fossil material was found, including mammoth, bison, horse, and deer.

The Kennewick roadcut is the earliest and most extensive of the fossil localities. Work conducted in 1981 recovered a minimum of 22 species of mammals, along with a small sample of lizard, snake, frog, and bird bones (Table 5 from Rensberger, Barnosky, and Spencer 1984). In all, nearly 15,000 specimens were collected. The fossils were deposited in windblown dust that originated in glacial sediments from ice sheets that lay to the north. The only visible sedimentary structures contained in the loess consist of eight calcium carbonate horizons and two tephra units, Mt. St. Helens set "S" and ash from Mt. Mazama. The discontinuity and dip of the carbonate horizons 


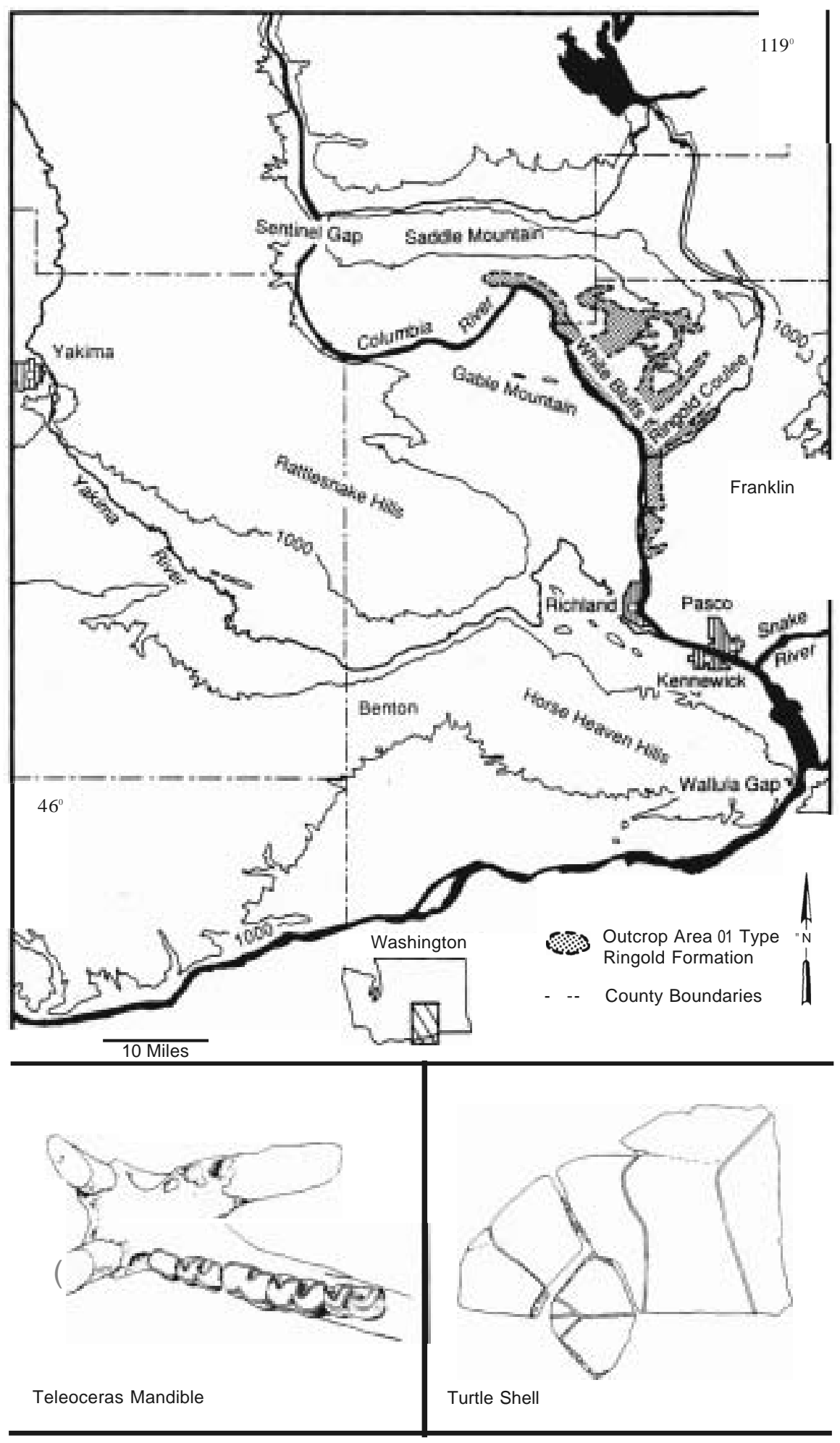

FIGURE D.1. The Ringold Fonnation and Other Topographical Features on the Hanford Site; Fossils Typical of the Fonnation 
and tephra suggest that deposition proceeded toward the north. Subsequent analysis of the faunal remains in light of the stratigraphic context indicate that there were changes in morphology as well as disappearances, appearances, reappearances, and variations in the relative abundance of taxa through time.

The mammalian fauna of the Kennewick roadcut is primarily a diverse assemblage of small burrowing animals. The collection includes northern water shrew, pigmy rabbit, mole, mountain cottontail, Townsend ground squirrel, chipmunk, Great Basin pocket gopher, Great Basin kangaroo rat, Ord kangaroo rat, northern pocket gopher. desert woodrat, bushy-tailed woodrat, deer mouse, sagebrush vole, heather vole, and an extinct form of arvicoline cricetid, Microtus meadensis. Non-burrowers and larger mammals include evening bats, mammoths, a coyote-like animal, and a single artiodactyl specimen (Rensberger, Bamosky, and Spencer 1984). The taxonomic presence and abundance of these animals yield paleoenvironmental indicators; however, without absolute-age chronologic control, climatic changes cannot be assigned to any particular time period.

The remainder of the fossil localities all date from the late Pleistocene and early Holocene. All isolated mammoth fmds occur in Touchet Beds, 1 to 3 meters below the top of the sequence, making them perhaps 13,000 years old. Deposition of nearly complete skeletons in slackwater sediments suggests that dead mammoths were washed down in the floods and settled out in quiet backwater locations. Fossils in the Horse Heaven Hills south of Kennewick range in age from greater than 12,000 years to 7000 years old (Fry 1969). Paleoenvironmental conditions are not strongly expressed by this limited faunal assemblage.

Holocene strata have not been systematically studied for paleontological resources. Many locations on the Hanford Site, most notably Dry Creek Canyon, dune deposits, and the Columbia River islands, have the potential to provide paleoecological information in the form of plant remains (especially pollen and phytoliths) and animal micro- and macrofossils, but these have been only cursorily identified, described, and sampled (Hanford Cultural Resources Laboratory 1988).

\section{$\underline{\text { References }}$}

Fry, W. E. 1969. "A Paleontological Site Survey Conducted in the Horse Heaven Hills of South-Central Washington." Northwest Science 43(4): 156-61.

Gustafson, E. P. 1978. The Vertebrate Faunas of the Pliocene Ringold Formation. South Central Washington. Museum of Natural History Bulletin 23, University of Oregon, Eugene, Oregon.

Hanford Cultural Resources Laboratory (HCRL). 1988. Basalt Waste Isolation Project Archacological and Cultural Resources Field Studies. Letter Report to DOE Richland Operations Office, Richland, Washington.

Newcomb, R. C. and C. A. Repenning. 1970. "Occurrence of Mammoth Fossils in the Touchet Beds, South-

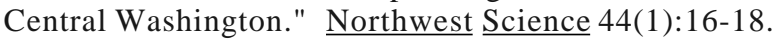

Rensberger,]. M., A. D. Bamosky, and P. Spencer. 1984. Geology and Balcontology of a Pleistocene-to-Holocene Loess Succession. Benton County. Washington. Report Number 100-39, Eastern Washington University Reports in Archaeology and History, Cheney, Washington.

Scott, W. F., and R. Clem. 1967. "A Mammoth From the Touchet Beds Near Walla Walla, Washington." Northwest Science 41(1):60-61 (Abstract). 


\section{D.2 PREHISTORY}

\section{The Anchacological Record of the Hanford Site}

The Hanford Site contains the least-disturbed archaeological record still to be found along a major river in the Columbia Basin Region. Because of limited public access and the absence of modem agricultural, industrial, hydroelectric, and residential development, the archaeological sites of Hanford have been less affected by land leveling, inundation, construction, and looting than their counterparts elsewhere in the region. Because most archaeological research in the Columbia Basin has been funded by government construction projects, and few such projects have been undertaken at Hanford, the archaeological record of the Site, which lies at the heart of the Basin, is the least known.

In many ways, the archaeological record of the Hanford Reach is a key to understanding the prehistory of the Columbia Basin Region. This is in part due to the timing and thoroughness of archaeological research in different parts of the Basin. From the late 1960s through the 1980s, large-scale hydroelectric, reclamation, and highway construction projects above Wenatchee on the Columbia (Campbell 1986; Chatters 1986; Galm and Masten 1985; Schalk and Mierendorf 1983) and above Lyons Ferry on the Snake River have funded intensive archaeological research (e.g., Ames, Green and Pfoertner 1981; Brauner 1975, 1976; Leonhardy 1970). Because of large budgets and the accessibility of modem research methods, the archaeological record of those upriver areas is well documented. Although there are a few exceptions (e.g., Burtehard 1981; Cleveland 1977; Schalk 1983), archaeological projects in the McNary, Ice Harbor, Priest Rapids, and Wanapum Reservoirs were conducted in the 1950s and early 1960s and have provided much less detail than the upriver studies about the prehistory of the region. More recent excavations have generally been small-scale operations (Burtehart 1981; Rice 1980) or were conducted with the aid of amateur groups and have not yet been fully analyzed or reported (see Oeveland and Uebelacker 1980; Schalk 1980). The outcome of this research history is that, in developing ideas about cultural development in the Columbia Plateau, archaeologists have had to place greater emphasis on data from the northern and eastern fringes of the Columbia Basin. The applicability of these ideas to the more arid, salmon-rich lower reaches of the Columbia and Snake rivers cannot be fully evaluated with existing data. Today, the best place to evaluate those ideas, and to determine how lower river areas differ from the fringes of the Columbia Basin is the Hanford Site. Elsewhere, most archaeological sites, especially those pertaining to the late prehistoric period, have been inundated or destroyed by development or looting.

Knowledge of the Hanford Site's archaeology, at least as it has been reported, is minimal. Knowledge accumulated to date comes from numerous small and large-scale archaeological surveys and a few minor excavations. Key archaeological sites are shown on the map in Figure 0.2.

\section{$\underline{\text { Archaeological Surveys }}$}

As of June 1988,64 archaeological surveys had been conducted on the Hanford Site. A list of these, including the date of the survey, area covered, techniques employed, results, location of collections, if any, and report references, is provided in Appendix AI, Table AI.I. Maps of survey locations, keyed to Table AI.I., are provided in the map pocket.

Thirty-one surveys, covering 137.9 square kilometers, were conducted prior to the creation of the Hanford Cultural Resources Laboratory in 1987. The largest of these were the Ben Franklin Dam survey in 1967, which resulted in the discovery and recording of 85 archaeological sites within the Hanford boundaries (Rice $1968 \mathrm{a} ; 39.82$ square kilometers), the Hanford Site Reconnaissance in 1968, which recorded an additional 26 sites (Rice 1968b), and surveys for the Washington Public Supply System, which recorded two sites (Rice 1980, 1983; 13.7 square kilometers).

Techniques used in these surveys varied considerably. Some, such as the Ben Franklin Dam and Hanford Site Surveys, were conducted with amateur assistants, Others, such as the surveys for the planned Skagit-Hanford Nuclear plant (ERTEC 1982) employed professional archaeological technicians. Some should be considered reconnaissance, since they selectively inspected the landscape (euphemistically called a judgemental sample) (e.g., Drucker 1948; Lee 1955; Rice 1968b). Other surveys covered the entire landscape of the survey plot in parallel transects, but transect intervals varied from as little as 4 meters to as much as 100 meters. The difference in intensity is not ordinarily justified by report authors, but Rice (1984) suggests that in one case a 100-meter interval was appropriate on the 200 Area Plateau/Cold Creek Syncline because of the low expected density of sites.

The concept of "archaeological site" varied among investigators. Rice, for example (e.g., 1968b, 1983, cf. 1980) reported fmding small concentrations of food grinding tools, cobble tools, chipped stone and/or fire broken 


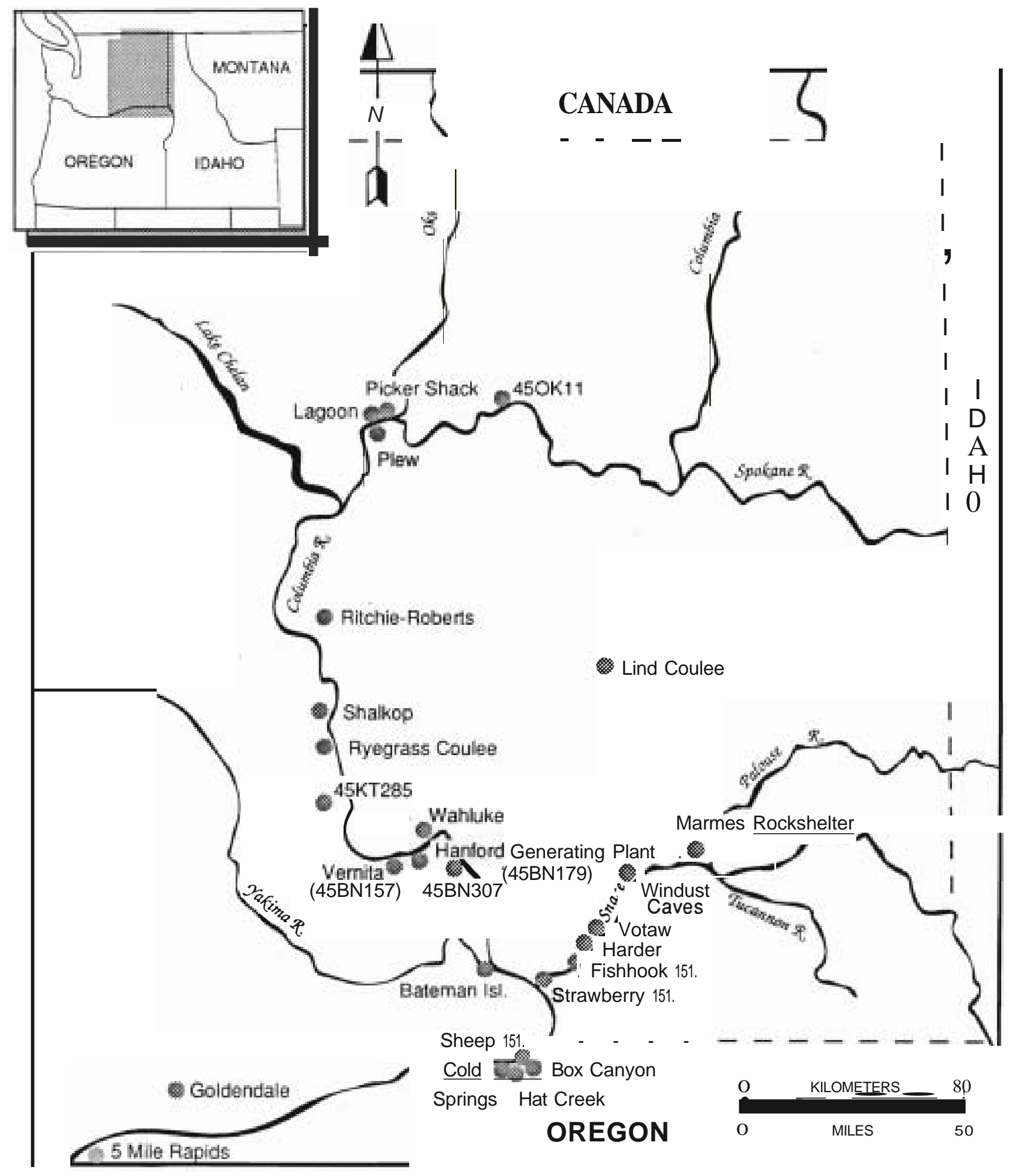

FIGURE D.2. Archaeological Sites Referenced in the Text 
rock but did not record these as archaeological sites. Other investigators (e.g., Smith et al. 1977; ERTEC 1982) recorded all artifact concentrations, and even isolated artifacts, as sites. Examples of some artifiacts found on the Hanford Site are shown in Figure D.3. Consequently, although 120 "sites" have been registered for the Hanford Site, the meaning of that number in cultural-resource terms is obscure.

Since the establishment of the Hanford Cultural Resources Laboratory (HCRL) in 1987,33 surveys have been conducted, ranging in size from .01 to 3.24 square kilometers. The total area covered has been 10.6 square kilometers. All surveys have been of the intensive type, with transect intervals of no greater than 20 meters. Any cluster of three or more artifacts is considered to be a site; smaller concentrations are isolates. Six prehistoric sites and nine historic archaeological sites have been found to date, and numerous isolated artifacts have been recorded. Although 32 of the survey projects were impact driven, the largest survey, conducted, as part of the Basalt Waste Isolation Project, employed a random stratified sampling design in an attempt to obtain data on the kinds, densities and distributions of sites and isolated artifacts in different topographic settings of the Site (HCRL 1988).

\section{$\underline{\text { Prehistory }} \underline{\text { as }} \underline{\text { Indicated }} \underline{\text { by }} \underline{\text { Survey }} \underline{\text { Data }}$}

A statistical analysis of site distributions cannot be performed on existing data, due to variations in the definition of "site" used, the intensity of survey coverage, and the nonprobabilistic character of most surveys. However, it is possible to summarize the kinds and apparent topographic distributions of sites that have been found Sites have been described as housepit villages, open campsites, fishing stations, lithic scatters, cairns, hunting blinds, and cemeteries.

Housepit Sites. Sites of this kind consist of chipped stone and evidence of domestic activity such as firecracked rocks (which are the residue of the basket-boiling of water), animal bone, bivalve shell, and charcoal. They contain one or more man-made circular to oval depressions. Twenty-three sites of this kind have been recorded, concentrated in four clusters along the Columbia River. Seven housepit sites occur scattered along the Columbia River within 15 kilometers of Richland. Except for a large site on Wooded Island, which contains 18 housepits, each site contains from 3 to 10 depressions. Another cluster of 10 housepit sites is located upstream of the Hanford Townsite, opposite the White Bluffs, particularly on the shore and islands between 100-F and 100-D Areas. The largest housepit cluster in this group is site 45GR302a, which contains at least 60 large (6 to 8 meters in diameter) circular depressions, some up to 1.8 meters deep, and numerous smaller depressions interpreted by Rice (1968a) as storage pits. Two other sites contain 20 or more housepits. According to information recorded on site forms (Rice 1968a,b), sites of this kind commonly contain food-grinding equipment (bases for hopper mortars, pestles), cobble tools (hammerstones, chopping tools), chipped stone tools, fishing implements, and an assortment of food detritis and other domestic debris. Most housepit sites contain only small and large comer-notched or small side-notched projectile points, indicating that they post-date 2500 yr B. P. (see 4.4.2, Summary of Regional Prehistory). Four sites also contain narrow, contracting-stemmed points of the style that dates between 2500 and $3500 \mathrm{yr}$ B. P., but these may predate the housepits. However, one site (45GR315) in which silted-in house depressions were found contains only large, broad-stemmed points that may be as old as $4500 \mathrm{yr}$ B. P. Some of these sites are known to have been inhabited as late as the twentieth century (Relander 1986).

Open Campsites. This site type is something of a catch-all category including all sites with remains of domestic activity but lacking pithouses. Such sites have been found lining both banks of the Columbia River, on the mid-channel islands, at springs, and on the banks of Snively Creek. These sites commonly contain similar artifacts to those of the housepit sites, although content is quite variable. This category probably includes sites used for an assortment of functions. Likewise, a wide range of ages is evident Like the housepit sites, most sites contain only small and/or large comer-notched projectile points, but older styles are also common. Leaf-shaped projectile points of Cascade style are reported at two sites (45FR264 and 45BN171, based on surveys only). Large, stemmed projectile points that may be of the Windust style were found in one site (45FR264).

Eishing Stations. These are concentrations of notched and grooved net sinkers and cobble tools along the Columbia River bank. Rice (1968a) reported numerous sites of this kind scattered along the Hanford Reach; however, the collection of the net weights by workers and the public over the past 20 years has obliterated many of the concentrations.

Lithjc Scatters. Small concentrations of chipped stone that lack such domestic debris as fire-cracked rock and bone are called lithic scatters. They are believed to represent short-term tool-preparing and/or food-processing localities. Sites of this type are common around the bases of buttes (especially near hunting complexes), in the active sand dunes, and may occur elsewhere in topographic settings not yet surveyed. Ages of such sites are often 

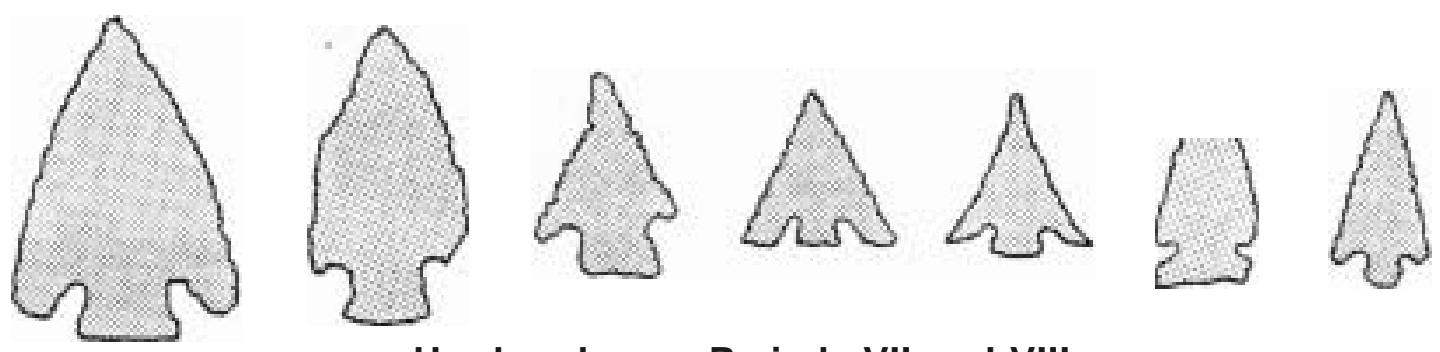

Harder phase - Periods VII and VIII
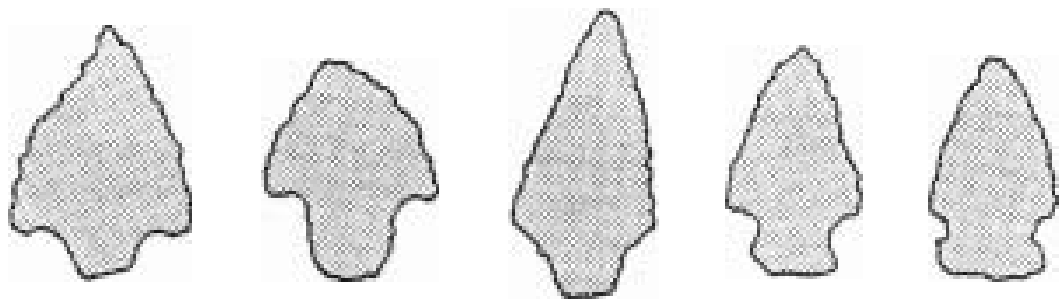

Tucannon phase - Periods IV, V, and VI
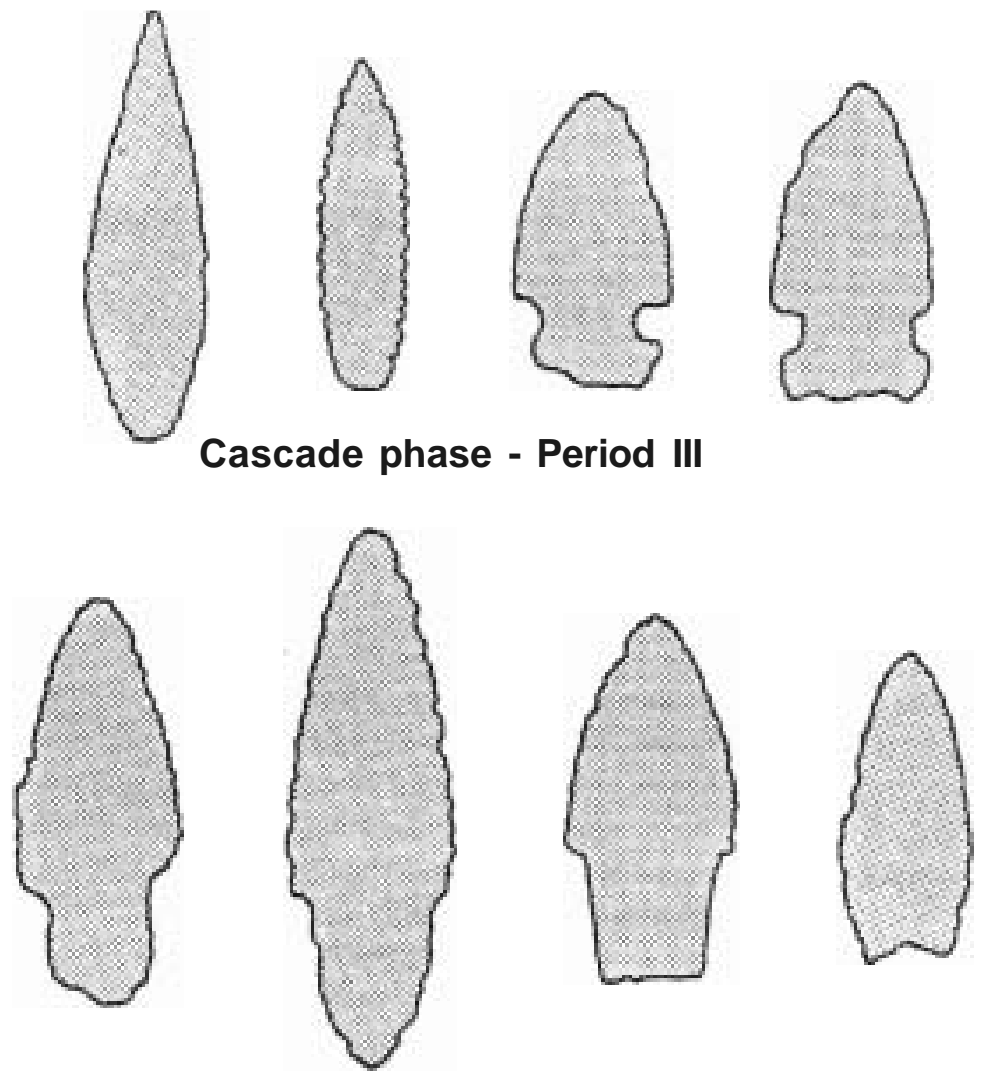

Windust phase - Period II

FIGURE D.3. Projectile Point Styles Typical of Prehistoric Time Periods II Through VIII in the Hanford Area 
impossible to establish, since they commonly lack projectile points and other chronologically variable tools. Those that have been found containing projectile points generally date to within the last 2500 to $3500 \mathrm{yr}$ B. P.

Hunting Complexes. Associations of loosely piled rock walls and shallow talus pits often occur at points where local topography constricts game movement These are thought to be hunting trap and blind complexes and are commonly associated with isolated projectile points and lithic scatters. Three such sites have been found in the Gable Butte area. Projectile point styles indicate an age range of at least 2500 years.

Rock Cairns. Piles of angular rock on high buttes, ridges, and Rattlesnake Mountain are believed to be piles left by youths on their spirit quest vigils. Ten such piles or groups of piles have been recorded as sites, but others are known to exist. No estimate of ages is yet possible.

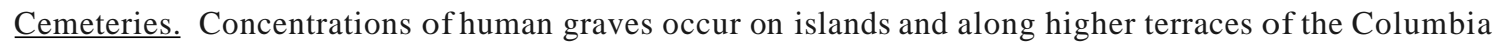
River. Three are associated with habitation sites, and eight others are isolated from domestic sites. As many as 1000 graves may be included in the cemeteries, and other, unrecorded cemeteries are likely to exist Artifacts found on the surface of cemetery sites indicate that most date to within the last 2000 years (Rice 1968a)

\section{Archacological Excavations}

Records show that small-scale excavations have been conducted at 12 and possibly 13 archaeological sites that are now within Hanford's boundaries (Appendix A.1, Table A.1.2). Twelve of these are prehistoric archaeological sites, and one is an historic cabin (Rice 1976) and is not discussed here. In no case has the material recovered from any of these excavations been analyzed fully and reported in detail; the excavation techniques often are not mentioned.

Unreported Excavations. Test excavations were conducted in 1968 or 1969 at sites 45BNI06, 45BN149, 45GR302A, 45GR302B, 45GR316, and possibly 45BN175, by the Mid-Columbia Archaeological Society under the direction of David G. Rice, then a student at Washington State University (Rice 1968b, 1973). None of the findings from this work has been reported, nor apparently, were the pits filled in. The location of the artifacts and records is unknown at this writing, but they may be archived by members of the Mid-Columbia Archaeological Society.

Wahluke Village (45GR306). In 1927, Herbert Krieger of the Smithsonian Institution excavated housepits and graves in what is now called 45GR306, on the left bank of the Columbia River just above the White Bluffs. He described the site as a row of 30 depressions each of which consisted of "a stone-capped rim of earth surrounding a centrally excavated pit of varying depth with a diameter of 30 or more feet" (Krieger 1928). The cemetery is located on a higher terrace behind the housepits. Krieger makes brief mention of the housepits, having devoted most of his attention to the exhumation of graves. The number of individuals or grave groups excavated is not mentioned, but from the description, one gets the impression there were many. Krieger reports that there were individual, in situ cremations; group secondary cremations of individuals who had been exposed, allowed to decompose, and then cremated in a group ceremony; and primary, non-cremated interments. Great numbers of artifacts were found in the graves, including stone bowls and pestles, arrow points and knives, tubular stone pipes, nephrite adze blades, selfhandled mauls, pendants and beads of marine shell, objects of native copper, and a variety of bone implements, ornaments and gaming pieces. Copper and the burning process preserved many objects of wood and fiber, including sinew and Indian hemp string, and pieces of basketry and tule or cattail matting. The art styles that decorate many objects were similar to those found elsewhere on the Columbia River from Wenatchee to the Cascades. The small, comer-notched projectile points from the site, shell bead forms, and decorative motifs on gaming pieces and other items date the site at approximately 500-1000 yr B. P. (Rice 1983, p. 82; see also Nelson 1969; Leonhardy and Rice 1970). Artifacts are housed in the Smithsonian Institution, Washington D. C.

The Hanford Generating Plant Site (45BN179 and 45BN180_. Rice $(1973,1983)$ conducted test excavations at these two sites in 1973 as part of cultural resource compliance activities conducted for the Washington Public Power Supply System. The sites are situated just upstream from the 100-N Area on the modem floodplain of the Columbia River.

Rice and University of Idaho students excavated a contiguous 32-square-meter area of 45BN179, which he estimates to have been 2.4 percent of the site. The deposit consisted of river gravels (Stratum 6) overlain by four natural strata, beginning with well-grounded cobble to pebble gravel mixed with fme yellow sand (Stratum 5), fme yellow sand (Stratum 4), massive fme brown sand (Stratum 3), and moderately fme brown sand mixed with cobbles (Stratum 2) (Rice 1973, Table 10). Mixed material from modem reactor construction capped the sequence. Cultural material from four prehistoric periods was identified, one period with each stratum. Stratum 2 contained glass beads 
and a clay pipe and was interpreted as the Historic Wanapum Component. Stratum 3 contained the remains of a housepit approximately 4 to 5 meters in diameter. A storage pit had been excavated into its floor. Artifacts from this stratum were typical of the Cayuse Phase (Nelson 1969). and a dendrocorrected radiocarbon date of A. D. $88+36$ (WSU-1421; Rice 1980. p. 84) was obtained from the base of this stratum. Faunal remains are not described in detail. but included large and small mammals. river mussel. bird. and fish. Stratum 4 contained a Frenchman Springs Phase occupation. including narrow-bladed. contracting-stemmed projectile points and a variety of flake and core tools. Faunal remains were scarce. but included the same sorts of animals as Stratum 3. Rice (1973) estimated that the age for this assemblage of artifacts is 2000 to $4000 \mathrm{yr}$ B. P. Assemblages found mixed with gravels in Strata 5 and 6 were similar. including leaf-shaped and large side-notched projectile points. edge-ground cobbles. a mano. and a variety of core and flake tools. These artifacts are characteristic of the late Vantage (a.k.a Cascade) Phase. and probably date between 7000 and $4000 \mathrm{yr}$ B. P. The site remains in its original condition today. including open pits left by the excavators.

Site 45BN180 consisted of two housepit depressions approximately 7 meters in diameter. One housepit had been disturbed, evidently by relic collectors. so Rice (1973) and his staff excavated one 1- by 5-meter trench across the center of the other depression. The housepit had been 5 meters in diameter. 1 meter deep. and had a saucershaped profile. They found numerous salmon bones in the floor. but few artifacts. The site was assumed to be from the Cayuse Phase. although no stylistically variable artifacts were found. Construction of a BPA powerline structure later destroyed the site. Artifacts from both sites are curated at the University of Idaho.

45BN257. This site consisted of a single hearth in river gravels that was discovered during excavation of the water-intake structure for WPSS Generating Plants 1 and 4 (Rice 1983). The hearth was radiocarbon dated at approximately 1600 A.D.

vernita Site 45BN157. A team. led by Rice. consisting of amateurs from the Mid Columbia Archaeological Society and students from the University of Idaho. conducted excavations at the Vernita site in 1973 and 1974 (Den Beste and Den Beste 1974; Rice 1980). The site was being severely damaged by artifact collectors and was scheduled for leveling under the Hanford Site Cleanup project. Activities included test excavation and excavation of a large pit in the east end of the site. Reports indicate that prior to excavation on the Jaeger Island portion of the site. which is reported to have been a cemetery. a bulldozer was used to remove at least one meter of disturbed soil.

Finds at Vernita closely resembled those from the Hanford Generating Plant. There was an Late Cayuse Phase component that had been extensively disturbed by relic collectors. a Frenchman Springs Phase component. and an extensive Vantage Phase deposit at the base. The Vantage Phase component was in fine sand deposits at Vernita. and associated with it were large side-notched and leaf-shaped projectile points. and edge-ground cobbles. Large amounts of bone and charcoal-stained features were also present Some of the stained features were extensive. and may be house floors. A sample of bone was submitted for radiocarbon analysis. and was dated at 2903+117 B. C. (Rice 1980. p. 72) or approximately $4240 \mathrm{yr}$ B. P. The bones and artifacts have not been analyzed in detail. and are currently archived in the home of a member of the Mid-Columbia Archaeological Society.

45BN307. As part of their cultural resource compliance efforts for the Puget Power and Light Company.

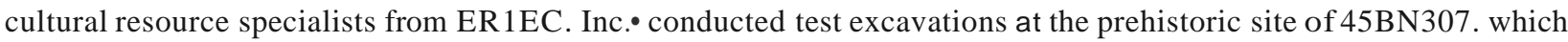
is in the vicinity of the old Hanford townsite. They excavated 20 one-meter-square test pits over an area of 60 by 220 meters. Results showed a continuous scatter of artifacts. both horizontally and vertically. but investigators discerned two horizontal concentrations. On the basis of two projectile points from one of those areas (Locus A). and the similarity of artifacts to those in the other area (Locus B). they concluded that both represented the late Cayuse Phase. A date of 1500 A. D. to historic times is suggested.

Review of illustrations provided in the ER1EC report (Figures 14. 15 of ERTEC 1982) shows that their conclusion is incorrect. First, there are at least two vertical concentrations of artifacts in most test excavations. Second, the two projectile points illustrated are a square-shouldered. expanding-stemmed form (Figure 14.c) usually associated with the late Frenchman Springs Phase (ca 2800-3500 B. P.) and a Cold Spring side-notched form (Figure 14,c), attributable to the late Vantage Phase (7QQQ-4000 yr B. P.). A reanalysis of artifacts from $45 \mathrm{BN} 307$ will be necessary before this material can be used to understand local prehistory. The artifacts are at the HCRL. 


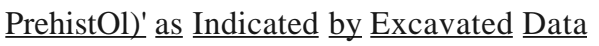

None of the modern excavations on the Hanford Site have been conceived of as anything more than tests of the sites involved.

Krieger's (1928) Wahluke excavations were extensive, but focused on graves. Only three radiocarbon dates have been obtained on materials from the area, and there has been no detailed analysis of faunal: remains, stone tools, or sedimentology for any of the sites. Therefore, it is not possible at this time to suggest a sequence of human adaptations to the Hanford Site environment, and little can be contributed to the discussion of past environments. What can be said is that the few excavated sites show that artifacts representing at least the past 5000 to 7000 years are abundant, that semi-subterranean houses were used at least during the last 2000 years, and that the inhabitants utilized a variety of animals for food. From the artifacts found in the cemetery at Wahluke, it is evident that during the last millennium, people of this reach frequently interacted with other Columbia River groups and participated in an artistic tradition common to that area. They also engaged in active trading, using nephrite and perhaps copper from British Columbia and shells from the Puget Sound and Pacific Coast.

\section{Conclusions}

Archaeological research on the Hanford Site has consisted almost entirely of impact-driven surveys and a few small-scale excavations. Much of the archaeological work has been done by professional-led amateur organizations and the majority of the archaeological survey has been at the reconnaissance level. Excavations have been reported in a cursory manner, if at all. Many of the early surveys selectively inspected areas that were considered likely to have sites, whereas areas considered to have low archaeological site potential were inspected only on an impact-driven basis. No attempt was made to sample the environmental variability of the Site to obtain statistically valid estimates of site distributions. As a result, although we know the whereabouts of many archaeological sites on Hanford, we cannot be sure that they are the only sites in the areas surveyed, and we do not know what proportion of the total site population is represented by the already recorded sites. Finally, although we know that there are archaeological sites on Hanford, that some are cemeteries, cairns, or hunting blinds, and that some contain housepits while others do not, we know practically nothing .about the people who left those sites. Questions remain: When did people first occupy the Hanford Reach of the Columbia River? How did their lifeways change over the centuries? How did their adaptations differ from those observed in upriver regions? When did societies become organized in the manner observed in the nincteenth century? These questions cannot be answered with the knowledge that we possess today.

\section{Summary of Regional Prehistorv}

While the Hanford Site has received little archaeological research, more-extensive studies elsewhere have provided information that can be used to create a picture of human adaptations and material culture for the Columbia Plateau. Because of the history of archaeological research in eastern Washington, most of the information used in this synthesis comes from areas on the northern and eastern fringes of the Columbia Basin. As mentioned above, most archaeological research within $50 \mathrm{~km}$ of the Hanford Site was conducted at a time when funds for cultural resource data collection and reporting were minimal and archaeological methods were not well developed. Excavations in the McNary pool area (Shiner 1961; Osborne, Bryan, and Crabree 1961), the Ice Harbor pool (Kenaston 1966; Grater 1966), and the Priest Rapids and Wanapum pools (Swanson 1962; Greengo 1982) were conducted with minimal funding under different research paradigms. Excavations were small-scale with respect to site sizes and many of the artifacts and records that were collected have never been analyzed or reported in a manner now considered thorough. This accident of history means that a great deal is now known about human adaptations and population fluctuations, and something is known about the social organization of people who lived near the mountainous edges of the Columbia Basin. However, much less is known about the arid, salmon-rich lower reaches of the Columbia and Snake rivers.

Various authors have offered models of plateau prehistory. Most early models (Browman and Munsell 1969; Daugherty 1962, Nelson 1969; Swanson 1962) are culturallhistorical; that is, they are concerned with issues of cultural origins and histories or material cultures. More recent attempts at regional synthesis have relied more heavily on ecological theory, seeking to understand changes in human interactions with their environments and each other as environments change and populations increase. Galm, for example (Galm and Masten 1985; Galm et al. 1985), invokes a continuously increasing population to account for ever-increasing site numbers and an expansion of human activity outward from the primary river valleys. Schalk (1981; Schalk and Cleveland 1983) divides the 11000 -year prehistory of the region into three periods, characterized by fundamental differences in mobility patterns and resource gathering and use strategies. His "broad-spectrum foragers" (11000 to ca. 4500-3500 yr B.P.) consisted 
of small bands moving frequently throughout their environment exploiting foods as they became available seasonally. "Semisedentary foragers" (4500-3500 B. P. to ca. 250 B.P.) spent cold months in semisubterranean dwellings. living off stored foods, and spent the remainder of the year harvesting and processing food for the winter. While changes are acknowledged during this period. ideas about those changes are not developed extensively. "Equestrian foragers" (250 B.P to ca 100 B.P.) had higher mobility than their predecessors owing to the possession of horses. This occasioned the development of interregional trade and specialization in commodities production. and cultural interaction with far distant groups on the Plains and elsewhere. Otherwise. most aspects of the semisedentary forager adaptation remained.

It is the opinion of this author that the models of Schalk and Galm. and many of the earlier authors mentioned. while useful and often correct in their broad frameworks. are too restricted in their viewpoint. neglect much of the chronological and regional variability of Plateau prehistory. and generally are not based on a systematic analysis of the region's archaeological record. The following reconstruction of regional prehistory is presented as an overview of current knowledge as interpreted through a method that uses artifact and site distributions to interpret the characteristics of human adaptations (Chatters 1987). It is intended as a hypothetical construct, but is based on an extensive review of the region's archaeological literature, including both the more recent. detailed studies of the 1970s and 1980s and the less detailed, small scale. but still useful data collected earlier. Because of the region's research history this construct is more detailed for the fringes of the Plateau and can only make suggestions about how the more arid down-river areas, which include Hanford, resemble or differ from the upriver areas.

In the brief summaries presented here.(a) the general pattern is presented first, followed by evidence for or against the existence of that pattern in the vicinity of Hanford and the existance of sites on Hanford that might contribute to understanding of local adaptations.

\section{Basis for the Reconstructions}

The following reconstructions are based on inter-site settlement pattern and site structure. Adaptive strategies are seen as being comprised of at least three dimensions: mobility. predation. and technology. each of which subsumes a group of potentially independent variables (for details see Chatters 1987). Mobility. for example, includes such variables as frequency of residential moves. duration of residence episodes. kind of mobility (residential vs.logistical; see Binford 1980). scheduling. annual variations in group size. and annual range. Predation (which in this case means acquisition of both plant and animal "prey")includes niche breadth (number of species used for food). predation mode and scheduling. while time budgeting is a major component of technology. The state of each variable leaves a more or less characteristic residue in the archaeological record in the content of. and variation among. tool inventories. debitage. faunal and floral remains. spatial patterning. and depositional history (Binford 1977. 1980. 1982; Chatters 1984. 1985. 1987; Thomas 1983). These characteric residues can be studies to measure the state of each variable. Combined measurements of all variables for sites created during one period of time reflect the strategy mix that constituted a prehistoric human adaptation.

In characterizing adaptive strategies of prehistoric Plateau peoples. use is made of the tenninology of Binford (1977. 1980) who posits that all adaptive strategies of hunter-gatherers fall somewhere on a continuum between foraging and collecting. Foragers utilize a mobility strategy in which people move their residences close to food resources that are then gathered during a series of daily excursions. Food resources are acquired opportunistically using a generalized technology. Little or no attention is given to food storage; instead. foods are consumed shortly after acquisition. Collectors. in contrast. employ a logistical kind of mobility; they change residences less frequently than foragers. and., instead. send task-oriented groups to resource locations where they amass specific foodstuffs for future consumption. There is a tendency to pursue those resources that can be gathered in quantity and stored. To ensure successful acquisition of such resources. technologies may include specialized tools or facilities for each behaviorally or structurally distinct food type (see Torrence 1983). The archaeological record of foragers should reflect frequent residential moves between briefly occupied sites. Only two site types are expected: residential camps and the locations where resource acquisition occurred (Binford 1980). Because of the generalized technology. little variation would be evident among tool and feature inventories from base camps used at various seasons of the year.

(a) The summary of regional prehistory presented here is derived in large part from J. C. Chatters. 1986. "Evolution in Hunter-Gatherer Adaptations on the Columbia Plateau." In Archaeological Predictive Modeling: Yakima Firing Center. W. C. Smith and J. C. Chatters. Letter report prepared by Central Washington University for the U.S. Anny. Fort Lewis, Washington. 
even though the species composition of food resources varied. Opportunistic predation would result in an even representation of prey species, with a broad niche (wide range of species exploited) represented at all camps (taking into account seasonal variations in availability of taxa). The generalized technology would consist of a narrow range of simple, multi-purpose tools, each represented in similar frequencies at-all camps. No evidence for food storage is expected. Collectors would leave base camps, plus a variety of task-oriented sites (a.k.a. field camps). The duration of occupancy at base camps might tend to be longer than with foragers, but this depends entirely on the balance between population and resources and on the distribution of seasonally available food. Occupancy of task-oriented sites would be brief, and tool and feature assemblages should vary with the resources procured and processed. Foodgathering locations and caches complete a wide array of site types. Predation strategies would show a focus on a few species, leaving an uneven representation of species among plant and animal remains, especially at task-oriented sites. An emphasis on tool preparation, needed for readiness to amass foods when they are available, would be expressed in a complex, diverse technology. Evidence of food storage would be common.

To avoid confusion among phase names from myriad local chronologies time is considered here in eight periods, during which environmental conditions and/or human adaptations seem to have been more or less stable, or, in the case of Period VII for which analyses have been hindered by discrepancies in the quality of the database. Dates are always given in radiocarbon years B.P. (international standard half life $=5568$ years). Mobility is described in some cases as subannual and supra-annual, the former referring to moves after residency of less than a year (seasonal movement), the latter to moves after residency of one year or longer. Environmental conditions extant during each time period have been presented in Appendix 0.1.

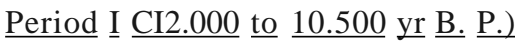

We do not know when people first arrived, although the occasional discovery of Clovis projectile points (Carlson 1984), including the recent discovery of a massive cache of tools near Wenatchee (called Ritchie-Roberts site) hints at a minimum date between 12,000 and 11,000 yr B. P. (Bonnichsen, Stanford, and Fastook 1987). Clovis materials from Washington have yet to be studied, so the characteristics of local adaptations associated with this tool complex are as yet unknown. However, if evidence from elsewhere in the United States can be extrapolated into the Northwest, it is likely that small, highly mobile bands moved through the region, cropping the largest prey species, so long as these remained available. As simple foragers, they probably utilized whatever other prey was available, when necessary, but preferentially took what was most efficiently obtained first. They made elongated, triangular spear or dart points with broad flakes called flutes at the base, large bifacially flaked knives or point preforms, scraping tools of various kinds, gravers for working bone, and cylindrical foreshafts of bone. Other bone items have been found in the Ritchie-Roberts Site, but these have not yet been described. No Clovis artifacts have been found on the Hanford Site, but amateurs report the discovery of one projectile point of this style south of Kennewick.

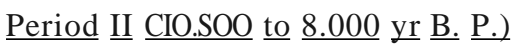

By 10,500 yr B. P. the developing grasslands and riverine galleries were sparsely populated by small, highly mobile bands who lived by a seasonally structured, well planned adaptation. Small group size and frequent mobility are indicated by sparse scatters of artifacts covering areas no greater than a few hundred square meters at sites such as Five Mile Rapids (Cressman 1960), Marmes (Harrison horizon; Fryxell and Keel 1968) and Lind Coulee (Irwin and Moody 1978). Uniform site sizes and the apparent absence of task-specific sites show that mobility was characteristically residential. Sites were frequently reused, and often for the same purposes. Lind Coulee (dated 8600 yr B. P. but stylistically more reminiscent of the over 10,OOO-year-old Harrison Horizon at Marmes Rockshelter) was repeatedly used as a bison-hunting camp, Five-Mile Rapids was a fishing camp, and Marmes Rockshelter itself was a foraging camp. Two cases strongly suggest that sites were often reused by the same individuals or lineages. One is a tool cache at Five Mile Rapids (Cressman 1960), the other a cremation hearth 3 meters in diameter in which five individuals had been cremated over a period of time sufficient for the accumulation of 50 centimeters of rockfall (Rice 1969). Extensive use of high-quality cryptocrystalline materials (Leonhardy and Rice 1970), often acquired many kilometers away, shows that people's annual ranges were extensive.

There was a marked seasonality of subsistence activities, with predation focused on a few, large, abundant animals during productive seasons of the year, and being opportunistic in winter. This phenomenon is expressed both in tool type frequencies and the taxonomic composition of animal remains. Sites at rapids contain fishing equipment and knives and, where faunal preservation is adequate, fish and birds predominate. The most completely investigated of these sites, Five Mile Rapids, contained remains of thousands of salmon and hundreds of birds, but only a few mammals (Cressman 1960). At Lind Coulee (Irwin and Moody 1978) in the open Columbia Basin, a 
hunting and skin-processing tool kit consisting of projectile points, knives, scrapers, and needles in all stages of manufacture was associated with a fauna consisting almost entirely of bison and elk (74 percent). The Goldendale site, in the foothills north of Five Mile Rapids, contained over 30 percent milling stones (Warren 1963) and was probably a seed-gathering site occupied in late summer or fall. Winter activities were generalized and any species was acceptable fare, especially the easily acquired but not-so-nutritious river mussel (Rice 1969).

The technology was rich and complex, weighted heavily toward preparation of tools. Stone tools include large stemmed and lanceolate projectile points, ovate biface knives, wide, flat end scrapers, gravers, boons, bolas stones, large grooved net-sinkers, and milling stones, plus an assortment of "choppers" and simple flake tools (Leonhardy and Rice 1970; Cressman 1960). Richer still is the bone tool inventory, with wedges, composite and single piece harpoons, foreshafts, atlatl spurs and tiny, eyed needles (Cressman 1960; Irwin and Moody 1978). There is also a high frequency of composite tools: atlatl and dart, harpoons with single piece and composite tips, nets, and bolas.

No evidence of dwellings has yet been found with the exception of hearth groups at Marmes Rockshelter. Structures may have been constructed of poles covered by mats, such as those preserved as clay impressions at Goldendale (Warren 1963), or skins of large mammals sewn into tents, as may have been done at Lind Coulee (Irwin and Moody 1978). Evidence for storage technology is lacking.

Period II Summary. Early Holocene inhabitants of the Columbia Basin moved about together in bands of a few families on a planned annual round. During winters they occupied rockshelters, caves and open areas, and subsisted on hoofed mammals, small mammals, fish, the ever-present mussels and probably (given their planned behavior otherwise) some amount of stored food. Bands in some areas left their riverine sanctuary in early spring to intercept bison en route to calving grounds in the plains and mountains. There, they stripped meat (perhaps drying some), prepared hides and replaced worn out clothing and perhaps tents. Summer salmon runs drew people to major rapids where they speared and netted fish in quantities great enough that some may have been saved for winter. Where the climate was suffIciently dry, seeds were collected in later summer or fall, and ground to flour on flat milling stones with the edges of cobbles. The picture is one of scattered bands using a complex, varied technology to ensure efficient acquisition of resources in a climate of severe seasonal extremes. Daugherty's (1962) concept of a diversified economy with seasonal hunting, gathering, and fishing in various settings is generally correct (see also Rice 1972; Leonhardy and Rice 1970).

Local Manifestations. On the lower Snake River, the archaeological remains of this adaptation are called the Windust Phase (Leonhardy and Rice 1970), but there is no manifestation of this phase has yet been recorded for the Columbia River between McNary Dam and Wenatchee. Artifacts of Windust type may occur at 45FR264 on the Hanford Site (Rice 1968a).

\section{Period III (8000 to $4000-5000$ yr B. P.)}

Faced with a lack of water and general paucity of prey elsewhere, people restricted their ranges to riverine and (if unpublished reports are correct) some montane areas. Sites and isolated projectile points of this age are abundant, in fact nearly ubiquitous, along river canyons, but they are rare to nonexistent in the central basin or foothills more than 10 kilometers from the rivers (Chatters 1980, 1982). Although cryptocrystalline stone was still used, lithics were primarily of coarse, local material, often derived from river cobbles (Bense 1972; Chatters 1986; Leonhardy and Rice 1970). This is further evidence of a restricted range. Sites most often consist of flake, core, and mussel shell scatters; and, where single occupation events can be discerned, debris covers an area of 200 square meters or less (e.g., Chatters 1986; Leonhardy 1970; Fryxell and Keel 1969). Some places were occupied repeatedly, others but once. Occupancy events were generally brief, often appearing to lasted no more than a few days (Chatters 1986). Short-term occupancy, small site size, high site numbers. and a lower frequency of site reuse than occurred in Period II are indicative of small, highly mobile bands. At the Plew and Lagoon sites near the confluence of the Okanogan, Methow and Columbia Rivers, for example, there are indications of small, portable dwellings (Chatters 1986). The Plew case is a 2.5 -meter diameter ring of small boulders surrounded by occupation debris; each of several spatially distinct shell midden and tool scatters at the Lagoon Site is adjacent to a small natural depression 3 to 4 meters across; similar stone circles have been found in sites of equivalent age on the Hanford Site. Houses were probably simple tipi or dome-like frameworks covered with skins or mats. Domestic groups may have been no larger than the single nuclear family, social groups being composed of loose aggregatives of such families.

Subsistence activities became progressively less variable seasonally as the environment dried out People preyed opportunistically on a narrow range of species. Faunal collections consist largely of mussels. Rabbits and hoofed mammals (usually deer) alternate in the position of most common vertebrate; dogs or coyotes and birds are 
frequently included, but other animals are rare. Salmon, sucker, sturgeon, or trout remains occur in a few sites (e.g., Burtehard 1981; Butler 1961; Chatters 1986; Randolph and Dahlstrom 1977). Mussels were such an important part of the food supply that at the Picker Shack and Lagoon sites shells outnumber bone fragments by over 500: 1 (Chatters 1986). Similar proportions have been seen at the Box Canyon Site behind McNary Dam (Burtehard 1981) and at other sites of this age or the lower snake (Leonhardy 1970, Fryxell and Keel 1969).

The tool kit of Period III people consisted almost exclusively of leaf-shaped (Cascade) and large side-notched (Cold Spring side-notched) projectile points, ovate knives, end scrapers, engraving tools, edge-ground cobbles and simple flake and core tools. Bone technology is limited to awls, the occasional wedge of antler or beaver tooth chisel, and a very few partS of composite harpoons. Atlatl-dart and harpoon are the only apparent composite implements. Stone tools were typically made from readily available local materials, which commonly included river cobbles of fine-grained basalt (Bense 1972; Chatters 1986; Leonhardy and Rice 1970). There is little change in tool technologies throughout this period. On the lower Snake and mid-Columbia rivers, however, the large-side-notched Cold Spring style projectile points appear after about 6850 yr B. P. (Leonhardy and Rice 1970; Nelson 1969), and long, dugout-canoe-shaped atlatl weights have been found with graves at Marmes Rockshelter. Graves in that site also contained olivella shell beads, showing that some (at least indirect) trade linkage existed between the Pacific coast and interior river basins.

One stone and grass-lined storage pit occured in the early Period III levels at Marmes Rockshelter, and two are present in later Period III deposits at the same site. Thus, some technology for food storage was known, although it does not seem to have been extensively used.

Period III Summary. These people were organized as highly mobile family groups, foraging throughout the year along the riverine strip. They caught salmon in season, but otherwise acquired much of their protein opportunistically, consuming both large and small herbivores and even turning their attention to carnivores when necessary. They appear to have preferred larger-bodied species, but simply encountered a narrow range of large animals in their desert habitat. Sessile resources, especially mussels, were important parts of the diet, and seeds may have been used extensively.

Local Manifestations. Artifacts left by Period ill people are referred to on the mid-Columbia River as Vantage Phase (Nelson 1969), and on the lower Snake River as Cascade Phase (Leonhardy and Rice 1970), although there seems to be no consistent difference between them. The Cascade Phase is divided into the Early and Late subphases, which are distinguished solely on the basis of the absence or presence (respectivley) of the Cold Springs side-notched projectile point. A similar division of the Vantage Phase is probably appropriate. Excavated sites containing manifestations of the Vantage/Cascade Phase that are within 50 kilometers of the Hanford Site include Ryegrass Coulee (Munsell 1968), upstream; Votaw (Grater 1966) and Windust Caves (Rice 1965) in the Ice Harbor Reservoir; and the Hat Creek, Cold Spring (Shiner 1961), and Box Canyon (Burtehard 1981) sites behind McNary Dam. On the Hanford Site, 45BN307 and the Vernita and Hanford Generating Plant sites contain late Vantage/Cascade assemblages, surface fmds of Cascade projectile points have been made at sites 45FR264, 45GR322 and 45BNI71, and numerous other sites appear to belong to this time period.

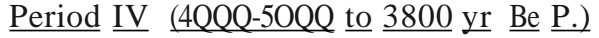

An increase in precipitation starting between 4700 and $4500 \mathrm{yr}$ B. P. significantly altered the riverine environment, distribution of non-riverine surface water, and productivity of ecological communities. In response to these changes, we should expect an expansion into nonriverine habitats, but this did not occur immediately. People seem to have remained near the rivers throughout the year during Period IV; no sites dated to this time are over 10 kilometers from a river in the Columbia Basin, although montane sites may exist. Some people were more-or-less sedentary foragers living in widely dispersed pithouses in prime game wintering areas. Others, especially to the south and west along the lower Columbia River, continued the highly mobile adaptive strategy of their forebearers. Where pithouse sites have been found in the upper and mid-Columbia and on the eastern parts of the lower Snake River and its tributaries, they occur at mouths of large, low drainage basins (Ames, Green, and Pfoertner 1981; Brauner 1976; Chatters 1984, 1986; Hartmann 1975; Lohse 1984) or a short distance inside those basins on small streams (e.g., Swanson 1962). Such sites are rare in proportion to non-pithouse sites, which are scattered all along the upper and mid-Columbia (Campbell 1985; Chatters 1984, 1986; Chatters and Zweifel 1987; Greengo 1982; Leeds, Jermann, and Leeds 1980), but rarely have been identified elsewhere. The non-pithouse sites usually consist of light scatters of debris, perhaps a few hearths and, frequently, heaps of mussel shell. Chatters (1984) and Campbell (1985) have called these food-gathering locations. 
Sizes of domestic groups seem to have increased somewhat over Period III. Pithouse diameters range from 4 to 6.5 meters at the Okanogan/Columbia River confluence (Chatters 1986) to 8 to 12 meters at 450K1I (Lohse 1984) and Hatwai (Ames, Green, and Pfoertner 1981) on the upper Columbia and lower Clearwater, respectively. It can be estimated from this pattern that domestic groups consisted, at least, of extended families with 8 to 20 individuals. They were rarely, if ever larger. Many sites contain single pithouses (Swanson 1962; Chatters 1984; Hartmann 1975; Kennedy 1976). Where groups of houses occur, close analysis of the occupation sequences shows that no more than two structures could have been inhabited at anyone time (Ames et al. 1981; Lohse 1984; Chatters 1984, 1986). House occupancy was brief on a supra-annual scale, as indicated by variable but usually low densities of artifacts in floor deposits and the high resolution of activity patterning (e.g., Chatters 1986; Sammons-Lohse 1986). House reoccupation was infrequent The shallowness of house pits, which ranges from 20 to 80 centimeters and clusters at 40 centimeters, indicates that people planned to stay only for a short time. The subannual duration of occupancy was probably variable as well, but faunal analyses show year-round use of at least some pithouses (Chatters 1986; Livingston 1984). Sites without pithouses resemble Period III camps, and vary in seasonality from early to mid-summer. Fall or winter habitations may also be included (Chatters 1984, 1986; Chatters and Zweiffel 1987). As one progresses downriver, this site type comes to dominate and pithouses seem to disappear, although this may be an artifact of the small scale of most downriver excavations and the belief of excavators that pithouse habitation did not begin until much later.

This evidence indicates that the mobility strategy was extremely flexible, varying on the subannuaI scale from full sedentism to high residential mobility, with frequent moves on the supra-annual scale for the more sedentary groups. This need for flexibility is readily explained by reference to the predation strategy. While pithouses were usually situated in game wintering areas, and there is evidence in some areas of more extensive reliance on ungulates (Chatters 1986; Lohse 1984), predation remained opportunistic, and the niche remained broad (Chatters 1984, 1986). The use of sessile resources continued (some say expanded, e.g., Ames and Marshal 1980; Leonhardy and Rice 1970). Plant use is indicated by varying numbers of grinding tools in pithouse sites (e.g., Lohse 1984; Ames et al. 1981) and by the presence of root tissue and seeds at several localities (Rhode 1986; Stenholm 1984). Extensive shell middens are common, and mussel consumption is considered a hallmark of this and succeeding Periods V and VI (Leonhardy and Rice 1970).

Technologically, this period is ambiguous. Except for a renaissance in bone tool technology in the forms of needles, single-piece and composite harpoons and various decorative items, and the addition of the hopper mortar to food grinding technology, there was little change from Period III. Basalt continued to be the primary lithic material on the Snake River (supporting the notion that people remained near the rivers), and the decline in quality of the lithic technology has been described by various authors (e.g., Leonhardy and Rice 1970; Kennedy 1976). Projectile point styles that date to this period are various, making recognition difficult without some other means of age determination. Common styles include leaf-shaped specimens reminiscent of Cascade points, broad-stemmed projectile points with rounded shoulders, and triangular-bladed points with expanding, concave bases (eared). There is little evidence for food storage.

Period IV Summary. These people lived in small groups, moving frequently during the year or remaining sedentary for a few seasons to several years at a time. They occupied the riverine habitat year round, often living in small semi-subterranean dwellings that were probably mat or skin covered The food supply included a very broad array of species, although ungulates were often important. Deer, elk, mountain sheep, pronghorn, jackrabbits, salmon, suckers, plants, mussels, and numerous smaller animals were exploited in a generalized, opportunistic manner. Roots and/or seeds comprised varying portions of the diet.

Local Manifestations. In the Mid-Columbia, artifacts dating to this period are assigned to the early Frenchman Springs Phase (Swanson 1962; Nelson 1969), and on the Snake River they are called Tucannon (Leonhardy and Rice 1970). The triangular projectile point forms are more characteristic of Tucannon Phase assemblages, while the stemmed type is associated with the early Frenchman Springs. Both types occur on the Hanford Site (Rice 1980).

Very few archaeological sites in the vicinity of Hanford Site have been reported that contain manifestations of Period IV. Shalkop, upstream ofWanapum Dam, contained a single shallow housepit, the farthest downriver manifestation of this settlement type (Swanson 1962). Site 45KT285, up Hanson Creek on the Yakima Firing Center, was a small residence camp used once each in the fall and late spring (Chatters and Zweifel 1987), and several sites in the Wanapum and Priest Rapids Reservoirs appear to have contained such material (Greengo 1982). The date 
of 4240 on late Cascade/Vantage Phase artifacts at Vernita, in association with what may be one or more house floors (Rice 1980), may be a manifestation of Period IV, rather than Period III (which the phase designation would indicate).

\section{$\underline{\text { Period }} \underline{\mathrm{V}} \underline{(3800}$ to $\underline{3400 \mathrm{yr}} \underline{\mathrm{B}}, \underline{\mathrm{P}})$}

Pithouses temporarily disappeared shortly after $3800 \mathrm{yr}$ B. P. and did not reappear until around 3400. Of the few discovered sites that belong to the intervening four centuries (Salo 1983), most resemble the short-term camps of earlier periods (III and IV). Pithouse use either disappeared or became so infrequent that no evidence of it is found, This time period is not associated with a phase name; it is simply a gap in knowledge during the Frenchman Springs and Tucannon Phases. Local manifestations have not been identified.

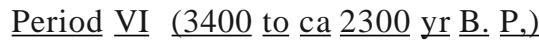

Pithouses recurred during Period V, but this time they were part of an incipient collector strategy. They still occured singly or in small groups, and were widely dispersed in tributary canyons and at various locations along river bottoms (Chatters 1984, 1986; Campbell 1986; Swanson 1962) and began to appear on the lower Columbia by around 3000 yr B. P. (Cole 1968; Dumond and Minor 1983). At least on the upper Columbia River, where the issue has been studied, non-pithouse sites now formed functionally distinct groups, each with an evident task orientation (Campbell 1986; Chatters 1986). There were hunting camps, shellfIsh-processing camps, fishing camps, and plant-processing camps with large earth ovens and numerous hopper mortar bases (e.g., Campbell 1986; Chatters 1986; Daugherty 1952; Ames andiMarshall980). Housepits tended to be large [8 to 12 meters in diameter; an oval dwelling at Shalkop was 14 meters long (Swanson 1962)] and were on the whole deeper and more steepwalled than their predecessors (80 to over 100 centimeters deep). Dense concentrations of occupation debris (Sammons-Lohse 1986) are indicative of extended periods of occupancy. House reoccupation was still rare, however, although it did occur later in the period.

The subsistence base had narrowed. On the upper Columbia, for example, people focused on large ungulates (usually deer and mountain sheep), salmon, and river mussels, with some secondary reliance on marmot (e.g., Grabert 1968; Chatters 1986). The importance of roots is evident from processing equipment at task-oriented camps. These field camps contained a narrow range of animal species and features. There were hearths and remains of deer, sheep, and marmot at hunting camps (Chatters 1984), and earth ovens and an assortment of small game at gathering camps (Campbell 1986; Daugherty 1952). Storage facilities, such as those found in Marmes Rockshelter (Rice 1969) and Cedar Cave (Swanson 1962), became increasingly common and often occurred in house floors (Sammons and Lohse 1985). Mass processing of salmon, roots, river mussels and deer indicate that all these foods were being harvested for storage.

The adaptation remained largely riverine in its focus, but a few field camps of both kinds began to occur in more remote areas (Dancey 1975b; Daugherty 1952; Hartmann 1980; Osborne 1967). Limited non-riverine activity is confirmed by lithic materials, which are primarily local (basalts on the Snake River and opals on the Columbia), Quarry sites of this age, often exploiting poor-quality stone, are common in the breaks of the mid-Columbia (Chatters 1980, 1982).

Artifacts are much like the earlier Frenchman Springs and Tucannon Phases. In fact, no distinction has been made in the artifact chronology of the Tucannon phase between artifacts found with earlier and later pithousedwelling episodes. Late Frenchman Springs is distinguishable by the predominance of narrow-bladed, contraetingstemmed projectile points, often called "Rabbit Island stemmed points."

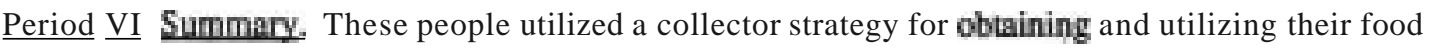
resources (Chatters 1989). They lived during winter in single or small groups of large, deep, steep-walled pithouses, but continued to move their residences on a supra-annual scale. Only occasionally did they reoccupy the same location and same housepits. The mobility strategy on the subannual scale was logistical, and food (specifically salmon, roots, deer and river mussels) was being amassed for storage. Salo (1983) has presented evidence that populations were increasing, which may account for the wider geographic distribution of sites in late Period VI.

Local Manifestations. Artifacts attributable to the late Frenchman Springs Phase are common in the hills northwest of Hanford (Hartmann 1979) and in sites excavated in the Priest Rapids, Wanapum, and McNary Reservoirs (Greengo 1982; Hartmann, Lanis, and Morgan 1982; Shiner 1961). Numerous sites on the Hanford Reach of the Columbia are reported to contain surface artifacts from this period (Rice 1968a.b). and late Frenchman Springs Phase occupations are present in the Hanford Generating Plant and Vernita sites (Rice 1980). 


\section{$\underline{\text { Period VII }} \underline{(2300}$ to $\underline{200}$ yr B. P. $)$}

There was a return to drier climate by 2300-2200 yr B. P. In general, an environment with more-or-Iess dispersed, evenly distributed resources changed to one where foods were concentrated into fewer, productive patches (Chatters 1984). Faced with declining resource availability and increasing distances between resource concentrations, people had two selectively advantageous alternatives: 1) to intensify resource collection behavior in the few resource patches within their territory, or 2) to increase their travel time between resources. They did both. The result was a virtual revolution in mobility strategies and demography. The central basin became intensively reoccupied; numerous quarries (Chatters 1980), hunting camps (Osborn 1967) and root-gathering camps (Hartmann 1980; Chatters 1982; Dancey 1975a,b; Greene 1976) appeared in rocky foothills and around lakes in the central basin. Along the river there is a drop in site numbers (Salo 1983), followed by the appearance of pithouse groups properly identified as villages. After $1500 \mathrm{yr}$ B. P., clusters from 10 to over 200 and more house depressions are widely distributed on the middle and upper Columbia, the Snake River, and around large lakes (Daugherty 1952; Daugherty, Purdy, and Fryxe111967; Grabert 1968; Greengo 1982; Kenaston 1966). Groups of a hundred or more are found on the lower Columbia (Cleveland 1977; Cole 1968; Shiner 1961; Schalk 1983) but such large groups are rare to nonexistent much above the Snake-Columbia River confluence (Schalk 1980). Where pithouses occur singly or in small groups, they are often very large, [up to 18 meters in length (e.g., Galm and Masten 1985)] and show evidence of occupancy by more than one family unit Larger villages, in which there is clear evidence of simultaneous occupancy of many dwellings (Kenaston 1966; Schalk 1983; Schiner 1961), were usually built on islands or at the downstream ends of broad point bars, areas which were readily defensible and where driftwood provided a renewable source of fuel and structural timber to such large concentrations of humanity. Housepits commonly have light concentrations of floor debris and contain multiple floor levels, demonstrating long-term occupancy and frequent reuse of abandoned dwelling sites.

The logistical strategy became increasingly effective. River mussels are much less common at housepit sites of this age (Leonhardy and Rice 1970; Chatters 1986; Swanson 1962), indicating both that pithouses were no longer situated to take advantage of this resource and that such unproductive resources were relied upon less heavily. Indeed, evidence of food storage is ubiquitous. Salmon remains (vertebrae only) occur in task-oriented hunting camps occupied in winter, in root-gathering camps many kilometers from rivers or spawning streams and even in camps occupied in early spring (Chatters 1980, 1984; Hartmann 1978, 1979). Storage facilities are found in nearly every cave and rockshelter in the vicinity of winter habitations (e.g., Combes 1969; Mallory 1966; Swanson 1962). Expanded annual range and increasingly efficient storage technology seem to have fueled a population explosion as the human habitat expanded in time and space. This growth is evident, not only in the numbers of sites and the numbers of houses in each site, but in apparent increases in the exploitation of salmon in downriver areas by 14001600 yr B. P. (e.g., Shiner 1961; Dumond and Minor 1983; Schalk and Olson 1983), and in some increase in niche breadth (Chatters 1986; Schalk and Olson 1983).

An intriguing characteristic of large village sites downstream from Wenatchee is the occurrence among many small housepits of one or two very large depressions (Shiner 1961; Schalk 1980, 1983). These may have been ceremonial lodges, like the longhouses of today, and seem to indicate development of communal religious rituals resembling those of modem times.

The occurrence of large villages and possible ceremonial structures on the mid-Columbia distinguishes that area from upper portions of the Columbia Basin. It is evident that cultural diversity, including differences not only in settlement pattern but also in socio-political organization and probably details of adaptation were developing (Schalk 1980). This is a continuation, but reversal of earlier differences most strongly expressed during period IV, when sedentary settlement on the fringes of the Columbia Basin was apparently matched by high mobility in downstream areas.

There is evidence of intergroup competition for resources in the fortification of root camps as early as 2000 yr B. P. (Smith 1977): the location of villages on islands, and evidence of homicide as early as $1640 \mathrm{yr}$ B. P. (Chatters 1986; Sprague and Mulinski 1980; Osborne, Bryan, and Crabtee 1961). Cemeteries are large and common, occurring in dunes and midchannel islands. Communal burial is common in the middle Columbia, but rarer upstream, further marking the differences noted above (e.g., Crabtree 1978; Sprague 1967).

Tools continue to be primarily the ubiquitous flake and core tools, but stone bowls, elongated pestles, selfhandled mauls, nephrite adze blades, tubular stone pipes and an assortment of decorative items appear in collections. Beads of clam, olivella, and dentalium shell, pendants of abalone shell, and anthromorphic and zoomorphic carvings are common, especially in down-river areas. Projectile point styles vary from the narrow contracting-stemmed 
Rabbit Island type to large, triangular basal or comer-notched Quilomene Bar styles prior to about 2000 yr B. P. After that time, arrow points appeared and became increasingly common. At first the arrow points were the small, delicate corner- and basal-notched forms (Wallula rectangular-stemmed), but later, side-notched, and narnow-bladed contracting-stemmed types became common. Artifacts found in graves along the middle Columbia River show development of a regional art tradition that is also reflected in petroglyphs (rock etchings) in that area. The period is divided into two and sometimes three subphases. On the lower Snake River, it is called the Harder Phase (Leonhardy and Rice 1970); on the Mid Columbia it is the Cayuse. Early Harder/Cayuse I includes the large, triangular and contracting stemmed point styles, and generally is not associated with large villages. Late Harder/Cayuse II. III is marked by arrow points of various types, and large villages.

Period VII Summary. Generally speaking, Period VII consists of five and sometimes six site types, exclusive of cemeteries. In winter, people inhabited pithouse clusters, often in defensible locations. They dispersed to small root camps or fishing camps in the spring or to foraging camps, then to root camps (depending on the area's resource timing). Fishing took up varying parts of summer and fall, again dependent on the timing of fish resources relative to roots. In fall and/or winter, task groups left winter habitations to hunt in remote areas of the river. The produce from fishing, gathering and hunting parties was cached in storage facilities near winter camps. These people were consummate collectors. Regional differences in village size, art, burial practices, and perhaps reliance on fish are markedly evident during the latter part of this period and connote ethnic and adaptation differentiation in the Plateau.

Local Manifestations. Excavations have been conducted at many sites of this time period, although all were small in relation to the size and complexity of the investigated sites. 45BN53, which contained 182 house pit depressions, was located near Plymouth, Washington, not far downriver from Hanford (Shiner 1961). Excavation into less than $5 \%$ of the houses in this site served only to indicate its approximate age. Strawberry Island (Cleveland 1977; Schalk 1983) and the Harder Site (Kenaston 1966) on the lower Snake River, as well as several sites in the Wanapum Reservoir (Greengo 1982), were excavated to about the same extent. 45BN53, (which is now under water) and Strawberry Island include large, possibly ceremonial dwellings (Schalk 1980, 1983). Cemeteries of this age were excavated at Sheep Island (Osborne, Bryan, and Crabree 1961), Bateman Island, Fishhook Island, and Wahluke (Krieger 1928).

On the Hanford Site proper, most sites that have been recorded include at least some Period VII material. Rice $(1973,1980)$ reports pithouses at 45BN179 and 45BN180, and found a heavily disturbed Cayuse Phase component at the Vernita site. The Wahluke site and site 45BN302a, on Locke Island are the largest villages (30 and $60+$ depressions, respectively); there are many cemeteries.

\section{$\underline{\text { Period VIII }} \underline{(200} \underline{\text { to }} \underline{100}$ yr $\underline{\mathrm{B}}, \underline{\mathrm{P}})$}

The horse was introduced around $200 \mathrm{yr}$ B. P., occasioning a revolution in mobility and intergroup contact. Few sites of this most recent period ( $\mathrm{m}$ have been studied (see Greengo 1982; Campbell 1987), but a comparison of historic records with the pre-horse archaeological record provides some insight into the nature of change. People became even more mobile in their seasonal food collection rounds, often traveling hundreds of miles to prime gathering, fishing or hunting grounds. Aggregations of people at optimum resource patches numbered in the thousands who engaged in large-scale trade in foodstuffs, raw materials, and other items (e.g., Ross 1849; Ruby and Brown 1965). Inter-regional trade blossomed, and regional specialization in commodities developed. Many people abandoned their traditional pithouses for large, portable, mat-eovered longhouses sheltering several families each (for archaeological examples, see Greengo 1982), Formerly a seasonal shelter used by task groups, the mat house, enlarged, was readily adaptable to the increased mobility provided by the horse.

Local Manifestations. Many sites on Hanford are known from ethnographic reports to have been used in t.he last few centuries. Certainly some archaeological evidence of this time period is present Excavation at the Hanford Generating Plant Site uncovered some artifacts from this time period (Rice 1973).

\section{Summary}

Columbia Plateau prehistory is marked by extreme changes in spatial and seasonal distributions of resources, to which local hunter-gatherers became adapted Other changes in adaptation, particularly in the last 2000 years may result from population pressures and resource competition. The earliest identifiable inhabitants used a well-planned, strategy characterized by residential mobility and narrowly prescribed seasonal resource niches. When the markedly seasonal, moist environment became drier and less seasonally variable after $8000 \mathrm{yr}$ B. P., the descendants of these people evolved an even more mobile, highly generalized adaptation based on riverine foraging of 
deer, rabbits, salmon, plants, and shellfish. An increase in precipitation around $4500 \mathrm{yr}$ B. P. created a productive environment into which some of the forgers settled year-round in dispersed, single pithouses. Maintaining the plasticity necessary to their foraging existence, they were residentially mobile on a year-ta-year scale and often reverted to the higher subannual mobility of their ancestors. There was a tendency for lower mobility in upper basin settings and high mobility in the downriver areas. Around $3800 \mathrm{yr}$ B. P., an apparent decline in environmental productivity or the presence of increased population led, in the upper basin area, to a centuries-long reversion to the pattern of mobile riverine foraging.

Sedentary life returned around $3400 \mathrm{yr}$ B. P. as the climate cooled and resources became more seasonally disjunct The sedentary lifestyle first reached the downriver areas around Hanford around 3000 yr B.P. Settlements consisted of dispersed houses clinging to the riverine habitat, but people were now supported by a more logistically oriented adaptation focused on salmon, ungulates, roots, and shellfIsh. The higher population attained by these people was faced with famine 2300 years ago, as a drier, warmer climate returned and resources became more scattered. Use of dispersed resources led to competition. People responded by aggregating in winter, enlarging their home ranges, and increasing the effectiveness of their collector strategy. Thereafter, populations increased radically, and large villages and interpersonal conflict became commonplace. Increasingly marked differences developed between inhabitants of the mid-Columbia and upper-Columbia/lower Snake Rivers. Downriver groups were larger, and perhaps more politically organized, with evidence for widespread religious activity. Upriver groups were smaller, and apparently less strictly organized, without evidence for religion control. Introduction of the horse to these already mobile people simply enhanced their ability to travel and take advantage of the most productive resource patches. Enhanced interregional trade and regional commodities specialization were two results. Between 150 and $100 \mathrm{yr}$ B. P. (A.D. 1800-1850) Eurasian disease and competition with rapidly growing agrarian populations brought the system to a crisis from which it has not yet emerged.

\section{$\underline{\text { References }}$}

Ames, K. M., J. P. Green, and M. Pfoertner. 1981. Hatwaj ClONP143): Interim Report. Archaeological Reports No.9, Boise State University, Boise, Idaho.

Ames, K. M., and A. G. Marshall. 1980. "Village, Demography and Subsistence Intensification on the Southern Columbia Plateau." In NQrth AmeriCan ArchaeQlQgist 2:25-52.

Bense, J. A. 1972. The Cascade Phase: A Study in the Effect of the Altithermal Qn a Cultural System." Ph.D. dissertation, Washington State University, Pullman, Washington.

Binford, L. R. 1977. "Forty-Seven Trips: A Case Study in the Character of ArchaeolQgical Formation Processes." In $\underline{\text { StQne Tools }} \underline{\text { as }}$ Cultural Markers: Change, RevolutiQn and CQmplexity, ed. R.V.S. Wright, pp. 24-36. Australian Institute of Aboriginal Studies, Canberra, Australia.

Binford, L. R. 1980. "Willow Smoke and Dog's Tails: Hunter-Gatherer Settlement Systems and ArchaeolQgical Site FormatiQn." American AntiQuity 45:4-20.

BinfQrd, L. R. 1982. "The ArchaeolQgy QfPlace." JQurnal of AnthropQlQgjcal Archaeology 1:5-31.

Bonnichsen, R., D. Stanford, and J. L. Fastook. 1987. "Environmental Change and Developmental History of Human Adaptive Patterns; The Paleoindian Case." In NQrth America and Adjacent Oceans During the Last DeglaciatiQn, ed. W. F. Ruddiman and H. E. Wright, Jr., pp. 403-424. The GeolQgical Society Qf America, Inc., BQulder, ColoradQ.

Brauner, D. R. 1975. ArchaeolQgical Savage Qf the Scorpian KnQll Site. 45A541. SQutheastern Washington. Washington ArchaeolQgical Research Center Project Reports 23. WashingtQn State University, Pullman, Washington.

Brauner, D. R. 1976. AlpQwa: The Cultural History Qf the Alpowa LQcality. Ph.D. Dissertation. Washington State University, Pullman, WashingtQn. 
Browman, D. L., and D. A. Munsell. 1969. Columbia Plateau prehistory: Cultural Development and Impinging Influences. American AntiQuity: 34: 249-264.

Burtehard, G. C. 1981. Test Excavations at Box Canyon and Three $\underline{\text { Other }} \underline{\underline{\text { Site }}} \underline{\underline{\text { Canyon }}} \underline{\underline{\text { Sites }}} \underline{\text { in }} \underline{\text { the McNary }}$ Reservoir. Laboratory of Archaeology and History, Washington State University, Pullman, Washington.

Butler, B. R. 1961. The Old Cordilleran Culture in the Pacific Northwest Occasional Papers of the Idaho State College Museum No.5, Pocatello, Idaho.

Campbell, S. K. 1985. "Synthesis." In Summary of Results. Chief loseph Dam Cultural Resources Project. Washington, ed. S. K. Campbell, pp. 481-514. Office of Public Archaeology, University of Washington, Seattle, Washington.

Campbell, S. K. 1987. A Resource Protection Planning Process Identification Component for the Eastern Washington Prehistoric Study Unit. Washington State Office of Archaeology and Historic Preservation, Olympia, Washington.

Carlson, R. L. 1984. "The Far West." In Early Man in the New World, ed. R. Shutler, Jr., pp.73-96. Sage Publications, Beverly Hills, California.

Chatters, J. C. 1980. Cultural Resources of the Columbia Basin Project: An Inventory of Selected Parcels. Reconnaissance Report No. 32, Office of Public Archaeology, University of Washington, Seattle, Washington.

Chatters, J. C. 1982. "Prehistoric Settlement and Land Use in the Dry Columbia Basin." Northwest Anthropological ReSearch Notes 16:125-147.

Chatters, J. C. 1984. Human Adaptation Along the Columbia River $\underline{4700-1600}$ BP. (A report of test excavation at River Mile 590, north central Washington), Research Reports 84-1, Central Washington University, Ellensburg, Washington.

Chatters, 1. C. 1985. The EJlisford Cremations. Central Washington Archaeological Survey Archaeological Report 85-1, Central Washington University, Ellensburg, Washington.

Chatters, J. C. 1986. The Wells Reservoir Archaeological Project. Vol. I and II. Washington. Central Washington Archaeological Survey Archaeological Report 86-6, Central Washington University, Ellensburg, Washington.

Chatters, J. C. 1987. "Hunter-Gatherer Adaptations and Site Structure. An Evaluation of Dimensions." Paper presented at the 50th Annual Meeting of the Society for American Archaeology, Denver, Colorado.

Chatters, J. C. and M. W. and Zweiffel. 1987. Archaeological Excavations $\underline{\text { in }} \underline{\underline{\text { MultiDumose }}} \underline{\underline{\text { Range }}} \underline{\underline{\text { Complex. }}}$ Yakima Firing Center. Washington. Central Washington Archaeological Survey Archaeological Report 86-6. Central Washington University, Ellensburg. Washington.

Cleveland, G. C. 1977. Preliminary Archaeological Investigations at the Miller Site. Strawberry Island. 1976: $\underline{a}$ Later Prehistoric Village Near Burbank. Franklin County. Washington. Washington Archaeological Research Center Project ReportNo. 46, Washington State University, Pullman, Washington.

Cleveland, G. C., and M Uebelacker. 1980. Evaluation of Two Prioritized Sites. 45BN161 and 45FRI01. in the McNary Reservoir. Washington Archaeological Research Center Project Reports No. 66. Washington State University, Pullman, Washington.

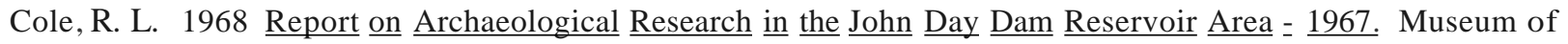
Natural History, Eugene, Oregon. 
Combes, J. D. 1969. The Excavation of Squirt Cave. 45WW25. Laboratory of Anthropology, Washington State University, Pullman, Washington.

Cressman, L. S. 1960. "Cultural Sequences at the Dalles, Oregon." Transactions of the AmeriCan Philosophical Society 50(10)..

Dancey, W. S. 1975a The Wood Box Spring Site (45KY202): A Breliminary Report. Office of Public Archaeology, Reports in Highway Archaeology 1, University of Washington, Seattle, Washington.

Dancey, W. S. 1975b. "Vantage Area Archaeology, 1975." Paper presented at the XXVII Northwest Anthropological Conference, Seattle, Washington, April 1975. Abstract publ. in Transactions of the American Philosophical Society.

Daugherty, R. D. 1952. "Archaeological Investigations of O'Sullivan Reservoir, Grant County, Washington." American Antiquity. 17:374-383.

Daugherty, RD. 1962. "The Intermontane Western Tradition." American Antiquity 28:144-150.

Daugherty, R. D., B. Purdy and R Fryxell. 1967. The Descriptive Archaeology of the Three Springs Bar Site [45FR392. Laboratory of Anthropology, Report of Investigations 40, Washington State University,.Pullman, Washington.

Den Beste, K. and L. Den Beste 1974. Background and Historv of the Vernita Site(45BNI57). Annual Report of the Mid-Columbia Archaeological Society, pp. 10-15, P.O. Box 901, Richland, Washington.

Drucker, P. 1948. An Appraisal of the Archaeological Resources of the McNary Reservoir. Oregon-Washington. Columbia Basin project, River Basin Surveys, Smithsonian Institution, Washington, D. C.

Dumond, D. E. and R. Minor. 1983. Archaeology in the John pay Reservoir: the Wildcat Canyon Site. $\underline{\text { 35-GH-9. }}$ Anthropological Papers No. 30, University of Oregon, Eugene, Oregon.

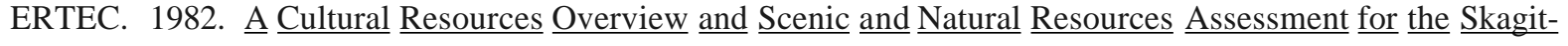
Hanford Nuclear Power Project ERTEC Northwest, Seattle, Washington.

Fryxell, Rand B. C. Keel. 1969. Emergency Salvage Excavations for the Recovery of Early Human Remains and

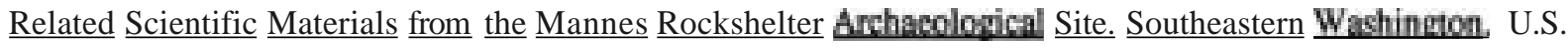
Army Corps of Engineers, Walla Walla, Washington.

Galm, J. F., G. D. Hartmann, and RA. Masten. 1985. An Archaeological Overview of the Mid-Columbia Study Unit. Benton. Franklin. Klickitat and Walla Walla counties. Eastern Washington University Reports in Archaeology and History 100-47, Cheney, Washington.

Galm, J. F. and R A. Masten (eds.). 1985. Avey's Orchard: Archaeological Investigation of a Later Prehistoric Columbia River Community. Reports in Archaeology and History 100-42, Eastern Washington University, Cheney, Washington.

Grabert, G. F. 1968. North-Central Washington Prehistorv. Reports in Archaeology No.1, University of Washington, Seattle, Washington.

Grater, B. A. 1966. The Archaeology of the Votaw Site. Lower Snake River. Washington. Masters thesis, San Francisco State College, San Francisco, California

Greene, G. S. 1976. Prehistoric Utilization of the Channeled SCablands of Eastern Washington. Ph.D. Dissertation, Washington State University, Pullman, Washington. 
Greengo, R. 1982. Studies in the Prehistory of Priest Rapids and Wanapum Reservoir Areas. Columbia River Washington. A final report to the United States Department of the Interior. University of Washington, Seattle, Washington.

Hartmann, G. D. 1980 Cultural Resources Reconnaissance and Testing on the Yakima firing Center. Kittitas and Yakima Counties. Washington Phase II, Central Washington Archaeological Survey, Central Washington University, Ellensburg, Washington.

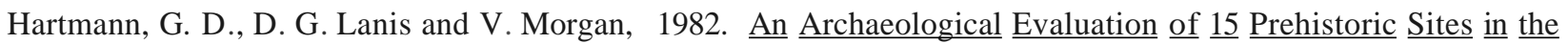
Priest Rapids Reservoir Area. Grant. Kittitas. and Yakima Counties. Washington. 100-23, Eastern Washington University, Cheney, Washington,

Hartmann, G. H. 1975. The Archaeology of Cox's Pond Site. 45DOI72. Washington Archaeological Research Center, Washington State University, Pullman, Washington.

Hartmann, G. H. 1979. Cultural Resources ReconnaiSSance and Testing on the Yakima Firing Center. Yakima and Kittitas Counties. Washington. Central Washington Archaeological Survey, Central Washington University, Ellensburg, Washington.

Irwin, A. M. and U. Moody. 1978. The Lind Coulee Site (45GR97). Washington Archaeological Research Center Project Report No. 56, Washington State University, Pullman, Washington.

Kenaston, M. R. 1966. The Archaeology of the Harder Site. Franklin County. Washington. Laboratory of Anthropology, Report of Investigations No. 35, Washington State University, Seattle, Washington.

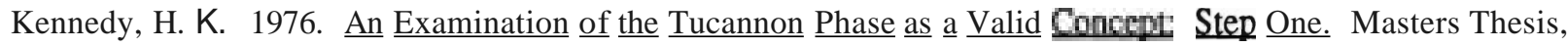
University of Idaho, Moscow, Idaho.

Krieger, H. W. 1928. "A Prehistoric Pit House Village Site on the Columbia River at Wahluke, Grant County, Washington." No. 2732 from Proceedings of the U.S. National Museum, Vol. 73, Article 11, pp. 1-29. U.S. Government Printing Office, Washington, D.C.

Lee, W. 1955. "An Archaeology Survey of the Columbia Basin Project in Grant County, Washington." Davidson Journal of AnthrQWlogy 1(2):141-45.

Leeds, L. L., J. V. Jermann and L. A. Leeds. 1980. Cultural Resource RecQnnaissance fQr the Proposed Downstream River Bank Stabilization Program Grand Coulee. WashingtQn. Office of Public Archaeology Reconnaissance Report No. 35, University of Washington, Seattle, Washington.

Leonhardy, F. C. 1970. Artifact Assemblages and ArchaeolQgical Units at Granite Point Locality (45WT41) SQutheastern WashingtQn. Ph.D. Dissertation, University Microfilms, Ann Arbor.

Leonhardy, F. C. and D. G. Rice. 1970. "A Proposed Culture Typology for the Lower Snake River Region, Southeastern, Washington." NQrthwest AnthrQPQIQgical Research Notes 4(1):1-29.

Livingston, S. 1984. "Faunal Analysis." In ArcheaQIQgical InvestigatiQns at $\underline{\text { Site }} \underline{450 K 11 .}$ Chief JQseph pam PrQject. WashingtQn, ed. E.S. Lohse, pp.185-198. U.S. Army Corps of Engineers, Seattle, Washington.

Lyman, R. L. and S. D. Livingston. 1983. "Late Quaternary Mammalian Zoogeography of Eastern Washington." Ouaternary Research 20:360-376.

Mallory, O. L. 1966. A CQmparative Cultural Analysis Qf Textiles frQm McGregQr Cave. Washingtqn. Masters Thesis, Washington State University, Pullman, Washington. 
Munsell. D. A. 1968. The Ryegrass Coulee Site. Masters Thesis, University of Washington, Seattle, Washington.

Nelson, C. M. 1969. The Sunset Creek Site <45KI28) and its Place in Plateau Prehistory. Anthropology Report of Investigations No. 47, Washington State University, Pullman, Washington..

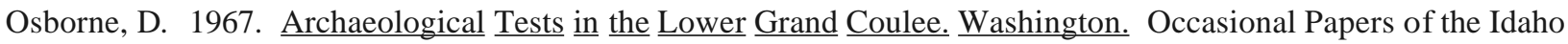
State University Museum, No. 20, Pocatello, Idaho.

Osborne, D., A. Bryan, and R. H. Crabtree. 1961. The Sheep Island and the Mid-Columbia Valley. River Basin Survey Papers, No. 24. Bureau of American Ethnology Bulletin 179, pp 267-306, Washington, D.C.

Randolph, J. and M. Dahlstrom. 1977. Archaeological Test Excavations at Bernard Creek Rockshelter. University of Idaho Anthropological Research Manuscript Series No. 42, Moscow, Idaho.

Relander, C. 1986. Drummers and Dreamers. Pacific Northwest National Forest Association, Seattle, Washington. Reprint of 1956 edition.

Rhode, D. E. 1986. "Archaeobotanical Investigations in the Wells Reservoir Archaeological Project, Eastern Washington." In The Wells Reservoir Archaeological Project, Vol. I, edited by J. C. Chatters. Central Washington Archaeological Survey Archaeological Report 86-6, Central Washington University, Ellensburg, Washington.

Rice, D. G. 1968a. Archaeological Reconnaissance: Ben Franklin Reservoir Area. 1968. Washington State University, Pullman, Washington.*

Rice, D. G. 1968b. Archaeological Reconnaissance: Hanford Atomic Works. U.S. Atomic Energy Commission, National Park Service and Washington State University, Pullman, Washington.*

Rice, D. G. 1969. Preliminary Report. Marmes Rockshelter Archaeological Site. Southern Columbia Plateau. Report submitted to the National Park Service, Seattle, Washington.*

Rice, D. G. 1972. The Windust Phase in Lower Snake River Region Prehistory. Ph.D. Dissertation, Washington State University, Pullman, Washington.*

Rice, D. G. 1973. Archaeological Investigations of the Washington Public Power Supply System Hanford No.1 Nuclear Power Plant. Benton County. Washington. Univeristy of Idaho Anthropological Research Manuscript Series No. 25. Moscow, Idaho.

Rice, D. G. 1976. A Log Structure at White Bluffs Landing Franklin County. Washington: A Case Study in Historical Archaeology. University of Idaho Anthropological Research Manuscript Series, No. 25, University of Idaho, Moscow, Idaho.

Rice, D. G. 1980. Overview of Cultural Resources on the Hanford Reservation in South Central Washington State. RL-E-80-0043, prepared for the U.S. Department of Energy, Richland Operations, Richland, Washington.

Rice, D. G. 1981. Archaeological Transects Through Interior Dunes on the Hanford Reservation. Washington. Report to the US Department of Energy, Richland, Washington.*

* This unpublished report is available through the Hanford Cultural Resources Laboratory, Pacific Northwest Laboratory, Richland, Washington. 
Rice, D. G. 1983. Archaeological Investigations at Washington Public Power $\underline{\text { Supply }} \underline{\text { System Nuclear }}$ Plants on the Hanford Reservation. Washington. Washington Public Power Supply System, Richland, Washington.*

Rice, D. G. 1984. Archaeological Inventory of the Basalt Waste Isolation Project. Hanford Reservation. Washington. SD-BWI-TA-(X)7, Rockwell Hanford Operations, Richland, Washington.*

Rice, H. S. 1965. The Cultural Scquence at Windust Caves. Masters Thesis, Washington State University, Pullman, Washington.*

Ross, A. 1849. Adventures of the First Settlers on the Oregon or Columbia-River. Smith and Elder, London. March of American Facsimile Series 58. University Microfilms, Ann Arbor.

Ruby, R. H. and J. A. Brown. 1965. Half-Sun on the Columbia. University of Oklahoma Press, Norman, Oklahoma.

Salo, L. V. 1983. "Post Hypsithermal Archaeological Population Cycles in the Northern Columbia Plateau." Paper presented at the 36th Annual Northwest Anthropological Conference, Boise, Idaho.

Sammons-Lohse, D. 1986. "Features". In Summary of Results. Chief Joseph pam Cultural Resources Project. Washington, ed. S. K. Campbell, pp 455-480. Office of Public Archaeology, University of Washington Seattle, Washington.

Schalk R. F. 1981. "The Cultural Sequence of the Southern Columbia Plateau." In Cultural Resource Investigation for the Second Powerhouse Project at McNary Dam. near Umatilla Oregon, edited by Randall F. Schalk. Washington State University Laboratory of Archaeology and History Project Report No.1, Chapter 3. Pullman, Washington.

Schalk, R. F., and G. C. Cleveland. 1983. "A Sequence of Adaptations in the Columbia-Fraser Plateau." In Cultural Resource Investigations of the Lyons Ferry Fish Hatchery Project. Near Lyons FeTTY. Washington Washington State University Laboratory of Archaeology and History Project Report No.8, pp 11-56. Pullman, Washington.

Schalk, R. F. ed. 1983. The 1978 and 1979 Excavations at Strawberry Island in the McNary Reservoir. Laboratory of Archaeology and History Project Report No. 19, Washington State University, Pullman, Washington.

Schalk, R. F., and D. L. Olson. 1983. "The Faunal Assemblages." In the 1978 and 1979 excavations at Strawberry Island in the McNary Reservoir, ed. R. F. Schalk, pp.75-110, Laboratory of Archaeology and History Project Report No. 19, Washington State University, Pullman, Washington.

Schalk, R. F. and R. R. Mierendorf, editors. 1983. Cultural Resoures of the Rocky Reach of the Columbia River. Center for Northwest Anthropology Project Report No. 1. Washington State University, Pullman, Washington.

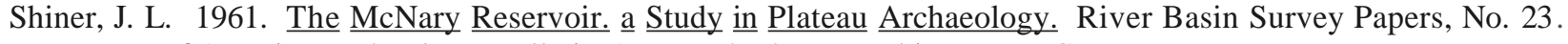
Bureau of American Ethnology Bulletin 179, ppI49-266, Washington, D.C.

Smith, W. C. 1977. Archaeological Explorations in the Columbia Basin: A Beport on the Mesa Project 19731975. Central Washington Archaeological Survey, Central Washington University,Ellensburg, Washington.

* This unpublished report is available through the Hanford Cultural Resources Laboratory, Pacific Northwest Laboratory, Richland, Washington. 
Smith, W. C. M.L. Uebelacker, T.E. Eckert, and LJ. Nickel. 1977. An Archaeological-Historical Survey of the Proposed Transmission Power Line Corridor from Ashe Substation Washington to Pebble Springs Substation. Oregon. Archaeological Research Center Project Report 42, Washington State University, Pullman, Washington.

Sprague, R. and J. Mulinski. Ancestral Burial Relocations. Chief Joseph Pam 1979. University ofIdaho Anthropological Research Manuscript Series, No. 63, Moscow, Idaho.

Stenholm, N. 1984. "Botanical Analysis." In Archacological Investigations at Site 45QK11. Chief Loseph Pam Project. Washington, edt E.S. Lohse, pp.193-213, U.S. Anny Corps of Engineers, Seattle, Washington.

Swanson, E. H. Jr. 1962. The Emergence of Plateau Culture. Occasional Papers of the Idaho State College Museum No.8, Pocatello, Idaho.

Thomas, P. H. 1983 "The Archaeology of Monitor Valley. 1. Epistemology." Anthropological Paners of the American Museum of Natural History, Volume 58, Part 1.

Torrence, R. 1983. "Time Budgeting and Hunter-Gatherer Technology." In Hunter-Gatherer Economy in Prehistory. a European Berspective, edt G. Bailey, pp.II-22, Cambridge University Press, Cambridge, England.

Warren, C.N. 1963 "The Goldendale Site and its Place in Plateau Prehistory. Tebiwa 6:1-21. 


\section{D.3 ETHNOHISTORY. ENTHNOGRAPHY AND INDIAN USES OF THE $\underline{\text { HANFORD SITE }}$}

When the first white explorers visited the interior northwest, the Hanford region was inhabited by people with a unified culture, who spoke languages of the Sahaptian family, and speakers of Cayuse, an unidentified, nowdead language. These were the people whose descendents are now called Cayuse, Palouse, Nez Perce, Umatilla, Walla Walla, Yakima, and Wanapum. To the north were the Salish-speaking Sincayuse, who made use of northern areas of the Site, at least seasonally. In 1855, the Cayuse and representatives of most Sahaptian tribes and bands signed a treaty with the U.S. Government, establishing their exclusive right to the reservations (Yakima, Nez Perce, and Umatilla) and maintaining the right to fish, hunt, erect fish-curing structures, gather food, and graze stock on open and unclaimed portions of the lands they ceded to the U.S. Government (Figure D.4). Others, particularly the Palouse and Wanapum, refused to treat with the whites and continued to live in and use their lands.

This section briefly explores the history of Sahaptian peoples since the early eighteenth century, describes their culture as it has been reported by explorers and ethnographers, and discusses their fonner use of the Hanford Site. It is intended as an outline of extant knowledge, not a thorough academic ethnohistory or ethnography of the region. It is anticipated that this section will be revised substantially as new infonnation is obtained from tribal elders and a more comprehensive review of historical documents has been accomplished. Spellings of tribal or band names are those preferred by the members of those groups, and do not always confonn to anthropological usage.

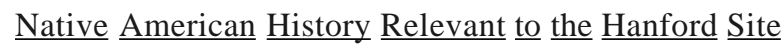

The following chronology includes brief descriptions of major events in the history of Sahaptian relations with non-Indians in the Columbia Plateau; more thorough reviews are presented in Relander (1986) and Trafzer and Scheuennan (1986). This history begins before 1730 and ends in 1943 with the establishment of the Hanford Site. A more detailed history, from a different point of view, is found in Section D.4.

Prior to 1730. Smallpox ard other infectious diseases are thought to have reached the Columbia Basin region as early as the late 16th century (Campbell 1989). Having been introduced by Spanish explorers in the Southeast during the first half of that century, diseases traveled from village to village as people interacted. The effect of these diseases on Plateau cultures has yet to be measured.

Approximately 1730. One of the most important events in Sahaptian history was the acquisition of horses. Within about one generation after the Cayuse and Nez Perce obtained horses from their Shoshone neighbors, they had learned to use the animals with great effectiveness, extending their territories and their resource base. With long distance travel, people were able to congregate at root grounds and other resource areas as never before. Travel to the Great Plains became common, and resulted in extensive cultural change. Sahaptians and Cayuse adopted the dress and housing styles of Plains hunters and took on aspects of their political systems. They also carne into contact with Euro-American traders, particularly in the Upper Missouri and Green River areas of the Rockies.

1775-1792. Sometime close to 1775 , a second (there may have been more earlier, however) wave of smallpox swept through the Plateau Sahaptian populations. This wave of the disease is thought to have been brought to these people from the West Coast by traders, but it may also have been contracted by Sahaptian and Cayuse bison hunters during their contacts with white traders in the Rockies.

1801-1806. In 1801 a third wave of smallpox struck the Plateau region, diminishing the Indian populations and causing serious social disruption, the extent of which is only surmised by historians. Lewis and Clark's expedition descended the Snake and Columbia rivers in October 1805 and returned up the rivers in April and May of 1806. (See D.4 for their observations). Lewis and Clark estimated that there were about 3,900 Sahaptians occupying the shores of the Columbia River between Priest Rapids and the Dalles. This figure includes the Wanapums and some of their very close cultural and linguistic relatives (the Chamnapums) on and near the present Hanford Site.

Boyd (1985) estimated 7020 Columbia River Sahaptians, a figure that seems to be more accurate when one considers the ecology of the area and its major root and fish species upon which the people subsisted (Hunn 1988). This is equivalent to about one person for every two square miles of land surface (Boyd 1985), a dense population for groups living at the hunting and gathering level of subsistence. Boyd also estimated that the mid-Columbia population might already have been reduced by $45 \%$ between 1770 and 1805 due to smallpox epidemics. 


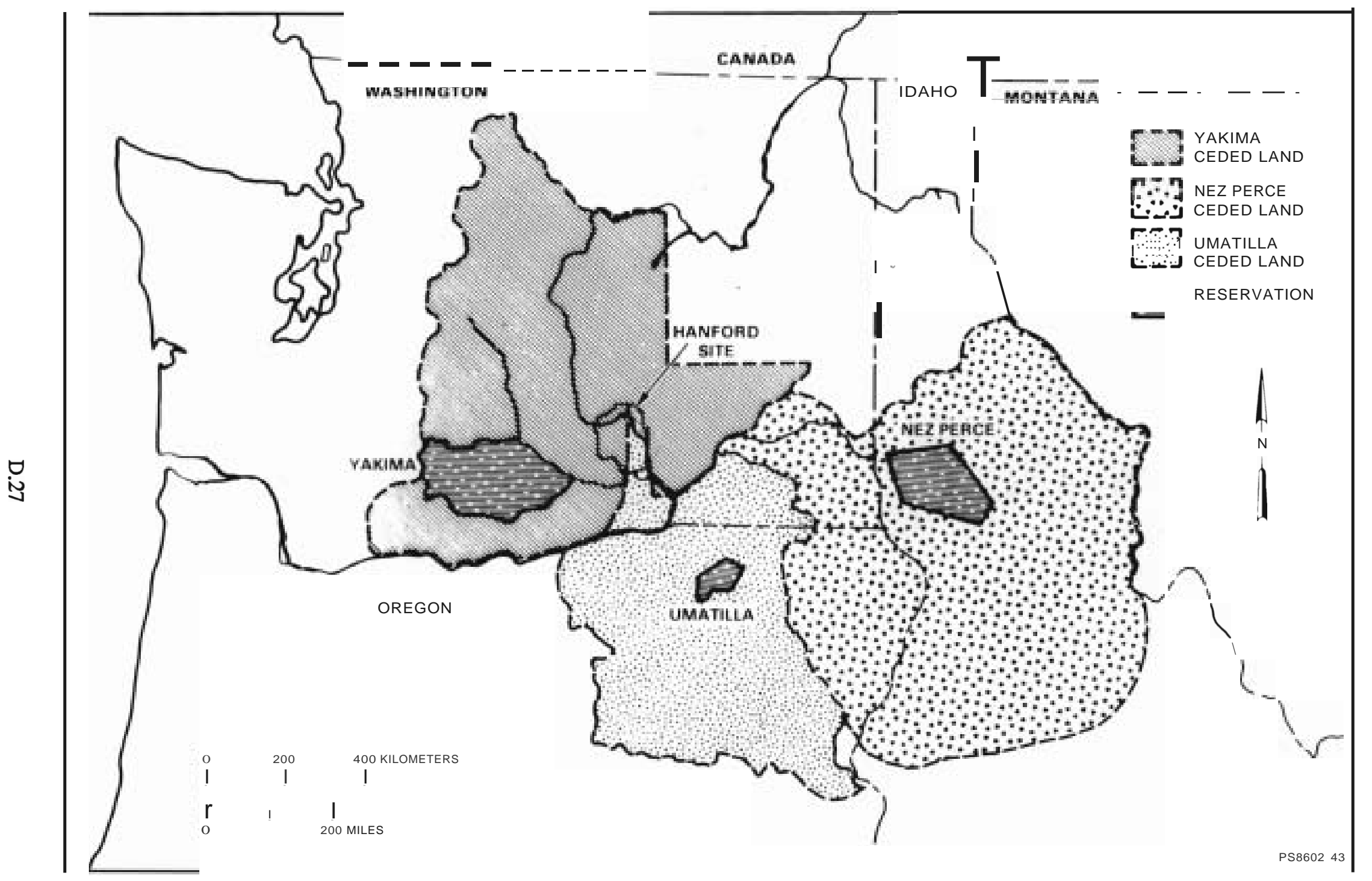

FIGURE DA. Map Showing Indian-Ceded Lands in the Hanford Region. From "Indian Treaty Boundaries, Portland Area Jurisdiction." U.S. Department of the Interior, Bureau of Indian Mfairs, Portland Area Office, 1977. 


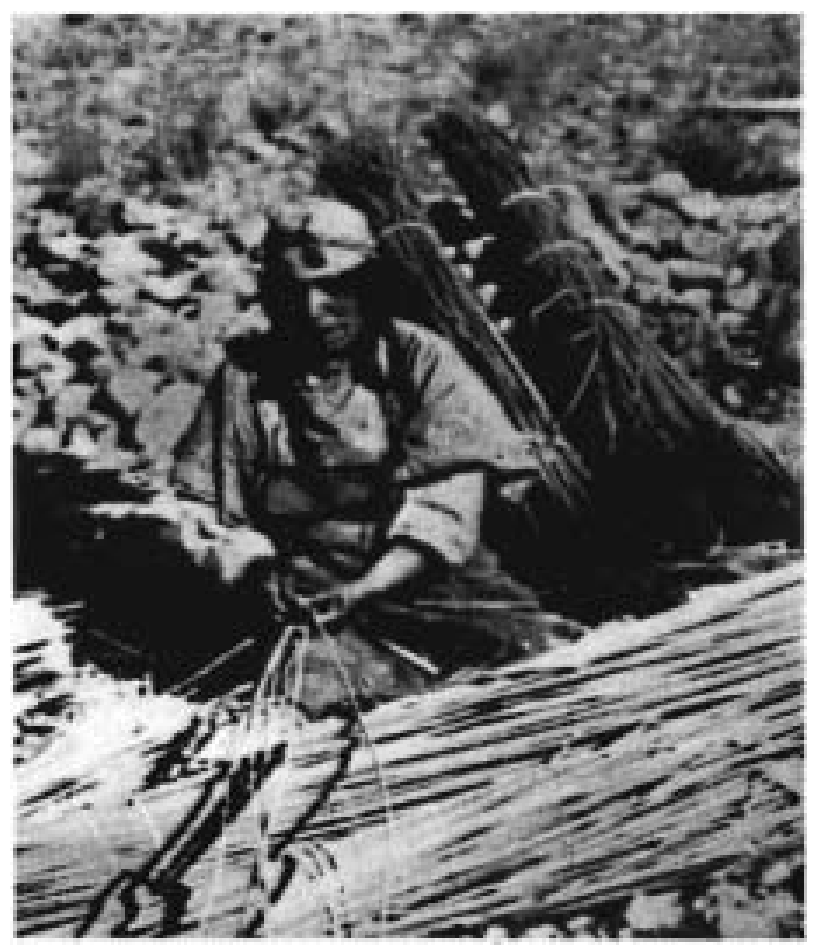

Woman Weaving a Reed Basket

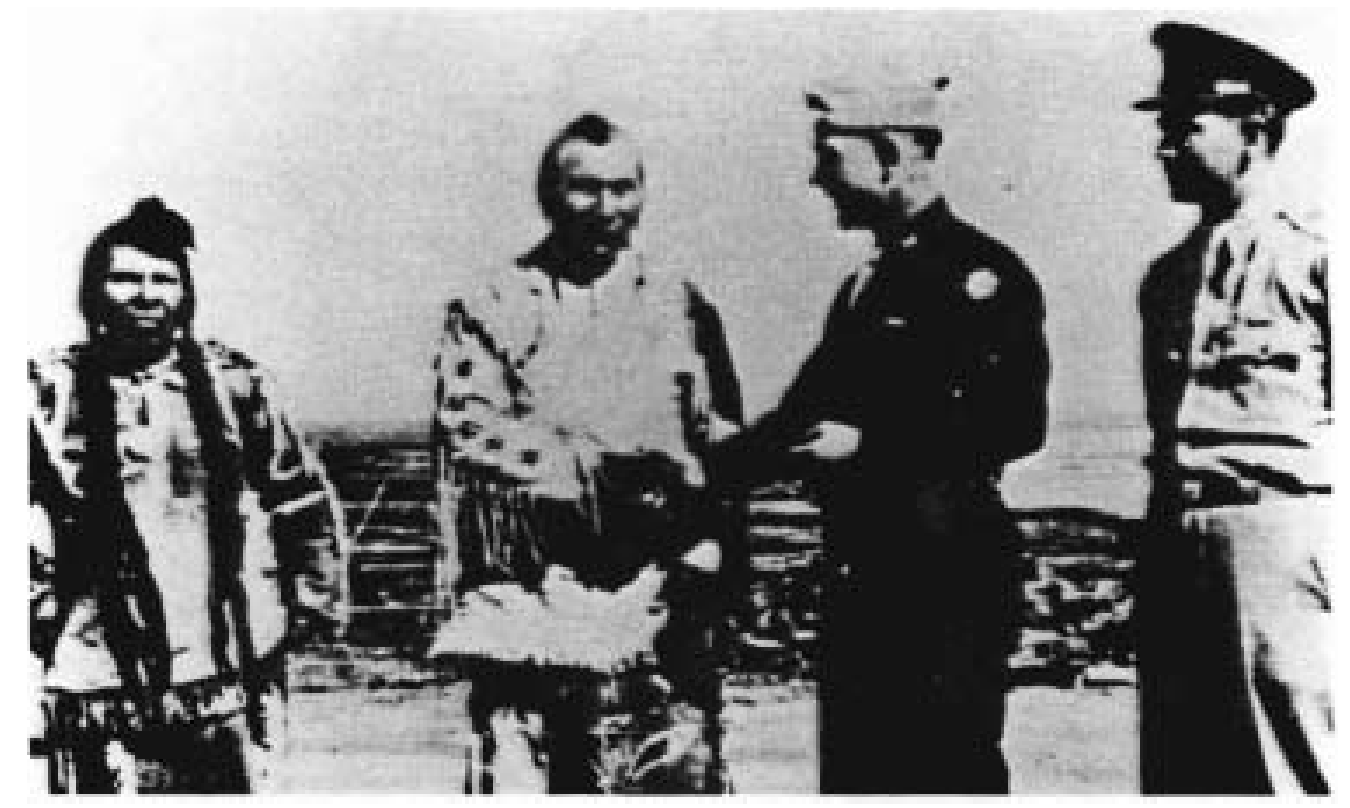

Puck Hyah Toot and Colonel Matthias, 1943

FIGURE D.5. Historic Indian Activities in the Hanford Region 
1808-1812. David Thompson of the North West Company traveled through the upper reaches of the Columbia River and set up fur-trading posts for the company between 1807 and 1810. In 1811 Thompson traveled down the Columbia River to Astoria and returned on the Palouse and Spokane rivers. Robert Stuart and Alexander Ross of John Jacob Astor's Pacific Fur Company traveled with Thompson up the Columbia. Stuart and Ross established trading posts at Okanogan and Kamloops. The Pacific Fur Company attempted to establish a post at Lapwai among the Nez Perce bands, but the Indians were contemptuous of fur trading and were suspicious of white intrusion into their lands.

The Sahaptians traded with whites during most of the 19th century, but they rarely engaged in trapping beavers, a task the fur traders encouraged among all bands they encountered. Some of the Salishan-speaking bands engaged in intensive fur trading, while Sahaptian bands showed little interest, in part because of the sparse population of beaver, but largely because it distracted them from critical subsistence activities (Trafzer and Scheuerman 1985). Sahaptian country was not suited to beaver trapping and was somewhat removed from some of the main-market economic influences of the global fur trade. Historic records suggest that from 1805 (the first white contact) to the arrival of Smowhala, the Wanapum spiritual leader, the Wanapum and other Sahaptian-speakers maintained much of their aboriginal culture. However,like the bands surrounding them, they adopted many of the new instruments of Euro-American culture--metal utensils, buttons, fishhooks, needles, rifles, axes, commercial tobacco, alcohol and other items of convenience and entertainment. And from neighboring tribes they adopted horses, which (as with all bands in the mid-Columbia) extended their range and contacts with, other bands (Anastasio 1972).

1812-1824. When war broke out between the United States and Britain in 1812, the Pacific Fur Company sold out to the North West Company. Donald MacKenzie of the North West Company relocated his major post from Spokane to the mouth of the Walla Walla river (Fort Walla Walla, formerly Fort Nez Perce) in 1818 to support fur traders along the Snake River. However, the Indians of the region did not cooperate, as the company representatives had hoped, to conduct a successful trade.

1824-1835. Another major smallpox epidemic struck the Sahaptian bands throughout their region (1824-25).

"A delegation of Nez Perce traveled to St Louis, Missouri, to request Protestant missionaries after initial contacts with Hudson's Bay Company-trained native proselytizers. In 1835, the Reverend Marcus Whitman traveled to the Nez Perce and other Sahaptian bands to establish missions for the American Board of Committees for Foreign Missions.

1836-1846. The Whitman Mission was built in 1836 at Wailatpu among the Cayuse, and a second mission was established at Lapwai among the Nez Perce by Henry Harmon Spalding. Most of the native population resisted conversion to Christianity; but between 1840 and 1843, about 250 Nez Perce and Cayuse band members were reported as settled farmers in the vicinity of the missions, and a comparable number of children were in schools. Whitman, discouraged at his minimal success, soon turned to promoting white immigration, much to the displeasure of his Cayuse and Walla Walla hosts. Schisms quickly formed in the native communities between Christian and non-Christian, Catholic and Protestant, weakening the potential for unified resistance to the Euro-American invasion.

With Whitman's encouragement, the U.S. government sent a surveying expedition into Sahaptian country in 1841 as the Wilkes United States Exploring Expedition. Miners followed, and later railroad surveyors worked in the region. By 1842 the first non-Indian immigrants moved along the Oregon Trail to the Pacific Northwest, using the Whitman mission as a rest and provisioning stop. By 1843 and until 1845, the Trail was heavily used; and despite the Indians' efforts to discourage immigration through random attacks on wagon trains, about 5,000 immigrants settled in the Willamette valley. These wagon trains brought whooping cough, measles, cholera, and scarlet fever to the mission compounds, from whence it quickly spread to the non-resistant native population.

1847-1848. In 1847, Father E. C. Chirouse and Paschal Richard established a mission on the upper Ahtanum River, home of the famous Yakima leader Kamiakin. In the same year, there was a measles epidemic in the Columbia Plateau. The Whitmans and 12 other people were killed by Cayuse Indians living near the mission in Waiilatpu; the assailants held Whitman responsible for white immigration, the introduction of new disease, and the deaths of many tribal members. A punative expedition of vigilantes was led into the area from the Willamette Valley, but was repulsed by the Palouse (Trafzer and Scheuerman 1985). To avoid open war, Cayuse leaders turned over five perpetrators of the Whitman killings to the whites, who executed them. 
Open hostilities ended with the executions and the cessation of the work by the American Board of Commissioners for Foreign Missions (Protestant) among the interior tribes.

The United States and Britain established a boundary at the 49-degree north boundary in 1846, bringing the Sahaptian territory solely under U.S. government hegemony.

1850-1854. In 1850 the United States Congress passed the Donation Act, which opened Northwest lands for settlement pending treaty negotiations with Indian peoples, and established the first Army post along the Columbia River at the Dalles. Three years later (1853) Washington Territory was separated from Oregon, and Isaac I. Stevens was named governor and Indian Agent, charged with establishing treaties to enable white settlement. During this same year, the first wagon train passed through the Yakima valley over Naches Pass to the Puget Sound, violating what had been up until then the private lands of the Yakima people.

A Pacific Railroad survey party then explored the Klickitat and Yakima country in 1853. The following year, as white incursions into Sahaptian country continued, an inter-tribal council was called by Karniakin (Yakima) in northeastern Oregon (Grande Ronde) to plan a response to Stevens' effort to appropriate Indian lands.

Smowhala, prophet of the Walla Walla, Wanapum and Palouse, had been gaining strength as a spiritual leader. At about this time he received the revelations that became the heart of the Dreamer sect of the native Waashani religion.

- $\quad$ 1855. Treaty negotiations with Columbia River tribes were completed and treaties signed with the Yakima Nation, the Tribes of Middle Oregon (Warm Springs), the Nez Perce Tribe, and the Walla Walla, Cayuse, and Umatilla Tribes. The provisions of these treaties were nearly identical: the tribes ceded most of their lands, but reserved rights to hunt, fish, gather food, and graze stock. The treaties contained provisions reserving to tribal members exclusive rights to fish within their reservations and rights to fish at "all usual and accustomed fishing places ... in common with citizens" of the United States. Provisions were to take effect in three years. However, Govenor Stevens prematurely opened lands east of the Cascades to non-Indians, and in the same year gold was discovered at Colville, Washington. Miners frequently violated treaty provisions, trespassing, stealing stock, and abusing native women. This resulted in the execution of many trespassers by Indian warriors, particularly the Yakima (Trafzer and Scheuerman 1985). In 1855, Yakimas killed A. I.

Bolon, the often-inflamatory regional Indian agent A punitive expedition against the Yakimas was defeated, but the U. S. Army responded by establishing Ft. Simcoe on the Yakima Reservation.

1856-1859. Between 1856 and 1858, the so-called "Yakima Wars" occurred. These consisted of a series of skirmishes between the U. S. Army and Palouse, Yakima, and Walla Walla Indians. After initial Army losses, Colonel G. Wright ultimately defeated these combattants, as well as Coeur d'Alenes, and Spokanes, who had refused until then to live under white rule. Thereafter, the U.S. Army attempted to keep non-Indian settlers out of the vast region east of the Cascades pending ratification of the 1855 treaties. In 1859 the treaties were ratified, and the Army withdrew from Ft. Simcoe. The Yakima Indian Affairs agency took over administration of the region.

1860-1864. Between 1860 and 1864, J. H. Wilbur became the first Yakima agency teacher; he later became the principal of the school. He made every effort to forbid Indian religious activities, particularly the Waashani spirit quest and the Dreamer religion. The second Nez Perce treaty was signed in 1863, removing the Wallowa country from Nez Perce hands. The treaty caused a deep division among the Nez Perce between Chief Joseph's anti-treaty faction and Chief Lawyer's pro-white, pro-treaty faction.

1865-1871. The Warm Springs treaty was signed, confming Indians from three disparate cultural groups (about 3,400) to one reservation in north-central Oregon. In 1871 the Colville Reservation was created by an executive order, and the Wenatehi, Methow, Sinkaietk, Sincayuse (Columbia Salish or "Moses' Band), Sanpoil, Nespelem, Okanogan, Palouse, and Colville bands were assigned to it

1872-1879. The "Nez Perce War" broke out in 1877 and lasted into 1878. Chief Joseph and other Nez Perce and Palouse leaders resisted a treaty with the U.S. government After a heroic flight across Idaho, during which they repeatedly defeated Army contingents, Joseph and his followers were captured. Survivors were first sent to Oklahoma, but were were ultimately returned to the Nez Perce Reservation or forced to reside on the Colville Reservation with many of their former enemies. 
1880-1905. J. Slocum's vision in 1882 resulted in the founding of the Indian Shaker Church at Mud Bay on the Puget Sound. In 1883 the Northern Pacific Railroad opened a line through the Yakima Valley, bringing settlers into the valley in large numbers.

During the same year, the Homestead Act was extended to apply to Indians. About 100 Indian homesteads were established in Klikitat country by 1891. In 1885 the Umatilla Reservation was reduced considerably from its original size to make way for non-Indian homesteaders. The General Allotment Act (the Dawes Act) was passed in 1887, allowing for allotment of Indian land. The result was further constriction of reservation lands. In 1899 the first Indian Shaker Church east of the Cascades was established at White Swan. In 1904 Jake Hunt founded the Feather Dance religion. Also during 1904, the United States Supreme Court affIrmed Yakima treaty rights of access to off-reservation fishing sites in the case of U.S. vs. Winans.

1906-1918. In 1906, the towns of Toppenish, Parker and Wapato were established on allotments sold to whites. In 1907 some of the Yakima Reservation land was leased for the fIrst time. These events were followed by violent conflicts between Indians and non-Indians over allotted lands. Allotments were halted after 440,000 acres of Yakima land had changed hands; 90,000 of these were in fee patent and 27,000 had been sold.

1919-1927. In 1919, the Winans court ruling was extended beyond the provision of the Yakima treaty by another U.S. Supreme Court ruling (Seufert Brothers vs. U.S.). In 1924, the Indian Citizen Act granted Indians the power of the vote.

1928-1937. In 1928, the Merriam Report detailed the plight ofIndians allover the United States, including the Sahaptian peoples. The U.S. Congress passed the Indian Reorganization Act in 1934, which provided for Indian powers to set up business enterprises, elect councils, establish resource management institutions, and enjoy other broad powers of self-government

1938-1942. In 1938, the Bonneville Dam was built, and construction on the Grand Coulee Dam commenced in 1938. These greatly diminished salmon runs, especially for inhabitants of the Colville Reservation.

- 1943. In 1943, the Hanford Site was established for development of nuclear weapons materials. More than 33 Wanapums agreed to move from the White Bluffs area. Indian people went to Priest Rapids as their second choice of possible places to conduct summer fishing and other social, religious and economic activities.

- $\quad$ 1974. In the case of U.S. versus Washington, Judge Boldt of the U.S. Circuit Court of Appeals mandated that the treaty Indian Fishery and the non-treaty Fishery are each entitled to 50 percent of the harvestable number of fish destined for usual and accustomed fishing grounds and stations of Indian peoples.

\section{A Synopsis of Sahaptian Culture}

The following pages contain a brief summary of those elements of Sahaptian culture pertinent to Hanford Site cultural resource management

\section{Sahaptian Social and Political Qrganization}

This section describes Sahaptian kinship structure and political organization. The chief sources for these topics are Anastasio 1972; Hunn 1988; Schuster 1975; and Walker 1967.

The Wanapum, Umatilla, Nez Perce, Yakima and Palouse, and other aboriginal bands possessed a common form of kinship system and political organization. All of these groups were hunters and gatherers and were on either the band or tribal level of social organization (Service 1966).(a)

(a) Service defines bands as mobile groups of 30 to 100 persons, hunting and collecting food as their major means of support, choosing leaders on the basis of personal characteristics rather than inheritance, practicing exogamy (females marrying out into neighboring bands) or ambilocal residence (a newly married couple sets up residence with the male's or female's descent group) and practicing bilateral or patrilineal descent reckoning, shamanism and animism. Exogamy fostered peace among groups whose young people married, and each group opened its local resources to the groups into which its youth had married. 
All of the Columbia River Sahaptian-speaking peoples traced their descent through both the male and female lines, as they continue to do today. This form of descent reckoning is common in most hunting and gathering cultures, and it served a useful purpose in allowing flexibility in post-nuptial residence and in frequent intermarriage, between bands. The Sahaptians readily intermarried and in doing so they ensured their survival, formed alliances and friendships, and shared resources from one location to another.

Although the Nez Perce, Palouse, and Cayuse possessed large numbers of horses and gained reputations among non-Indians as wealthy and dominant over other Sahaptian peoples, the Umatillas, Walla Wallas and YakimaWanapums were richer in riverine resources. The vast numbers of salmon and the large quantities of wild root and berry plants, along with a very well-developed technology for fishing, collecting plants, and preserving these resources, gave riverine peoples a means to support relatively dense populations without cultivating plants or domesticating animals.

Local Group Autonomy. The Plateau Indian cultures, which include the mid-Columbia Sahaptian speakers, were characterized largely by local group autonomy in economic and political functions. However, loose band, composite-band, and tribal organization often superceded the power of the local group in what might be called international relations. Production and consumption occurred for the most part on the local level, although there was sharing of some local resources with neighboring and distant groups (such as the camas meadows at Weippe Prairie, Kittitas, and Glenwood, and the fisheries at the Dalles, Celilo Falls, Little Celilo, and Priest Rapids). The Sahaptians more readily shared economic resources with members of their own band or tribe. Sahaptian speakers received preference over non-Sahaptians, although Salishans, particularly the Sincayuse, were frequently the object of Sahaptian sharing and vice versa (Walker 1\%7). Disparities among groups in the access to critical resources were evened out through extensive trade networks.

The local family unit was more precisely a kindred group composed of from 30 to perhaps 100 persons related to each other by blood (consanguineal kin) or marriage (affinal kin) (Service 1966). However, there were slaves included in these local groups who were taken in battles: Shoshones, Bannocks, and Blackfeet, among others. Marriage between bands (exogamy) was the rule. The local groups practiced generalized reciprocity--giving to others without an expectation of immediate return. All members of local groups gave to one another of the harvests from the waters and the lands, and no one was expected to hold surpluses for personal gain. Hoarding was abhorrent to the Sahaptian peoples, and giving and generosity were expected and respected. According to Huon (1988) this ethical and moral force remains strong today.

"An elk or deer brought down by rifle fire and transported home on the bed of a pickup truck is not hoarded in the hunter's freezer but proudly shared among the hunter's kin in his and other households. The subsistence fisherman's salmon harvest likewise ends up spread among households throughout the reservation. Women bring canned huckle-berries and bags of root cakes or of baked camas when they drop by to visit relatives and friends, and worshippers in the hundreds are fed from the collective stores of the Indian women each Sunday in the longhouses of the Seven-drums religionists."

The pattern of sharing continues today in the use of equipment, labor, and mutual aid. The rules of reciprocity state that one must give, one must accept a proffered gift, and one must make a return gifl This reciprocity is found among all hunter-gatherer peoples, past and present. It is a moral impemtive, the rule rather than than the exception.

Equivalent gifts and exchanges were more common among unrelated persons. These accompanied marriages and bride service; and among the Sahaptian-speakers, gift-giving was, and continues to be, frequent at mourning ceremonies. The deceased's family receives gifts from those who pay respect to the deceased. Upon the death of the mourner, the gifts are returned. Thus a series of exchanges continues from family group to family group, among friends and relatives.

Upon betrothal, a man in traditional Sahaptian culture was married to his wife and to her sisters should the sister's husbands die; and conversely, if a woman lost her husband, she became the spouse of one of her husband's brothers. These customs of brother/sister marriage provided some security for widows and widowers that would not have been otherwise available. It was a frequent practice among nearly all hunters and gatherers (Schuster 1975, pp. 124-26).

These networks of exchanges, reciprocity, and mutual assistance were intelligent social and economic means of survival. They served the people well, and they allowed groups to maintain peace. 
There were also trade networks that extended beyond the local groups. These were less important as devices for meeting the basic human needs of food, shelter, defense, economic organization, and caring for infants and children than were those provided by the local group. Nonetheless, they bonded groups in special ways by establishing certain economic and social ties. These ties were increasing when non-Indians made their ftrst contacts with the Sahaptian people.

In the middle and lower Columbia River regions, Sahaptian bands traded salmon for meats and plants from the upper end of the what is now Idaho (Kalispell and Flathead bands), pipestone, buffalo meat and hides, horses, and certain styles of clothing and ornaments from the Great Plains bands. Obsidian and roots came to the Columbia region from Shoshone and Bannocks in what is now northwest Utah and northeastern Nevada. Slaves, basketry, and wocas (a food) came from the Northern Paiutes of Oregon and Nevada, and marine shells came from the Puget Sound bands and chiefdoms (Zucker, Hummel, and Hogfoss 1983, p. 43).

Salmon, berries, and roots were stockpiled at the Dalles and Celilo Falls for later transfer to trading partners outside the Sahaptian area in return for the goods mentioned. The lower Columbia had become an incipient market, and Indians used shells and beads as media of exchange. Furthermore, relations, exchanges and interactions provided essential information, entertainment, courtship, and other delights. The use of horses, canoes, and rafts added greatly to the speed and efftciency with which goods, rituals, dress style, and information moved; such conveniences transformed Indian ideas and customs.

Political Organization. Sahaptian political organization was heirarchical, being minimally established at the village level. The'villages were, as described above, economically autonomous, with the exception of intervillage and intra-regional exchange. Political authority was based on the special characteristics of leaders in fairness, intelligence, and generosity (Walker 1967; Hunn 1988). Inherited leadership was rare, and seemed evident only in cases when a leader's son proved equal to or surpassed his father's talent. Formal inheritance of leadership was not practiced.

A village headman normally held his position for life. On some occasions a headman held authority over several villages along a water course (Marshall 1977, p. 143). In such cases a headman was elected to his position by a gathering of villages. Village headmen employed heralds to proclaim decisions and announce and convey news. Justice was meted out by chiefs through whippers who enforced mores and rules.

There was further division of labor in the offices and functions of the war chiefs and salmon chiefs, whose authority was based on spiritual talents and powers. Each had authority over his respective activity, and headmen did not interfere with them. Shamans comprised a third division of labor and authority. They were endowed with great spiritual powers and were largely responsible for curing the sick.

The Sahaptian system of governance was maintained by checks against excesses. Leaders in economic, social, and spiritual affairs had to prove their worth. If they failed, villagers withdrew their support (usually without violence). Furthermore, a clear division of authority usually guaranteed social stability.

Additional levels in the heirarchy consisted of confederations of villages into bands, confederations of bands into macro-bands, and confederations of these into tribes. The leadership of each political level was recognized by all villages in the grouping. Each level in the hierarchy also had its ruling council with formal rules and procedures of government More regional political integration occurred as confederacies maintained by intertribal aliances, but these were weak and usually short-lived.

\section{Economy: Use of $\underline{\text { Resources }}$}

The Sahaptian people fished, hunted, and gathered wild foods, and they continue to do this to some extent. The traditional economy was based on cooperation among men and women.

Fish. The major source of food was the anadromous salmonids (salmon, steelhead trout) in the Columbia River and many of its tributaries. Fish runs provided a stable source of food. At least 40 percent of the food eaten by the Sahaptian people in the mid-Columbia came from salmon (Hewes 1973; Hunn 1981, p. 12). This estimate is lower than earlier assumptions about the contribution to total annual food intake of salmon in proportion to other foods and has been contested by some scholars. In fact, the importance of salmon varied from group to group. The Columbia River Sahaptians, past whom the entire stock swam, were the most ftsh-dependent, followed upstream by the Nez Perce and fmally the largely non-riverine Cayuse. All of the salmon species were harvested: chinook, sockeye, chum, and pink. 
Salmon numbers also fluctuated seasonally, with few fish available from late October and late April. High water prevented fishing in most years from late May to late June. Furthermore, salmon runs peaked for only a few days to weeks at a time. Salmon were taken with dip nets from platforms, with gill nets from the shore, with seines from canoes and shore, with gaffs, with weirs along the tributaries of the Columbia, and by hand after spawning.

Two kinds of suckers were caught, the large-scale sucker and bridge-lip sucker. These spawn in the tributaries of the Columbia and Yakima rivers and were caught in willow-basket traps or were (and are) snagged with a hook on a line. Rock and Satus Creeks were among the favored sites for sucker harvests. Sucker spawned in late February and March and arrived before the Chinook salmon.

Eels (a lamprey) swim up the Columbia to spawn, and as they did they were taken (at night) with dip-nets at eddies and some rapids. Today, this subsistence pursuit is waning because of the decline in favorable sites. One of the last eel-fishing sites is Rainbow Falls on the Chehalis River. Sturgeon were taken by most Sahaptian and Salish groups living on the Snake and Columbia rivers.

Other fish taken were trout, whitefish and red-sided shiner, all with hook and line. Whitefish served as one of the few available winter species of fish; they were taken from streams through the ice. Neither Dolly Varden nor sturgeon were taken by the mid-Columbia Sahaptian. Sculpin, of which there are eight species in the Columbia River basin, were regarded as weather-changers, and were used by medicine men to predict or control weather. They were also a food source. Crayfish were treated likewise (Hunn 1988, p. 30). Freshwater mollusks were eaten. They were collected from river bottoms, where they grew in large quantities. No other invertebrates were used as sources of food.

Plants. Plants constituted the major source of food for Plateau Indians in general. As measured by caloric values, plants, particularly bitterroot, skolkol and camas, comprised an estimated 55 percent of the annual diet. Salmon and other fish comprised 33 percent and other animals, especially venison, 12 percent (Benton et al. 1973; Keely 1982; Norton et al. 1984; Huon 1981; Watt and Merrill 1963). The most common plants collected, processed in several ways, and consumed were (and frequently continue to be) bitteroots, cous, Indian celeries (lomatiums) camas, and huckleberries.

Some of these plants were available near or on the Hanford Site. For example, the Wanapum and Palouse traded with "Tribes to the west ... " (Relander 1986, p.112) who sought skolkol, or "Indian carrot" (Lomatium canbyi), the small, mealy bulb which tastes oily and served as one of the major food plants in the midColumbia. This plant is found only at Priest Rapids in quantities sufficient for significant harvests. Another of the root plants (Lomatium hambleniae) was also confined to the Priest Rapids area A third (Calochortus macrocarpus) is a winter root of the deserts, and it was likely taken at the Hanford Site.

Other localized root plants in the mid-Columbia are Lomatium samoniflorum, found along the Snake River where the Nez Perce used them; a root plant (Tauschia hooveri), found only in the Yakima country; and another Indian celery (Lomatium minus), in the John Day and Umatilla areas. Many plants whose stems were collected were accessible to most of the Sahaptian-speaking peoples in their regions, such as additional Indian celery (Lomatium gravi, nudicaule) balsam root (Balsamorhiza careyanalB. sagitatta), mule's ear (Wyethia ampleicaulis) and cow's parsnip (Heracleum lanatum).

- Roots. Roots were essential to the diet of the mid-Columbia Sahaptian Indians, and women harvested them with digging sticks and collecting bags or baskets. Most of the 25 species of root plants used by the Sahaptian are small, herbaceous, spring-flowering species, and the edible parts consist variously of tubers, corms, bulbs, tuberous roots, and underground sprouts (Hunn 1988, p. 37). All of these plants are available from March to July.

The most widely used of these are cous (Lomatium cous), skolkol (L. canbyi), "Indian carrot" (Perideridia gairdnen) "Indian potatoes" (Claytonia lanceolata), camas (Camassia quamash) the Yellowbell (Fritillaria pudica) and a hyacinth (Brodiaea hyacinthina). A woman could collect as much as about 60 pounds of roots (skolkol or cous) in a day's work, and could harvest about 180 pounds in a season (Hunn 1988, p. 41). This underscores the importance of roots as a source of food, but it is also important to remember that the season of abundance lasted only a few weeks.

- Berries. Fruits and Nuts. These plants are collected in summer and fall. Together they contributed only about five percent of the total annual average food intake for the mid-Columbia people. Rigid containers of hemp cord and cedar root baskets were used by the women who collected these plants. 
The most important of these plants, the black mountain huckleberry (Vaccinium membranaceum), was collected in mid-August, and a celebration feast was held at that time. This custom is being revived by several Sahaptian communities. The berry season opened with collection of sweet currants in June, followed by the white dogwood fruits that ripened at the end of June in the low elevations along the rivers. Between late June and mid-August chokecherries (Prunus virginians) and serviceberries (Amelanchian ainifolia) were collected in the lowlands and foothills. Grouseberries (Vaccinium scoparium) were also collected but in much smaller quantities than the mountain huckleberries. The blue mountain huckleberry (Vaccinium parvifolium) was found with the black mountain huckleberry, another important source of food in summer. The low mountain blueberry (Vaccinium caespitosum) was also collected, but it was much less important than the black mountain huckleberry. When huckleberries were collected into October, black tree lichen (Bryoria fremontil) was gathered and baked for use as a confection to go with the berries.

- Trees. Sahaptian-speak:ing Indians recognized over 30 species of trees in their region. Most of the trees used for foods and other purposes were located outside the Hanford Site. The whitebark pine (Pinus albicaulis) was (and is) a source of pine nuts. The Ponderosa pine (Pinus ponderosa) provided edible inner bark and is a source of sugar; it also marks the lower timber line. The lodgepole pine (Pinus contorta) was used, as the name indicates, to construct poles for lodges.

Only one oak tree, Garry Oak (Quercus garryana), was used as a source of food. Its acorns were leached of bitter tannins and eaten. This tree was not present on or near the Hanford Site. Oak: was used as a digging stick plant as well, and was prefeired for this purpose. The Douglas maple was used for dip-nets, and the Ocean spray (Holodiscus discolor) was used for braces in the dip-nets.

The major source of ftrewood, particularly in winters whose temperatures fell below -20"F, was sagebrush (Artemisia tridentata). Driftwood was also, of course, an important source of frrewood. Elderberry wood (Sambucus caerulea) was used for venting underground ovens. The Peachleaf willow (Salix amygdaloides), which occasionally grows to 50 feet without a branch, was used for longhouse frames.

Trees are also important in myths. Hemlock (Tsuga spp.) saved Coyote from drowning in one of the Yakima stories.

- Eibers. Mid-Columbia people used fibers for containers because of their need for mobility to search for food and fuel. Nets, bindings, and baskets were essential to the hunting and gathering way of life. Mats and clothing were also made of plant fibers Indian hemp (Apocynum cannabinum) and tule or bulrush (Scirpus actus/Sovalidus) are most useful as ftbers. Indian hemp grows at low elevations, but the choicest sites for the best plants are not disclosed by Yakima women today (Runn 1988, p. 54). String made of Indian hemp was fashioned into a ball by Indian women. The string was knotted to mark special occasions (the "time ball") in the women's lives. Cedar root served as the main structure of berry-collecting baskets. These were imbricated with bleached beargrass leaves (Xerophyllum tenas) and the red bark of the bitter cherry (Prunus emarginata).

Winter longhouses and summer teepees were covered with tule mats. These grow in low elevations and were certainly available on the Hanford Site to the Wanapum and other Sahaptian speakers. Twig needles of the greasewood plant (Sarcobates vermiculatus) were also woven into tule mats, and the common reed (Phragmites communis) was also used for this purpose. Large, soft containers were made of cattails (Typha lali/olia); these were used for storing dried salmon. Giant wild rye (Elymus cinereus) was used to separate sections of salmon.

- Use as Medicines. Sahaptian-speakers used more than 75 species of plants for medicines. Many of these were used for body and spirit. The most commonly used plant used for this purpose is the fern-leaved lomatium, which was also used as a fish poison and spring vegetable. As a medicine, it was used for humans and animals. It was used to rinse the hair to treat scalp-itch, and the root pulp was applied as a poultice to treat infected wounds and boils. It was also used to kill lice and certain infectious bacteria. Diluted in a drink, it was used to treat upper respiratory infections. The root was chewed to treat sore throats. The lovage (Liqusticum canbyi) was also used for this purpose.

Conifers were used for medicines; the pilCh of these plants was applied to sores and wounds. Young Ponderosa pine and larch were used for teas to treat influenza and tuberculosis, respectively. Balsam firs (Abies spp.) were cleansers for spirit and mind. The grand and silver frrs are still used in sweat lodges, and the 
steam is strengthened by the subalpine fir (Abies lasiocarpa) (Hunn 1988, p. 52). Sumac (Rhus alabra) was used to treat venereal disease.

There were several plants used to aid the human spirit. Spruce was boiled to make a tea to assist one with spiritual malaise, and one might drink wild tobacco (Nicotiana attenuata) during an emotional crisis such as the death of a loved one. Wild rose (Rosa spp.) was used to overcome spiritual sickness; branches of juniper and red cedar were often used as substitutes for rose. Many flowering plants were also appreciated for their beauty (e.g., globe mallow, Indian paintbrush, shooting star, lupine, and others).

Mammals. Mammals were an important part of the annual food for the Sahaptians of the Columbia Basin. They provided as little as $12 \%$ of the diet for riverine Sahaptians, but much more for upriver and nonriverine groups such as the upper Yakima, Nez Perce, and Cayuse. Hunting was an important pursuit for boys and men, and a source of pride. Indeed, a boy's first kill inaugurated his entry into manhood. Hunting was conducted year round, but autumn was the most productive period, when elk and deer aggregated for the rut and moved toward their winter ranges.

The bow and arrow was the primary weapon of the hunt until guns were introduced. Arrows were flechted with hawk feathers bound with Indian hemp and sealed with spruce. The mule deer (Odocoileus hemionus) and the black-tailed deer (Odocoileus hemionus colwnbianus) were hunted most often. The American elk (Cervus canadensis) was hunted infrequently. White-tailed deer (Odocoileus wirginiana) were hunted occasionally, as were bighorn sheep (Ovis canadensis), mountain goat (Oreamnos americanus) and the pronghorn (Antilocapra americana, (now absent from the region). Bison were a major part of the diet for equestrian groups (Yakima, Nez Perce, Cayuse, Palouse), who moved en masse to the plains for year-long hunts. The hides of all of these large mammals were used for clothing and tools.

Hunting parties consisted of men and boys, who tracked their prey and kept in contact with sounds that imitated animals. If a boy were the successful hunter in the party and the kill his first, he ate nothing of the animal, thus displaying his willingness to give and ensure the survival of the coming generation. Wasting game is still an offense in the moral order of the Plateau Indians; punishment is sickness or bad luck in hunting. Sharing game from the hunt remains a common practice.

The yellow-bellied marmot, often weighing five to ten pounds, was hunted near summer fishing grounds. The hoary marmot, the whistling creature of higher elevations, was not hunted because it was associated with the "little people" whose whistling might seduce the lone hunter into losing his sense of time, space, and identity (Hunn 1988, p. 7).

The Townsend's ground squirrel (prairie dog) was another important source of food. They were found in large numbers in sandy soils of the plains and foothills. Streams were diverted to flood the animal's colonies, after which the hunters clubbed or shot the squirrels. Jackrabbits and cottontails were netted in sagebrush flats. Women, children, and men hunted these rabbits communally, using Indian hemp nets three feet wide and several hundred feet long. Rabbit fur was used for winter vests and socks.

Mid-Columbia peoples trapped beaver, otter, muskrat and other fur-bearers, but they did not engage in trapping as a major source of food. Trapping was conducted to obtain furs; otter skins were used to braid one's hair for decoration and symbolic ornamentation. The beaver's musk gland was used an an aphrodisiac and love charm.

Birds. The Sahaptians recognized between 60 to 70 of the 260 bird species that are found in the midColumbia region. The 21 species of ducks found in the region are placed under a single generic Sahaptian name. Many species were hunted, as is the Canada goose (Branta canadensis moffitu), on islands in the Columbia River. Eggs of some species of waterfowl were collected, but the ethnographic data on Sahaptian hunting of waterfowl and egg-collecting are sparse (Hunn 1988, pp. 11-12). Mallard ducks (Anas platyrhynchos) and the common merganser (mergus merganser) were among the most frequently hunted waterfowl. Tundra and trumpeter swans (Otar colwmbianus, O. buccinator) were in large numbers in winter along the Columbia River, and they provided additional food to the stores of dried winter stocks. Two types of grouse--the sharp-tailed grouse (Pedioecetes phasianellus) in the grassland and sage grouse (Centrocercus urophasianus) on the sage brush steppes along the Snake and Columbia rivers--were hunted frequently and were considered very good to eat The blue and ruffed grouse (Dendraga pus obscurus. Bonasa umbellus), occupants of forests, were hunted much less often.

Birds were used for aesthetic, technical, and religious purposes. The flicker's red-orange flight feathers (Colaptes cafer) and the tail feathers of bald and golden eagles (Haliaeetus leucocephalus. Aquila chrysaetos) were 
required to dress the remains of the deceased for a journey to another world Hawk feathers kept arrows in true flight. Eagle feathers still have power in men's dance costumes.

\section{$\underline{\text { Religion }}$}

In the Plateau Indian world view, people were placed on the land by the supreme creator to serve as caretakers of the natural world. Each group was created in place and given the responsibility for that place in perpetuity. The earth and all that lives on it is thus part of a sacred trust. The religion based on this trust is the Waashani.

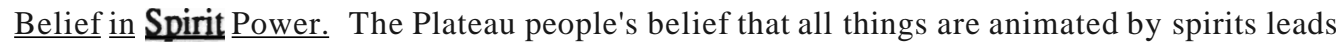
anthropologists to identify the religion as animistic. The spirits, which inhabit the physical forms of animals, plants, rocks, clouds, and streams, have separate wills. Humans must treat them with respect. This respect for the individual character, feelings, desires, intelligence, and motives of spirits is the basis for Plateau Indian morality. Hunn (1988, p. 4) states, "Animism extends the benefits of human society to the entire local ecosystem." All things are to be treated with the same respect one would show to oneself and to other humans. Rudeness and disrespect entail withdrawal of support (animals and fish and other sources of life will abandon one or persistently evade one's efforts in the hunt). Special messages of dread or joy are delivered by Coyote, the chief figure in Sahaptian morality tales, also by the raven, the great horned owl (which conveys chilling communications), and the meadowlark (a tease). Each living thing teaches a lesson, and just as these beings must be treated with respect, so must each human being.

In earlier times, vision quests for guardian spirits were central to the moral development of a human being, to each person's strength to survive and endure the hardships of life, and to the cultivation of one's unique talents. The vision quest entailed lonely vigil, a vision, a sickness following newly acquired power, and a "coming out" with assistance from a spiritually endowed relative. This sequence often took years (Ray 1939, pp. 68-131; Schuster 1975, pp. 114-20). The quests were undertaken by boys and girls nine or ten years old, and the coming out (public display of new powers) took place in winter with the shamanic power dances (Ray 1939, pp. 69-70). Often, years spaced the time between receipt of a vision and the disclosure of powers. The vision powers were to be kept secret during that interval. The guardian spirit was a mammal, bird, or reptile, bestowing its special gifts to the seeker of the vision. The vision seeker was not always improved by a vision; the recipient of vision could receive the worst features of mammals, snakes, or birds. Some seekers received no vision.

The Rise of Waashani Sects. Although the arrival of Euro-Americans caused declines in Sahaptian populations from diseases and cultural catastrophe (see summary of Sahaptian ethnohistory), the people made efforts to give themselves hope. Some joined the non-Indian world in trade, religion, and politics; others eschewed the nonIndian beliefs, institutions and devices. Many of these latter people were led by prophets who spoke of the restoration of the Indian ways and rejection of Euro-American customs and powers.

The prophet cults or religions might have begun with the advent of smallpox in the Plateau region. This catastrophe, later manifestations of which were accompanied by the economic, religious, and technical upheavals brought about by Euro-Americans, seemed to foster conditions ripe for the ascent to power of prophets (Hunn 1988). The prophet initiated sects were found among all of the Sahaptians, and many other linguistic and cultural groups as well. The most powerful of these was found among the Wanapums, whose founder, Smowhala, spent most of his life near what is now the Hanford Site.

Smowhala was born sometime soon after 1810. He is first mentioned in the literature in an 1861 military report. The army was then scouting the mid-Columbia River and attempting to prevent conflicts between Indians and whites when the Northern Pacific Railroad was being constructed across the plateau. Smowhala's greatest influence was in his ability to foretell events and to enter a trance state, journey to the Spirit Land (hence the term "dreamer" for the adherents of his Prophet Dance religion), and return with messages of the world's renewal and songs of spiritual power. He rejected Caucasian culture and was appalled at the non-Indian world's alterations to the land, the sacred being of Sahaptian religion.

Smowhala held meetings near Priest Rapids. From there he taught his religion, which was largely a formalization of the traditional Waashani. He designed a flag based on his vision, which came to him on the eastern prominence of Rattlesnake Mountain within the border of what is now the Hanford Site. A carved image of his spirit bird (Bullock's Oriole, Icterus bullockii) stood on a pole atop Smowhala's tule-mat home and religious edifice, and called to the salmon on their spring run. A similar image was placed at Celilo Falls and on the Yakima Reservation at Union Gap in the 1860s. The Dreamer religion was the dominant sect among theWanapum and 
Palouse, although it also exerted a powerful influence on some members of all bands of the Sahaptian and some Salish groups, (Mooney 1896).

Many Sahaptians continue to practice rituals derived from the Waashani, including prominently the Dreamer sect common to the Dreamers of Smowhala's time. These make up the "longhouse religion." In 13 long houses from Nespelem on the north, to Lapwai to the east, to Warm Springs to the south (Hunn 1988, p. 40), the adherents dance to the seven drums, incorporating ancient rites of gratitude for the fruits of the earth on Sunday and other feast days. Sahaptian people gather at Priest Rapids, Toppenish, White Salmon, Lapwai, and elsewhere for feasts of thanksgiving. Sunday meetings are held at all the longhouses.

The Indian Shaker religion, a syncretic religion combining elements of traditional Puget Sound Salish religion with Christianity, is also practiced on some of the reservations. Likewise, generalized shamanism, by "Indian doctors," is commonplace.

Despite efforts by federal and church officials to destroy the traditional religion in its various forms, these cherished customs continue. The Columbia River bands of Yakima and Wanapum escaped some of the worst of the persecutions because of geographical distance from missionary and government posts.

Today, traditional religions are experiencing revitalization as more and more young people again take part. Many of today's longhouse leaders are young.

Native-American Use of the Hanford Site

This section details the use made of the Hanford Site by the Wanapum, Palouse, Walla Walla, Umatilla and Nez Perce peoples. Information on which statements were based has been obtained from published sources and from Wanapum, Palouse, and Umatilla elders identified by their tribal governments as knowledgeable about such matters.

Wanapum and Yakima Use Sites, $\underline{\text { Resources, and Locations }}$

According to most authors (Smith 1982), the Hanford Site area was inhabited by two groups, the Wanapum and the Chamnapum. The Chamnapum are most often considered to have been a band of lower Yakima, although Black (in Rich 1947) described them as part of the Walla Walla on the basis of language. Like the Walla Walla, Palouse, Yakima, and Umatilla, the Chamnapum and Wanapum spoke dialects of the Sahaptin language, a member of the Sahaptian family. Because of linguistic similarity, the Chamnapum could have as easily been classified with any of these groups.

Based on a few historical and ethnographic accounts (Ross 1923; Ray 1936, 1938; Relander 1986; Suphan 1974; Mooney 1896), the Wanapums customarily occupied the right bank of the Columbia River from the confluence of Crab Creek in the north to some point between the White Bluffs and the confluence of the Snake in the south, and on the left bank from just below Priest Rapids to the same southern area, Immediately downriver were the Chamnapum on the right bank and the Palouse on the left bank. To the north were the Sincayuse. There was intermarriage between the Wanapums and Chamnapum and all their neighbors.

They routinely traveled westward and northward to mingle with Yakimas at sites which are now the locations of Toppenish and Ellensburg, and northeastward to mingle with the lower Palouse and Sincayuse in the rich root grounds of the Badger Mountain and Soap Lake areas (Relander 1986). The lower section of the Yakima River and the Columbia above the junction of the two rivers was used primarily by the Chamnapum band of Yakima and the White Bluffs and Priest Rapids Wanapum (Suphan 1974, p. 141).

A trail from Priest Rapids and White Bluffs to the Yakima River was used by the Yakima and Wanapum Indians to visit each other for feasting and dancing. These gatherings and other, less-formalized, visits resulted in frequent contact and intermarriage. At Celilo Falls on the Columbia River, which has since been inundated by a reservoir created by The Dalles Dam, the Wanapums fished and mingled and intermarried with their cultural and linguistic kindred, the Wyampums, Skeinpahs, Wascopums, Klickitats, and Yakimas (Relander 1986, p. 34).

The Wanapums were the primary seasonal occupants of two fishing places, one named Wy-yow-now, close to the village at White Bluffs; and a second, Wan-a-wish, at the Horn Rapids irrigation dam site on the lower Yakima River. Other Indians came to these places to visit, but the Wanapums (and presumably Chamnapums) had sovereignty over the fishery there (SwindeIr 1942, p. 248-88).

The Wanapum informants of the 1940s and 1950s identified the village and other use sites for Relander (1986). These are shown in Table D.1. 
TABLE D.I. Wanapum Villages and Other Use Sites--Aboriginal and Historic Periods. (Relander 1986, pp. 296318)(a,b)

Place Name (f) Location

Near Pasco, Washington

One-half mile upstream from Pasco

Kennewick, Washington. Also name of an island near Kennewick

Confluence of Yakima and Columbia Columbia rivers

Richland, Washington

Eight miles upstream on Columbia River from Richland(c)

Rattlesnake Mountain, western edge of Hanford Site

Townsite of Hanford, Washington

Upstream from (near) townsite of Hanford, Washington

Upstream from townsite of Hanford, Washington

About 3 miles upstream from townsite of Hanford, Washington

Near (the above)

White Bluffs townsite

Several miles north of White Bluffs townsite

Near White Bluffs townsite

Bordered (the above site)

Locke Island. Near Wyone

Gable Mountain. Near upstream end of White Bluffs
People and Uses

Main Lower Palouse village; meeting place of the region's various Indian bands. Eel fishing was the main activity.

Village site. Tribal association not mentioned, but probably Palouse.

Used by "family bands." Types of uses not mentioned.

Permanent village site of the Chamnapums, people "almost identical with Wanapums" (p. 299). This is near Hom Rapids, a fishing site, and (prosser, Washington), a second and very important fishing site.

A winter camp.

Favorite fishing place after salmon had spawned.

One of 4 major places along a lao-mile stretch of Columbia River where girls and boys were sent on vision quests.

One of the main Wanapum camps.

Occasional camp, one of a series of almost continuous villages between Hanford townsite and townsite of White Bluffs.

Wanapum mined white-face paint for mid-winter dance.

Wanapum village.

A small Wanapum village.

One of the major sedentary Wanapum villages. Fishing, collecting, ceremonial sites used until 1943 (Hanford Site established). At least 33 Wanapums were moved from here to Priest Rapids in 1943.

Wanapum fishing village. Often visited by Palouse.

Salmon-drying place.

Wanapum fishery.

Wanapum burial site until 1912.

One of the major locations forWanapum vision quests. (The other two were Saddle Mountain and the Twin Sisters.) 
TABLE D.1. (contd)

Place Name (f)

Five miles east ofWahluke

Near 100 N Reactor.

At Coyote Rapids

Upstream from Vernita Bridge

Two miles from the above site (d)

Upper end of China Bar

One-half mile upstream from

China Bar

Near McCoy Canyon

Three miles north of Vernita

Bridge(outside the Hanford Site)
People and Uses

Head ofWanapum trail to the Yakima Valley.

Wanapum trail to Palouse country and Soap Lake.

Wanapum dog-salmon fishing site.

Place of first Dreamer dance. Also site of Wanapum driftwood collection.

Large Wanapum village.

Wanapum summer fishing camp.

Wanapum summer fishing camp. Also, a main trail to Priest Rapids passed by here.

Wanapums made rafts here and stored dried salmon to keep it cool. The raft of Speelyi (the hero, Coyote) is still here, not far from the stone body of Sun Man. (For details on this site and Sacred Island and on Wanapum religion, see pp. 21-38).

Wanapum women left this site to spend 3 days digging for roots. Men waited here for them. Speelyi hung his net here when he left the river.

Important spring for Chamnapum in early 1900s (and probably much earlier). "Whippers" guarded the spring from human misuse.

(a) The stretch of the river between Richland and Hanford was one of the few where there were no permanent villages.

(b) From this camp upstream for about 20 miles there were many small Wanapum villages. According to Relander's informants, most of the Wanapum lived on this part of the river, where fishing was particularly productive because of the rapids (page 307).

(c) The stretch of the river between Richland and Hanford was one of the few where there were no permanent villages.

(d) From this camp upstream for about 20 miles there were many small Wanapum villages. According to Relander's informants, most of the Wanapum lived on this part of the river, where fishing was particularly productive because of the rapids (p. 307).

(e) Beyond this site the Salish-speaking Kawachkin of Chief Moses's birth comprised the bulk of aboriginal inhabitants when the historic period opened.

(t) Place names removed at the request of Native-American informant

The Palouse: Their Linguistic Ties, Location, and Use $\underline{\text { Areas }}$

In the early 19th Century, the Palouse people (a.k.a. Palus) inhabited the Snake river from approximately the Idaho-Washington border to the Snake's confluence with the Columbia. Due to political events of the last century, they have since been scattered to the Colville, Yakima, Umatilla and Nez Perce Reservations, and no longer exist as a separate band with political identity.

The Palouse were linguistically very closely related to the Walla Walla (also referred to as the Wallula); indeed, Walla Walla and Palouse are considered to be the same (Chalfant 1974). In western Palouse river Sahaptian settlements, Palouse dialects were more closely related in language to the Wanapum who resided along the mid- 
Columbia This linguistic connection indicates frequent Palouse-Wanapum contacts. Scholars of Sahaptin ethnography and ethnohistory have experienced considerable difficulty in separating Palouse from other Sahaptinspeakers (Chalfant 1974).

According to Trafzer and Scheuerman (1985), who have chronicled Palouse history with the aid of elders, the Palouse consisted of three groups with separate resource territories. The upper Palouse of the Almota-Lewiston area interacted extensively with the Nez Perce and utilized lands in extreme eastern Washington and adjacent northern Idaho. The middle Palouse--or Paluso-whose central village was at the mouth of the Palouse river, gathered resources largely from the Blue Mountains, especially the Tucannon River basin. There, they interacted closely with the Walla Walla and Cayuse, with whom they shared hunting and root and berry gathering areas. The lower Palouse, called Nahanum, occupied the area around, and a few miles above, the mouth of the Snake River. Their principal village was Quosispah, near present-day Sacajawea State Park at the mouth of the Snake. Smaller villages were located up the Snake and on the Columbia River between the confluences of the Snake and Columbia. They cohabited Columbia River villages with the Chamnapum and Wanapum, at least during the early fall fishing season. According to Mary Jim, a Nahanum elder, her people occasionally visited the White Bluffs area for fishing and often fished at Hom Rapids. They were familiar with lower portions of the Hanford Reach of the Columbia, and she confirmed many of the uses for places described in Table D.2. Nahanum root-gathering grounds were primarily in the Soap Lake, Badger Mountain and Moses Lake areas, which they shared with Wenatchee, Sanpoil, and Wanapum peoples.

\section{Umatilla. and Walla Walla Locations and Use Areas}

These two groups occupied the Columbia River and surrounding terrain downriver from the mouth of the Snake. The Walla Walla occupied the left bank from immediately below the mouth of the Snake downriver to what is now Alderdale, Washington. This included the lower reaches of the Walla Walla River. Beyond alderdale to the mouth of the Umatilla River lived the Umatilla. The hunting and gathering grounds of these people overlapped with the Cayuse in the upper Umatilla and Walla Walla river basins. They fished in common with neighboring groups in their own territory and at outside sites, such as Hom Rapids on the Yakima or Celilo Falls, over which they did not have resource sovereignty.

Suphan (1974), who was a consultant to the U. S. Government during Indian land claims cases in the 19508, interviewed numerous members of these groups. From this he drew conclusions that are not inconsistent with those of Trafzer and Scheuerman (1985) and Relander (1986), who were strongly supported by the tribes they wrote about. His conclusions are also consistent with nuances of the treaty language signed by the Walla Walla and their allies in 1855 .

Each resource-gathering area or village site, according to Indian informants who worked with Suphan, was shared by at least one other Indian band, an observation that seems to apply to all Indian use sites. The Blue and Wallowa mountain areas were exploited with Nez Perce and Cayuse bands. Sites along the left bank of the Columbia River in the mountains and valleys of what is now Grant County, Oregon, were commonly used with downstream-dwelling Tenino-speakers. Information available to Suphan (1974) suggests that the lower Yakima River and the White Bluffs-to-Priest Rapids region was of "relatively little interest to the Umatilla, Walla and Cayuse." Indian informants who assisted Suphan, "... became quite vague--perhaps purposely so--and had virtually no comments to make regarding these lands in contrast to the intimate knowledge and ready discussion of areas now in Oregon" (Suphan 1974, p. 54). Suphan continues,

"The sole information obtained from informants may be summed up as follows:

1. Prosser, Washington, was once the site of a falls famous for its fishing 'a little Celilo' - at which the Umatilla occasionally fished.

2. The White Bluffs Indians (the Wanapum) were not the same ethnic group as those with which we are here concerned; they spoke a distinct dialect, and the Walla Walla visited them to trade."

Suphan concluded that the Umatilla and Walla Walla visited and exploited certain places along the lower portion of the Yakima River and the Columbia River above the junction of the Yakima and Columbia rivers, but it was primarily the Yakima (or Chamnapum) and the Wanapum that exploited this land. The Umatilla, Walla Walla, Cayuse, and Nez Perce visited this area to trade and to participate in the "inter-ethnic rendezvous so common on the Plateau; whatever exploitation of the natural resources they engaged in was decidedly secondary to that of the Yakima and Wanapum as well as secondary to their own utilization of the land east of the Columbia and south of the Snake" (Suphan 1974, pp 53-4). 
It is noteworthy that Peo Peo Mox Mox, a principal chief of the Walla Walla, reserved a fishing and trading site for himself on the lower Yakima river, and that he insisted on including the Hanford Reach of the Columbia River within ceded lands of the Walla Walla, Umatilla, and Cayuse confederation. This is further evidence that these fisheries under the resource sovereignty of the Wanapum and lower Yakima were also used and valued by the Walla Walla and their confederates.

\section{The Cayuse and Nez Perce: Their Linguistic Affiliations. Location and Use Areas}

These peoples spoke languages mutually unintelligible with Sahaptin dialects and with each other. Nez Perce spoke a Sahaptian language, while Cayuse language was non-Sahaptian.

Both groups resided east and south of the Hanford region, separated from it by the Blue Mountains and the territories of at least one other group. Cayuse occupied the upper Grande Ronde Valley, parts of the upper Walla Walla River basin, and the upper John Day River basin, straddling the crest of the Blue Mountains. They had no fishery of their own, but utilized fisheries of their neighbors. The Nez Perce occupied areas east of the Blue Mountains in central Idaho and northeastern Oregon. They had sovereignty over fisheries on the Clearwater River and adjacent portions of the Snake River.

Neither of these groups is known to have utilized the Hanford area as a resource base, relying more on areas to the south and east. According to Suphan (1974), however, they visited the area to trade and participate in rendezvous, and may have engaged in some minor resource-gathering activities at the same time. Given the limited resource potential of the Hanford area, fishing for spring Chinooks at Prosser or Hom Rapids, or for fall chinooks at White Bluffs are the most likely resource gathering activities for these peoples.

\section{$\underline{\text { References }}$}

Anastasio, A. 1972. "The Southern Plateau: An Ecological Analysis of Intergroup Relations." Northwest AnthrQpological Research NQtes 6: 109-229.

Benton, E. M., 1. M. Peters, M. A. Edwards, and L. A. Hagen. 1973. "Wild Edible Plants of the Pacific Northwest." JQurnal Qfthe American Dietetic AssQciatiQn 62:143-147.

Boyd, R. T. 1985. The IntroductiQn QfInfectiQus Diseases AmQng Indians Qf the Pacific NQrthwest. 177-1874. Ph.D. Dissertation, University of Washington, Seattle, Washington.

Campbell, S. K. 1989. PQst CQ1umbian Culture History in the Northem CQ1umbia Plateau. $\underline{\text { AD }} \underline{1500-1900 .}$ Ph.D. Dissertation, University Micromms, Ann Arbor, Michigan.

Chalfant, S. A. 1974. EthnQ-HistQrical Report Qn Aboriginal Land Qccupancy and UtilizatiQn by the Palus Indians. The Confederate Tribes of the Colville Reservation, as the representative of the Palouse Band et al., Indian Claims Commission, Docket No. 222.

Hewes, G. 1973. "Indian Fisheries Productivity in Pre-Contact Times in the Pacific Salmon Area." NQfthwest AnthropolQgical Research NQtes 7:133-155. (Originally printed in 1947.)

Hunn, E. S. 1981. "On the Relative Contribution of Men and Women to Subsistence Among Hunter-Gatherers of the Columbia Plateau: A Comparison With Ethnographic Atlas Summaries." JQurnal QfEthnobiQIQgy 1:124134.

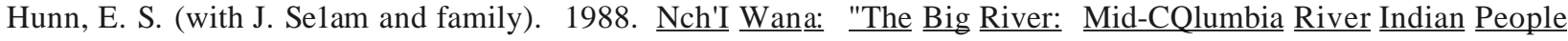
and Their Land. University of Washington Press, Seattle, Washington.

Keely, B. 1982. Nutrient CompQsitiQn Qf Selected Important Plant Foods Qf the Pre-CQntact Diet Qf the NQrthwest Native American Peoples. Masters Thesis, University of Washington, Seattle, Washington.

Marshall, A. G. 1977. Nez Perce SQcial Groups: An ECQIQgical IntewretatiQn. Ph.D. Dissertation, Washington State University, Pullman, Washington. 
Mooney, J. 1896. "The Ghost-Dance Religion and the Sioux Outbreak of 1890." Fourteenth Annual Report of the Bureau of Ethnology, Part 2, pp. 641-1136.

Norton, H. H., E. S. Hunn, C. S. Martinsen, and P. B. Keely. 1984. "Vegetable Food Products of the Foraging Economies of the Pacific Northwest" Ecology of Food and Nutrition 14:219-228.

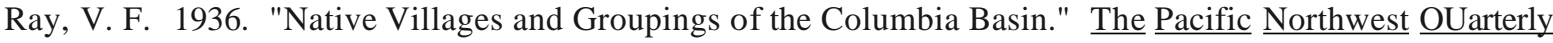
27:99-152.

Ray, V. F. 1939. Cultural Relations in the Plateau of North-Western America. Publications of the Federick Webb Hodge Anniversary Publication Fund, Volume II. The Southwest Museum, Los Angeles, California.

Relander, C. 1986. Drummers and Dreamers. Pacific Northwest National Parks and Forests Association, Seattle, Washington. (Originally printed in 1953.)

Rich, E. E., editor. 1947. Simpson's 1828 Loumey to the Columbia The Champlain society, Toronto, Ontario, Canada.

Ross, A. 1923. The Fur Traders of the Far West Adventures of the First Settlers on the Oregon or Columbia Rover. ed. M. M. Quaife. The Lakeside Press, Chicago.

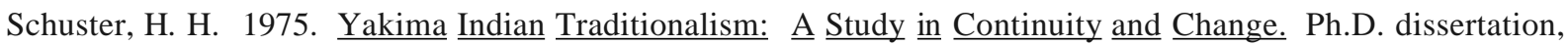
University of Washington, Seattle, Washington.

Service, E. 1966. Primitive Social Organization. University of Chicago Press, Chicago.

Smith, A. H. 1982. "Ethnohistory and Ethnography of the Priest Rapids Reservoir." In An Archaeological Survey of the Priest Rapids Reservoir: 1981, edited by R. F. Schalk, pp. 38-111. Project Report no. 12, Laboratory of Archaeology and History, Washington State University, Pullman, Washington.

Suphan, R. J. 1974. "Ethnological Report on the Umatilla, Walla Walla and Cayuse Indians Relative to SocioPolitical Organization and Land Use," In Oregon IndianS II, ed. D. A. Horr, pp. 85-180. Garland Publishing, New York. (Originally docket number 264, defense exhibit number 18, Indian Claims Commission.)

Trafzer, C. E., and R. D. Scheuerman. 1986. Renegade Tribe: The Palouse Indians and the Invasion of the Inland Pacific Northwest. Washington State University Press, Pullman, Washington.

Uebelacher, M. L. 1984. Time Ball: A Story of the Yakima People and Their Land. The Yakima Indian Nation, Toppenish, Washington.

Walker, D. E., Jr. 1967. Mutual Cross-Utilization of Economic Resources in the Plateau: An Example from Aboriginal Nez Perce Fishing Practices. Laboratory of Anthropology, Report of Investigations, Number 41, Washington State University, Pullman, Washington.

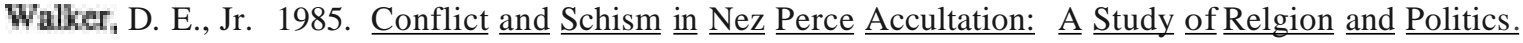
Washington State University Press, Pullman, Washington.

Watt, B. K., and A. L. Merrill. 1963. Composition of Foods. Handbook Number 8, United States Department of Agriculture, Washington, D.C.

Zucker, J., K. Hummel, and B. Hogfoss. 1983. Oregon IndianS: Culture. History. and Current Affairs: An Atlas and Introduction. Western Imprints, Oregon Historical Society, Portland, Oregon. 


\title{
D.4 EURO-AMERICAN HISTORY OF THE HANFORD AREA
}

\author{
Explorers. Fur Traders. Missionaries. Travelers. and Soldiers 0805-1855)
}

For the purposes of this narrative, the tract of land referred to as the Hanford vicinity, region, neighborhood, locale, district, area, or as the territory surrounding the Hanford Site, shall mean that expanse lying between Crab Creek to the north, the Columbia River at the Oregon-Washington border to the south, the Whitman Mission site to the east, and the town of Sunnyside on the west.

Beginning in 1805-1806, when Captains Meriwether Lewis and William Clark became the first non-Indians known to visit the vicinity of the Hanford Site, several parties of explorers, fur traders, missionaries, travelers, and soldiers passed through this area and recorded descriptions of it The neighborhood of the Hanford Site did not begin to fill with permanent non-Indian settlers until after 1858, when local Indian tribes were subjugated and when military orders closing large areas east of the Cascade Mountains to settlement were rescinded. Between the years of the Lewis and Clark expedition and the December 1855 fighting between Oregon volunteers and Indians in the Walla Walla Valley, traders and agents of the Pacific Fur Company, the North West Company, and the Hudson's Bay Company often traveled along the major arteries of the Columbia and Snake Rivers and along smaller streams such as the Walla Walla, Yakima, and Touchet Rivers and Cold, Crab, Satus, and Selah Creeks. During the 1830s, Benjamin Bonneville and Samuel Parker came west on privately fmanced exploring trips, and Dr. and Mrs. Marcus Whitman established the first religious mission in the region on the Walla Walla River in 1836. The first United States Naval Exploring Expedition, under Lieutenant Charles Wilkes, examined the Columbia River as far upstream as The Dalles, and sent an overland party which traversed the Hanford region in 1841. In 1843, Marcus Whitman accompanied a large wagon train of settlers, which sojourned in this area on the way to Oregon's WilIamette Valley, and ten years later the Longmire party crossed the locality and became the first emigrant group to scale the Cascade Range with wagons. Beginning in 1847, the first resident Catholic missionaries began their work in the Yakima Valley, although after the first year their activities were centered west of the Hanford Site, near Yakima City (now Union Gap). Captain John Mullan investigated the region in 1853 and 1854, as part of a group appointed to survey a northern railroad route, and returned to the area to survey and build the Mullan Road between 1858 and 1863.

\section{Exploners and Fur Traders}

The voyage of Captains Lewis and Clark and their "Corps of Discovery of the Northwest" was the first and most famous of the explorations to pass through the Hanford vicinity. Under the political leadership of President Thomas Jefferson, the mission sought to find for the United States the elusive Northwest Passage, a water route to the Pacific Ocean, the possibility of which had intrigued explorers of many nations for more than a century. Locating this route would aid the "external commerce" and trading ability of the young country in relation to Britain and Spain, both of which possessed extensive sailing fleets. Another important reason for the expedition was to obtain knowledge about indigenous Indian tribes, flora, fauna, mineral deposits, and geography of the transMississippi West. Concepts about land fertility, the size, height, and location of interior mountain ranges, and the sources and drainage patterns of internal rivers were vague and almost mythical in the minds of even the most learned Americans. An additional-and crucial-purpose for the trip was Jefferson's belief that settlers must bind the newly acquired Louisiana Purchase to the populated eastern section of the country. Until Americans penetrated and possessed the land west of the Mississippi River, that area truly would not belong to the nation. Furthermore, he feared that Spaniards from the south, French and British from the north, and additional Englishmen arriving from Pacific Coast ships would populate the areas west of the Mississippi if Americans did not do so first.

Lewis and Clark traversed areas near the Hanford Site twice on their historic voyage. They first entered the area in October 1805, journeying down Idaho's Clearwater River to its confluence with the Snake, and following the latter stream to its junction with the Columbia on the 16th of the month. They had taken along the Nez Perce chief Twisted Hair and his son as guides, and as they approached this region from the northeast, many Indians from the Cayuse and Walla Walla tribes stood along the shore watching them. Twisted Hair later told them that the sight of their female Indian interpreter, Sacajawea, assured the native Indians that they were not on a mission of war. The salmon season was then ending, and little fresh fish was available. Members of the exploring party quickly grew tired of eating dried fish, and blamed the food for the stomach troubles that many of them developed. Soon, most of the group was buying dogs from the local Indians and roasting the meat.

The party stopped to repair equipment for three days at the confluence of the Snake and Columbia Rivers near Pasco, at the site of present-day Sacajawea Park. In their diaries, neither Lewis nor Clark expressed special relief or joy at entering the Columbia, probably because, instead of finding a gentle country of wide plains sloping to the Pacific, they were confronted by the Cascade Range. Clark commented: "In every direction from the junction 
of those rivers [the Snake and Columbia] the country is one continued plain low [sic] and rises from the water gradually, except a range of high Country which runs from S.W. and N.E. and is on the opposite Side about 2 miles distant from the Columbia. .. the great Columbia River... is now very wide about $3 / 4$ of a mile in General the country in general Smooth plains for about 10 miles down then the baron hills make close to the River on each side" (Eide 1969, pp. 124, 126). Clark also described smoking with local Indians and presenting gifts to assure them of friendly intentions.

Lewis recounted a "very disagreeable" passage through a number of rapids as the party descended the Snake River to its junction with the Columbia, and portrayed the local area around the confluence as "a continued plain, which is low near the water, from which it rises gradually .... There is through this plain no tree and scarcely any shrub, except a few willow bushes; and even of smaller plants there is not much more than the prickly pear, which is in great abundance, and is even more thorny and troublesome than any we have yet seen." He noted that they measured the two rivers at their juncture and found the Columbia to be 960 yards wide and the Snake (which they called Lewis' River) to be 575 yards wide. He described the local Indians (whom he called the Sokulks and the Chimnapum) as being numerous. Their summer sheds, he noted, were constructed of mats and rushes, with flat roofs, "which seems to indicate that rains are not common in this open country" (Lewis 1961, pp. 419-21). Before leaving the Hanford vicinity, William Clark explored the desert country around and north of the mouth of the Yakima River. He found the local Indians engaged in splitting and drying salmon, and observed that "the multitudes of this fish are almost inconceivable. The water is so clear that they can readily be seen at the depth of fifteen or twenty feet ... neither in the low grounds nor in the highlands is any timber to be seen ... [Clark] shot several grouse and ducks... he also killed a prairie cock [probably sage grouse].... This bird we have seen no where but on this river" (pp. 424-25).

The Lewis and Clark expedition traveled through the vicinity of the Hanford Site once again in April 1806, on its return trip from the Pacific Coast. The party approached this area from the west by land, hiking along the north side of the Columbia River. As they proceeded towards the mouth of the Yakima River, they reported killing several rattlesnakes and lizards, as well as six yellow-legged ducks which were "of a different species from any we had yet seen .... The country extends in level plains to a very great distance, and... produces an abundant supply of low grass, which is an excellent food for horses. This grass must indeed be unusually nutritious; for... after wintering... many of these horses are perfectly fat, nor have we, indeed, seen a single one which was poor" (Coues 1965a, p. 968). The voyagers spent the night of April 25 playing the violin and dancing with a group of Indians which they called the Pishquitpahs (Yakimas), and then were joined along their route of march the next day by several families of "Wollawollahs." The explorers complained of dusty roads and monotonous food consisting of dogmeat, jerked elk, mullets (sucker), and roots. They cooked their food over fires built of sagebrush stalks, and doctored several of the Indians by splinting a broken arm and administering ointments for skin eruptions, "but our most valuable medicine was eye-water, which ... they required very much; the complaint of the eyes, occasioned by living on the water and increased by the [me sand of the plains, being universal" (pp. 973-74).

After the mission of Lewis and Clark, several fur traders and explorers visited the vicinity of the Hanford Site, beginning in 1811. John Jacob Astor's men of the Pacific Fur Company, arriving in the ship the Tonquin, established Fort Astoria at the mouth of the Columbia River on the Pacific Coast in March 1811. David Thompson, official geographer for the rival North West Company, started west through Canada in 1810, and passed through what is now the Hanford Reach of the Columbia River in July 1811. On the 9th of the month, at a spot along the Columbia River one-half mile above its junction with the Snake, he "erected a small Pole, with a half Sheet of Paper well tied about it, with these words on it--Know hereby that this country is claimed by Great Britain as part of its Territories, \& that the N W Company of Merchants from Canada $\bullet$. do hereby intend to erect a Factory in the Place for the Commerce of the Country around. D. Thompson" (Coues 1965b, p. 748). Thompson then proceeded down the Columbia to its mouth, where he found the Astorians already established. A few days later, both Thompson and Robert Stuart, an Astorian, started separate journeys up the Columbia River to explore and establish interior trading posts. Stuart proceeded directly up the river to establish the company's post at Fort Okanogan, at the mouth of the Okanogan River. He is credited by some historians with naming Priest Rapids on the Columbia, near a location where he apparently witnessed a Wanapum religious ceremony (Rice 1980, p. 28). Other historians, however, credit Alexander Ross, another Astorian, with naming Priest Rapids for the same reason (Harris 1972, p. 6; Relander 1986, p. 47). David Thompson, on his journey up the Columbia in 1811, veered north-eastward and overland from the present-day Hanford Reach, in order to explore the mountain ranges of the Spokane country which he could see to the northeast. When he later arrived at the junction of the Okanogan and Columbia rivers, he found that once again he had been beaten by the Pacific Fur Company. 
Other fur traders have left their wrinen impressions of the neighborhood of the Hanford Site. No furs were to be found here in the timberless tract, but the area was traversed often along the highways of the Snake and Columbia rivers. In 1810, at the same time that he had sent the Tonquin, Astor had sent an overland party to proceed to the Pacific Ocean. The overland party was led by Wilson Hunt, an American, and Donald McKenzie, a Canadian. Wintering during 1810-11 at Nodowa on the Missouri River, they were joined by trader Robert McClellan and guide John Day. After an exhausting and circuitous trip, they reached the Columbia River near the mouth of the Walla Walla on January 21, 1812. "It [the Columbia] was a beautiful stream, three-quarters of a mile wide, totally free from trees; bordered in some places with steep rocks, in others with pebbled shores." Proceeding overland along the north side of the river, the party enjoyed "temperate" weather, and found the "country in general, in the neighborhood of the river, was a continual plain, low near the water, but rising gradually; destitute of trees, and almost without shrubs or plants of any kind, excepting a few willow bushes" (Irving, reprint of Astoria, pp. 285-86).

Other picturesque and revealing descriptions of the Hanford vicinity in the next few years have been left by Astorians. David Stuart, traveling from Astoria to Ft. Okanogan with supplies in June 1812, reported killing a "vast number of rattlesnakes which infested the rocks about the rapids and portages ... [and] in quantities about the encampments. In one place, a nest of them lay coiled together ... and thirty-seven [were] killed and wounded." Stuart enjoyed the "hospitable ... Wallah-Wallah" people and purchased 20 fine horses from them (Irving, reprint of Astoria, pp. 326-27). Ross Cox spent five years on the Columbia from 1812 to 1817, making nine journeys up the river and sometimes traveling with Stuart. Originally an Astor man, Cox stayed on when the treaty ending the War of 1812 passed control of the American fur trading forts in the Northwest to Britain. Cox commented frequently on the multitudes of rattlesnakes in the Hanford vicinity, and on the best methods for killing and cooking them! (Cox, reprint of Adventures, pp. 22-24).

Alexander Ross, a Scottish school teacher in Canada who came to Astoria in the Tonquin, also chose to stay on when the North West Company took over in 1813. He continued in the Washington-British Columbia area even when the Hudson's Bay Company merged with the North West Company and subsequently took it over in 1821. He participated in the Hudson's Bay forays into the Snake River country in the early 1820s, and witnessed the beginning of the loss of British domination of the Northwest as American settlers began to enter the region. Ross termed the Columbia-Snake junction "the Great Forks," and reported that some of the Indian villages in the area had "upwards of a thousand inhabitants," (Ross 1956). He characterized the Priest Rapids as "a succession of bad steps", and recounted the Horse Heaven Hills area as being filled with "hordes of wild horses ... of all the animals seen on our journey they were the wildest, for none of them could be approached. Their scent is exceedingly keen, their hearing also, and in their curiosity they were never known to come at any time within gunshot One band of these contained more than 200. Some of them were browsing on the face of the hills, some were running like deer up and down" (pp. 94, 137).

Ross has left us one of the most complete descriptions of Fort Nez Perce (known today as Old Fort Walla Walla and located at present-day Wallula). Constructed by the North West Company in 1818, the palisades were made "of sawn timber ... twenty feet long ... two and a half feet broad by six inches thick ... on account of the many warlike tribes that infest the country. ... On the top was a range of palisades four feet high .... The whole was supported by a strong gallery five feet broad all round At each angle was placed a large reservoir sufficient to hold two hundred gallons of water as a security against fire, the element we most dreaded in the designs of the natives. Inside of this wall were built ranges of stone houses and dwelling houses for the hands. And in front of these buildings was another wall twelve feet high, of sawn timber also, with port holes and slip doors" (Ross 1956, pp. 144-45).

One of the most famous fur traders of the North West was Peter Skene Ogden, a Canadian who became a clerk with the North West Company in 1810, and who stayed throughout a distinguished career which lasted over four decades. He first traveled through the Hanford vicinity in the spring of 1818 on his way to Fort George, and he described the junction of the Columbia and Walla Walla Rivers as "a pleasant place to camp after it had been cleared of numerous rattlesnakes--and not everyone found the snakes unwelcome. The voyageurs skinned and spined several and roasted them over a brush fire. Rattlesnake, they said, tasted like the white meat of chicken, only more delicious" (Binns 1967, p. 51). While dining, Ogden's party was attacked by arrows and bullets coming from the Walla Walla River, a rare event at that time because the tribe in whose territory the assault occurred was particularly friendly.

In 1828, Ogden's supervisor and joint governor of the Hudson's Bay Company (with responsibility for the entire Oregon Country), George Simpson, made his second inspection tour of the Columbia River territory. Hoping 
to forestall American settlement of the region west of the Snake River, he decided to adopt a new company policy of completely trapping out the Snake country. He reasoned that by making the Snake district totally barren of furs, his company could create a sterile buffer zone that would be unattractive to American traders and trappers coming west in increasing numbers. At the same time. his company would realize a tremendous, short-term profit, and the area west of the Snake River would have a chance to replenish its stock of furred animals.

Simpson appointed Ogden to head the rapacious new Snake brigade, and the latter made numerous trips through the Columbia,Basin in the following years. One July 1835 voyage through this region proved exceptionally difficult due to "blistering heat and sand and dust storms ... [in the] treeless desert country" (Binns 1967, p. 271). Eventually, Simpson's Snake country strategy proved ineffective because American settlers continued to flow westward, with the Reverend Jason Lee beginning the non-Indian settlement of Oregon's Willamette Valley in 1834 (Dodds 1986, pp. 39-41, 51). In 1847, Ogden returned to the Hanford vicinity on one of the most famous missions of his life, to negotiate the ransom of the captives taken at the time of the Whitman killings (discussed later).

Captain Benjamin Bonneville, after being denied money from Congress for an expedition, interested private businessmen in financing an exploring-trading mission throughout the American West during the years 1831-35. He spent the winter of 1834-35 at Fort Nez Perce, which was then under the supervision of Pierre Pambrune of the Hudson's Bay Company. He did not get along with the Walla Walla Indians, but saw the Nez Perce as "among the gentlest, and least barbarous people of these remote wildernesses . . . they use a number of roots for food .... Among these is the camash, a sweet root, about the form and size of an onion. ... The cowish, also, or biscuit root, about the size of a walnut, which they reduce to a very palatable flour" (Irving 1961, pp. 259-60).

Samuel Parker, a wealthy member of a 6O-person trade and fact-fmding expedition, traveled through the Hanford vicinity via the Columbia River in the autumn of 1835 and the spring of 1836. Parker left some of the most extensive descriptions to date of this region. Traveling down the Walla Walla River toward its mouth, he reported: "We find but very little game of any kind" (parker 1967, p. 121). Parker was extremely impressed with Wallula Gap, reporting that "where the Columbia passes through, it is walled up on both sides with basalt, in many places three hundred feet perpendicular height. ... The channel through the volcanic mountain ... is one of the wonders of nature; how it was formed through those immensely hard basaltic rocks ... and for the distance of two or three miles, remains unexplained" (pp. 123-35). The Snake River was described by Parker as "a large river, yet on account of the summer's drouth, there is less water flowing down its channel than I anticipated. . . . The country differs very much from what I had expected; for while the soil is generally good, and furnishes a supply for grazing, yet there is such a want of summer rains, that some kinds of grain cannot flourish . . . There is a great want of wood for building, fencing and fuel" (pp. 118.19). Parker stayed at Fort Nez Perce for two days, and he liked and trusted the Walla Walla Indians as well as the Hudson's Bay Company men. He admired the Company for its "good treatment of the Indians .... [It has] become rich in the fur trade, and they intend to perpetuate the business; therefore they consult the prosperity of the Indians as intimately connected with their own. I have not heard as yet of a single instance of any Indians being wantonly killed by any of the men belonging to this company. Nor have I heard any boasting among them of the satisfaction taken in ... abusing Indians, as I have elsewhere heard" (p. 124).

Parker returned to Fort Nez Perce for two weeks in late April and early May 1836, on his way east He recounted the strong, cold, spring winds and the stiff current on his journey up the Columbia approaching the fort, and was amazed to see his horses and mule, which he had left with the Indians over the winter, "in fine condition ... . They had run out on the prairies without any shelter from the storms, and nothing more to eat than what the remains of the previous summer's growth afforded. ... [Yet] they fattened during the winter. This fact shows the superior mildness of the climate, and nutritive quality of the prairie grass" (p. 273). Parker was enchanted once again with Wallula Gap, and hiked the two miles from the fort to its borders one morning, observing "a great variety of scoria and lava, the latter varying much in color and density; some sufficiently porous and light to swim upon water. Two-thirds of the way down this deep channel, are two high eminences called the Pillars. ... They stand upon conical bases of eighty or a hundred feet high above the river. ... They are a curiosity; but there are so many singular formations in this volcanic country, that curiosities become common." (p. 273). The sandy area around the confluence of the Snake and Columbia Rivers was a "very pleasing ... prospect" to Parker, but he reported that "Towards and through the night the wind blew very strongly, and so shook the bastion which I occupied, that it seemed it would be prostrated to earth; but such wind in this particular section of country is common" (p. 274). 


\section{MissiQnaries}

A new era in the histQry Qf the HanfQrd vicinity began in 1836, when Marcus and Narcissa Whitman arrived and established the Waiilatpu missiQn Qn the nQrth bank Qf the Walla Walla River about six miles west Qf presentday Walla Walla. The Whitmans were sent west, alQng with Henry and Eliza Spaulding, by the American BQard Qf FQreign MissiQns, a cQmposite grQUP Qf Presbyterians, CQngregatiQnalists, and Dutch RefQrmed denQminatiQns. (The Spauldings established Lapwai missiQn, near present-day Lewiston, IdahQ.) The Whitman party was the frrst to drive cattle Qverland to this regiQn, but failed in its attempt tQ pull wagQns the length Qf the trail. At Waiilatpu (meaning "place Qf the rye grass" in the Cayuse language), the Whitmans established the first agrarian, nQn-military post in the HanfQrd neighborhood. The settlement included a school, living quarters, a blacksmith shop, 200 acres Qf cultivated land including an orchard, a sawmill, and three gristmills.

Marcus Whitman reported that "we have far mQre good land fQr cultivatiQn here than at any Qther place Qn the upper CQlumbia" (Lavender 1963, pp. 380-81). The Whitmans' Qnly child, Alice Clarissa, born in March 1837, was the frrst white child Qf American parents born west Qf the Rocky MQuntains and north Qf CalifQrnia In 1842, frictiQn between Whitman and Reverend Spaulding led the MissiQns Board to decide to clQse both Waiilatpu and Lapwai, and tQ maintain in this regiQn Qnly their remaining missiQn at Tshimakain, near Spokane. Whitman traveled back tQ BQston and persuaded the BQard to continue all three Qf the missiQns. He then journeyed west as far as Independence, Missouri, where, in May 1843, he convinced the large, discouraged wagQn train Qf the Oregon EmigratiQn Society Qf Bloomington, IQwa tQ undertake the lQng trek west. After nearly six mQnths, the party Qf almQst 1,000 people and 5,000 animals reached Waiilatpu, thus becQming the frrst to make the Qverland jQurney in wagQns (Lavender 1963, pp. 362-69,380-81).

The Waiilatpu settlement experience ended Qn NQvember 29,1847, when the Whitrnans and twelve Qther people were killed at the missiQu. FQrty-seven Qthers were taken captive by the Cayuse Indians, whQ were angry at the increasing flQW Qf white settlers through their lands and cQnvinced that Dr. Whitman was inflicting on them a murderous smallpox epidemic. Peter Skene Ogden, by this time one Qf the twQ members Qf the BQard Qf Management Qf the Hudson's Bay CQmpany, was nQtified of the situation on December 6. AlthQugh the CQmpany was nQt responsible in any legal way, Ogden packed a IQad of goods for ransom and headed up the CQlumbia River, reaching FQrt Nez Perce on December 19. He summQned Cayuse and Nez Perce chiefs to the fort. When they arrived, he spoke to them harshly, but blamed their YQung men fQr the killings. The chiefs agreed to release the prisoners in exchange fQr ransom, and the transfers took place on December 29 and on New Year's Day, 1848.

Catholic missionaries frrst came tQ the district surrounding the Hanford Site in the same year that the Whitmans were massacred at Waiilatpu. The Oblate fathers Paschal Ricard and E. C. Chirouse first visited the Yakima Indians in 1847, at the request Qf Chief Kamiakin. Ricard established a mission at "Simkoe" in the tract southwest of the Yakima River near present-day White Swan, and Chirouse founded the St. Rose mission at "Chemna" close to the mouth of the Yakima. Chirouse began baptizing people and marrying couples, but had to leave the fQllQwing year because of the Cayuse War. He returned to the Yakima Valley in the spring of 1849, along with Fathers Blanchet and J. Charles PandQsy, establishing Mission St. Joseph on the north side of the Yakima. Three years later, that mission was mQved south of the river on Ahtanum Creek, near present-day UniQn Gap, but the site had to be abandoned during the Indian wars of 1855. While the priests took refuge with Indian families, Oregon and Washington volunteer militiamen camped at the mission in the days after the battle of Union Gap. The soldiers found a buried powder keg and decided that the fathers were supplying ammunition to the Indians, so they burned the mission. The site remained abandQned from 1855 to 1S67, but in the latter year Father St Onge came and began to rebuild. The following year, the Reverend J. B. Boulet arrived as an assistant, but he left when President Ulysses Grant assigned the Yakima Reservation to the Methodist Church. St. Onge stayed on, and in 1870 Father Caruana, formerly in charge of the CQuer D'Alene district, was assigned to the Ahtanum mission. St Onge taught him the Yakima language, and the two Jesuits tended their territory, which stretched from the Klickitat Valley to the Okanogan region, for ten years. They setout an apple orchard in 1872, and three years later they began St. Joseph's Academy with the help of three Catholic sisters. Another CathQlic mission was founded at Umatilla in 1869 (Splawn 1980, pp. 330-65).

\section{$\underline{\text { Settlers }}$}

For 11 years following the Whitman Massacre, white settlement did not progress in the Hanford neighborhood. Military personnel and at least one wagon train did gQ through the area and leave written impressiQns, hQwever. In 1853, the Longmire party traveled from Indiana to Puget SQund, becQming the frrst wagQn train to cross the Cascades. They entered this regiQn Qverland at FQrt Nez Perce, where they purchased drift 
lumber and built a raft to cross the Columbia. The immigrants saw the Whitman mission and met the Walla Walla chiefPeopeomoxmox, or Yellow Serpent, whom they described as "a very important person ... a fine looking Indian, fully aware of his power as chief' (parker 1979, pp. 394-95). On September 8, they contracted with local Indians to swim their stock across the river by forming a line of 25 canoes below the crossing animals. In midstream, the Indians laid down their oars and demanded more money, which the party paid, and the animals were landed safely. The party then traveled to the Yakima River, where one man died of an unnamed malady. After crossing the Yakima, they proceeded north and west onto the present-day Hanford Site, accompanied by a band of Indians "who chatted and laughed as they rode along with us." At Wells Springs (now called Rattlesnake Springs) the party reached a canyon described as "an obstacle ... which it seemed impossible to cross." The Indians, concerned that early snows in the Cascades would prevent their reaching Fort Steilacoom, directed the party northeastward toward Fort Colville. They traveled in that direction for "one or two days ... and saw before us a perpendicular bluff, which looked a thousand feet high, extending far away into the mountains, and which we later learned was White Bluffs." After camping there for the night, they retraced their route south and east to Wells Springs and traversed the feared canyon "for about a mile or two of the roughest travel I ever experienced, and came out on a beautiful plain" at Cold Creek. They then followed the Selah Valley to the Yakima, crossed that river and advanced along Wenas Creek to its source, crossed and recrossed the Naches River 68 times in four days, and crossed the Cascades 25 miles north of Mt. Rainier (pp. 394-95).

\section{$\underline{\text { Soldiers }}$}

During the years when the Whitmans occupied Waiilatpu, no other non-Indian settlements were established in the Hanford Vicinity. However, a glimpse of the area during those years is available from a military expedition which passed through the region. Naval Lieutenant Charles Wilkes, as a part of his four-year mission to explore the Pacific Ocean from Antarctica to the Oregon Coast, sent an overland party to examine the interior of present-day Washington State. In the summer of 1841 this party, under Robert Johnson, became the first American group to cross the Cascade Mountains. They traveled on horseback over Naches Pass, down the Yakima Valley, and then up the Columbia's banks through the Hanford Reach area to the Hudson's Bay Company posts at Fort Okanogan and Fort Colville. They circled back south to Fort Nez Perce at Wallula, then north and west to the mouth of the Yakima, up the Yakima Valley, and across the Cascades to Puget Sound. They were awed, but not favorably. impressed, by the country they saw. Of the large expanses of sagebrush, bunchgrass and sandy soil north of Fort Nez Perce, William Brackenridge said: "Not two acres out of a hundred would produce wheat that would pay the farmer for his trouble" (Buerge 1987, pp. 77-79).

During the 10 years between 1853 and 1863, another military man developed a more favorable view of the region. Army Captain John Mullan ventured in and out of the Hanford region several times. Mullan was one of the assistants to Washington Territorial Governor Isaac Stevens in his survey of a northern railroad route in 1853, and in 1858 he joined Colonel George Wright's punitive expedition against the Indians of eastern Washington. Advancing from the southeast in midsummer of 1858, he wrote his first description of the Hanford vicinity: "We had a fine view of the valley of the Walla Walla ... one of the most beautiful pictures that could break upon the view ... in front lay the ocean of rolling prairie that forms the divide of waters of the Walla Walla River and those of the Snake. To our left lay the majestic Columbia ... while between them lay the beautiful valley ... with its mild and generous climate, rich soil .... With the Columbia navigable for steamers drawing from three to five feet of water to old Wallah Wallah [Fort Nez Perce], what may we not anticipate from this valley as years shall fully develop this region and bring it to our nation's notice?" (payette 1968, p. 15).

Between the years 1859 and 1863, Mullan realized his dream of building a wagon road between Fort Nez Perce and Fort Benton on the upper Missouri River near its junction with Teton Creek (northeast of present-day Great Falls, Montana). This road, constructed and funded by the War Department, provided the essential overland link for thousands of immigrants coming to Washington Territory via the Mississippi and Missouri River route. Once the road was finished, immigrants were able to ship their belongings up the two rivers, then unload their animals and wagons and trek over the northern Rocky and Bitterroot Mountains, enter Washington just south of present-day Spokane, follow the road southwest to the junction of the Walla Walla and Columbia Rivers, and continue their westward journey as far as desired by water. The road was begun at Wallula on June 25,1858, from whence it proceeded northeast and crossed the Snake River at the mouth of the Palouse River. Lyon's ferry began to operate at this crossing, and served for over a century until it was replaced by a bridge in 1968.

Mullan, anxious for white settlement and cultivation to come to Washington, did not consider such potential problems as overgrazing, deforestation, soil depletion, and pollution. He was an unmitigated booster of development, and experienced great satisfaction when, in the summer of 1863, a party of 364 emigrants from 51. 
Louis to Walla Walla became the first group to complete its journey over his road. Later in life, he wrote of the eastern Washington region: "If there was any conviction firmly lodged in my mind, it was the conviction that the day was coming when a line of Pullman Sleepers would cross down through Hell Gate Canyon ... making an overland trip from St. Paul to the Columbia in five days. ... It was for that purpose that our surveys were made and our wagon road construction was conceived, and under my direction were executed .... Night after night, I have laid out ... on the pathless prairies ... and in my imagination heard the whistle of the engines, the whirr of machinery, the paddle of the steamboat wheels .... In my enthusiasm, I saw the country thickly populated, thousands pouring over the borders to make homes in this far western land" (payette 1968, p. i; Oberst and Smith 1983, pp. 57-60).

\section{Summary}

During the years between 1805 and 1855, many parties of explorers, fur traders, missionaries, settlers, and soldiers passed through the Hanford region. Most non-Indian visitors simply traversed the area, using the major Snake, Columbia, and Yakima Rivers as highways, and did not come to stay. The lack of timber, and fur-bearing animals, the sparse, sandy soil which did not seem promising for agriculture, the presence of numerous, well established Indians, and the scorching summer climate were among the salient reasons that the district was not settled earlier by non-Indians. Fort Nez Perce and the Whitman Mission were the first quasi-permanent, non-Indian settlements in the Hanford district, and each of these was constructed for a specific purpose. Fort Nez Perce was a commercial fur trading post chosen to gain the Northwest Company access to the Snake River country, and it was abandoned in 1855 in the midst of war threats from the Cayuse Indians. The Whitman Mission, a religious station, was abandoned in 1847 after the Whitmans' murder. Almost all of the travelers who passed through the Hanford vicinity noted some of the same physical characteristics. Chief among these were wide and swift rivers, with challenging rapids; level plains close to the river banks; stunning geologic wonders such as Wallula Gap, the White Bluffs, and the Grand Coulee; light, ashy soil; absence of timber for fuel and cover; frequently high winds; and an abundance of bunchgrass, sagebrush, and reptiles.

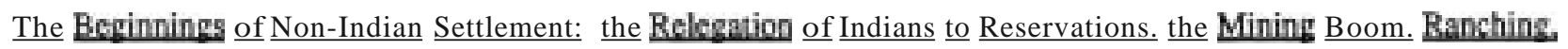

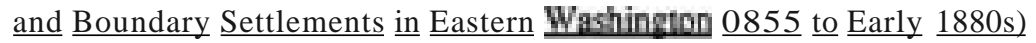

Inhabitants of the Hanford vicinity from 1855 through the early 1880 s witnessed wars with the Indians and the consignment of Indians to reservations. They experienced a mining and developmental boom, the rise and peak years of the cattle business in the area, and the settlement of boundaries to present-day demarcations. Following the disastrous winter of 1881-82, most cattlemen near the tract were ruined, and many disappointed miners and cattlemen turned to dryland farming. At the same time, the important future activity of river commerce in the Columbia Basin was presaged when Army engineer Thomas Symons led a surveying party through the upper Columbia River and the present-day Hanford Reach to examine the transportation and navigation potential of the waterway. Scenes from this era are shown in Figure D.6.

\section{$\underline{\text { Indian }} \underline{\text { Treaties. }} \underline{\text { Reservations. Conflicts and Subjugation }}$}

From 1855 to 1859 , Indian reservations were devised, Indian wars were waged and finished, and treaties were concluded in and around the present-day Hanford Site. In June 1855, Washington Territorial Governor Isaac Stevens met in council at Walla Walla with representatives of the Yakima, Cayuse, Walla Walla, Umatilla, and Nez Perce Indian tribes. As a result of this council, reservations were created and the tribes agreed to live on these parcels of land, apart from future non-Indian settlers. The treaty with the Yakima Nation delivered the western half (approximately) of the present-day Hanford Site to the United States, while the treaty with the Walla Walla Tribe ceded the eastern half (approximately), west of the Columbia River along the current Benton-Franklin County boundaries. The 1855 treaties reserved for the Indians the traditional uses of the land and waters for hunting, fishing, and gathering and, on unclaimed portions, pasturing their horses and cattle (1855 Treaty, pp. 3-6). However, these documents contained within themselves the first cause of subsequent severe conflicts between the tribes and the incoming non-Indians. The Yakima treaty in particular was problematic because it designated the Yakima chief Kamiakin as the head of a diverse "confederation" of tribes and bands including the "Palouse, Pisquouse, Wenatshapam, Klickitat, Klinquot, Kah-milt-pah, and Se-ap-cat," and consigned these widely varying people to one large "Yakima" reservation (p. 3). The Sahaptin-speaking Palouse and the Salish-speaking Columbia, Chelan, Entiat, and Wenatchee peoples were especially opposed to relocation because their languages, traditions, and homelands were so different from those of the Yakima. In the following 30 years, after wiblessing entrenched resistance to settlement on the Yakima Reservation by some of these tribes, Congress created the Columbia Reservation (in 1879) for the Chelan, Entiat, and Columbia people, and later (in 1883) granted rights on the Colville 


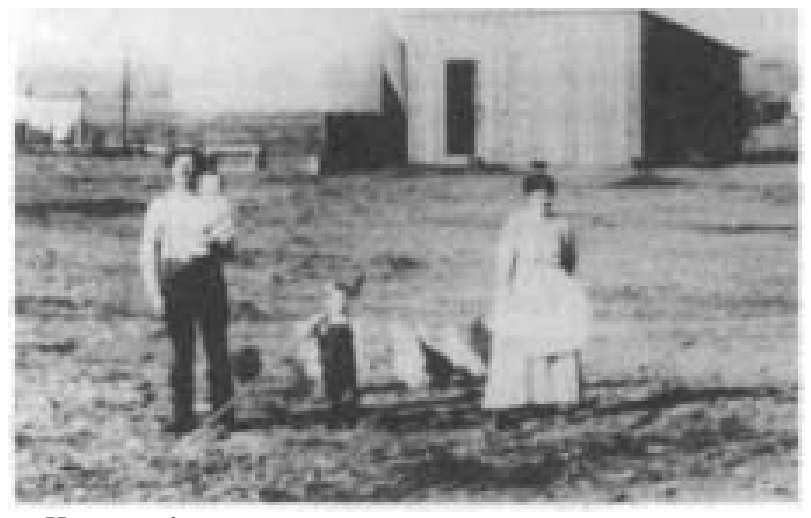

Homesteaders

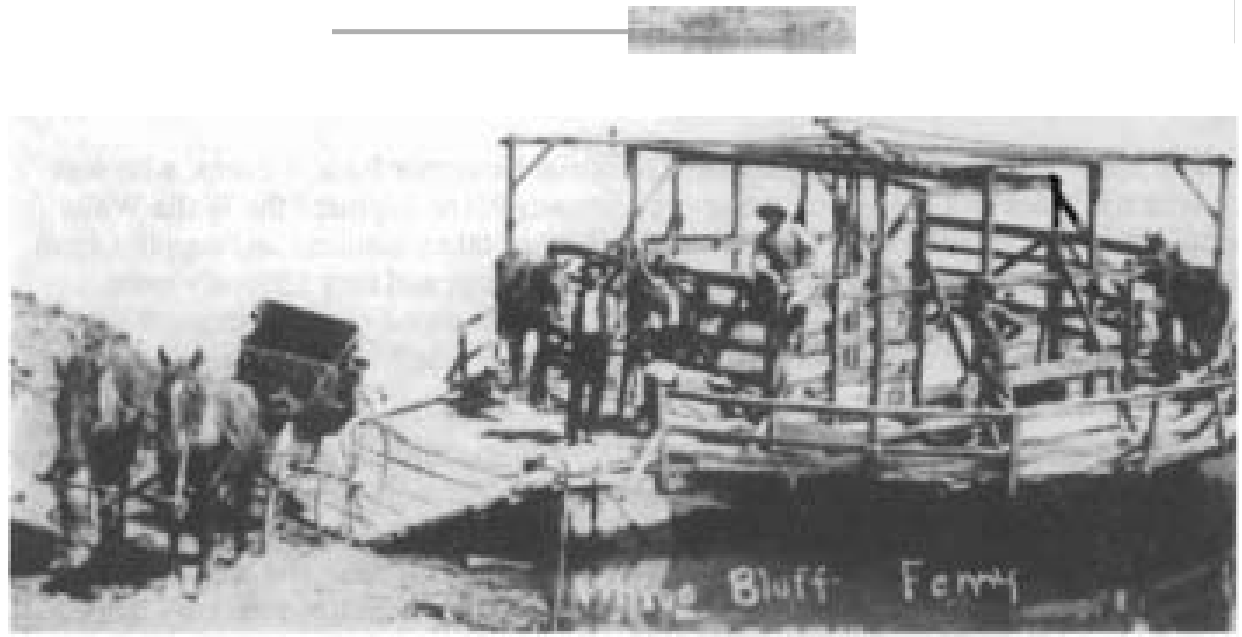

White Bluffs Ferry

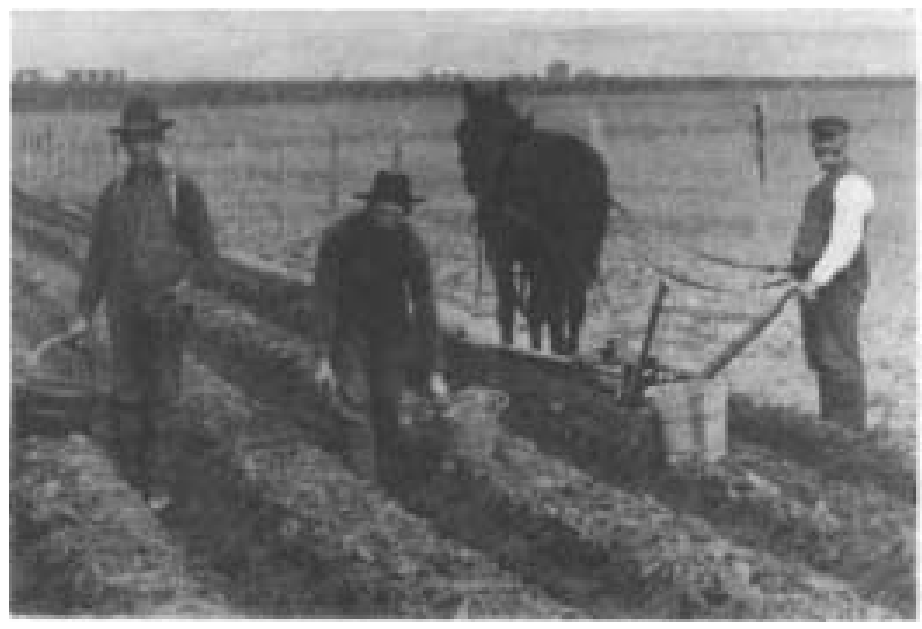

Plowing

FIGURE D.6. Images of Early Homesteading in the Hanford Region 
Reservation to these Indians and to the Wenatehees. The federal government also passed the Indian Homestead Act in 1884. allowing Indians from the Colville Reservation to settle 640-acre plots of land in the same manner as white homesteaders (Liebow. Younger. and Broules 1987. pp. 14-15).

An additional problem between the Native Americans and the non-Indian newcomers in the territory was that of boundary violations. The treaties did not become valid until they were ratified by Congress. and this did not take place until 1859. During the interim four years. uncertainties abounded concerning which tribes were committed to which boundaries. and the point at which reservation settlement would become mandatory. In 1855 . reports circulated that rich lodes of gold had been found near Fort Colville in present-day Stevens County. Although the rumors proved false. many California and Oregon prospectors crossed the Yakima Valley that summer and some were executed by Yakima warriors and other Indians for crimes against their people. When Indian Agent Andrew J. Bolon left The Dalles to investigate the killings. threatening reprisals. he too was killed. His case became a cause celebre. raised repeatedly to illustrate the Indians' 'perfidy,' but the press and others who denounced the Yakimas failed to mention that Bolon also was a gold miner whose actions seemed hypocritical and greedy to the Native Americans. In October 1855 Joel Palmer. superintendent of Indian affairs for Oregon. reported to his superiors that the miners routinely disregarded the rights of the Indians. and that crimes such as robberies and murders committed by the miners often were blamed on the tribesmen (Berland 1988. p. 7).

After the Bolon killing. warfare ensued. Non-Indians battled Yakima. Nez Perce. Walla Walla. and Cayuse tribes from October 1855 to September 1858. Major Granville O. Haller and two companies of Army regulars were defeated by the Yakimas at Toppenish Ridge on October 3. 1855. and the soldiers retreated back to Fort Dalles. One month later. Major G. J. Rains and a combined force of regulars and volunteers attacked the Yakima at Union Gap. The Indians withstood the troops until a "flanking movement over Ahtanum Ridge" caused them to retreat (Guie 1937. p. 8).

At the same time. Oregon volunteers escorting Washington Territorial Governor Isaac Stevens, who was returning from a treaty council with the Blackfoot Indians on the upper Missouri River, captured the Walla Walla chief Peopeomoxmox and four of his important followers. The Walla Wallas had taken blankets and supplies from Fort Nez Perce after it was abandoned earlier that year by the Hudson's Bay Company, and they allegedly were threatening non-Indian settlers in the valley. Under suspicious and very poorly understood circumstances, the five imprisoned Indians were killed in early December, as the white volunteers and the Walla Wallas engaged in a four-day set of running skirmishes (Berland 1988, pp. 8-9).

Oregon Governor George L. Curry sent more volunteers to the Walla Walla district, and these troops further exacerbated the tension there, committing depredations against the Indians and driving more Nez Perce and Cayuse into hostilities. In mid-March, near the mouth of the Tucannon River in the Palouse country. the Oregonians killed nine Palouses. and many minor engagements took place throughout the territory between there and the upper Yakima Valley. In July, pack trains bringing supplies to volunteers in the Nez Perce country were turned back by 2,500 angry Indians. Later that month, Colonel B. F. Shaw led Washington Territorial volunteers in an attack on a group of Walla Walla families gathering roots in the Grande Ronde valley eight miles south of present-day Elgin, Oregon. and killed about 40 people (Ruby and Brown 1972, pp. 228, 232-41).

General John Wool, commander of the Army of the Pacific, deplored the Grande Ronde "strike" and charged that "the whole object was to plunder the Indians of their horses and cattle, and provoke a prolongation of the war" (p. 240). Wool repeatedly admonished Caucasian homesteaders to be more patient and "to wait for the Indians to discover the advantages of living and trading with them." and on August 20, 1856, he closed to non-Indian settlement the district east of the Cascades and extending into western Montana (the eastern border of Washington Territory at that time) (Berland 1988, p. 7). Intermittent skirmishing continued for two more years, until Colonel George Wright led a punitive expedition against eastern Washington Indians in September 1858. The Spokane, Palouse. Cayuse, Walla Walla, Yakima, and other tribes were defeated, and forced to dwell quietly on the reservations. The military orders closing the territory to settlement were revoked on October 31,1858, and the United States Senate officially ratified Stevens' 1855 treaties with the Indians on March 9. 1859.

\section{Gold Mining}

The primary impetus for non-Indian settlement of eastern Washington came from the discovery of gold in British Columbia during the late 1850s, and in present-day Idaho and Montana during the early 1860s. Two years later. gold was discovered along the Fraser River in British Columbia north of Fort Colville. In the next few years. even richer deposits of the ore were found along the Thompson River and Williams Creek, known as the Cariboo district, in British Columbia. In 1860, gold was located on the Clearwater River near present-day Oro Fino, Idaho. 
Captain E. D. Pierce, the finder, returned to the small village of Walla Walla with the news, secured financial backing for a larger party, and rushed back to the strike. The following March, this group sent $\$ 800$ in gold dust to Walla Walla, from whence it was shipped down the Columbia River to Portland, creating a virtual stampede of miners up the river and through southeastern Washington. It has been estimated that 25,000 to 30,000 men were engaged in mining in the eastern sector of Washington Territory (now Idaho) in 1861 and 1862. Approximately $\$ 1,000,000$ in gold was shipped through Walla Walla in 1861, and nearly seven times that amount was shipped the following year (pollard 1937, Vol. II, p. 121). In August 1862, gold was discovered in Boise Basin, and the most valuable export leaving Portland became gold dust shipped to the mint at San Francisco.

The presence of rich lodes of gold in areas adjacent to, and directly north and east of, the borders of presentday Washington State caused prospectors during the 1860s to explore virtually the entire length of the Columbia River upstream from The Dalles. A little float gold was found in the northern Big Bend of the Columbia in 1864 and 1865, and this area was expected to be the richest new location of 1866, but the predictions proved false (Oliphant 1968, p. 67).

In the Pacific Northwest, mining claims generally were 150 feet by 250 feet, but they varied according to the lay of the land and certain territorial laws. Claims were filed in the nearest town, but miner's judges, sheriffs, and recorders were established in each major mining camp in order to secure quick and accessible resolution of conflicts. After a claim had been worked to the owner's satisfaction, he could sell it on a secondary basis to any "gleaner" wishing to prospect it further. In Washington Territory, thousands of Chinese gleaners bought up secondary claims in the late 1860s and early 1870s, and established camps and settlements of their own (p. 61). Many of the Chinese miners came from California with their life savings to buy claims, and some were imported from China to prospect for their more successful kinsmen (pollard 1937, Vol. II, p. 129). One observer noted that in 1864, "Hundreds of Chinamen were at this time mining along the bars of the Columbia for a distance of 150 miles" upstream from Umatilla. The largest group of about one hundred Chinese were working a few miles above Rock Island near Wenatchee. They had bought a large gravel bar the previous year from white miners, had built a big "ditch" (feeder trough and sluice) and were sluicing (Splawn 1980, pp. 200-10). The Chinese continued mining in eastern Washington until the Northern Pacific Railroad began building through the district in the late 1870s. At that time and during the early 1880s, many of them switched to railway work (Sung 1967, pp. 31-33).

During the mining period in eastern Washington, the present city of Walla Walla experienced its greatest growth and became the most important city in the region. Originally established in 1856 as a military post under Colonel Edward Steptoe, the town was called Steptoeville at first. In 1859, it was described as having "ten stores, two hotels, [and] a dozen gambling and drinking saloons." (Oliphant 1968, p. 59). By 1862, the year of its incorporation as a city, Steptoeville's central location in the unsettled expanse between the Cascade and Rocky Mountains had made it the primary center for supplies and shipment of gold from the mining districts to the north and east. By the spring of 1859, steamboats were operating on the Columbia from Portland to White Bluffs with portages at the Cascades, The Dalles, and Celilo Falls. The Dalles, Umatilla, Wallula, Walla Walla (by short trip up the Walla Walla River), and White Bluffs became central points of transfer from river shipment to pack trains carrying supplies to the miners (Splawn 1980, pp. 195-210). Walla Walla's population quadrupled between 1860 and 1870, far surpassing that of King County (including Seattle) on Puget Sound. During the 1870s, Walla Walla County (that area of Washington Territory south of the Snake River and east of the Columbia River) became third in the territory in industrial capital, and first in the number of manufacturing plants. Although most of these plants were small, they demonstrated an active and fluid business climate, suited to meeting the market demands of a large and varied district (Splawn 1980, pp. 61-82; Pollard 1937, Vol. I, pp. 306-07).

\section{Cattle Ranching}

Of all the needs of the mining country that were supplied by Walla Walla and other, smaller settlements at Umatilla, White Bluffs, and The Dalles, none was more urgent than that for beef cattle. The first cattle had been introduced into the Hanford region by Chief Factor John McLoughlin of the Hudson's Bay Company, who sent four calves to Fort Nez Perce in 1831. He sent four more the following year, and a small herd was begun. Marcus Whitman first drove cattle overland from the East in 1836, and by the time of his death 11 years later, Waiilatpu possessed 290 head of cattle, 92 sheep, and 46 horses (Oliphant 1968, p. 12). [Horses had come to the Hanford region previously as a result of local Indians trading for them with the Shoshone and Snake tribes of present-day southeastern Idaho and northern Utah (Splawn 1980, pp. 245-65). Sheep were brought into the Hanford area by the Hudson's Bay Company, beginning in the late 1830s.] The Walla Walla, Yakima, and other local Indians obtained their cattle through trade with the Hudson's Bay Company, the Whitmans, and subsequent immigrants traveling through the district By the mid-1850s, these tribes were well supplied with cattle, and one American soldier 
reported at that time that the cattle of the Yakima were especially healthy, having found "good bunch-grass on the hills" (Oliphant 1968, p. 37, citing U.S. War Deparunent, Reports of Explorations and Surveys, Washington, D.C., 1855). The punitive 1858 campaign of Colonel George Wright against the eastern Washington Indians resulted in the destruction or loss of a substantial portion of the Indians' stock.

The earliest, and also the richest and most successful, of the cattlemen in the Hanford vicinity was Benjamin Snipes. An immigrant to Oregon Territory from Iowa in 1852, Snipes spent a season in 1854 prospecting for gold on the Fraser River in British Columbia In that northern mining district, he learned of the shortage of meat and of the subsequent high prices paid for that commodity. At that time, beef came to the mines from Oregon's Willarnette Valley, by ship through Puget Sound to Victoria, Vancouver, and then overland to the east Snipes returned to The Dalles area, and in the late winter of 1855 he and a Yakima Indian guide examined the region north from the upper Yakima valley, through present-day Wenatchee, to the juncture of the Okanogan and Columbia Rivers, and then down the Columbia Basin, fording the river at White Bluffs, crossing the Hanford Site diagonally to the southwest, traversing the Rattlesnake Hills, and returning to the Yakima valley. They observed rich bunchgrass throughout the Yakima River Valley, which gave way to rockier soil, thinner, shorter grass, and more abundant sagebrush from the Okanogan River down to the Hanford Site. South and west of the Site, the grass again became abundant where the Horse Heaven Hills rose from the basin (Sheller 1957, pp. 35-38).

Snipes' first cattle drive through the Hanford neighborhood and north to British Columbia required nearly two years of effort, but it yielded him enough profit to establish himself fmnly in the cattle business in the Yakima Valley. In March 1855, the penniless 20-year old Snipes negotiated an agreement with cattle dealer John Jeffries of Amity, Oregon, to drive a large herd of cattle from The Dalles up to the Fraser River and the Cariboo mining district, splitting the profits evenly but receiving no pay for his efforts on the drive. He obtained the cattle at Fort Dalles, then drove them with the help of his Yakima guide, Jobe, as far as the Yakima Valley. He wintered with them there, fattening them and allowing them to reproduce. In the spring of 1856, he and Jobe drove the herd along the route which Snipes and many other major cattlemen would use in the ensuing years. They crossed the Columbia a few miles below Priest Rapids, enlisting experienced Wanapum men to aid them by paddling canoes on either side of the swimming herd. The Wanapums, who had used the White Bluffs crossing with their Cayuse ponies for many generations, were paid with one steer. Above this point, Snipes drove the herd along the north bank of the Columbia, between the river and the Saddle Mountains, to a point where the trail narrowed to a rocky ledge through the "gorge" of that small range. That route offered plentiful water; thus it was preferable to a trail over the mountains, which would deprive the herd of water for two to three days. Following the east bank of the Columbia northward, the herd forded the river again at its junction with the Okanogan, which was followed north for 10 days to the Canadian border at Lake Osoyoos. Continuing north, Snipes sold the herd to an eager buyer at the junction of the Fraser and Thompson Rivers, far south of the Cariboo mines, for $\$ 125.00$ per head (Sheller 1957, pp. 45-60).

The market for beef in the British Columbia gold-mining district continued to be the most lucrative one for ranchers in the Hanford region until the mid-1860s, and it was the factor most responsible for the earliest permanent non-Indian settlement of the area. In 1859, Snipes drove his second herd of cattle into the Yakima Valley near Satus Creek and built a cabin just southwest of present-day Sunnyside, thus becoming the first white settler in that neighborhood. In the fall of 1860, F. M. Thorp drove a small herd of cattle into the upper Yakima Valley from the Klickitat Valley across the Simcoe Mountains to the south. Seeing Snipes' herd in the Satus Creek area, Thorp drove his cattle on to Moxee, just southeast of present-day Yakima. He built a permanent residence there and brought his wife and nine children to live there the following February. Thorp established a rope cable ferry across the Yakima at present-day Union Gap. In June 1861, sixteen-year old Andrew Jackson Splawn and two others drove a cattle herd destined for the Cariboo mines from the Klickitat Valley to Thorp's ferry crossing. They swam the cattle across and ferried the horses, then proceeded north to the Kittitas Valley, crossed the Wenatchee Mountains, and struck the Columbia River at "We-nat-sha" (Splawn 1980, pp. 149-65). Splawn and the herd then forded the Columbia and continued north along the east bank, following the same route as had Snipes. Splawn was as fascinated as Snipes with the rich bunchgrass of the Yakima Valley and Horse Heaven Hills. He described the expanse as "an empire .... As I gazed upon its vastness ... I wondered why the pioneers had located in the Klickitat and other small valleys, leaving this Eden of the Northwest untouched" (p. 145). Camped along the Columbia just north of the mouth of the Wenatchee River, Splawn was saved and befriended by Chief Moses, who prevented some of his warriors from killing the white drovers and stealing their cattle. Moses, whom Splawn described as "tall and commanding, with a massive frame, a large head set on broad shoulders and keen eyes ever on the alert," shamed his men by declaring: "The old man [Major John Thorp] is brave; he must not die. And the boy with the white hair [Splawn] is no cowardly dog to be killed so. My people are bloodthirsty" (p. 164). 
Other ranchers and traders who settled in the Hanford vicinity in the early 1860s were also drawn to the unpopulated district by the lure of supplying the mining districts. J. B. Nelson located a ranch on the south side of the Yakima River near the mouth in the early 1860s, but moved to present-day Mabton in 1864. That same year, John Cartwright settled six miles upstream from the Yakima's mouth. Jordan Williams located a herd of cattle on the first White Bluffs townsite (on the east bank of the Columbia) in 1861, attracted to the location as a "noted range with its sandgrass and white sage. We could gather fat cattle in winter and spring when they were poor in every other place" (parker 1979, p. 15). John Golden, John Allen and his son Bart, Elisha McDaniel, William Parker, George Goodwin, and a Mr. Green, in charge of cattle owned by Dr. Dorsey Baker of Walla Walla, all brought herds to the rich grass of the Yakima Valley between 1860 and 1864 (Splawn 1980, pp. 216-20). In 1859, Amos Stark, working alone, rolled logs together to build the first cabin in the Klickitat Valley, which lay between the Columbia River and the Simcoe Mountains. He then left for California to settle business affairs, and when he returned the following year with a partner, Stanton Jones, he found the 15OO-foot high valley of rich grassland populated by a small group of settlers and their stock (May 1972, pp. 2-7).

\section{White Bluffs Landing and Ferry}

The White Bluffs landing, long a favorite river crossing and debarkation point of local Indians, became a central fording, supply, and transshipment place for traders seeking to supply the British Columbia mines. Even though landing at White Bluffs necessitated a steep pull to the mesa at the top of the bluffs, the soil at the site was more solid and rocky than the powdery mixture of sand and volcanic ash at other nearby locations. Horses could neither pull wagons nor carry packs through the fine amalgam underfoot at such places as Vernita, Wahluke, and the foot of Priest Rapids. At the latter crossings, loads would have to be unpacked, laboriously carried by men, and then refitted into wagons and packs:

In either 1859 or 1860 , General Joel Palmer became the first man to take a wagon supply train from The Dalles across the White Bluffs landing to the northern gold diggings (Harris 1972, pp. 15-30).(a) He sent his load of provisions and mining tools from Celilo Falls to Priest Rapids aboard the steamer Colonel Wright, the first such vessel to navigate the Columbia River to the latter destination. This ship was piloted by William P. Gray, the Hanford region's most famous river captain and later a founder of Pasco. At the same time, Palmer and his party drove his wagons from The Dalles to Walla Walla, then proceeded north across the Snake River, veered northwest to the Columbia, and followed the north (or east) bank to the foot of Priest Rapids. There, the supplies were transferred from ship to wagons, and the group headed north until it reached the Saddle Mountains. At that point, the animals were unhitched and driven through the narrow, rocky trail that had been used by Benjamin Snipes' cattle, while the wagons were poled up the river on wide boards lashed between two large canoes. This strenuous portage continued for approximately two miles to the mouth of Crab Creek, where the wagons were brought ashore and joined to the stock. The party then continued north along the east side of the Columbia, following the remainder of the Snipes route (Splawn 1980, pp. 384-85).

The White Bluffs crossing was prized highly during the next decade, and was an important link in the volatile supply business. By 1860, Thomas Howe was operating a ferry at the site, and in that year, fearing that the stampede to provision the mines might attract competition for the location, he petitioned the Territorial legislature for protection. His fee schedule ranged from ten cents for a sheep or a swine, through $\$ 1$ for an animal carrying packs (full packs on one animal usually weighed from 90 to 100 pounds), to $\$ 3$ for a wagon with two animals attached (Harris 1972, pp. 7-8). The following year, Andrew J. Splawn's brother Charles, along with Major John Thorp, travelled with a group of horses and pack saddles loaded with provisions from The Dalles to the gold diggings at Oro Fino in Nez Perce country. They traversed the Yakima Valley and crossed the Hanford Site diagonally from a point just northwest of Rattlesnake Mountain to the Columbia at the White Bluffs ferry. There, they turned east through the Palouse country to present-day Lewiston, Idaho, and then proceeded north along the Clearwater River to the mines (Splawn 1980, pp. 150-60).

By 1863, the ferry belonged to A. R. Booth, who also operated a small trading post and supplied pack horses. His business received a boost in 1865, when the ChiefFactor of the Hudson's Bay Company ordered all of that organization's shipments from Portland to Fort Colville and the northern district to be sent via White Bluffs (Splawn 1980, pp. 9-10). For two years in the mid-1860s, Andrew Splawn and some partners operated a pack train

(a) Ms. Harris gives the 1860 date, but Splawn recorded the same voyage as occurring a year earlier (see Splawn 1980, pp. 384-85). 
business between The Dalles and Rock Island. They established their route to ford the Yakima River near presentday Granger, crossed the Hanford Site diagonally from northwest of Rattlesnake Mountain to the White Bluffs ferry, and then followed Benjamin Snipes' cattle trail northward along the east bank of the Columbia (pp. 200-16). During those same years, a stagecoach operated between the British Columbian mines and White Bluffs, carrying gold dust to the Columbia River to be shipped to Portland and then to the San Francisco mint Shortly after the Civil War, this stagecoach was robbed near White Bluffs, giving rise to rumors of, and searches for, treasure in the pinnacles opposite the future townsite of Hanford on land that was later owned by Charles Foster, who ranched on it for at least seventy years.

In the late 1860s, the abandonment of the British Columbian mines and the rising popularity of the Mullan Road, with its advantage of avoiding the sandy stretches north and east of White Bluffs, caused a sharp decline in the ferry traffic at White Bluffs. The decade of the 1870 s witnessed shifts in the ownership of the White Bluffs ferry and landing site, but the importance of the location proved to be resilient and ongoing. In 1870, partners Edgar French and Jordan Williams took over the ferry and opened a small store. Both men had experience in cattle trading and ranching. Two years later, French sold his share to J. W. "Bill" Parker, the previous founder of Parker Bottom (present-day Parker) in the Yakima Valley. When Parker died of cancer in 1875, his family moved to Yakima City (now Union Gap), but Williams stayed and operated the ferry until 1900.

The significance of the White Bluffs crossing can be seen when it is noted that in 1876, 20 soldiers were stationed there to protect travelers and ranchers because Smowhala the Dreamer, chief and priest of the Wanapums, was thought to be inciting trouble. When Fort Chelan was built just west of the Columbia River and just north of the southern point of Lake Chelan, the soldiers were removed to that site.

The presence of the soldiers at Fort Chelan, however, was not enough to prevent the most famous murders of the early ranching era in the Hanford neighborhood. In July 1878, Wahluke Slope ranchers Lorenzo and Blanche Perkins crossed the Columbia on the White Bluffs ferry, traversed the Hanford Site on their way to visit Yakima City (now Union Gap), and were killed by renegade Indians at Rattlesnake Springs. For a brief time afterwards, the entire Hanford vicinity was beset by rumors and fears of Indians (Harris 1972, pp. 13-45).

The cattle business in the expanse around the Hanford Site remained the most important endeavor in the area during the 1860s. It was a volatile undertaking, largely because of the weather and shifting patterns of demand. The winter of 1861 was terribly harsh and snowy, and more than half of the stock in the vicinity perished because the new settlers had neither time nor resources to raise a crop of hay for winter feed. In the spring of 1862, the shortage of meat at the British Columbian mines was so severe that the provincial governor issued an urgent letter calling for the importation of sheep and cattle from the "Southern frontier" (Oliphant 1968, p. 62). The northern mining market for beef remained strong until late 1865, but by 1868 it was played out In 1866, Benjamin Snipes drove a large herd of cattle to Montana, hoping to supply meat to some of the gold-mining areas of that territory and Idaho. As with the drives to British Columbia, he began by moving northeast from just northwest of the Rattlesnake Hills, traversing the Hanford Site, and fording the Columbia at White Bluffs. Heading northeast from the river to Sprague Lake, the cattle went two days without water. Then they traveled to Spokane, Lake Pend Oreille, and continued due east through Thompson Falls, the Bitterroot Valley, Missoula, and Deer Lodge, Montana. Snipes found the market to be somewhat glutted there, and his beef brought only moderate prices (Sheller 1957, pp. 140-90). In 1868, the completion of the first transcontinental railroad further depressed meat prices in western Montana, since cattle could be brought northward cheaply from railheads in Utah (Oliphant 1968, p. 74). Desperate for new markets, Hanford area cattlemen began driving stock over Naches Pass in 1868, and over Snoqualmie Pass in 1869, seeking to supply the Puget Sound district. However, the latter market could absorb only a small portion of the beef available, and meat prices paid to ranchers dropped as low as two cents a pound. Depressed prices and a full market remained as the extant conditions for local stockmen until 1871 (Sheller 1957, pp. 200-10).

The years of the 1870 s represented the second decade of dominance by the ranching trade in the expanse surrounding the Hanford Site. Major shifts occurred in the stock business, again largely due to the weather and to changing demands and marketing practices. The winter of 1871-72 was frigid and snowy; up to three-fourths of the cattle in the region perished. Benjamin Snipes lost much of his fortune for the second time, but his herds had been so large that he was able to remain solvent and even to make money in the ensuing few years by restocking the decimated herds of Montana and Wyoming cattlemen (Sheller 1957, pp. 210-20). In 1872, as a result of the new shortage of stock, the price of a cow with calf was nearly $\$ 45$ in the Columbia Basin. Over the rest of the decade, however, a widespread oversupply existed in the district, and prices varied between $\$ 10$ and $\$ 25$ per head (Oliphant 1968, p. 110). In an effort to expand the market overseas, a small beef-canning industry was begun on the lower Columbia River in 1874 , and by 1876 several firms had entered the field. In the latter year approximately 40,000 
cases of beef were put up on the lower Columbia. However, the demand in England proved soft, primarily because a fresh-meat and live cattle trade was developing at the same time between Britain and the American East Coast (p. 113).

For the most part, large cattle drives out of the Hanford vicinity were fmished by the early 1870 s. After that time, most stock was driven to The Dalles, sold there, and taken away on ships by the buyers. The Oregon Steam Navigation Company, which possessed a monopoly on the Columbia between Portland and Wallula, built special boats for cattle and charged freight rates that were injurious to the inland stock business (Sheller 1957, pp. 215-25). Also, by the mid-1870s, the sheep business had expanded so rapidly in the Columbia Basin that conflicts arose between cattlemen and sheepherders. In the two Washington counties south of the Snake River, Walla Walla and Columbia, the wool business was especially lucrative, and these counties led the whole territory in numbers of sheep. By 1877, according to one observer, cattlemen were "hurling bitter anathemas at the sheepmen ... [for] Cattle will not feed where sheep have been; consequently the cattle men have good reason to be alarmed at the aggressive movements of the rapidly increasing flocks of sheep around them" (Oliphant 1968, p. 338, citing the Walla Walla Union, February 1877). However, the sheep business declined as sharply as it had arisen, and by 1890 there was less than one-third the number of sheep in the Walla Walla area as there had been 10 years previously. All types of stockmen in tracts surrounding the Hanford Site were affected by the same historical forces, leading to an overall slump in their enterprises (pp. 341-45).

The early 18808 saw a generalized decline of the ranching business in the Hanford vicinity. The reasons were many: the major new development of a railroad through the region, extensive farming and fencing, and overgrazing and subsequent range depletion. The winter of 1880-81 was another severe one, described by Andrew J. Splawn as follows: "A little before Christmas, snow came on and reached a depth of fifteen inches by New Year's. A Chinook wind settled it to twelve, then came a freeze, leaving a heavy crust on top. There was more snow about January 10, another chinook and another freeze,leaving the whole country covered with snow and ice to a depth of from eighteen to thirty inches. With the weather clear and extremely cold, there was a glare of crust and ice over everything. The cold weather lasted about two months, making the length of this memorable winter over ninety days" (Splawn 1980, p. 323). Many stockmen in the tracts surrounding the Hanford Site were ruined. Benjamin . Snipes survived, but never restocked to his previous levels, investing in banking and Seattle real estate instead. [He later lost all of his assets in the financial panic of 1893, but had started a small cattle herd near The Dalles at the time of his death in 1906 (Sheller 1957, pp. 190-96).] The initial, short-lived rise in beef prices during and following the killing winter encouraged many cattlemen to attempt risky winter drives over the ice to The Dalles. In some cases, the Columbia's ice proved too thin to bear the weight of the cattle, but strong and bulky enough to stop the ferries from running, and the supplies of hay at Rockland, on the north bank of the river opposite The Dalles, were depleted early. Herds and drovers alike suffered physical and fmancial punishment (Oliphant 1968, pp. 130-31). In an effort to make their cattle more attractive in the oversupplied market that returned after 1883, many stockmen of the Hanford vicinity (and throughout the inland Pacific Northwest) upgraded their animals by importing purebred cattle, mostly Durham shorthorns along with some Herefords, to breed with their stock (pp. 202..03). Alexander McNeil, a former range rider for Benjamin Snipes and others in the Yakima Valley, defied the poor markets by establishing a successful cattle ranch on the south side of the Yakima River near the Columbia (parker 1943, p. 23).

\section{The Northern Pacific Railroad}

The establishment of a transcontinental railroad through the district surrounding the Hanford Site delivered the most telling blow to the ranching business of the area. In 1881, the Northern Pacific Railroad was making its way from Spokane through the Snake River country southwest to the present-day ghost town of Ainsworth. The railroad brought large numbers of settlers interested in farming and fencing, and the corporation had the money to fmance irrigation projects to make the land productive and saleable. Andrew J. Splawn participated in loading the first trainload of stock to be sent eastward from the Columbia Basin. The Northern Pacific Railroad had built a corral and loading chute in a ravine surrounded by a wide plain at Twin Wells, north of present-day Connell. Splawn reported of that first loading: "The iron horse, hitched to the long string of cars, set me to thinking. ... I scented danger in ... this advance agent of a great migration of settlers, which signalled the beginning of the end of that vast cattle range which had been ours for so many years .... Twenty as good cowboys as ever sat in the saddle ... [did not realize] what the coming of the railroad meant to the cowboy. Reckless and happy, they joked about the loading, oblivious of the future" (Splawn 1980, p. 295).

From the late 1850 s through the early 1880 s, the dominance of the ranching business in the region surrounding the Hanford Site can be seen clearly in the preeminent legal and electoral issues of the era. While actual rustling was universally condemned, the practice of "slickearing," or roping and branding calves that turned up on the 
range without mothers, was a common occurrence and was the subject of many disputes. Brands and marks had to be registered with the auditor in the home county each year, and brand books were published annually. Beginning in 1886, the territorial legislature required that lists of all local brands be published for three successive days in newspapers doing county printing. Legislation regarding strays was precise, enforced strictly, and designed to remove all possible profit motive from the taking up of stray animals. The Washington Code of 1881 provided that any householder might take up a stray animal found near his property, but that he must post descriptive notices about the stock within 10 days in at least three public places. If an owner wished to claim astray, he had to pay all costs incurred to the fmder; but if no claimant appeared within 10 days, the fmder was required to have the animal appraised and reported to the county auditor. Still, ownership of the stray did not pass to the fmder; after 30 days the animal was sold at public auction, to benefit the county. Additionally, under the open-range conditions existing in the Hanford region, no animal could be considered as a stray between April 15 and December 15, and no animal bearing a brand ever could be considered a stray in its home county (Oliphant 1968, pp. 216-33).

The predominance of stockmen in the tracts near the Hanford Site, as well as the growing challenge of farmers, can be viewed most sharply in the controversial debate over the "no-fence" or herd law between 1880 and 1883. Cattlemen opposed the herd law, which would have made them responsible for any damages done to crops, railroad lines, and other property inflicted by their open-range (unfenced) cattle. Farmers entering the region favored the law, because in its absence they would have to fence their farms to prevent injury to their crops, irrigation ditches, water wheels, and other possessions. Barbed wire did not become common in this area until the mid-1880s; until then, the difficulties and expense of building fences in the treeless expanses of eastern Washington were significant for whichever side lost the debate. A special election was held on the matter in November 1880, and arguments were vehement and emotional on both sides of the question. Spokesmen for the farmers portrayed cattlemen as rich and often absentee tyrants, able but unwilling to fence, while the poorer farmers struggled against insurmountable odds to establish themselves and build up the district Partisans for the stockmen argued their case on the basis of free enterprise and the time-honored Western practice of open-ranging. A herd law, they claimed, would drive stock out of the counties adopting it, and thus would increase beef prices and taxes on other property. In the Hanford vicinity, the herd law was beaten badly in the 1880 election; Walla Walla County voted more than three to one against it, and Yakima County (which included all of present-day Benton County as well) balloted more than ten to one in opposition. However, just three years later, the Washington territorial legislature passed a herd law, reflecting the strength of the mounting agricultural majority. The 1883 law did contain the very large loophole that the law would apply only in those counties in which a majority of voters expressed (in the next election) their desire for such a statute! As a practical matter, the herd law never was enforced in eastern Washington; indeed, in 1887 the Washington Supreme Court declared that no law required cattle to be fenced or herded (Oliphant 1968, pp. 334-37). [That decision stood the test of time, for during World War n, Franklin County cattlemen were able to force the Navy to fence the 25-square-mile target range near Juniper Flats by reminding the commander of the Pasco Naval Air Station that the tract of land was under the open range law, and that people were required to fence livestock out of their property rather than vice versa (Oberst 1978, p. 104).]

During the peak years of ranching in the Columbia Basin, there were a few large-scale stockmen, but most herds in the region consisted of only a few hundred head each. Benjamin Snipes had the largest operation; possessing approximately 25,000 head of cattle and 20,000 head of horses in the late 1860s. John Switzler, with a ranch on Switzler's Island in the Columbia River (now immersed by the backwaters of the McNary Dam), had the largest single horse herd in the area. Snipes' foreman Ren Ferrell, who married the daughter of John Switzler and also received Snipes' original ranch and cabin as a result of the cattleman's bankruptcy proceedings after the Panic of 1893, became the richest stockman in the Hanford vicinity in the 1890s (Sheller 1957, pp. 198-205). Nick McCoy, John Qemens, and Elisha McDaniel were termed "cattle kings" by Yakima newspapers of the period, but none had operations even half the size of Snipes' (Oliphant 1968, p. 187).

Benjamin Rosencrance was one of the largest stockmen of the neighborhood. In 1878, he located a ranch near the mouth of the Yakima River on the south side at the famous "Y," the meeting place of three old paths that came south from the White Bluffs crossing, east-southeast from the upper Yakima Valley, and northwest from Wallula to a favored crossing point on the Yakima near present-day Prosser. Rosencrance raised horses, and developed such a big enterprise that he supplied most of the horses used to build the Northern Pacific Railroad from Spokane to Ainsworth (established at the mouth of the Snake River in 1879). He started with a pre-emption claim, a homestead claim, and a desert entry, and later acquired three sections of railroad land at 50 cents an acre. He could have bought 16 sections, but he did not consider the land to be worth the price! When the federal Homestead Law was enacted, he took up 1,700 acres across the Yakima River on the north side,locating his barns in present-day Richland (parker 1979, p. 16). 
In the early 1880s, Thomas Blythe raised a large number of horses and cattle on his acreage west of Lind on Crab Creek (near present-day Othello). In 1879 Max Harder began an orchard and cattle ranch at Three Springs on the Snake River near present-day Kahlotus. Harder's brothers, Hans and Jacob, arrived in 1883 and 1884 and started sheep herding (phillippay 1972, pp. 5-6; Phillippay 1973, p. 7). The Harders, along with their descendents, expanded the ranch northward, until today the family's holdings near Sprague constitute one of the biggest ranches in eastern Washington.

\section{Boundaries}

During the period when mining and ranching were the foremost businesses in the expanses surrounding the Hanford Site, many of the formal county, territorial, and state boundaries were established, often as a direct result of the population shifts caused by those businesses. However, these jurisdictional divisions will be understood better if the earlier circumstances which formed Oregon and Washington Territories are examined first

In 1848, Congress created Oregon Territory out of all of the land to which Britain had ceded claims in the treaty of 1846. The new territory encompassed land lying west of the summit of the Rocky Mountains and between the 42nd-degree parallel on the south and the 54th-degree, 40th-foot parallel on the north. In 1852, several Oregonians, primarily from the region south of the Columbia River and east of the Cascades, met in convention and petitioned Congress for creation of a new territory north of the Columbia. Most of the delegates reserved the most populous and settled portions of Oregon for themselves, and gave little thought to the lopsided region which was cast as Washington Territory in 1853. The Puget Sounders did not wish to be deprived of the rich Walla Walla Valley, primarily because it was a pivotal point on the Oregon Trail. They persuaded Congress to reserve for Washington Territory the southeastern corner of the present-day state boundaries, between the Snake River and the 46th-degree parallel (Dodds 1986, pp. 94-95). Due to the Indian wars which occurred in the middle and late 18508 in the Hanford vicinity, most of that portion of the new Washington Territory east of the Cascade Mountains remained empty during those years.

The presence of gold miners who rushed into eastern Washington Territory in the early 1860s, and also the subsequent rapid commercial development of Walla Walla, soon created new boundary questions in the vicinity. By 1862, many Walla Wallans believed that their city should become the territorial capital instead of Olympia, because Walla Walla was more centrally located in the huge expanse, and because they resented political control by the"clam-diggers" ofPuget Sound. Enough votes existed in Walla Walla and the gold fields to move the capital. Olympians wanted to be rid of the political threat of the growing inland region and rid of the administration problems related to the remote gold fields; yet, they wanted to retain the valuable Walla Walla Valley. With the aid of Washington Territory's delegate to Congress, William H. Wallace, the Puget Sounders solved their problems by persuading Congress to form the Idaho Territory in 1863. The Montana Territory was constructed in 1864, containing portions of Idaho (formerly Washington Territory). In that year and in 1866, the idea of devising a separate territory, to be called either Columbia or Jefferson, and composed of the inland expanse lying between the Cascade and Rocky Mountains and north of the Snake River, was debated seriously. This sparsely settled tract, however, did not have the political power to effect a new division. On three separate occasions, in 1868, 1873, and 1875 , the power of the stockmen of the Hanford region was sufficient to cause the Washington territorial legislature to ask Congress to transfer the northern counties of Idaho to Washington. Each time, the transfers were blocked by internecine struggles in Idaho, Montana, Utah, and Nevada (Deutsch 1960).

In the mid-1860s, at the same time when the larger territorial boundary questions were being debated, the present-day Hanford Site itself came under its first official government In 1863, the Washington territorial legislature proposed the creation of Ferguson County, named for House Speaker James L. Ferguson of Chehalis. The large tract would have stretched from the Simcoe Mountains on the south and the Cascades on the west, to the Wenatchee River on the north and Walla Walla and Stevens counties on the east Thus, it would have encompassed the entire Hanford Site. However, the approximately 100 white ranchers living in the proposed area refused to approve the per capita tax, and the entity was not constructed. Two years later, with more settlers in the vicinity. the new county of Yakima was formed in almost the same location. The only change involved the eastern border, which became the Columbia River from Wallula north to the Wenatchee River. The county seat was located at Yakima City (now Union Gap).

\section{The Symons $\underline{\text { Survey }}$}

A last look at the district surrounding the Hanford Site at the time when stock raising was the dominant enterprise can be found in the report of an Army engineer who surveyed the upper Columbia River late in the ranching period. In the autumn of 1881, Thomas W. Symons was in the region commanding a team from the Army 
Corps of Engineers. He was commissioned to examine "the navigable waters of the Upper Columbia River and its tributaries, and the resources of the country through which such navigable waters pass, and the character and cost of improvements required to render said Upper Columbia available [for] transportation" (Symons 1967, pp. 1-2).

Symons described Saddle Mountain as "a range of grass-covered hills," and the area northeast of White Bluffs as "a desert plain ... composed of sandy, gravelly, worthless soil. Some grass exists and some large areas of sagebrush, but what soil there is seems to be more alkaline and powdery than in other sections of the Columbia Basin .... [It is] of poor quality and not well fitted for any purpose of agriculture. The hills back from the river appear more fertile." The Columbia River, at a characteristically low autumn flow rate, was portrayed as "very sluggish, wide, and deep, and on the beautiful day during which we passed over it, it seemed to be more like a lake than a river" (Symons 1967, pp. 46-67). Symons depicted the Priest Rapids at length, recounting that they consisted of seven rapids in total, the second one (coming from the upstream direction) being "about as bad a place as there is on the whole river ... jagged masses threaten ... destruction to anything that touches them," and the lower three rapids "boiling and foaming ... . with great swiftness of current ... [and] ugly-looking projecting points ... of black basaltic rock .. " We tore along with the united speed of the raging torrent and our yelling Indian oarsmen" (p. 48). The stretch of river from the Priest Rapids to the mouth of the Yakima River (almost the entire Hanford Reach), was reported to be "almost perfect for steamboating," but the country along the banks was recounted to be " ... a desert. Back from the river, especially to the east, the soil is good, though light, and the only drawback to its successful cultivation is the lack of rains in the summer and the facility with which it becomes powdery and dry .... Numbers of cattle and some horses were seen which graze on the plateaus along the river" ( $\mathrm{p}$. 49).

\section{Summary}

The years from 1855 to the early 1880s witnessed serious, sustained armed conflicts between non-Indian newcomers and Native Americans in the territory surrounding the Hanford Site. The Indians were assigned to reservations in a series of treaties signed in 1855 . When they were reluctant to accept the designated boundaries, hostilities ensued until the Indians were defeated by U.S. forces in September 1858. Caucasians and other non-Indian newcomers first were drawn to tracts around the Hanford Site in great numbers in the mid-1850s by rumors and actual discoveries of gold to the north and east of the Columbia Basin. A little gold was found along the Columbia River in and close to the Hanford region, but no rich deposits were uncovered. The Chinese first came to this area in the 1860s to glean gold from second-hand claims, and they stayed on to take railroad construction jobs when the Northern Pacific built through the nearby expanses beginning in 1879. A thriving ranch commerce developed in the Columbia Basin and the Yakima, Walla Walla, and Klickitat Valleys in the late 1850s and the 1860s, in order to supply the miners to the north and east. Rich bunchgrass and unfenced expanses allowed the stock business to grow, but over the next 20 to 25 years, ranchers suffered from killing winters as well as changes in demand, transportation, and marketing situations. By the early 1880s, ranching was in a state of decline as a result of the Northern Pacific Railroad and the concomitant rush of settlers, farms, and fences, and because overgrazing had depleted the range. Throughout the mining and ranching era, the White Bluffs landing and ferry remained an important, well-used pathway in the vicinity. This crossing point quickly became as familiar to, and favored by, non-Indians as it traditionally had been to Native Americans. The present-day state boundaries were delineated from the $1850 \mathrm{~s}$ to the 1880 s, and county demarcations were established in the Hanford locale. In the early 1880s, a party of Army engineers commanded by Thomas Symons surveyed the upper Columbia River to determine its navigation and transportation potential. This team made many of the same observations about the physical characteristics of the Hanford neighborhood as had earlier explorers. They noted the low, sandy plains, wide river with many treacherous rapids, geologic wonders, and the hot, dry climate, and they greatly underestimated the agricultural potential of the area.

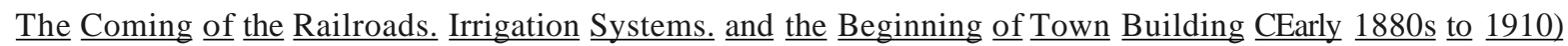

During the years from the early 1880s until approximately 1910, the region surrounding the Hanford Site experienced vast transformations. The transcontinental Northern Pacific Railroad, the primary factor in the development of the entire Northwest during this era, established the station towns of Pasco and Kennewick in 1884. Between 1904 and 1908, the Spokane, Portland, and Seattle Railroad was built west from Spokane through central and southern Washington. Between 1907 and 1909 the Chicago, Milwaukee, and St Paul Railroad constructed a line that crossed north of the present-day Hanford Reservation through Adams County, Beverly, and Ellensburg. These carriers created many new towns along their routes, and made possible the rapid growth of others. Additionally, spur lines aided the economies of even smaller settlements such as White Bluffs, Hanford, and Vernita. The railroads, in order to pay for their construction costs, advertised the expanses in the Hanford vicinity to 
prospective buyers throughout the nation. The carriers brought in immigrants and made money by transporting them to the region, selling them sections of land, and subsequently by shipping their grain, fruit, and other produce to markets outside of the area.

The most pressing need of settlers coming to farm the area was for irrigation systems to cultivate their crops. At first, they irrigated individually or banded together in local cooperatives, but many of these small ventures failed because they were undercapitalized. Later in the period, the railroads and the federal government helped to fund larger irrigation projects that made the district a virtual cornucopia of agricultural products. It was during this era that the principal towns and cities evolved, usually as commercial centers to serve the needs of neighborhood farmers. The great influx of population, as well as the introduction of barbed wire and the practice of enclosing cultivated property, heralded the [mal decline of the large stock herds that previously had dominated the region.

\section{The First Railroad: The Northern Pacific}

From the early 1880s until 1910, the most significant occurrence in the area was the coming of the Northern Pacific Railroad. This carrier alone brought enough population and development in its path across the Northwest to allow the States of Washington, Montana, North Dakota, and South Dakota to be admitted to the union in one package in 1889. The Northern Pacific was being constructed in a rush, in order to forestall efforts by powerful Congressional supporters of the rival Union Pacific Railroad to revoke the northern carrier's charter. The route through Yakima and across the Cascades through Stampede Tunnel was not completed, however, until 1888 (Wood 1968, pp. 20-30).

The Northern Pacific Railroad passed through the Hanford region in a somewhat convoluted way, necessitating construction of bridges across both the Snake and Columbia Rivers. In order to understand the reasons for this route, it is necessary to examine some of the transportation background of this area. The first railroad in the district surrounding the Hanford Site was built during 1872-75 from Walla Walla to the Oregon Steam Navigation Company's steam-boat landing at Wallula, at the junction of the Columbia and Walla Walla Rivers. Built by a Walla Walla physician turned businessman, Dorsey Syng Baker, the carrier was known as the "Rawhide Road" because the financially strained Baker allegedly covered his cheap wooden rails with strap iron, or, according to some stories, with rawhide which dried as hard as iron. Eventually, the citizens of Walla Walla raised the money to replace the makeshift rails with steel ones from England, and the small railway began to serve its purpose of carrying Walla Walla's surplus wheat to the Columbia. In 1878, the Oregon Steam Navigation Company, seeking to maintain its monopoly in the area, bought Baker's railroad and formed the Oregon Railway and Navigation Company (O.R.\&N.). It completed tracks between the various rail portages already existing on the south side of the Columbia between Wallula and Portland, and allowed the Northern Pacific to use its tracks in order to meet the latter's construction deadline of 1883. The Northern Pacific began work in 1879 to connect its tracks from Spokane with a short spur line up from Wallula to the construction town of Ainsworth on the south side of the Snake River near its mouth. The bridge across the Snake from Ainsworth to present-day Pasco was built between 1881 and 1884 . At the same time, the company decided to build its own tracks to Puget Sound, running through Yakima and crossing the Cascades through the Stampede Tunnel (Lavender 1958, pp. 364-83). To gain access to the Yakima Valley, the railroad constructed a span across the Columbia to the new settlement of Kennewick between 1884 and 1888 (Oberst 1978, pp. 4-18).

The railroad construction town of Ainsworth was rough and busy, and it followed the short-lived course of many other Western boom towns. The Northern Pacific laid out the townsite in November 1879, and the company's chief engineer, H. M. McCartney, predicted that the hamlet would be the capital of Washington Territory within two years! The isolated site was headquarters for the thousands of men building tracks to the northeast through the railroad's Pend Oreille Division to join tracks being laid west across Montana. The $\$ 18,000$ payroll drew gamblers, thieves, and prostitutes to the town, which was described by various visitors as "one of the most uncomfortable, abominable places in America," "a hard place," and the "toughest town on record." One observer proclaimed that "Before any reputable town can arise where Ainsworth is, it will be necessary for the present Ainsworth to be totally wiped out" (Meyer 1977, pp. 13-14).

Over 2,000 railroad ties were required each day, and timber was scarce, initially coming from the Blue Mountains south and east of Walla Walla, later from logging camps in the Cascades near the headwaters of the Yakima River, and even from the upper Clearwater River in Idaho Territory. The logs were floated down the rivers to the company sawmill at Ainsworth, and to other sawmills operating along the Columbia between The Dalles and the mouth of the Snake. As the rails proceeded northward from the Snake River, water became scarce in the sandy desert between Ainsworth and the next town at Sprague Lake, 100 miles away. Initially, water was hauled to the 
men and construction stock in tanks drawn from the Snake by teams of horses. Beginning about seven miles north of the river, the railroad then dug a series of wells and erected water tanks at such present-day locations as Eltopia, Mesa, and Connell (Meyer 1977, pp. 8-11).

Thousands of Chinese laborers were employed in the toughest aspects of railroad building work in the Hanford region, and conflicts developed between these men and Caucasian workers. The Chinese, often imported specifically for railroad jobs, usually toiled directly for a Chinese employment broker, who in turn contracted with the railroad. Chinese railroad workers usually were assigned to grading the roadbeds, while the whites laid the tracks. Records show that the Chinese often worked for far less pay than white employees, and under conditions of weather and safety that were considered to be too hazardous by whites (Sung 1967, pp. 32-33). Much resentment was engendered among the whites, who often harassed the Chinese.

During the building of the Northern Pacific's Snake River bridge between Ainsworth and present-day Pasco, railroad cars carrying supplies from Portland and The Dalles had to be ferried across the river. For this task, the company built the steam-powered ferry Frederick Billings in 1880, and hired the young river pilot William P. Gray. Gray's father had come west with the Marcus Whitman party, then prospected for gold in British Columbia in the 1850s. He built a boat to transport supplies to the mines, and became an expert pilot. Later, he and his son made steam and sail-powered trips throughout the Hanford region, freighting supplies along the Columbia, Snake, and Clearwater Rivers, navigating successfully among the worst rapids and weather conditions. Ferry landings with tracks on an incline were laid down to the river's edges, and Gray transferred as many as 213 railroad cars a day in the ferry. When the bridge was completed in 1884, he took the ferry to Celilo Falls to be overhauled, and then piloted it between Pasco and Kennewick from 1884 to 1988, while the railroad was building the Columbia River bridge (Oberst 1978, pp. 20-30).

\section{The Creation of Towns; Pasco. Kennewick. Richland. and White Bluffs}

Pasco. The town of Pasco, named during a dust storm by Northern Pacific engineer (Y. C. Bogue) for a windy. dusty Andes Mountain point called Cerro de Pasco. was created and supported during its earliest years by the railroad. As soon as the Snake River bridge was completed in 1884, the company surveyed and filed a plat for Pasco, and moved its construction and district administrative headquarters there from Ainsworth. During the previous year, the population influx created by the railroad building resulted in Franklin County's being carved from the southwestern end of Whitman County, and Ainsworth's being designated as the county seat However, the county seat was moved to Pasco in 1886 (Oberst 1978. p. 144). In order to attract settlers (customers) to the area, the railway instigated a widespread promotional campaign, which emphasized the mild climate, beautiful and accessible rivers, and cheap and plentiful land in the vicinity of Pasco. The Northern Pacific's original charter had granted it a 2OO-foot wide right-of-way. plus the alternate (odd-numbered) sections of land for 20 miles on each side of the right-of-way. An abundance of other land still was available in and around Pasco under the Donation Land Law of 1851 and the Homestead Act of 1862. The terms of these two laws were similar, granting 160 acres of free land to settlers willing to live on and improve (cultivate) the property. The Donation Law allowed an additional 160 acres to the spouse of a settler, and the Homestead Act, after 1873. allotted a concomitant 160 acres if the immigrant planted trees on at least one fourth of his real estate (Henretta et al. 1987, p. 594).

Captain William P. Gray became perhaps the most active speculator and promoter of the new town of Pasco. When the railroad moved its headquarters to Pasco in 1884, he bought nineteen acres of land near the Columbia River for $\$ 100$ and for another $\$ 100$ he acquired the railway's Ainsworth sawmill. He used the lumber from the sawmill to build the first hotel in Kennewick, and in 1885 he bought 100 additional acres in Pasco, surveyed and platted it, and marketed it as Gray's Addition. He became the local land agent for the Northern Pacific, and sold many thousands of dollars' worth of real estate in the Pasco region. although the railway also encouraged private agents to sell its land for a commission which ranged from five to seven percent.

When Washington became a state in 1889. Gray was active in the effort to boost Pasco as the state capital. Even though the new little town lost badly in a popular vote on the subject, it received valuable publicity. Two years later, Gray and a former Denver promoter, Louis C. Frey, incorporated the Pasco Land Company. They advertised heavily in Seattle, Portland, and eastward to Chicago. Cincinnati. and Baltimore, and town lots in Pasco climbed to prices fluctuating between \$100 and \$200 each. The speculative spiral crashed downward in the Panic of 1893, however, and the Pasco Land Company went bankrupt (Oberst 1978. pp. 20-37). A period of slow growth and then decline followed for the entire Hanford vicinity after the 1893 fmancial contraction.

Kennewick. The newly created railroad town of Kennewick followed a growth pattern similar to that of Pasco. The site for Kennewick (derived from the Indian term Kin-I-Wak, meaning "a grassy place") was determined 
in 1883 by Northern Pacific engineer H. S. Huson, who was searching the area for a suitable location to build a bridge across the Columbia River on the railway's route from Pasco up to the Cascades tunnel. There were no permanent white settlers in Kennewick at that time, but the locale, especially present-day Clover Island, was favored by Indians because their horses thrived on the rich bunchgrass and wild timothy which grew with the sagebrush. When the bridge site was chosen, the railroad moved about 400 construction workers to the position and placed about 750 more across the river. Kennewick became the eastern headquarters for the Northern Pacific's Cascade Division, and the railway surveyed a town plat in 1884 but did not file it in the county courthouse at Yakima until two years later.

When the bridge was fmished in 1888, many of the railroad employees left and others moved to Pasco. Northern Pacific station agent Charles Conway, appointed and sent west from Minnesota in 1888, recalled: "When we reached Pasco, a blinding dust storm was raging we waited for hours for the wind to subside the little station at Kennewick [was in] the sand and sagebrush There wasn't a tree, not a spear of grass It was a scene of desolation through which swept two mighty rivers! I said, 'If this is Washington, I don't want it!' " (parker 1986, pp. 1-17).

After the railroad bridge crews left in 1888, Kennewick almost died. The Portland Oreqonian reported in April 1889 that the "town of Kennewick has met the fate of her sister, Ainsworth, and has been dismantled" (Van Arsdol 1972b, p. 5). However, the town's development was spurred that same year when brothers Frank and I. W. Dudley began constructing an irrigation system between Kennewick and Hom Rapids on the Yakima River. They and the Northern Pacific promoted the region in glowing terms. One early settler recalled: "Everybody thought that everybody was going to make money--that there would be a large city here. This was where rail and water met Everybody came on the train, and .... Every train was met. [The person] interested in looking for land ... was never left alone" (parker 1986, p. 41). Similar efforts were made when lots were put up for sale in nearby Finley and in the ferry crossing town of Hover, across the Columbia from Wallula, with agents meeting travelers at the Kennewick station to interest them in land in the two smaller towns to the south. When the Dudley irrigation project went bankrupt in the Panic of 1893, Kennewick experienced a time of slow growth parallel to that of Pasco (pp.30-41).

Richland. Settlement of Richland also was boosted as a result of the Northern Pacific's promotions of the Kennewick neighborhood in the late-1880s and early 189Os. Brothers August (Ed) and John Timmerman carne in 1894 and filled an urgent need by constructing a cable ferry at Columbia Point, southeast of present-day Richland. Their 2,910 foot long cable was brought across the Columbia to the Franklin County side by Captain W. P. Gray for a fee of $\$ 25$. Benjamin and Mary Rosencrance, ranchers at the "Y" at the mouth of the Yakima River since 1880, were required by the new Homestead Act to move to the north side of the Yakima (in today's Richland) in 1888. Their barns and buildings were located at the current comer of Lee Boulevard and Goethals Drive. In 1889 their daughter, Lena, became the first white child to be born in Richland. Five years later, they built a large waterwheel to irrigate their land. Other families also homesteaded in the area (parker 1979, pp. 23-27).

The Wbite Bluffs Area. The coming of the Northern Pacific Railroad to the territory surrounding the Hanford Site caused the development of many small towns in addition to Pasco, Kennewick, Finley, and Hover (see Figure D.?). The majority of new settlers were interested in farming, and their arrival hastened the transition of the regional economy from stock-raising to agriculture. So many settlers carne to take up homestead claims in the White Bluffs area between 1892 and 1894 that there was not room for them on the east bank of the Columbia between the river and the bluffs, and most settled on the west bank opposite the original White Bluffs townsite or on the Wahluke Slope (meaning "soaring up like birds" in the Wanapum language) above the north bank.

John and Jennie Crawford, a brother and sister from Ellensburg, claimed their homestead in 1893 on the Wahluke Slope just north of the short east-west stretch of the Columbia, and the Craig brothers Edwin, Will and Sam, also from Ellensburg, filed to the south, across from the Wahluke Slope and about five miles above the White Bluffs ferry landing on the west bank. The Charles McGlothlins from Yakima took land five miles below the ferry landing, and John Brice from Wenas claimed a plot one mile above the landing in 1892. In the same year, William Pitt of Wenas filed for a homestead about two miles above the old Indian corral at "Smohallie Flat." The Muirs, Wrights, Oggs, Hoffmans, and Randalls also carne to the White Bluffs vicinity during 1892-1894. They found that the Terrell family had staked a claim at Juniper Springs above Vernita at the foot of the mountains and was growing grapes and other fruiL Henry Gabel, who "ran horses" on either side of present-day Gable Mountain on the Hanford Site, had a shack "down near the slough", across from the island in the Columbia which he owned (Gabel Island). At the turn of the century, Gabel bought the White Bluffs ferry and store business (see Section 4.6.2) from old Jeordie Williams, and Gabel and his rider George Borden and Borden's family moved into Williams' home on the east 

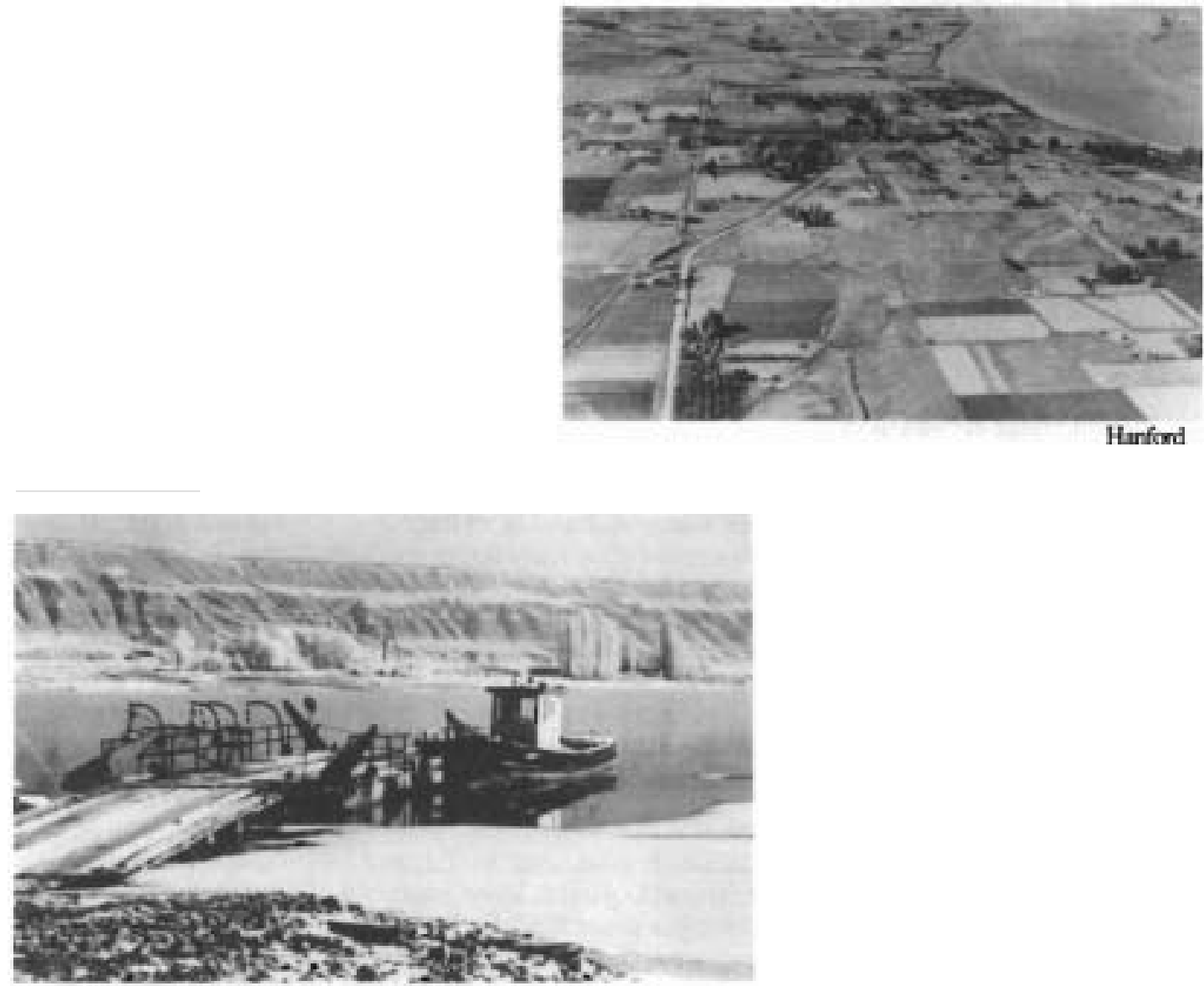

White Bluffs Steam Ferry

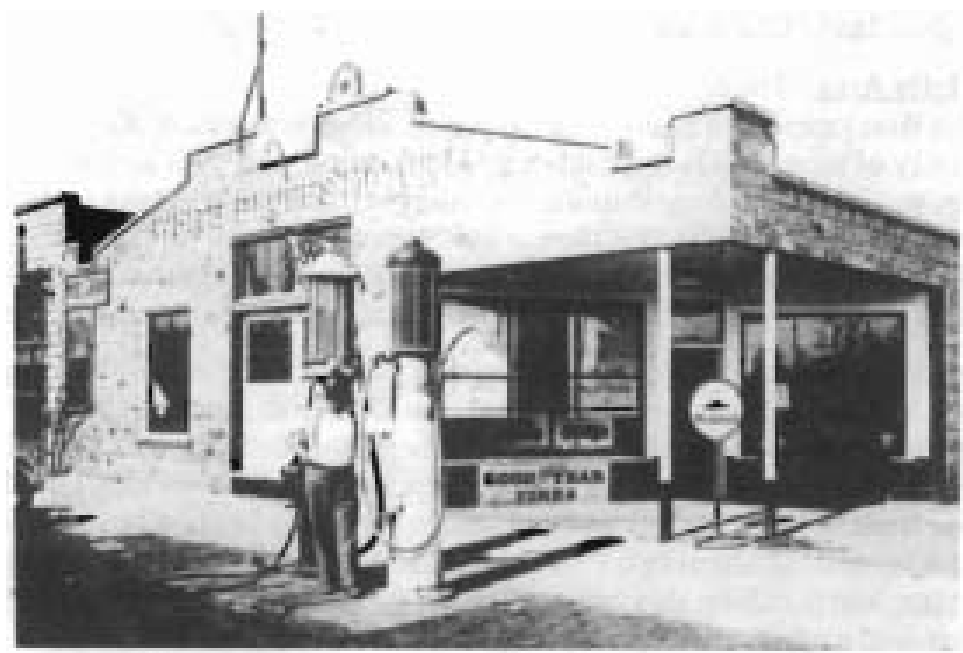

Downtown White Bluffs

FIGURE D.? The Creation of Towns in the Hanford Region 
side of the river. The small burst of settlers who came into the White Bluffs area in 1892-1894 also found a little log cabin on the west bank of the Columbia near the southward bend of the river. This cabin had been built by a settler family named Kent, who left after only a few seasons (Harris 1972, pp. 35-52,63,85). After a severe flood washed out their homestead in 1894, the Pitt family moved to Pasco, but in 1896 they succeeded in changing their filing to the island near the Brice unit (one mile above the ferry landing). They built a bam of cedar logs, and used cedar shakes to roof the bam and house. They then bought Hay Island, upriver from their home island, a traditional winter feeding ground for horses belonging to the Indians. Hay grew waist-high on this island, and the family put up over 80 tons a year as winter feed for their animals. In the late summer and fall, when the Columbia's water level was low, the island actually became part of the mainland, and teams and wagons (or later cars) could be driven across a marshy area and onto the island. In 1904, Hay Island was sold to a railroad engineer named Barrett for use in his retirement, and it became known as Barrett Island. Later, after being sold to the Lock family, it was called Lock Island, [now spelled Locke--ed.] but it was owned by Archie Borden by the time the federal government requisitioned the land in 1943 (pp. 81-82).

\section{$\underline{\text { Railroads }}$}

The second major ralline through the expanses around the Hanford Site, the Spokane, Portland and Seattle (S.P.\&S.), was built between 1904-1908. The S.P.\&S. was owned jointly by the Northern Pacific and the Great Northern. The Great Northern, owned by the famous James J. Hill, had completed tracks across the northern states, through Spokane, across Washington State well north of the Hanford neighborhood, and to Seattle and Everett in 1893. Eleven years later, after the two big carriers had both suffered losses in the Panic of 1893 and from their own fierce competition, they decided to cooperate in building the S.P.\&S. in order to share in complete domination of the Northwest and to undercut the Union Pacific's Portland trade.

The building of the S.P.\&S. was responsible for the creation and/or growth of many of the small towns in the expanses around the Hanford Site. Initially, the railroad's construction revived the town of Ainsworth, fonner production headquarters for the Northern Pacific in the district, because the S.P.\&S. designated Ainsworth for the same function. However, the town declined once again after the carrier was completed (Meyer 1977, pp. 7-8).(a) From Spokane, the S.P.\& S. built southwestward across central Washington's lava plains, then south through Devil's Canyon (just below Kahlotus Lake) to the Snake River. It then followed the north bank of the Snake to Pasco, went along the north bank of the Columbia to Portland (reaching that city in 1908), and then turned north to Seattle. The S.P.\&S. crossed the Columbia from Pasco to Kennewick and established its depot in the latter city in 1908. From Kennewick westward, it was known as the "north bank line", and it added to the already considerable importance of both Kennewick and Pasco as produce shipping centers (parker 1986, pp. 45-60).

The third major interstate railroad to be built through the territory surrounding the Hanford Site was the Chicago, Milwaukee and St. Paul (known at that time as the S1 Paul), constructed between 1907-09. In the Hanford vicinity, the S1 Paul's primary importance lay in the founding of several small station stops that grew into towns such as Othello, to the north, and, even more significantly, in constructing a spur line from Beverly on the Columbia River to the town of Hanford in 1913. This spur, known as the "Priest Rapids Line," allowed fruit from Hanford, White Bluffs, Vernita, and other towns along the northern edge of the Hanford Site to be brought to market much more easily and quickly. The location of the White Bluffs depot caused the city of White Bluffs to move once again. The town had moved to the west bank in 1907 when irrigation developments brought in so many new settlers that there was not room for them in the original settlement on the east bank between the river and the bluffs. This time it moved further west from the ferry landing on the west bank of the Columbia (Harris 1972, pp. 35-40; Parker 1979, p. 165).

\section{Irrigation: $\underline{1877-1900}$}

After advertisements by the Northern Pacific Railroad and the Dudley brothers' irrigation project began to fill the Columbia Basin with settlers, the most urgent need of the newcomers was for irrigation water. Most immigrants to the Hanford vicinity initially planned to grow wheat, hops, and/or alfalfa, but they soon found that "anything will grow if we can only get water." Experimental crops of melons, vegetables, berries, sugar cane, peanuts, maize, flowers and fruit trees all thrived (Harris 1972, p. 50). An additional incentive for attempting crop

(a) Periodically, through the 1940s, Ainsworth served as a riverboat construction site, but the town died after World War II. 
irrigation came from the Desert Land Act, passed by Congress in 1877, which allotted 640 acres of land to a homesteader if he irrigated at least 80 of those acres (Lavender 1958, pp. 434-39).

Methods were diverse. A number of individual farmers in the White Bluffs-Priest Rapids area used "a sort of water elevator, an endless chain of buckets, which combined with the power of one horse, enabled them to irrigate" (Harris 1972, p. 63). Other small irrigation devices such as individual windmills, water wheels, or makeshift dams diverted water from nearby rivers and creeks throughout the Columbia Basin into wooden ditches or flumes to flow by gravity short distances into fields. By 1890, many small stearn vacuum pumps, placed directly over wells or streams, were in use in the lower Yakima Valley; however, power was weak, and piping systems were makeshift and usually inadequate. Benjamin Rosencrance did install a 36-foot "dip wheel" on the Yakima River in 1894 to water his land in present-day Richland. The wheel made four revolutions per minute, delivering water through a flume four feet wide by one foot high. It was one of the largest and most successful water wheels in the district, but when river flow dropped off in late summer, the system delivered far less water than was needed. A 125 foot wingdam built into the river to correct the low water problem was only partially successful. On the peninsula between the Yakima and Columbia rivers, Nelson Rich dug a private canal about one and one-half miles long, headed on the Yakima River several miles below the Horn. In 1893 he grew two successive crops of alfalfa, barley, hops, cabbages, onions, and potatoes on former sagebrush land which had not been considered worth even ten cents per acre two years previously (Van Arsdol1972b, pp. 24, 38-39; Parker 1979, pp. 19,43).

The first large commercial attempt to irrigate cropland in the Hanford region was made by the Dudley brothers, who formed the Yakima Irrigating and Improvement Company (Y.I.\&I.) in 1888. They bought 20,000 acres of Northern Pacific land (odd-numbered sections) lying along the lower Yakima and Columbia Rivers between present-day Kiona and Kennewick, and built a small dam at Horn Rapids on the Yakima. They planned two new towns, Kiona and Riverside (near present-day Richland) and began lavish advertising of tracts in and near these towns and Kennewick, hoping to sell land and water rights to new settlers. They planned three irrigation canals (usually called "ditches") to head from spots on the Yakima River, one from the Hom Rapids dam. Nelson Rich received the contractto build it(a) During 1889, claims were entered at the Walla Walla land office on thousands of acres of land along the proposed canals, especially one that ranged from Hom Rapids south and east of Kennewick. Settlers moved onto the arid sagebrush territory, convinced that their early purchases would lead to great profits in the future. When only eight miles of the Kennewick ditch had been completed by mid-1890, the restive settlers on the evennumbered land sections lying along its proposed path (who had claimed their lands under the Homestead and Desert Land Laws) voted into existence their own co-operative canal association, the Dell Haven Irrigation District

Dell Haven surveyed and completed plans for building an irrigation ditch along the same route that had been selected by the Dudleys. That same year, interested capitalists from New York and Portand, directed by C. H. Leadbetter, reached an agreement with the Dell Haven members, and funded and incorporated their association as the Yakima and Kennewick Irrigation Company. The new Leadbetter company announced plans to irrigate 18,000 acres of land in a strip about four miles wide and twenty-five miles long on the west side of the Columbia River, including the approximately 10,000 acres of the Dell Haven association, as well as some additional property south of the Yakima. This company also designed another canal, watering 30,000 to 40,000 acres, to begin at Kiona and run along the south side of the Yakima River to the Columbia at Kennewick. This 28-mile ditch also would carry some water through conduits across the Yakima to lands on the north side (Van Arsdol1972b, pp. 8-10).

The stage now was set for competitive and rapid canal building by the Y.I.\&1. and the Leadbetter companies. During 1892, the Y.I.\&1. spent nearly $\$ 100,000$ on its main canal from Kiona to Kennewick, completing 20 miles from Kiona eastward. This line, known as "the Kennewick Ditch," was 15 feet wide at the bottom and 26 to 30 feet wide at the top. The next spring, many fruit orchards, especially peaches, were set out by the settlers along the Kennewick Ditch. In 1893, the 34-mile stretch of canal to Kennewick was completed, and the following year the water reached Hover (across from Wallula). The company's flowery promotions of the Kennewick locale continued, and in April 1894, "colonizing agent" Captain W. Brown relocated nine families from Rockford, Peoria, and Elgin, Illinois, to the eastern end of the Yakima Valley. The Y.I.\&1. canal along the north side of the Yakima was completed as far as the Grosscup ranch in 1893. Meanwhile, in late 1892, the Leadbetter company expanded its interests to surveying and grading for an irrigation canal from Priest Rapids on the Columbia River to Prosser on the Yakima River. The line was planned to skirt Rattlesnake Mountain on the east side through the

(a) Parker 1979, pp. 18-19. The west end of this ditch can be seen today from Highway 240, about one mile from Richland. 
fertile Rattlesnake Flat, proceed north and east to Gable Mountain, join the Columbia at the foot of Priest Rapids, and to water 100,000 acres. It was incorporated as the Prosser Falls and Priest Rapids Canal Company in July 1893. Overextended, the Leadbetter interests encountered severe fmancial troubles in the Panic of 1893, and the Y.I.\&1. bought out their holdings in the projected Kennewick canal. (For this reason, Y.I.\&1. was in a position to transfer part ownership of the Kennewick Ditch to the Dell Haven farmers in October 1893.) In 1894, the Prosser Falls and Priest Rapids Canal Company also failed after having built only a few miles at the southern (Prosser) end, and the northern section of that line could not be completed (Van Arsdo11972b, pp. 15-30; Parker 1979, pp. 100-02).

The completion of the Y.I.\&I.'s Kennewick Ditch allowed the town of Kennewick to survive as a shipping and supply center for area farmers, but the Panic of 1893 was followed by a general business depression and a time of slow growth for Kennewick for almost a decade. The years from 1894 to 1897 included many surface changes in the tract between Prosser and Kennewick, as fruit orchards blossomed and alfalfa and wheat fields ripened. However, land values, previously over-inflated by the railroad and irrigation company promotions, dropped sharply after 1893 . There was severe flooding and washout of the Kennewick Ditch in 1894, and again in 1896, and the Dell Haven farmers had insufficient funds to make adequate repairs. Many went bankrupt and left, and in 1896, the Dell Haven Irrigation Company was sold to Eastern interests for $\$ 2,000$. Kennewick's Hotel Columbia closed in 1894 for lack of business (Van Arsdol 1972b, pp. 32-47).

The Newlands Reclamation Act

The passage of the federal Newlands Reclamation Act in 1902 revived irrigation development and consequent business activity in Kennewick and other parts of the Hanford vicinity. The Newlands Act authorized the federal government to participate directly in constructing land reclamation projects, with the costs to be repaid over time by the beneficiaries. President Theodore Roosevelt, visiting the Hanford area in 1903, termed the new law "a policy more important to this country's internal development than any since the Homestead Law of LincoIn's time . .. we shall see [in] the so-called arid and semi-arid regions a development during the next 50 years literally unparalleled ... a very great good will come of it" (Relander 1961, p. 147).

The first necessary step in the Hanford area and other affected regions was to survey existing water claims. Especially on the Yakima River and its tributary creeks, these claims were chaotic and disputed Also, stream flow was extremely variable in the Hanford vicinity. The Columbia River's autumn flow rate could differ from spring rates by a factor of six, and yearly totals on all of the district's major rivers diverged widely, based upon the snowpack in widely separated areas.

As soon as the Newlands Act was passed, so many new water claims were filed hastily in the Yakima Valley that the Reclamation Service withdrew. Finally, however, the Service re-entered the upper Yakima Valley, bought out private interests, and fmished the biggest irrigation project to that date. This project was the Sunnyside Canal, which watered virtually the entire upper valley from Yakima to Sunnyside (Lavender 1958, pp. 434-38).

Irrigation: 1902-1918

In the lower Yakima Valley, including Prosser, Kiona, and Kennewick, the Northern Pacific Railroad acted quickly to assure its renewed profits from land sales after the passage of the Newlands Act In 1902, the railway purchased nearly 20,000 acres of land in the lower valley, as well as the old Dell Haven Ditch. At the same time, the Northwestern Improvement Company, a Northern Pacific subsidiary, bought 23,000 acres in and near Kennewick, plus the remains of the old Kennewick, Kiona, and "lower Yakima" (Riverside) ditches. A few months later, a new subsidiary, the Northern Pacific Irrigation Company, purchased all of Northwestern Improvement's Kennewick holdings, and placed town lots in Kennewick up for sale. Working with adequate capital, the railroad completed four miles of ditch reconstruction in May 1902, and three and one half miles more in June. By the end of the year, the rebuilding was complete for the 32 miles of canal from the Hom Rapids dam to Hover, bringing irrigation to well over 15,000 acres. The first water came through the canal in February, 1903, and later that year the Northern Pacific Irrigation Company con-structed a permanent dam across the Yakima at Hom Rapids (parker 1986, pp. 30-40).

In other sections of the Hanford vicinity, the construction of large irrigation systems was a necessary precursor to development of the townships themselves, and the same general pattern which evolved in Kennewick was followed in most of the nearby settlements. During the years from the early 1880 s to 1910 , cooperative or commercial irrigation systems were tried for the first time. Many of them failed in the Panic of 1893, and larger, more fmancially stable, watering enterprises were built after 1900. The coming of land reclamation produced miniature booms in the townships, because for the first time a dependable economic base was possible. In the 
White Bluffs locale, after the Prosser Falls - Priest Rapids Canal Co. ceased construction in 1894, the Northern Pacific Railroad commissioned H. K. Owen to survey the White Bluffs locale for an irrigation system in 1896. Owen reported the necessity of diverting water at the head of Priest Rapids, conducting it nearly 18 miles eastward in a large canal, raising it from between 60 to 400 feet in various places, and then letting it fall to generate the irrigation power. The railway deemed the proposal 100 expensive and risky compared with simpler projects along the Yakima, and did not proceed with the plan. In 1904, engineers Price and Jacobs surveyed the Priest Rapids region once again for Tacoma and Seattle businessmen H. E. Cover and and W. R. Todd. In 1905 Cover, who represented the Northwestern Improvement Company, told a Kennewick newspaper that his company planned to water about 30,000 acres of land near White Bluffs, and that same year he placed the steamer $W$. $R$. Todd in service to carry prospective land buyers up the Columbia from Kennewick. However, the Price and Jacobs survey concluded, as had Owen's, that diversion of reclamation water should begin at the head of Priest Rapids. They reported that a canal on the west side of the Columbia would be impractical, because the first 12 miles would have to be along the steep slopes of the basaltic cliffs lining the river. Therefore, they recommended that water be diverted and brought down the east shoreline, and then transferred by flume to the township and farms of White Bluffs on the west side. This last necessity raised the cost of the project enough that neither the Northwestern Improvement Company nor the Reclamation Service (which was already busy in the upper Yakima Valley with its main project, the Sunnyside Canal) decided to fund the enterprise (Harris 1972, pp. 90-103; Parker 1979, p. 43).

The first real boom caused by an irrigation endeavor came to the White Bluffs area in 1905, when Judge Clarence H. Hanford of Seattle, his son-in-law Manley Haynes, G. B. Smith of Tacoma, and other Tacoma businessmen formed the Priest Rapids Irrigation and Power Company. The company, capitalized at $\$ 250,000$, planned to reclaim 32,000 acres of land on the west side of the Columbia, 30 miles north of Richland. Water to irrigate the first 15,000 acres was to be raised 50 feet by an electric pumping plant at Coyote Rapids, and the company hoped to raise water 100 feet at a later date to irrigate the remaining acreage. A dam and electric generating plant to power the pumps was to be built at Priest Rapids. Land was bought at White Bluffs and at an undeveloped site about six miles downriver (the future Hanford townsite, whose plat was approved in 1907). The company encouraged its stockholders to buy lots, offering them a discounted rate for each ten shares of stock held. Eventually, about 3,700 acres were taken up by the stockholders, the Hanford, Bleakley, and de Veuve ranches being among the largest and most noted. Rivalries within the company split it into two competing businesses by 1907, the White Bluffs Irrigation Company and the Hanford Irrigation and Power Company. That same year, the Hanford company's low-line ditch was completed. While it stood empty, awaiting completion of the pumping plant at Coyote Rapids, adjoining lots with perpetual water rights sold for $\$ 90$ to $\$ 350$ per acre. Signs of a boom were plentiful. In August 1907, 40 prominent businessmen from Seattle and Tacoma chartered the steamer Mountain Gem to tour Hanford, White Bluffs and Richland, while new hotels in each of the former towns "were full all the time ... from early 1907 until 1909, there was a period of great activity, with new settlers arriving everyday by boat ... or overland by horseback or horse and buggy" (Harris 1972, pp. 114-15; Parker 1979, p. 43). In early 1908, the Hanford Company's dam, headgates, power intake canal, and pumping plant at Coyote Rapids were completed, and the White Bluffs Company had brought 21 tons of wooden pipe and other supplies upriver by steamer (parker 1979, pp. 56$65)$.

Settlers bought lands in the Hanford and White Bluffs district, even though the tracts remained dry throughout 1907 and 1908. Many orchards set out in anticipation of water died during those two years, and when farmers threatened to sue the Hanford Company for the loss of their crops and trees, the business paid for their losses. In 1908, The Hanford canal's bank broke three miles from its beginning, and the White Bluffs Company's pumping plants burned. However, the greatest problem in this territory, and around Richland, was the extremely thirsty nature of the fme, sandy soil. There was much seepage, with the soil refusing to pack and seal, and the two companies had to line the bottoms of their ditches with cement Meanwhile, new settlers were busy plowing, harrowing, and loosening their soil for planting, with the result that the endemic windstorms of the area deposited ashy dust into the newly lined ditches. Men were hired to shovel out the ditches when they were dry, but when water fmally ran through them in 1909 the canals had to be cleared by a heavy chain dragged along the bottoms by teams of horses. It was these unexpected expenses resulting from the soil problems that caused the White Bluffs and Hanford companies to pool their equipment and supplies in 1909, and to merge completely in 1910 into the Hanford Irrigation and Power Company. Later that same year, American Power and Light Company of New York bought out the entire project, in the largest business purchase ever negotiated up to that date in the Northwest. The electric company, through its subsidiary Pacific Power and Light Company, wanted to expand the small pumping plants to generate electric power to the developing Columbia Basin. By 1910, the population of White Bluffs stood at 323, while Hanford was slightly larger at 369 (Harris 1972, pp. 105-09; Parker 1979, pp. 48-84, 139-41). 
In Richland. development accompanied the construction of two expanded irrigation projects in 1905 and 1908. In 1904. W. R. Amon and his son Howard bought the large Rosencrance ranch on the present-day site of Richland. and installed a gasoline pump over the Yakima to supercede the Rosencrance waterwheel. The following year. W. R. Amon bought the huge Rich ranch. which was then being watered by the one and one-half-mile long private irrigation canal built by Nelson Rich. Amon and his son arranged for this short ditch to be enlarged to a sixmile canal heading on the north side of the Yakima about one mile above the present-day Fallon bridge between Richland and West Richland. They planned for the new ditch to water all 2,300 acres of both their ranches. and they incorporated as the Benton Water Company and subdivided the land into 10-acre tracts. They built a floating dock at present-day Amon Park on the Columbia to accommodate prospective land buyers and increasing ship traffic. began to advertise their new town. and held a contest to name it The name "Benton" was chosen. perhaps to honor pioneer Benjamin Rosencrance or perhaps to affirm the name of the newly formed Benton county. However. postal officials declared that this name was too similar to Bentsen in Pierce County. so the name "Richland" was substituted. recognizing both Nelson Rich and the fertile soil of the region. That same year. Amon and 35 men who bought plots to be watered by the new irrigation canal worked together to build a 612-foot dam at the headgate in two days, and ensured a full supply of water flowing through the ditch by the end of July (parker 1979. pp. 43-45).

The second seminal reclamation project completed in Richland during the years from 1905 to 1908 was that of the Lower Yakima Irrigation Company. In late 1903, the Northern Pacific Irrigation Company had constructed a permanent dam on the Yakima River at the head of the Hom Rapids canal (which supplied the Kennewick Ditch). By 1908. two Kennewick land companies had formed to promote Kennewick. White Bluffs. and Hanford: the Residents Park Land Company and the Kennewick-Richland Realty Company. These also began to boost Richland. In 1909. the Richland Development League was formed to improve the area's sales potential by bettering local roads. One year later. Richland became a city. with a population of 721 (parker 1979. pp. 19.26.30.41.47-65).

During the years from 1906 to 1910. when Richland. White Bluffs. and Hanford were experiencing their greatest irrigation booms. promotions of the region were lavish. In a newspaper advertisement, The Richland Land Company predicted that "Richland is certain to be one of the most important towns on the Columbia River. surrounded as it is by 16.000 acres of the frnest irrigated land in the west" (parker 1979.p. 61. citing Kennewick Courier, 1908). In another flyer. the same business pronounced that "People in general are commencing to awaken to the immense possibilities of this part of the great Columbia River Valley. and all the signs point to an era of tremendous development just ahead" (pp. 125-26). Even the Rattlesnake Hills. as yet not under any land reclamation project. was publicized as "an immense stretch of frne sage brush land ... these lands ... offer the best field for speculation in the state today. They are the cheapest lands in the valley from a standpoint of price. and none other is superior from an agricultural standpoint ... a number of choice homestead and desert relinquishments [are available] for as low as $\$ 25$ per acre. Deeded land is obtainable at from $\$ 40$ to $\$ 75$ per acre" (pp. 132-33).

Photographer Asahel Curtis was hired by land companies. railroads. and commercial clubs during the height of the promotional boom in Eastern Washington. and his work illustrated many of the advertising brochures of the Hanford vicinity between 1906-1910. Curtis captured some of the most diverse and unique pictures of the irrigation and development boom in the expanses surrounding the Hanford Site. His photographs of new orchards near Grandview decorated a land sales brochure which claimed: "The orchardist here can pick the winners from the best sellers grown in the world ... the grower does not have to specialize. ... Spraying is done in the Grandview district as prevention rather than cure. There are few pests to contend with ... the people here are healthy .... The low altitude makes it desirous for persons afflicted with nervous disorders. Epidemics. like cyclones and blizzards, are unknown" (Edwards 1981, pp. 112. 119). However. despite the bountiful promotions and an increase in the number of both settlers and irrigated acres during the reclamation boom of 1906-1910. at least one newcomer to Richland observed that, as of 1910. the locale was "a rolling sagebrush desert .... Not all the ten-acre tracts were sold. Cultivated ones were somewhat scattered .... No one got rich during my time there" (parker 1979. pp. 150-56).

In Franklin County. perhaps the driest in the state. irrigation projects had to be large and expensive in order to be workable. and so they developed later. Outside of Pasco. the county remained sparsely settled during the period from the mid-1880s to 1910. Dryland farmers began to replace stockmen in the county during the 1880 s. when overgrazing and poor markets caused the ranching business to decline. The early farmers planted wheat almost exclusively. and then alternated with a fallow year to allow the land to collect moisture. However. after only a few rotations. the land was so parched that the crops could not thrive. and swirling dust storms drove off many disillusioned new settlers. One pioneer woman recalls that land along the Snake River was promoted as excellent for agriculture. but that prospective buyers outside the area were not informed that the river's cliffs were rocky and steep. 
commonly with 100-foot walls up to the table land (phillippay 1973, pp. 12-13). During the 1890s, Franklin County residents tried to interest outside capital in developing irrigation projects, but few projects started and most of those failed. In 1909, for example, private speculators formed the Pasco Reclamation Company, planning to pump water from the Snake River. They built a pumphouse and long wooden pipes, but became insolvent about 1917 because the pipes rotted and the unlined dirt ditches soaked up much of the water passing through them. Shortly afterward, Franklin County Irrigation District Number One was organized. It went into receivership several times, but always reorganized, and remains solvent and independent today. In 1918, the first article was published suggesting the current Columbia Basin Irrigation Project for Franklin County. Although the idea required 30 years to come to fruition, it was the only truly viable project to reclaim large areas of land in Franklin County, and to achieve settlement of the majority of the county north of Pasco (Oberst 1978, pp. 61-71; Vogel 1977, pp. 84-89).

\section{Agriculture}

From the early 1880 s to 1910 , agricultural settlement of the Hanford vicinity was realized largely because of the success, or even the partial success, of irrigation projects. It has been estimated that by 1890, approximately one in ten farmers in the acreage from the foot-hills of the Cascade Mountains to the mouth of the Yakima River watered his land. Wheat was still the dominant crop, although it was noticeably more successful in the valleys from Walla Walla eastward, which had more rainfall and a richer, loamier topsoil. By 1910, Yakima, Benton, and Klickitat Counties contained more than two-thirds of the artificially watered land in Washington state, with Yakima County having the highest percentage $\mathbf{( 8 8 \% )}$ ) of irrigated lands within it of any single county. By that time, there were 2,594 miles of main irrigation ditches in the state, with the capability of watering approximately 400,000 acres. Projects already under way soon would bring the total to over 800,000 acres. The period from 1900 to 1910 saw the greatest population booms, in terms of percentages, in the towns and cities of eastern Washington, with the exception later of the boom associated with the Hanford project in Richland, Pasco, and Kennewick. Between 1900 and 1910, Kennewick, Richland, White Bluffs, Hanford, Prosser, Grandview, Sunnyside, Granger, North Yakima (present-day Yakima), and Ellensburg all were founded and/or grew by huge proportions as a result of land reclamation projects and their promoters. By 1910, the population of the new Benton County stood at 7,937. In the same year, the federal census revealed that, for the first time, more people in Washington state lived in cities than on farms. However, in the districts surrounding the Hanford Site, farm population still OUUlumbered that of the towns and cities, and many of the most successful businesses in the region were cooperatives owned by the growers. In the Columbia Basin, the greatest increase came in the number of farms composed of less than 100 acres, and the diversified, family-owned farm became the dominant economic unit of the area. In the upper Yakima Valley, farms often specialized as fruit orchards; these generally were larger because more capital investment was required to build large reservoirs and piping systems to carry irrigation water from the Cascade Mountains (pollard 1937, Vol. 2, pp. 48-58,263-74; Edwards 1981, pp. 112-13; Parker 1979, pp. 149-50).

\section{$\underline{\text { Schools }}$}

Among the highest priorities of the agricultural pioneers in the region surrounding the Hanford Site was the education of their children, and most of the earliest schools in the area were established soon after the influx of population brought by the Northern Pacific Railroad began.

The one-room schoolhouse that had operated in the construction town of Ainsworth was moved to Pasco in 1885 , but soon a new school site was donated by the company. A well, schoolhouse, two outhouses, and a woodshed were built by volunteer labor (mostly parents), and the new facility opened in September 1888 . The Pasco school was unusually progressive; it operated for nine months of the year, while for the first few years most schools in the Hanford vicinity were open for only three months. The Pasco teacher received $\$ 40$ for the first month, a typical salary for the territory, but the remuneration jumped to an uncharacteristic $\$ 50$ for each subsequent, "satisfactory" month (Oberst 1978, pp. 125-45).

In Kennewick, the first school also was organized almost as soon as Northern Pacific workers and settlers arrived. The school district, created in 1885, originally included the expanse east of Kiona, west of Wallula, north of the Klickitat county line, and south of Priest Rapids. It operated for three months each year, and the teacher was paid $\$ 40$ per month. The first school population was 15 students; growth fluctuated, but generally was slow during the years of the early irrigation attempts. When the Northern Pacific acquired the irrigation ditches and began to promote Kennewick in 1902, the school population boomed along with the town. The town of Kennewick itself jumped from 50 inhabitants in 1902 to 400 people in 1903, and the school population rose from 100 students in 1904 , to 362 in 1906 . Kennewick built its first high school at a cost of $\$ 11,000$ in 1907, and graduated its first class its following year (parker 1986, pp. 13-14,35-40,43-50). 
In the tracts immediately around Richland, schools were established in the late 1880s. The first Richland school was started about 1889 in the home of Mrs. Harry Van Horn, who taught the youngsters from the neighboring homesteads for $\$ 1$ per day. The children traveled to her home "by wagon or sled, depending on the weather, taking their own chairs or stool with them." In 1906, one year after Richland became an official town, Howard Amon donated Block 6 of the townsite for a new school, and the school population doubled in the next year (parker 1979, pp. 21,47,55).

In White Bluffs, the first school opened in the early 1890s in the home of Mrs. Ed Craig, after the homesteaders had filed a petition with the county school board in Yakima City requesting the formation of a new district. A few books were supplied by the county superintendent, but most were donated by the local settlers. Many people also wrote back East to friends, asking them to send books for the new school. The second year, school was held in the abandoned Kent cabin on the west riverbank. Pieces of clay from the white bluffs were used as chalk in the cabin school, and local fathers built the furniture. In 1895, the first certified teacher came to the White Bluffs-Priest Rapids district, brought from Yakima in a lumber wagon by the Ed Craig family. The teacher was Mary Young, a graduate of the Ellensburg Normal School, and she was paid \$35 per month plus room and board for the three-month school term. In 1897, a new White Bluffs school was built of logs gathered from drift along the Columbia and dragged to the school site by horse teams. Lime and sand from the bluffs were made into plaster to fill in the spaces between the logs. A white frame schoolhouse was built in 1905; it served the community, along with a new high school built in 1922, until the federal government appropriated the town in 1943 (parker 1979, p. 34; Harris 1972, pp. 70-75, 80, 120-25; Phillippay 1973, pp. 51-55).

\section{Summary}

In the years from the mid 1880s to 1910, the territory sWTounding the Hanford Site was transformed from an open ranching area to an agricultural region dotted with small towns and cities. Franklin and Benton Counties were officially created during this era, and the towns of Pasco, Kennewick, Richland, and Hanford were begun. The White Bluffs ferry landing and supply post also became a town.

The two developments most responsible for this transformation were the coming of the railroads and the construction of viable irrigation systems. Beginning in the early 1880s with the Northern Pacific Railroad building between Spokane and Ainsworth, three major railroads were forged through the Hanford vicinity. The Spokane, Portland and Seattle line came between 1904 and 1908, and the Chicago, Milwaukee and St. Paul traversed the expanses just north of the present-day Hanford Site between 1907 and 1909. The railroads promoted the Columbia Basin lavishly. However, farmsteaders soon realized the need for land reclamation. Individual watering schemes worked inefficiently or not at all, and the early cooperative and commercial irrigation plans often failed because they were poorly funded. Larger reclamation efforts, usually sponsored by the federal government or the Northern Pacific Railroad, achieved much more success in the locale after 1900. In the years between 1903 and 1910, the region around the Hanford Site, with the exception of Franklin County, experienced economic booms. In Franklin County, a brief boom initiated by S.P.\&.S. construction was not sustained after 1908 because viable irrigating systems were not developed there until later.

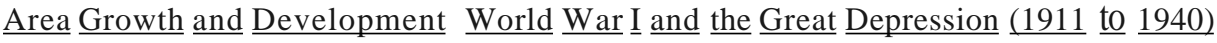

In the region surrounding the Hanford Site, the years from 1911 to 1940 were ones of slow but steady development of farms and agricultural businesses, irrigation systems, town and city services, and roads and bridges. Although there were no major economic booms, two notable projects during this period were the Roza Project, an irrigation system in the lower Yakima Valley, and the Grand Coulee Dam,located in the northernmost sector of the district The dam was the largest and most significant federal enterprise in the vicinity because it created jobs at the time of its construction in the Depression era, generated electricity to fuel future growth, and created Lake Roosevelt, the huge reservoir which feeds the ditches of the Columbia Basin Irrigation Project in Lincoln, Grant, Adams, and Franklin counties.

During the years of 1917 and 1918, towns and cities in the Hanford neighborhood participated avidly in the World War I effort A Soldier Settlement Project, sponsored by Washington state, subsidized veterans and their families who wanted to buy uncultivated land near the towns of Hanford and White Bluffs. Prohibition came and went in the region, first by local option and then by federal decree. Riverboat traffic declined precipitously during these years, despite the completion of the Dalles-Celilo Canal in 1915. However, in the 1930s, the beginnings of port system development in Kennewick and Pasco made possible a later revival of river freighting. The Rattlesnake Hills were the focus of excited drilling for natural gas during the interwar era, but the deep reservoirs which were 
envisioned could not be found. Airplanes. paved roads. and several new bridges appeared in the territory. automobiles and electricity became commonplace. and many old ferries went out of service.

In the Hanford vicinity. the effects of the Great Depression were felt later than they were in most parts of the eastern and midwestern United States. However. when the impacts of the nationwide business decline and the lowered commodity prices did become apparent in the Columbia Basin. individuals. and overstrained county budgets suffered dramatically. While district crops remained large and healthy. farmers had to resort almost to the pioneer lifestyle of bartering for services. paying in produce whenever possible. and having no discretionary cash income with which to sustain local businesses.

\section{$\underline{\text { The Dalles }}$ = Celilo $\underline{\text { Canal }}$}

In the years before World War I. one of the most heralded and long-awaited achievements in the expanses around the Hanford Site was the construction of the Dalles-Celilo Canal between 1905 and 1915. Area farmers and shippers had endured higher freight rates than Portland and coastal cities since the earliest years of shipments through and from the Columbia Basin. In the mining and ranching era. the Oregon Steam Navigation Company [later reorganized as the Oregon Railway and Navigation (OR.N.) Company] had held a monopolistic stranglehold on freight rates (Western Writers of America 1978. pp. 212-14). The coming of the Northern Pacific Railroad was supposed to introduce competition to the rates. but that railway reached an agreement to use the OR.N:s tracks along the south side of the Columbia River from Pasco to Portland (via Wallula). and then fmished its own route to Puget Sound by building through the Cascade Mountains to a terminus at Tacoma (Dodds 1986. p. 138). Shippers in the Hanford vicinity still were forced to pay the high rates of the O.R.N. in order to send goods to the nearest major trans-shipment hub at Portland. The construction of the Spokane. Portland. and Seattle Railroad along the north bank of the Columbia River from Pasco to Portland between 1905 and 1908 was promoted as a solution to the rate imbalance. but the inland and coastal tariffs were not equalized until a judicial ruling was issued under the MannElkins Act in 1911 (Lavender 1958. pp 385-86.411). In the meantime. shortly after the tum of the century. merchants and growers from Lewiston. Idaho. to Umatilla, Oregon. formed an Open River Association and petitioned Congress to build a canal through the Columbia's rapids and falls at The Dalles and at Celilo Falls. Such a canal would eliminate the most expensive and time-consuming railroad portage required of river traffic between Portland and Lewiston. Shippers in the Columbia Basin and Walla Walla were among the most active members of the Open River Association. In 1905. Congress appropriated the funding. and the Army Corps of Engineers began construction of the canal. It was only eight and one-half miles long. with five locks. but it cost almost $\$ 5.000 .000$. and it took 10 years to accomplish because it was cut through solid rock on the south (Oregon) side of the Columbia (pp. 145-59).

The completion of the canal was greeted enthusiastically. but it did not bring to fruition the hopes of its boosters. When it was fmished. Open River jubilations were held for five days from Lewiston to Astoria. Pasco and Kennewick celebrated together with a parade and mock wedding of Miss Columbia and Mr. Snake. That same year. the new riverboat Ellen was launched from Pasco. Other important regional river carriers of the era were the Vulcan. which operated between Pasco and Lewiston. the Relief. which worked between Pasco and White Bluffs. the Richland Flyer. which won the mail contract between Kennewick. Richland. and White Bluffs in 1914. the J.N. Teal. the Gerome. the Mountain Gem. the W.R. Todd. and the dredge Umatilla. Although river traffic revived a bit when the Dalles-Celilo Canal became a reality. Pasco and Kennewick did not become significant shipping centers because the railroads had been forced to become more competitive following the 1911 Mann-Elkins ruling and another decree (issued under the Panama Canal Act in 1912) that forbade the same company to own both shipping and rail lines serving the same market Also. automobiles were beginning to absorb some of the river passenger traffic (Oberst 1978. pp. 81-86; Parker 1986. pp. 145-59). By the mid-1930s. river steamers and freighters had disappeared almost completely from the Columbia in the Hanford neighborhood. and only an infrequent oil barge came upriver as far as Pasco and Kennewick. Still. local newspapers periodically promoted hopes and plans to resume freight service between Portland and White Bluffs (parker 1979. p. 351).

\section{$\underline{\text { Social Reform Movements }}$}

A number of significant social reforms took place in the Hanford vicinity in the years before World Warl. In 1910. elections in both Washington state and in Benton County granted the franchise to women. fully 10 years before the Nineteenth Amendment to the Constitution extended voting rights to all American women.

Prohibition was a hotly debated issue during the pre-World War I era. The Women's Christian Temperance Union. a national group dedicated to eradicating liquor. organized chapters in most of the regional towns between 1890 and 1910. In the years 1909-1912. the counties and towns in the Hanford area held "local option" elections. 
wherein Benton County voted itself "dry" (prohibiting the sale of liquor within its boundaries), while Franklin County voted "wet". When this circumstance occurred, the saloon owner in White Bluffs moved his business from the west (Benton County) side of the Columbia into the old pioneer saloon on the east (or north) bank (parker 1979, p. 59; Harris 1972, pp. 129-38). In 1916, Washington voted for statewide prohibition in a statute which also banned all gambling except dice and cards. In Kennewick, the three existing saloons did not close, but served soft drinks instead of liquor (parker 1986, pp. 155-61). In 1919, national prohibition went into effect under the Eighteenth Amendment to the Constitution. There was some bootlegging activity in the Hanford district, most notably an infamous still which operated on the Wahluke slope. Truckloads of sugar went into the locale aboard the Wahluke ferry, and suspicious revenue officers tried to find the illegal enterprise for years, but they never succeeded (Harris 1972, pp. 125-38). In 1933, Washington became the 24th state to vote to repeal federal prohibition. Richland voted by a majority of two to one to retain the Eighteenth Amendment, but the rest of Benton County voted in favor of repeal (parker 1979, p. 311).

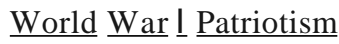

When President Woodrow Wilson declared war in April 1917, a wave of patriotic fervor surfaced in the Hanford vicinity. Service group activities flourished. Red Cross chapters were organized in regional towns and cities almost as soon as war was declared. In the small town of Prosser, membership soared from 13 to over 1,100 in 13 months. The Junior Red Cross in Benton County collected the pits of peaches, apricots, plums, cherries, and nuts to make carbon filters for military gas masks, and county and city/town War Food Committees urged people to plant gardens in backyards and vacant lots to support servicemen's dependents and the needy. Auctions, as well as innumerable dinners, parades and musicals, enabled the small towns of the vicinity , to raise substantial sums of money during the war years.

Soon after the United States entered the war, it became Red Cross policy to offer a free meal to every serviceman stopping in area towns on the troop trains. The Northern Pacific and S.P.\& S. trains, most often carrying young men to the Camp Lewis training station at American Lake near Tacoma, were met at each depot, and bountiful meals, replete with the neighborhood's best produce, were served to the soldiers (Fridlund 1985, pp. 12728).

People in the Hanford region seem to have taken seriously the easily circumvented restrictions, and in some cases patriotism assumed a dark side. In Kennewick, during April 1918, a "noisy campaign" was conducted against "slackers", and vigilantes burned all of the German language textbooks which' they could fmd. German families were "harassed," and a Lutheran church which used German in its religious services was pressured into closing its parochial school (parker 1986, pp. 172-80).

Men in the Hanford neighborhood, as well as some women nurses, served in military campaigns during World War I. In White Bluffs, Fred Weil began drilling local boys in military maneuvers as early as 1915 , and in Kennewick, city attorney Frank Jeffrey taught similar skills starting in 1917. The Prosser high school substituted military drills for music class two days each week, and required the participation of both boys and girls; local schools offered night classes in subjects such as wireless telegraphy and automobile repairing to men of draft age. Captain Fred Weil enlisted in 1917, went to Europe with artillery Battery E in the American Expeditionary Force, and sent back articles to the White Bluffs Spokesman.

\section{The Soldier Settlement $\underline{\text { Project }}$}

The soldier settlement project was one of the most notable experiments in promoting agriculture and land colonization in the vicinity of the Hanford site during the era of World War I and the 1920s. This plan was initially discussed by the Prosser and Yakima Commercial Clubs in 1918 as a way to have Congress fund low-interest loans to war veterans, in order to help them settle and cultivate undeveloped land in the region. Unable to persuade Congress to finance the enterprise, eastern Washington businessmen and politicians obtained state support, and in 1921, the Washington Department of Conservation and Development opened the bidding for a soldier "settlement" to interested communities throughout the state. Communities had to provide at least 1,000 acres of land for sale to the state at a price per acre not to exceed the cost of state school tracts. The state, in turn, would sell the land to interested veterans on a lottery basis, with the soldiers repaying the land debt at four-percent interest. The task of investigating neighborhoods that desired the project, and of selecting the final site, was delegated by the state to a special committee of the American Legion. Within the district surrounding the Hanford Site, bids for the settlement project were submitted by Richland and jointly by White Bluffs-Hanford. Richland's acreage was part of the old Grosscup ranch, located at the "Y" on the north side of the Yakima River near its mouth. However, White Bluffs veteran Fred Weillocated records in the Benton County courthouse wherein Grosscup had requested that his taxes be 
lowered because he claimed that a large portion of his land had become alkaline. Following this disclosure, the American Legion chose White Bluffs- Hanford as the community most suited to receive the undertaking, with Manson on Lake Chelan as the second choice (Fridlund 1985, p. 166; Harris 1972, pp. 117-19; Parker 1979, p. 206).

The White Bluffs-Hanford Soldier Settlement Project was promoted avidly, but after five years it was declared a fmandal failure. Initially, 58 tracts of 20 acres each were made available to eligible veterans. The total number of plots later reached 90 . Each tract came with a well containing an irrigation pump and motor, a threeroom cottage with two porches and a cellar, a combination bam and cow shed, and a small poultry house. The total cost to each soldier was nearly $\$ 5,000$, with slightly over $\$ 600$ required as a down payment. To discourage speculation, resale within one year was not allowed. Fliers advertised the region's "mild climate similar to that of Southern California," long growing season ("204 days"), location "in the heart of one of the world's most famous irrigation belts . . . easily tillable [soil] with no danger of an alkali problem," and great productivity (parker 1979, pp.244-47).

The first settlers moved onto their land in 1922, and the American Legion held dances to help 13 of them get acquainted in the district Director Dan Scott, a state Senator from Ritzville, and manager J.C. Scott, a Franklin County farmer, advised the newcomers on the techniques of farming in the dry, volcanic soil. Settlers were instructed "not to level too much, but to disturb the earth as little as possible, and to keep it wet to prevent it from blowing. It was to be seeded to alfalfa or some other cover crop that would come up quickly to prevent the loss of topsoil." Additionally, they were told to plant early fruits and vegetables such as strawberries, cherries, and asparagus, in order to compete favorably with established fruit-raising communities. However, drought, falling crop prices, and difficulties with the light, airy soil caused many veterans to default on their payments and leave the area, and some tracts of land were never sold at all. In July 1926, the state declared the enterprise a failure, sold unsettled or foreclosed tracts at public auction, and gave deeds in lieu of further trouble to 50 soldiers who had made partial payments. At the auction, two White Bluffs speculators bought over 20 of the plots (Harris 1972, pp. 118-20; Parker 1979, p. 259).

\section{$\underline{\text { Wartime Agriculture }}$}

Agriculture in the Hanford vicinity was affected by World War I and forces in the first decades of the 20th century. There were no major booms or new irrigation projects in the territory between 1911 and the war years, with the exception of an ill-fated effort to irrigate the Horse Heaven Hills. Farms in the Hanford neighborhood, for the most part, experienced steady growth during the immediate prewar years, when the first mandatory spraying laws and fruit shipping laws were enacted. Many of the regional growers' associations were formed during these years. The Richland Growers' Association organized in 1911, the White Bluffs District Growers Association and the Hanford Growers Association both were founded in 1912, the Benton County Poultry Association and the White Bluffs Hog Breeders Association were created in 1911, and the KahlobJS Warehouse Company (later the Kahlotus Co-op) was constibJted in 1916. In Kennewick, the Big Y and the Three Rivers Growers Associations also were founded during this era. The two organizations were bitter rivals for many years until their merger in 1929. Corn became an important crop, and a Prosser man took first place in the St. Paul Com Show in 1916 (parker 1986, pp. 180-220; Parker 1979, p.15S; Phillippay 1973, pp. 26-32).

World War I brought worldwide shortages of food and subsequent prosperity to farmers in the Hanford locale. Food production increased in 1918, and federal food administrators called for a 50-percent increase in food shipments to the Allied nations in 1919. In Franklin County, wheat remained the dominant crop. In Benton County, row crops were important but fruit crops, especially apples, became foremost. In 1918, the county shipped almost 500,000 boxes of apples, with a total value of over $\$ 700,000$. Three years later, Delicious Apples brought a price of $\$ 100$ per ton, while pears brought $\$ 35$. Both were important cash crops for the area. In 1920, John H. Smith of Kennewick introduced winter-hardy walnut trees into the district

The greatest agricultural problem created in the expanses around the Hanford Site as a result of World War I was the farm labor shortage. The absence of so many men of draft age was devastating during the harvest season; in 1917 and 1918, many area schools closed for a month, beginning in mid-September, in order to allow children to help their families with the harvests (Fridlund 1985, pp. 12-15).

Following World War I, a drought lasting nearly 10 years began in the territory surrounding the Hanford Site. The effects were felt most harshly in Franklin County, because that area contained the fewest acres under irrigation; the wheat crop there declined noticeably. With the exception of some pear blight, fruit and other crops in Benton County remained large and healthy, but market prices began to slump downward beginning in 1922 . The 
dairy industry throughout the region experienced severe price downturns lasting throughout the 19205 and into the Great Depression. Many dairy fanners went out of business, and milk for the local cities and towns had to be bought from several far-flung sources (phillippay 1973, pp. 32-40; Parker 1986, pp. 185-90; Parker 1979, pp. 29596).

However, in contrast to the poor record of the Soldier Settlement Project, some outstanding fanns existed in the vicinity of the Hanford Site during the years of World War I, the 1920s, and the 1930s. Ballygreen Farm, a 60acre tract located about equidistant between White Bluffs and Hanford, was pmchased in 1907 by C. F. Whaley and Company. The owners placed the unit in the charge of $\mathrm{H}$. W. Reaugh, a young graduate of the state agricultural college (later Washington State University). One portion of the farm was planted to apples, pears, and grapes, in order to make notable jellies and marmalades. Alfalfa, grain, and field peas were grown on the rest of the tract as feed for the hogs for the farm's famous Little Pig Sausage and Mincemeat Some cattle and chickens were kept as a sideline, and head cheese as well as canned chicken also were marketed. Over the ensuing years, the farm won a number of awards for its Black Tokay grapes, pears, and livestock at agricultural shows throughout the area. In 1939, the farm was purchased by a Seattle woman, and it was still operating when the federal government took possession of the land in 1943 (parker 1979, pp. 87-88, 352).

While a few notable fanns highlighted the Hanford vicinity in the interwar period, agricultme on a small, family-owned scale continued as the dominant occupation and lifestyle in the district There were some changes in farming in the territory during these years. Perhaps the biggest material changes were the introduction of gasolinepowered farm machinery and the widespread replacement of diesel-powered irrigation pumps with electrical pumps. One electrical pump usually was substituted for two of the diesels, since the electrical pumps were so much more reliable (parker 1979, p. 83).

The most significant policy changes in agriculture in the Hanford area during the interwar era were measures introduced by the federal government during the Great Depression: acreage limitations, production curtailments, price supports, and low-interest fann loans. Other alterations in local agricultural patterns were relatively minor. Farmers in the tracts remained conservative, as they amply demonstrated in a pitched battle, conducted with clubs, pipes, chains, hoses, and rocks, against striking fruit pickers from the Industrial Workers of the World union in the Yakima Valley in 1933. Local growers also patrolled the trainyards searching for "potential troublemakers" from the union, and on some occasions beat, tarred, and feathered transients suspected of being union organizers (Newbill 1977, pp. 80-86).

The Northern Pacific Railroad remained active in boosting settlement and "homesteading" in the Hanford neighborhood throughout the 1930s, holding festive promotional picnics at Volunteer Park in Pasco and at other locations. Between 1931 and 1937, about 488 families of midwestern immigrants, as well as those from Alaska, Canada, and other locations, bought irrigated fanns in this region through the railway's land agent, A.C. Larsen (Van Arsdol 1958, pp. 31-36; Oberst and Smith 1983, pp. 59-64).

Land colonizers also came to the Hanford vicinity in the 1930 s as part of the overall migration out of the midwestern "dustbowl," in response to district advertising efforts and as the result of independent searches. In 1939, after two years of extensive investigation of irrigated farmlands from Texas to the Pacific Northwest, a group of Mormon families chose the Hanford-White Bluffs district for permanent settlement, and they began to move in (parker 1979, p. 352). Nevertheless, there was still abundant non-irrigated land in the territory. In 1938,20,000 sheep from Kittitas and Yakima Counties wintered either on or near the Hanford Site at Gable Mountain, near Priest Rapids, and between Vernita and White Bluffs (Parker 1979, pp. 276, 341).

By 1935, agriculture still dominated the economy of the Hanford area, and new crops and preserving techniques gave clear indications that farming would continue to expand and thrive in the region. Nine of Kennewick's eleven manufacturing plants revolved around agriculture in 1935. Among these, Church's Grape Juice Factory, Twin Cities Creamery, two canneries, a meat-packing company, and a flour mill were highly successful. The technique of quick-freezing produce began in the area in 1938, and more than 1,000 tons of asparagus was frozen in Kennewick that year. The following year, the rivalry between Pasco Growers and the Big Y Growers intensified as each added freezing units and competed for the bean, peach, and asparagus crops. That same year, a large Walla Walla company opened a new local branch with a new vacuum-sealing process. In 1940, both apricots and baby lima beans were grown for the first time in lands surrounding the Hanford Site, onions were cultivated successfully, and mint acreage in Richland increased to 400 acres. The mint crop, introduced only a few years previOUSly, flourished in the fine, volcanic soil, and yields were as high as 60 to 100 pounds per acre. The J. K. Lake Company designed a special label for the clear, light mint oil that was extracted in six local stills, and "Richland, Washington, Mint Oil" brought \$50,000 into the economy (parker 1979, pp. 341, 357; Parker 1986, pp. 271-74, 291-96). 


\section{$\underline{\text { IrrigatiQn Activities }}$}

There were few changes in the reclamatiQn systems in the lands arQund the HanfQrd Site in the interwar years, and nQ majQr irrigatiQn cQnstructiQn was undertaken. The federal gQvernment aided area watering districts with imprQvement loans and grants during the DepressiQn years, and cQnstructed the Grand CQulee Dam, which WQuld permit widespread land reclamatiQn in the CQlumbia Basin in the post-WQrld War II era. In the meantime, the watering systems of both White Bluffs-Hanford and Richland were involved in bankruptcies, protracted court suits, and reorganizatiQn plans. The Hanford IrrigatiQn and Power Company went banknupt in 1913. Eastern investQrs bought the rights to the Hanford Company's prQperties, but, facing fmancial difficulties themselves, decided to liquidate in 1928. In 1931, after further legal delays, water users in the district were able to purchase the facilities fQr themselves. At a CQst of only $\$ 45,000$, they acquired the entire system, which had cost $\$ 1,500,000$ to build in 1907, and renamed it the Priest Rapids Irrigation District. The new owners made immediate improvements to the Priest Rapids power plant and the lateral ditches, and throughQut the 1930s they expanded the acreage under their system. In 1938, they installed sprinkler systems, which eliminated the need fQr much of the difficult leveling Qf the fme, sandy SQil (parker 1986, pp. 139-50).(a)

The sale Qf surplus power from the Priest Rapids Dam to the Pacific Power and Light Company paid for much of the wQrk, especially after new generating machinery boosted the dam's Qutput to 2,000 kilQwatts in 1939. Later that year, the voters in the system authorized a $\$ 250,000$ bond issue tQ increase the acreage served by their ditch to 10,500. Prosperity seemed to be returning to the locale, and the White Bluffs Spokcsman proclaimed: "The valley has the climate and the land, and with sufficient water, there is nQ reason why it should nQt be permanently and prominently on the map." (parker 1979, pp. 165,268,280,341; Harris 1972, pp. 149-52.)

In 1912, the Lower Yakima Valley Irrigation Company, attempting tQ stave off fmancial collapse, reorganized as the Horn Rapids Irrigation Company. Later, after lengthy court discussions, Richland's reclamation system was purchased by its users and broken into two separate entities: the Richland Irrigation District ditch (the old "Riverside" canal) headed on the north side of Horn Rapids Dam; and the Columbia Irrigation District canal (originally the private Nelson Rich canal, expanded by the ArnQns in 1905) headed on the south side of the same structure, watering tracts on both sides of the Yakima (parker 1979, pp. 157, 276).

During the interwar era, when agriculture still dQminated the local economy in the vicinity of the HanfQrd Site, cQmmunity organizatiQns were centered in farming. Granges, chapters Qf the national Order of the PatrQns of Husbandry (founded in 1867), addressed the problems Qf transportation, marketing, obtaining affordable seed and machinery, special educational and social barriers created by the isolation of farm life, and other difficulties faced by farmers.

The natural environment in the vicinity Qf the Hanford Site provided ongoing challenges to the farmers. They were bothered particularly by animals whQ preyed upon their crops and their poultry; community drives to kill jackrabbits, rattlesnakes, crows, hawks, magpies, coyotes, and pocket gophers were held "whenever necessary" (parker 1979, p. 178). It was nQt unusual for several thousand rabbits or birds to be killed in a single drive. In the 19408, however, the large influx of population to the Hanford neighborhood brQught so many sport hunters that the numbers of troublesome animals was kept down, and the need fQr drives ended (parker 1979, pp. 183,260; Harris 1972, pp. 145-46; Parker 1986, pp. 160-61).

Another natural challenge of the territQry surrQunding the Hanford Site, the fierce dust storms, affected all residents. Perhaps the WQrst wind and dust storm in local memQries occurred in June 1937, when packing sheds blew dQwn and electrical wires became tangled from Yakima to PendletQn, OregQn (parker 1986, pp. 322-28).

ISQlation also was a problem in the dusty expanses around the HanfQrd Site in the years before modern roads were CQnstructed, but area residents banded together and shared each other's interests. A school teacher, new to White Bluffs in 1922, recalled her first impressions as she approached the town "through more dry sagebrush country, then a patch of green and a ditch with a good head of water running in it. Sandy soil and sparse sagebrush were to Qur left .... Soon we came to the first buildings of the town. They looked old, dried out, hot and tired. Later we found the homes pleasant and comfortable .... It was a wonderfully free sort of place to live. The buildings weren't

(a) The U.S. Department of Agriculture had been experimenting with sprinkler irrigation in the region since 1971. Sprinklers removed the need for extensive land leveling, always an arduous task in the light ashy, windblQwn soil Qf the Columbia Basin. 
elegant but they were adequate ..., White Bluffs was isolated by indifferent roads and mountainous hills, which made it feel even more isolated than it really was" (Harris 1972, pp. 136-39).

\section{Natural Gas in the Rattlesnake Hills}

Although agriculture and a rural lifestyle continued to be the dominant norms in the territory surrounding the Hanford Site during the interwar period, some notable developments did not focus on farming. One such development was the discovery of natural gas underneath the Rattlesnake Hills. As early as World War I, drilling was begun there, and profitable pools of gas were found. By 1930, a great deal of drilling had taken place, four companies still were searching actively for the fuel, and a small settlement known as Gas Wells was in place. The Yakima Valley Natural Gas Company was already serving two hundred customers in Prosser, Grandview, Mabton, Sunnyside, Zillah, and Toppenish through a 40-mile pipeline, with 40 more miles of smaller distribution lines. This company also was planning a line to Yakima and Wapato, and another along the irrigation canal from Horn Rapids on the Yakima River through Badger Canyon, culminating in serviceable connections in Kennewick and Pasco. Rumors of big oil discoveries abounded, especially in 1930 when Shell Oil Company sent representatives to lease land and investigate the Rattlesnake Hills. The Richland Advocate predicted: "We are now on the threshold of a real oil and gas boom in the district." (Harris 1972, p. 277.) However, oil was not found.

By 1934, about 50 additional customers in the middle and upper Yakima Valley were being served by 15 natural gas wells in the Rattlesnake Hills, and a test well had reached down almost 2,000 feet. The Yakima Valley Natural Gas Company had gone into bankruptcy, however, without building its Kennewick-Pasco line. By 1936, Northwest Natural Gas had become the controlling enterprise in the region. Company geologists were convinced that low pressure in the existing wells meant that the gas which they were tapping near the surface was merely seepage from a huge pool of gas existing beneath the hard basaltic cap of the terrain. However, in 1937, when a test well penetrated nearly 3,000 feet and found nothing, the true picture of a small and declining gas reserve had to be faced. Northwest Natural Gas had to supplement the gas being supplied to its customers with butane, and installed a larger compressor just to squeeze gas from the existing wells. The company's compressor station on Rattlesnake Hills finally closed in 1941 (parker 1979, pp. 323, 365-66; Parker 1986, pp. 175-80,270-72).

\section{$\underline{\text { Automobiles }} \underline{\text { and }} \underline{\text { Roads }}$}

Several crucial improvements in roads and bridges during this period helped to make auto travel through the Hanford territory more feasible. In 1915, the "Yellowstone Trail" was completed; it was the first auto highway spanning the nation. Its route went westward from Albany, New York, through Chicago, Butte, and Spokane, then south through Colfax. It then turned southwestward and traversed the vicinity of Hanford through Walla Walla and Pasco, crossed the Columbia River via the Timmerman cable ferry at Richland, and proceeded up the Yakima Valley and across the Cascades to Seattle. An alternate, "scenic" route through this neighborhood, marked on the Trail's map, crossed the Columbia by ferry at Wallula, and then continued through Kennewick and Richland (Parker 1979, p. 181). In 1917, Benton County let a contract for a steel bridge spanning the Yakima River south of Richland, and the Richland-Benton City Road was finished and surfaced (p. 187). During this era, the more expensive and welltraveled roads were surfaced with crushed rock and then oiled. The first cement-paved road in Benton County was a five-mile stretch between Richland and Kennewick, poured in 1926 and financed by Washington State. Later that same year, the state extended the highway through Kennewick to the Columbia River bridge leading to Pasco (parker 1986, pp. 206-16).

Importantbridge and road construction continued in the Hanford neighborhood throughout the interwar years. In 1922, a group of private investors finished building the first Pasco-Kennewick highway bridge. In the spring of 1928, portions of the bridge were washed out by heavy water flow and jammed driftwood, and travelers had to resort to ferry service while repairs took much of the year. Washington State bought the bridge in 1931, removing the tolls (Oberst 1978, pp. 150-56).(a) The present steel and concrete Fallon bridge between Richland and West Richland was built in 1923, the same year in which the Hanford-Vernita and the Horn Rapids-Hanford Roads were completed. Also in 1923, Benton County's portion of the Inland Empire Highway (Van Giesen Street) was surfaced with crushed rock, and the highest volume ever handled by an American highway, 64,022 autos, passed over

(a) The bridge closed in 1978, when it was replaced by the present cable-stay span. At 80 feet wide and over 2,500 long, it was the world's longest such bridge at the time it was constructed, and the first such stayedgirder structure in the United States. The second Pasco-Kennewick span, the "Blue Bridge," was dedicated in 1954. 
the Yellowstone Trail (parker 1979, p. 211). The cement highway traversing Columbia Park between Kennewick and Richland was fmished in 1926. 1929 saw the opening of the Lolo Pass Highway to Montana, the Naches Pass Highway to Puget Sound, and a road between White Bluffs and the Yakima County line.

The following year, the state announced that Kennewick would be on the 765-mile loop highway to be built from Seattle to Spokane. That development in 1930, combined with the increased popularity of camping and auto travel, gave impetus to the building of Richland's first business, combining a cabin campground, gas station and lunch counter, located at the "Y" on the north side of the Yakima River. In 1933, the 2Q-mile road from Richland to White Bluffs-Hanford, part of the state's effort to improve farm-to-market roads, was completed. At that point, Benton County had a total of 350 miles of roadway, 52 miles of which were oiled. In 1938, Washington State assumed operation of the Hanford Ferry, removing the tolls, because it was considered to be a vital link in the Yakima-Connell Road. The White Bluffs and the Wahluke ferries also still operated at that time. Additionally in 1938, the White Pass-White Bluffs Highway Association held a big picnic to pressure for the construction of such a road. (The route was fmished shortly after World War II.) As evidence that the auto public was "moving about" more, two new garage businesses opened in Richland in 1938 (parker 1979, pp. 259, 277, 305, 343; Parker 1986, pp. 225-31).

\section{The Great Depression}

Although road building and the purchase of automobiles indicate some degree of prosperity in the territory surrounding the Hanford Site during the interwar period, the Great Depression of the 1930s inflicted severe suffering in the area. Crop prices had begun to fall in the postwar contraction of the early 1920s, and they did not reach the high levels of World War I again until the World War II years. The agriculturally based Hanford district had not experienced the speculative, inflationary boom that occurred in the industrialized portions of the United States in the late 1920s. Consequently, this region did not undergo an economic "crash" in late 1929 or 1930. The Great Depression was slow to reach the Hanford vicinity; in fact, farm prices rose slightly in 1929, and this rise, combined with railroad competition which lowered freight rates in 1930 and 1931, brightened the area's agricultural picture a bit. The impact after 1931, however, was devastating.

The Great Depression reached the expanses around the Hanford Site with terrible force in 1932. By then, overall values for farm products and feed had fallen off by 30 percent from the levels of 1930. By 1934, all Washington farm goods except potatoes and wool were selling at prices below those of 1917. Each issue of local newspapers carried stories of tight money and business closures, as retail stores, banks, insurors, and other firms dependent on sales to the local agricultural population found themselves without paying customers. In 1932, railroad employees in the territory received a 10-percent cut in their wages; many lost their jobs entirely and waited two to four years to be recalled. The same year, a cattle drive, reminiscent of an era 60 years earlier, was made by Yakima Valley ranchers as a way to save shipping costs and realize a profit Five hundred head of Herefords from Toppenish were driven to the Rattlesnake Hills, then across the Hanford Site where they swam the Columbia River at White Bluffs, and then northward along Benjamin Snipes' route to British Columbia (Parker 1979, p. 295-98, 315).

Despite these desperate developments, Kennewick's newspaper professed: "The eyes of the state are on Kennewick. This valley is least hurt by the general depression conditions." Fruit and vegetable crops remained abundant, and two local growers' cooperatives, Priest Rapids Valley Growers of Hanford and Washington Early Crops of Kennewick and Pasco, invested along with three other farm associations in a warehouse in Spokane. The opening of a new asparagus cannery in Walla Walla brought hope to farmers in the Hanford vicinity, and some growers, especially in the Highlands section of Kennewick, removed fruit trees in order to have room to plant more asparagus (parker 1986, pp. 271-76). The quality of fruit crops remained high, however, and both Black Tokay and Thompson Seedless varieties of grapes from Richland went to the Chicago World's Fair in 1933. Preserved in a large glass jar, they received extravagant praise (parker 1979, p. 315).

\section{Electric Power Regulation}

County governments in Washington were charged by the state constitution with the "entire and exclusive superintendence of the poor" during the early Great Depression years, but state government became more responsive and helpful as the desperate economic conditions continued. The state's greatest contributions lay in regulating the electric power industry. In August 1933, after hearing complaints that exorbitant prices were being charged for power, the State Board of Public Works ordered the three major power suppliers in the state to reduce costs for the operation of irrigation and spraying pumps. In late 1934, Public Utility Districts (PUDs) were approved by the state legislature. Under this system, counties voting to become PUDs could buy power distribution facilities from the 
private companies previously operating them, and sell electricity to district residents at cost. However, most counties in Washington waited to form PODs until after 1937, when the Bonneville Dam was finished and the Bonneville Power Administration (BPA) was created. The BPA was established by the national govemment to sell federally produced electric power at cost to PODs and to the Rural Electrification Administration. However, even before the Bonneville Dam was completed, more electricity was generated than was used in Benton County. The power plants on the Yakima River at Prosser and on the Columbia River at Priest Rapids, which were both originally erected to power irrigation pumps, generated surplus power, and this situation intensified when the Priest Rapids station added new machinery in 1938 (parker 1979, pp. 323, 341).

Despite the efforts of local and state governments to help the district surrounding the Hanford Site during the Great Depression, it was several federal projects that sustained the area and prevented much more severe, regional fmancial collapse. The Agricultural Adjustment Act of 1933 established a domestic allotment system for seven major commodities, among which wheat was the most significant in this neighborhood. Growers in the territory formed a Wheat Control Association, and 70 percent signed to receive payments for reducing their wheat acreage in the first year of the program. In 1933, Richland's Columbia Irrigation District received a Reconstruction Finance Corporation (RFC) loan, and subsequent loans to irrigation boards in Richland funded the addition of sprinklers and improvements to both the upper and lower aprons of the Hom Rapids Dam. Another 1933 RFC loan to the Highlands Irrigation Project in Kennewick added 1,000 acres to be developed as 70 subsistence homesteads available only to those on relief. A total of 150 such farms were developed over the ensuing five years. The large Roza Irrigation Project in the lower Yakima Valley began hiring men, with veterans receiving preference, in August 1933. The 1936 Soil Conservation and Domestic Allotment Act allowed agricultural loans to be refinanced for extended time periods and compensated farmers who improved their lands in accordance with specific recommendations, enriched the soil, and reduced production. The Federal Surplus Commodity Corporation purchased more than 50 million pounds of surplus food in Washington in 1936, with the results that market prices increased slightly and then stabilized. The surplus food was given to relief agencies for distribution.

In 1935, less than one-tenth of Hanford area farms were served by electricity. That year, the national Rural Electrification Administration (REA) was created to promote the formation of non-profit farm cooperatives to bring electric power to rural homes. Low interest federal loans were made available to fund installation of the power lines. In subsequent years, REA loans brought electricity to much of the agrarian Columbia Basin. One 1939 loan for \$104,000 fmanced an additional 92 miles of power lines in Benton County. In 1937, a Public. Works

Administration (pWA) grant to the new, small Riverland Irrigation Project at Vernita made possible the reclamation of 3,000 acres ofland (parker 1979, pp. 308-30; Parker 1986, pp. 291-330).

The entire territory was assisted by the formation of the Federal Deposit Insurance Corporation in 1933. Also, national programs such as the PWA and the Civil Works Administration (CWA) permitted the construction of schools, community recreation halls, and many other projects in the Hanford district. As early as 1933, the CWA was sponsoring 29 undertakings in Benton County, although it reduced men's wages from 50 cents to 30 cents per hour in order to keep operating. Among the CWA and PWA benefits in the territory were extra teachers at schools in Richland, White Bluffs, and Hanford, funds for new schools in Richland and Kennewick, community halls in both White Bluffs and Hanford, jail and fire station improvement monies, and roadbuilding aid. In May 1941, all minor WAP projects in the nation were cancelled due to the defense emergency. Richland's irrigation work was among those programs affected, and 20 local men lost their jobs (parker 1979, pp. 308-36; Parker 1986,291-325; May 1972, p. 70; Phillippay 1973, pp. 55-60).

Although the Hanford region realized many advantages from the national programs of the Depression era, the most decided and far-reaching impacts were produced by the construction of the Grand Coulee Dam. This dam made possible enormous electrical power generation as well as the development of the vicinity's largest reclamation enterprise, the Columbia Basin Irrigation Project, in the post-World War II period. Ground was broken at Grand Coulee in July 1933, with actual construction work commencing the week of October 12. In June 1935, President Roosevelt ordered the Bureau of Reclamation to proceed with the high dam (Lavender 1958, p. 443).

The Grand Coulee Dam's first benefits to the territory surrounding the Hanford Site were the jobs it created, and there is no question that these jobs eased considerably the burden of relief in the district. Applications poured in at an average rate of 150 per day as soon as the building contract was signed, and one year after the building began, slightly over 1,500 people were employed in the project Eventually the enterprise employed approximately 7,000 people (Sundborg 1954, pp. 273-76). Water began to be retained in the partially completed reservoir (Lake Roosevelt) behind Grand Coulee Dam in 1939, and the first power was delivered out of the huge generators in October 1941. Bonneville Dam was completed and started electrical generation in 1938. In 1940, the Midway 
Substation,located just upstream from Vernita on the northwest edge of the Hanford Site, was built for the mammoth Bonneville-Grand Coulee power lines (parker 1979, pp. 350-51; Lavender 1958, p. 443).

\section{Columbia Basin Port $\underline{\text { Systems }}$}

At the same time that the Grand Coulee Dam was being built, many people living in the Hanford vicinity began promoting the development of a port system and the construction of additional darns in the area. In 1934, R. M. Huntington, President of the Walla Walla Chamber of Commerce, compared the extremely high inland freight rates to ocean-going rates. He urged residents along the entire stretch of the Columbia between Wallula and The Dalles and along the Snake River from Lewiston, Idaho, to Pasco to unite behind a regional port systems plan. Huntington advocated the immediate building of navigation dams on the Columbia River at Umatilla Rapids, at Celilo, and at the junction with the John Day River, construction of five lesser dams along the Snake River, channelization of the Columbia between Umatilla and Celilo, substimtion of sea-going locks for barge locks in the Bonneville Dam plans, improvement of navigation possibilities on the Columbia above Kennewick, and unification of all local community organizations into one central body to press for river development. Under this plan, both Pasco and Kennewick would become seaports.

Later that same year, Marshall W. Dana, Portland's Regional Public Works Director, urged the federal government to establish a Columbia River Authority, similar to the Tennessee Valley Authority, to oversee hydroelectric development, irrigation, drainage, fisheries and transportation along the Columbia. Such an agency was not created, so in 1935 local communities along the Columbia and Snake Rivers formed the Inland Waterways Association to promote Huntington's plans. Leaders in the Hanford district agitated strongly for a dam at Umatilla Rapids throughout the 1930s, and the Army Corps of Engineers conducted a survey of the site in July 1938. However, funds already had been committed to the John Day Dam, and Congress denied funding for the Umatilla construction on the basis that too large a proportion of development funds already were being spent in the Pacific Northwest (parker 1986, pp. 302-03, 320-34; Parker 1979, pp. 321, 341). The McNary Dam at Umatilla Rapids was completed in 1954 and The Dalles Dam was built at Celilo Falls. Priest Rapids Dam was completed in 1960, Wanapum Dam in 1966, and Wells and Chief Joseph dams were finished further upstream near Chelan and Brewster. Four darns were erected along the Snake River: Ice Harbor, Lower Monumental, Little Goose, and Lower Granite; and in 1975, Lewiston, Idaho, became a seaport. The Port of Pasco was created by the voters in April 1940, allowing that city to build large docks, wharves, warehouses, grain elevators, and oil storage tanks. Dedicated in October 1941, it was called the Port of Pasco Industrial Park, and became known during World War II as "Big Pasco" (Oberst 1978, p. 84; Oberst and Smith 1983, pp. 40-49).

\section{Town-Building Milestones}

The cities and towns of the Hanford region also passed many of the traditional milestones of development during the interwar years. Hospitals, libraries, new schools, police and fire departments, and other institutions were constructed or improved during this era. A Kennewick school building was completed in 1911 at the fabulously expensive cost of $\$ 50,000$. Hanford's high school, along with the gymnasium housing the grade school, burned in 1937, and the pupils were sent to White Bluffs. The latter town voted funds to build a new high school in 1938 . In 1927, Sacajawea State Park was established at the confluence of the Snake and Columbia Rivers by the Pasco Daughters of the Pioneers, and the Washington State Historical Society placed a marker commemorating Lewis and Clark in the park. In 1931, the park was deeded to the state (Oberst and Smith 1983, pp. 5-9).

As in earlier eras, fires and illnesses were among the events feared most in the territory. Major hotel, school, and business fires occurred throughout the vicinity, most notably in 1929 when flames destroyed the Vernita school, the Yakima Fruit and Cold Storage plant in Kennewick, the apple warehouse in Hanford, the Richland Cash Store, and the Richland AdVocate building. Grass fires were a scourge in the hot, dry, windy district, and 1939 brought a spate of them. Thirty thousand acres across the Columbia from White Bluffs burned in a two-day blaze that summer, and another grass fire destroyed much of the range along the Priest Rapids-Yakima Road. The flu epidemic of 1917-18, a problem for the whole nation, was the most serious plague to affect the Hanford region during this era. To help control the illness, schools were closed, travel was discouraged,large gatherings were prohibited in most towns, and many children were kept at home by anxious parents. A smallpox seige affected the area during the winter of 1922-23, a wave of scarlet fever swept through the schools in 1935, and during the following year a polio scare caused local doctors to urge people away from crowds. Schools instituted health testing and immunization programs during the 1930s. Tuberculin tests, physical exams, and vaccinations for diptheria, smallpox and typhoid were offered beginning in 1932 (parker 1979; Oberst 1978, p. 142; Oberst and Smith 1983 , pp. 82-95; Phillippay 1973, pp. 36-48). 
The interwar period was a time of extremely slow population growth in the district, and in some cases the harsh economic conditions caused declines. The greatest growth occurred early in the era. The population fluctuations of Richland, White Bluffs, and Hanford can be seen in Table 0.2.

As the patterns in Table 0.2 demonstrate, population shifts between some decades were extremely slight Between 1920 and 1930 the population of Benton County increased by only 49 people (parker 1979, pp. 201, 277, 357).

\section{Summary}

In the years between 1910 and the beginning of World War II, the territory surrounding the Hanford Site underwent significant development, but it retained its predominantly agrarian character. Major transportation advances were made with the building of The Dalles-Celilo Canal and several important highways and lesser roads. Agriculture and irrigation continued to expand, although many farms were foreclosed and many irrigation properties went into receivership during the Great Depression. The small family farm remained the primary economic unit in the region, and land colonization and additional cultivation of farm acreage continued to be desirable goals. Towns continued to grow and to develop social institutions.

The Hanford locale participated avidly in efforts to win World War I. After the war, an abortive Soldier Settlement Project was attempted in the White Bluffs-Hanford district after World War I, but Northern Pacific Railroad recruitment of new farmsteaders, along with some independent colonization attempts, was more successful.

Extensive natural gas development in the Rattlesnake Hills proved elusive, but electric power became more widespread and affordable with aid from the federal Rural Electrification Administration and state legislation authorizing the creation of Public Utility Districts. Although local counties struggled to provide for unemployment relief, federal public works programs had the greatest impact in helping the region through the Great Depression. As the Hanford area began to emerge from the Depression, many residents spoke out in favor of comprehensive river development, dam construction, and port facilities to permit direct, upriver shipping by large vessels.

Military Endeavors. the Hanford Nuclear Reservation. the Columbia Basin Irrigation Project. and Population Demographics $\underline{0940}$ to $\underline{1980)}$

Examples of the new activities that would take place at the Hanford Site are shown in Figure 0.8. The territory in and around the Hanford Site sustained profound changes in the World War II era and in the postwar period. By far the most striking alteration was the creation of the Hanford Nuclear Reservation itself. The Hanford Site became a closed, military area, fenced and guarded by armed security patrols. The towns of White Bluffs and Hanford were evacuated completely; all residents sold their property to the government and relocated. The town of Richland also was requisitioned, and experienced phenomenal growth as it became the headquarters for the private industrial contractors that operated the Site for the Army, and later for the Atomic Energy Commission. First the E. I. du Pont de Nemours Company, and subsequently the General Electric Company (GE), built housing, schools, roads, a hospital, and many other facilities for its employees and their families. Pasco, Kennewick, and the entire surrounding region also underwent substantial expansion as a result of the Hanford installation.

Another large government enterprise, the Columbia Basin Irrigation Project (CBIP), was developed in the Hanford neighborhood in the period after World War II. This endeavor filled the northern half of Franklin County and parts of Adams, Grant and Lincoln Counties with settled farms to an extent never before witnessed. New towns such as Basin City were platted and constituted, while other small towns such as Othello, Moses Lake, and Ephrata experienced prodigious increases in population.

TABLE 0.2 . Populations in Richland, White Bluffs, and Hanford, Washington: 1910-1940

$\begin{array}{lrrrr} & \mathbf{1 9 1 0} & \mathbf{1 9 2 0} & \mathbf{1 9 3 0} & \mathbf{1 9 4 0} \\ \text { Richland } & 721 & 1,042 & 764 & 567 \\ \text { White Bluffs } & 323 & 387 & 672 & 501 \\ \text { Hanford } & \mathbf{3 6 9} & \underline{429} & \underline{429} & \mathbf{4 6 3} \\ \text { Totals } & 1,413 & 1,858 & 1,865 & 1,531\end{array}$




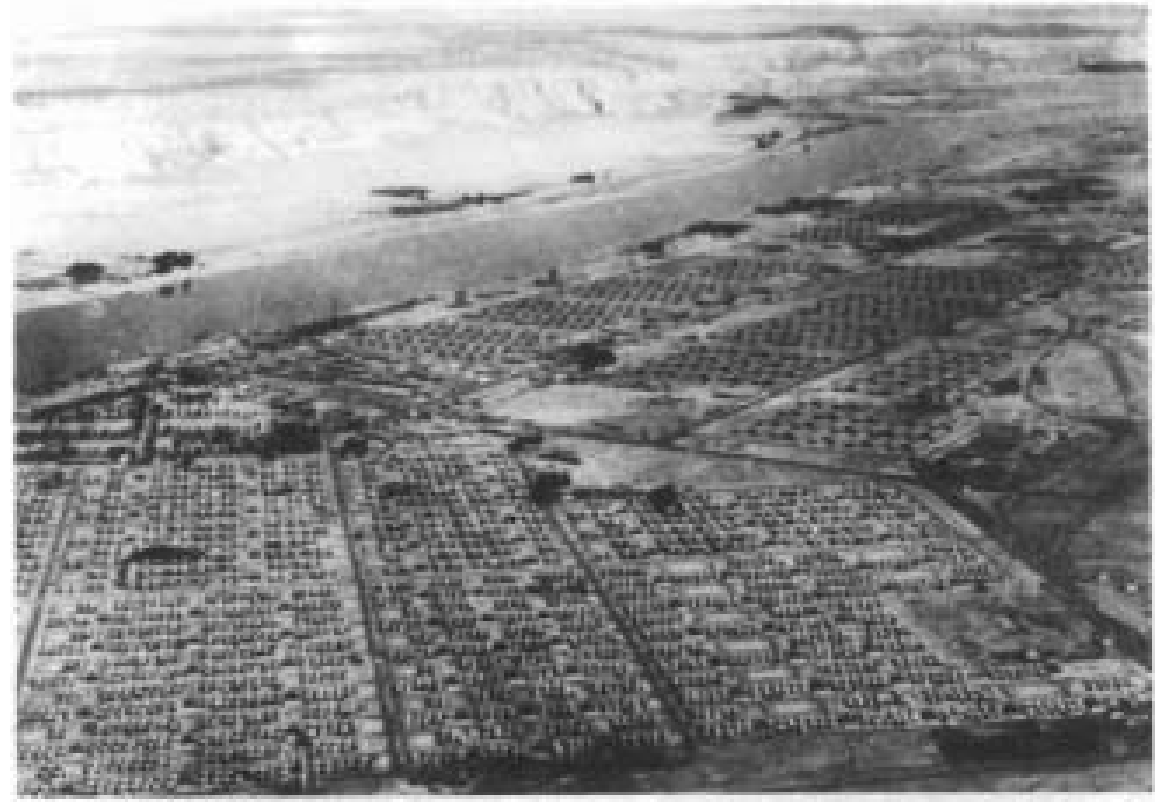

Early Construction Town
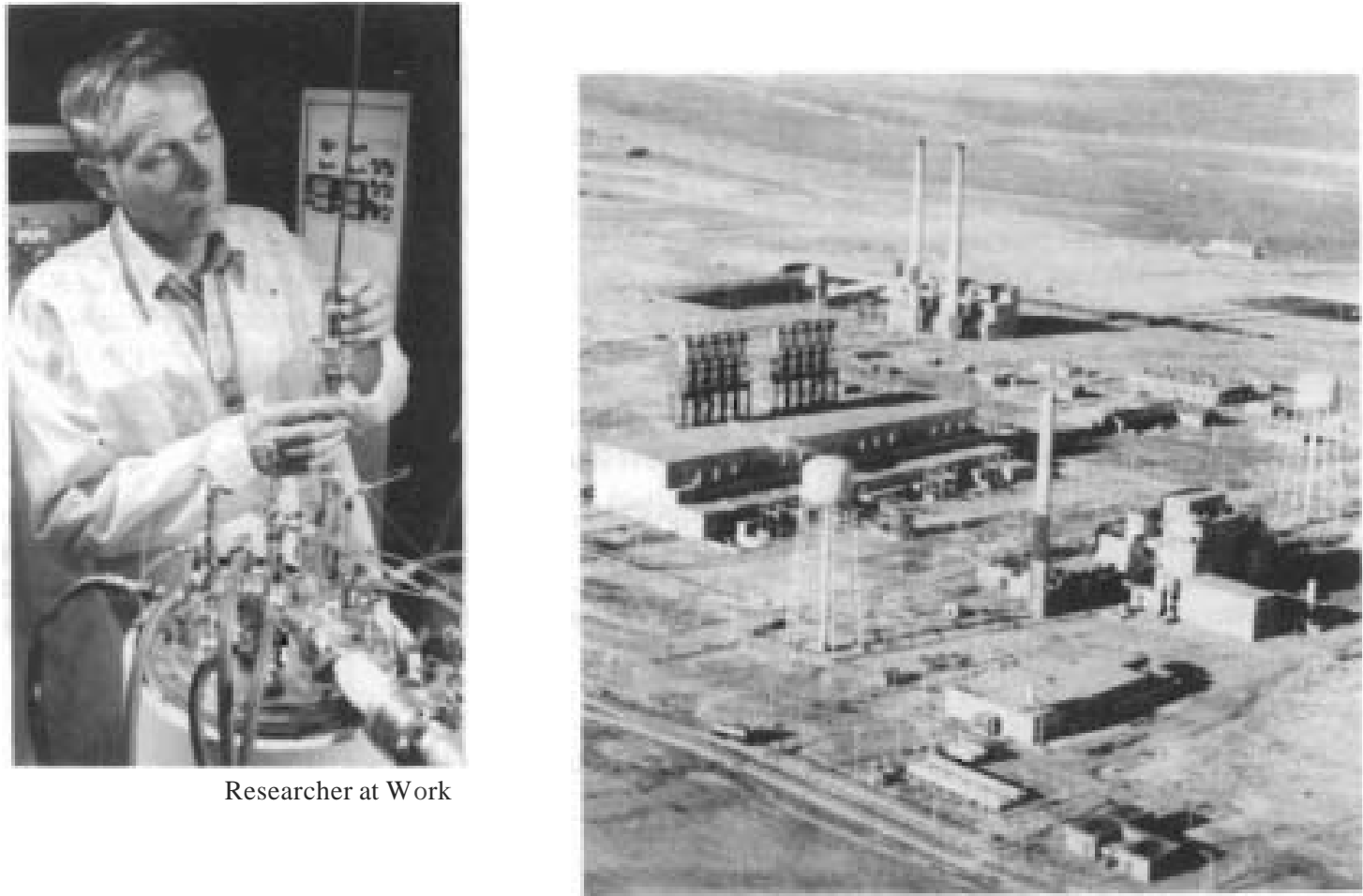

Nuclear Reactor

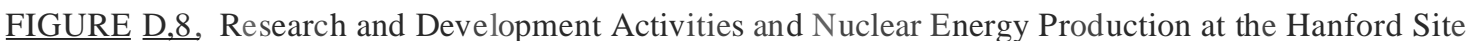


Aside from sheer growth, the district around the Hanford Site also changed in population composition. The building of the atomic reserve brought appreciable numbers of black people to the vicinity for the first time, and the farm labor shortage caused by World War II and by Hanford's construction brought Mexican migrants to the area to perform agricultural work. Additionally, Richland mushroomed with highly educated white-collar scientists and technicians, yet another distinct group in the regional population.

\section{The Military Endeavor}

In the early months of World War II, the territory surrounding the Hanford Site participated heartily in supplying the agricultural needs of the war effort, and in responding to draft calls, rationing programs. and fund and scrap drives. Harvests in the Hanford district were bountiful in 1940, 1941. and 1942, and in the months before the Japanese attack on Pearl Harbor, the Farm Security Administration (FSA) offered loans to help growers expand production. After the war began, skilled agricultural workers were urged not to leave the farms, and as each crop became ready for picking, growers scrambled frantically to fmd workers. In many cases, women volunteers saved the cherries. tomatoes. and other crops (parker 1979. pp. 365-67).

In 1941, the federal government sent a surveying team through the Saddle Mountain area and the bluffs along the Columbia River north of the Hanford Site to search for mineral and clay deposits that could be used in the manufacture of aluminum. Local drives for scrap aluminum and iron, tinfoil, rubber, rags, and paper were held during that year. In August 1941, small towns were asked to accept war industries as part of a plan to decentralize war production. The Kennewick City Council voted in favor of receiving war industries. and new housing construction began in 1942 in preparation for a sharp population increase (parker 1986. pp. 359, 369).

In 1942. Pasco became the focus of the Hanford area's direct military participation. Early that year, the Navy selected Pasco as the site of an aviation training base for primary (inexperienced) pilots. Navy procurement officers bought 2,285 acres of land near the present-day Tri-Cities airport from Franklin County, the Northern Pacific Railroad, and Franklin County Irrigation District \# 1. Residents of Benton and Franklin Counties helped the Pasco United Servicemen's Organization (USO) by providing free Sunday evening suppers and by donating much additional volunteer time. In recognition of Pasco's contributions to the war effort, the Navy commissioned the building of the frigate USS Pasco, which was launched from the Kaiser Corporation's shipyards in California in 1943. In late 1942, because it was planning to convert the Pasco air base to a retraining and regrouping station for experienced pilots, and hence would need more flight space for faster combat planes, the Navy took options on several long strips of land in the vicinity of Priest Rapids and the Saddle Mountains. One such tract was 86 miles $1001 \mathrm{~g}$ and 30 to 40 miles wide, and was intended for use as an air-to-air gunnery range. Permission for use of this irspace was granted at the highest military levels. The Navy also procured land options and contracted to build another air training station at Vista Field west of Kennewick. In early 1943, both projects were suddenly and inexplicably canceled. A few months later. Army Colonel Franklin Matthias, in charge of a secret endeavor near Hanford and White Bluffs, visited Captain B. B. Smith, commander of the Pasco Air Station, and apologized for canceling the two Navy enterprises, explaining that "the community facilities were already overtaxed with government projects" (Oberst 1978, pp. 84-91).

The Navy also expanded its operations to portions of the territory around the Hanford Site other than Pasco. After Navy plans to establish air training facilities near White Bluffs and Kennewick were annulled, the Army promised to fmd other gunnery space for the Navy near Prosser, but local and state politicians blocked this plan, asserting that it would "interfere too much with the agricultural economy of the community." The Army withdrew from the negotiations, but Captain Smith later went to Prosser and persuaded the owners to rent the land in question to the Navy on a "patriotic basis," with no legal challenges. Even though Smith was allowed to pay a very small portion of the land's value in rent, the landowners permitted the Paterson Ridge Range to function. This operation necessitated closing the Paterson-Prosser Road as well as the Paterson Ferry, but these facilities later reopened for night use. The Navy also rented land for an air-to-ground gunnery range near Juniper Flats in eastern Franklin County. (In the early 1960s, portions of this land, with its dwarf juniper forests and vast sand dunes, were used as a survival training ground by the first American astronauts.) In 1947, the Navy began leasing the old air-training station at Pasco to that city for use as a municipal airport. When the base was declared surplus, the city purchased it for $\$ 1$ and leased some of the buildings to the Pasco School District for use as junior high classrooms. In 1955, Pasco's possession of this large expanse of land was a key factor in determining the location of the Columbia Basin Community College. One hundred and fifty seven acres of excess airport land was designated for the college, and in its early years the school conducted classes in the former Navy recreation building. The city continued to operate the airport portion of the old base until the Port of Pasco assumed management in 1962. A new terminal building was 
dedicated in 1966. and a new control tower was erected in 1973 (Oberst 1978. pp. 101-06.133; Oberst and Smith 1983, pp. 68-70).

The Yakima Firing Center, located northwest of the Hanford Site in the high ridges between the upper Yakima and Ellensburg Valleys, was also created in the early World War II era. In 1941, as part of its massive preparation and retraining program, the Army recognized the need for a "maneuver area large enough to contain an infantry division." Army personnel arranged to lease 160,000 acres on Umtanum Ridge, at the western end of the current, larger Yakima Range, and began to conduct anti-aircraft artillery tests. In the subsequent two years, many military units from the Pacific Northwest (including Army artillery, infantry, engineer corps, and reserve and national guard outfits) utilized the range for training, temporary camp buildings were erected, and the Civilian Conservation Corps moved additional buildings from the Yakima Airport to house personnel. In the years immediately following the war, the range was used very little, and in 1947 approximately 60,000 acres were "dedudded" and returned to their former owners. In 1949 and 1950, Washington National Guard Wlits used the firing center for their summer training exercises. However, in 1950. the Army decided to expand the facility, and acquired additional lands to the east, bordering the Columbia River just west of Priest Rapids Pool. At that time, the range grew to $261,198.6$ acres, and since then it has been enlarged slightly to 263,130.83 acres. The range was used throughout the 1950s and until the mid-1960s by various units of the Army's Fourth Infantry Division based at Fort Lewis, Washington. A full-scale division maneuver was conducted in 1964, and a joint air-ground exercise was held by the Marine Corps in 1965. During the years from 1965-1972, no division was based at Fort Lewis, and the Yakima Firing Center was used almost exclusively for weekend and summer training missions by Reservists and National Guardsmen. Since 1974, the range has been utilized by many regular service units from the Army, Marine Corps, and Air Force, as well as by the Reserve Officers Training Corps (ROTC) and part-time branches of the military (Yakima Firing Center 1978, pp. 1-4). Most recently, the center has served as the Middle East desert simulation training groWld for the Army's Ninth Infantry Division, based at Fort Lewis, as well as a prime training facility for the Washington National Guard.

\section{The Hanford Nuclear Reservation}

The story of the beginning of the Hanford Engineer Works in 1943 has been told many times. In September 1942, General Leslie R. Groves, Deputy Chief of Construction for the Army Corps of Engineers, was appointed as the head of the Manhattan Engineer District (MED). The Clinton Engineer Works in Tennessee (now Oak Ridge National Laboratory) was chosen for the plants that would produce uranium-238 and plutonium. Two months later, Groves secured the services of E. I. DuPont de Nemours Company in a contract to build the plutonium production facilities. When DuPont accepted the assignment, company president Walter S. Carpenter suggested that, "for safety's sake ... because of ... unknown and unanticipated factor[s)" in the production process, the plant should be located far from populous Knoxville. Additional factors favoring a different site were the already heavy industrial drains on electric power near the Clinton Works, and the fact that about 75,000 acres of extra land would be required in an already crowded corridor. In December 1942, Groves agreed to choose another site, and sent Colonel Franklin T. Matthias on a two-week scouting tour of the western United States from Washington State to the Mexican border. Searching for a place which possessed ample electric power and a large water supply, and which was proximate (but not closer than ten miles) to rail transport lines, Matthias found the territory which comprises the present-day Hanford Site (Groves 1962, pp. 1-74).

Acquisition of the land for the Hanford Engineer Works took place in 1943, one of the biggest government land acquisitions ever initiated. On March 6, notices of evacuation came to affected residents of the lower Yakima and Priest Rapids Valleys, and the next weekly issue of the Kennewick Courier-Benonter was headlined: "RICHLAND. WHITE BLUFFS AND HANFORD AREA TO BE TAKEN BY HUGE WAR INDUSTRY ... MASS MEETING CALLED AT RICHLAND TO EXPLAIN THE WAR PROJECT TO RESIDENTS." (Groves 1962, pp. 74-77; Parker 1979, p. 375.) The truth about the secret atomic project could not be disclosed to the displaced people, but they were told that once they "knew the purpose for which they were giving up their property they would be proud of their part in assisting the government" (Harris 1972, pp. 151-53). The people affected were given between two weeks and three months to evacuate. although General Groves granted some extensions to enable farmers to harvest early crops.

Growers in the territory surrounding the Hanford Site expressed many concerns about the new project's effect on agriculture, and some of these problems were addressed briefly in 1943. The Priest Rapids Irrigation District was among the properties requisitioned by the government, and the company's pumping plant, main canal, and other watering facilities changed ownership on April 1. After that time, the few remaining ranchers and farmers who were permitted to stay on through the ripening and harvesting of their crops relied on old wells to supply water 
needs. The Richland Irrigation District was allowed to operate until it could collect all due tax bills. In May 1943, DuPont hired an agricultural specialist to oversee irrigation matters and the orchards on the government site; subsequently, Italian prisoners of war were brought in to transplant many of the fruit trees to the Yakima Valley (Van Arsdol 1958, p. 27).(a)

The original construction phase of the Hanford Engineer Works lasted slightly less than two years, and involved procurements and efforts of Herculean proportions. The ftrst basic structures for plutonium production, offices, 158 miles of railroad and 386 miles of roadway, equipment fabrication and machinery shops, hundreds of miles of fencing, over 50 miles of heavy electrical transmission lines and four step-down substations, a huge construction camp located at the Hanford townsite, and a new city of Richland large enough to house 17,500 people, were built between March 1943 and February 1945. The railyards at Pasco, as well as the Pasco Reconsignment Depot and the Port of Pasco. were kept busy around the clock during those 23 months, as 11,169 pieces of major construction equipment were brought into the region and then usually floated by barge up the Columbia River to the reservation. Forty thousand tons of structural steel and 780,000 cubic yards of concrete were among the many supplies used in the construction phase (Van ArsOOl 1958, pp. 24-25; Groves 1962, p. 89). Colonel Matthias spent most of his time procuring scarce, strictly rationed materials such as aluminum. copper. lumber, iron, steel, and graphite. Worker morale often was low on the isolated. windy Hanford tract; turnover and absenteeism ranged between 8 and 21 percent per month. In June 1944, to alleviate boredom and loneliness, DuPont built a large recreation hall and auditorium in two weeks, and brought in all forms of entertainment, including circuses and top dance bands. Early in 1945. the large construction camp at the Hanford townsite. which had housed and fed 51,000 people at the peak of the building phase, was abandoned. Most of the trailers were moved later to North Richland to house the families of General Electric and Atomic Energy Commission employees. The mess hall, recreation hall, and barracks were partially dismantled and used as temporary public buildings, office space, and even as homes in the early postwar period when construction could not keep pace with population growth (Van Arsdol1958, pp. 33,3740; Van ArsdolI970).

All of the construction work at the Hanford Site was done in utmost secrecy. In order to avoid informing the War Production Board of the project's true nature, the enterprise was not given the highest priority rating (AAA) for procurement and transport of materials. However, in a complicated wartime system, it could obtain an overriding priority when necessary. Only a small minority of the employees on the project knew the nature or purpose of the facilities they were building. Most people who viewed the massive walls of the plants being constructed, including journalists, offtcials, and workers. assumed that they were designed to protect against explosions. Almost no one at that time had heard of radiation (Van Arsdol1958, pp. 30,41-49; Groves 1962, pp. 27-28, 35).

In the territory surrounding the Hanford Site. rumors flew during the construction phase. Most prevalent among the stories were those which alleged that the plants constituted a huge (conventional) munitions factory, a bombing range, a chemical or germ warfare facility, a prisoner-of-war camp, a nylon and experimental synthetics plant, or a series of mines where valuable ores had been discovered. Critics claimed that the reservation was a makework refuge for privileged draft evaders, and jokesters asserted that it was a factory making President Roosevelt's ftfth-term reelection buttons or a summer home for the Roosevelts. One grim, persistent rumor of human experimentation circulated, and it was theorized that people were being killed and their bodies brought out under the ruse that Indian graves were being moved.

Plutonium production was first achieved at Hanford in early 1945, and it continued into the postwar period. The ftrst uranium (U-235) was charged into Hanford's B-Reactor (often called "pile" at that time) in September 1944, and the two other original reactors built by DuPont on the site came on line in 1945. Hanford plutonium was used in the world's ftrst nuclear detonation. the Trinity bomb test at Alamogordo, New Mexico, in July 1945, and it supplied the core for the second atomic bomb (the "Fat Man"). dropped on Nagasaki. Japan, on August 9, 1945. That same day, the cities and towns around the Hanford reservation learned the secret purpose of the massive construction enterprise.

After Japan sued for peace on August 14, many production workers and others believed that Hanford's mission was fmished and that the plants would soon close. However. in late 1946 a United States suggestion that the United Nations supervise all atomic energy production and eventually destroy all atomic weapons was rejected by

(a) For information from this era, see also Franklin T. Matthias, unpublished journal, February-April 1943. Available in the U.S. Department of Energy Public Reading Room. Richland. Washington. 
the Soviet Union. In 1947, President Harry S. Truman, informed of the tiny supply of plutonium in existence in America and aware of the Russian push to build an atomic bomb, ordered increased production of fissionable material at Hanford. Meanwhile, on September 1, 1946, the General Electric Company had replaced DuPont as the site contracter, or operator, at the government-owned Hanford Site. On January 1,1947, control of American atomic policy and production passed from the military (the Manhattan Engineer District of the Army) to the new civilian Atomic Energy Commission (AEC). The military retained a voice in production decisions through a Military Liaison Committee to the AEC (Groves 1962, pp. 389-94; Van Arsdo11958, p. 69; Garraty and McCaughy 1987, pp. 830-33).

Construction and production activity at the Hanford Site has varied over the years since 1947, and many different private companies have operated portions of the facilities and functions there. In September 1947, Carleton Shugg arrived at Hanford as the new AEC manager, and he moved quickly to implement construction projects almost as large as those undertaken in 1943 and 1944. Building began on two new reactors in early 1948, and G.E. scientists were instructed to start design studies on a large Redox (chemical separations) plant, a plutonium purification facility, and a fabrication shop to shape plutonium for use in weapons. During the 1950s, three more reactors were built at Hanford, and the world's biggest fuel reprocessing plant, PUREX (plutonium-uranium extraction), was completed in 1956. In 1963, ground was broken for N-Reactor, the ninth and last such facility constructed at Hanford. N-Reactor contained many design differences from the eight older reactors. The most salient of these was a closed cooling system, which did not pass cooling water laden with radionuclides directly into the Columbia River. N-Reactor also possessed the secondary capacity to generate about 800,000 kilowatts of electricity from steam.

For 10 years, beginning in 1951, Army and Air Force guards were stationed at Camp Hanford to protect the defense production facilities against enemy attack or sabotage. However, by 1961 the development of long-range, intercontinental ballistic missiles and sophisticated missile tracking systems had rendered a locally stationed guard force obsolete, and Camp Hanford was dismantled. While the military camp operated, its headquarters was housed in the old Hanford construction camp trailers and Navy base trailers that had been brought to North Richland to help house the influx of G.E. and AEC emplyees after World War II. Camp Hanford also installed forward guard positions on the high ground of the Site in the Saddle Mountains, Rattlesnake Hills, and on Gable Butte. In 1958, the AEC released control of portions of the easements, or buffer lands, along the north, east, and south borders of the Site, thereby making Richland an independent city and allowing subdivision and sale of farmland on the east and north banks of the Columbia River in Franklin County.

In 1965, operation of the reservation passed from G.E. to six diversified contractors: U.S. Testing Co.; Battelle Memorial Institute; Computer Sciences Corp.; Hanford Environmental Health, Inc.; Douglas United Nuclear, Inc.; and Isochem, Inc. In subsequent years, other corporations, including ITT Federal Support Services, Inc., Atlantic Richfield Hanford Co., Rockwell Hanford Operations Co., Boeing Computer Services Richland, Inc. (a Boeing subsidiary), J. A. Jones Construction Services, Kaiser Engineers, and Westinghouse Hanford Co., have operated portions of the Site. In 1970, Hanford was chosen as the location for the Fast Flux Test Facility (FFTF), a large test breeder reactor (Hewlett and Duncan 1972, pp. 145-46; U.S. AEC 1968).

In 1971, President Richard Nixon announced that the last two reactors functioning on the Hanford Site, K and N, would be closed in an economizing measure. However, pressure from Senators Henry Jackson and Warren Magnuson, the governors of Washington and Oregon, and other powerfullobbies resulted in a reversal of the decision to close N-Reactor. From 1971 to 1987, it remained as the only operating defense production reactor at Hanford. In 1972, 1975, and 1978, ground was broken on the Site for three Washington Public Power Supply System (Supply System) commercial nuclear power generating plants. One of these, \#2, was completed. One was mothballed, and another was terminated.

\section{Columbia Basin Irrigation Project}

The other large government endeavor that came into the territory surrounding the Hanford Site in the postWorld War II period was the Columbia Basin Irrigation Project (CBIP). However, the CBIP experienced long delays caused by the exigencies of war, by the continued peacetime operation of the Hanford Site, and by the need for flood control along the Columbia River. In June 1935, when President Frank.lin D. Roosevelt authorized construction of a "high" dam at the Grand Coulee gorge of the Columbia River, he committed the federal enterprise to the dual mission of generating electrical power and of providing reservoirs and necessary canals to feed a huge pump irrigation system to water parts of Frank1in, Adams, Grant, and Lincoln Counties. However, by March 1941, when the first electricity was produced at the dam, the threatening war situation had made power generation almost the sole focus of 
national leaders. Even the Commissioner of Reclamation urged Congress in that year to appropriate over $\$ 15,000,000$ to speed work on the power plant and the installation of three generating units, and Roosevelt asked Congress to grant $\$ 10,900,000$ to hurry construction of electrical transmission lines from Bonneville Dam to Grand Coulee Dam in order "to meet unforseen defense industry demands" (Sundborg 1954, p. 376). Also in 1941, Spokane was chosen as the location of two light metals reduction factories, one for aluminum and one for magnesium, and this choice required the extension of large power lines from the dam into that city. Other new aluminum plants, as well as shipbuilding and airplane factories on the lower Columbia River and on Puget Sound that used electric welding techniques, consumed so much electrical power in the early war years that Washington and Oregon came near to experiencing shortages. The construction operations on the Hanford Site, both during and after the war, employed so much power that many additional generators were requested and built at both Bonneville and Grand Coulee darns. Businesses also continued to utilize power after World War II, most notably the aluminum industry, which manufactured the fuel rod casings for the uranium-235 slugs irradiated in the Hanford reactors as part of the plutonium production process.

By June 1947, 10 generators were functioning at Bonneville, and 6 were running at Grand Coulee, producing a total of 8,753,737,320 kilowatt hours of energy. Yet, by December of that year, Washington and Oregon were utilizing slightly more than 99 percent of the electricity that could be generated by all of the steam and hydroelectric plants in the two states. In February 1948, Grand Coulee's eighth power generator was brought on line, and 18 units were scheduled for completion by 1952. Vast expansion of the transmission network also was planned. In fiscal year 1948, the sale of electric power from Bonneville and Grand Coulee gained the Federal Treasury $\$ 22,082,000$, and the installation of the scheduled additional generators was projected to increase annual revenues to $\$ 30,000,000$ by 1952 (Sundborg 1954, pp. 377,414-16). Consequently, by 1948 it appeared that Grand Coulee's power generation purposes were being fulfilled, and backers of the CBIP hoped that now work could progress on the vast reclamation system. A new Columbia Basin Commission had been established by the state in 1943, with irrigation booster James O'Sullivan of Ephrata as its full time paid representative to push for headway on the project (p. 398).

One of the biggest floods in recorded history deluged parts of Washington, Idaho and Oregon in May 1948, postponing the CBIP once again. Heavy rains and high temperatures east of the Cascade Mountains caused the Snake and Columbia Rivers, which usually crest about two weeks apart, to peak at the same time. Large portions of Pasco, Kennewick, Richland, and the expanses surrounding them were inundated. At Vanport, across the Columbia from Portland, Oregon, dikes gave way and a flood of water streamed through that city almost without warning, tearing loose houses and floating them away in pieces. Thirty-eight thousand homes were destroyed along the Columbia, and 52 people died. After the huge inundation, large segments of the Northwest's public, as well as powerful interest groups, became attentive to a regional system of new dams proposed by the Army Corps of Engineers.

The Columbia Basin Irrigation Project made some progress in the early postwar period. A total of just under $\$ 220,000,000$ was made available to the CBIP by late 1946 , and work got underway on the main canal from Long Lake (now Billy Clapp Lake) to the division point east of Soap Lake. The huge ditch was 110 feet wide at the top, 50 feet wide at the bottom, and capable of carrying water 18 feet deep. Construction of Potholes Dam, a crucial structure in the CBIP and fourth largest dam in the United States at the time, was about half completed by February 1948. The towns of the district, such as Ephrata, Moses Lake, Soap Lake, and Coulee City, were booming with new businesses, platted subdivisions (43 in Grant County alone in 1946-47), and skyrocketing property values (Sundborg 1954, pp. 410-17). A temporary pumping rlant was built on the Columbia River about 15 miles northwest of Pasco to pump irrigation water to Block 1, a group of farms totalling about 5,000 acres, and also known as Pasco Heights. (Later, when the Esquatzel Diversion Canal reached far enough south to water Block 1, this plant was abandoned.)

From the time the Block 1 settlers were chosen until the late 1950s, homesteaders in the CBIP were drawn by lottery from lists of eligible interested veterans. The Bureau of Reclamation wanted experienced farmers with enough capital to make a success of their venture, so it required letters from associates confirming the veterans' agricultural knowledge and bank statements proving the existence of a savings account Still, so many veterans qualifIed that some waited as long as 10 years, placing their names in the drawings every year, to be allowed to purchase farms. Once chosen, they bought the farm units, usually for $\$ 11$ to $\$ 12$ per acre, at favorable government terms, usually 10 percent down with 20 years to repay and low but varying interest rates. They agreed to terms somewhat similar to those of the old Homestead Act They had to cultivate a certain number of acres each year, to erect a "habitable" residence on their land, and to live in it for at least 12 out of 18 months. Actual houses were required, not trailers or tents, although permanently anchored trailers were allowed later when the postwar industry of 
"modular homes" developed. In the early years, many farmers purchased and moved halves of government-built aparunent houses from Richland to meet the housing requirements on their land

In Block 1, most of the plots consisted of about 70 acres, but these were found inadequate to support a fann family. Drawings were suspended for several months in the early 1950s while the Bureau of Reclamation resurveyed the tracts further north and enlarged them by splitting up adjoining units. This action resulted in many fanns being L-shaped, a disadvantage when efficient, circular sprinkling rigs became popular. By the 1960 s, plots of 200 acres or more were laid out, shaped as much as possible (Vogel 1977, pp. 12-13).

By mid-1948, only ten percent of the irrigation construction for CBIP was completed, but already more than one and one-half times as much earth and rock had been moved as had been involved in the entire Grand Coulee Dam construction. Four dams, including Potholes Dam (later named O'Sullivan Dam), were built along with two huge lateral canals and two other major canals. The West Canal was completed first, and reclamation water passed through it in 1952, running southwestward from the division point (just east of Soap Lake) and flowing past Ephrata and Quincy. The East Low Canal, flowing south past Warden and Connell and reaching the outskirts of Pasco, was completed in the next few years. Waste water from these two canals led to a large reservoir (potholes) behind Potholes (O'Sullivan) Dam, which covered much of the barren sand dunes to the south of Moses Lake. In the late 1950s and 1960s, the Potholes Canal was built south and slightly eastward out of the reservoir, flowing past Othello and Eltopia. Later, the Royal Branch Canal was built off the West Canal below Frenchman's Tunnel to water lands south of the Saddle Mountains and east of the Priest Rapids Pool on the Columbia River above the Hanford Site. Numerous smaller siphons, lateral canals, pumps and other structures were built along these four major canals, in order to reclaim a total of 502,091 acres by 1967. This figure represented about half of the 1,029,000 acres authorized for development in the CBIP. The amount of acreage watered could not be expanded until after construction of the Second Bacon Siphon and Tunnel, located about two miles south of Banks Lake, in the late 1970s (Oberst 1978, p. 75). Since that facility was built, only about 50,000 additional acres have been brought "under the ditch" (Le., reclaimed), and a planned East High Canal, which would have swung south and east of the other canals through Lincoln, Adams, and Franklin Counties, was never dug.

The impact of the huge CBIP on the economy of the Hanford vicinity, and indeed on all of the Pacific Northwest, has been enormous, and today farms in the project are experiencing great changes. By the mid-1970s, the total crop value involved was over $\$ 220,174,440$ per year. The gross crop value averaged $\$ 441$ per irrigated acre at that time, and 36 different crops were grown on project soil. Alfalfa hay, wheat, potatoes, and sugar beets, in that order, were the most valuable (Oberst 1978, p. 76). By 1986, the total crop value stood at \$342,315,663, with average gross crop value per irrigated acre at $\$ 664$. Thirty-four different crops were grown in 1986, with potatoes, alfalfa hay, apples, asparagus, and wheat (in that order) being the most valuable.

The biggest changes in the past 10 years have been a complete disappearance of the regional sugar beet crop after the Utah \& Idaho Corp. sugar beet refmery in Moses Lake closed in the late 1970s, and a strong upturn in fruit production. In 1977, the total CBIP acreage planted in fruit was 6,232, but in 1986 it had jumped to 25,235. In 1977 , the total value of the CBIP fruit crop was $\$ 16,714$, but by 1986 that figure was $\$ 66,595$. The fact that fruit crops are so much more valuable per acre than staples such as hay, potatoes, and wheat helped the total CBIP crop value to rise during some of the same years that farm commodity prices fell overall (Columbia Basin Project 1987).

\section{Ponulation Demographics}

While the veterans and other settlers who bought farms in the CBIP over the years came from all parts of the United States, they all were experienced farmers, and they also were mostly Caucasians. As such, they fined easily into the dominantly agrarian, also mostly Caucasian, communities already established in the Hanford vicinity. The construction of the Hanford Nuclear Reservation brought appreciable numbers of black people to the area for the first time. As in the U.S. Armed Forces at that time, Negroes at the Hanford construction camp were segregated, being housed in a separate barracks (Matthias unpubl. journa11943). After the building phase, many blacks stayed on as production workers at Hanford, and those who did settled almost exclusively east of the railroad tracks in Pasco. "Thus," one local historian has stated, "the black population was housed in a situation of de facto segregation ... there [was] ... little or no communication between the newly arrived residents of East Pasco and the rest of the town." (Oberst 1978, p. 163.) During and after the 1950s, relations between blacks and whites improved slowly. In 1972, the first blacks were elected to the Pasco School Board and the Pasco City Council (Oberst 1978, pp. 163-67).

The acute agricultural labor shortages in the territory surrounding the Hanford Site during World War II caused another racially distinct group to migrate to the district Hispanic people, both Mexican nationals and 
Chicano immigrants to the southwestern United States, came to the region beginning in 1943. The previous year, the federal government had signed an informal farm labor agreement with Mexico, allowing the temporary importation of "braceros" (Mexican nationals) into the United States as an emergency wartime labor measure. The braceros were bound by written contracts arranged by the government, and American officials also secured transportation and housing for the workers. In the spring of 1943, an ad hoc group of Yakima farmers and community leaders called the Community Harvest Emergency Committee (CHEC) contracted through the federal government and to bring the first large contingent of braceros to the Yakima Valley to perform agriculbJral work. The braceros were housed in the Farm Security Administration labor camp in Yakima, and were "jubilantly welcomed ... as no less than the saviors of the valley" by the local press and growers. At season's end, the Yakima Chamber of Commerce sent a letter of appreciation to the Mexican President (Gamboa 1981, p. 124).

The situation involving Mexican agricultural laborers underwent subtle changes during the following year. CHEC incorporated as the Yakima Valley Food-For-Victory Farm Labor Corporation (YVFFVFLC) and began to procure braceros and contract with them, independent of federal involvement Contractual provisions regarding housing, transportation, and labor conditions began to loosen. Without government supervision, the large farm operators of the upper Yakima Valley sometimes subcontracted with smaller farms in the lower valley and Franklin County for short-term employment of Mexicans on Hanford area farms. Additionally during the war years, farmers and public officials in many areas of Washington united to recruit migrant Chicano farm workers to help with keen labor shortages at harvest times. The smaller, family farm operations of the Hanford vicinity often employed Hispanic laborers for short periods once they had come to eastern Washington. Private labor camps were built in the Yakima Valley for the braceros and migrant Chicanos, and in many cases these workers "abandoned their migratory status for permanent residence in private labor camps scattered throughout the valley. ... At the close of the 19408, Chicano people had established themselves in pockets near valley towns" (Gamboa 1981, p. 130).

Gradually, these newcomers rented or bought private homes, often in the poorest sections of the district towns, and by the 19708 there was a substantial Spanish-speaking population in East Pasco and in rural areas near Pasco. By 1977, the Pasco schools had the ninth highest number of students in the state with Spanish surnames, and a bilingual education program was instituted. Also in the 1970s, the Pasco school system joined a cooperative migratory education program wherein the school records of migrant children were transferred by computer to the various districts in which their parents performed seasonal work (Oberst 1978, pp. 173-76). Most recently, the drop in farmland values in the territory near the Hanford site has attracted many Hispanic people to the region, and has enabled several to buy their own farms and businesses. Towns in the CBIP area such as Othello, Connell, and Pasco now have significant numbers of Spanish-speaking inhabitants.

The scientific and technical employees of DuPont, and later of General Electric and subsequent contractor companies, as well as the Atomic Energy Commission, the Energy Resource and Development Administration, and the Department of Energy, constituted yet another distinct addition to the diversity of the Hanford region. DuPont, which laid out and built an entirely new town of Richland beginning in 1943, required its employees to live there. Richland's population had jumped to 13,500 people by the time DuPont left in 1946. General Electric Co. and the AEC also required their employees to live in Richland, and the city's population reached 22,800 by 1958, when Richland was released from direct government ownership and became a "nonnal," incorporated city. In the early years, the only housing available was four different styles of pre-fabricated units. No outbuildings, sheds, car shelters, garages, or any other individual endeavors were pennitled. The contractor companies and government agencies operating the Hanford Nuclear Reservation were very conscious of security. The years of enforced conformity, combined with the long distances from which the inhabitants had moved and their unusually high level of education, functioned to make Richland a very tightly knit, closed community, and set Richlanders apart from other groups in the area.

Along with the huge population growth in the territory around the Hanford Site in the post-World War IT era, many technological changes occurred and several new institutions were established. As Richland boomed to a size comparable to that of Pasco and Kennewick, the three municipalities became informally known as the TriCities. In 1947, the Pasco Herald was bought by Scott Publishing Company of Seattle, and the name was changed to the Tri-City Herald. On November 13 of that year, the newspaper became the first in the Hanford region to publish a daily edition. In the early postwar period, strong industrial and nuclear bases seemed to promise growth and prosperity for the territory surrounding the Hanford Site. However, the more recent past has seen declines in the economy and in population figures. 


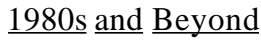

It is too soon to place into proper historical perspective the events of the 1980s and their impacts on Hanford Site. Some general directions can be seen. however. Radioactive wastes stored on the Site as a result of defense production are being disposed of according to a plan developed in consultation with state and regulatory agencies. The DOE is working closely with PNL. Indians. and other public groups in a dose reconstruction study of historical radiation releases on the Site. Also. the DOE is implementing the decontamination and decommissioning of the Site's defense reactors. now all shut down.

It is clear that whatever activities take place on the Hanford Site during and beyond the 1980s. they bear direct relevance to the Cultural Resource Management Plan. Through the Slructure of the Plan. a framework of policy and methodology will ensure that proper attention is paid to the protection of cultural resources on the Site.

\section{References}

1855 Treaty. 1966. "Treaty Between the Yakima Nation on Indians and the United States". Facsimile reproduction. Shorey Book Store. Seattle. Washington.

Berland. S. 1988. "Strategy Strife on the Indian War Front" Columbia 2(1):4-9. *

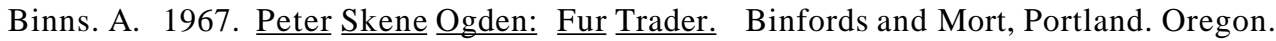

Buerge. D. M. 1987. "The Wilkes Expedition in the Pacific Northwest" Washington 3(7):65-81.

Columbia Basin Project. 1987. 1986 Crop Report Summary Sheet. U.S. Bureau of Reclamation. Ephrata. Washington.

Coues. E. ed. 1965a. History of the Expedition Under the Command of Lewis and Clark. Dover Publications. New York. (Reprint of the 1893 ed.).

Coues. E.•ed. 1965b. New Light on the Early History of the Greater Northwest: The Manuscript Journals of Alexander Henry and David Thompson. Vol. III. Ross and Haines. Inc. Minneapolis. Minnesota. (Reprint of 1897 ed.)

Cox, R. No date. Adventures on the Columbia River: An Overland Loumey in the Fur Trade Country. Binfords and Mort. Portland. Oregon. (Reprint of 1831 ed.)

Deutsch. H. J. 1960. "The Evolution of Territorial and State Boundaries in the Inland Empire of the Pacific Northwest" Pacific Northwest Quarterly 5(3):115-131.

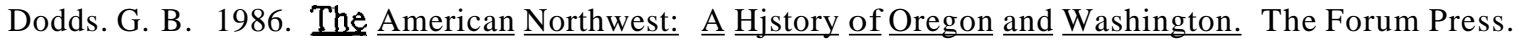
Arlington Heights. Illinois.

Edwards. G. T. 1981. "Irrigation in Eastern Washington. 1906-1911: The Promotional Photographs of Asahel Curtis." Pacific Northwest Quarterly 72(3): 112-120.

Eide, I. H. 1969. AmeriCan Odyssey: The Journey of Lewis and Clark. Rand. McNally and Co., New York.

Fridlund. P. 1985. Prosser: Gojng Back. 1910-20. Ye Galleon Press. Fairfield. Washington.

Gamboa. E. 1981. "Mexican Migration Into Washington State: A History, 1940-1950." Pacific Northwest Ouarterly 72(3):121-131.

Garraty. J. A., and R. A. McCaughey. 1987. The American Nation. Vol. II. 6th ed. Harper \& Row. Inc. New York. 


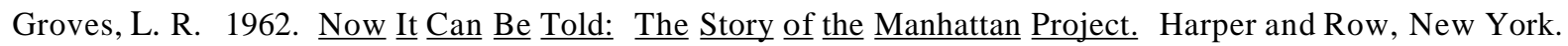

Guie, D. D. 1937. Tribal Days of the Yakimas. Published by Author, Yakima, Washington.

Harris, M. P. 1972. Goodbye. White Bluffs. Franklin Press, Yakima, Washington.

Henretta, J. A., W. E. Brownlee, D. Brady, and S. Ware. 1987. America's History. Vol. II. Dorsey Press, Chicago, Illinois.

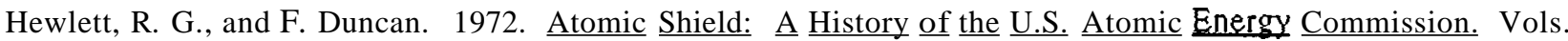
I and II. U.S. Atomic Energy Commission, Washington, D.C.

Irving, W. No date. Astoria. Clatsop edition. Binfords and Mort, Portland, Oregon. (Reprint of 1835 ed.)

Irving, W. 1961. The AdvenhIres of Capiain Bonneville. USA. E. Todd, ed. University of Oklahoma Press, Norman, Oklahoma. (Originally published 1837.)

Lavender, D. 1958. Land of Giants: The Drive to the Pacific Northwest. 1750-1950. Doubleday and Co., Garden City, New York.

Lavender, D. 1963. Westward Vision: The Qregon Trail. McGraw Hill, New York.

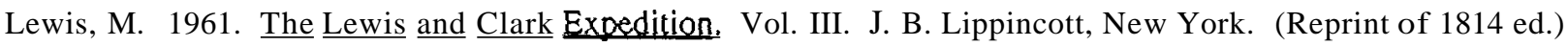

Liebow, E. B., A. Younger, and J. A. Broyles. 1987. A Synthesis of Ethnohistorical Materials $\underline{\text { Concerning the }}$ Administration of Federal Indian Policy Among the Yakima. Umatilla. and Nez Perce Indian People. Prepared for the U.S. Department of Energy by Battelle Human Affairs Research Center, Seattle, Washington.

May, P. 1972. 100 Golden Years: Goldendale. Washington. 1872-1972. Goldendale Centennial Corp., Goldendale, Washington.

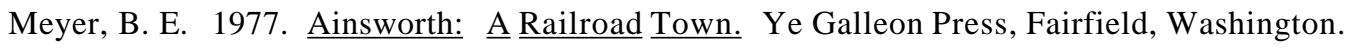

National Academy of Sciences/National Research Council (NAS/NRC). 1978. Radioactive Wastes at the Hanford

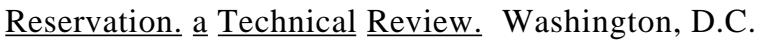

Newbill, J. G. 1977. "Farmers and Wobblies in the Yakima Valley, 1933." Pacific Northwest OUarterly 68(2):8087.

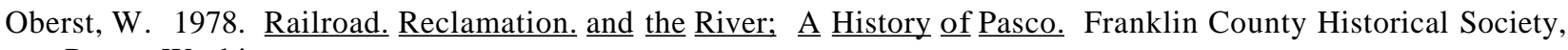
Pasco, Washington.

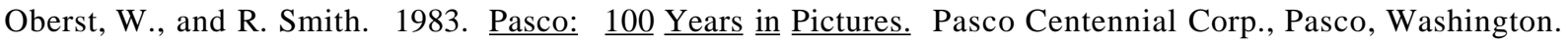

Oliphant, J. O. 1968. On the Cattle Rangers of the Oregon Country. University of Washington Press, Seattle, Washington.

Parker, M. B. 1979. Tales of Richland. White Bluffs \& $\underline{\text { Hanford. }} \underline{1805-1943 .}$ Ye Galleon Press, Fairfield, Washington.

Parker, M. B. 1986. Kin-I-Wale. Kennewick. Tehe. Kennewick. Ye Galleon Press, Fairfield, Washington.

Parker, S. 1967. Journal of An Exploring Tour Bevond the Rocky Mountains. Ross and Haines, Minneapolis, Minnesota. (Reprint of 1838 ed.) 
Payette, B. C., compiler. 1968. CaPtain John Mullan: His Life: Building the Mullan Road. Payette Radio Ltd., Montreal, Canada

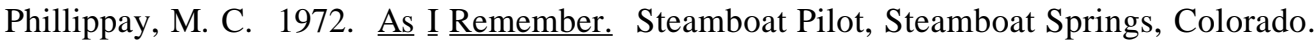

Phillippay, M. C. 1973. Kahlotus $\underline{\text { Is }} \underline{\text { Home. }}$ Steamboat Pilot, Steamboat Springs, Colorado.

Pollard, L. 1937. A History of the State of Washington. Vols. I-IV. The American Historical Society, New York.

Relander, C. 1961. "The Battleground of National Irrigation." Pacific Northwest Ouarterly 52(4):144-150.

Relander, C. 1986. Drummers and Dreamers. Northwest National Parks \& Forests Association, Seattle, Washington. (Reprint of 1956 ed.)

Rice, D. G. 1980. Overview of Cultural Resources on the Hanford Reservation in South Central Washington State. RL-E-80-0043, prepared for the U.S. Department of Energy-Richland Operations, Richland, Washington.

Ross, A. 1956. The Fur Hunters of the Far West. K. Spaulding, ed. University of Oklahoma Press, Norman, Oklahoma. (Originally published 1855)

Ruby, R. H., and 1. A. Brown. 1972. The Cayuse Indians: Imperial Tribesmen of Old Oregon. University of Oklahoma Press, Norman, Oklahoma.

Sheller, R. 1957. Ben Snipes: Northwest Cattle King. Binsford and Mort, Portland, Oregon.

Splawn, A. J. 1980. Kamaikin = Last Hero of the Yakimas. Caxton Printers, Caldwell, Idaho. (Reprint of 1917 00.)

Sundborg, G. 1954. Hail Columbia: The Thirty Year Struggle for the Grand Coulee Dam. Macmillan and Co., New York.

Sung, B. 1967. Mountain of Gold: The Story of the Chinese in America. MacMillan and Co., New York.

Symons, T. W. 1967. The Symons Report On the Uoper Columbia and the Great Plain of the Columbia. Ye Galleon Press, Fairfield, Washington. (Reprint of 1882 Senate Document 186, 47th Cong.)

U.S. Atomic Energy Commission (U.S. AEC). 1968. The Hanford Story, Richland, Washington.

Van Arsdol, T. 1958. The City That Shook the World, Columbia Basin News, Richland, Washington.

Van Arsdol, T. 1970. Boomers on Wheels: The Story of IraUers in the DevelQpment of the Tri-Cities. Published by author. Vancouver, Washington.

Van Arsdol, T. 19718. Big House on the Columbia. Published by author, Vancouver, Washington.

Van Arsdol, T. 1972b. Desert Boom and Bust: The Stmy of Irrigation Efforts and Town Building in Benton County. Washington 1888-1904. Published by author, Vancouver, Washington.

Vogel, L. 1977. Years Plowed Under. University Press, Spokane, Washington.

Western Writers of America. 1978. Water Trails West. Doubleday and Co., Garden City, New York. 
Wood, C. R. 1968. The Northern Pacific: Main Street of the Northwest. Superior Publishing Co., Seattle, Washington.

Yakima Firing Center. 1978. Yakima Firing Center History. U.S. Anny, Yakima, Washington. 


\section{APPENDIXE}

\section{ESTABLISIDNG THE SIGNIFICANCE OF CULTURAL RESOURCES}




\title{
APPENDIXE
}

\author{
ESIABUSHING THE SIGNIFICANCE \\ OF CULTURAL RESOURCES
}

The purpose of this attachment is to establish a basis for assessing significance of historic and cultural properties, including places of traditional Native American religious significance. These issues are addressed here through establishment of historical and cultural contexts, as described in the Secretary of the Interior's Guidelines for Historic Preservation Planning. Contexts are developed under three headings: Cultural, Historic, and Scientific. The approach taken to establish the contexts differs in each case, but the results always are categories of cultural resources. To determine the significance of any particular cultural resource on historical, scientific or traditional use grounds, the HCRL will consider whether or not it meets the minimum criteria for any resource category and whether a sufficient number of similar properties are already listed as eligible for, or on, the National Register (see 6.1.2.1.) Cultural contexts are treated somewhat differently when places of importance to traditional religions are considered. In those cases, the concern is simply whether or not a place has religious importance, without any attention to the existence or number of similar properties. An inventory is provided at the end of each section that lists the temporal and/or thematic context, property type, and criteria for assignment to the property type, and any known properties that have been listed on, or are considered eligible for, the National Register. In the case of religous sites and traditional use areas, localities identified by tribal elders or in ethnohistoric texts are listed in the place of National Register properties. When a traditional use area coincides with a listed historical property, the property name is also given.

\section{E.1 CULTURAL CONTEXTS}

This section considers the values placed on the Hanford Site by traditional Indian cultures, and identifies specific issues and properties that are mentioned by them as having special significance. It is written as much as possible to express the viewpoint of Indian people, although as non-Indians, the authors of this chapter have only an outsider's limited understanding of Indian beliefs and concerns.

The Issue of Ceded Lands

The Yakima and Umatilla Indian Reservations were established by treaty with the United States in 1855. The Yakima Reservation was created under treaty with Yakima bands, and the Umatilla Reservation under the treaty with the confederated Walla Walla, Cayuse and Umatilla tribes. Each treaty cedes to the United States, all right, title, and interest in lands that were formerly the territories of the respective tribes and bands, and retains certain use rights for the bands' members. Article 3 of each treaty states that the ceding parties retain the right to fish in common with non-Indian citizens at their reasonable and accustomed places, erect buildings for curing fish, and to hunt, gather roots and berries, and pasture stock on open and unclaimed land. Although the issues of access to sacred places and control over cemeteries and archaeological sites are not mentioned in the treaties, it is the assertion of the Tribes that any right not specifically ceded to the US in the treaties is retained by them. The Walla Walla ceded rights to portions of the Hanford Site from White Bluffs south to Hom Rapids on the Yakima and east to the Columbia River, while the Yakima ceded all other portions of the Site.

The issue of retained rights is the primary cultural concern thus far expressed by the Tribes, who state that fish, roots. religious sites, and ancestral grave and living sites are all their cultural resources. It is recognized in this plan that the Tribes have the rights of consulting parties when religious sites, cemeteries, and archaeological sites are at issue (under AIRFA and ARPA), and that their concerns are to be taken into account when DOE undertakings threaten cultural resources (under NHPA). Issues of ceded land rights will not be addressed here nor will the issue of access to religious sites and resource gathering areas. What will be addressed here are the sacred places, cemeteries and traditional resource collecting areas themselves and their importance to traditional cultures.

\section{Places Important to Traditional Religions}

The principal traditional religion of the Wanapum, Yakima, Umatilla, and Colville is the Washane (a.k.a.Seven-Drums or Dreamer). Practitioners consider the earth as a living thing that must cared for through the continuation of rituals and traditionallifeways. This care includes continued collection and consumption of wild foods, and use of ritual and medicinal plants. If not properly cared for, the earth may become ill and will cease to provide for the Indian people. 
The current Washane ritual began in the area that is now the Hanford Site. Smohalla, originally a member of the Wallulapum (a Walla Walla band) undertook a quest for spiritual guidance on what is now called Rattlesnake Mountain. To his people and their neighbors it was the remains of Laleech, a principal player in the creation of the world as they knew it. After seven days of fasting and near death, he received from the spirit realm a dance and seven songs. He first led members of the Wanapum band in the performance of the songs and dance at the winter village near Coyote Rapids. Subsequently the seven-drums ritual, or washat, has become the principal mode of public worship among Sahaptian-speaking peoples.

Private worship or, more appropriately, private expression of the local religion, includes the quest by Indian youths for visitation by a spirit guide. When their elders deem it appropriate, young boys (and often girls) are sent to remote locations believed to be conduits to the supernatural world. There, as Smohalla did, they fast, meditate and await visitation by the animal or plant spirits that will guide them throughout life. Sometimes they leave objects as evidence of their visit or pile rocks to remain active throughout the vigil. Some of these piles and objects remain at spirit quest locations.

To the Washane practicioners, there are many actual and potential sacred areas on the Hanford Site. They believe that the earth itself is sacred, and many are especially concerned that the presence of radioactive and hazardous wastes and the continued damage to the earth's surface may poison and wound the earth. A weakened earth may lose its spiritual power and cease to feed the Indian people. The Columbia River is sacred water, and is the bringer of food in the form of salmon (itself sacred). The Tribes are concerned that pollution, sports fIShing and excavation activity may threaten the salmon runs (which are also an economically important resource). Places where spirit quests can be performed may lose their power if left too long unused. If that happened, the contact to the supernatural realm would be lost and the Indian people would wither. Traditionalists fear that the spiritual vitality of Indian youth may deteriorate if they do not take part in the spirit quest and gain the necessary guidance..

There are other places where the spirit quest can be conducted, and there are salmon streams elsewhere in the Sahaptian peoples' territories. What makes the places on the Hanford Site unique is their central position, both geographically and spiritually in the Sahaptian world. It was there that the powerful prophet Smohalla revitalized traditional religion; many places that are important in the local myth of creation are there.

Tribal elders and younger leaders, including Mary Jim and Carrie Nightwalker of the Palouse, Ellen Saluskin, Bobby Tomanawash, Rex Buck, Jr. and the late Frank Buck of the Wanapum, Walter Spedis, Russell Jim, and Lonnie Selaro of the Yakima, Louie Dick of the Umatilla, and Allan Slickpoo of the Nez Perce all have been sources of information on religious values in order to protect sacred places. The places identified as most important in direct interviews and references made in public meetings are listed in Table E.1. Other locations may be identified in the future.

\section{$\underline{\text { Cemeteries }}$}

Probably the most sensitive issue relevant to this plan concerns Native American Cemeteries. Indian people frequently express outrage at the desecration of their ancestors' graves. This desecration occurs in the name of progress (during construction), and at the hands or relic collectors who deny the sanctity of the graves. The elders especially view the apparently thoughtless or, worse, methodical scattering of their ancestors' bones with alarm and bitterness. wondering if their remains, too, will be desecrated. They fear that, if the bones are dug up and separated. the deceased will not be able to rise in the hoped-for time when the creator brings all Indian people back to life. As different as these concerns may be from Judea-Christian beliefs, they are nonetheless just as real. and they motivate much of the Indian viewpoint toward non-Indians.

DOE-RL is resolved to prevent intentional desecration of Indian graves and to avoid whenever possible the inadvertent disruption of human remains during its undertakings. There are nine known cemeteries on the Hanford Site; none are now in the path of any planned or proposed projects. Nevertheless, they will receive the most intensive attention during monitoring and surveillance activities. Policies for grave disturbance have been and will continue to be discussed with the Tribes. Grave locations are confidential and are not described in this plan (except in a very general way; see TableE.1).

\section{Traditional Areas of Residence and Resource-Gathering}

Wild food resources and medicinal and ritual plants are important to Native Americans, not only because they are used in rituals. but also because their use provides a tie with the past beyond memory. In many ways it is the intimate knowledge of wild resources and their uses that sets the Indian people apart from more recent 
TABLE E.1. Traditional Cultural Contexts and Associated Properties on the Hanford Site

\begin{tabular}{|c|c|c|c|}
\hline nMEPERIOO & THEME & CRITERIA & IDENTIFIED PROPERTIES (1) \\
\hline \multirow[t]{4}{*}{$\begin{array}{l}\text { Ethnohlstorlc } \\
\text { and Modem }\end{array}$} & Sacrod Pleces & $\begin{array}{l}\text { Information supplied by } \\
\text { Tribal elders }\end{array}$ & Gable Mountain \\
\hline & & $\begin{array}{l}\text { Information supplied by } \\
\text { Tribal elders }\end{array}$ & Gable Bune, including an outcops \\
\hline & & $\begin{array}{l}\text { Information from Wanapum } \\
\text { and Yakima Informants }\end{array}$ & Goose Egg Hill \\
\hline & & $\begin{array}{l}\text { Recorded in Relander } 1986 \\
\text { Told by Wanapum leader }\end{array}$ & $\begin{array}{l}\text { Rattlesnake Mountain, particularly the ridge } \\
\text { crest }\end{array}$ \\
\hline
\end{tabular}

Saddle Mountain, crest and rocky outcrops

Information from Indian The Columbia River

leaders, elders; Relander 1987

\section{Cemelertes (also sacred)}

Identified by Wanapum Leader

FiVe the south end ortes Hanford Townsite and the $100 \mathrm{~K}$ Area Specific locations confidential

Located during archaoologka surveys

Fishing Locations Identified by Wanapum elders reported In Relander 1986

identified by Wanapum and Palouse elders

Four additional cemeteries, on Islands and river lerrace., location. confidential

A place for gathering spawned-out fish localed 8 miles north of Richland, west bank $\alpha$ the Columbia River

Banks, Islands and channel

Columbia River the White Bluffs Ferry landing and the 1000 Area

Moollmooll,at $100 \mathrm{~N}$ Area, was an Important dog salmon fishing place

Ahnukwhum to Mookmookhah, localed from Jaeger Island to the upper end $\alpha$ China Bar

Food Plant Information elicited from None identified; area nol known for plant food Areas

\section{MPORTANCE}

Plays pari In origin myth, and one of principal spirit quest placos

Formerly a splrlt quest place

Plays central role In origin myth

Play. central role in origin myth, Important spirit quest place where the Waashat prophet Srnohalla the songs of the seven drum. religion

one of principal spirit quest places

Water Is sacred, brings food (salmon)

Relatives of living people are burled In these locations

Anceslors of the Tribes are burled here, remains are sacred

indian people may to reestablish fishing activity here

Indian people may to reestablish fishing activity here; used the area until 1943

Indian people may sook to reestablish fishing activity here; used Ihe area until 1943

Wanapum fish this reach loday
NATIONAI REGISTER LISTING

To be nomlnaled as the Gable IGabie Butte Cultural District

to be nominated as the Gable $M$ Gabie Butte Cultural District

none

none

none

Belng considered for Wild and Scenic River designation

One such site Is in a regls-tared Archaeological District

none

none

fishing stations and camps are induded In Locke Island and Wahluke Archaeological Dists.

none

none 
TABLE E.1. (contd)

TIME PERIOD THEME CRITERIA IDENTIFIED PROPERTIES

MPORTANCE

NATRONAL BEGISTERLISTING

Ethnohlstorlc Medicinal and Information elicited from None Identified

and Modem Ritual Plant Areas Wanapum and Palouse elders

Hunting Areas No Information obtained

Residence Areas Identified by Wanapum and

Palouse eterers, also in

Relander 1986

A location near al the Hanford Townsite

A location between White Bluffs townsite and the $100 \mathrm{D}$ Area

a viHage site at Coyote Rapids

A location between Highway 240 and Jaeger Island.
Wanapum winter village

none

Wanapum winter village visited by Walla Walla, Palouse and Yakima in fishing season

Included In Locke Island and Wahluke Archaeological Districts

Small winter village, location of Localed in Coyote Rapids Smohalla's IIrst Waashal Ceremony Archaeological District

Major winter village, the late

Archaeological District
Wanapum leader Frenk Buck was which meets criteria for the born here; home of Puck Hyah Tool, National Register.

former Waashat and Wanapum leader 
immigrants to this area and establishes their prior claim to the land. To many, especially the elders, traditional foods also remain an important part of the food supply. This is especially true of salmon, elk, deer, huckleberries, and some roots.

Discussions with Indian elders and from a review of ethnohistorical records (Section 4.5) reveal that the Hanford Site played two primary roles in the lifeway of its Wanapum, Chamnapum, and sometimes Palouse and Walla Walla inhabitants. It contained (and still contains) the best fishery for upriver bright fall chinook salmon. Its low elevation, riverside setting, and low snowfall made it ideal for winter encampment Root gathering was practiced nearby, for the most part in parts of the Yakima Firing Center, Kittitas Valley, Soap Lake area, Waterville Plateau, and Blue Mountains. Berries are rare on site. No information has yet been elicited on hunting.

The principal fishing areas which have been mentioned for the Columbia River are the China Bar area, the Hanford Reach from Wahluke and 100 D reactor to the White-Bluffs landing (Table E.1). The rrrst area is still exploited by the Wanapum, but the second is more often mentioned by informants as a center of summer activity. Winter villages were in the same general locations, perhaps to minimize the movement of dried fish from storage locations near the fIsheries. Wanapum people were still living just downstream from China Bar and around White Bluffs when the Hanford Site was established in 1943.

\section{E. 2 mSTORICAL CONTEXTS}

The area that is now the Hanford Site played a peripheral role in the Eura-American exploration and settlement of the Columbia Basin (Appendix D.4). In fact, it was not until the area became a facility for nuclear materials production and research that the activities there had an important impact on regional, national and international affairs. In addition to that general lack of historical signifIcance outside the local area, most buildings and structures predating the Hanford Site have been demolished over the past 45 years. Few properties of historic signifIcance remain that have not been reduced to archaeological sites.

Table E. 2 is an encapsulated history of the Hanford Site, listing time periods, themes associated with each time period, property types expected to be associated with each theme, characteristics and integrity required for a property of that type to be considered eligible for the National Register, and the properties on the Hanford Site that have been identified to date as meeting those criteria. The time periods are intervals characterized by distinct combinations of events, activities, and industries. Themes are generated from the subheadings of those time periods. Extensive justification of periods and themes is, therefore, not necessary here.

\section{E.3 SCIENTIFIC CONCERNS}

ScientifIc concerns can be addressed in two realms, paleontological, and anthropological. The latter is further subdivided into culture historical and theoretical components.

\section{Paleontological Concerns}

Paleontological properties that are not associated temporally or spatially with archaeological deposits are minimally protected under federal law and are not ordinarily considered for nomination to the National Register. They may, however be placed on the register of National Monuments. At the Hanford Site, this sort of designation would only be considered if a site or area contained an extraordinary density of fossil material. However, DOE-RL does intend, in the course of other duties performed by the HCRL, to locate and consider for protection or scientific study any sources of information on past biota and climates.

The research question is asked: What is the sequence of biotic communities that existed in the Hanford Site area since the Miocene epoch, and what can the content of those communities tell us about the past climates and geography of the Columbia Basin region? Table E.3 lists the time periods, associated sediment formations that may contain paleontological deposits, and the kinds of sedimentary and geomorphic settings in which different kinds of information might be obtained. No specific localities have yet been identified precisely enough to be listed.

\section{Anthropological Concerns}

Anthropology addresses issues of human behavior that vary in scale from specific localities to the entire world. At the smallest scale, a researcher might attempt to understand the human occupation of one site during a brief interval of time; at the largest scale, whole classes of cultural behavior are of interest, regardless of the location in which they occurred. Archaeological remains that exist on the Hanford Site may contribute knowledge to issues at all scales. Here we discuss two kinds of study, culture history and theoretical anthropology as they pertain to the archaeological resource base of theHanford Site. Culture history is the more specifIc issue; theoretical anthropology takes a worldwide perspective. 
TABLE E.2. Inventory of Euro-American Period Historic Contexts, Property Types and NR Eligible Properties on the Hanford Site

TIME PERIOD THEME PROPERTY TYPE REQUIRED CONDITION AND CHARACTERISTICS

1805-1855

Exploration

None Expected (a)

Fur Trade

Ovemight camps

Small clusters of fur trade era artifacts in the absence of native-made artifacts; any condition

Religion

None expected

Immigration

Wagon trails

1855-1880's Indian-White

Relations

$m$

Religion

Gold Mining

Mines

Treaty sites

Camps of non. treaty Indians

Skirmish sites

Places where rituals first performed

Mining camps, Chines

Ruts following historically reported immigrant routes; condition: perceptible on land surface

not locally applicable

Localities where those who opposed submission to whites resided; location with natural setting

Locations where fighting or ambush took place; location with natural setting

The location, with evidence for structures where rituals took place; site and natural setting

Extensive pits and piles of mine tailings, over 4 ha not extensively eroded or modified

Domestic sites with food debris, artifacts of Chinese manufacture predominate, evidence of dwellings. Archaeological, separable as distinct component

Mining camps, Whites Same as above, but including predominantly EuroAmerican artifacts

Cattle Business Ranches

Cow camps

Cattle drive routes
Sites with standing structures dating to this period separated from mines, and lacking farm equipment; structure condition not critical, may be ruins

Small scatters of food cans and other artifacts distant from river in steppe lands; setting natural

Routes distingUishable from maps or descriptions; natural setting.

\section{ELIGIBLE PROPERTIES}

none Identified

White Bluffs Road

none Identified

Rattlesnake Springs

Archaeological District

Coyote Rapids Archaeological

District (first Washat)

none Identified

none identified

none identified

Cabin at East White Bluffs

none identified

White Bluffs Road 
TABLE E.2. (conld)

1855-1880's Commerce

1880's to 1910 Commerce
Wagon roads

Horse trails

Ferry landings

Freight landings

Railroad lines \& spurs

Railroad const. camps

Steamships

Steamship landings

Warehouses

Homesteads

Field systems

Equipment

Dams

Pumping plants
Routes on early maps, road still visible, mayor

may not still be In use; original surface preferred

Route distinguishable on early maps, still visible

as a trace on land; natural setting

Landing and grade; Intact but not substantially modified by modern activity.

Location where trade goods were unloaded from boats to pack trains or wagons; no material

evidence,

Self explanatory, Intact, earliest built

\section{none located in area}

Ships of correct era, known to have been used in Columbia R. Shipping, may be In ruins, not modernized

Intact frelghVpassenger loading slips, associated structures; intact and minimally remodeled

Structures reportedly used for purpose and lacking evidence of domestic use; intact structure, not remodeled

Domestic buildings and associated structures, fields fields, or farm equipment; not remodeled

Fenced fields, evidence of plowing; no use since 1910

Farm machinery; corroded, but all parts present

Concrete, wood or earthen dams; may be in ruins, but not extensively modified by more recent construction

Concrete structures housing, or having once housed electric or diesel pumps associated with Irrigation lines; structure intact, not modified by new const. none identified

White Bluffs Road

none identified

White Bluffs and Vernita Ferry Landings

East White Bluffs landing

none identified

none identified

none Identified

none identified

none Identified

none identified

\section{Allard Pumping Plant}


TABLE E.2. (coord)

\begin{tabular}{|c|c|c|c|c|}
\hline TIME PERIOD & THEME & PROPERTYTYPE & REQUIRED CONDITION AND CHARACTERISTICS & ELIGIBLE PROPERTIES \\
\hline \multirow[t]{4}{*}{1880 's-1911 } & Water Control & Irrigation ditches & $\begin{array}{l}\text { Earth, concrete or wood-lined ditches, shown on maps } \\
\text { of period; rural setting, at least } .5 \mathrm{~km} \text { length }\end{array}$ & Hanford Ditch \\
\hline & & $\begin{array}{l}\text { Water distribution } \\
\text { systems }\end{array}$ & $\begin{array}{l}\text { Flumes, wooden, tile, or concrete pipes; form Intact, } \\
\text { at least } 50 \mathrm{~m} \text { continuous length remaining }\end{array}$ & none identified \\
\hline & Religion & Churches & $\begin{array}{l}\text { First church buildings; if no longer In use for } \\
\text { originalpurpose, integrity of design etc }\end{array}$ & none present \\
\hline & Education & Schools, libraries & $\begin{array}{l}\text { Intact structures built for purpose and not } \\
\text { subsequently modified for a different purpose }\end{array}$ & none from this era \\
\hline \multirow[t]{9}{*}{ 1911-1943 } & Commerce & Warehouses & Same as above & Bruggeman Fruit Warehouse \\
\hline & & Others same as above & & none Identified \\
\hline & Automobile & Roads & Same as above, Macadam or gravel surfacing & none identified \\
\hline & & $\begin{array}{l}\text { Service stations! } \\
\text { repair shops }\end{array}$ & $\begin{array}{l}\text { Shop with gasoline pumps and/or liftl grease pit and } \\
\text { associated auto.related trash; original design of } \\
\text { structure intact }\end{array}$ & none expected on site \\
\hline & Education & Schools & Same as previous period & Old Hanford High School \\
\hline & $\begin{array}{l}\text { Energy: natural } \\
\text { gas exploration }\end{array}$ & Well sites & Mud pit, drill pad, and assodated trash & none identified \\
\hline & & Gas lines & Pipelines; not converted to other uses & none identified \\
\hline & & Support settlements & Townsite, historical records show single econ. focus & none identified \\
\hline & Other themes, pr & erty types and criteria & me as previous period & none identified \\
\hline \multirow[t]{2}{*}{ 1943-Present } & Warfare & Reactors & $\begin{array}{l}\text { Containment building and internal equipment; intact, } \\
\text { public access potential }\end{array}$ & 100-B reactor \\
\hline & & $\begin{array}{l}\text { Materials processing } \\
\text { facilities }\end{array}$ & $\begin{array}{l}\text { Structure and Internal machinery; extensive } \\
\text { remodeling not present, public access potential }\end{array}$ & T-Plant ? \\
\hline
\end{tabular}


TABLE E.2. (contd)

\begin{tabular}{|c|c|c|c|c|}
\hline TIME PEBIOD & THEME & PROPERTY TYPE & BEQUIRED CONDITION AND CHARACTERISTICS & ELIGIBLEPROPERTIE \\
\hline \multirow[t]{2}{*}{ 1943-Present } & Warfare & Missile sites & $\begin{array}{l}\text { Silos, associated buildings; intact, not extensively } \\
\text { remodeled }\end{array}$ & ALE facility? \\
\hline & Energy: Electrical & Substations & $\begin{array}{l}\text { Transformers, original support settlement; jntact, } \\
\text { remodeling not extensive, associated with early dam }\end{array}$ & Midway substation? \\
\hline
\end{tabular}

(a) No overnight stops have been reported on what is now the Hanford Site. 
TABLE E.3. Settings With Potential Paleontological Significance on the Hanford Site

\begin{tabular}{|c|c|c|c|}
\hline TIME PERIOD & GEOLOGL FORMATION & PALEONTOLOGICALDATA & $\begin{array}{c}\text { SEDIMENT I } \\
\text { GEONORPAKC SETTING }\end{array}$ \\
\hline \multirow[t]{4}{*}{ Recent $(10,000$ yr $)$} & Holocene Sediments & Paleohydrology & $\begin{array}{l}\text { Columbia River Floodplain, } \\
\text { dated flood deposits }\end{array}$ \\
\hline & & & $\begin{array}{l}\text { Dry, Cold, and Snively } \\
\text { Creøk Basins, dated } \\
\text { colluvium and alluvium }\end{array}$ \\
\hline & & $\begin{array}{l}\text { Plant communitiesl } \\
\text { climates }\end{array}$ & $\begin{array}{l}\text { Dated alluvium and eolian } \\
\text { deposits, fine sediment }\end{array}$ \\
\hline & & Animal communities & $\begin{array}{l}\text { Archaeological sites, caves, } \\
\text { eolian deposits }\end{array}$ \\
\hline \multirow[t]{3}{*}{$\begin{array}{l}\text { Late Pleistocene } \\
\text { (ca 30,000-10,000) }\end{array}$} & $\begin{array}{l}\text { Touchet Beds, Pasco Gravels } \\
\text { (Hanford Formation) }\end{array}$ & Paleohydrology & $\begin{array}{l}\text { Bedded glaciaillood deposits, } \\
\text { channels }\end{array}$ \\
\hline & & Plant communities & $\begin{array}{l}\text { Buried soils in fine flood } \\
\text { deposits; dating potential }+\end{array}$ \\
\hline & & Animal fossils & $\begin{array}{l}\text { Eddy locations; fine flood } \\
\text { sediments }\end{array}$ \\
\hline \multirow[t]{3}{*}{$\begin{array}{l}\text { Pleistocene (ca 30,000- } \\
2,000,000)\end{array}$} & $\begin{array}{l}\text { Loess Deposits in Saddle } \\
\text { Mts and Snively Basin }\end{array}$ & Animal communities & $\begin{array}{l}\text { Fine sediment traps; lee sides } \\
\text { of hills }\end{array}$ \\
\hline & Uppermost Ringold & Plant communities & Organic-rich clay and silt \\
\hline & & Animal communities & $\begin{array}{l}\text { Coarse alluvial sand and } \\
\text { gravel deposits }\end{array}$ \\
\hline Pliocene $\quad(>2,000,000)$ & Ringold Formation & $\begin{array}{l}\text { Animal and plant } \\
\text { communities }\end{array}$ & Same as Pleistocene \\
\hline
\end{tabular}

\section{Culture Historical Contexts}

The tenn "culture history" is used here in an inclusive sense, meaning the sequence of human adaptations that existed in the prehistoric past As managers of cultural resources, the DOE and other federal land-holding agencies in the vicinity of the Hanford Site work with the SHPO to retain a record of human prehistory, This may be achieved by preservation of properties listed on the National Register of Historic Places, or by data recovery from properties threatened with destruction. In either case the objective is to retain a representative sample of the prehistoric record. So long as a representative record of cultural history is available for research, it should be possible to answer any question about regional prehistory and to contribute to research that addresses principles of human behavior. There are limits to this, however. What is considered to be a "representative sample" will depend on the number of periods into which time is divided and on the variety of categories into which archaeological sites for each time period are placed.

General Research Ouestions. To generate a representative picture of prehistory, we pose three general research questions: What environmental and cultural changes have occurred in the region? What impact did they have on subsistence behavior, technological development, population size, social organization, interaction patterns, religion, and population size? What were the mutual interactions among these variables?

From the overview of regional prehistory presented in Section 4.4, it is evident that the direct applicability of the overview (or for that matter any of the other extant, less detailed models of regional prehistory) to the Hanford Reach and vicinity cannot be ascertained from current knowledge. The goal of prehistoric cultural resource 
management at Hanford is to reserve a data base from which the applicability of the overview to local prehistory can be detennined. Several sites of each discernable type representing the full range of time represented by each period would constitute a representative sample. The knowledge about local prehistory, combined with that concerning other local prehistories, should create a complete picture of the human history of the Columbia Basin region.

Table E. 4 converts the overview into time periods and themes, which are the prehistoric contexts. For each context there is a list of property types, the criteria for assignment of properties to each type, and the National Register (listed or considered eligible) properties that may be assigned to that property type. When representative properties have been identified for each context, covering the entire time span represented by the context, then a complete record of local prehistory should be obtainable. Expansion ofknowledge maty, however, show that a wider range ofproperty types exists, so additions will be made as needed.

$\underline{\text { Specific }}$ Research Questions. Archaeologists studying the prehistory of the Columbia Plateau Region have observed discontinuities in the archaeological record that warrant explanation. In developing the evaluation component for the Resource Planning and Protection Process Mid-Columbia Study Unit, the Washington Office of Archaeology and Historic Preservation compiled some of these questions, and a few more are added here (Table E.5). The answers to all of these questions could be obtained from the representative sample of the archaeological resource base of the area, as described above (Table E.4); therefore, details of the data required to answer each question are not presented. This task is left to any individual investigator seeking a permit to conduct research on one or more of these questions on the Hanford Site.

\section{Theoretical Issues}

Throughout prehistory, the inhabitants of the Hanford Site subsisted by hunting, plant gathering, and fIShing. Anthropologists designate such peoples hunter-gatherers or hunter-flSher-gatherers. Because of the dependence on naturally occurring food species as opposed to domestic ones, some anthropologists believe that the ecological and social adaptations of these people differ from those of agriculturalists. These adaptations, and the processes that control them are the subject matter of theoretical anthropology as it pertains to hunter-gatherers.

Three issues currently command the attention of anthropologists studying hunter-gatherers. The most widespread school is led by Binford (e.g. 1977, 1978, 1980, 1982) and addresses the relationship between environmental potentials, mobility patterns, predation strategies, demography, and technological organization. A second school is concerned with the development of organizational complexity in hunter-gatherer societies (e.g., Price et al. 1985; Thomas 1981). Finally a diverse group addresses the intensification of food resource use and and the energetics of foraging strategies (e.g., Earle and Christensen; Winterhalder and Smith 1981).

Based on these schools of thought, an extensive array of specific research questions could be asked of the archaeological record at the Hanford Site. For example: What processes lead to the development of sedentary lifestyles? What is the relationship between the distribution of anadromous fish in time and space and the complexity of social organization? What are the relationships between the effective latitude of an area, population size, and people's mobility strategies? As human populations rise, does resource intensification follow a consistent pattern of change? Each question could be posed by all schools, but with different emphases.

All these questions require data on settlement patterns, settlement size, dwelling type and size; floral and faunal remains; stone, bone and shell tools; and/or various facilities used 10 process and slOre food. These kinds of data would be available for the Columbia Basin region if a representative sample of the prehistoric record were preserved. The reverse is not true, however. Theoretical questions often require less than the complete prehistoric record for their solution because they address only a portion of the human behavioral repertoire. Therefore, archaeological contexts have not been developed from theoretical research questions. The archaeological resource base would be afforded no added protection if theoretical questions were added to the list of contexts, but there is a potential for damage to the data base if only such questions were considered..

Theoretical questions will be considered for the issuance of ARPA permits to conduct archaeological data collection on the Hanford Site. To avoid the potential loss of significant information, however, data collection in pursuit of such questions will in all cases have to be as thorough as the state of the art will allow and will be used to complete the image of regional culture history. 
TABLE E.4. Inventory of Archaeological Contexts and the Historic Properties Associated with Them in the Mid-Columbia Area

\section{TIME PERIOD}

$12,000-10,500$

THEME

Mobility/Settlement

Pattern

Predation

r

\section{PROPERTY TYPE \\ Residence sites representing the full range of seasons}

Quarries, tools

\section{Caches}

Sites with dwellings

Kill sites

Faunal/floral assemblages

from residence sites

\section{Physical Characteristics}

Environmental Setting

\section{/Settlement} Pattern

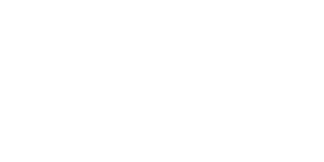

\section{Graves}

Pollen, animal fossil, sediment deposits

Residence sites representing the full range of seasons

Quarries, tools

\section{Cactes}

Sites with dwellings
REQUIRED DATA AND INTEGRITY

LISTED PROPERTIES IN THE MID.COLUMBIA

Any site representing this time that contains scattered tools and may include features, flora and faunal remains

Raw material sources, artifacts made from source material

Dense, spatially restricted clusters of tools and raw materials

Post holes patterns, depressions, concentrated domestic debris

Faunal remains In association with weapons and/or butchering tools

Numerous faunal remains identifiable to taxon, bone, part; charred or uncharred food plant remains

Any human remains of this age

Dated deposits of this age with concentrated biotic remains; distinctly bedded sediments

Any site representing this time that contains scattered tools and may include features, floral and faunal remains

Raw material sources, artifacts made from source material

Dense, spatially restricted clusters of tools and raw materials

Post holes, depressions, concen. trated domestic debris none identified

none identified

Ritchie-Roberts Site(East Wenatchee)

none Identified

none Identified

none Identified

none Identified

Kennewick Road Cut

Rattlesnake Springs A.D. (a)

Lind Coulee, Marmes Rockshelter, Windust Caves, Glade Creek

none identified

none identified

Marmes Rockshelter(?) 
TABLE E.4. (contd)

\section{Kill sites}

Faunal/floral assemblages from residence sites

\section{Physical Characteristics}

Environmental Setting

8000 to $4000-$ 5000 BP

\section{Graves} deposits
Mobility/Settlement Pattern

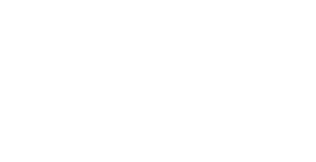

Housing, Demography

Predation

Food Storage
Faunal remains In association weapons and/or butchering

tools

Numerous faunal remains identifiable to taxon, bone, part; charred or uncharred food plant remains

Pollen, animal fossil, sediment Dated deposits of this age with

concentrated boitic remains distinctly bedded sediments

\section{Residence sites representing the full range of seasons}

Quarries, tools

\section{Cactios}

Sites with dwellings

Kill sites

Faunal/floral assemblages from residence sites

Sites with storage facilities
Any site representing this time that contains scattered tools and and faunal remains

Raw material sources, artifacts made from source material

Dense, spatially restricted clusters of tools and raw materials

Post holes, depressions, concentrated domestic debris

Faunal remains in association weapons and/or butchering tools

Numerous faunal remains identifiable to taxon, bone, part; charred or uncharred food plant remains

Dated depressions or pits containing remains of processed food may include features, floral none identified

Lind Coulee, Marmes Rockshelter (b)

Marmes Rockshelter

Marmes Roc:kshelter, Rattlesnake Springs, Windust Cave, Burr Cave

Marmes Rockshelter, Rattlesnake Springs, Lower Snake R. A.D., Savage Island A.D.

Trl Cities A.D.(?)

none identified

none Identified

none Idenitfied

none Identified

Marmes Roc:kshelter, Lower Snake River A.D. Savage Island A.D.(?)

Marmes Rockshelter, Palouse Canyon Archaeological District (?) 
TABLE E.4. (contd)

TIME PERIOD

8000 to 4000 $5000 \mathrm{BP}$

Physical Characteristics

Environmental Setting

Religion

Mobillty/Setlement

4000-5000 to

3800 BP

Pattern

$\frac{\pi}{s}$
PROPERTYIYPE

Graves

REOUIRED DATAAND INTEGRTY

Any human remains of this age

Pollen, animal fossil, sediment Dated deposits of this age with deposits distinctly bedded sediments

\section{Cemeteries}

Rock art sites

Residence sites representing

the full range of seasons

\section{Food-processing camps}

Quarries, tools

\section{Caches}

Housing, Demography

Predation

Rock surfaces with pictographic or petroglyphlc panels

Any site representing this time

that contains scattered tools and may include features, floral made from source material

Dense, spatially restricted trated domestic debris

Faunal remains In association
Sites with dwellings

Kill sites

Faunallfloral assemblages

from residence sites

Sites with storage facilities

LISTED PROPERTIES IN THE MID-COLUMBIA concentrated biotic remains

Marmes Rockshelter

Marmes Rockshelter, Rattlesnake Springs Windust Cave, Burr Cave, Savage Island A.D. Hanford North A.D., Tri-Cities A.D.,

\section{Marmes Rockshelter}

none known and faunal remains, and represents

the full range of domestic activities

Site containing a predominance of one or two feature types and limited diversity florallfaunal remains

Raw material sources $\cdot$ artifacts

clusters of tools and raw materials

Post holes, depressions, concenweapons and/or butchering tools

Numerous faunal remains identifiable to taxon, bone, part; charred or uncharred food plant remains

Dated depressions or pits containing remains of processed food
Vernita Site (1), 45KT285

Savage Island (1)

45KT285 (1)

none identified

none identified

Vernita Site (?), Shalkop Site

none Identified

Vernita Site (?)

Marmes Rockshelter, Palouse Canyon A.D.(?) 


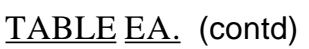

\begin{tabular}{|c|c|c|c|c|}
\hline TIME PFBIOD & -THEME & PROPERIYIYPE & REQUIRED DATAAND INTEGRITY & LISTED PROPFBTIES IN THE MID-COШU \\
\hline \multirow{4}{*}{$\begin{array}{l}4000-5000 \\
3800 \text { BP }\end{array}$} & Physical Characteristics & Graves & Any human remains of this age & none identified \\
\hline & Environmental Setting & $\begin{array}{l}\text { Pollen, animal fossil, sediment } \\
\text { deposits }\end{array}$ & $\begin{array}{l}\text { Dated deposits of this age with } \\
\text { concentrated biotic remains; } \\
\text { distinctly bedded sediments }\end{array}$ & $\begin{array}{l}\text { Savage Island A.D., Windust Caves, Burr } \\
\text { Hanford North A.D., }\end{array}$ \\
\hline & Religion & Cemeteries & Buried/cremated human remains & none identified \\
\hline & & Rock art sites & $\begin{array}{l}\text { Rock surfaces with pictographic } \\
\text { or petroglyphic pannels }\end{array}$ & \\
\hline \multirow[t]{8}{*}{$3800-3400 \quad$ BP } & $\begin{array}{l}\text { Mobility/Settlement } \\
\text { Pattern }\end{array}$ & $\begin{array}{l}\text { Residence sites representing } \\
\text { the full range of seasons }\end{array}$ & $\begin{array}{l}\text { Any dated site representing } \\
\text { this time that contains tools and } \\
\text { may include features, floral } \\
\text { and faunal remains, and represents } \\
\text { the full range of domestic activities }\end{array}$ & $\begin{array}{l}\text { Savage Island(?), Vernita (?), Hanford } \\
\text { Generating Plant Site (?), Lower Snake } \\
\text { River A.D. (?) }\end{array}$ \\
\hline & & Food-processing camps & $\begin{array}{l}\text { Site containing a predominance of } \\
\text { one or two feature types and limited } \\
\text { diversity f10rallfaunal remains }\end{array}$ & none identified \\
\hline & & Quarries, tools & $\begin{array}{l}\text { Raw material sources, artifacts } \\
\text { made from source material }\end{array}$ & none identified \\
\hline & & Cactes & $\begin{array}{l}\text { Dense, spatially restricted } \\
\text { clusters of tools and raw materials }\end{array}$ & none identified \\
\hline & Housing, Demography & Sites with dwellings & $\begin{array}{l}\text { Post holes, depressions, concen- } \\
\text { trated domestic debris }\end{array}$ & none identified \\
\hline & Predation & Kill sites & $\begin{array}{l}\text { Faunal remains In assodation with } \\
\text { weapons and/or butchering } \\
\text { tools }\end{array}$ & none identified \\
\hline & & $\begin{array}{l}\text { Faunallfloral assemblages } \\
\text { from residence sites }\end{array}$ & $\begin{array}{l}\text { Numerous faunal remains } \\
\text { identifiable to taxon, bone, part; } \\
\text { charred or uncharred food plant } \\
\text { remains }\end{array}$ & none identified \\
\hline & Food Storage & Sites with storage facilities & $\begin{array}{l}\text { Dated depressions or pits containing } \\
\text { remains of processed food }\end{array}$ & none identified \\
\hline
\end{tabular}


TABLE EA. (contd)

\section{TIME PERIOD}

THEME

PROPERTY 1YPE

3800-3400 BP Physical Characteristics, Graves

Environmental Setting

Religion

Pattern

$\frac{\pi}{6}$ deposits

Cemeteries

Rock art sites

\section{REQUIRED $\underline{\text { DATA AND }} \underline{\text { INTEGRITY }}$}

Any human remains of this age

Pollen, animal fossil, sediment Dated deposits of this age with

Residence sites representing the full range of seasons

\section{Food-processing camps}

Quarries, tools

\section{Caches}

Housing, Demography

Predation

Kill sites

Faunal/floral assemblages from residence sites

Sites with storage facilities concentrated biotic remains distinctly bedded sedim

Buried/cremated human remains

Rock surfaces with pictographic or petroglyphic panels

Any dated site representing this time that contains tools and may include features, floral and faunal remains, and represents the full range of domestic activities

Site containing a predominance of one or two feature types and limited diversity floral/faunal remains

Raw material sources, artifacts made from source material

Dense, spatially restricted clusters of tools and raw materials

post holes, depressions, concentrated domestic debris

Faunal remains in association weapons and/or butchering tools

Numerous faunal remains Identifiable to taxon, bone, part charred or uncharred food plant remains
Dated depressions or pits containing remains of processed food
LSTED PROPERTIES IN THE MID-COLUMBIA

Savage Island A.D., WIndust Caves, Burr Cave Hanford North A.D.

none identified

none identified

Savage Island(?), Vernita (?), Hanford Generating Plant Site (?), Lower Snake

River A.D. (3 Spr Bar), Marmes Rockshelter

$45 \mathrm{GR} 27$ (c)

none Identified

Lower Snake River A.D. (3 Spr Bar), Shalkop

none identified

Marmes Rockshelter, Savage Island A.D. (?)

Marmes Rockshelter, Cedar Cave (b), Lower Palouse Canyon A.D. (?) 
TABLE EA. (contd)

TIME PERIOD

$3400-2300 \quad \mathrm{BP}$

THEME

Physical Characteristics,

Environmental Setting

Religion

Mobility/Settlemen Pattern

(TI

2300-200 BP $\begin{aligned} & \text { Mobility/Settlement } \\ & \text { Pattern }\end{aligned}$

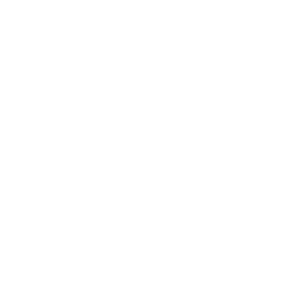

Housing, Demography

Predation

REOUIRED DATA AND INTEGRITY

LISTED PROPERTIES IN THE MID-COLUMBIA

Rock art sites

Residence sites representing the full range of seasons

Sites with dwellings

Kill sites

Fish traps/control features

Any human remains of this age

Dated deposits of this age with concentrated biotic remains; distinctly bedded sediments

Buried/cremated human remains in groups

Rock surfaces with pictographic or petroglyphic panels

Any dated site representing this time that contains tools and may include features, floral and faunal remains, and represents the full range of domestic activities

Food-processlng camps

Quarries, tools

\section{Cactes}

Site containing a predominance of one or two feature types and limited diversity floral/faunal remains

Raw material sources, artifacts made from source material

Dense, spatially restricted clusters of tools and raw materials

Post holes, depressions, concentrated domestic debris

Faunal remains in association

weapons and/or butchering tools

Artificial rock alignments in river bed

\section{Yakima Firing Center}

Savage Island A.D., Windust Caves, Burr Cave Hanford North A.D.,

Hanford Island, Hanford North A.D., Wooded Island A.D., Strawberry Island, Paris, Locke Island A.D., Lower Snake River A.D., Tricities A.D., Ryegrass A. D. , Wahluke, Hanford Generating Plant

Snively Basin A.D. , Rattlesnake Springs

Savage Island A.D. Wooded Island A. D., Locke Island A. D.

Hanson Creek A.D., niles on Saddle Mts.

none Identified

Strawberry Island A.D., Wooded Island A. D. ,

$45 \mathrm{GA} 17$ (c) 
TABLE EA. (contd)

\section{TIME PERIOD}

THEME

2300-200 BP

Predation

PROPERTY TYPE

Game traps, hunting blinds

Faunallfloral assemblages

from residence sites

Sites with storage facilities

Food Storage

Physical Characteristics

Graves

Environmental Setting

Religion

$\overbrace{00}^{\pi}$

Mobility/Settlement

Pattern

Rock art sites

Spirit quest areas the full range of seasons

\section{REQUIRED DATA AND INTEGRITY}

Artificial rock walls, pits at game

Numerous faunal remains

Identifiable to taxon, bone, part;

charred or uncharred food plant

remains

Dated depressions or pits containing remains of processed food

Intact human remains of this age

Dated deposits of this age with concentrated biotic remains distinctly bedded sediments

Buried/cremated human remains in groups

Residence sites representing

Food processing camps

Rendezvous

Trails

or petroglyphic panels

Cairns atop ridges, buttes this time that contains tools and may Include features, floral

and faunal remains, and represents the full range of domestic activities

Site containing a predominance of one or two feature types and limited diversity f10rallfaunal remains

Sites which historic reports state were used as meeting places for members of diverse tribes

Traceable pathways with associated Intercept points

LISTED PROPERTIES IN THE MID-COLUMBIA

Gable Butte/Gable Mountain A.D.

All districts and sites noted under Mobility have potentia

Locke Island A.D., Wooded Island A.D., Palouse Canyon A.D., Marmes Rockshelter

Wahluke, Locke Island A.D., Ryegrass A.D. Hanford North A.D... Marmes Rockshelter

All sites noted under Mobility; Burr Cave,

Windust Caves

Wahluke, Locke Island A. D., Ryegrass A.D.

Hanford North A.D.

Telegraph Island Petroglyphs

Gable MtIGable Butte A.D.

Wooded Island A.D., Locke Island A.D., Hanford Generating plant, Vernita (largely destroyed)

Locke Island A.D. scatter of artifacts, hist. records of use 
TABLE EA. (coord)

TIME PERIOR

200-7 BP

Housing, Demography

Sites with dwellings

Predation

Fish traps/control features

Game traps, hunting blinds

Faunal/floral assemblages

from residence sites

Food Storage

Religion

Sites with storage facilities

Cemeteries

Spirit Quest areas
BEOUIRED DATA AND INTFGRITY

Post holes, depressions, concentrated domestic debris

Artificial rock alignments in river bed

Artificial rock walls, pits-at game intercept points

Numerous faunal remains

Identifiable to taxon, bone, part;

charred or uncharred food plant

remains

Dated depressions or pits containing remains of processed food

Buried/cremated human remains

in groups

Cairns atop ridges, buttes
USTFD PROPFRTIES IN THF MID.CO UIMBIA

Wooded Island A.D. (?), Locke Island A.D. (?)

All districts and sites noted under Mobility have potential

Locke Island A.D., Palouse Canyon A.D.

Wooded Island A.D. (?)

Wahluke, Locke Island A. D., Ryegrass A.D.

Strawberry Island, Hanford North A.D.(d)

Fishhook Island (c), Ford Island (c), Sheep Island (c)

Gable MtlGable Butte A.D.

(a) A.D. stands for archaeological district

(b) Rocovery may not have been complete due to use of older techniques.

(c) Site destroyed or excavated before NHPA became law.

(d) Not treated as potential source of data. 
$\underline{\text { Table E,5 }}$ Research Questions Posed for the Mid-Columbia Study Unit(a)

A. Is there a relationship between the dependability of water or minimum annual river flow and the continuity of cultural traditions? Those areas near riverine systems that would be least affected by climatic fluctuations seem to have the most stable cultural systems. Is this observation correct?

B. Which of the various competing land use models currently in use is the most accurate? Is each, in fact, applicable to only a portion of the region?

C. What is the sequence of burial practices for the Middle Columbia? What are the origins and details of the Middle Columbia "cremation complex"? Why is there a paucity of burial sites prior to ca. 2,000 B.P.?

D. What is the character of the lithic assemblage through time? What are the lithic sources and why do they change through time? What is the projectile point sequence, especially that from the Hanford Site?

E. Does the Plateau pattern really exist? If so, what are its spatial and temporal origins?

F. What is the correlation between site types and microenvironments? Do such microenvironments as springs, dunes, basaltic badlands, rapids, and major and minor tributaries, contain specific site types? How important are such factors as sun and wind exposure, and proximity of botanical resources? Have the correlations changed through time?

G. What are the origin, spread, and temporal distribution of pit house villages in the Mid-Columbia region? Are they in evidence at the Hanford Site early in its sequence? How unique are The Dalles sites? How many houses in a village were occupied contemporaneously? What is the seasonality of house occupancy in different time periods? What are the characteristics of the supporting adaptations?

H. What are the temporal and spatial variations in subsistence orientation? This infonnation should be manifest in tool assemblage, faunal and floral assemblages, projectile point frequencies, and site locational data. What are the environmental parameters of these variations? Do such variables as salmon variability and annual mean river level fluctuations play a major role in these variations?

I. What was the process of change from pre-historic cultures to those observed ethnographically? What were the cultural imports of: the horse. the fur tade economy, depopulation from disease, the inlroduction of new tool technologies, and the introduction of domestic plants and animals (other than the horse)?

J. What is the history of ethnic groups in the Plateau region since earliest habitation. How long have the different groups held their historically observed territories?

K. What is the history of trading patterns in the Plateau and how has trade contributed to the stability of adaptations?

(a) Largely from: Stilson 1987, Chance 1980. 


\section{E.5 REFERENCES}

Binford, L. R 1977. "Forty-Seven Trips: A Case Study in the Character of Archaeological Formation Processes." In Stone Tools as Cultural Markers: Change. RevolutiQn and CQmplexity, ed. RY.S. Wright. pp.24-36, Canberra: Australian Institute Qf Aboriginal Studies.

BinfQrd, L. R 1978. Nunamuit EthnQarchaeQlQgy. Academic Press. New YQrk, New Yark.

BinfQrd, L. R 1980. "WillQW SmQke and Dog's Tails: Hunter-Gatherer Settlement Systems and ArchaeolQgical Site FQrmatiQn." American AntiQuity. 45:4-20.

BinfQrd, L. R 1982. "The ArchaeolQgy Qf Place." Journal Qf AnthrOJ)Ological Archaeology. 1:5-31.

Chance, D. H. 1980. ReSearch QuestiQns and Aporoaches fQr the Middle Columbia River Area. PQrtland District, U. S. Army CQrps Qf Engineers, Portland, QregQn.

Earle, T. K., and J. B. Christensen 1980. Modeling Change in PrehistQric SUbsistence ECQnQmies. Academic Press, New YQrk, New York.

Relander, C. 1986. Drummers and Dreamers. Pacific NQrthwest NatiQnal FQrest Association, Seattle, Washington. Reprint Qf 1956 editiQn.

StilsQn, M. L. 1987. "EvaluatiQn CQmponent". In ResQurce Planning and Protection process, Mid-Columbia Study Unit. Washington State Office Qf ArchaeolQgy and Historic PreservatiQn, Department Qf CQmmunity DevelQpment, Olympia, Washington.

Winterhalder, B. and E. A. Smith. 1981. Hunter-Gatherer Eoraging Strategies. University Qf ChicagQ press, ChicagQ, IllinQis. 


\section{APPENDIXF}

\section{ARCHAEOLOGICAL SURVEYS PERFORMED ON THE}

HANFORD SITE PRIOR TO APRIL 30,1988 


\section{APPENDIXF \\ ARCHAEOLOGICAL SURVEYS PERFORMED ON THE}

HANFORD SI1E PRIOR TO APRIL $\underline{\text { 30. } 1988}$

The table contained in this appendix is being reproduced for Cultural Resource Management Staff only. Copies are available upon request from K. C. Clarke, DOE-RL. 


\section{APPENDIXG}

\section{WASHINGTON STATE HISTORIC PRESERVA nON OFFICER'S STANDARDS FOR ARCHAEOLOGICAL SURVEY AND REPORTING}




\title{
STATE OF WASHINGTON \\ OFFICE OF ARCHAEOLOGY AND HISTORIC PRESERVATION
}

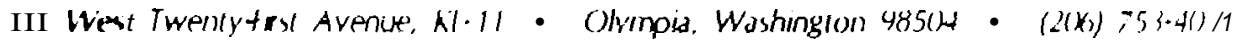

\author{
$\underline{\text { ARCHAEOLOGICAL SURVEY NID REPORTING GUIDELINES }}$
}

\section{INTRODUCTION}

Agencies are required to assess the effects of their proposed projects on significant archaeological and historic properties under both federal and state law. In order to accomplish this, agencies and the public consult th the Office of Archaeology \&Historic Preservation (OARP) concerning the significance of discovered properties and the effect of the proposed project upon any signifioant archaeological or historic property.

This document details the general principles and methods in conducting an archaeological surveg for compliance purposes and lists the organizational format of a professional archaeological survey report and the kinds of information needed to make a reasoned evaluation of the data by independent third party reviewers.

Because varying federal and state laws mas be involved in any specific project, this docuent provides only general summary information. Specific references for further detailed information as of this publication date for identifying archaeological properties are provided. For speciflo procedural and legal details, we refer you to the lead Federal or State Agency.

These guidelines are not regulatory and do not set or interpret any agency's policies, regulations, or permit requirements. The document is intended to provide general technical advice about archaeological activities and methods. Agencies conducting multiple small scale surveys are encouraged to oontact OAHP regarding field strategies and reportage requirements for classes of projects requiring archaeological survey.

Questions regarding archaeological ooncerns on specific projects should be addressed to the identified lead agency and/or the State Historic Preservation Officer (SHPO).

These guidelines are in large part adapted from the Department of Interior, National Park Service, Secretary of the Interior's Standards and Guidelines for Archaeology and Historic Preservation: Federal Register Vol. 90, \$o. 140:44716. 


\section{PART 1. ARCHAEOLOGICAL IDENTIFICATIOH \& SURVEY ACTIVITIES}

Survey activities are undertaken to gather information about archaeological properties in a specific area. The scope of the survey activities will depend on existing knowledge about properties and the project area, goals for survey activities developed in the project planning process, and current management needs.

\section{Principle \& Identification od Suryey of Archaeological ProDerties} are Undertaken to the Degree BeQuired to Hake Specific Decisions.

Archival research and on site inspection activities should be designed to gather the information Docessary to achieve defined identification goals. The objectives, chosen methods, techniques, and expected results are specified in the survey research design.

These activities may include archival research and other techniques to develop archaeological contexts, sampling an area to gain a broad understanding of the kinds of property types in an area, or examining all ressonably locatable archaeological properties to arrive at property specific decisions.

Identification activities should use a search procedure consistent with the management needs for 1nformation and the character of the area to be investigated. Careful selection of methods, techniques, and level of detail is necessary so that the gathered information will provide a sound basis for making decisions.

Principle 2 Results of Identification Actiyities are Integrated Into the Rlaning Process

Results of identification activities are reviewed for their contribution to existing planning data. Arohival research or field data may.refine the understanding of one or more archaeological contexts or property types. Incorporation of the identification activities into the planning process is necessary to ensure that the planning process is always based upon the best available information.

Principle 3, Identification Actiyities Inqlude ExpliQit Proqedures 200 Record Keeping and Information Distribution

Information gathered in identifioation activities is useful in other preservation planning activities and scientific studies only when it is systematically gathered and recorded and made available to those responsible for preservation planning and scientific research and cominuicated to the interested public.

The results of identification activities should be reported in a format that summarizes the design and methods of the identification activities, provides a basis for others to review the results, and states where information on identified properties is maintained.

Sensitive information, such as the location of fragile resources, must be safeguarded consistent with public disclosure requirements. 
Principle 4 Conoerned Tribes. Local Goyernments, Concerned Members of the Public and Professional Community and state and Federal Agencies Wth Teohnioal Expertise

Archaeological survey and research requires effective communication and consultation with concerned Tribes, local governments, historical organizations, and state and federal agencies that have technical expertise or review responsibility. All identification activities should be coordinated with concerned entities to assure that their concerns and data are incorporated into the survey project. 


\section{PART 2. GUIDELINES FOR IDENTIFICATION ACTIVITIES}

These guidelines link the principles of identification with more specific guidance and technical information. The guidelines presented here outline one approaoh to meet identification needs.

Identification is undertaken for the purpose of loosting archaeological properties and is composed of a number of activities whioh include,but are not limited to arohival researoh,informant interviews, field survey and analysis.

Combinations of these activities may be selected and appropriate levels of effort assigned to produoe a flexible series of options.

\section{Performing Identification}

Researoh Design

Identifioation activities are essentially research activities for whioh a statement of objectives or research design should be prepared before work is performed. The research design provides a meohanism for integrating the various aotivities performed during the identifioation prooess and for linking those activities direotly to the goals and the arohaeo10gioal oontexts for whioh the goals were defined. All surveys regardless of size should have a researoh design.

The research design stipulates the logical integration of archaeo10gioal contexts and field and laboratory methods. Additionally, the researoh design provides the foous for the integration of interdisciplinary studies.

The research design should include the to110wing:

1. Objectives ot the identifioation aotivities. The statement ot objeotives should refer to ourrent knowledge about the archaeological contexts or property types in the area based upon background research. It should olear1y define the physioal extent of the area to be investigated and tha amounts and kinds of information to be gathered about properties in the area.

2. Methods to be used to obtain the identifioation intormation. Archival and on-site survey methods should be caretu11y explained so that others using the gathered information oan understand how the information was obtained. Particular attention should be devoted to establishing the linkage between the statement of objectives and the selection of specific methods in order to realize those objeotives given a specific project area and particular environmental oonditions.

3. The expected results and the reasons for those expectations. Expeotations about the kind, number, location, oharacter and condition of archaeological properties are derived from the backgound researoh,proposed or tested models of prehistoric land use and settlement, or analogy to property types known to exist in 
areas of similar environment or history.

Archival Research

Archival or background research is generally undertaken prior to any field inspection. Arohival researoh should address speoifio issues and topios relevant to the area under study. It should not duplicate previous work. Souroes should inolude, but are not limited to, historic maps, tax reoords, photographs, previous historio and archaeologioal researoh, etanographies, review of databases and records maintained by state and federal agenoies,consultation knowledgeable experts in the area, ooncerned tribes and interested public as appropriate for the research design and area under study.

Field Survey

The variety of field survey techniques available, in combination with the varying levels of effort that mag be assigned, give great

flexibility to implementing field surveys. It is important that the selection of partioular field survey teohniques and level of efforts be responsive to the identification goals, research design, and management needs that direot the survey.

Field survey is neoessary when it is required to know precisely what arohaeological properties exist in a given area and what types of information are needed to evaluate the National Register eligibility of individual arohaeological properties.

In oonducting a field survey particular attention should be given to evaluating the desirablity of employing remote sensing teohniques to assist in site identification and to aid in the non-destruotive examination of subsurfaoe deposits of the discovered sites.

Field surveys should desoribe the distribution of arohaeological properties in the study area, determine the number, looation,.and types of properties aotually present with in the area, allows classifioation of individual properties and reoords the physioal extent of individual properties.

The field survey should document:

1. The kinds of properties looked for;

2. The boundaries of the areas surveyed;

3. The method of survey, desoription of transect and subsurfaoe examination prooedures, and a oaloulation of the actual area inspected;

4. A record of the preoise looation of all properties identified;

5. Information on the appearanoe,significanoe, integrity and boundaries of each property.

Analysis and Reportage

Arohaeological identification activities are not complete without analysis of the collected data. Data analysis is an integral part of 
the-identification process and should be planned for in the research design. Analytical techniques should be selected that are relevant to the objectives of the investigation.

Archaeological documentation concludes th written reports including sinimally the tollowing topics:

1. Description of the study area;

2. Relevant historical dooumentation,paleoenvironmental and environmental data and background research.

3. The research design.

4. The field operations as actually implemented including any changes or alterations trom the research design and the reason for those changes.

5. All field observations.

6. Analyses and results, illu8trated as appropirate with tables, charts and graphs.

7. Evaluation of the investigation in terms of the goals and objectives of the study.

8. Sources, references, and agencies, tribes, and informants contacted.

9. Information on the location of the original data in the form of tield notes, photographs, and other materials. 


\section{PART 3. REPORTING FORMAT}

The outline presented below indicates the organizational format of a professional archaeological survey report and contains the kinds of information needed to make a reasoned evaluation of the archaeological survey by independent third party reviewers. All reports regardless of the survey's size should oontain this basic information.

I. Front Matter.

A. Title Page.

1. Report Title indioating projeot and location

2. Principal Investigator, Author and Organization conducting survey.

3. Date

4. Contracting Sponsor, Permit Number, Contract Number

5. If on federal or state oontrolled land, the manasing agency.

B. Executive Summary or Abstract

C. Table of Contents

D. List of Figures

E. List of Tables

II. Introduction

A. Describe the proposed project that precipitated the survey.

1. looation, size of impact area,nature of expected 1opacts,

2. Include "a project area map'CU.S.G.S. Quad indicating Section, Township, Range and Quad Naoe) showing general area, and specific project area $\cdot$.

3. Identify the proponent, landowner and lead sisency and permit or compliance action survey is addressing.

III. Research Design

A. Objectives.

1. Current knowledge about archaeological context and property types based upon review of existing archaeological research,ethnographic data and historic records, and consultation with concerned tribes, local preservation officials, SHPO, federal and state agencies with technical information.

2. Summary of Study area Environment with an emphasis upon vegetational, geomorphic, and human factors that would affect recognition and preservation of the archaeological properties identified in III.A.1. 
3. Expectations based upon III.A.1. and III.A.2. for the' study area. Specific expectations of archaeological property types, their location, structure, and how they may manifest themselves in the area under consideration.

B. Methods

1. Describe the methods proposed to be employed to identify if the archaeological property types occur in the area to be surveyed. Relate specific on-site methods to the expectations generated under III.A.

\section{Field Inspection}

A. Background Research

1. Detail dates of background research including sources contacted, interviews with ooncerned tribes local preservation officials, federal and state agencies with expertise, contact with knowledgeble informants.

B. On-Site Inspection

1. Detail the date of the on-site field inspection noting observed field conditions relating to vegetation, surface exposures, weather conditions, and contempory use of the study area.

2. Describe the search procedures, listing person-time spent on each activity.

3. Describe the percent of mineral soil exposed in the survey area.

4. Describe any special inspection or remote sensing techniques that were employed.

5. Quantify the amount of sub-surface testing or manual surface-exposing activities that were carrried out.

6. Describe any cbanges in the actual field methods from proposed field methods.

7. Describe how artifacts and other oultural materials were recorded and oollected.

8. Provide a map of the surveged area lodicating specific areas surveyed, location of all subsurface oores, mineral so11 exposures, areas of recent disturbance, isolated artifacts, oontemporary structures and features.

V. Results

A. Findings of Fact

1. Detail what was actually observed in a systematic fashion; provide quantitative information.

2. If cultural material was observed or collected provide a description, drawings or photographs of the materials. 
B. Conclusions

1. Detail research conclusions based upon the expectations generated in III.A.

2. Qualifications of results should be explicitly related to methods employed and field conditions.

C. Recommendations

1. Provide recommendations related to on-site observations and expectations generated by the research design.

2. If no properties were found relate this back to expectations generated by background research and identify probable reasons.

3. If a property was found but it appears to lack integrity/National Register eligibility, specify how you have defined integrity/National Register eligibility and how your examination demonstrated that the property lacks integrity or National Register eligibility.

4. If a property is discovered and in the professional opinion of the principal investigator has integrity or additional work is required to establish National. Register eligibility is warranted detail wat that work entails.

5. If construction monitoring is recommended detail precisely the area to be monitored, why monitoring is necessary, what techniques should be employed to . onitor, and what kind of resources may be expected in the identified area.

\section{Referenoes}
A. Published and limited distribution reports in American Antiquity bibiliography eorsat.
B. Archival sources and maps Title and Location of source and naps

VII. Consultations
A. Evidence of consultation with ooncerned tribes.
B. Evidence of consultation with SHPO.
C. Evidence of consultation with local preservation officer.
D. Evidence of consultation with Federal and State agencies with responsibility or expertise.
E. Copy of ARPA permit if on federal land.
F. Approval of report by federal agency if on federal land or under control of federal agency. Note: some federal agencies require their own approval and review sheet on the 
cover of the survey report.

VIII.Appendix

1. Location of original field data.

B. Site inventory forms

C. Informants 
PART 4. TECHNICAL REFERENCES

$\underline{\text { Survey }}$

King, T.F.

1978 The Archaeological Survey: Methods and Uses. GPO Number 024-010-0089-7

Lyons, T.R., and T.E. Avery

1978 Remote Sensing: \& Handbook tor Archaeologists and Cultural Resource Hanagers.

$\underline{\text { Section } 106} \underline{\text { Process }}$

36 CFR 800: Advisory Council on Historio Preservation Protection ot historic and cultural properties. 


\section{APPENDIXH}

\section{FORMS USED IN CULTURAL RESOURCES MANAGEMENT}




\section{HANFORD CULTURAL RESOURCES SURVEY FORM}

Page 1 of 3

Form of
Project name:

Date:

Start time:

End time:

Weather:

Light:

Map reference:

Description of project area and survey strategy:

Previous disturbance:

Topography:

Surface sediments (including depth indications):
Wind:

Project number:

Survey participants: 


\section{HANFORD CULTURAL RESOURCES SURVEY FORM (Cont'd.) Page 2 of 3

Date: $\quad$ Project number:

Plant types/communities and relative abundance. List in decreasing order of dominance:

Ground cover (\%):

Animals observed and inferred:

Cultural material observed:

Cultural material collected:

Evaluation of the potential for recovery of paleoenvironmental data: 
HANFORD CULTURAL RESOURCES SURVEY FORM (Cont'd.)

Page 3 of 3

Form of

Date: Project number:

Comments:

Sketch map:

match sheet -----

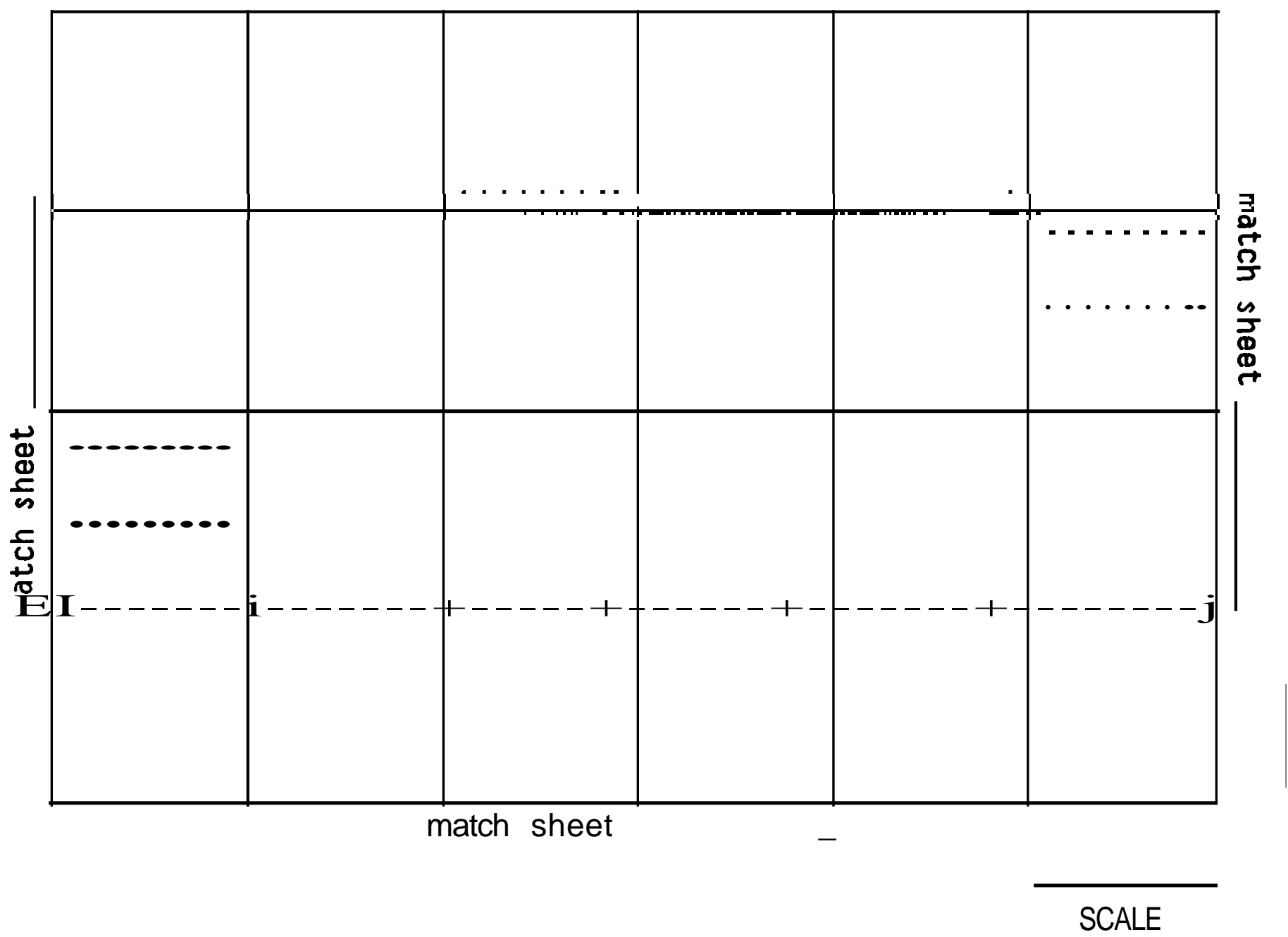

Recorder:

- Date: 
HCRC ISOLATE FORM

Page 1 of

Prehistoric Historic__ Isolate 非 (HI-year-sequence 非):

Project: $\mathrm{BWIP}_{-} \quad \mathrm{BER}$ Service Assessment_ Other_

Plot 非or Project 非 Microenvironment(s):

Elevation:

Location:

$1 / 4$ of

$1 / 4$ of

114 of $\mathrm{Sec}$

$\mathrm{R}$

Map reference(s):

Aerial photo reference:

UTM:Zone m.Easting

m.Northing

General location and access:

Description and functional type:

Topographic setting:

slope:

aspect:

Direction/distance to permanent water:

Name of permanent water source:

Surface sediments (including depth indications):

Recorder:

Date :

- LRB \#:

- Page \#: 


\section{HCRC ISOLATE FORM}

Isol ate 非

Plant types and relative abundance $(\mathrm{a}=\mathrm{abundant}$. $\mathrm{c}=\mathrm{common}$. $\mathrm{r}=$ rare $)$. List in order of dominance:

Ground cover $(\%)$ :

Animals observed and inferred:

Photograph 非:

Draw to scale if temporally diagnostic:

Comments:

Recorder :

$$
\text { - Date: }
$$$$
\text { - LRB \#: }
$$

Page \#: 
Hi stori $c_{-} \quad$ Prehistoric

Site 非 (HT-year-sequence 非):

Project: BWIP_BER_ Service Assessment_ Other_

Plot 非 or project 非:

MicroenvironmentCs):

Site type:

Elevation:

Location:

$1 / 4$ of

$1 / 4$ of

$1 / 4$ of Section

$\mathrm{T}$

. $\mathrm{R}$

Map referenceCs):

Aerial photo reference:

UTM: Zone ___

m.Easting

m.Northing

General location and access:

Description of site:

Site di mensions:

Site area:

Site condition: Excellent . Good - Fair - Poor Agent of impact:

Estimated depth of cultural material:

National Register potential: Justify: Significant Non-Significant

Topographic setting:

Degree of slope:

Aspect of slope:

Direction/distance to permanent water:

Name of permanent water source:

Surface sediments Cincluding depth indications) and depositional environment: 
Si te 非:

Plant types and relative abundance ( $a=$ abundant. $c=$ common. $r=$ rare). List species in order of dominance:

Ground cover $(\%)$ :

Animals observed and inferred:

Total number of objects:

Debitage: numbers present:

lithologies:

Formed tools:

Quantity
Maximum density of objects:

greatest concentration:

type:

Description

Features:

Site date: How dated:

Photograph 非:

Comments:

Recorder :

- Date: _ _ LRB 非

pg. $\quad-$ 


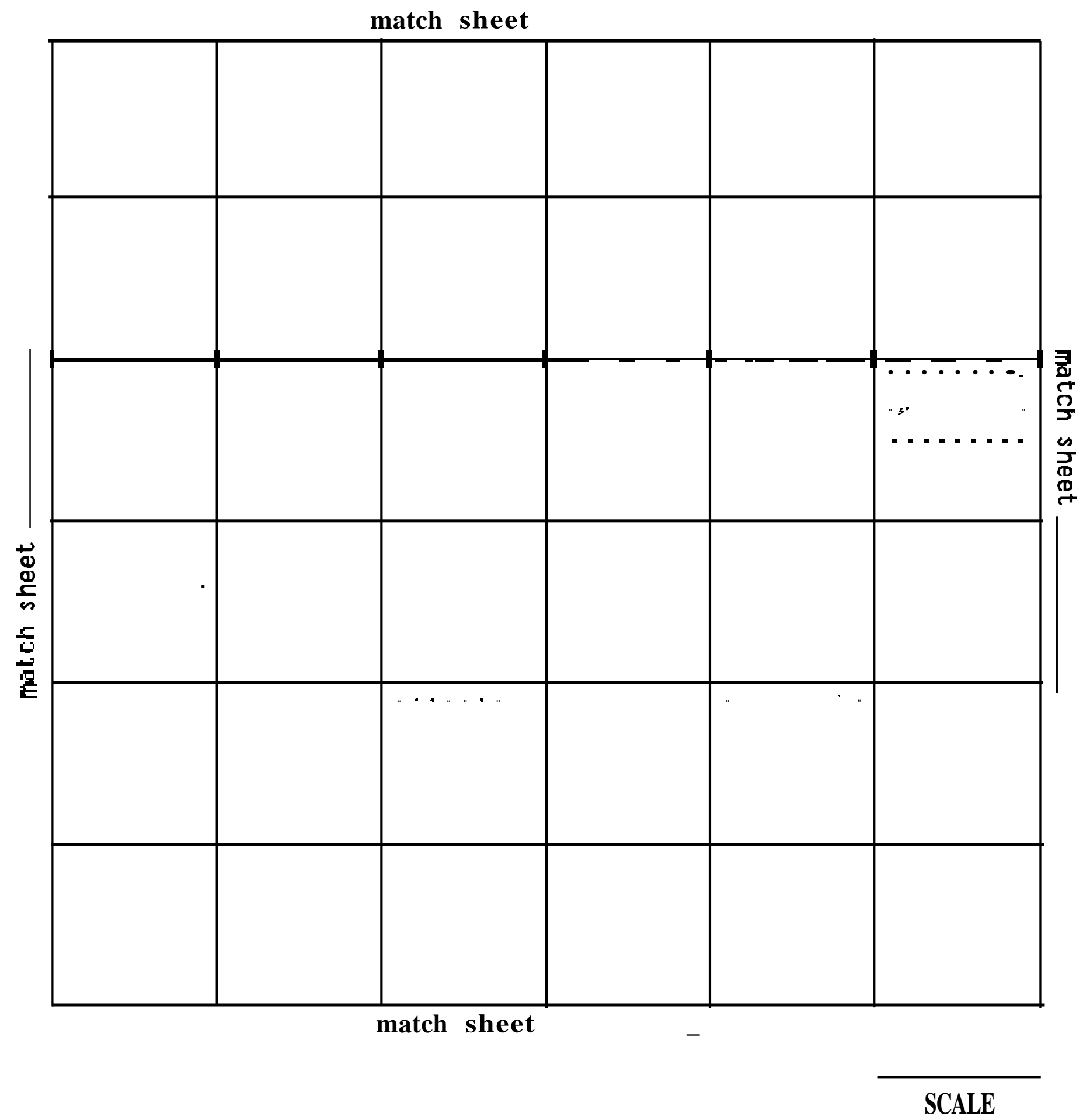

COMMENTS:

RECORDER: $\quad$ _ DATE: $\quad$ - PAGE_OF_

Recorder: $\_--------\ldots$ Date: $-\ldots--$

P9. 


\section{AUGER SUMMARY}

AUGER PROFILE

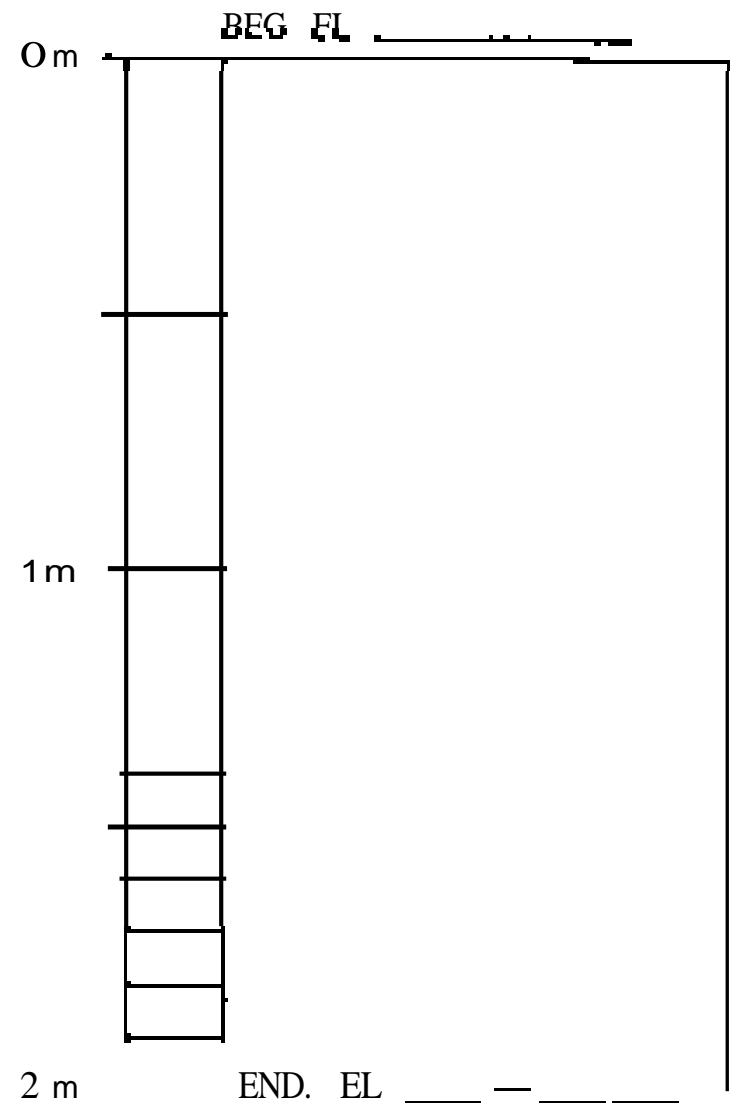

SITE

AREA

AUGER NO.

DATE

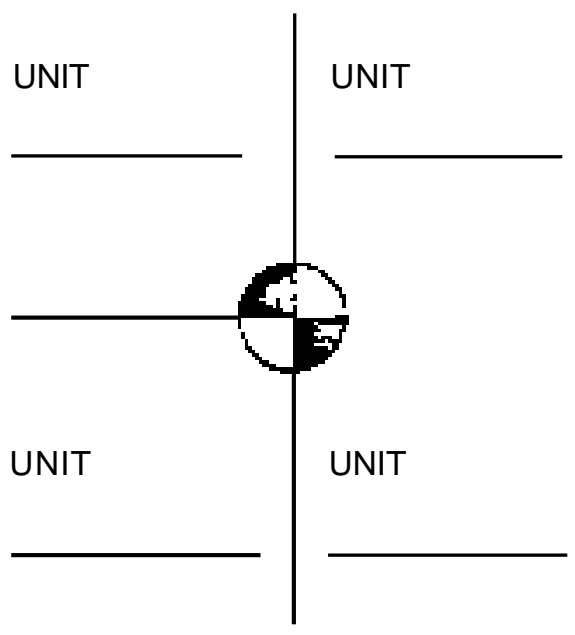

RECORDERS

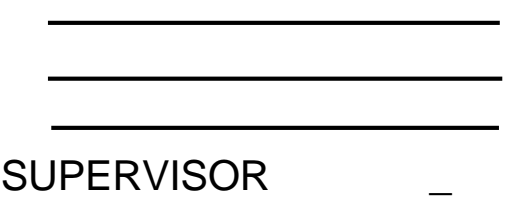

\section{COMMENTS}


LEVEL CONITENTS

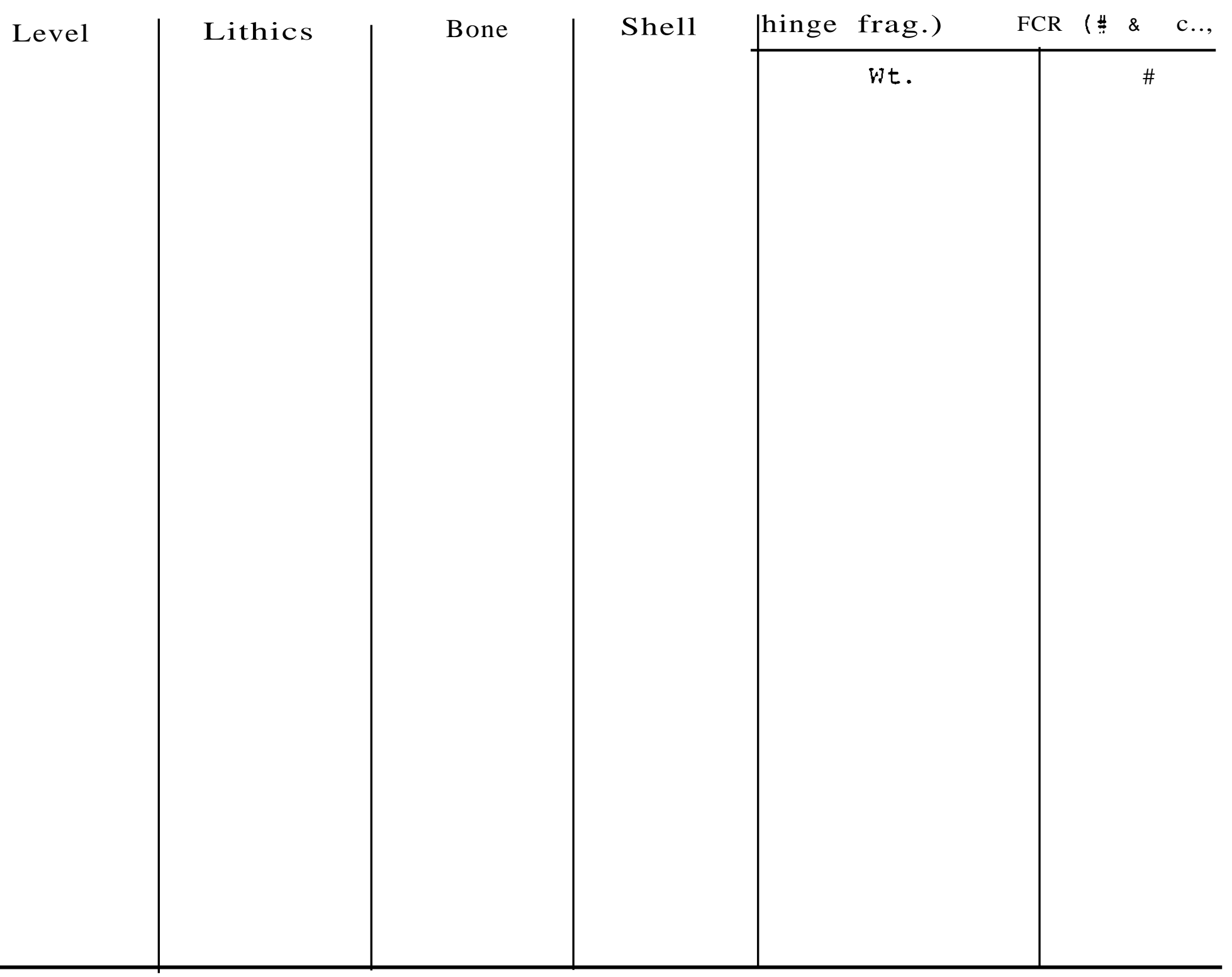


HCRC COMENTS/COHTINUATIOH FORM

Continuation of fonm

of 
Project:

\section{REQUEST FOR DETERMINATION OF ELIGIBILITY}

\section{NAME}

Historic

Common

Si te Number

\section{LOCATION}

\section{CLASS IFI CAT ION}

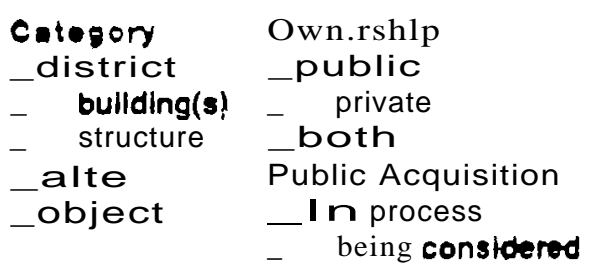

Category

district

structure

alte

- being constored

Statu.
_occupied
- unoccupied
Accessible
Accest in progress
- yes: restricted
- yel: unrestricted
_ no
Present $\mathrm{u}^{\bullet \bullet}$
- agriculture
- commercial
- educational
- entertainment
- government
Industrial
- military

\section{OWNER}

\section{REPRESENTATION IN EXISTING SURVEYS}

$\begin{array}{llll}\text { Federal State } & \text { County } & \text { Local }\end{array}$


Resource:

OESCRI PT ION

\begin{tabular}{|c|c|c|c|}
\hline $\begin{array}{l}\text { Condition } \\
\text { excellent } \\
\text { _good }\end{array}$ & $\begin{array}{l}\text { _terlorated } \\
\text { _ rulns }\end{array}$ & $\begin{array}{l}\text { Che ek one } \\
\text { unaltered } \\
\text { _ altored }\end{array}$ & $\begin{array}{l}\text { Check one } \\
-\quad \text { orlginal alte } \\
-\quad \text { moved date }\end{array}$ \\
\hline
\end{tabular}

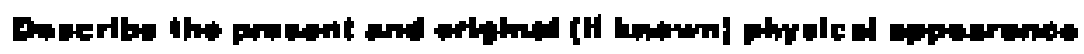

\section{SIGNIFICANCE}

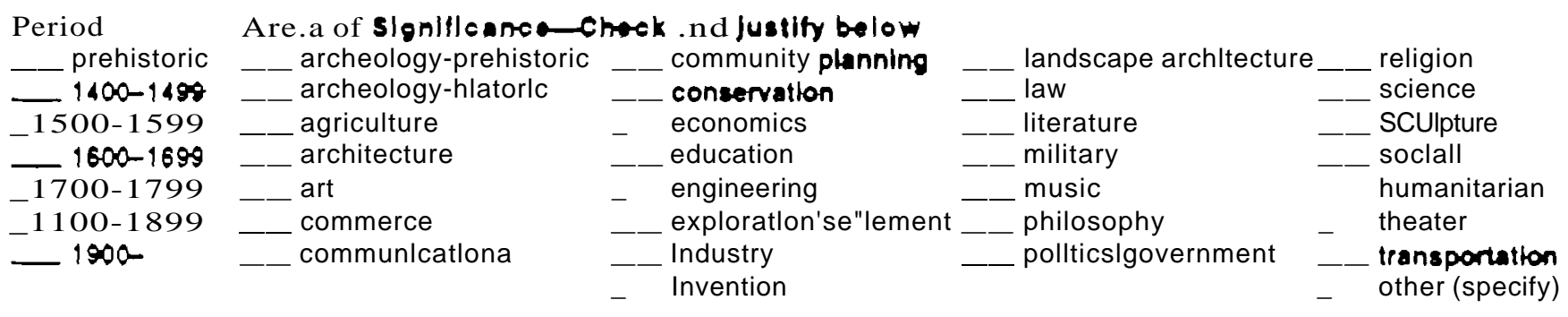

Specific date.

BullderlArchitect

$S^{\prime} . t e^{\prime}$, en' of Slgnlflc.nce 
Resource:

GEOGRAPHICAL DATA*

UTM References

Section Township Range

*Attach a copy of the U.S.G.S. Quad. indicating the property and UTM boundaries.

FORM PREPARED BY

Name:

Date:

Organization:

Phone:

Address:

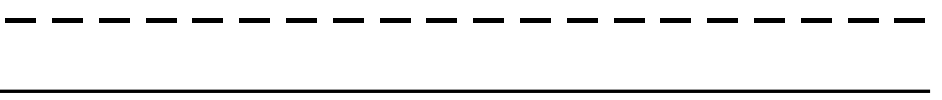

Recent photographs must be included as part of the determination. 
Resource:

\section{STATE HISTORIC PRESERVATION OFFICER}

I understand that the

is requesting the opinion of the State Historic Preservation Officer concerning the eligibility of inclusion in the National Register and that my opinion may be submitted to the Secretary of the Interior with a formal request for a determination of eligibility on this property. This statement confinms that I have been consulted as part of the determination of eligibility process.

(1) In my opinion. the property is eligible for inclusion in the National Register.

(2) In my opinion. the property is not eligible for inclusion in the National Register.

(3) I have no opinion and prefer to defer to the opinion of the Secretary of the Interior.

Comments:

Si gned: $\overline{\text { Jacoß̊ E. Thomas. State Fistoric Preservation Offícer }}$

Date: 
United States Department of the Interior

National Park Service

\section{National Register of Historic Places Inventory-Nomination Form}

For NPS u. . only

received

date entered

See instructions in How to Complete National Register Forms

Type all entries-complete applicable sections

\section{Name}

historic

and or common

\section{Location}

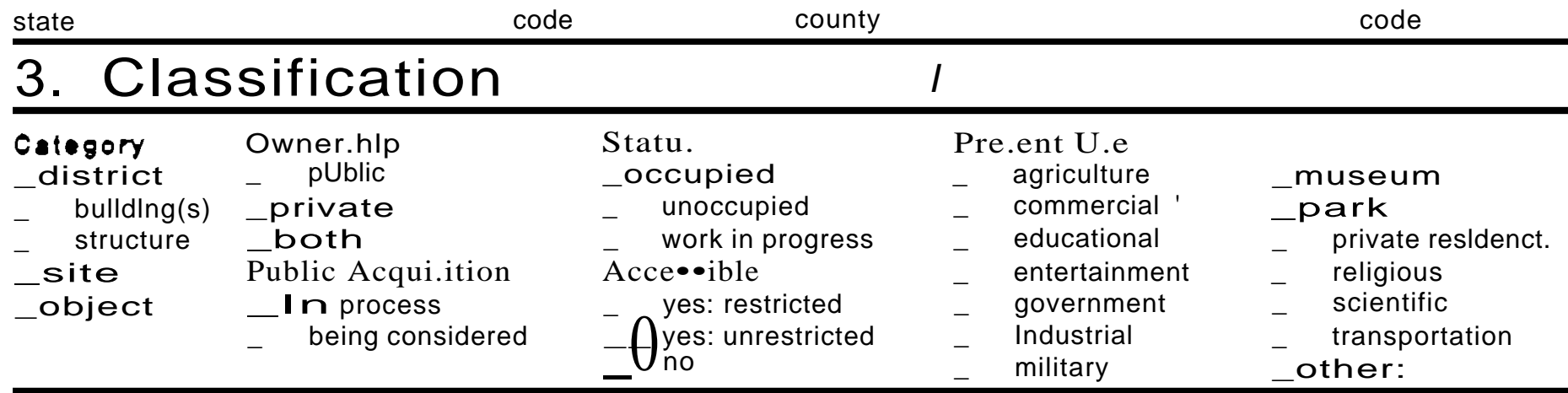

\section{Owner of Property}

name

street \& number

city, town $\quad$ - Vicinity of state

\section{S. Location of Legal Description}

courthouse, registry of deeds, etc.

- treet \& number

City, town

state

6. Representation in Existing Surveys

title 


\section{Description}
Condition excellent good fair

deteriorated
ruins
unexposed

Check one unaltered altered

Check one

- original site moved

Describe the present and original (It known) physical appearance 


\section{Significance}
Period prehistoric 1400-1499 1500-1599 $1600-1699$ $1700-1799$
-1800-1899 $1900-$

Areas of Significance-Check and justify below archeology-prehistoric _ _ community planning

""_ archeology-historic agriculture

_... architecture

- art

"_commerce communications
-... conservation

__ economics

_ education

-___ engineering

__. exploration/settlement

- industry invention landscape architecture"

law

literature

military

music

philosophy

politics/government religion science sculpture social/ humanitarian theater transportation other (specify)

\section{spoctite dotes}

Builder/Architect

Statement of Significance (in one paragraph) 


\section{Geographical Data}

Acreage of nominated property

Quadrangle name

Quadrangle scale

UTM References
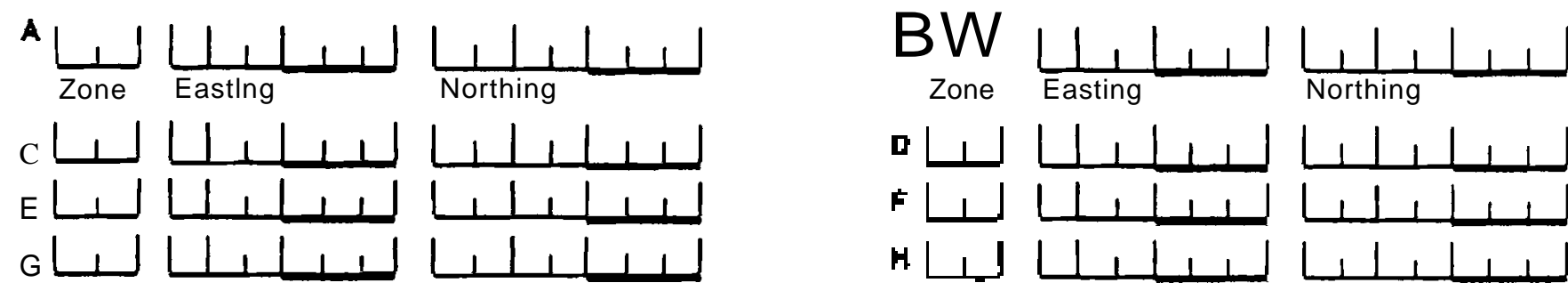

V.rbal boundary d.scription and justification

List all stat.s and counties for properties overlapping state or county boundaries

\begin{tabular}{llll} 
& code & county & code \\
\hline state & code & county & code
\end{tabular}

11. Form Prepared By

name/title

organization

date

street \& number

telephone

city or town

state

\section{State Historic Preservation Officer Certification}

The evaluated significance of this property within the state is:

national

state

local

As the designated State Historic Preservation Officer for the National Historic Preservation Act of 1966 (Public Law 89 665). I hereby nominate this property for inclusion in the National Register and certify that it has been evaluated according to the criteria and procedures set forth by the National Park Service.

State Historic Preservation Officer signature

title

date

For thes use only

I haroby cortity that this property I. Included In the National Register

date

\section{Keoper of the Nattonal Rogister}

Atton: 
United St.t-• Dep.rtment of the Interior National Park Service

National Register of Historic Places Inventory-Nomination Form

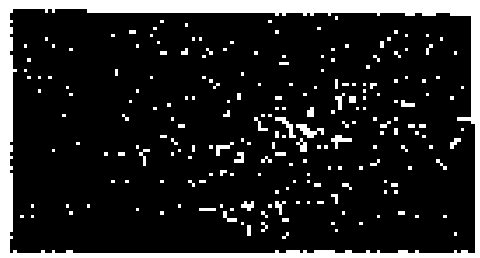


Cultural Resource Plan, Hanford Appendix I

APPENDIX I

\section{CONTRIBUTORS}




\section{CON1RffiUTORS}

\section{I.1 LIST OF CON1RIBUTQRS}

\begin{tabular}{|c|c|c|}
\hline Chanter/Anoendix & Section & Contributor(s) \\
\hline Chapter I & & James C. Chatters, Ph.D. \\
\hline Chapter 2 & $\begin{array}{l}\text { Section } 2.1 \\
\text { Section } 2.2\end{array}$ & $\begin{array}{l}\text { Charles A. Brandt, Ph.D. } \\
\text { James C. Chatters, Ph.D. }\end{array}$ \\
\hline Chapter 3 & & James C. Chatters, Ph.D. \\
\hline Appendix A & & Susan E. King \\
\hline AppendixB & & James C. Chatters, Ph.D. \\
\hline AppendixC & Section C.I & $\begin{array}{l}\text { Charles A. Brandt, Ph.D. } \\
\text { Karin A. Hoover } \\
\text { William H. Rickard, Ph.D. }\end{array}$ \\
\hline & Section C. 2 & James C. Chatters, Ph.D. \\
\hline AppendixD & $\begin{array}{l}\text { Section D.1 } \\
\text { Section D.2 } \\
\text { Section D.3 } \\
\text { Section D.4 }\end{array}$ & $\begin{array}{l}\text { Karin A. Hoover } \\
\text { James C. Chatters, Ph.D. } \\
\text { Lynn Robbins, Ph.D. } \\
\text { Michelle Stenehjem, Ph.D. }\end{array}$ \\
\hline AppendixE & & James C. Chatters, Ph.D. \\
\hline Appendix F, J & & Natalie A. Cadoret \\
\hline
\end{tabular}

\subsection{BIOGRAPHICAL SKETCHES $\underline{\text { OF }} \underline{\text { CONTRIBUTORS }}$}

CHARLES A. BRANDT, Research Scientist, Environmental Pathways and Assessment Section, Geosciences Department, Battelle-Northwest

B.S. Zoology, Oregon State University

Since 1986, Dr. Brandt has served as environmental task coordinator for the Basalt Waste Isolation Project, both for Rockwell Hanford Operations Site Licensing Department and for Battelle-Northwest In that capacity, he has managed and directed the formulation of technical plans for the assessment of ecological effects throughout the Hanford site. Since the termination of repository site characterization work at Hanford, Brandt has served as task leader for the arid lands revegetation and restoration project In this assignment, he developed technical plans for restoration of disturbed areas on the Hanford site, and has been responsible for monitoring the success of those efforts.

NATALIE A. CADQRET, Technical Specialist, Environmental Pathways and Assessment Section, Geosciences Department, Battelle-Northwest

B.S. Geology, University of Wisconsin - Madison

Graduate courses in Geology, University of Washington

Ms. Cadoretjoined Battelle in 1987 to work on site characterization activities for a waste repository project Her background and experience in cultural resources have been instrumental in implementing a cultural resources management project funded by the Department of Energy. Her position entails cultural resource inventory and 
evaluation on the Hanford Site to ensure compliance with Federal Laws regulating cultural resources on Federal Lands. Ms. Cadoret has nine years of archaeological experience in the western United States.

JAMES C. CHATTERS, Senior Research Scientist. Environmental Pathways and Assessment Section, Geosciences Department. Battelle-Northwest

B. A. Washington State University

M.A. University of Washington

Ph.D. University of Washington

Dr. Chatters has been involved in archaeological research in the Pacific Northwest for over 20 years. He is now the archaeologist/anthropologist for the Hanford Site, where he manages cultural properties and serves as a technical consultant to the U.S. Department of Energy. Prior to joining Battelle, Dr. Chatters managed cultural resource contracting programs for the University of Washington and Central Washington University. He has a wide range of expertise in the paleosciences and is a recognized expert on the archaeology and paleoecology of the Pacific Northwest.

KARIN A. HOOVER, Scientist, Environmental Pathways and Assessment Section, Geosciences Department, Bauelle-Northwest

B.A. Anthropology, University of California-Davis

Ms. Hoover has been working as a geologist and geomorphologist since 1980. Since joining Battelle in 1987, Ms. Hoover has worked primarily on characterization and conceptual modeling of transport and storage of radionuclides in the southern Columbia River basin, Quaternary stratigraphy and environmental reconstruction of the Pasco Basin, and on Hanford Site characterization activities for a waste repository project. Prior to joining Bauelle, Ms. Hoover taught geology and geomorphology courses in California and Washington.

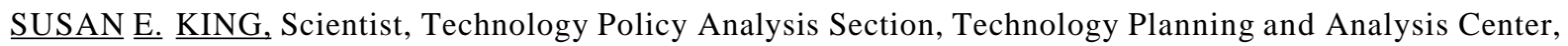
Battelle-Northwest

B.A. Anthropology, Washington State University

Additional coursework in environmental regulatory compliance

Ms. King specializes in the area of environmental policy and environmental regulatory compliance, and has detailed knowledge of statutory and case law pertaining to those issues. She was task leader for the development and implementation of the environmental regulatory compliance plan for the Basalt Waste Isolation Project, and has prepared an initial plan for integrating and coordinating NEPA compliance activities on the Hanford Site.

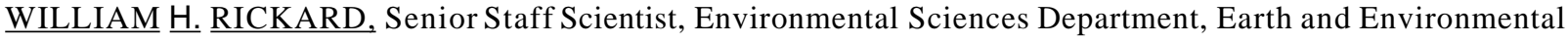
Sciences Center, Battelle-Northwest

B.A. Botany, University of Colorado

M.A. Botany, University of Colorado

Ph.D. Botany, Washington State University

Since joining Battelle in 1965, Dr. Rickard has conducted field and experimental research in terrestrial ecology. Research has centered around field sampling to measure primary productivity, soil-plant mineral relations, and manimposed perturbations, especially cattle grazing, severe soil disturbances, and airborne chemical contaminants in the semiarid Columbia Basin Region of eastern Washington. He has conducted baseline ecology studies for commercial nuclear power stations and prepared environmental impact assessments for NRC and DOE, especially terrestrial ecology sections. Dr. Rickard is project manager for wildlife surveillance perfonned on the Hanford Site for the U.S. Department of Energy's Richland Operations Office. 
LYNN E. ROBBINS, Professor, Environmental Sbldies Department, Huxley College, Western Washington University

Ph.D. Anthropology, University of Oregon

Dr. Robbins has conducted research on the effects of large energy projects on the social and economic life of NativeAmericans for the past 22 years. He was a senior researcher on the Lake Powel Research Project: an interdisciplinary study to assist tribal, state, and Federal officials with decisions about energy, water use, threats to human health from energy production, labor, and resettlement. Subsequently, Dr. Robbins has conducted research with Crow, Blackfeet, Southern Ute, Cheyenne, Upper Skagit, Yupik, and Inuipiat peoples on the social impacts of energy development

MICHELLE SJENEHJEM, Historian, Consultant

B.A. Sociology, State University of New York, Cortland

M.A. History, State University of New York, Albany

Ph.D. History, State University of New York, Albany

Dr. Stenehjem is a consulting historian residing in Richland, Washington. Before coming to the northwest, she conducted research and prepared historical texts for museums and historical societies in Ohio, New York, and Illinois. Her special interest is in the history of technology in 20th-century America. 


\section{APPENDIX]}

\section{LIST OF HISTORIC PROPERTIES ON THE HANFORD SITE}


TABLE J.1. Condition, Age and Potential Source of Impacts to Historic Properties on the Hanford Site

\begin{tabular}{|c|c|c|c|c|c|c|c|}
\hline PROPERIY & PROPERTY & SITE' & CURRENT CONDITKN & AGE, BY PHASE & POTENTIAL IMPACTS OF DOE MGT & COMMENTS & \\
\hline WOODED ISIAND A.D. & WOODEO ISLAND A.D. & 45BN107 & TOBE DETERMNEO & NO DHANOSTTCS REPORTED & PUBLIC ACCESS & & \\
\hline WOODED ISIAND A.D. & WOODED ISIAND A.D. & 45BN108 & TOBE DETERMNED & NO DIAGNOSTICS REPORTED & PUBLIC ACCESS & & \\
\hline WOODED ISIAND AD. & WOODED ISLAND A.D. & 45BN109 & TOBE DETERMNED & NO DAGNOSTICS REPORTED & PUBLIC ACCESS & & \\
\hline WOODED ISIAND A.D. & WOODED ISIAND A.D. & 45BN110 & TOBE DETERMNED & SMAII SIDE-NOTCHED RPTD & PUBLIC ACCESS & & \\
\hline WOODED ISIAND A.D. & WOODED ISIAND A.D. & 45BN111 & TOBE DETEHMNED & NO DAGNOSTICS REPORTED & PUBIIC ACCESS & & \\
\hline WOODED ISIAND AD. & WOOOED ISIAND A.D. & 45BN112 & TOBE DETERMNED & NO DAAGNOSTICS REPORTED & PUBLIC ACCESS & & \\
\hline WOODED ISIAND A.D. & WOODEO ISIAND A.D. & 45BN168 & TOBE DETERMNED & NO DAGAOSTICS REPORTED & PUBIIC ACCESS & & \\
\hline SAVAGE ISLAND A.D. & SAVAGE ISLAND A.D. & 45BN116 & TOBE DETERMNED & NO DAGNOSTICS REPORTED & PUBLIC ACCESS & & \\
\hline SAVAGE ISLAND A.D. & SAVAGE ISLAND A.D. & 45BN117 & TOBE DETERMNED & NO DAGNOSTTCS REPORTED & PUBLIC ACCESS & & \\
\hline SAVAGE ISIAND A.D. & SAVAGE ISLAND A.D. & 45BN118 & TOBE DETERMNED & NO DAGNOSTICS REPORTED & PUBLIC ACCESS & & \\
\hline SAVAGE ISLAND A.D. & SAVAGE ISLAND A.D. & 45BN119 & TOBE DETERMNED & FA. SPRINGS, CASCADE & PUBLIC ACCESS & & \\
\hline SAVAGE ISLAND A.D. & SAVAGE ISLAND A.D. & 45FR257 & TOBE DETERMANED & NO DIAGNOSTICS REPORTED & PUBLIC ACCESS & & \\
\hline SAVAGE ISLAND A.D. & SAVAGE ISLAND A.D. & 45FR258 & TOBE DETERMNED & CAYUSE & PUBLIC ACCESS & & \\
\hline SAVAGE ISLAND A.D. & SAVAGE ISLAND A.D. & 45FR259 & TOBE DETERMNED & FRENCHNAN SPRNGS & PUBLIC ACCESS & & \\
\hline SAVAGE ISLAND A.D. & SAVAGE ISLAND A.D. & 45FR260 & TOBE DETERMNED & CAYUSE & PUBLIC ACCESS & & \\
\hline SAVAGE ISIAND A.D. & SAVAGE ISLAND A.D. & 45FR261 & TOBE DETERMNED & NO DAGANOSTCS REPORTED & PUBLIC ACCESS & & \\
\hline SAVAGE ISLAND A.D. & SAVAGE ISLAND A.D. & 45FR262 & TOBE DETERMNED & NO DIAGNOSTICS REPORTED & PUBLIC ACCESS & & \\
\hline HANFORD ISIAND SITE & HANFORD ISIAND SITE & 45BN121 & TOBE DETERMNED & NO DIAGNOSTICS REPORTED & PUBLIC ACCESS & & \\
\hline HANFORD NORTH A.D. & HANFORD NORTH A.D. & 45BN124 & TOBE DETERMNED & HISIORIC CEMETERY & QDQUARRY?, WORKER ACCESS & & \\
\hline HANFORD NORTH A.D. & HANFORD NORTH AD. & 45BN125 & TOBE DETERMNED & NO DIAGNOSTICS REPORTED & WORKER/ PUBLIC ACCESS & & \\
\hline HANFORD NORTH A.D. & HANFORD NORTH A.D. & 45BN126 & TOBE DETERMNED & NO DAGNOSTTCS REPORTED & WORKER PUBLIC ACCESS & & \\
\hline HANFORD NORTH A.D. & HANFORD NORTH AD. & 45BN127 & TOBE DETERMNED & NO DIAGNOSTICS REPORTED & WORKER PUBLIC ACCESS & & \\
\hline HANFORD NORTH A.D. & HANFORD NORTH AD. & 45BN128 & TO BE DETERIMNED & HISTORIC, CAYUSE & WORKER PUBLIC ACCESS & & \\
\hline HANFORD NORTH A.D. & HANFORD NORTHA.D. & 45BN129 & 10BE DETERMNED & NO DIAGNOSTICS REPORTED & WORKER PUBLIC ACCESS & & \\
\hline HANFORD NORTH A.D. & HANFORD NORTH A.D. & 45BN130 & TOBE DETERMNED & NODIAGNOSTICS REPORTED & WORKER PUBLIC ACCESS & & \\
\hline HANFORD NORTH A.D. & HANFORD NORTH A.D. & 45BN131 & TOBE DETERMNED & NO DIAGNOSTICS REPORTED & WORKER PUBLIC ACCESS & & \\
\hline HANFORD NORTH A.D. & HANFORD NORTH A.D. & 45BN132 & TOBE DETERMNED & NO DIAGNOSTICS REPORTED & WORKER PUBLIC ACCESS & & \\
\hline HANFORD NORTH A.D. & HANFORD NORTH A.D. & 45BN133 & TOBE DETERMANED & NO DIAGNOSTICS REPORTED & WORKER PUBLIC ACCESS & & \\
\hline HANFORD NORTH A.D. & HANFORD NORTH AD. & 45BN134 & TOBE DETERANINED & NO DHAGNOSTICS REPORTED & WORKER PUBLIC ACCESS & & \\
\hline HANFORD NORTH A.D. & HANFORD NORTH A.D. & 45BN178 & TOBE DETERAMNED & CAYUSE & DECOMMSSIONNAG & & \\
\hline LOCKE ISIAND A.D. & LOCKE ISLAND A.D. & 45BN137 & TOBE DETERMNED & NO DIAGNOSTICS REPORTED & WORKER PUBLIC ACCESS & & \\
\hline LOCKE ISLAND A.D. & LOCKE ISIAND A.D. & 45BN138 & TOBE DETERMNED & NO DIAGNOSTICS REPORTED & WORKER/ PUBLIC ACCESS & & \\
\hline LOCKE ISIAND A.D. & LOCKE ISIAND A.D. & 45BN139 & TOBE DETERMMED & HISTORIC BURIAL & WORKER PUBLIC ACCESS & & \\
\hline LOCKE ISIAND A.D. & LOCKE ISLAND A.D. & 45BN140 & TOBE DETERMNED & NO DIAGNOSTICS REPORTED & WORKER/ PUBLIC ACCESS & & \\
\hline LOCKE ISIAND A.D. & LOCKE ISLAND A.D. & 45BN176 & TOBE DETERMNED & HISTORIC SITE & DECOMMSSIONING & & \\
\hline LOCKE ISIAND A.D. & LOCKE ISLAND A.D. & 45GR302A & SAME RECENT VANDALISM & QULOMENE BAR OR CAYUSE & WORKER PUBLIC ACCESS & VISITED $7 / 88$ & 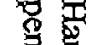 \\
\hline LOCKE ISIAND AD. & LOCKE ISLAND A.D. & 45GR302B & TO BE DETERMNED & NO DIAGNOSTICS REPORTED & WORKER/ PUBLIC ACCESS & & \\
\hline LOCKE ISIAND AD. & LOCKE ISLAND A.D. & 45GR302C & TOBE DETERMANED & HISTORIC, AT LEAST & WORKER PUBLIC ACCESS & & 는. \\
\hline LOCKE ISIAND A.D. & LOCKE ISLAND A.D. & 45GR303 & TOBE DETERMNED & NO DIAGNOSTICS REPORTED & WORKER PUBLIC ACCESS & & \\
\hline LOCKE ISIAND A.D. & LOCKE ISLAND A.D. & 45GR304 & 10BE DETERMNED & NO DIAGNOSTICS REPORTED & WORKER PUBLIC ACCESS & & \\
\hline LOCKE ISIAND A.D. & LOCKE ISLAND A.D. & 45GR305 & TOBE DETERMNED & NO DAGNOSTICS REPORTED & WORKER PUBLIC ACCESS & & \\
\hline
\end{tabular}


TABLE J.1. (contd)

\begin{tabular}{|c|c|c|c|c|c|c|}
\hline PROPERIY & PROPERIY & SITE' & CURAENT CONDTKON & AGE, BY PHASE & POTENTIAL IMPACTS OF DOE MGT & COMMENTS \\
\hline RYEGRASS A.D. & RYEGRASS A.D. & 45BN149 & TOBE DETERMNED & CAYUSE & DECOMMISSIONNG, CONSTRUCTION & \\
\hline RYEGRASS A.D. & RYEGRASS A.D. & 45BN150 & TOBE DETERMNED & NODAGNOSTICS REPORTED & DECOMMSSIONING & \\
\hline RYEGRASS A.D. & RYEGRASS A.D. & 45BN151 & UNDISTURBED & NODUGNOSTICS REPORTED & DECOMMSSIONING & VISITED $6 / 88$ \\
\hline PARIS SITE & PARIS SITE & 45GR317 & RECENT VANDALISM & LATECASCADE,CAYUSE & VANDALISM & VISITED $\quad 10 / 25 / 88$ \\
\hline \multicolumn{3}{|c|}{ RAffiESNAKE SPRINGS A.D. RATLESNAKE SPRINGS A.D. 4 SBN170 } & TOBEDETERMNED & NODAGNOSTICS REPORTED & WOPKERACCESS & \\
\hline \multicolumn{3}{|c|}{ RAffiESNAI<E SPRINGS A.D. RATILESNAKE SPRINGS A.D. 45BN171 } & TOBE DETERMNED & CASCADE & WORKERACCESS & \\
\hline SNIVELY CANYON A.D. & SNIVEIY CANYON A.D. & 45BNI72 & TOBEDETERMMNED & CAYUSE & WOPKERACCESS & \\
\hline SNIVELY CANYON AD. & SNIVEIY CANYON A.D. & 4SBN173 & TOBE DETERMNED & NO DAGAOSTICS REPORTED & WORKERAOCESS & \\
\hline WAHIUK <E A.D. & WAHIUL $<E A D$. & 45BN141 & TOBE DETERMNED & NODAGNOSTICS REPORTED & WORKERACCESS & \\
\hline WAHIUK<E A.D. & WAHIUI<E A.D. & 45BN142 & TOBEOETERMNED & CAYUSE & WORKERACCESS & \\
\hline WAHIUl<E A.D. & WAHIUl<E A.D. & 45BN143 & TOBE DETERMNED & HISTORIC CEMETERY & WORKERACCESS & \\
\hline WAHIUI<E A.D. & WAHIUI<E A.D. & 4SBN144 & TOBE DETERMNED & NODAGNOSTICS REPORTED & WORKERACCESS & \\
\hline WAHIUI<E A.D. & WAHIULEE A.D. & 45BN145 & TOBEDETERMNED & CAYUSE & WORKERACCESS & \\
\hline WAHIUK<E A.D. & WAHIUI<E A.D. & 45BN146 & TOBE DETERMNED & NO DAGNOSTICS REPORTED & WORKERACCESS & \\
\hline WAHIUI<E A.D. & WAHIULEE A.D. & 45BN147 & TOBE DETERMNED & NODAGHOSTICS REPORTED & WOPKER ACCESS & \\
\hline WAHIUl<E A.D. & WAHKUKE A.D. & 45GR306A & TOBE DETERMANED & NODHGAOSTICS REPORTED & WORKEPYPUBLIC ACCESS & \\
\hline WAHIUI<E A.D. & WAHEUKE A.D. & 45GR306B & TOBE DETERMNED & HISTORIC ARTIFACTS REPORTED & WORKERPUBL $C$ ACCESS & \\
\hline WAHIUl<E A.D. & WAHIUI<E A.D. & 45GR306C & TOBE DETERMNED & NODHGVOSTICS REPORTED & WORKERPUBLKCACCESS & \\
\hline COYOTE RAPIDS A.D. & COYOTE RAPIDS A.D. & 45BN152 & TOBE DETERMNED & NODMGNOSTICS REPORTED & WOPKEFACCESS & \\
\hline COYOTE RAPIDS A.D. & COYOTE RAPIDS A.D. & 45GR312 & TOBE DETERMNED & NODAGVOSTICS REPORTED & WOAKEPAOCESS & \\
\hline COYOTE RAPIDS A.D. & COYOTE RAPIDS A.D. & 45GR313 & TOBE DETERMNED & CAYUSE & WOAKERACCESS & \\
\hline$\underline{\text { COYOTE }} \underline{\text { RAPIDS }} \underline{\text { A.D. }}$. & 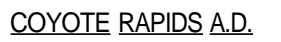 & 45GR314 & TOBE DETERMNNED & NODAGNOSTICS REPORTED & WORKEPACCESS & \\
\hline
\end{tabular}




\section{DISTRIBUTION}

No. of

Copies

OFFSITE

10 DOE/Office of Scientific and Technical Information

Jacob Thomas

State Historic Preservation Officer

Office of Archaeology \&Historic Preservation

III West 21st Ave., KL-1l

Olympia, WA 98504-5411

Thomas King

Advisory Council on Historic Preservation

The Old Post Office Building

1100 Pennsylvania Ave., NW \#809

Washington, D.C. 20004

Duane Hogan

U.S. Army Corps of Engineers

Box C-3755

Seattle, WA 98124-2255

Dennis Canty

National Park Service, Pacific Northwest Region

83 King St., Suite 212

Seattle, WA 98104

John Leier

U.S. Army Corps of Engineers

Walla Walla District

Building 602, City-County Airport

Walla Wa11a, WA 99362-9265
No. of

Copies

Bruce Crespin

U.S. Bureau of Land Management

Burns, OR 97720

2 Colville Confederated Tribes

Attn: Tribal Council Adeline Fredin

P.O. Box 150

Nespelem, WA 99155

2 Nez Perce Tribe

Attn: Tribal Council

P.O. Box 305 Alan Slickpoo

Lapwai, 1083540

2 The Confederated Tribes of the Umatilla Indian Reservation Attn: Tribal Council Jeff Van Pelt

P.O. Box 638

Pendleton $\mathrm{t}$ OR 97810

2 The Wanapum Indian Tribe

Attn: Tribal Council Rex Buck, Jr.

P.O. Box 275

Beverly, WA 99321

2 The Yakima Indian Nation

Attn: Tribal Council

P.O. Box 151 Bill Yallup

Toppenish t WA 98948 
No. of

Copies

ONSITE

16 DOE Richland Operations Office

J. H. Anttonen

K. V. Clarke (5)

P. F. Dunigan

N. M. Highland

M. B. Hitt

R. D. Izatt

K. H. Jackson

E. E. Pride

J. R. Shadel

P. H. Turner

K. J. Wheeless

DOE Legal Library

2 Westinghouse Hanford Company

G. D. Carpenter

D. L. Mills
No. of

$\underline{\text { Copies }}$

43 Pacific Northwest Laboratory

C. A. Brandt

T. L. Brown

N. A. Cadoret

J. C. Chatters (20)

L. R. Eberhardt

J. W. Falco

R. H. Gray

J. M. Hales

P. C. Hays

S. F. Liebetrau

T. J. McLaughlin

P. E. Minthorn

1. L. Page

W. H. Rickard

R. L. Skaggs

A. K. Stalker

R. E. Wildung

R. K. Woodruff

Publishing Coordination

Technical Report Files

Distr.2 